\title{
sises
}

Prepared in cooperation with the U.S. Environmental Protection Agency Chesapeake Bay Program

Spatial and Temporal Variation of Stream Chemistry Associated With Contrasting Geology and Land-Use Patterns in the Chesapeake Bay Watershed: Summary of Results from Smith Creek, Virginia; Upper Chester River, Maryland; Conewago Creek, Pennsylvania; and Difficult Run, Virginia, 2010-2013

Scientific Investigations Report 2016-5093

U.S. Department of the linterior U.S. Geological Survey 



\section{Spatial and Temporal Variation of Stream Chemistry Associated With Contrasting Geology and Land-Use Patterns in the Chesapeake Bay Watershed: Summary of Results from Smith Creek, Virginia; Upper Chester River, Maryland; Conewago Creek, Pennsylvania; and Difficult Run, Virginia, 2010-2013}

By Kenneth E. Hyer, Judith M. Denver, Michael J. Langland, James S. Webber, J.K. Böhlke, W. Dean Hively, and John W. Clune

Prepared in cooperation with the U.S. Environmental Protection Agency Chesapeake Bay Program

Scientific Investigations Report 2016-5093 


\title{
U.S. Department of the Interior SALLY JEWELL, Secretary
}

\section{U.S. Geological Survey Suzette M. Kimball, Director}

\author{
U.S. Geological Survey, Reston, Virginia: 2016
}

For more information on the USGS - the Federal source for science about the Earth, its natural and living resources, natural hazards, and the environment—visit http://www.usgs.gov or call 1-888-ASK-USGS.

For an overview of USGS information products, including maps, imagery, and publications, visit http://store.usgs.gov.

Any use of trade, firm, or product names is for descriptive purposes only and does not imply endorsement by the U.S. Government.

Although this information product, for the most part, is in the public domain, it also may contain copyrighted materials as noted in the text. Permission to reproduce copyrighted items must be secured from the copyright owner.

Suggested citation:

Hyer, K.E., Denver, J.M., Langland, M.J., Webber, J.S., Böhlke, J.K., Hively, W.D., and Clune, J.W., 2016, Spatial and temporal variation of stream chemistry associated with contrasting geology and land-use patterns in the Chesapeake Bay watershed — Summary of results from Smith Creek, Virginia; Upper Chester River, Maryland; Conewago Creek, Pennsylvania; and Difficult Run, Virginia, 2010-2013: U.S. Geological Survey Scientific Investigations Report 2016-5093, 211 p., http://dx.doi.org/10.3133/sir20165093.

ISSN 2328-031X (print)

ISSN 2328-0328 (online

ISBN 978-1-4113-4085-5 


\section{Acknowledgments}

Funding for this study was provided by the U.S. Geological Survey (USGS) Ecosystems Mission Area as part of the Priority Ecosystem Science (PES) Program. Sincere appreciation is extended to the many landowners in all four study watersheds who provided us with access to many of the study sites. Cooperation from the U.S. Department of Agriculture, Natural Resources Conservation Service, as well as the Soil and Water Conservation Service, was instrumental for better understanding each basin and for gaining access to study sites. Additional contributions of data and information were made by the Virginia Department of Environmental Quality, Pennsylvania Department of Environmental Protection, the Maryland Department of Natural Resources, and the U.S. Environmental Protection Agency. Appreciation is extended to the Stormwater Planning Division of the Fairfax County Department of Public Works and Environmental Services for supporting elements of water-quality monitoring in Difficult Run that were incorporated into this report and for providing data on the implementation of best management practices throughout Difficult Run.

We are indebted to the many USGS field technicians and hydrologists who have contributed to the collection of field samples and other technical content throughout the report. Technical reviews by Doug Burns of the USGS New York Water Science Center and Angie Crain of the USGS Indiana-Kentucky Water Science Center strengthened this report and are sincerely appreciated. 



\section{Contents}

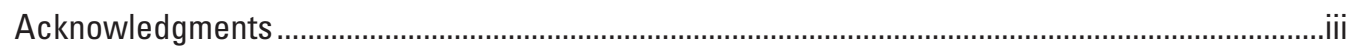

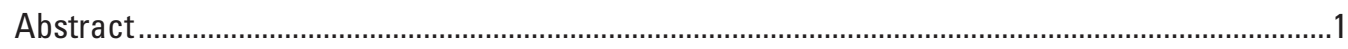

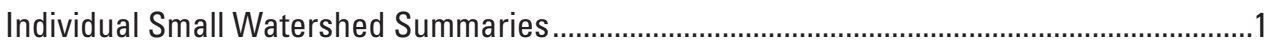

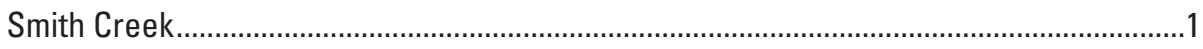

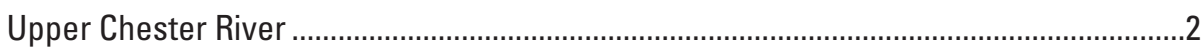

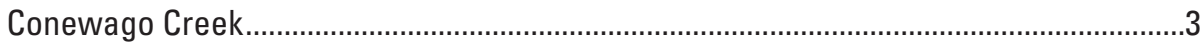

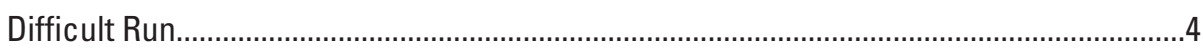

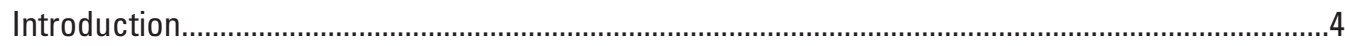

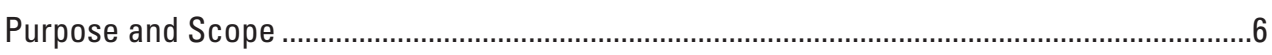

Description of Study Watersheds .................................................................................. 6

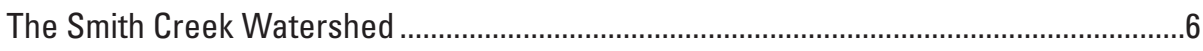

The Upper Chester River Watershed.........................................................................

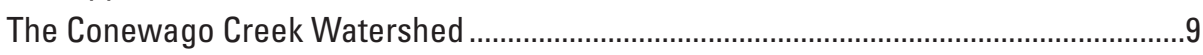

The Difficult Run Watershed ...................................................................................12

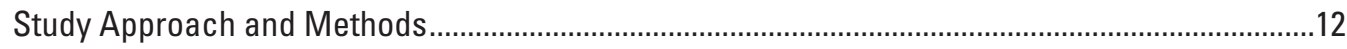

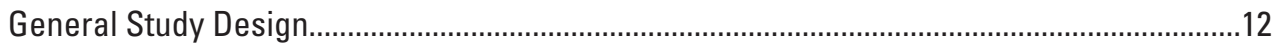

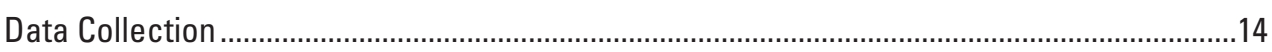

Collection of Discrete Water-Quality Samples ..............................................................14

Laboratory Analysis of Water-Quality Samples...........................................................14

Continuous Monitoring of Water Quality ....................................................................15

Statistical Analysis of Surface-Water and Water-Quality Data..............................................15

Development of Surrogate Water-Quality Models and Computation of Loads...............17

Hierarchical Agglomerative Cluster Analysis ................................................................19

Principal Components Analysis......................................................................................

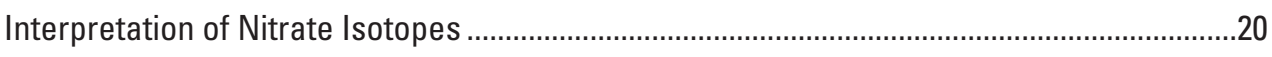

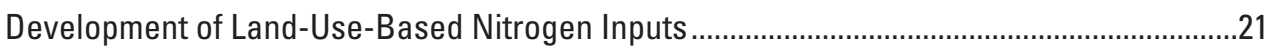

Development of Land-Use and Conservation-Practice Datasets............................................22

Smith Creek Watershed Water-Quality Characterization ...............................................................23

Streamflow and Water-Quality Characterization at the Intensive Monitoring Site................23

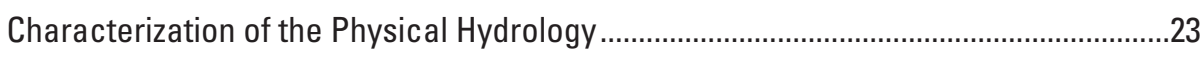

Characterization of Continuous Water-Quality Data ....................................................26

Characterization of Discrete Water-Quality Data ...............................................................

Surrogate Models for the Computation of Sediment and Nutrient Loads................................38

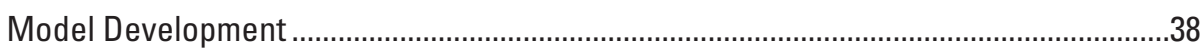

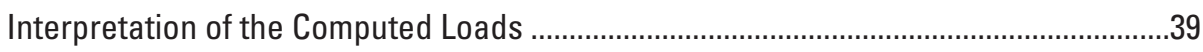

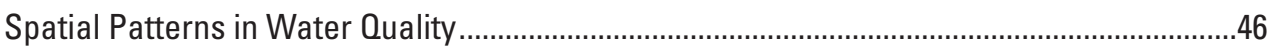

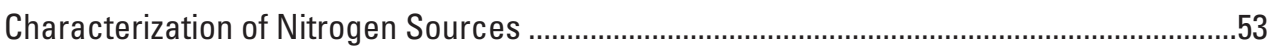

Implementation of Conservation Practices and Water-Quality Response .............................59

Conceptual Watershed Model and Implications for Management Actions ............................61

Upper Chester River Watershed Water-Quality Characterization...................................................64

Streamflow and Water-Quality Characterization at the Intensive Monitoring Site.................64

Characterization of the Physical Hydrology ................................................................64

Characterization of Continuous Water-Quality Data ........................................................67 
Characterization of Discrete Water-Quality Data ...........................................................72

Surrogate Models for the Computation of Sediment and Nutrient Loads..............................81

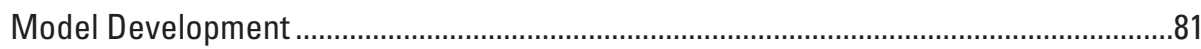

Interpretation of the Computed Loads …………………………………………….........

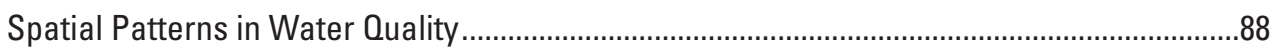

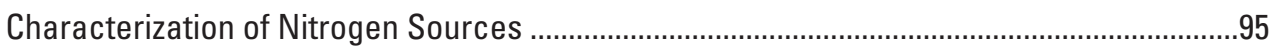

Implementation of Conservation Practices and Water-Quality Response .............................97

Conceptual Watershed Model and Implications for Management Actions ..........................100

Conewago Creek Watershed Water-Quality Characterization .....................................................102

Streamflow and Water-Quality Characterization at the Intensive Monitoring Site...............102

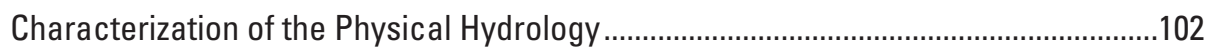

Characterization of Continuous Water-Quality Data ..................................................105

Characterization of Discrete Water-Quality Data .......................................................109

Surrogate Models for the Computation of Sediment and Nutrient Loads.............................121

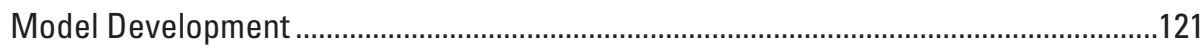

Interpretation of the Computed Loads ..................................................................125

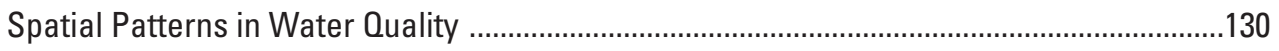

Characterization of Nitrogen Sources ..............................................................................133

Implementation of Conservation Practices and Water-Quality Response ..........................136

Conceptual Watershed Model and Implications for Management Actions .........................138

Difficult Run Watershed Water-Quality Characterization ............................................................141

Streamflow and Water-Quality Characterization at the Intensive Monitoring Site...............141

Characterization of the Physical Hydrology ..................................................................141

Characterization of Continuous Water-Quality Data ........................................................145

Characterization of Discrete Water-Quality Data ......................................................150

Surrogate Models for the Computation of Sediment and Nutrient Loads.............................158

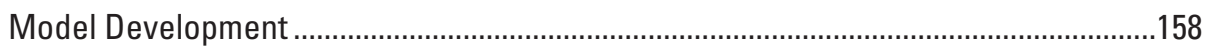

Interpretation of the Computed Loads ...................................................................158

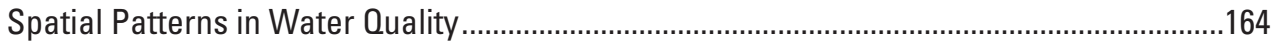

Characterization of Nitrogen Sources ………………....................................................170

Implementation of Conservation Practices and Water-Quality Response ............................174

Conceptual Watershed Model and Implications for Management Actions .........................175

Comparison of Water-Quality Patterns Among Study Watersheds ..............................................178

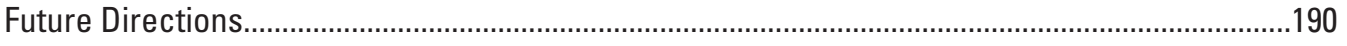

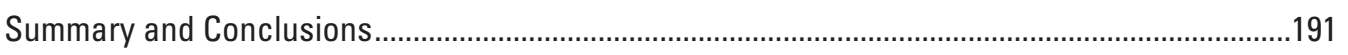

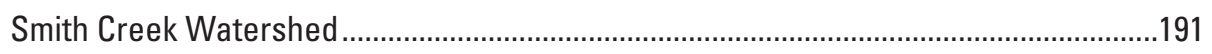

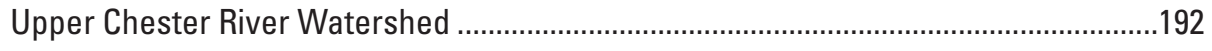

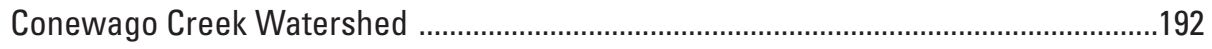

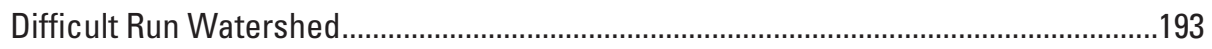

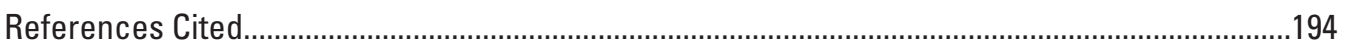

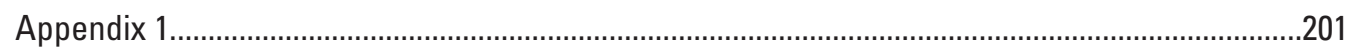




\section{Figures}

1. Map showing physiographic provinces and the location of the four study watersheds within the Chesapeake Bay watershed.

2. Maps showing monitoring stations, land use, underlying geology, and sinkhole density in the Smith Creek watershed....

3. Maps showing monitoring stations, land use, and underlying geology in the Upper Chester River watershed

4. Maps showing monitoring stations, land use, and underlying geology in the Conewago Creek watershed

5. Maps showing monitoring stations, land use, and underlying geology in the Difficult Run watershed

6. Graph showing typical variability in $\delta^{15} \mathrm{~N}$ and $\delta^{18} \mathrm{O}$ values for nitrate derived from various sources, with emphasis on conditions relevant to the Chesapeake Bay watershed

7. Map showing monitoring stations and the stream network within the Smith Creek watershed, Virginia

8. Hydrograph for the Smith Creek streamgage and quantiles that represent historical monthly flow data with the timing of various sampling events from April 2010 through September 2013

9. Contour plots showing continuous water temperature, dissolved oxygen, and $\mathrm{pH}$ data with the hydrograph from the Smith Creek streamgage, 2010-2013..........27

10. Contour plots showing continuous turbidity, specific conductance, and nitrate data with the hydrograph from the Smith Creek streamgage

11. Graphs and boxplots showing water temperature, specific conductance, and $\mathrm{pH}$ data from continuous monitoring and discrete storm and routine samples for warm (April to September) and cool (October to March) seasons, Smith Creek streamgage, 2010-2013

12. Graphs and boxplots showing dissolved oxygen, turbidity, and nitrate data from continuous monitoring and discrete storm and routine samples for warm (April to September) and cool (October to March) seasons, Smith Creek streamgage.

13. Cluster analysis dendrogram showing discrete samples from the Smith Creek streamgage with a heat map of constituent values and the breakpoint used to produce three cluster groups, 2012-2013.

14. Graph showing the first two principal component axis scores for discrete samples from the Smith Creek streamgage along with time and streamflow, 2012-2013

15. Graphs showing concentration-discharge data for discrete samples from the Smith Creek streamgage by warm and cool season....

16. Time-series plots showing concentrations of various constituents in discrete samples from the Smith Creek streamgage

17. Graphs showing variability in nitrate isotopes in discrete samples from the Smith Creek streamgage and potential causes for variability, 2011-2013

18. Diagnostic plots showing the observed and estimated values from the best suspended-sediment surrogate model for the Smith Creek streamgage and the residual plot of model predictions, 2010-2013

19. Diagnostic plots showing the observed and estimated concentrations of total nitrogen from the best and alternative surrogate models for the Smith Creek streamgage and the residual plot of model predictions, 2010-2013. 
20. Diagnostic plots showing the observed and estimated concentrations of total phosphorus from the best and alternative surrogate models for the Smith Creek streamgage and the residual plot of model predictions, 2010-2013

21. Graph showing the suspended-sediment load and total annual streamflow at the Smith Creek streamgage for water years 2011 through 2013

22. Time-series plots showing the suspended-sediment load at the Smith Creek streamgage for water years 2010 through 2013 along with the percentage of load accumulated and the hydrograph during the period of study and the accumulation of load and streamflow in each water year.

23. Graph showing the total nitrogen load and total annual streamflow at the Smith Creek streamgage for the 2013 water year.

24. Time-series plots showing the percentage of total nitrogen load accumulated and the hydrograph during the period of study and the accumulation of load and streamflow at the Smith Creek streamgage for water years 2012 and 2013.

25. Graph showing the total phosphorus load and total annual streamflow at the Smith Creek streamgage for water years 2011 through 2013.

26. Time-series plots showing the percentage of total phosphorus load accumulated and the hydrograph during the period of study and the accumulation of load and streamflow at the Smith Creek streamgage for water years 2010 through 2013.

27. Graphs showing streamflow inputs and drainage area for samples collected during each synoptic sampling event between sites 8 and 11 in the Smith Creek watershed.

28. Map showing monitoring locations, total nitrogen concentrations measured during each synoptic sampling event, and the stream network in the Smith Creek watershed.

29. Map showing monitoring locations, the percentage of the maximum total nitrogen load measured during each synoptic sampling event, and the stream network in the Smith Creek watershed.

30. Map showing monitoring locations, the total phosphorus concentration measured during each synoptic sampling event, and the stream network in the Smith Creek watershed.

31. Map showing monitoring locations, the maximum total phosphorus load measured during each synoptic sampling event, and the stream network in the Smith Creek watershed.

32. Cluster analysis dendrogram showing samples collected from each synoptic event within the Smith Creek watershed with a heat map of constituent values and the breakpoint used to produce four cluster groups.

33. Map showing synoptic sampling events at monitoring locations in the Smith Creek watershed as grouped in a cluster analysis.

34. Graphs showing nitrate isotope results from each synoptic sampling event within the Smith Creek watershed.

35. Pie charts showing percentages of land-use types from Homer and others (2015) within the Smith Creek watershed, Rockingham County and Shenandoah County, Virginia

36. Graphs showing nitrogen sources for Rockingham County and Shenandoah County, Virginia, from 1987 to 2012 and pie charts showing nitrogen sources in 2002 for Rockingham County and Shenandoah County, Virginia

37. Pie charts showing the percentages of input and output sources of total nitrogen for the Smith Creek watershed as generated by the 2002 Chesapeake Bay Total Nitrogen SPARROW model as described in Ator and others (2011). 
38. Time-series plot showing nitrate concentrations from the Smith Creek streamgage for water years 1979 through 2013.

39. Graph showing nitrate loads estimated from the Chesapeake Bay watershed model for the model segment containing Smith Creek with and without best management practice implementation with input sources and the annual percentage difference of load attributed to implementation, 1985-2012.

40. Map showing monitoring stations, select subwatershed boundaries, and the stream network within the Upper Chester watershed, Maryland

41. Hydrograph for the Chesterville Branch streamgage and quantiles that represent historical monthly flow data with the timing of various sampling events from July 2011 through September 2013 within the Upper Chester River watershed

42. Contour plots showing continuous water temperature, dissolved oxygen, and $\mathrm{pH}$ data with the hydrograph from the Chesterville Branch streamgage, 2012-2013

43. Contour plots showing continuous specific conductance, nitrate, and turbidity data with the hydrograph from the Chesterville Branch streamgage, 2012-2013

44. Graphs and boxplots showing water temperature, specific conductance, and $\mathrm{pH}$ data from continuous monitoring and discrete storm and routine samples for warm (April to September) and cool (October to March) seasons, Chesterville Branch streamgage, 2012-2013

45. Graph and boxplots showing dissolved oxygen, turbidity, and nitrate data from continuous monitoring and discrete storm and routine samples for warm (April to September) and cool (October to March) seasons, Chesterville Branch streamgage, 2012-2013.

46. Graph showing the Chesterville Branch hydrograph, continuous nitrate concentrations, and continuous specific conductance data, July 10 through July 16, 2013

47. Graphs showing concentration-discharge data for discrete samples from the Chesterville Branch streamgage by warm and cool seasons, 2011-2013

48. Time-series plots showing concentrations of various constituents in discrete samples from the Chesterville Branch streamgage, 2011-2013

49. Graphs showing variability in nitrate isotopes in discrete samples from the Chesterville Branch streamgage and potential causes for variability, 2011-2013

50. Cluster analysis dendrogram showing discrete samples from the Chesterville Branch streamgage with a heat map of constituent values and the breakpoint used to produce three cluster groups, 2011-2013

51. Graph showing the first two principal component axis scores for discrete samples from the Chesterville Branch streamgage along with time and streamflow, 2011-2013

52. Diagnostic plots showing observed and estimated values from the best and alternative suspended-sediment surrogate models for the Chesterville Branch streamgage and the residual plot of model predictions, 2012-2013

53. Diagnostic plots showing observed and estimated values from the best and alternative total phosphorus surrogate models for the Chesterville Branch streamgage and the residual plot of model predictions, 2012-2013

54. Diagnostic plots showing observed and estimated values from the best total nitrogen surrogate model for the Chesterville Branch streamgage and the residual plot of model predictions, 2012-2013. 
55. Graph showing the suspended-sediment load and total annual streamflow at the Chesterville Branch streamgage for the 2013 water year

56. Time-series plots showing the suspended-sediment load at the Chesterville Branch streamgage for water years 2012 and 2013 along with the percentage of load accumulated and the hydrograph during the period of study and the accumulation of load and streamflow in each water year..

57. Graph showing the total phosphorus load and total annual streamflow at the Chesterville Branch streamgage for the 2013 water year

58. Time-series plots showing the percentage of total phosphorus load accumulated and the hydrograph during the period of study and the accumulation of load and streamflow at the Chesterville Branch streamgage for water years 2012 and 2013

59. Graph showing the total nitrogen load and annual total streamflow at the Chesterville Branch streamgage for the 2013 water year

60. Time-series plots showing the percentage of total nitrogen load accumulated and the hydrograph during the period of study and the accumulation of load and streamflow at the Chesterville Branch streamgage for water years 2012 and 2013

61. Graphs showing streamflow and drainage area for samples collected from the Upper Chester River watershed during each synoptic event.

62. Map showing monitoring locations, total nitrogen concentrations measured during each synoptic sampling event, and the stream network in the Upper Chester River watershed

63. Stiff plots showing the major-ion chemistry from the December 2011 synoptic sampling event and pie charts representing percentages of land use within the Chesterville Branch, Foreman Branch, and Pearl Creek subwatersheds

64. Map showing monitoring locations, total nitrogen load measured during each synoptic sampling event, and the stream network in the Upper Chester River watershed.....

65. Map showing monitoring locations, the total phosphorus concentration measured during each synoptic sampling event, and the stream network in the Upper Chester River watershed.....

66. Map showing monitoring locations, the total phosphorus load measured during each synoptic sampling event, and the stream network in the Upper Chester River watershed

67. Cluster analysis dendrogram showing samples collected from each synoptic event within the Upper Chester River watershed with a heat map of constituent values and the breakpoint used to produce four cluster groups

68. Map showing monitoring locations as identified in a cluster analysis for each synoptic sampling event and the stream network of the Upper Chester River watershed

69. Graphs showing nitrate isotope results from each synoptic sampling event within the Upper Chester River watershed

70. Pie charts showing percentages of land-use types from Homer and others (2015) within the Upper Chester River watershed, Queen Anne's County, and Kent County, Maryland.

71. Graphs showing nitrogen sources for Kent County and Queen Anne's County, Maryland, from 1987 to 2012, and pie charts showing nitrogen sources in 2002 for Kent County and Queen Anne's County, Maryland

72. Pie charts showing the percentages of input and output sources of total nitrogen for the Upper Chester River watershed as generated by the 2002 Chesapeake Bay Total Nitrogen SPARROW model. 
73. Time-series plot showing nitrate concentrations from the Chesterville Branch streamgage between 1990 and 2013

74. Graph showing nitrate load estimated from the Chesapeake Bay watershed model for the model segment containing Chesterville Branch with and without best management practice implementation with input sources and the annual percentage difference of load attributed to implementation, 1985-2012

75. Map showing the stream network, monitoring stations, subwatershed boundaries, and sampling locations within the Conewago Creek watershed, Pennsylvania

76. Hydrographs for the Conewago Creek Bellaire and Conewago Creek Falmouth streamgages with the timing of various sampling events

77. Contour plots showing continuous water temperature and specific conductance data with the hydrograph from the Conewago Creek Bellaire streamgage, 2012-2013.

78. Contour plots showing continuous water temperature and specific conductance data with the hydrograph from the Conewago Creek Falmouth streamgage, 2011-2013.

79. Graphs and boxplots showing water temperature and specific conductance data from continuous monitoring and discrete storm and routine samples for warm (April to September) and cool (October to March) seasons, Conewago Creek Bellaire streamgage, 2012-2013

80. Graphs and boxplots showing water temperature and specific conductance data from continuous monitoring and discrete storm and routine samples for warm (April to September) and cool (October to March) seasons, Conewago Creek Falmouth streamgage, 2011-2013.

81. Cluster analysis dendrogram showing discrete samples from the Conewago Creek Bellaire and Falmouth streamgages with a heat map of constituent values and the breakpoint used to produce four cluster groups, 2011-2013

82. Graph showing the first two principal component axis scores for discrete samples from the Conewago Creek Bellaire and Falmouth streamgages along with time and streamflow, 2011-2013

83. Graphs showing concentration-discharge data for discrete samples from the Conewago Creek Bellaire and Falmouth streamgages by warm (April to September) and cool (October to March) seasons

84. Time-series plots showing concentrations of various constituents in discrete samples from the Conewago Creek Bellaire and Falmouth streamgages

85. Diagnostic plots showing the observed and estimated values from the best suspended-sediment surrogate models for the Conewago Creek Bellaire and Falmouth streamgages, the observed and estimated values along with streamflow, and the residual plot of model predictions

86. Diagnostic plots showing the observed and estimated values from the best total nitrogen surrogate models for the Conewago Creek Bellaire and Falmouth streamgages, the observed and estimated values along with streamflow, and the residual plot of model predictions.

87. Diagnostic plots showing the observed and estimated values from the best total phosphorus surrogate models for the Conewago Creek Bellaire and Falmouth streamgages, the observed and estimated values along with streamflow, and the residual plot of model predictions

88. Graphs showing the total sediment load and total annual streamflow at the Conewago Creek Bellaire and Falmouth streamgages for water years 2012 and 2013 
89. Time-series plots showing the total sediment load at the Conewago Creek Bellaire streamgage for water years 2012 and 2013 along with the percentage of load accumulated and the hydrograph during the period of study and the accumulation of load and streamflow in each water year...

90. Time-series plots showing the total sediment load at the Conewago Creek Falmouth streamgage for water years 2011 through 2013 along with the percentage of load accumulated and the hydrograph during the period of study and the accumulation of load and streamflow in each water year.

91. Graphs showing the total phosphorus load and total annual streamflow at the Conewago Creek Bellaire and Falmouth streamgages for the 2012 and 2013 water years

92. Time-series plots showing the total phosphorus load at the Conewago Creek Bellaire streamgage for water years 2012 and 2013 along with the percentage of load accumulated and the hydrograph during the period of study and the accumulation of load and streamflow in each water year..

93. Time-series plots showing the total phosphorus load at the Conewago Creek Falmouth streamgage for water years 2011 through 2013 along with the percentage of load accumulated and the hydrograph during the period of study and the accumulation of load and streamflow in each water year.

94. Maps showing instantaneous total nitrogen, total phosphorus, and suspended-sediment concentrations and loads at the Conewago Creek watershed monitoring locations, May 15, 2012.

95. Pie charts showing percentages of land-use types from Homer and others (2015) within the Conewago Creek watershed, Dauphin County, and Lebanon County.....

96. Graphs showing nitrogen sources for Dauphin County and Lebanon County from 1987 to 2012 and pie charts showing nitrogen sources in 2002 for Dauphin County and Lebanon County, Pennsylvania

97. Pie charts showing the percentages of input and output sources of total nitrogen for the Conewago Creek watershed as generated by the 2002 Chesapeake Bay Total Nitrogen SPARROW model.

98. Graph showing the nitrate loads estimated from the Chesapeake Bay watershed model for the Conewago Creek Bellaire land-river segment with and without best management practice (BMP) implementation with input sources and the annual percentage difference of load attributed to BMP implementation, 1985-2012

99. Graph showing nitrate loads estimated from the Chesapeake Bay watershed model for the Conewago Creek Falmouth land-river segment with and without best management practice (BMP) implementation with input sources and the annual percentage difference of load attributed to BMP implementation, 1985-2012.

100. Map showing monitoring stations and the stream network within the Difficult Run watershed, Virginia

101. Hydrograph for the Difficult Run streamgage and quantiles that represent historical monthly flow data with the timing of various sampling events from June 2011 through September 2013 within the Difficult Run watershed.

102. Graph showing the cumulative daily streamflow values from the Difficult Run streamgage for water years 2011 through 2013 with the median, 75th quantile, and 25th quantile of daily streamflow values observed from water years 1935 through 2010 
103. Contour plots showing continuous water temperature, dissolved oxygen, and specific conductance data with the hydrograph from the Difficult Run streamgage, 2013 water year.

104. Contour plots showing continuous $\mathrm{pH}$, turbidity, and nitrate data with the hydrograph from the Difficult Run streamgage, 2013 water year.

105. Graphs and boxplots showing water temperature, specific conductance, and $\mathrm{pH}$ data from continuous monitoring and discrete storm and routine samples for warm (April to September) and cool (October to March) seasons, Difficult Run streamgage, 2012-2013.

106. Graphs and boxplots showing Dissolved oxygen, turbidity, and nitrate data from continuous monitoring and discrete storm and routine samples for warm (April to September) and cool (October to March) seasons, Difficult Run streamgage, 2012-2013.

107. Cluster analysis dendrogram showing discrete samples from the Difficult Run streamgage with a heat map of constituent values and the breakpoint used to produce three cluster groups, 2012-2013.

108. Graph showing the first two principal component axis scores for discrete samples from the Difficult Run streamgage along with time and streamflow, 2012-2013.

109. Graphs showing concentration-discharge data for discrete samples from the Difficult Run streamgage by warm (April to September) and cool (October to March) seasons, 2011-2013.

110. Time-series plots showing concentrations of various constituents in discrete samples from the Difficult Run streamgage, 2011-2013

111. Graphs showing variability in nitrate isotopes in discrete samples from the Difficult Run streamgage and potential causes for variability, 2011-2013

112. Diagnostic plots showing the observed and estimated values from the best suspended-sediment surrogate model for the Difficult Run streamgage and the residual plot of model predictions, 2011-2013.

113. Diagnostic plots showing the observed and estimated values from the best total nitrogen surrogate model for the Difficult Run streamgage and the residual plot of model predictions, 2011-2013

114. Diagnostic plots showing the observed and estimated values from the best total phosphorus surrogate model for the Difficult Run streamgage and the residual plot of model predictions, 2011-2013.

115. Graph showing the suspended-sediment load and total annual streamflow at the Difficult Run streamgage for the 2013 water year.

116. Time-series plots showing the estimated percentage of suspended-sediment load accumulated and the hydrograph during the period of study and the accumulation of load and streamflow at the Difficult Run streamgage for the 2013 water year

117. Graph showing the total nitrogen load and total annual streamflow at the Difficult Run streamgage for the 2013 water year.

118. Time-series plots showing the estimated percentage of total nitrogen load accumulated and the hydrograph during the study period and the accumulation of load and streamflow at the Difficult Run streamgage for the 2013 water year.

119. Graph showing the total phosphorus load and total annual streamflow at the Difficult Run streamgage for the 2013 water year.

120. Time-series plots showing the estimated percentage of total phosphorus load accumulated and the hydrograph during the period of study and the accumulation of load and streamflow at the Difficult Run streamgage for the 2013 water year 
121. Graphs showing streamflow and drainage area for samples collected from the

Difficult Run watershed during each synoptic event.

122. Graph showing the ratio of streamflow to drainage area for each monitoring location during the synoptic sampling events in the Difficult Run watershed..

123. Map showing monitoring locations, the percentage of the maximum total nitrogen load measured during each synoptic sampling event, and the streamflow network in the Difficult Run watershed

124. Map showing monitoring locations, the total nitrogen concentration measured during each synoptic sampling event, and the streamflow network in the Difficult Run watershed

125. Map showing monitoring locations, the percentage of the maximum total phosphorus load measured during each synoptic sampling event, and the streamflow network in the Difficult Run watershed

126. Map showing monitoring locations, the total phosphorus concentration measured during each synoptic sampling event, and the streamflow network in the Difficult Run watershed.

127. Cluster analysis dendrogram showing samples collected from each synoptic event within the Difficult Run watershed with a heat map of constituent values and the breakpoint used to produce four cluster groups.

128. Map showing synoptic sampling events at monitoring locations in the Difficult Run watershed as grouped in a cluster analysis.

129. Map showing the streamflow network, watershed boundaries of each monitoring location, and county-level tax parcels served and not served by sewage infrastructure in the Difficult Run watershed.

130. Graph showing the median nitrate concentration results from synoptic sampling events within the Difficult Run watershed and from additional U.S. Geological Survey base-flow monitoring in Fairfax County compared to the septic tank density within the drainage area of each monitoring location.

131. Time-series plots showing nitrate concentrations by hydrologic event from Captain Hickory Run and South Fork Little Difficult Run for water years 2007 through 2012

132. Graphs showing nitrate isotope results from each synoptic sampling event within the Difficult Run watershed

133. Graphs showing median nitrate isotope results from synoptic sampling events within the Difficult Run watershed compared to the septic tank density within the drainage area of each monitoring location with dashed lines indicating literature values of nitrate sources.

134. Pie charts showing the percentages of input and output sources of total nitrogen for the Difficult Run watershed as generated by the 2002 Chesapeake Bay Total Nitrogen SPARROW model

135. Time-series plot showing nitrate concentrations for the Difficult Run watershed water years 1972 through 2013.

136. Graph showing the nitrate loads estimated from the Chesapeake Bay watershed model for the Difficult Run land-river segment with and without best management practice implementation with input sources and the annual percentage difference of load attributed to implementation, 1985-2012.

137. Graphs showing continuous specific conductance data compared to normalized streamflow quantiles measured at the Conewago Creek Bellaire and Falmouth, Smith Creek, Chesterville Branch, and Difficult Run streamgages with colored bands that represent the density of data points for a "warm" (April through September) and "cool" (October through March) season 
138. Graphs showing continuous nitrate data compared to normalized streamflow quantiles measured at the Smith Creek, Chesterville Branch, and Difficult Run streamgages with colored bands that represent the density of data points for a "warm" (April through September) and "cool" (October through March) season

139. Graphs showing continuous dissolved oxygen data compared to normalized streamflow quantiles measured at the Smith Creek, Chesterville Branch, and Difficult Run streamgages with colored bands that represent the density of data points for a "warm" (April through September) and "cool" (October through March) season.

140. Graphs showing the cumulative distribution of various water-quality constituents collected from the Smith Creek, Conewago Creek Bellaire and Falmouth, Chesterville Branch, and Difficult Run streamgages.

141. Cluster analysis dendrogram showing discrete samples collected from the Smith Creek, Conewago Creek Bellaire and Falmouth, Chesterville Branch, and Difficult Run streamgages with a heat map of constituent values and the breakpoint used to produce five clusters.

142. Boxplots showing streamflow for the five groups identified in a cluster analysis along with individual samples from the Smith Creek, Conewago Creek Bellaire and Falmouth, Upper Chester River, and Difficult Run watersheds

143. Graphs showing discrete data from the Smith Creek, Difficult Run, Chesterville Branch, and Conewago Creek Bellaire and Falmouth streamgages representing the ratio of nitrate to total nitrogen compared to streamflow and nitrate compared to total nitrogen concentrations, 2010 through 2013

144. Graphs showing discrete data from the Smith Creek, Difficult Run, Chesterville Branch, and Conewago Creek Bellaire and Falmouth streamgages representing the ratio of orthophosphate to total phosphorus compared to streamflow and orthophosphate compared to total phosphorus concentrations, 2010 through 2013

145. Graphs showing discrete data from the Smith Creek, Difficult Run, and

Chesterville Branch streamgages, and the relationships between $\delta^{15} \mathrm{~N}, \delta^{18} 0$, and nitrate results.

146. Graphs showing data from the Smith Creek, Difficult Run, and Upper Chester River watersheds from each synoptic sampling event and the relationships between $\delta^{15} \mathrm{~N}, \delta^{18} 0$, and nitrate results

147. Graphs showing the suspended-sediment yield and total annual streamflow and the suspended-sediment yield and streamflow yield for the 2013 water year from the Smith Creek, Chesterville Branch, Conewago Creek Bellaire and Falmouth, and Difficult Run streamgages.

148. Graphs showing the total nitrogen yield and total annual streamflow and the total nitrogen yield and streamflow yield for the 2013 water year from the Smith Creek, Chesterville Branch, and Difficult Run streamgages.

149. Graphs showing the total phosphorus yield and total annual streamflow and the total phosphorus yield and streamflow yield for the 2013 water year from the Smith Creek, Chesterville Branch, Conewago Creek Bellaire and Falmouth, and Difficult Run streamgages 


\section{Tables}

1. Watershed names, watershed areas, and streamgage station IDs and names..............14

2. Dates of continuous water-quality monitoring and sample-collection activities............14

3. Analysis of replicate and blank discrete water-quality data ............................................15

4. Constituents, parameter codes, analysis sources, method codes, reporting units, and reporting limits for discrete water-quality constituents collected at the Smith Creek and Difficult Run watersheds

5. Constituents, parameter codes, analysis sources, method codes, reporting units, and reporting limits for discrete water-quality constituents collected at the Upper Chester River watershed.

6. Constituents, parameter codes, analysis sources, method codes, reporting units, and reporting limits for discrete water-quality constituents collected at the Conewago Creek watershed

7. Continuous water-quality data collected within each watershed.....

8. Streamflow partitioning for streamgage station 01632900 in the Smith Creek watershed.

9. Loading of water-quality constituents collected at the Smith Creek streamgage on principal component axes 1 and 2 .

10. Summary of hydrologic and seasonal correlations for discrete water-quality constituents collected at the Smith Creek streamgage.

11. Statistical results of the top-ranked suspended sediment, total nitrogen, and total phosphorus concentration estimation models for the Smith Creek streamgage with an alternative model presented for total nitrogen and total phosphorus

12. Nitrogen delivery factors and source estimates identified by the SPARROW model for the Smith Creek watershed.

13. Number of USDA-compliant conservation practices implemented in water years 2007 through 2013 in the Smith Creek watershed, aggregated by sponsoring program

14. Implementation of USDA-compliant conservation practices within the Smith Creek watershed for water years 2007 through 2013.

15. Implementation of state-funded conservation practices within the Smith Creek watershed for water years 2007 through 2014.

16. Streamflow partitioning for streamgage station 01493112 in the Upper Chester River watershed.

17. Summary of hydrologic and seasonal correlations for discrete water-quality constituents collected at the Chesterville Branch streamgage..

18. Loading of water-quality constituents collected at the Chesterville Branch streamgage on principal component axes 1 and 2 .

19. Details of the top-ranked suspended sediment, total nitrogen, and total phosphorus concentration estimation models for the Chesterville Branch streamgage with an alternative model presented for each constituent.

20. Number of USDA-compliant conservation practices implemented in water years 2007 through 2013 in the Upper Chester River watershed, aggregated by sponsoring program

21. Implementation of USDA-compliant conservation practices within the Upper Chester River watershed for water years 2007 through 2013

22. Implementation of conservation practices sponsored by state programs or adopted on a voluntary basis within the Upper Chester River watershed for water years 2007 through 2013 
23. Streamflow partitioning for streamgage stations 01573695 and 01573710 in the Conewago Creek watershed

24. Summary statistics for discrete water-quality constituents collected at the Conewago Creek Bellaire streamgage with a comparison between storm and base-flow samples

25. Summary statistics for discrete water-quality constituents collected at the Conewago Creek Falmouth streamgage with a comparison between storm and base-flow samples

26. Loading of water-quality constituents collected at the Conewago Creek Bellaire and Falmouth streamgages on principal component axes 1 and 2 .

27. Summary of hydrologic and seasonal correlations for discrete water-quality constituents collected at the Conewago Creek Bellaire streamgage.

28. Summary of hydrologic and seasonal correlations for discrete water-quality constituents collected at the Conewago Creek Falmouth streamgage

29. Details of the top-ranked suspended sediment, total nitrogen, and total phosphorus concentration estimation models for the Conewago Creek Bellaire and Falmouth streamgages.

30. Station information, sampling time, and water-quality results from the high-flow synoptic samples collected in the Conewago Creek watershed

31. Number of USDA-compliant conservation practices implemented in water years 2007 through 2013 in the Conewago Creek watershed, aggregated by sponsoring program

32. Implementation of USDA-compliant conservation practices within the Conewago Creek watershed for water years 2007 through 2013

33. Implementation of State-level conservation practices sponsored by the EPA Section 319 Nonpoint Source Management Program within the Conewago Creek watershed.

34. Rainfall data from two NOAA weather monitoring stations including average precipitation for two historical time periods and total precipitation for water years 2011 through 2013

35. Streamflow partitioning for streamgage station 01646000 in the Difficult Run watershed

36. Loading of water-quality constituents collected at the Difficult Run streamgage on principal component axes 1 and 2

37. Summary of hydrologic and seasonal correlations for discrete water-quality constituents collected at the Difficult Run streamgage

38. Details of the top-ranked suspended sediment, total nitrogen, and total phosphorus concentration estimation models for the Difficult Run streamgage...........158

39. Estimated annual nitrate loads contributed by septic system leachate and residential fertilizer application at the Captain Hickory Run monitoring location (01645940)

40. The classes/types of conservation practices that were implemented in the Difficult Run watershed for water years 2009 through 2014.

41. Median concentrations of select discrete water-quality constituents at the Smith Creek, Difficult Run, Chesterville Branch, and Conewago Creek streamgages 


\section{Conversion Factors}

Inch/Pound to International System of Units

\begin{tabular}{lcl}
\hline \multicolumn{1}{c}{ Multiply } & By & \multicolumn{1}{c}{ To obtain } \\
\hline inch (in.) & Length & \\
foot (ft) & 2.54 & centimeter $(\mathrm{cm})$ \\
mile (mi) & 0.3048 & meter $(\mathrm{m})$ \\
\hline & 1.609 & kilometer $(\mathrm{km})$ \\
\hline acre & Area & \\
square mile (mi $\left.{ }^{2}\right)$ & 0.004047 & square kilometer $\left(\mathrm{km}^{2}\right)$ \\
& 2.590 & square kilometer $\left(\mathrm{km}^{2}\right)$ \\
\hline gallon (gal) & Volume & \\
gallon (gal) & 3.785 & liter $(\mathrm{L})$ \\
gallon (gal) & 0.003785 & cubic meter $\left(\mathrm{m}^{3}\right)$ \\
\hline & 3.785 & cubic decimeter $\left(\mathrm{dm}^{3}\right)$ \\
\hline cubic foot per second $(\mathrm{ft} / \mathrm{s})$ & Flow rate & \\
million gallons per day (Mgal/d) & 0.02832 & cubic meter per second $\left(\mathrm{m}^{3} / \mathrm{s}\right)$ \\
\hline & 0.04381 & cubic meter per second $\left(\mathrm{m}^{3} / \mathrm{s}\right)$ \\
\hline pound, avoirdupois $(\mathrm{lb})$ & Mass & \\
ton, short (2,000 lb) & 0.4536 & kilogram $(\mathrm{kg})$ \\
ton per year (ton/yr) & 0.9072 & metric ton $(\mathrm{t})$ \\
\hline
\end{tabular}

International System of Units to Inch/Pound

\begin{tabular}{|c|c|c|}
\hline Multiply & By & $\begin{array}{c}\text { To } \\
\text { obtain }\end{array}$ \\
\hline \multicolumn{3}{|c|}{ Length } \\
\hline micrometer $(\mu \mathrm{m})$ & 0.00003937 & inch (in) \\
\hline \multicolumn{3}{|c|}{ Area } \\
\hline hectare (ha) & 2.471 & acre \\
\hline hectare (ha) & 0.003861 & square mile $\left(\mathrm{mi}^{2}\right)$ \\
\hline \multicolumn{3}{|c|}{ Mass } \\
\hline kilogram (kg) & 2.205 & pound avoirdupois (lb) \\
\hline \multicolumn{3}{|c|}{ Application rate } \\
\hline kilograms per hectare per year [(kg/ha)/yr] & 0.8921 & pounds per acre per year [(lb/acre $) / \mathrm{yr}]$ \\
\hline
\end{tabular}

Temperature in degrees Celsius $\left({ }^{\circ} \mathrm{C}\right)$ may be converted to degrees Fahrenheit $\left({ }^{\circ} \mathrm{F}\right)$ as ${ }^{\circ} \mathrm{F}=\left(1.8 \times{ }^{\circ} \mathrm{C}\right)+32$.

Temperature in degrees Fahrenheit $\left({ }^{\circ} \mathrm{F}\right)$ may be converted to degrees Celsius $\left({ }^{\circ} \mathrm{C}\right)$ as ${ }^{\circ} \mathrm{C}=\left({ }^{\circ} \mathrm{F}-32\right) / 1.8$.

Specific conductance is given in microsiemens per centimeter at 25 degrees Celsius $\left(\mu \mathrm{S} / \mathrm{cm}\right.$ at $\left.25^{\circ} \mathrm{C}\right)$.

Concentrations of chemical constituents in water are given in milligrams per liter $(\mathrm{mg} / \mathrm{L})$ or micrograms per liter $(\mu \mathrm{g} / \mathrm{L})$. 


\section{Datum}

Vertical coordinate information is referenced to the North American Vertical Datum of 1988

(NAVD 88).

Horizontal coordinate information is referenced to the North American Datum of 1983 (NAD 83).

\section{Abbreviations}

$\begin{array}{ll}\text { AMLE } & \text { adjusted maximum likelihood estimation } \\ \text { BFI } & \text { base-flow index } \\ \text { BMP } & \text { best management practice } \\ \text { C-0 } & \text { concentration-discharge } \\ \text { CEAP } & \text { Conservation Effects Assessment Project } \\ \text { CTA } & \text { Conservation Technical Assistance } \\ \text { DCLS } & \text { Division of Consolidated Laboratory Services } \\ \text { DO } & \text { dissolved oxygen } \\ \text { E. coli } & \text { Escherichia coli } \\ \text { EPA } & \text { U.S. Environmental Protection Agency } \\ \text { FNU } & \text { formazin nephelometric units } \\ \text { FSA } & \text { Farm Services Agency } \\ \text { LOADEST } & \text { load estimator } \\ \text { MACS } & \text { Maryland Agricultural Water Quality Cost-Share Program } \\ \text { MDE } & \text { Maryland Department of the Environment } \\ \text { N } & \text { nitrogen } \\ \text { NAWOA } & \text { National Water-Quality Assessment } \\ \text { NLCD } & \text { national land-cover dataset } \\ \text { NRCS } & \text { Natural Resources Conservation Service } \\ \text { O } & \text { oxygen } \\ \text { PADEP } & \text { Pennsylvania Department of Environmental Protection } \\ \text { PCA } & \text { principal components analysis } \\ \text { R2 } & \text { coefficient of determination } \\ \text { SEP } & \text { standard error of prediction } \\ \text { SPARROW } & \text { SPAtially Referenced Regressions on Watershed attributes } \\ \text { SSC } & \text { suspended-sediment concentration } \\ \text { TMDL } & \text { Total Maximum Daily Load } \\ \text { TN } & \text { total nitrogen } \\ \text { TP } & \text { total phosphorus } \\ \text { TSC } & \text { total sediment concentration } \\ \text { TSS } & \text { total suspended sediment } \\ \text { USDA } & \text { U.S. Department of Agriculture } \\ \text { USGS } & \text { U.S. Geological Survey } \\ \text { VADCR } & \text { Virginia Department of Conservation and Recreation } \\ \text { VADE0 } & \text { Virginia Department of Environmental Quality } \\ \text { VIF } & \text { variance inflation factor } \\ \text { VSMOW } & \text { Vienna Standard Mean Ocean Water } \\ \text { WRTDS } & \text { Weighted Regression on Time, Discharge, and Season } \\ & \end{array}$





\section{Spatial and Temporal Variation of Stream Chemistry Associated With Contrasting Geology and Land-Use Patterns in the Chesapeake Bay Watershed: Summary of Results from Smith Creek, Virginia; Upper Chester River, Maryland; Conewago Creek, Pennsylvania; and Difficult Run, Virginia, 2010-2013}

By Kenneth E. Hyer, Judith M. Denver, Michael J. Langland, James S. Webber, J.K. Böhlke, W. Dean Hively, and John W. Clune

\begin{abstract}
Despite widespread and ongoing implementation of conservation practices throughout the Chesapeake Bay watershed, water quality continues to be degraded by excess sediment and nutrient inputs. While the Chesapeake Bay Program has developed and maintains a large-scale and long-term monitoring network to detect improvements in water quality throughout the watershed, fewer resources have been allocated for monitoring smaller watersheds, even though water-quality improvements that may result from the implementation of conservation practices are likely to be first detected at smaller watershed scales.

In 2010, the U.S. Geological Survey partnered with the U.S. Environmental Protection Agency and the U.S. Department of Agriculture to initiate water-quality monitoring in four selected small watersheds that were targeted for increased implementation of conservation practices. Smith Creek watershed is an agricultural watershed in the Shenandoah Valley of Virginia that is dominated by cattle and poultry production, and the Upper Chester River watershed is an agricultural watershed on the Eastern Shore of Maryland that is dominated by row-cropping activities. The Conewago Creek watershed is an agricultural watershed in southeastern Pennsylvania that is characterized by mixed agricultural activities. The fourth watershed, Difficult Run, is a suburban watershed in northern Virginia that is dominated by medium density residential development. The objective of this study was to investigate spatial and temporal variations in water chemistry and suspended sediment in these four relatively small watersheds that represent a range of land-use patterns and underlying geology to (1) characterize current water-quality conditions in these watersheds, and (2) identify the dominant sources, sinks, and transport processes in each watershed.
\end{abstract}

The general study design involved two components. The first included intensive routine water-quality monitoring at an existing streamgage within each study area (including continuous water-quality monitoring as well as discrete water-quality sampling) to develop a detailed understanding of the temporal and hydrologic variability in stream chemistry and sediment transport in each watershed. The second component involved extensive water-quality monitoring at various sites throughout each watershed to develop a detailed understanding of spatial patterns. Both components were used to improve understanding of sources and transport processes affecting stream chemistry, including nutrients and suspended sediments, and their implications for detecting long-term trends related to best management practices. This report summarizes the results of monitoring that was performed from April 2010 through September 2013.

\section{Individual Small Watershed Summaries}

Summaries for each of the four small watersheds are presented below. Each watershed has a more descriptive and detailed section in the report, but these summaries may be particularly useful for some watershed managers and stakeholders desiring slightly less technical detail.

\section{Smith Creek}

Smith Creek is a $105.39-\mathrm{mi}^{2}$ watershed within the Shenandoah Valley that drains to the North Fork Shenandoah River. The long-term Smith Creek base-flow index is 72.3 percent, indicating that on average, approximately 72 percent of Smith Creek flow was base flow, which suggests that Smith Creek streamflow is dominated by groundwater discharge rather than stormwater runoff. A series of cluster and principal components analyses demonstrated that the 
majority of the variability in Smith Creek water quality could be attributed to hydrologic and seasonal variability. Statistically significant positive correlations with flow were observed for turbidity, suspended sediments, total nitrogen, ammonium, orthophosphate, iron, total phosphorus, and the ratio of calcium to magnesium. Statistically significant inverse correlations with flow were observed for specific conductance, magnesium, $\delta^{15} \mathrm{~N}$ of nitrate, $\mathrm{pH}$, bicarbonate, calcium, and $\delta^{18} \mathrm{O}$ of nitrate. Of particular note, flow and nitrate were not statistically significantly correlated, likely because of the relatively complex concentration-discharge relationship observed in continuous and discrete datasets. Statistically significant seasonal patterns were observed for numerous water-quality constituents: water temperature, turbidity, orthophosphate, total phosphorus, suspended-sediment concentration, and silica were higher during the warm season, but $\mathrm{pH}$, dissolved oxygen, and sulfate were higher during the cool season.

Surrogate regression models were developed to compute sediment and nutrient loads in Smith Creek using the continuous water-quality monitors. The mean Smith Creek in-stream sediment load was approximately 6,900 tons per year, with nearly 90 percent of the sediment load over the 3-year study period contributed during the eight largest storm events during that period. The Smith Creek total phosphorus load was approximately 21,000 pounds of phosphorus per year, with the majority of the load contributed during stormflow periods, although a substantial phosphorus load still occurs during base-flow conditions. The Smith Creek total nitrogen load was approximately 400,000 pounds per year, with total nitrogen accumulation less dominated by stormflow contributions (as was the case for sediment and total phosphorus) and strongly affected by base-flow export of nitrogen from the basin.

Extensive water-quality monitoring throughout the Smith Creek watershed revealed how the complex geology and hydrology interacted to result in variable water chemistry. During relatively dry and low base-flow periods, much of the discharge in Smith Creek was contributed by a single dominant spring - Lacey Spring. During wetter base-flow periods, the flows in Smith Creek were largely generated by a mixture of headwater springs and forested mountain tributaries with very different geochemical composition. The headwater springs generally issued from limestone bedrock and were characterized as having relatively high nitrate, specific conductance, calcium, and magnesium, as well as relatively low concentrations of phosphorus, ammonium, iron, and manganese. The undeveloped, high-gradient, forested mountain sites were generally characterized by low ionic strength waters with low nutrient concentrations. Nitrate isotope data from the limestone springs generally were consistent with manure-derived nitrogen sources (such as cattle and poultry), although the possibility of other mixed sources cannot be excluded. Nitrate isotope data from the undeveloped, highgradient forested mountain sites were more consistent with nitrogen from undisturbed soils, atmospheric deposition, or nitrogen fixation. Regardless of the nitrogen source, oxygen isotope data indicate that the nitrate was largely a result of nitrification. Land-use data indicate that manure sources of nitrogen dominated watershed nitrogen inputs. Phosphorus sources were less well studied. The presence of a single pointsource discharge near the town of New Market contributed the majority of the phosphorus to Smith Creek under base-flow conditions, but nonpoint sources of phosphorus dominated the loading to Smith Creek during stormflow periods.

Implementation of conservation practices increased in the Smith Creek watershed during the study period, and even though a broad range of practice types was implemented, the most common practices included stream fencing (for cattle exclusion), the development of nutrient management plans, conservation crop rotation, and the planting of cover crops. While the implementation of these conservation practices is encouraging, results indicate small increases in nitrate concentrations at the streamgage over the last 29 years, concurrent with small decreases in nitrate fluxes. It will likely be years before the cumulative effect of these practices can be detected in the Smith Creek water quality, and the magnitude of the effect of these conservation practices detected in Smith Creek will depend largely on whether nutrient loading (of manure and commercial fertilizer) is reduced over time.

\section{Upper Chester River}

The Upper Chester River watershed includes the 36-square-mile $\left(\mathrm{mi}^{2}\right)$ watershed area around several nontidal tributaries that drain into the tidal Chester River. The streamgage is on Chesterville Branch, the largest nontidal tributary (approximately $6.12 \mathrm{mi}^{2}$ ) and is the site for continuous water-quality monitoring for this project. The base-flow index at Chesterville Branch is about 72 percent and indicates that, as in most of the Coastal Plain, groundwater is the greatest contributor to streamflow. As such, more than 90 percent of the nitrogen in the stream is in the form of nitrate from groundwater. Continuous and discrete data collected at Chesterville Branch show the effects of streamflow and season on water quality. Significantly positive correlations with flow were observed for ammonium, dissolved and total phosphorus, sediment, and turbidity as runoff carried these constituents from the land surface into Chesterville Branch. Other constituents that increased significantly with flow include potassium, sulfate, iron, and manganese, which are likely contributed from near-stream areas and ponds with high organic-matter content. Total nitrogen, $\mathrm{pH}$, and specific conductance, along with chemical constituents associated with groundwater inputs including nitrate, calcium, ratio of calcium to magnesium, silica, bicarbonate, and sodium, were negatively correlated with flow because concentrations of these constituents were diluted by runoff.

Seasonal differences in water chemistry, which are most likely related to increased biologic effects on the uptake and release of chemicals in the stream and near-stream areas, also were observed. Water temperature, orthophosphate, $\delta^{15} \mathrm{~N}$ of nitrate, bicarbonate, sodium, and the ratio of sodium to chloride were higher during the warm season, and dissolved oxygen, total nitrogen, nitrate, magnesium, sulfate, and manganese were higher during the cool season. 
Surrogate-regression models developed by using continuous water-quality data showed that the annual sediment load for the 2013 water year was about 2,600 tons, with more than 90 percent of this sediment contributed during two storms. The total phosphorus load in 2013 was about 13,000 pounds with more than 90 percent contributed during the same two storms as sediment. The load of total nitrogen, 140,000 pounds, accumulated steadily throughout the 2013 water year as nitrate in groundwater continuously discharged into the stream. The same two large storms that contributed 90 percent of the suspended-sediment and total phosphorus load only contributed about 20 percent of the annual total nitrogen load.

Extensive water-quality monitoring of stream base flow throughout the Upper Chester River watershed identified how differences in land use and hydrogeology affected water chemistry. In parts of the watershed with well-drained soil and thick sandy aquifer sediments, concentrations of nitrate and other chemicals associated with fertilizer and lime application increased in streams as agricultural land use increased. More than 90 percent of the nitrogen in streams from these areas was in the form of nitrate, and concentrations ranged from about 5 milligrams per liter $(\mathrm{mg} / \mathrm{L})$ to $8 \mathrm{mg} / \mathrm{L}$ as nitrogen in the two largest tributaries. Stream nitrate concentrations were about $1 \mathrm{mg} / \mathrm{L}$ as nitrogen where soils were more poorly drained, the surficial aquifer sediments were thinner, and forests and wetlands were more widespread than agriculture. Nitrate isotope data were consistent with inorganic fertilizers \pm atmospheric deposition and $\mathrm{N}_{2}$ fixation as sources of nitrogen, and with nitrification as the dominant nitrate-forming process. Nitrate reduction was indicated by elevated $\delta^{15} \mathrm{~N}$ and $\delta^{18} \mathrm{O}$ values in some samples from streams draining watersheds with poorly drained soils. An analysis of land-use data and SPARROW modeling input data attributed almost 90 percent of the nitrogen sources in the Upper Chester River watershed to inorganic fertilizer and fixation of atmospheric nitrogen by legumes, which is in agreement with the isotopic characteristics of nitrate in this watershed. Local sources of manure are limited in this area. Total phosphorus concentrations during base flow ranged from below detection to about $0.2 \mathrm{mg} / \mathrm{L}$. Stream phosphorus concentrations during base flow were generally lower than those measured during storms because most phosphorus transport likely occurs as phosphorus attached to sediment particles during runoff. Because manure is not widely used in this area, the major source of phosphorus is likely fertilizer.

The implementation of conservation practices in the Upper Chester River watershed increased substantially during the study period, with a total implementation of 1,194 U.S. Department of Agriculture-compliant practices. The most frequently used practices were oriented towards nutrient and sediment control, including cover crops, nutrient management planning, conservation crop rotation, conservation tillage, and irrigation management. The current Chesapeake Bay model for this area predicts that implementation of best management practices should result in a 13-percent decrease in overall delivery of nitrogen to the Upper Chester River. Because most nitrogen travels through the groundwater system for years to decades before being discharged to streams, the time period of monitoring was not sufficient to see the effects of these practices on water quality. The magnitude of the effect that may eventually be detected will depend on the degree to which nitrate leaching into the groundwater system is reduced over time. Loadings of phosphorus and sediment are primarily transported during large runoff events and are difficult to control and analyze for trends because of their timing and episodic nature.

\section{Conewago Creek}

Conewago Creek has two primary monitoring locationsone near the middle of the $47-\mathrm{mi}^{2}$ watershed and the other near the outlet just upstream of the Susquehanna River. The base-flow index was 47.3 percent for 2012-2013, indicating that on average, approximately 53 percent of the streamflow in Conewago Creek exited the watershed as surface flow, which suggests that the stormwater runoff was somewhat greater than groundwater discharge (base flow). A series of cluster and principal components analyses demonstrated that the majority of the variability in the Conewago Creek water quality could be attributed to hydrologic and seasonal variability. Statistically significant positive correlations with flow were observed at both monitoring sites for ammonium, total phosphorus, orthophosphate, iron, and manganese; additionally, at the upstream monitoring station, total nitrogen demonstrated a statistically significant positive correlation with flow. Statistically significant inverse correlations with flow were observed at both sites for water temperature, specific conductance (at the downstream site only), sulfate, chloride, calcium, and magnesium. Statistically significant seasonal patterns were observed for several water-quality constituents. Water temperature, phosphorus (upstream site only), and orthophosphate were higher during the warm season, and nitrate and total nitrogen (upstream site only) were higher during the cool season.

Surrogate regression models were developed to compute sediment and nutrient load in Conewago Creek by using the continuous water-quality monitors and water-quality samples. Conewago Creek sediment load was approximately 9,900 tons in 2012 and approximately 18,900 tons in 2013, with nearly 80 percent of the sediment load in 2013 contributed by the three largest storm events. Annual total nitrogen loads could not be estimated due to poor model performance. The addition of continued monitoring or a continuously recording nitrate sensor could improve estimates of total nitrogen loads. During 2012 and 2013, phosphorus loads in Conewago Creek were approximately 50,000 pounds in each year.

Combining data from one high-flow synoptic sampling with the data from routine sampling revealed how the geology and hydrology interact to result in variable water chemistry throughout the Conewago Creek watershed. The areas above the upstream gage in the headwaters are generally underlain by forested non-carbonate bedrock and are characterized by relatively low nitrate, specific conductance, calcium, 
Spatial and Temporal Variation of Stream Chemistry, Chesapeake Bay Watershed

and magnesium, as well as relatively low concentrations of phosphorus, ammonium, iron, and manganese. The more developed, agricultural areas below the upstream site were generally characterized by higher ionic strength waters with higher nutrient and metal concentrations. An analysis of landuse data and SPAtially Referenced Regressions On Watershed (SPARROW) modeling data indicates that manure sources of nitrogen dominate the input of nitrogen to the watershed.

Implementation of conservation practices increased in the Conewago Creek watershed during the study period, and while a broad range of practice types were implemented, the most common practices included residue and tillage management, cover crops, nutrient management, terracing, and stream fencing (for animal exclusion or bank restoration). While the implementation of these conservation practices is encouraging, the cumulative effects of these practices probably will not be detected in Conewago Creek water quality for several years. The magnitude of the effects of these conservation practices on water quality in Conewago Creek will depend largely on the extent to which nutrient loading (septic, manure, and commercial fertilizer) and sediment-producing activities are reduced over time.

\section{Difficult Run}

The Difficult Run watershed is a $57.82-\mathrm{mi}^{2}$ watershed that drains to the Potomac River. The long-term Difficult Run base-flow index (from 1936 to 2010) was 57.9, indicating that approximately 58 percent of streamflow exited the watershed as base flow and 42 percent as stormflow; however, with continued development and urbanization of the watershed, the base-flow index has decreased to 50 percent during the last 20 years. This base-flow index was less than those of the other watersheds evaluated in this study, likely because the Difficult Run watershed largely is underlain by crystalline piedmont metamorphic rocks and has a greater proportion of impervious urban land cover. A series of cluster and principal components analyses indicated that most of the variability in Difficult Run water quality could be attributed to hydrologic variability and seasonality. Statistically significant positive correlations with flow were observed for turbidity, dissolved oxygen, suspended sediments, ammonium, orthophosphate, iron, and total phosphorus. Statistically significant inverse correlations with flow were observed for water temperature, $\mathrm{pH}$, specific conductance, bicarbonate, calcium, magnesium, nitrate, $\delta^{15} \mathrm{~N}$ of nitrate, and silica. Statistically significant seasonal patterns were observed for numerous water-quality constituents: water temperature, ammonium, orthophosphate, and $\delta^{15} \mathrm{~N}$ of nitrate were higher during the warm season, and dissolved oxygen, nitrate, and manganese were higher during the cool season. Surrogate regression models were developed to compute sediment and nutrient loading rates. The Difficult Run sediment load was approximately 8,000 tons per year, with greater than 95 percent of the sediment load in the 2013 water year contributed by the seven largest storm events. The total phosphorus load in Difficult Run was approximately 14,000 pounds of phosphorus per year, with the majority of the load contributed during stormflow periods. The total nitrogen load in Difficult Run is estimated to have been approximately 140,000 pounds per year, with total nitrogen accumulation less dominated by stormflow contributions than that of phosphorus and strongly affected by base-flow export of nitrogen from the basin.

Extensive water-quality monitoring throughout the Difficult Run watershed revealed relatively uniform generation of flow per unit of watershed area, as well as spatial variation in water quality that is strongly related to land-use activities. Elevated nitrate concentrations were observed in a subset of monitoring sites that are inversely correlated with population density and positively correlated to the septic system density within each subwatershed. The majority of the elevated nitrate concentrations for these sites are hypothesized to be caused by nitrate leaching from septic systems, more so than homeowner fertilizer usage among these subwatersheds that have lower population densities than other parts of the watershed. Nitrate isotope data, temporal patterns in the water-quality data, mass-balance computations, and a separate land-use analysis all generally indicate that leachate from septic systems was the likely source of the elevated nitrate. Another group of waterquality sites have relatively low nitrogen concentrations, are located in areas that are served by city sewer lines, and have experienced stream restoration activities. A final group of sites drained the areas with the highest imperviousness and had strongly elevated specific conductance, chloride, and sodium, which were likely caused by a combination of road salting and other anthropogenic sources draining these urbanized areas in the watershed. A fourth group of sites represents a mixture of water sources and had water quality similar to that at the Difficult Run streamgage. Analysis of the nitrate isotope data generally indicates a broad range of composition indicative of mixed natural and anthropogenic nitrogen sources. Implementation of conservation practices increased in the Difficult Run watershed during the study period, and while a broad range of practice types was implemented, the most common practices included stream restoration. While the implementation of these conservation practices is encouraging, the cumulative effect of these practices probably will not be detected in Difficult Run water quality for several years.

\section{Introduction}

Despite widespread and ongoing implementation of conservation practices, the Chesapeake Bay water quality continues to be degraded as a result of excess sediment and nutrient inputs (U.S. Environmental Protection Agency, 2010). Elevated sediment and nutrient inputs are responsible for a cascade of problems, including elevated algal densities, the burial of aquatic habitats, as well the creation of anoxic zones throughout the Bay itself - all of which generally result in less favorable conditions for aquatic life such as fish, crabs, and oysters (Kemp and others, 2005). To date, most reductions in nutrient loadings have been related to the implementation of 
point-source controls, while nonpoint-source controls have been less effective in agricultural communities and growing urban areas (Weller and others, 2010).

In May of 2009, Executive Order 13508 was issued for the Protection and Restoration of the Chesapeake Bay (Obama, 2009). Executive Order 13508 recognized the Bay as a National Treasure and announced a new era of Federal leadership in the restoration of the Chesapeake Bay. The Order established a Federal Leadership Committee to oversee the activities of the various Federal agencies that are involved in the restoration of the Bay. The Executive Order further directed the involved agencies to prepare a coordinated strategy for the restoration and protection of the Chesapeake Bay (Obama, 2009), including the development of annual action plans and progress reports. One important element of the coordinated strategy for the protection and restoration of the Chesapeake Bay watershed committed the U.S. Geological Survey (USGS), U.S. Department of Agriculture (USDA), and U.S. Environmental Protection Agency (EPA) to initiate enhanced monitoring of water-quality conditions in small agricultural and urban watersheds to help document the effectiveness of conservation practices and restoration activities (Federal Leadership Committee for the Chesapeake Bay, 2010).

Insufficient progress of the Bay and its tributaries towards meeting basic water-quality criteria, including clarity, submerged aquatic vegetation, and dissolved oxygen (DO), resulted in the EPA developing a Total Maximum Daily Load (TMDL) for the entire Chesapeake Bay watershed in 2010 (U.S. Environmental Protection Agency, 2010). A TMDL is a calculation of the maximum amount of pollution that a water body can receive and still meet water-quality standards. The TMDL is designed to reduce sediment and nutrient inputs to the Bay for improving water quality by identifying the necessary pollution reductions from the major nitrogen and phosphorus source sectors through the implementation of best management practices (BMPs) and other conservation efforts. The established TMDL calls for a 25-percent decrease in nitrogen loading, a 24-percent reduction in phosphorus, and a 20 -percent reduction in sediment loadings to the watershed from 2010 levels (U.S. Environmental Protection Agency, 2010). The assigned nutrient and sediment limits are subdivided by jurisdiction and major river basin, highlighting the need for extensive implementation of conservation practices throughout the watershed (U.S. Environmental Protection Agency, undated). The TMDL calls for the development of phased Watershed Implementation Plans, with 60 percent of all conservation practices to be installed in Phase I by 2017, and the remainder of the implementation activities to be completed by 2025. Phase II and Phase III Watershed Implementation Plans are expected to provide local targeted areas for implementation at smaller scales (U.S. Environmental Protection Agency, 2010); consequently, small-scale information regarding how water quality responds to focused implementation activities will be of great value in the development of these watershed improvement plans and the local decisionmaking related to the implementation of new conservation practices.
While the Chesapeake Bay Program has developed and maintains a large-scale and long-term monitoring network to detect improvements in water quality throughout the Bay watershed (Langland and others, 2012), few resources have been dedicated toward monitoring of smaller watersheds, even though the monitoring of smaller watersheds offers a number of distinct benefits for the detection of water-quality improvements that are related to the implementation of conservation practices. The benefits of monitoring at smaller watershed scales were described by a pair of recent Chesapeake Bay Program summary documents (Weller and others, 2010; National Research Council, 2011) to include the following:

- Intensive monitoring of smaller watersheds can be used to isolate different basin types (for example, agricultural without urban), while larger watersheds tend to represent mixtures of land-use types and sources.

- Within these relatively isolated land-use types, the specific sources of sediment and nutrients (manurederived nitrogen or commercial fertilizer-derived nitrogen) can be studied and potentially resolved in a more controlled setting.

- Intensive monitoring of smaller watersheds can be used to understand the transport processes that are responsible for routing sediment and nutrients into streams.

- Monitoring at smaller scales provides the best mechanism for directly measuring the water-quality response to BMP implementation.

- Monitoring at smaller spatial scales can provide vastly improved spatial resolution within a given basin that can reveal stream reaches or "hot spots" with disproportionately higher or lower nutrient and sediment contributions.

- Monitoring at smaller watershed scales provides a natural complement to edge-of-field studies which are generally performed at the plot scale and are effective at determining the efficacy of individual practices, while small watershed studies can document the cumulative effect of many practices that are distributed over a landscape.

- Monitoring results from these smaller scales can be critical for setting public expectations regarding the timescales of change (also known as time lags) and the magnitude of expected change in these and other watersheds.

Despite the benefits of these small watershed studies, they are not without challenges because small watershed studies can be rather expensive, data may be affected by extended timescales of response (depending on the system), and understanding generated at the smaller scale may not be immediately applicable to larger scales. Even so, small watershed studies represent a critical component of monitoring in the Chesapeake 
Bay watershed and are likely the type of monitoring that is best able to link the implementation of management actions to watershed-scale changes in water quality.

While anthropogenic activities, including intensive agriculture and urbanization, have long been known to adversely affect water quality and runoff dynamics (Paul and Meyer, 2001; Feminella and Walsh, 2005; Meyer and others, 2005; Mueller and Spahr, 2006), most studies have struggled to document water-quality improvements that are related to the effects of BMP implementation (Meals and others, 2010; Corsi and others, 2013). Working in small watersheds to understand nutrient and sediment sources and transport processes generally requires an interdisciplinary "toolbox" approach that uses various hydrologic, geochemical, and modeling approaches to understand the occurrence and transport of sediment and nutrients through these relatively complex small watersheds. Because of the inherent variability among watersheds, the particular response of a given watershed to management or development will depend heavily on the site-specific conditions within a given watershed, such as land use, watershed hydrology, lithology, the presence of wastewater treatment plants, and the design and age of existing stormwater and sewage infrastructure (Paul and Meyer, 2001). Detailed hydrologic analysis can be used to understand how urbanization and other changes to the landscape affect hydrologic conditions (Burton and Pitt, 2002; Walsh and others, 2009). A broad characterization of the major-ion water chemistry can be used to characterize differences between sites and to elucidate mixing patterns among water sources (Böhlke and Denver, 1995; Hyer and others, 2001; Denver and others, 2010; Clune and Denver, 2012). Nitrate isotopes (Heaton, 1986; Böhlke, 2003; Kendall and others, 2007), groundwater age dating (Plummer and others, 1993), and sediment fingerprinting techniques (Gellis and others, 2009) can be used to identify the sources of nitrogen and sediment within a stream system. In the study described herein, a complex suite of hydrologic and geochemical data were used to determine the sources and transport mechanisms of sediment and nutrients within differing watersheds.

In 2010, the USGS partnered with the EPA and USDA to initiate long-term water-quality monitoring in selected small watersheds that were targeted for increased implementation of conservation practices. The objective of this study was to investigate sediment and nutrient dynamics in four relatively small watersheds that are representative of a range of land-use patterns and underlying geology types to (1) characterize current water-quality conditions in these watersheds, (2) identify the dominant sources, sinks, and transport processes in each watershed, (3) provide guidance to stakeholders (USDA, the Natural Resources Conservation Service [NRCS], and local watershed groups) related to the implementation of conservation practices, and (4) document changes in water quality and relate those changes to the implementation of various water-quality improvement activities. By intensively monitoring water quality in four relatively common watershed types, observations and conditions encountered should be representative of regional patterns in the Chesapeake Bay watershed.

\section{Purpose and Scope}

This report provides an initial characterization of water quality in four intensively monitored small watersheds by presenting the water-quality data collected from 2010 through 2013. To the extent possible, the major sources, sinks, and transport processes for sediment and nutrients are identified in each watershed. A summary of the conservation practices that have been implemented in each watershed is provided, along with ideas of how future conservation practices can be targeted or optimized within these watersheds to potentially improve efficiency. Lastly, plans for future work to achieve the remaining project objectives are described.

This report also represents a contribution to the objectives of the USGS Chesapeake Bay Science Plan (Phillips and Blomquist, 2015) and a contribution to several of the integration questions contained therein, such as

- What are the relationships among land use, water quality, contaminants, and the health of fish and wildlife?

- How is the water quality of rivers and estuaries responding to restoration actions and changing land use?

- What are some of the best opportunities for management actions and monitoring approaches to benefit multiple restoration outcomes?

\section{Description of Study Watersheds}

The intensive water-quality study is ongoing at four small (less than 150-square-mile $\left[\mathrm{mi}^{2}\right]$ ) watersheds as part of Executive Order 13508 (fig. 1). Agricultural land use is dominant in three of these small watersheds, which are being studied in partnership with USDA and NRCS. The fourth watershed is being studied in partnership with Fairfax County, Virginia. These four study watersheds provide a range of land-use and geologic settings for study of sediment- and nutrient-transport processes. These watersheds also have a range of conservation practices being implemented for the improvement of water quality.

\section{The Smith Creek Watershed}

Smith Creek is a $105.39-\mathrm{mi}^{2}$ watershed within Shenandoah and Rockingham Counties, Virginia (fig. 2). The watershed is within the Shenandoah Valley and is part of the Valley and Ridge Physiographic Province (fig. 1). The Massanutten Mountain ridge transects the watershed north to south and is the division between the two predominant land uses: agriculture and forest. The predominant agricultural activities on the valley floor include extensive pastureland (41 percent of the watershed area) devoted to beef and dairy cattle production, poultry production, and, to a lesser extent, row cropping ( 3 percent of the watershed area). The relatively undeveloped eastern part of the watershed along the mountain slope is dominated by deciduous forests, with forests making 


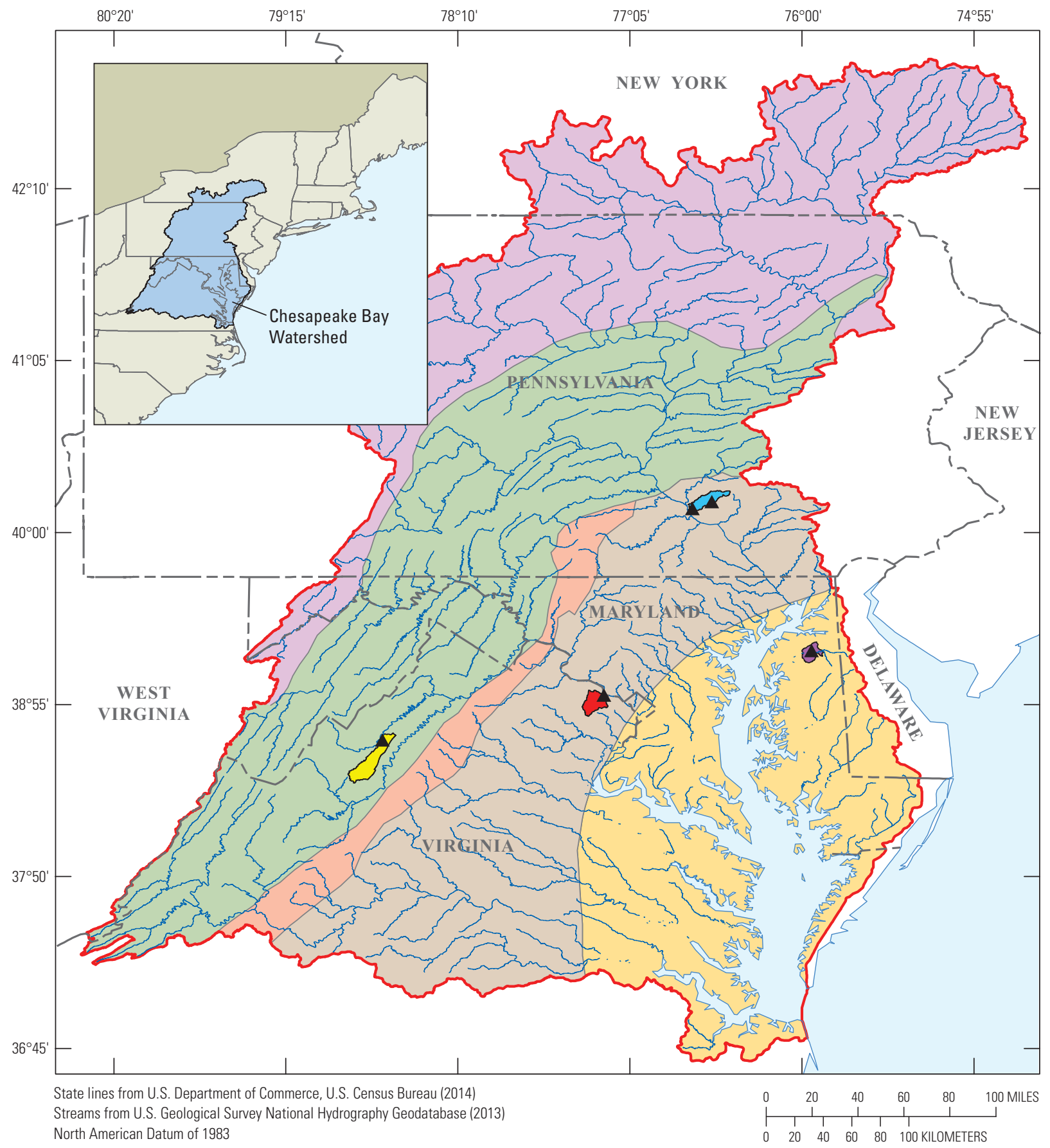

North American Datum of 1983

\section{EXPLANATION}

Physiographic Province (from Fenneman and Johnson, 1946)

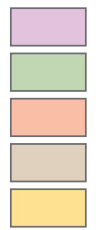

Appalachian Plateau

Valley and Ridge

Blue Ridge

Piedmont

Coastal Plain
Watershed boundaries

Smith Creek

Upper Chester River

Conewago Creek

Difficult Run

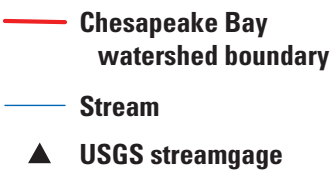

A USGS streamgage

Figure 1. Physiographic provinces and the location of the four study watersheds within the Chesapeake Bay watershed. 

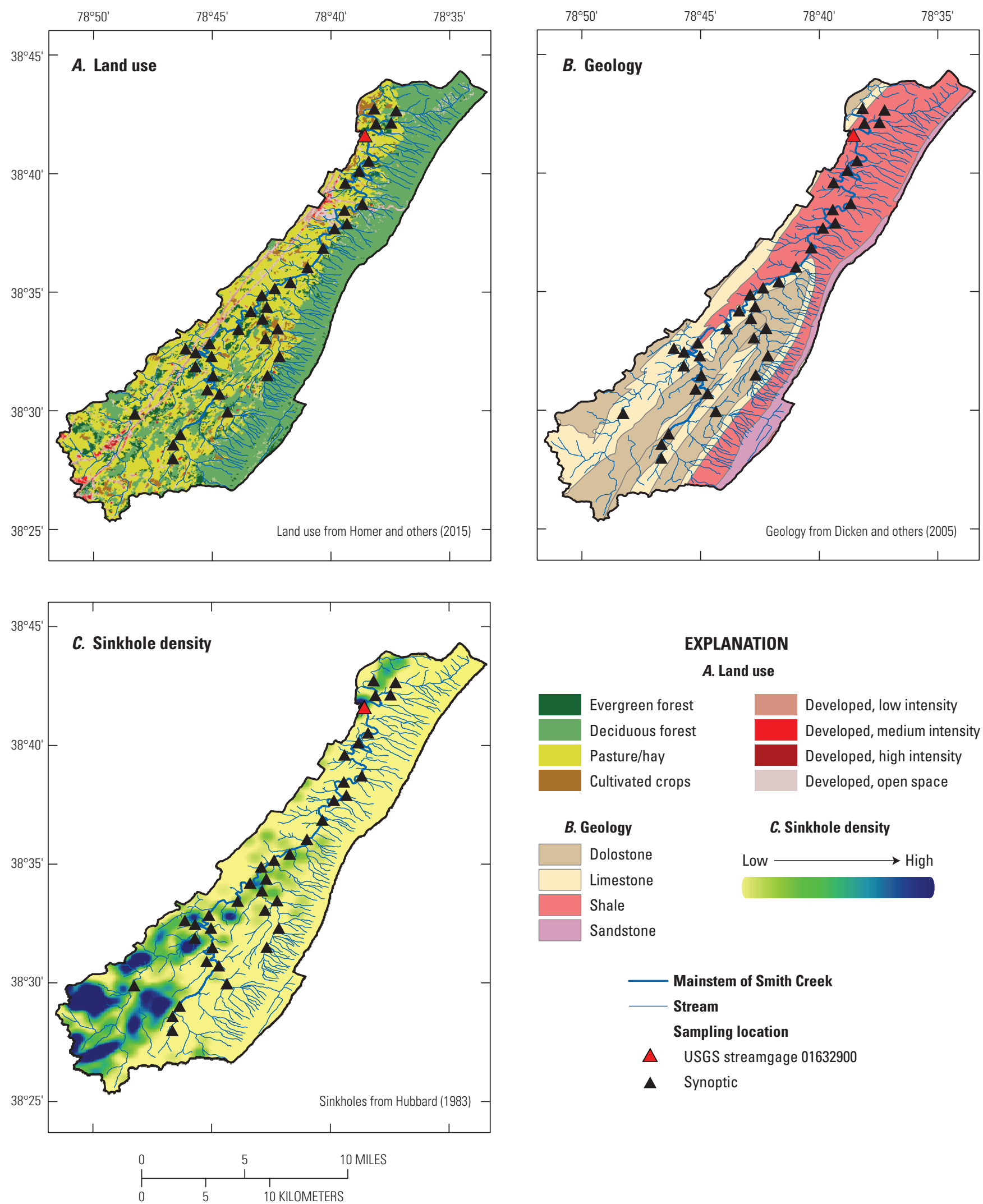

\section{EXPLANATION}

A. Land use

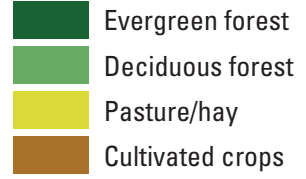

B. Geology

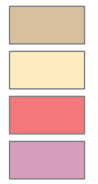
Dolostone Limestone
Shale Sandstone

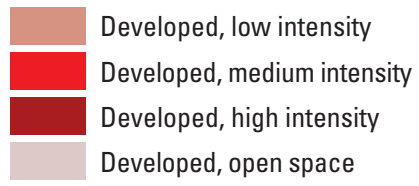

C. Sinkhole density

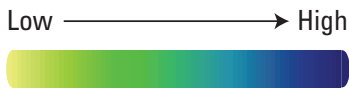

\section{_ Mainstem of Smith Creek Stream \\ Sampling location}

$\triangle \quad$ USGS streamgage 01632900

A Synoptic

Streams from U.S. Geological Survey National Hydrography Geodatabase (2013) Drainage area from Hayes and Wiegand (2006) North American Datum of 1983

Figure 2. Monitoring stations, $(A)$ land use, $(B)$ underlying geology, and $(C)$ sinkhole density in the Smith Creek watershed. 
up 48 percent of the watershed area. Approximately 90 percent of the land use within the Smith Creek watershed is represented by agriculture and forest, in relatively even proportions, and 6 percent is developed, primarily in the headwaters near Harrisonburg, Virginia.

Smith Creek is a third-order stream that flows south to north and is a tributary of the North Fork Shenandoah River. The headwaters display a typical dendritic pattern as a result of erosion of Middle Cambrian to Middle Ordovician carbonate rocks (a series of limestone and dolostone units including the Elbrook Dolomite, Conococheague Limestone, Beekmantown Group, New Market Limestone, Lincolnshire Limestone, Edinburg Formation, and the Stickley Run Member of Martinsburg Formation) that underlie the upper part of the watershed (fig. $2 B$ ). These carbonate rocks in the watershed are characterized by numerous headwater springs and sinkholes (fig. $2 C$ ). The lower part of the watershed is generally underlain by Middle to Late Ordovician Martinsburg Formation (primarily shale and secondarily sandstone). The very top of the mountains on the eastern edge of the watershed is underlain by the Silurian Massanutten Sandstone (Rader and Gathright, 2001a,b). Numerous zero- and first-order streams flow off the forested mountainside into Smith Creek in this lower section (fig. $2 B$ ).

Previous water-quality monitoring by the Virginia Department of Environmental Quality (VADEQ) revealed that sections of Smith Creek were in violation of State standards for bacteria and benthic macroinvertebrates. In response, a TMDL was established in 2004 for Escherichia coli (E. coli) and fecal coliform, and sediment was identified as a primary stressor to aquatic life (Virginia Department of Environmental Quality, 2014). The implementation of BMPs and waterquality monitoring increased in response to these listings, and the Smith Creek Partnership was formed to improve coordination and communication within the watershed. This partnership benefits from input by a number of State, local, and Federal agencies as well as citizen environmental groups. A detailed description of these TMDL listings, potential sources of pollutants, and various management activities is presented in the 2009 Smith Creek Watershed Implementation Plan (Virginia Tech Department of Biological Systems Engineering and University of Virginia Institute for Environmental Negotiation, 2009). The selection of Smith Creek as a Showcase Watershed within this study has contributed to the additional implementation of management practices and water-quality monitoring.

\section{The Upper Chester River Watershed}

The Upper Chester River watershed is a $36.54-\mathrm{mi}^{2}$ watershed located in the Coastal Plain on the Eastern Shore of the Chesapeake Bay in Maryland (fig. 1). The watershed is generally characterized as 64 percent agricultural land use with predominantly row-crop agriculture (54 percent of the watershed area) (fig. $3 A$ ). Subtle differences in the soils and topography on the northern and southern sides of the Upper Chester River manifest themselves in the land use. On the northern side of the river, topography is gently rolling, soils are well drained, and land use is mostly agricultural. In contrast, the southern part of the watershed has shallower stream incision and a smaller area of well-drained soils, resulting in a lesser amount of agricultural activity and a greater amount of forested, undeveloped land.

The Upper Chester River watershed includes the watershed area around several nontidal tributaries that drain into the tidal Chester River. The watershed is largely underlain by fine-grained sands and clays of the Calvert Formation of Miocene age or glauconitic sands of the Paleocene age Aquia Formation, which are, at the surface in many incised stream channels (fig. $3 B$ ). On the watershed uplands, deposits of gravel and sand of Quaternary age overly these formations and form a surficial unconfined aquifer that supplies most of the flow to local streams. The geologic configuration of the watershed affects transport of nitrate to streams. Where streams are underlain by sandy deposits, nitrate can be present at relatively high concentrations in discharging groundwater. In contrast, where streams are incised through the sandy deposits into finer grained sediments, nitrate in groundwater is more likely to be removed through denitrification prior to stream discharge.

The Upper Chester River watershed in this study is part of the larger area of the Upper Chester River regulated by the State of Maryland. The Maryland part of the Upper Chester River was listed as impaired by nutrients in 1996 by the Maryland Department of the Environment (MDE). TMDLs for nitrogen and phosphorus were later developed by the MDE and approved in 2006 by the EPA (Maryland Department of the Environment, 2006). Since that time, numerous BMPs have been implemented in this area. The designation of this watershed as a Showcase Watershed by NRCS in 2010 directed more resources to this area and increased implementation of practices intended to improve water quality in the Upper Chester River.

\section{The Conewago Creek Watershed}

Conewago Creek watershed is a $52.5-\mathrm{mi}^{2}$ agricultural watershed located in southeastern Pennsylvania (fig. 4A). Predominant agricultural activities include cattle production and row cropping. Approximately 43 percent of the watershed is forested, and 17 percent is developed. The basin is underlain by several different types of rock (fig. $4 B$ ). The watershed lies entirely in the Piedmont Physiographic Province (specifically the Gettysburg-Newark Lowland Section; fig. 1) and is underlain by red sandstone, mudstone, conglomerate, and thin beds of limestone of Triassic age that have been intruded by diabase of Jurassic age. The Gettysburg-Newark Lowland Section consists mainly of rolling low hills and valleys developed on red sedimentary rock deposited in a long, narrow inland basin. There are also isolated higher hills (forming the eastern and southern watershed boundaries) that are developed on diabase and conglomerates. A horseshoe-shaped diabase sill extends through the upper and middle part of the watershed and forms its southern boundary (fig. 4B).

The basic drainage pattern is dendritic (fig. 4). Soils are usually red and often have a striking contrast to the green vegetation. Relief is generally on the order of 


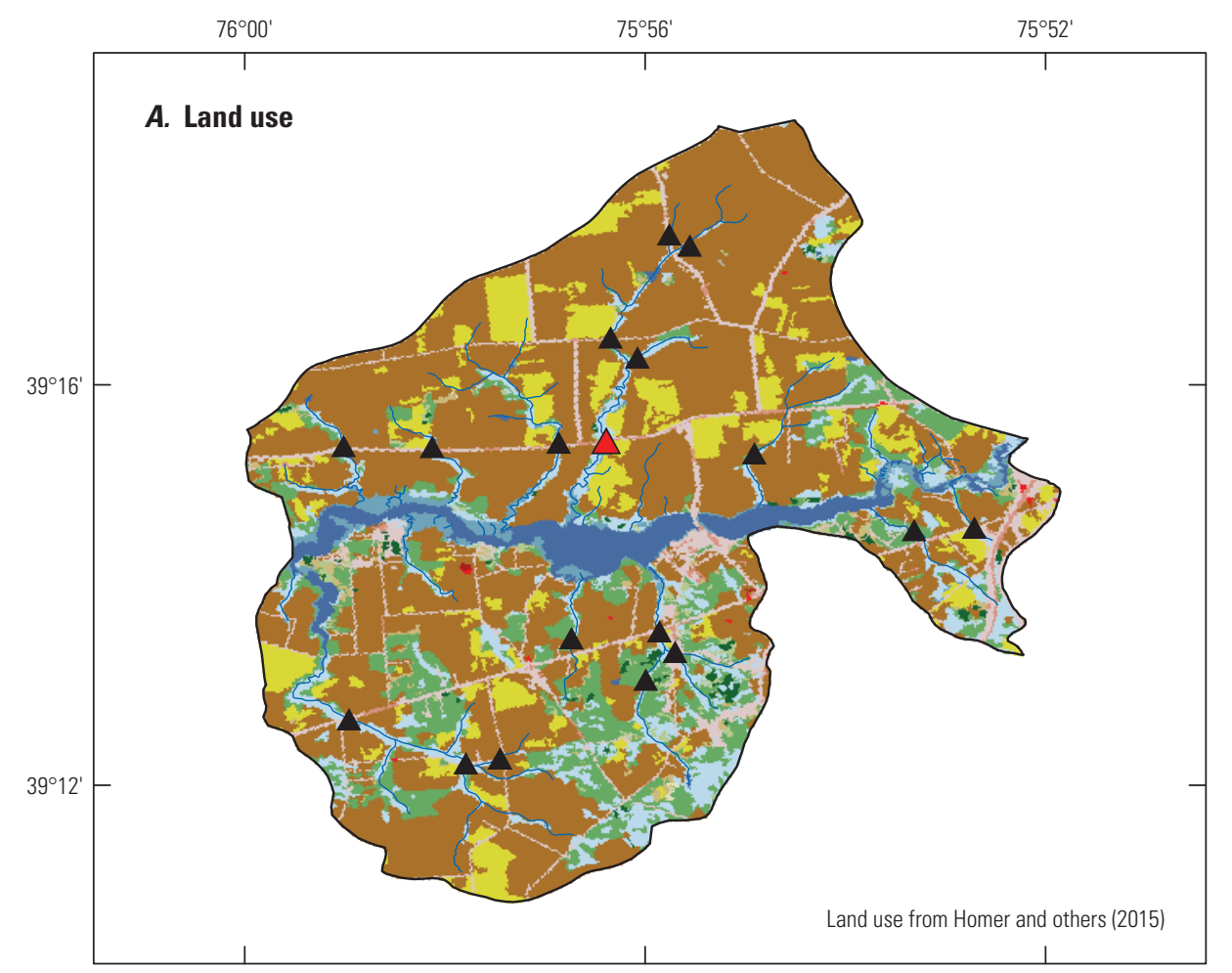

\section{EXPLANATION \\ Stream \\ Sampling location \\ $\triangle \quad$ USGS streamgage 01493112 \\ A Synoptic}

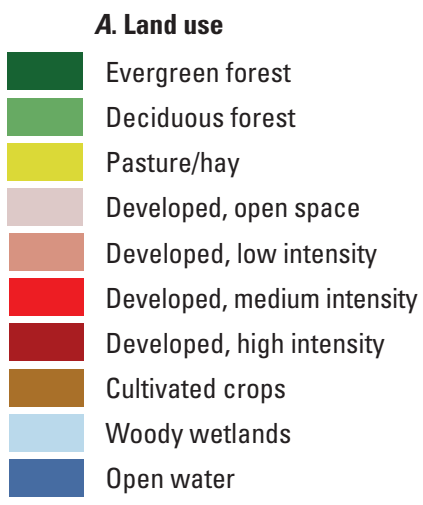

\section{B. Geology}

Lowland deposits-Gravel, sand, silt, and clay

Upland deposits-Cross-bedded, poorly sorted, medium- to coarse-grained white to red sand and gravel

Aquia Formation-Dark green to gray-green, argillaceous, highly glauconitic, well sorted fine- to medium-grained sand; locally indurated shell beds

Calvert Formation - Interbedded dark green to dark bluish-gray, fine-grained argillaceous sand and sandy clay

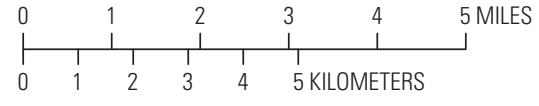

Streams from U.S. Geological Survey National Hydrography Geodatabase (2013)

Drainage area from U.S. Department of Agriculture, Natural Resources Conservation Service unpub. data for HUC 020600020605, 2005

North American Datum of 1983

Figure 3. Monitoring stations, $(A)$ land use, and $(B)$ underlying geology in the Upper Chester River watershed. 


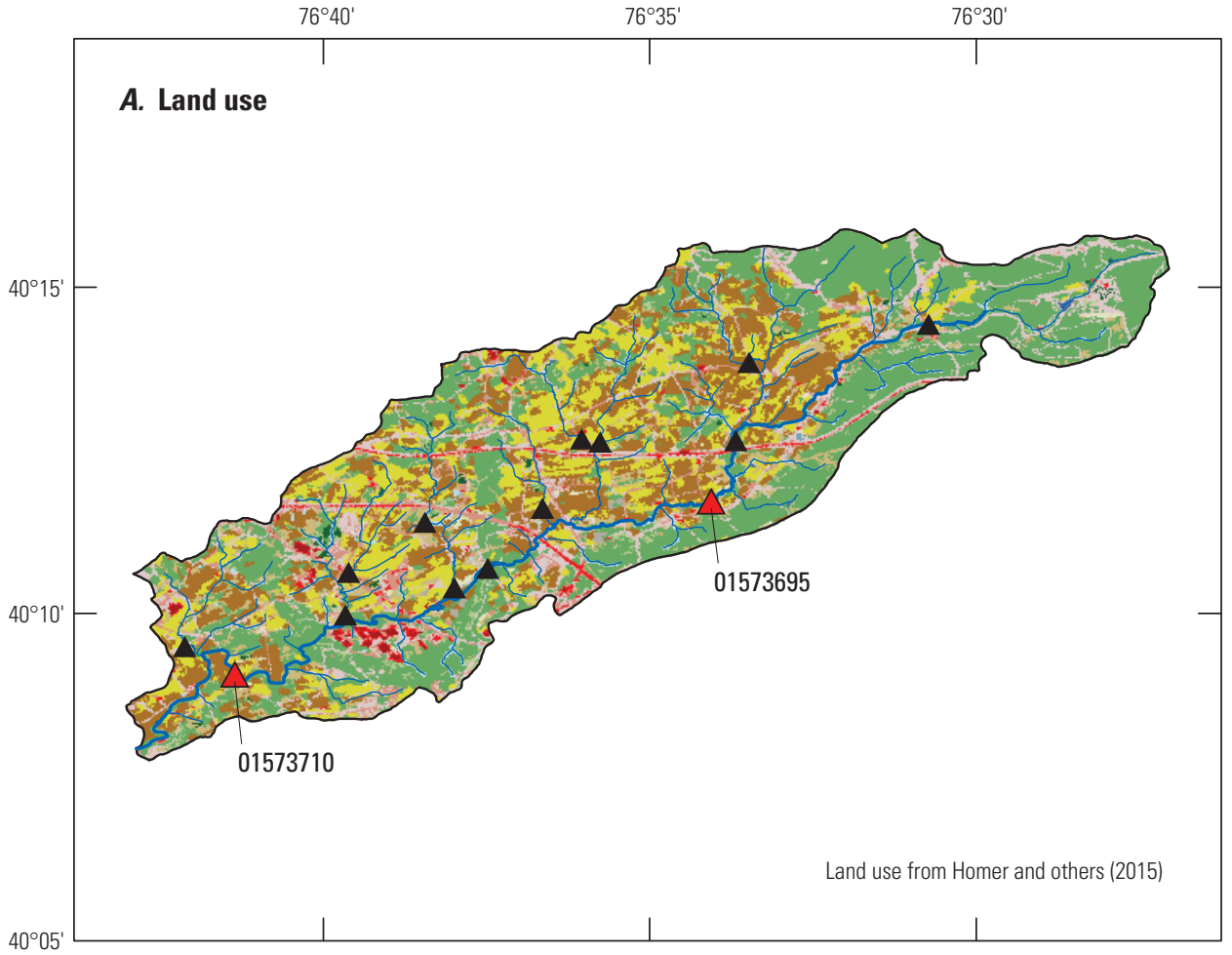

\section{EXPLANATION}

$\begin{array}{ll} & \text { Mainstem of Conewago Creek } \\ & \text { Stream } \\ & \text { Sampling location } \\ \triangle \quad & \text { USGS streamgage and number } \\ \Delta \quad & \text { Synoptic }\end{array}$

A. Land use

Evergreen forest

Deciduous forest

Pasture/hay

Developed, open space

Developed, low intensity

Developed, medium intensity

Developed, high intensity

Cultivated crops

Woody wetlands

Open water

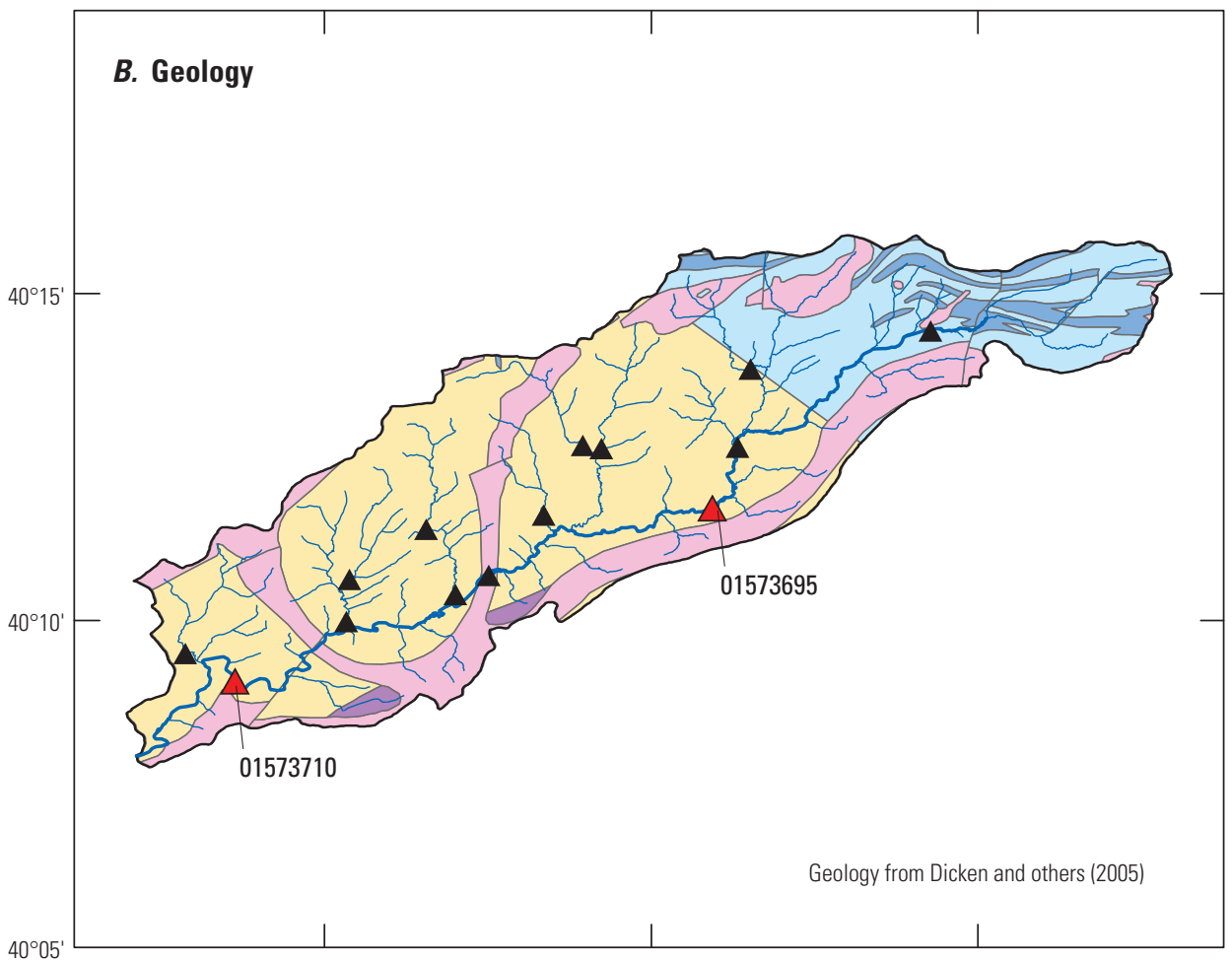

\section{B. Geology}

Diabase

Mudstone

Arkose

Sandstone

Conglomerate

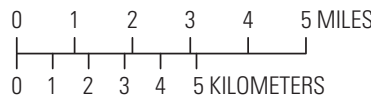

Streams from U.S. Geological Survey National Hydrography Geodatabase (2013)

Drainage area from U.S. Geological Survey StreamStats program (2012b)

North American Datum of 1983

Figure 4. Monitoring stations, $(A)$ land use, and $(B)$ underlying geology in the Conewago Creek watershed. 
100 to 200 feet (ft), but locally is up to $600 \mathrm{ft}$ on some of the isolated hills. Elevations in the Conewago Creek watershed range from approximately 300 to $1,120 \mathrm{ft}$.

Approximately 40 percent of the entire stream length is listed as impaired, with sediment being primarily responsible for the impairment (Pennsylvania State University Environmental Resources Research Institute, 2001). Approximately two-thirds of the mainstem Conewago Creek is impaired. Three tributaries, Lynch Run and two unnamed tributaries, are 100 percent impaired. A fourth tributary, Hoffer Creek, is approximately 50 percent impaired. Siltation is the leading impairment and likely resulted from the migration and erosion of soil from higher slopes after lands were cleared of forest for farming activities, mainly growing of crops, in the mid-1800s to early 1900s. Land stewardship was minimal, which helped to create more slope erosion. As a result of past anthropogenic actions, including the building of milldams, streams in many areas of Piedmont, including Conewago Creek, are elevated, entrenched streams with steep, erodible banks. Compounding the problem is that the majority of the streambank sediments are cohesive silts and clays, and in agricultural areas, these soils can be enriched with nutrients.

\section{The Difficult Run Watershed}

The Difficult Run watershed is a $57.82-\mathrm{mi}^{2}$ watershed in the Piedmont Physiographic Province (figs. 5 and 1). Difficult Run is the largest watershed within Fairfax County, which is part of the Washington, D.C., metropolitan area and is the most populous jurisdiction in Virginia (U.S. Census Bureau, 2013). Historically, this region was heavily used for row-crop agricultural activities and pastureland until intense urbanization began in the 1960s. Residential land use now accounts for more than 57 percent of watershed area, and much of this development is alongside the Difficult Run stream channel (Fairfax County Stormwater Planning Division, 2007) (fig. 5). Commercial land use makes up 9 percent of the watershed and is generally accounted for by three main urban areas-Reston to the northwest, the city of Fairfax to the south, and Tysons Corner to the east (Fairfax County Stormwater Planning Division, 2007). Scattered pockets of open area make up 20 percent of additional land use and are typically found near the stream valleys that are preserved by the Fairfax County Park Authority (Fairfax County Stormwater Planning Division, 2007).

Difficult Run is a fourth-order stream that flows northeast for 39 stream miles to the Potomac River. First- and secondorder tributaries join the mainstem of Difficult Run and contribute 106 stream miles that are predominantly pool-riffle flow regimes with gravel and cobble substrates (Fairfax County Stormwater Planning Division, 2007). The majority of the watershed is underlain by schist and meta-argillite of the Late Proterozoic to Early Cambrian Mather Gorge Formation, with minor contributions from numerous metamorphic and sedimentary rock formations (fig. 5B). Four major impoundments are located throughout the watershed: Lake Anne, Lake Fairfax, Lake Thoreau, and Lake Audubon.
The VADEQ and the Fairfax County Health Department have monitored water quality throughout the watershed for several years. This work revealed impairments that placed sections of Difficult Run on the 303(d) list for benthic aquatic communities and fecal coliform bacteria (Virginia Department of Environmental Quality, 2014). These impairments, as well as a detailed description of ongoing work and management plans are presented in the Difficult Run Watershed Management Plan that was developed by Fairfax County in 2007. The watershed has been the focus for understanding nutrient and sediment dynamics within an urban setting for many USGS scientists, and monitoring has continued to increase as part of this study (Hupp and others, 2013; Noe and others, 2013; Schenk and others, 2013; Jastram, 2014).

\section{Study Approach and Methods}

Described below is the study design for the small watershed study, including the methods used for the collection and analysis of samples, as well as the statistical analysis and interpretation. A wide range of monitoring and analysis tools were used throughout the study; however, slight study design differences were necessary for some sites for a number of reasons that involved site constraints, research questions, available funding, and water-quality constituents of interest.

\section{General Study Design}

The small watershed study design is based on two fundamental study components:

- Intensive monitoring at the streamgage within each study area to develop a detailed understanding of the temporal and hydrologic variability in nutrient and sediment transport in each watershed. These intensive data also provide substantial understanding of the nutrient and sediment transport processes operating within each study watershed. The Smith Creek, Upper Chester River, and Difficult Run watersheds each had a single intensively instrumented site, but the Conewago Creek watershed had two intensively monitored sites (table 1).

- Extensive monitoring at various sites throughout the watershed to develop a detailed understanding of the spatial patterns in sediment and nutrient transport throughout the watershed. These extensive data also provide an enhanced understanding of the nutrient and sediment sources and transport processes within each watershed. The extensive data collection efforts generally involved segregating each watershed into 15 to 40 roughly evenly spaced stream and tributary reaches that could be sampled within 1 to 2 days to provide a "synoptic snapshot" of the water-quality conditions over a period of relatively uniform flow conditions. 


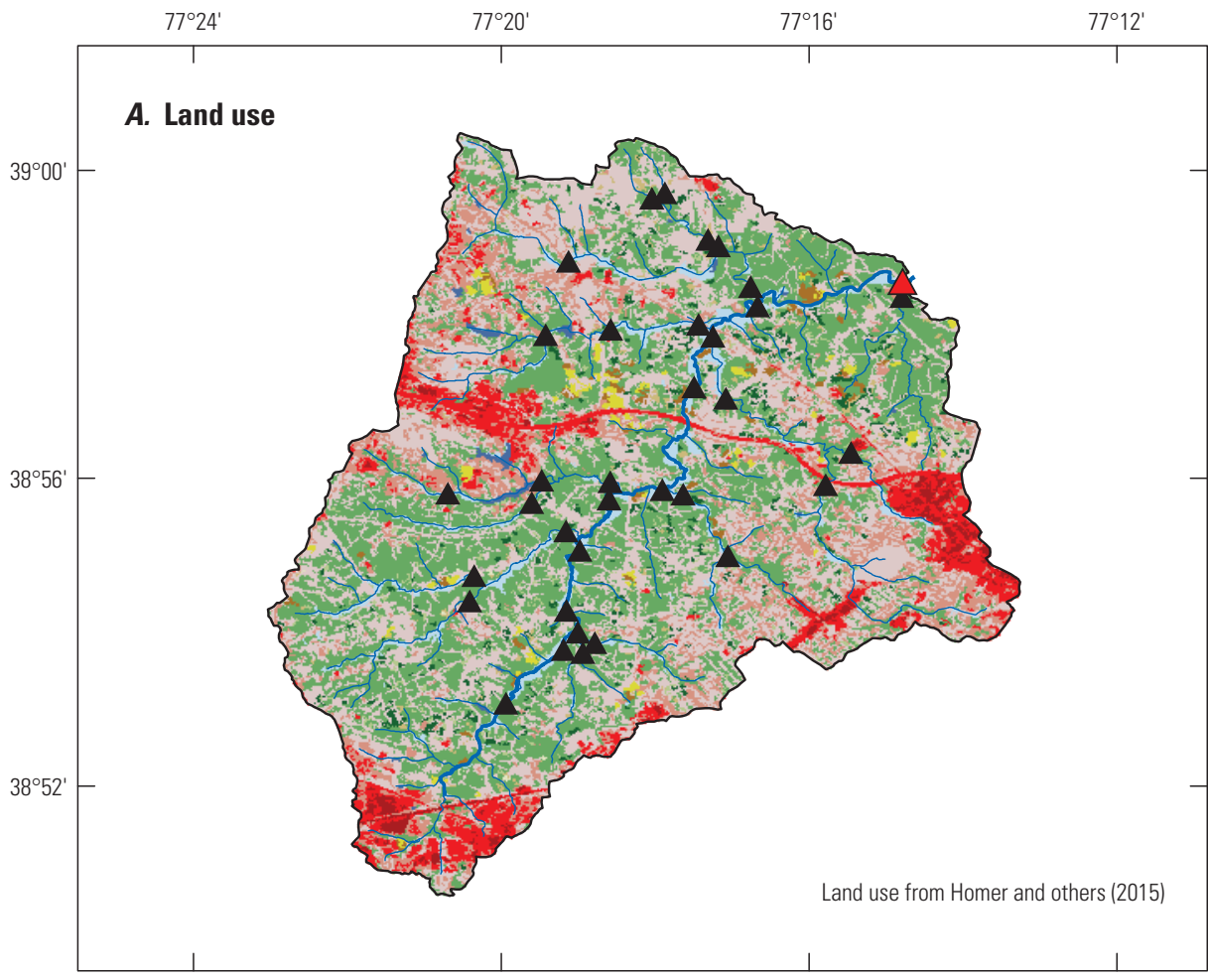

\section{EXPLANATION \\ — Mainstem of Difficult Run \\ Stream \\ Sampling location \\ $\triangle \quad$ USGS streamgage 01646000 \\ A Synoptic}

\begin{tabular}{|l}
\hline A. Land use \\
\hline Evergreen forest \\
\hline Deciduous forest \\
\hline Pasture/hay \\
\hline Developed, open space \\
\hline Developed, low intensity \\
\hline Developed, medium intensity \\
\hline Developed, high intensity \\
\hline Cultivated crops \\
\hline Woody wetlands \\
\hline Open water
\end{tabular}

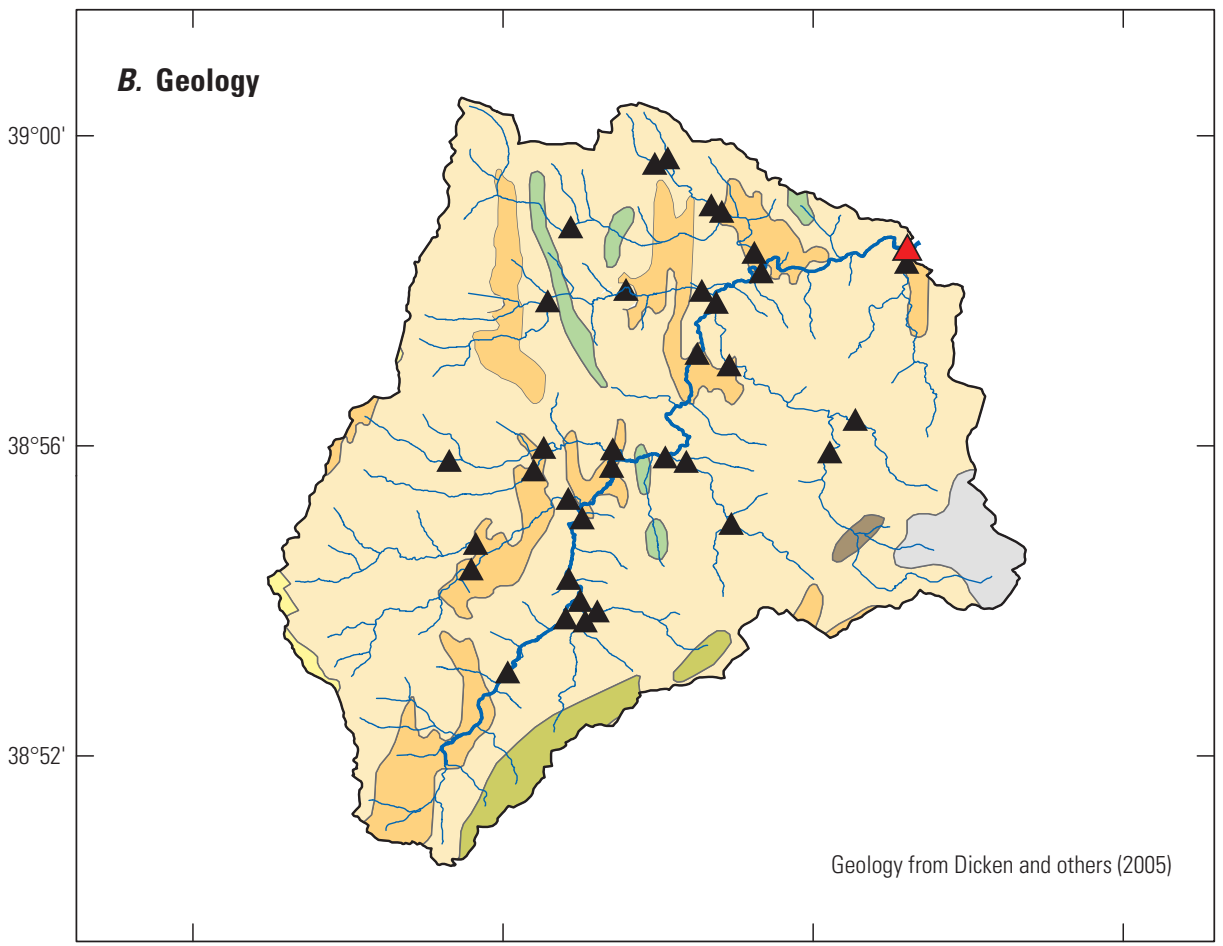

\section{B. Geology}

Conglomerate Schist

Meta-argillite

Gravel

Granodiorite

Ultramafatite

Mafic gneiss

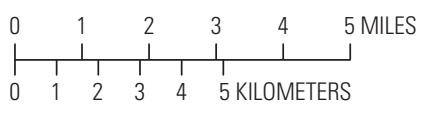

Streams from U.S. Geological Survey National Hydrography Geodatabase (2013) Drainage area from Hayes and Wiegand (2006)

North American Datum of 1983

Figure 5. Monitoring stations, $(A)$ land use, and $(B)$ underlying geology in the Difficult Run watershed. 


\section{Data Collection}

Standard USGS methods were used for the collection of water-quality data. The following section describes data collection efforts for the study, including discrete water-quality sampling and laboratory analysis procedures, as well as the methods used to operate the continuous waterquality monitors.

\section{Collection of Discrete Water-Quality Samples}

Collection of discrete water-quality samples was completed following standard USGS methods (U.S. Geological Survey, variously dated). Discrete water-quality samples were collected on one predetermined date each month (routine samples) and during eight targeted hydrologic conditions

Table 1. Watershed names, watershed areas, and streamgage station IDs and names.

[USGS, U.S. Geological Survey; $\mathrm{mi}^{2}$, square mile]

\begin{tabular}{lccc}
\hline \multicolumn{1}{c}{ Watershed } & $\begin{array}{c}\text { Watershed } \\
\text { area }\left(\mathbf{m i}^{2}\right)\end{array}$ & $\begin{array}{c}\text { USGS } \\
\text { station } \\
\text { ID }\end{array}$ & $\begin{array}{c}\text { USGS } \\
\text { streamgage } \\
\text { name }\end{array}$ \\
\hline Smith Creek & 105.39 & 01632900 & $\begin{array}{c}\text { Smith Creek near New } \\
\text { Market, VA }\end{array}$ \\
Difficult Run & 57.82 & 01646000 & $\begin{array}{c}\text { Difficult Run near } \\
\text { Great Falls, VA } \\
\text { Upper Chester River }\end{array}$ \\
Conewago Creek & 52.53 & 01573695 & $\begin{array}{c}\text { Conerville Branch } \\
\text { near Crumpton, MD } \\
\text { near Bellaire, PA }\end{array}$ \\
& & 01573710 & $\begin{array}{c}\text { Conewago Creek } \\
\text { near Falmouth, PA }\end{array}$ \\
\hline
\end{tabular}

(storm samples, periods of elevated discharge) from each streamgage (table 2). Water-quality samples were collected by using width- and depth-integrated sampling procedures. Width integration was accomplished by dividing the stream into equally spaced intervals (usually 5 or 10). Depth integration was accomplished by using isokinetic samplers during appropriate conditions.

Extensive synoptic sample collection was performed four times at various sites within the Smith Creek, Difficult Run, and Upper Chester River watersheds during low-flow hydrologic conditions (table 2). Synoptic sampling locations were selected to characterize the spatial differences within each basin. Width- and depth-integrated sampling methods were followed at all but the smallest streams where a grab sampling approach was used. An instantaneous discharge measurement was paired with these discrete water-quality measurements. All discharge measurements were made using hand-held acoustic doppler velocity profilers, following the mid-section method described by Turnipseed and Sauer (2010) in accordance with USGS procedures.

Collection of field blanks and sequential replicates was built into all discrete-sampling activities to estimate contamination bias and variability in the data (table 3 ). Most field blank concentrations were below the laboratory detection limits, indicating that no contamination issues were caused by sample collection, processing, or analysis. All detectable field blank concentrations were insignificant compared to sampled values. Variability between replicate pairs generally was low, particularly for major ions and nutrients.

\section{Laboratory Analysis of Water-Quality Samples}

Discrete water-quality samples were analyzed by a number of different laboratories for a range of nutrients, cations, anions, trace elements, and isotopes (tables 4, 5, and 6). All samples were immediately processed and preserved

Table 2. Dates of continuous water-quality monitoring and sample-collection activities.

[-, activity did not occur]

\begin{tabular}{|c|c|c|c|c|c|c|c|c|}
\hline \multirow{2}{*}{$\begin{array}{c}\text { Watershed } \\
\text { Smith Creek }\end{array}$} & \multirow{2}{*}{$\begin{array}{c}\begin{array}{c}\text { Streamgage station } \\
\text { name }\end{array} \\
\begin{array}{c}\text { Smith Creek near New } \\
\text { Market, VA }\end{array}\end{array}$} & \multirow{2}{*}{$\begin{array}{c}\begin{array}{c}\text { Monthly and } \\
\text { storm sample } \\
\text { collection }^{1}\end{array} \\
\text { April } \\
2010\end{array}$} & \multicolumn{4}{|c|}{ Extensive synoptic sample collection ${ }^{2}$} & \multirow{2}{*}{$\begin{array}{c}\begin{array}{c}\text { Collection of } \\
\text { continuous }\end{array} \\
\begin{array}{c}\text { water-quality } \\
\text { data }^{1}\end{array} \\
\text { April } \\
2010\end{array}$} & \multirow{2}{*}{$\begin{array}{c}\text { Collection of } \\
\text { continuous } \\
\text { nitrate data }\end{array}$} \\
\hline & & & $\begin{array}{l}\text { August } \\
2011\end{array}$ & $\begin{array}{l}\text { December } \\
2012\end{array}$ & $\begin{array}{l}\text { May } \\
2012\end{array}$ & $\begin{array}{l}\text { April } \\
2013\end{array}$ & & \\
\hline Difficult Run & $\begin{array}{l}\text { Difficult Run near } \\
\text { Great Falls, VA }\end{array}$ & $\begin{array}{l}\text { July } \\
2011\end{array}$ & $\begin{array}{l}\text { September } \\
2011\end{array}$ & $\begin{array}{l}\text { December } \\
2012\end{array}$ & $\begin{array}{l}\text { April } \\
2012\end{array}$ & $\begin{array}{l}\text { May } \\
2013\end{array}$ & $\begin{array}{l}\text { October } \\
2012\end{array}$ & $\begin{array}{l}\text { October } \\
2012\end{array}$ \\
\hline $\begin{array}{l}\text { Upper Ches- } \\
\text { ter River }\end{array}$ & $\begin{array}{l}\text { Chesterville Branch } \\
\text { near Crumpton, MD }\end{array}$ & $\begin{array}{l}\text { July } \\
2011\end{array}$ & $\begin{array}{l}\text { July } \\
2011\end{array}$ & $\begin{array}{l}\text { December } \\
2012\end{array}$ & $\begin{array}{l}\text { May } \\
2012\end{array}$ & $\begin{array}{l}\text { April } \\
2013\end{array}$ & $\begin{array}{l}\text { June } \\
2012\end{array}$ & $\begin{array}{l}\text { July } \\
2012\end{array}$ \\
\hline $\begin{array}{l}\text { Conewago } \\
\text { Creek }\end{array}$ & $\begin{array}{l}\text { Conewago Creek near } \\
\text { Bellaire, PA }\end{array}$ & $\begin{array}{l}\text { May } \\
2011\end{array}$ & - & - & $\begin{array}{l}\text { May } \\
2012\end{array}$ & - & $\begin{array}{c}\text { January } \\
2012\end{array}$ & - \\
\hline & $\begin{array}{l}\text { Conewago Creek near } \\
\text { Falmouth, PA }\end{array}$ & $\begin{array}{c}\text { October } \\
2011\end{array}$ & - & - & $\begin{array}{l}\text { May } \\
2012\end{array}$ & - & $\begin{array}{l}\text { June } \\
2011\end{array}$ & - \\
\hline
\end{tabular}

${ }^{1}$ Date activity began.

${ }^{2}$ Date of each sample-collection event. 
Table 3. Analysis of replicate and blank discrete water-quality data.

[USGS, U.S. Geological Survey; $\mathrm{B}_{\mathrm{N}}$, number of field blanks; $\mathrm{B}_{\mathrm{ND}}$, number of blanks that were above the laboratory detection limit; $\mathrm{B}_{\mathrm{MAX}}$, maximum reported concentration in field blanks; $\mathrm{R}_{\mathrm{N}}$, number of replicates; $\mathrm{R}_{\mathrm{UNC}}$, estimated uncertainty in reported concentrations, in percent; $\mathrm{mg} / \mathrm{L}$, milligram per liter; $\mu \mathrm{g} / \mathrm{L}$, microgram per liter; —, value does not exist]

\begin{tabular}{|c|c|c|c|c|c|c|c|}
\hline \multirow{2}{*}{ Constituent } & \multirow{2}{*}{$\begin{array}{l}\text { USGS } \\
\text { parameter } \\
\text { code }\end{array}$} & \multirow{2}{*}{$\begin{array}{l}\text { Report- } \\
\text { ing } \\
\text { units }\end{array}$} & \multicolumn{3}{|c|}{$\begin{array}{c}\text { Contamination } \\
\text { bias }\end{array}$} & \multicolumn{2}{|c|}{$\begin{array}{c}\text { Analytical } \\
\text { uncertainty }\end{array}$} \\
\hline & & & $B_{N}$ & $B_{\mathrm{ND}}$ & $\mathbf{B}_{\text {MAX }}$ & $\mathbf{R}_{\mathrm{N}}$ & $\mathbf{R}_{\mathrm{UNC}}{ }^{1}$ \\
\hline \multirow[t]{2}{*}{ Calcium } & 00915 & $\mathrm{mg} / \mathrm{L}$ & 14 & 3 & 0.03 & 16 & 0.79 \\
\hline & 00916 & $\mathrm{mg} / \mathrm{L}$ & 1 & 0 & - & 3 & 0.90 \\
\hline \multirow[t]{2}{*}{ Magnesium } & 00925 & $\mathrm{mg} / \mathrm{L}$ & 14 & 0 & - & 16 & 0.46 \\
\hline & 00927 & $\mathrm{mg} / \mathrm{L}$ & 1 & 0 & - & 3 & 0.87 \\
\hline Sodium & 00930 & $\mathrm{mg} / \mathrm{L}$ & 14 & 1 & 0.069 & 16 & 0.89 \\
\hline Potassium & 00935 & $\mathrm{mg} / \mathrm{L}$ & 14 & 0 & - & 16 & 1.17 \\
\hline Bicarbonate & 00453 & $\mathrm{mg} / \mathrm{L}$ & 1 & 1 & 4.2 & 15 & 1.75 \\
\hline Sulfate & 00945 & $\mathrm{mg} / \mathrm{L}$ & 15 & 0 & - & 19 & 0.42 \\
\hline Chloride & 00940 & $\mathrm{mg} / \mathrm{L}$ & 15 & 0 & - & 19 & 0.19 \\
\hline Nitrate-N & 00631 & $\mathrm{mg} / \mathrm{L}$ & 22 & 3 & 0.021 & 37 & 0.56 \\
\hline Total nitrogen & 00600 & $\mathrm{mg} / \mathrm{L}$ & 8 & 0 & - & 15 & 0.82 \\
\hline Ammonium & 00608 & $\mathrm{mg} / \mathrm{L}$ & 22 & 6 & 0.04 & 26 & 3.11 \\
\hline Orthophosphate & 00671 & $\mathrm{mg} / \mathrm{L}$ & 22 & 3 & 0 & 28 & 1.41 \\
\hline Total phosphorus & 00665 & $\mathrm{mg} / \mathrm{L}$ & 22 & 4 & 0.01 & 32 & 1.59 \\
\hline \multirow[t]{2}{*}{ Iron } & 01046 & $\mu \mathrm{g} / \mathrm{L}$ & 14 & 1 & 3.419 & 16 & 3.73 \\
\hline & 01045 & $\mu \mathrm{g} / \mathrm{L}$ & 1 & 0 & - & 3 & 7.57 \\
\hline \multirow[t]{2}{*}{ Manganese } & 01056 & $\mu \mathrm{g} / \mathrm{L}$ & 14 & 5 & 0.33 & 16 & 0.92 \\
\hline & 01055 & $\mu \mathrm{g} / \mathrm{L}$ & 1 & 0 & - & 3 & 1.63 \\
\hline Silica & 00955 & $\mathrm{mg} / \mathrm{L}$ & 8 & 1 & 0.05 & 10 & 0.66 \\
\hline $\begin{array}{l}\text { Suspended- } \\
\text { sediment } \\
\text { concentration }\end{array}$ & 80154 & $\mathrm{mg} / \mathrm{L}$ & 7 & - & 2.13 & 13 & 14.89 \\
\hline $\begin{array}{l}\text { Total suspended } \\
\text { solids }\end{array}$ & 00530 & $\mathrm{mg} / \mathrm{L}$ & 8 & 0 & 5 & 15 & 0.00 \\
\hline
\end{tabular}

${ }^{1}$ Estimated uncertainty is the median of the relative standard deviation of reported concentrations for replicate sets in which the compound was detected in all replicates. The relative standard deviation is the standard deviation divided by the mean.

according to methodological specification and delivered to the appropriate analytical laboratories within specified holding times. Discrete monthly and storm samples from Smith Creek and Difficult Run were delivered on the same day as collection to the Division of Consolidated Laboratory Services (DCLS) in Richmond, Virginia, for analysis of nutrients and sediment. Discrete monthly and storm samples from the Upper Chester River and Conewago Creek were delivered to the USGS Sediment Laboratory in Louisville, Kentucky, for sediment analysis. All samples collected from Conewago Creek were analyzed by the Pennsylvania Department of Environmental Protection (PADEP) laboratory in Harrisburg, Pennsylvania. Monthly, storm, and extensive synoptic samples from Smith
Creek, Difficult Run, and the Upper Chester River were analyzed for nitrogen and oxygen isotope ratios of nitrate by the Reston Stable Isotope Laboratory in Reston, Virginia. All other samples were chilled to 4 degrees Celsius $\left({ }^{\circ} \mathrm{C}\right)$ and shipped overnight to the USGS National Water Quality Laboratory in Denver, Colorado.

Samples for nitrate isotope analysis were pumped through 0.45 -micrometer $(\mu \mathrm{m})$ capsule filters, followed by $0.2-\mu \mathrm{m}$ syringe filters, and preserved with potassium hydroxide. All nitrate concentrations are presented in units of milligrams per liter as nitrogen $(\mathrm{N})$. Isotopic analyses of $\mathrm{N}$ and oxygen $(\mathrm{O})$ in nitrate were done at the USGS in Reston, Virginia, by using the bacterial reduction method with Pseudomonas aureofaciens (Sigman and others, 2001; Casciotti and others, 2002; Coplen and others, 2004). The data were calibrated by analyzing international nitrate isotopic reference materials and applying normalization data from Böhlke and others (2003). Variations in the isotope ratios of $\mathrm{N}$ and $\mathrm{O}$ are reported as delta values, defined as the relative difference between the molar (or atomic) ratio of isotopes in a sample and that in a standard: $\delta \mathrm{E}=\mathrm{R}_{\text {sample }} / \mathrm{R}_{\text {standard }}-1$. For nitrogen, $\delta^{i} \mathrm{E}$ is $\delta^{15} \mathrm{~N}, \mathrm{R}$ is $\mathrm{n}\left({ }^{15} \mathrm{~N}\right) / \mathrm{n}\left({ }^{14} \mathrm{~N}\right)$, and the standard is atmospheric nitrogen gas. For oxygen, $\delta^{\mathrm{i}} \mathrm{E}$ is $\delta^{18} \mathrm{O}, \mathrm{R}$ is $\mathrm{n}\left({ }^{18} \mathrm{O}\right) / \mathrm{n}\left({ }^{16} \mathrm{O}\right)$, and the standard is Vienna Standard Mean Ocean Water (VSMOW). Delta values are reported in parts per thousand (per mil, or \%o); for example, $\delta^{15} \mathrm{~N}=0.006, \delta^{15} \mathrm{~N}=6 \%$, or $1,000 \times \delta^{15} \mathrm{~N}=6$. Uncertainties ( 2 sigma) of normalized $\delta^{15} \mathrm{~N}$ and $\delta^{18} \mathrm{O}$ values were approximately \pm 0.5 per mil (\%o) and $\pm 1.0 \%$, respectively.

\section{Continuous Monitoring of Water Quality}

Continuous water-quality data were collected at each small watershed monitoring station (table 7). All continuous water-quality data were collected following USGS guidelines (U.S. Geological Survey, variously dated; Wagner and others, 2006). Modified field protocols were used for servicing the Conewago Creek sites because of sonde-accessibility issues. Fouling and calibration checks were performed approximately monthly during the servicing of each continuous monitor. Continuous water-quality records were refined by applying appropriate fouling and drift corrections following these inspections. Records were then reviewed and approved by different hydrographers or hydrologists.

\section{Statistical Analysis of Surface-Water and Water-Quality Data}

Only final, approved USGS data were used in statistical analyses. The streamflow record was analyzed by using the hydrograph separation software package PART to compute a base-flow index (BFI) for the watershed over multiple time periods (Rutledge, 1998). The BFI represents the ratio of the total base-flow volume to the total streamflow volume for a given period and is indicative of whether a given stream is dominated by groundwater discharge or direct runoff during storms. 
Table 4. Constituents, parameter codes, analysis sources, method codes, reporting units, and reporting limits for discrete waterquality constituents collected at the Smith Creek and Difficult Run watersheds.

[USGS, U.S. Geological Survey; NWQL, National Water Quality Laboratory; DCLS, Division of Consolidated Laboratory Services; EPA, U.S. Environmental Protection Agency; NFM, National Field Manual; ICP-MS, inductively coupled plasma mass spectrometry; mg/L, milligram per liter; ASTM, American Society for Testing and Materials; $\mu \mathrm{g} / \mathrm{L}$, microgram per liter]

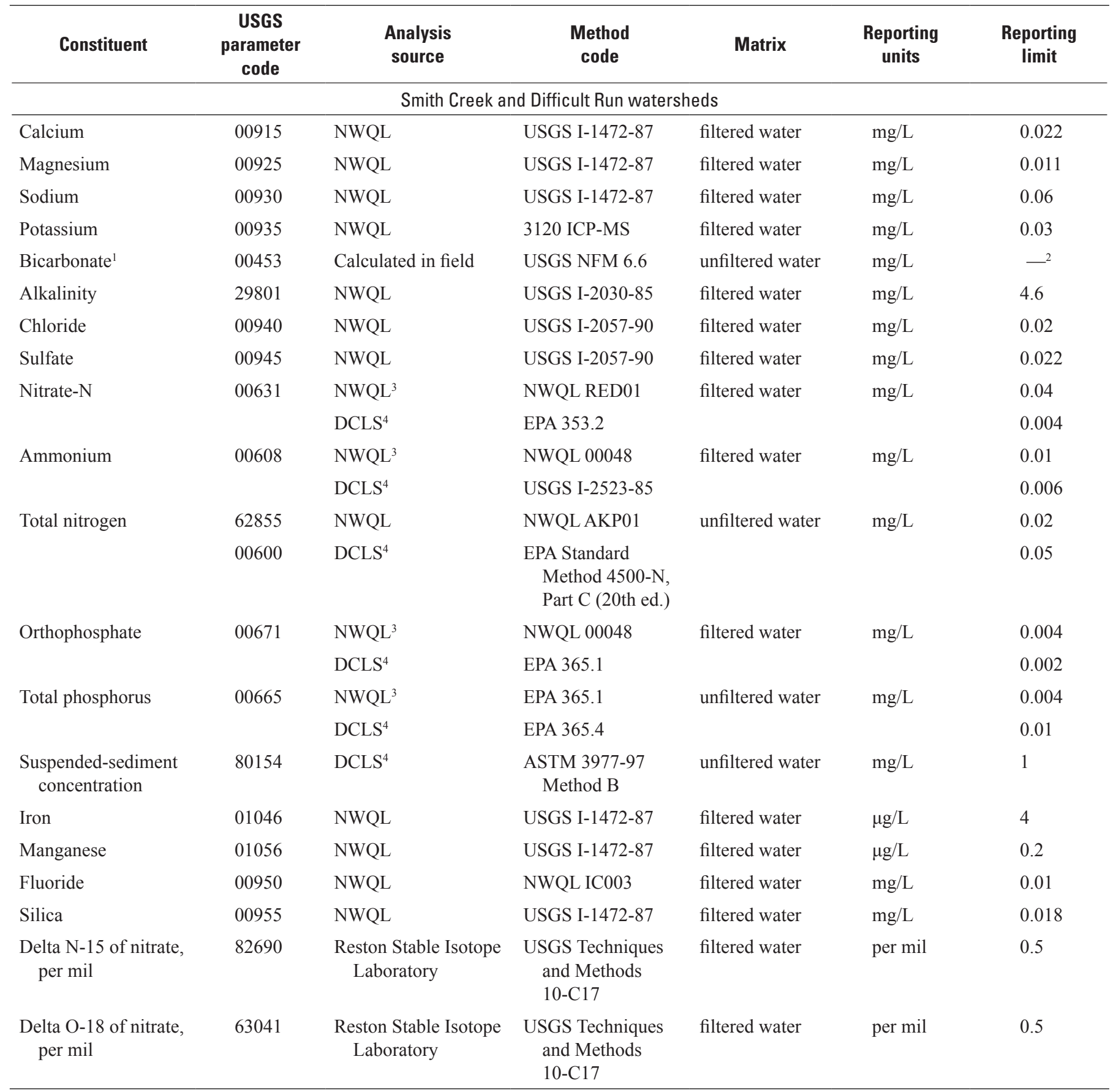

${ }^{1}$ Missing bicarbonate values were calculated from alkalinity results (U.S. Geological Survey, 2012a).

${ }^{2}$ Errors associated with the calculation of bicarbonate values using the advanced speciation method are typically limited to less than 10 percent of the sample alkalinity (U.S. Geological Survey, 2012a).

${ }^{3}$ Analysis source used during synoptic samples only.

${ }^{4}$ Analysis source used during monthly and storm samples only. 
Table 5. Constituents, parameter codes, analysis sources, method codes, reporting units, and reporting limits for discrete waterquality constituents collected at the Upper Chester River watershed.

[NWQL, National Water Quality Laboratory; EPA, U.S. Environmental Protection Agency; USGS, U.S. Geological Survey; NFM, National Field Manual; ICPMS, inductively coupled plasma mass spectrometry; mg/L, milligrams per liter; ASTM, American Society for Testing and Materials; $\mu \mathrm{g} / \mathrm{L}$, microgram per liter]

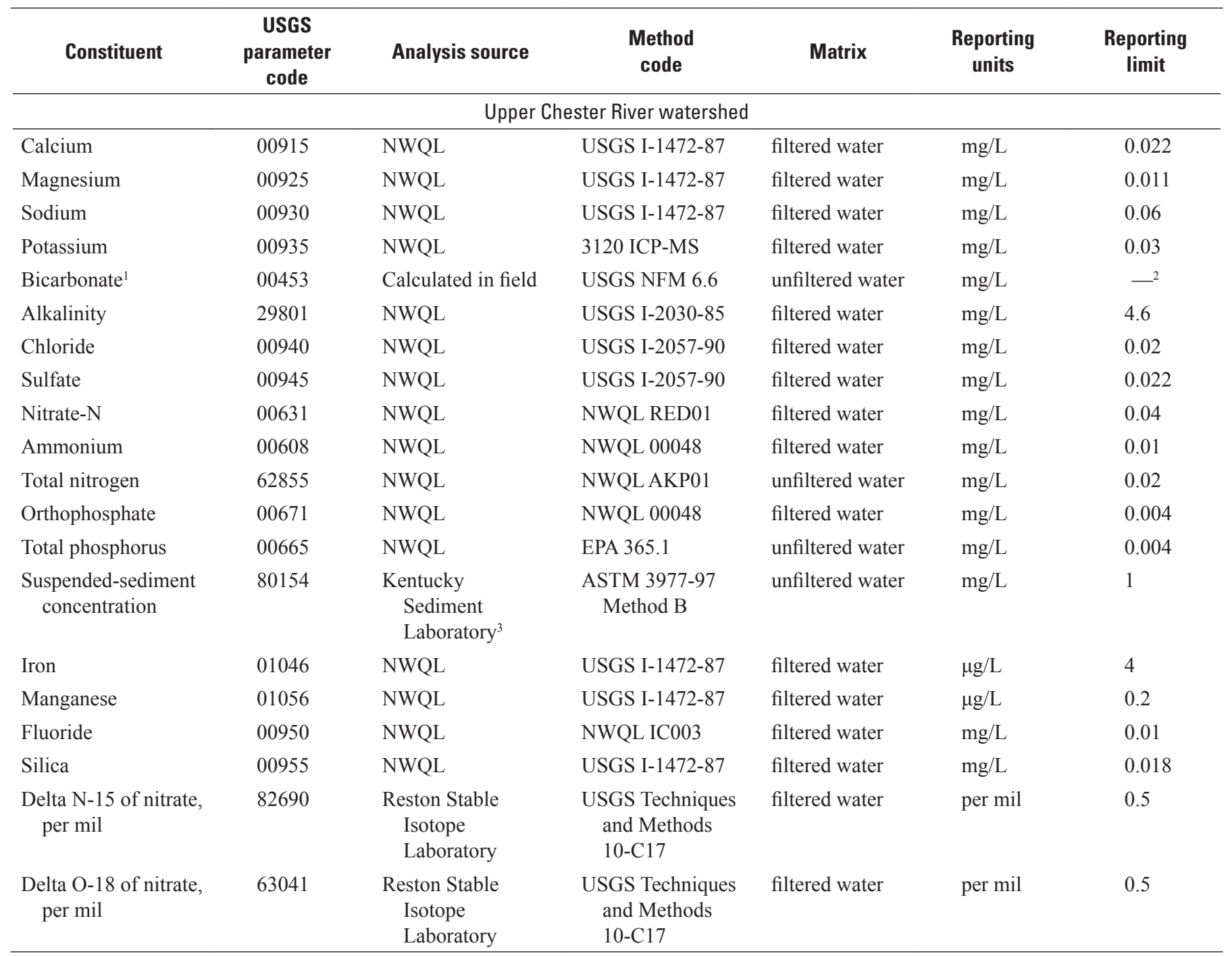

\footnotetext{
${ }^{1}$ Missing bicarbonate values were calculated from alkalinity results (U.S. Geological Survey, 2012a).

${ }^{2}$ Errors associated with the calculation of bicarbonate values using the advanced speciation method are typically limited to less than 10 percent of the sample alkalinity (U.S. Geological Survey, 2012a).

${ }^{3}$ Analysis source used during monthly and storm samples only
}

In general terms, most water-quality data used in these analyses were collected between April 2010 and September 2013. Non-parametric analyses were used to describe statistical relationships in the data following recommendations by Helsel and Hirsch (2002). All statistical tests were evaluated at the 95-percent confidence level $(a=0.05)$. Concentrationdischarge plots were created to visualize relations to flow and season, with seasons classified as "warm" (April through September) or "cool" (October through March). Statistical relationships of discrete parameters to flow and season were defined using Spearman's rho correlation matrices and Wilcoxon test of rank scores, respectively. Several statistical methods deserve special mention in addition to these aforementioned analyses.

\section{Development of Surrogate Water-Quality Models and Computation of Loads}

Continuous water-quality parameters were used to create surrogate models that estimate suspended-sediment, total phosphorus (TP), and total nitrogen (TN) concentrations. The surrogate regression models were developed following published USGS approaches (Helsel and Hirsch, 2002; Jastram and others, 2009; Rasmussen and others, 2009), so only a summary of the pertinent details is presented here.

Models were built and evaluated by using JMP version 11.0. Models were developed using best subsets 
Table 6. Constituents, parameter codes, analysis sources, method codes, reporting units, and reporting limits for discrete waterquality constituents collected at the Conewago Creek watershed.

[USGS, U.S. Geological Survey; NWQL, National Water Quality Laboratory; PADEP, Pennsylvania Department of Environmental Protection; EPA, U.S. Environmental Protection Agency; mg/L, milligram per liter; $\mathrm{CaCO}_{3}$, calcium carbonate; <, less than; mm, millimeter; $\mu \mathrm{g} / \mathrm{L}$, microgram per liter]

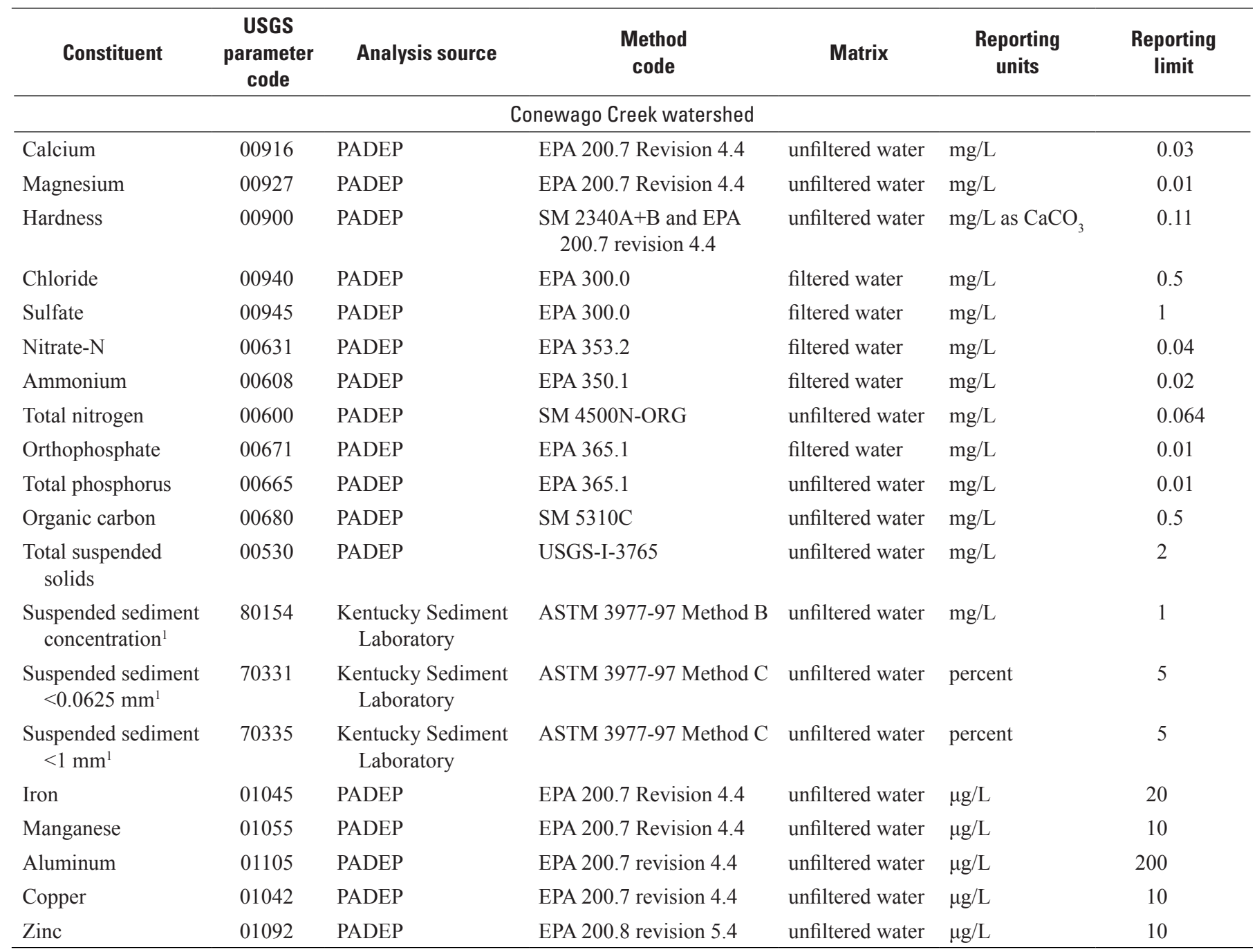

${ }^{1}$ Constituent collected during storm samples and synoptic samples.

Table 7. Continuous water-quality data collected within each watershed.

[ $\mathrm{x}=$ parameter collected; deg $\mathrm{C}$, degrees Celsius; $\mathrm{mg} / \mathrm{L}$, milligram per liter; FNU, formazin nephelometric unit; $\mu \mathrm{S} / \mathrm{cm}$, microsiemens per centimeter]

\begin{tabular}{|c|c|c|c|c|c|c|c|}
\hline \multirow[b]{2}{*}{ Parameter } & \multirow[b]{2}{*}{$\begin{array}{l}\text { USGS param- } \\
\text { eter code }\end{array}$} & \multirow[b]{2}{*}{ Method code } & \multirow[b]{2}{*}{$\begin{array}{l}\text { Reporting } \\
\text { units }\end{array}$} & \multicolumn{4}{|c|}{ Watershed } \\
\hline & & & & $\begin{array}{l}\text { Smith } \\
\text { Creek }\end{array}$ & $\begin{array}{l}\text { Difficult } \\
\text { Run }\end{array}$ & $\begin{array}{c}\text { Upper } \\
\text { Chester } \\
\text { River }\end{array}$ & $\begin{array}{c}\text { Conewago } \\
\text { Creek }\end{array}$ \\
\hline Water temperature & 00010 & THM01 & $\operatorname{deg} \mathrm{C}$ & $\mathrm{x}$ & $\mathrm{x}$ & $\mathrm{x}$ & $\mathrm{x}$ \\
\hline Specific conductance & 00095 & $\mathrm{SC} 001$ & $\mu \mathrm{S} / \mathrm{cm}$ & $\mathrm{x}$ & $\mathrm{x}$ & $\mathrm{x}$ & $\mathrm{x}$ \\
\hline $\mathrm{pH}$ & 00400 & PROBE & Standard units & $\mathrm{x}$ & $\mathrm{x}$ & $\mathrm{x}$ & \\
\hline Dissolved oxygen & 00300 & LUMIN & $\mathrm{mg} / \mathrm{L}$ & $\mathrm{x}$ & $\mathrm{x}$ & $\mathrm{x}$ & \\
\hline Turbidity & 63680 & TS087 & FNU & $\mathrm{x}$ & $\mathrm{x}$ & $\mathrm{x}$ & \\
\hline Nitrate-N & 99137 & UV012/UV013 ${ }^{1}$ & $\mathrm{mg} / \mathrm{L}$ & $\mathrm{x}$ & $\mathrm{x}$ & $\mathrm{x}$ & \\
\hline
\end{tabular}

${ }^{1}$ UV012 is used at Smith Creek and Difficult Run; UV013 is used at the Upper Chester River. 
regression, which calculates all possible $2^{k}$ regressions (where $k$ is the number of explanatory variables evaluated). The minimization of Mallows' Cp was used as an initial decision point for model selection. Mallows' $\mathrm{Cp}$ is an overall measure of model quality that balances the goals of explaining the most amount of variability in the response variable, while minimizing standard error by reducing the number of predictor variables (Helsel and Hirsch, 2002).

Models with the smallest Mallows' $\mathrm{Cp}$ were further evaluated by using the adjusted $\mathrm{R}^{2}$ statistic. This statistic is similar to the $\mathrm{R}^{2}$ parameter, which represents the amount of variability explained in a model, but is weighted based on the number of explanatory variables (Helsel and Hirsch, 2002). Models with the smallest mean squared error have the highest adjusted $\mathrm{R}^{2}$. This statistic compensates for the weakness that $\mathrm{R}^{2}$ will always increase with each additional model parameter (Helsel and Hirsch, 2002).

Selected models were also evaluated based on reasonableness. Reasonable models contain variables with significant terms and with coefficients that accurately represent relationships to the response variable. Variables with a p-value $<0.05$ indicate that the parameter explains a significant amount of variation and should be present in the model (Helsel and Hirsch, 2002). All selected models were forced to include a flow variable to function properly within Load Estimator (LOADEST). Because of this limitation, some models contain a flow parameter with an insignificant term. The sign and magnitude of assigned coefficients were compared to the relationship between each predictor and response variable. Conspicuous coefficients with inverse relationships often indicate a multicollinearity concern.

Multicollinearity occurs when at least two model parameters are closely related to one another (Helsel and Hirsch, 2002). The variance inflation factor (VIF) was used to test for excessive multicollinearity. The variance inflation factor determines the independence of each explanatory variable and should be minimized, with serious concern occurring at VIF>10 (Helsel and Hirsch, 2002).

Explanatory and response variables were log or square-root transformed, if necessary, to develop linear relationships and homoscedasticity in the data. These two characteristics are assumptions required by linear regression (Helsel and Hirsch, 2002). Natural logarithm transformation was used instead of $\log$ base 10 to coincide with the transformation choices used by LOADEST.

Nutrient and sediment loads were calculated by using the rloadest version 0.1.0 package in RStudio. Total mass loading of a constituent can be defined using the equation

$$
L_{t}=\int_{0}^{t} Q C d t
$$

where
$L_{t} \quad$ is the total load,
$Q \quad$ is the instantaneous streamflow,
$C$ is the concentration, and
$t$ is the time.

Loads were generated for each water year based on an hourly time step (24 observations of concentration and discharge per day). An average hourly value was calculated from the 15-minute continuous dataset. After being provided a selected surrogate-concentration model, LOADEST calculated concentration by using ordinary least-squares regression (Runkel, and others, 2004). Instantaneous loads were then estimated in log space and were retransformed and summed over the entire time period to obtain total load (Runkel and others, 2004).

Loads were reported from the adjusted maximum likelihood estimation (AMLE) method. The AMLE method was selected because it effectively handles retransformation bias and provides a measure of uncertainty on each estimate of load (Runkel and others, 2004). The standard error of prediction (SEP) calculated for each load is the sum of parameter uncertainty and random error (Runkel, and others, 2004). The SEP was used to develop 95-percent confidence intervals around each estimate of load. Caution should be applied in the interpretation of these confidence intervals, however, when using continuous water-quality surrogates because serially correlated predictors could affect the computation of these confidence intervals.

LOADEST requires an uninterrupted record of discharge and model parameters used to predict concentration to function properly, so steps are required to replace missing data. Missing values were replaced using the fillMissing command within the USGSwsBase version 0.7 package in RStudio. This method uses interpolation to substitute values by incorporating information from data surrounding the missing point. During extended periods (typically greater than 8 hours) of missing data, the fillMissing command produced unrealistic results, and a median value was substituted for the missing points (Jastram and others, 2009).

\section{Hierarchical Agglomerative Cluster Analysis}

Hierarchical agglomerative cluster analysis is a multivariate statistical technique that is used to determine if samples can be combined into distinct groups based on their water chemistries. Cluster analyses have been previously used to explore patterns in surface-water-quality data (Guler and others, 2002; Ryberg, 2006) and were used in this study to describe spatial and temporal trends. A cluster analysis was used to identify which of the extensive synoptic water-quality sites were geochemically similar and to describe waterchemistry patterns at the intensive streamgage locations.

A subset of water-chemistry parameters was used in each cluster analysis. This specific suite of parameters was selected to inform the analysis as much as possible without providing undesirable redundancy. Inclusion of variables that are strongly related reduces the strength of the analysis (Guler, and others, 2002). For example, water temperature and turbidity were not included because they are mostly explained by DO and TP, respectively. Clustering methods require values for all selected parameters, so samples with missing values were not included in the analysis. 
Cluster analyses require normally distributed variables with equal variance, so a data transformation was applied prior to evaluation (Guler and others, 2002). Data were subtracted from the column mean and divided by the standard deviation to meet these assumptions.

The hierarchical agglomerative clustering method was run in JMP version 11.0. Hierarchical agglomerative clustering places no constraints on the number of groups formed, which allows for an optimal group structure (McCune and Grace, 2002). The method places each sample into its own cluster, and then the two closest clusters are joined based on similarity and a specific linkage method. Similarity measurements were calculated using Euclidean distance. This similarity matrix calculates the straight line distance between two points and leads to distinct group formation (Guler and others, 2002). Ward's method was used as the linkage rule. Ward's method joins clusters together to minimize the within-cluster sum of squares.

\section{Principal Components Analysis}

Principal components analyses (PCA) were used to identify patterns in water-chemistry data collected from discrete sampling efforts at the streamgage locations. PCA is an ordination technique that attempts to describe the maximum amount of variability in a dataset by generating axes that represent a combination of parameters (Helsel and Hirsch, 2002). Principal component axes can be related to external characteristics such as flow and season to explore processes influencing stream chemistry. PCA has been previously used to interpret water-quality patterns in the Chesapeake Bay watershed (Liu and others, 2000; Ator and others, 2004). The analysis was run in JMP version 11.0.

This ordination technique requires linear relationships among variables, so water-chemistry results were ranked prior to analysis (McCune and Grace, 2002). PCA requires values for all selected parameters, so samples with missing values were excluded from analysis.

\section{Interpretation of Nitrate Isotopes}

Patterns of nitrogen and oxygen isotopic variation in nitrate generally were related to between-site (spatial) and within-site (temporal) variations in (1) sources of nitrogen contributing to nitrate in groundwater recharge, (2) direct atmospheric nitrate contributions during runoff events, and (3) nitrate reduction (denitrification, assimilation) in groundwater or surface water. Compilations of published data indicate considerable variability of $\delta^{15} \mathrm{~N}$ of nitrate derived from different nitrogen sources (for example, Heaton, 1986; Hübner, 1986; Fogg and others, 1998; Böhlke, 2003; Kendall and others, 2007; Xue and others, 2009). Some variability may be related to climatic differences. For example, $\delta^{15} \mathrm{~N}$ values of plant and soil organic matter may vary in relation to temperature, moisture, and other factors affecting the openness of soil systems to net loss of ${ }^{15} \mathrm{~N}$-depleted gases (Handley and others, 1999; Amundsen and others, 2003; Houlton and others, 2006), and those variations may be transmitted to nitrate formed by nitrification in soils (McMahon and Böhlke, 2006). Other variability may be related to differences in soil properties or handling of anthropogenic nitrogen sources causing isotopic fractionation prior to nitrification. For example, reduced forms of nitrogen in domestic wastewater commonly have bulk $\delta^{15} \mathrm{~N}<6 \%$, but nitrogen losses and transformation processes cause $\delta^{15} \mathrm{~N}$ to increase during nitrogen passage through septic systems, such that $\delta^{15} \mathrm{~N}$ of nitrate leaving the systems and recharging groundwater typically is $>6 \%$ (Schroeder and others, 1993; Fogg and others, 1998; Hinkle and others, 2008). Likewise, $\delta^{15} \mathrm{~N}$ of nitrate derived from animal waste may be relatively high where manure is spread on the land surface and ammonia volatilization losses are substantial (Krietler, 1975), but not so high where nitrate is formed in subsurface septic system infiltration beds (Hinkle and others, 2007). Similar shifts occur between relatively low $\delta^{15} \mathrm{~N}$ values of reduced nitrogen fertilizers (urea, ammonia) and slightly higher $\delta^{15} \mathrm{~N}$ values of recharging nitrate beneath fields receiving those fertilizers (Krietler, 1975; Böhlke, 2002; Böhlke and others, 2002).

The $\delta^{18} \mathrm{O}$ values of nitrate also can vary depending on the source of the nitrate (Michalski and others, 2003; Kendall and others, 2007; Jackson and others, 2015). Atmospheric nitrate formed in part by photochemical reactions between NOx and ozone has much higher $\delta^{18} \mathrm{O}$ (typical mean value of $+75 \%$ ) than biogenic nitrate formed by microbial oxidation (nitrification) of reduced nitrogen from various sources. Biogenic nitrate $\delta^{18} \mathrm{O}$ values can vary with climate and other local conditions, including the $\delta^{18} \mathrm{O}$ of water, during nitrification. Approximate $\delta^{18} \mathrm{O}$ values of biogenic nitrate commonly are estimated from $2 / 3 \times \delta^{18} \mathrm{O}\left[\mathrm{H}_{2} \mathrm{O}\right]+1 / 3 \times \delta^{18} \mathrm{O}\left[\mathrm{O}_{2}\right]$ (Amberger and Schmidt, 1987). For example, if $\delta^{18} \mathrm{O}\left[\mathrm{O}_{2}\right]=+24 \%$ (the atmospheric value) and $\delta^{18} \mathrm{O}\left[\mathrm{H}_{2} \mathrm{O}\right]=-7 \%$ (for example, representing precipitation and soil water), this equation would yield $\delta^{18} \mathrm{O}\left[\mathrm{NO}_{3}^{-}\right]=+3 \%$. This simplistic representation of oxygen incorporated into nitrate during nitrification has been proposed on the basis of laboratory experiments with isotopic tracers. Its general applicability in environmental systems is questionable because of potential variation in the parameters of the equation, plus potential isotopic fractionation and exchange during the nitrification process; nonetheless, it appears to be consistent with data for samples most likely to represent biogenic nitrate in parts of the Chesapeake Bay watershed.

Typical intervals of $\delta^{15} \mathrm{~N}$ and $\delta^{18} \mathrm{O}$ values used to interpret the nitrate isotopic data in this report are summarized in figure 6 . Ranges of values in figure 6 can vary and are presented primarily as context for site-specific discussions. Published $\delta^{18} \mathrm{O}$ values of nitrate can be difficult to compile because of unreported analytical biases in some studies (Révész and Böhlke, 2002). For example, reported $\delta^{18} \mathrm{O}$ values of atmospheric nitrate were relatively low in some early studies, but higher in later studies that used improved methods. To minimize various sources of uncertainty and variability, the 


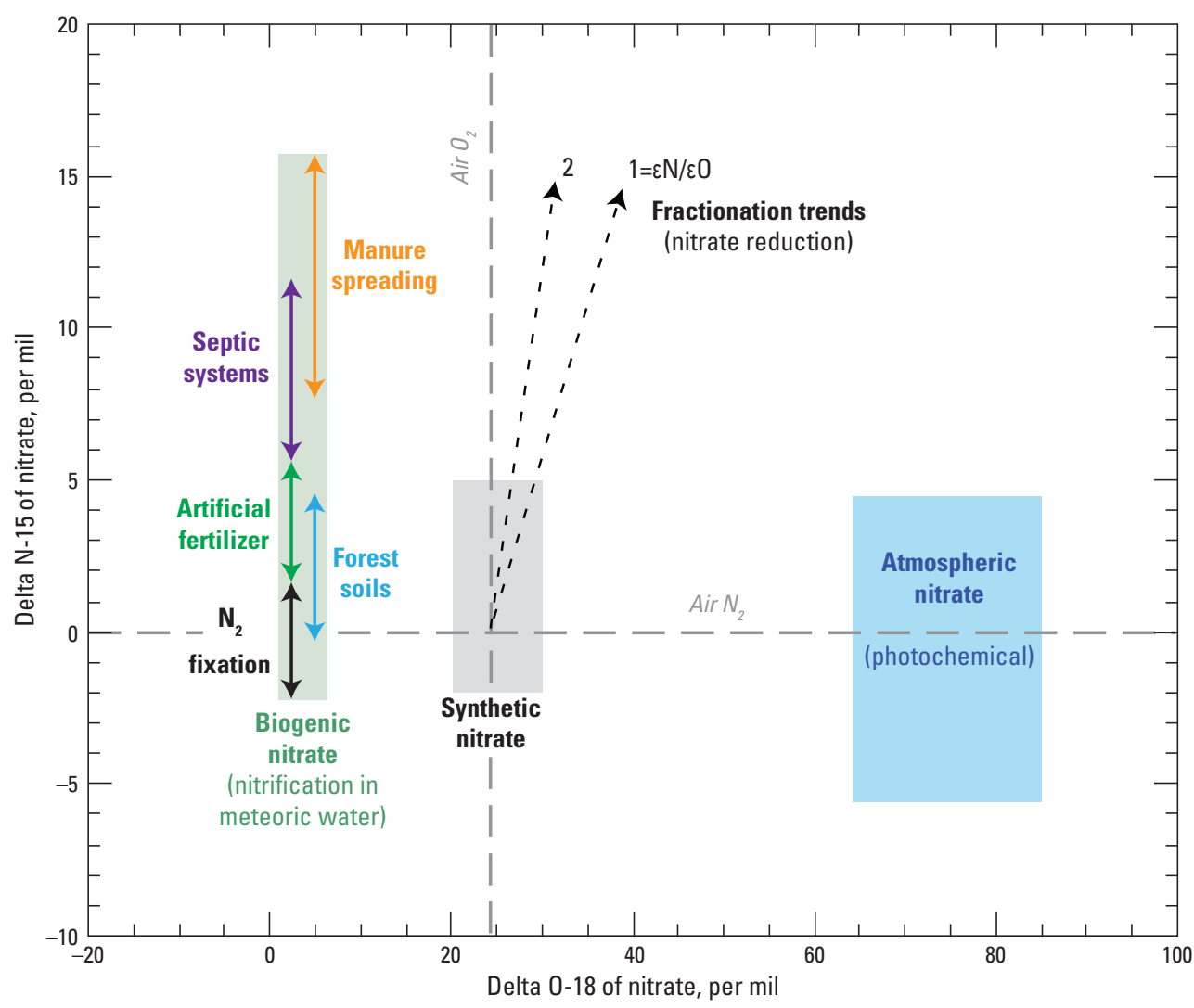

Figure 6. Typical variability in $\delta^{15} \mathrm{~N}$ and $\delta^{18} 0$ values for nitrate derived from various sources, with emphasis on conditions relevant to the Chesapeake Bay watershed.

nitrate isotopic data were interpreted with reference to selected previous studies done with current methods and calibrations, and data from within or near the Chesapeake Bay watershed or similar representative climate and land-use conditions were primarily considered (Aravena and others, 1993; Böhlke and Denver, 1995; McMahon and Böhlke, 1996; Plummer and others, 2001; Böhlke and others, 2002; Böhlke, 2003; Hinkle and others, 2008; Böhlke and Hannon, written commun.; J.K. Böhlke, 2015). Note that ranges given for $\delta^{15} \mathrm{~N}$ of nitrate from different sources are not necessarily the same as the $\delta^{15} \mathrm{~N}$ values of the source materials themselves because the nitrate values may reflect common isotope fractionation effects related to ammonia volatilization and other losses prior to conversion of source materials to nitrate. Similarly, although atmospheric nitrate can be an important source of nitrogen in some areas, the characteristically high $\delta^{18} \mathrm{O}$ value of atmospheric nitrate may not be found in groundwater and surface water if the atmospheric nitrate is assimilated, remineralized, and regenerated by nitrification in soils prior to recharge or runoff.

Figure 6 also shows previously published isotopic trajectories for nitrate undergoing progressive biologically mediated reduction, such as denitrification to $\mathrm{N}_{2}+\mathrm{N}_{2} \mathrm{O}$, or assimilation into organic $\mathrm{N}$ compounds. Laboratory studies indicate that nitrate reduction causes $\delta^{15} \mathrm{~N}$ and $\delta^{18} \mathrm{O}$ of residual (unreacted) nitrate to increase approximately equally $\left(\Delta \delta^{15} \mathrm{~N} / \Delta \delta^{18} \mathrm{O} \approx 1\right)$ (Granger and others, 2004, 2008). Field studies of groundwater and surface-water nitrate commonly indicate nitrate loss attributable to denitrification with apparent $\Delta \delta^{15} \mathrm{~N} / \Delta \delta^{18} \mathrm{O}$ between 1 and 2 (Böttcher and others, 1990; Lehmann and others, 2003; Böhlke and others, 2006; Houlton and others, 2006; Kendall and others, 2007). Explanations for reported variations in this ratio include artifacts in some analytical procedures (Révész and Böhlke, 2002), as well as variations in reaction processes such as re-oxidation of intermediate NOx species, oxygen exchange between water and nitrate or intermediate NOx species, and mixing of different sources of nitrate. Acknowledging some uncertainty about the processes, positively correlated variations in $\delta^{15} \mathrm{~N}$ and $\delta^{18} \mathrm{O}$ of nitrate with $\Delta \delta^{15} \mathrm{~N} / \Delta \delta^{18} \mathrm{O}=1$ to 2 were interpreted in the current study as permissive evidence for nitrate reduction (denitrification or assimilation) if associated with nitrate loss in groundwater or streams (fig. 6).

\section{Development of Land-Use-Based Nitrogen Inputs}

Evaluation of land-use-based nitrogen inputs to the study watersheds relied on previously published methods and publicly available data for computing the relative mass inputs of nitrogen from fertilizer applications, manure applications, atmospheric deposition, and wastewater sources. Fertilizer 


\section{Spatial and Temporal Variation of Stream Chemistry, Chesapeake Bay Watershed}

inputs were computed by using the approach outlined by Gronberg and Spahr (2012). Manure inputs were computed based on the approach of Ruddy and others (2006), using livestock counts reported in the appropriate Virginia, Maryland, or Pennsylvania Census of Agriculture. Atmospheric wet deposition (nitrate plus ammonium) to the study watersheds was computed by using the methods described in Ruddy and others (2006) and data from the National Atmospheric Deposition Program. Although this approach uses only wet deposition data, the wet fraction is the majority fraction in this region (Sickles II and Shadwick, 2007). Wastewater inputs were computed by using the approach of Lindsey and others (2009), with population data obtained from the United States Census Bureau.

\section{Development of Land-Use and Conservation- Practice Datasets}

Land use was calculated from the 2011 National Land Cover Database (NLCD) (Homer and others, 2015). Agricultural BMP conservation implementation data were obtained from the USDA by using methods outlined in Hively and others (2013). The USGS signed Conservation Cooperator agreements with the USDA NRCS and the USDA Farm Services Agency (FSA) in 2010. This allowed the USGS to gain access to privacy protected conservation implementation data for farm locations throughout the Chesapeake Bay watershed. Aggregated totals of the implementation data can be released to the public as long as five or more farmers are enrolled in the reported practice within the aggregated area, in this case within the boundary of each Showcase Watershed. Implementation totals reported here were obtained from the USDA in April 2014, and the data for any practice with less than five customers per Showcase Watershed were deleted. The dataset included implemented practices for which the NRCS or FSA had provided cost-share dollars, as well as implemented practices for which the NRCS had provided Conservation Technical Assistance (CTA). In addition to the USDA data, information on non-Federal BMP implementation was provided by the Virginia Department of Conservation and Recreation, the PADEP, and the Maryland Department of Agriculture. 


\section{Smith Creek Watershed Water-Quality Characterization}

\author{
Lead Author: Kenneth E. Hyer
}

To characterize water quality within the Smith Creek watershed, 38 water-monitoring stations were established (fig. 7). Intensive monitoring activities were performed at site 32, the site of the existing streamgage (USGS station number 01632900), and extensive monitoring was performed at all stations identified in figure 7 . The intensive site provides sufficient data to compute annual loads and trends of sediment and nutrients, and the extensive monitoring sites provide data to characterize the sources, sinks, and transport processes for nutrients. The extensive monitoring sites were selected to provide a distribution of monitoring sites along the length of Smith Creek, as well as to provide data from springs and tributaries.

\section{Streamflow and Water-Quality Characterization at the Intensive Monitoring Site}

The intensive Smith Creek monitoring location (site 32) is approximately 4.6 miles above the confluence with the North Fork of the Shenandoah River. This site was selected for intensive monitoring because of the presence of an existing streamgage, which provided a continuous record of discharge since 1960. Presented in this report section is an overview and characterization of the physical hydrology and water-chemistry data that were collected at this intensive monitoring site.

\section{Characterization of the Physical Hydrology}

Smith Creek hydrology during the monitoring period and long-term hydrology are presented in figure 8 , with divisions used to indicate each water year (beginning October 1 and ending September 30). Relatively typical streamflow conditions occurred during the monitoring period, with base flows typically in the range of the 25 th to 75 th percentiles of flows that were observed over the long-term record of the gage. During periods of heavy rainfall, instantaneous discharge values as great as 3,000 cubic feet per second $\left(\mathrm{ft}^{3} / \mathrm{s}\right)$ were observed during the monitoring period, while flows as low as $10 \mathrm{ft}^{3} / \mathrm{s}$ were observed during extremely dry periods. Because the hydrologic conditions were relatively typical during the monitoring period, the geochemical patterns and processes observed should be fairly representative of long-term patterns in the basin.

The computed long-term BFI for Smith Creek is 72.3 percent, indicating that approximately 72 percent of the Smith Creek flow exits the watershed as base flow (table 8), which suggests that the Smith Creek hydrology is likely dominated by groundwater discharge rather than stormwater runoff. This finding is consistent with earlier work of Sanford, Nelms, and others (2012), who utilized chemical separation techniques to demonstrate that groundwater inputs and base flow were the dominant sources of flow in the Smith Creek watershed (with potentially as much as 83 percent of streamflow occurring as base flow). Of particular note, the BFI during the 2010-2013 study period is identical to the longterm BFI of 72.3 percent, further confirming that relatively typical hydrologic conditions occurred during the 2010-2013 monitoring period described in this report. 


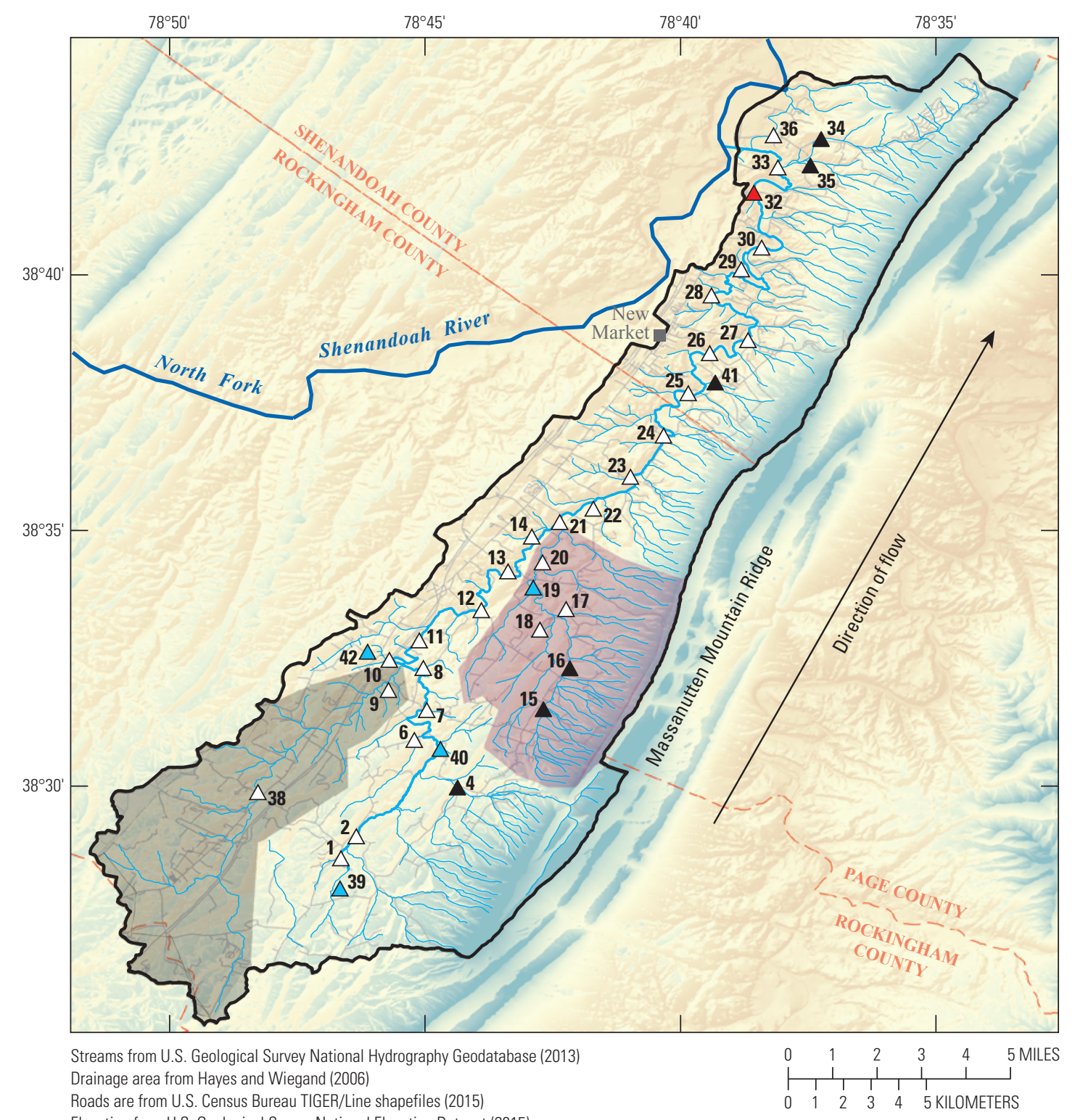

Roads are from U.S. Census Bureau TIGER/Line shapefiles (2015)

Elevation from U.S. Geological Survey National Elevation Dataset (2015)

North American Vertical Datum of 1988

North American Datum of 1983
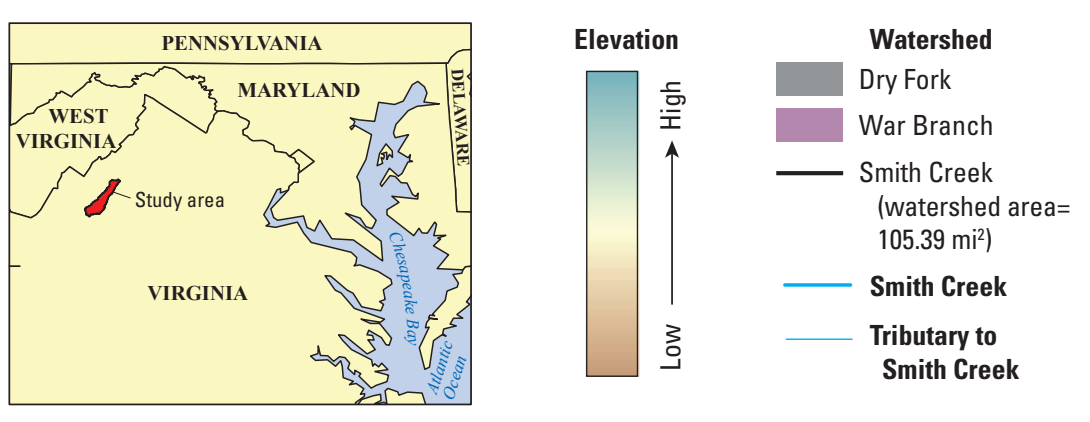

\footnotetext{
Monitoring station and identifier

$\triangle 32$ USGS streamgage 01632900

Synoptic sampling location and identifier

$\triangle \mathbf{4 0}$ Spring sampling location

39-Smith Creek spring

42-Lacey spring

40-Big spring

19-Unnamed tributary

to War Branch

$\Delta_{35}$ Draining Massanutten Mountain ridge

$\triangle 38$ Other
}

Figure 7. Monitoring stations and the stream network within the Smith Creek watershed, Virginia. 


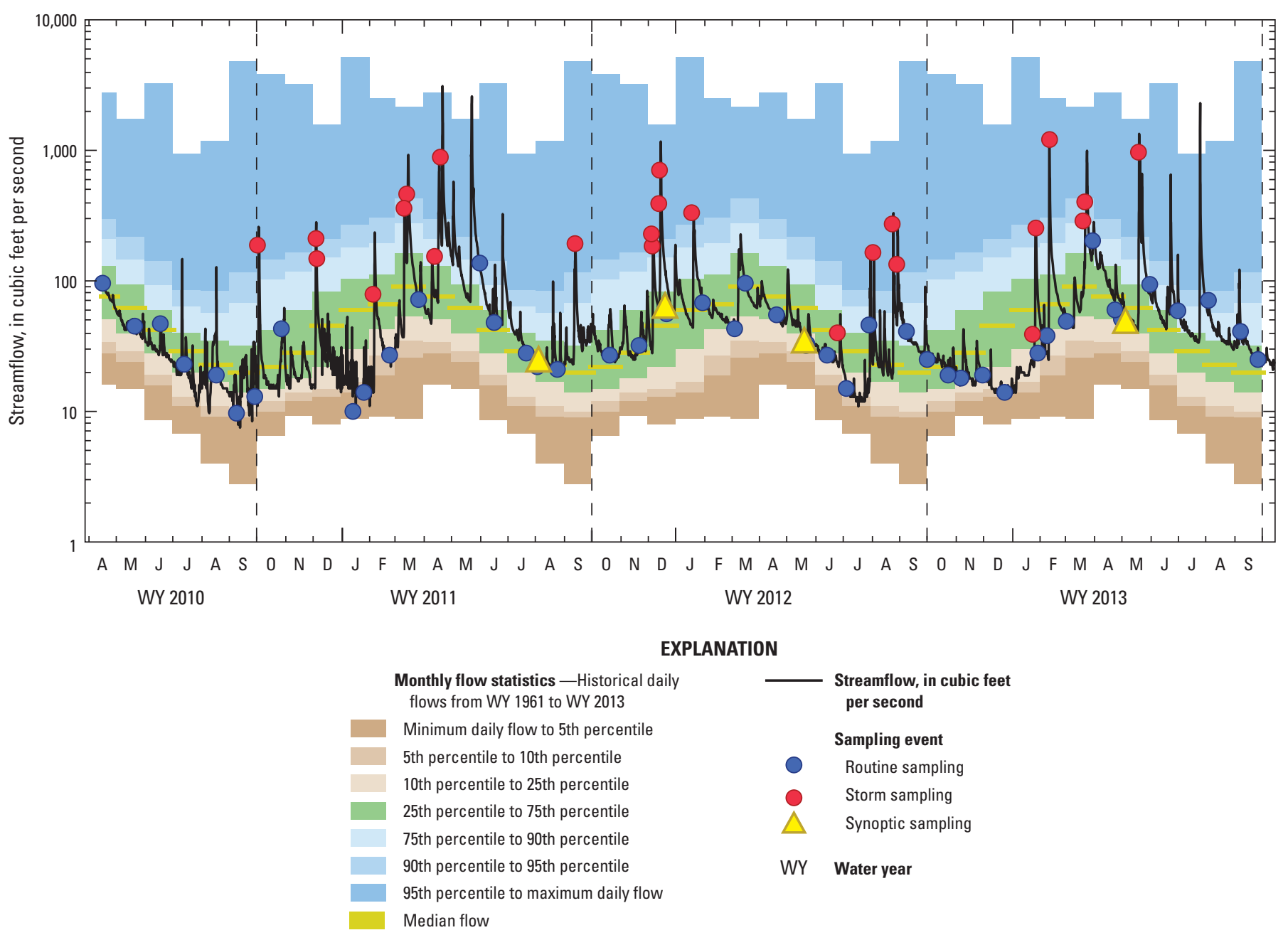

Figure 8. Smith Creek streamgage and quantiles that represent historical monthly flow data with the timing of various sampling events from April 2010 through September 2013.

Table 8. Streamflow partitioning for streamgage station 01632900 in the Smith Creek watershed.

$\left[\mathrm{mi}^{2}\right.$, square mile; $\mathrm{ft}^{3} / \mathrm{s}$, cubic foot per second; in $/ \mathrm{yr}$, inch per year; \%, percent; data were computed using the software package PART (Rutledge, 1998)]

\begin{tabular}{|c|c|c|c|c|c|c|c|}
\hline \multirow[t]{2}{*}{ Watershed } & \multirow{2}{*}{$\begin{array}{c}\text { Drainage } \\
\text { area } \\
\left(\mathbf{m i}^{2}\right)\end{array}$} & \multirow{2}{*}{$\begin{array}{l}\text { Period of } \\
\text { record }\end{array}$} & \multicolumn{2}{|c|}{$\begin{array}{c}\text { Mean } \\
\text { streamflow }\end{array}$} & \multicolumn{2}{|c|}{$\begin{array}{l}\text { Mean } \\
\text { base } \\
\text { flow }\end{array}$} & \multirow{2}{*}{$\begin{array}{c}\text { Base-flow } \\
\text { index }(\%)\end{array}$} \\
\hline & & & $\mathrm{ft}^{3} / \mathrm{s}$ & in/yr & $\mathrm{ft}^{3} / \mathbf{s}$ & in/yr & \\
\hline \multirow[t]{2}{*}{ Smith Creek } & 93.6 & 1970-2013 & 78.79 & 11.43 & 56.94 & 8.26 & 72.3 \\
\hline & & 2010-2013 & 69.94 & 10.15 & 50.55 & 7.34 & 72.3 \\
\hline
\end{tabular}




\section{Characterization of Continuous Water-Quality Data}

Temporal variability in the continuously monitored water-quality constituents is presented for the monitoring period as multidimensional contour plots in figures 9 and 10 . Seasonal, diel, and hydrologic fluctuations in most of the continuously monitored constituents can be observed to varying degrees, depending on the constituent. Not surprisingly, water temperature showed some of the strongest seasonality fluctuations with summertime temperatures commonly reaching greater than $25^{\circ} \mathrm{C}$ and wintertime temperatures falling below $5^{\circ} \mathrm{C}$. DO solubility varies inversely with water temperature; consequently, observed concentrations of DO are inversely related to the water temperature. The DO concentrations generally remained above 6 milligrams per liter $(\mathrm{mg} / \mathrm{L})$, indicating that $\mathrm{DO}$ concentrations are unlikely to be a stressor on the Smith Creek biota near the intensive monitoring site. The Smith Creek $\mathrm{pH}$ generally ranged from 7.9 standard units to 8.5 standard units, which is fairly typical of limestone basins in the Shenandoah Valley. The DO concentrations and $\mathrm{pH}$ levels demonstrate some fairly pronounced diel variations, with maximum levels occurring around 3:00 p.m. The in-stream turbidity concentrations were generally low, except during stormflow periods, when the turbidity values commonly exceeded 50 formazin nephelometric units (FNUs), a pattern which is typically observed because of re-suspension of in-stream sediment, erosion of stream banks, and other nonpoint-source contributions of sediment. Specific conductance values were generally about 475 to 500 microsiemens per centimeter at $25^{\circ} \mathrm{C}\left(\mu \mathrm{S} / \mathrm{cm}\right.$ at $\left.25^{\circ} \mathrm{C}\right)$, with variability related to variability in the flow conditions; higher specific conductance levels occurred during relatively dry periods, and lower levels were observed during stormflow periods. This pattern in specific conductance is generally indicative of a groundwater-dominated system, whereby water with relatively high specific conductance at base flow is diluted to a lower specific conductance by runoff water from other sources. The continuous nitrate monitor was operated for a much shorter time period, but substantial variability in concentrations was observed that seem poorly explained by either season or flow. Observed nitrate concentrations ranged from less than $1 \mathrm{mg} / \mathrm{L}$ to greater than $3 \mathrm{mg} / \mathrm{L}$; nitrate patterns are further explained in subsequent report sections to improve understanding of this constituent.

The hydrologic variability in the continuously monitored constituents was explored by using a series of concentrationdischarge plots (known as C-Q plots) that were subset according to warm periods (April-September) and cooler periods (October-March). For this assessment, the continuously monitored parameters were combined with available discrete water-quality samples for this same collection of continuously monitored constituents, and each constituent was further characterized seasonally by using the C-Q plot and seasonal boxplots to provide the distribution in parameters (figs. 11 and 12). Water temperature had a pronounced seasonality, with greater temperatures observed during the April-September period. Specific conductance values showed little seasonal variability; however, water samples had substantial dilution during elevated flow conditions during both periods. Levels of $\mathrm{pH}$ were slightly higher during the cooler months and decreased during wet weather conditions, regardless of season. DO concentrations were sharply different between warm and cool periods, and the difference was likely driven by water-temperature-controlled saturation dynamics. The DO response during wet weather conditions was variable, and likely was still controlled by temperature variations during wet-weather periods. Turbidity levels were generally strongly related to hydrology, with elevated turbidity values occurring during higher flows. Interestingly, the turbidity C-Q curve had greater variability during the spring and summer months than during the winter months; this increased variability could be the result of convective thunderstorms which develop more often in the summer, or it could be related to greater exposed soil and erosion during the spring months. Nitrate concentrations showed little seasonal difference, in contrast to other watersheds in this study but not uncommon elsewhere (Martin and others, 2004). Peak nitrate concentrations occurred at flows of about 70 to $80 \mathrm{ft}^{3} / \mathrm{s}$, with lower concentrations observed during particularly low flows and higher flows. It is hypothesized that dilution processes were responsible for the decreased concentrations during high flows and that biologic processing or changing groundwater inputs were responsible for the lower nitrate concentrations at extremely low flows, although contributions from lower nitrate groundwater sources during low flows also could be responsible for this pattern and cannot be ruled out. 


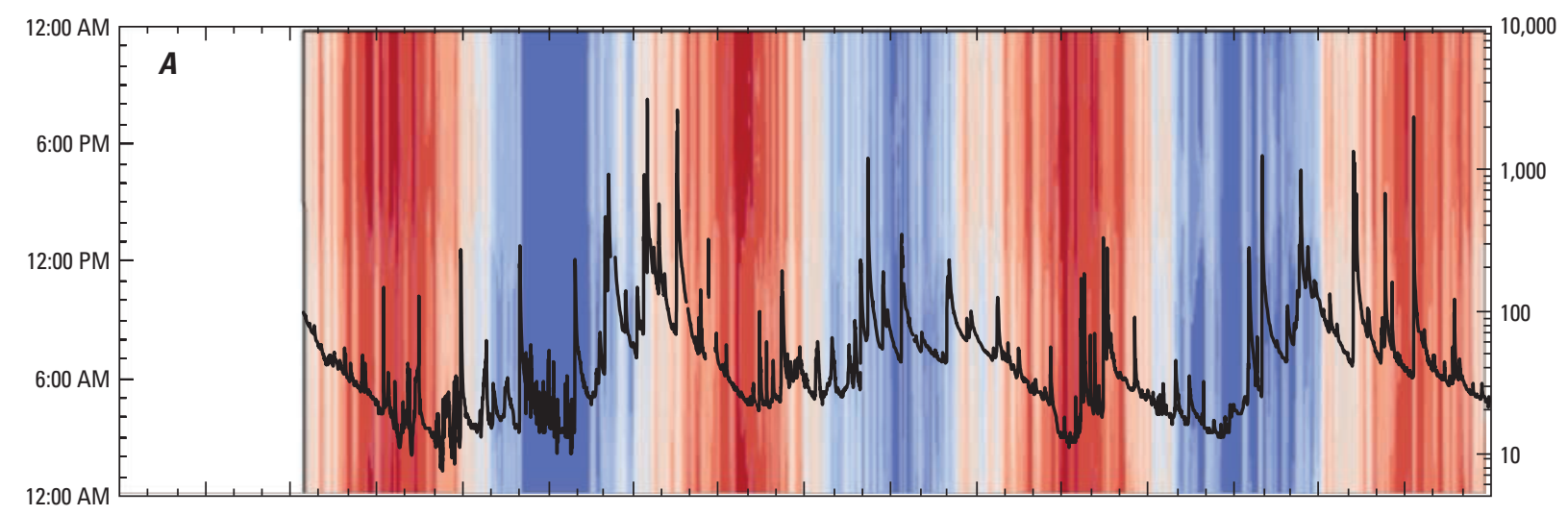

EXPLANATION

Water temperature, in degrees Celsius

0.00 to $5.00 \quad 16.01$ to 18.00

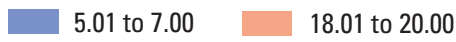

7.01 to $9.00 \quad 20.01$ to 22.00

9.01 to 11.00

11.01 to 13.00

13.01 to 16.00

— Streamflow, in cubic feet per second

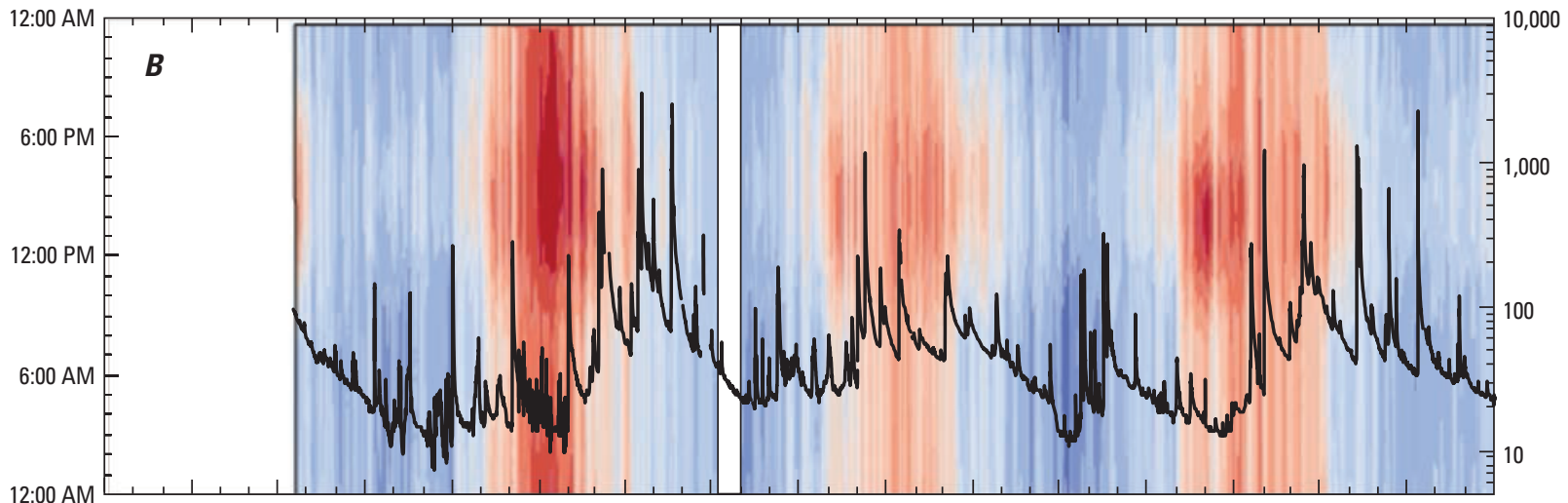

Dissolved oxygen, in milligrams per liter

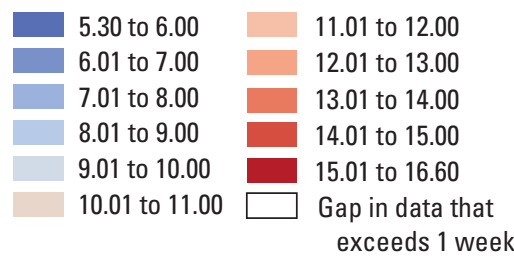

- Streamflow, in cubic feet per second

Figure 9. Continuous $(A)$ water temperature, $(B)$ dissolved oxygen, and $(C)$ pH data with the hydrograph from the Smith Creek streamgage, 2010-2013. 


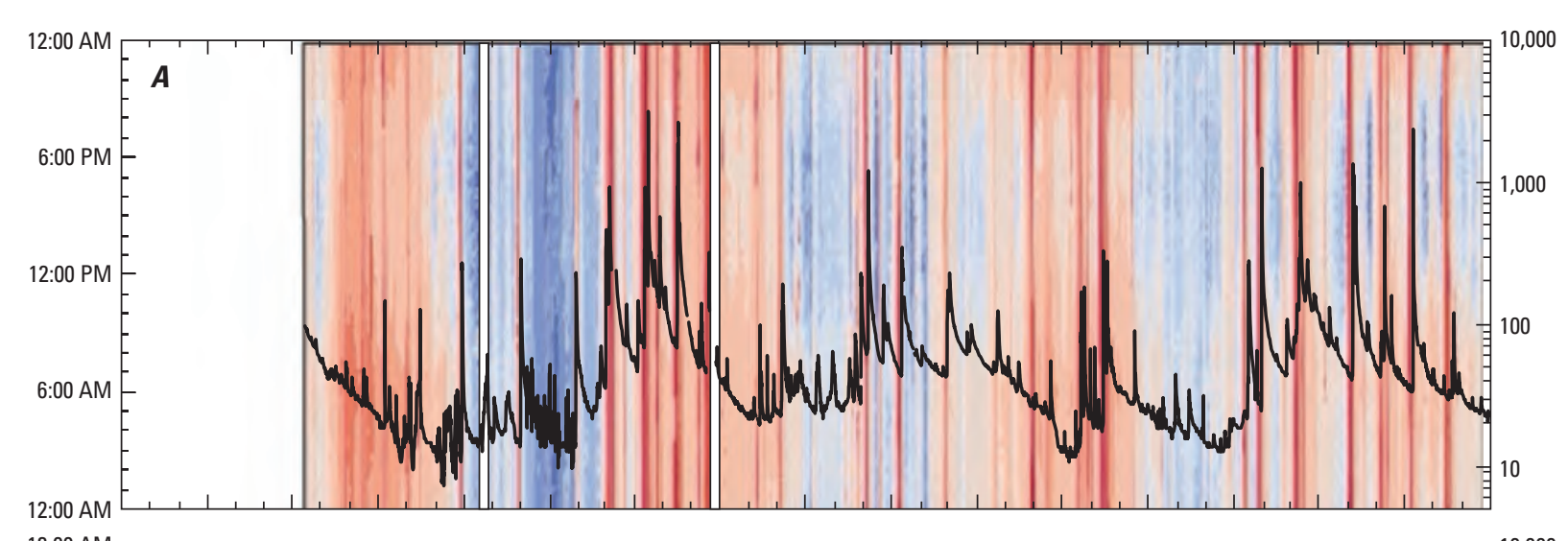

\section{EXPLANATION}

Turbidity, in formazin nephelometric units

\begin{tabular}{l|l}
0.00 to 1.00 & 5.01 to 10.00 \\
1.01 to 1.50 & 10.01 to 15.00 \\
1.51 to 2.00 & 15.01 to 20.00 \\
2.01 to 2.50 & 20.01 to 50.00 \\
2.51 to 3.00 & 50.01 to $1,190.00$ \\
3.01 to 5.00 & $\begin{array}{l}\text { Gap in data that } \\
\text { exceeds } 1 \text { week }\end{array}$ \\
& \\
\hline
\end{tabular}

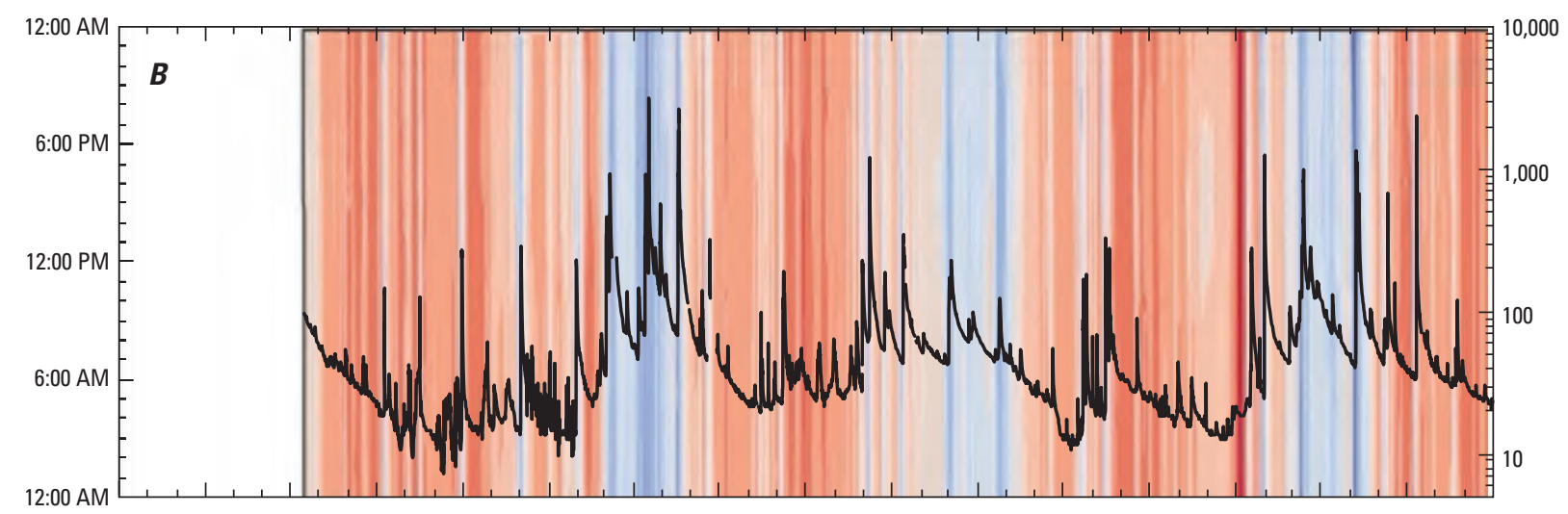

Specific conductance, in microsiemens per centimeter at 25 degrees Celsius

151 to $300 \quad 476$ to 500

301 to $350-501$ to 525

351 to 400

401 to 425

426 to 450

526 to 550

- Streamflow, in cubic feet per second

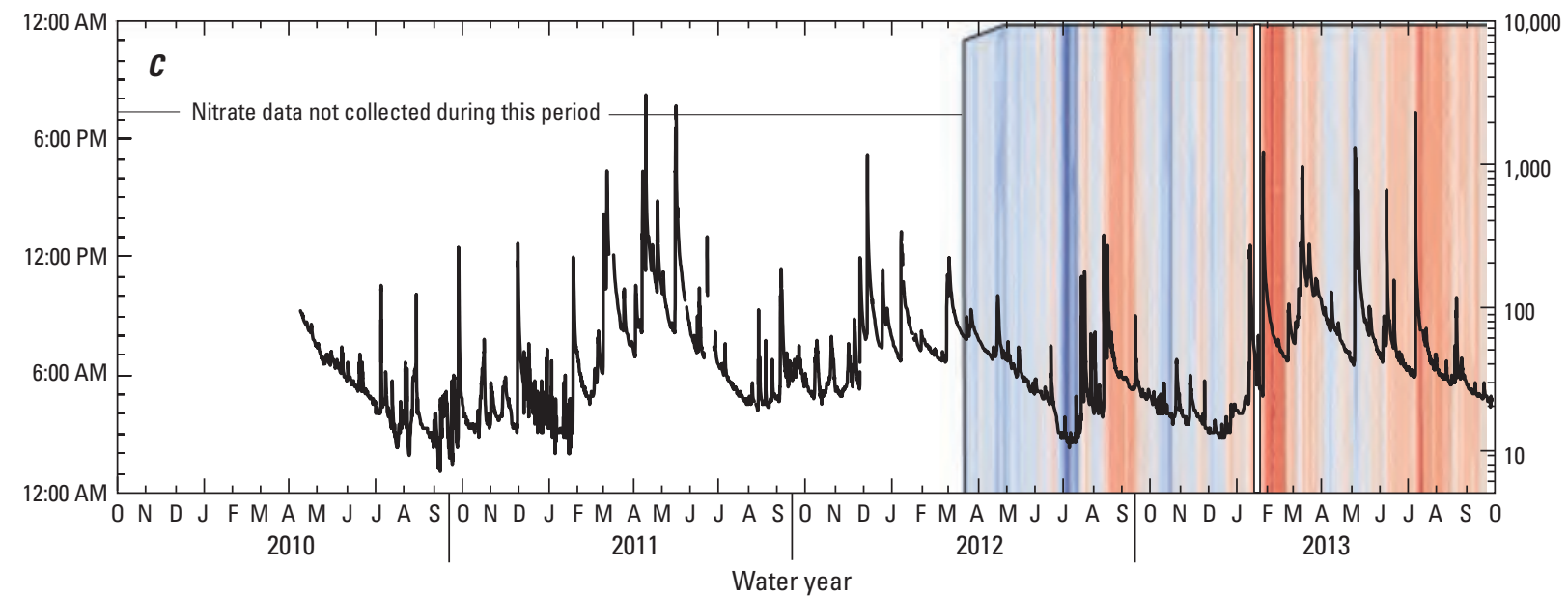

Nitrate plus nitrite, in milligrams per liter as nitrogen

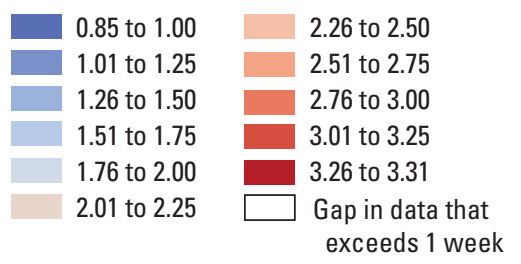

Figure 10. Continuous $(A)$ turbidity, $(B)$ specific conductance, and $(C)$ nitrate data with the hydrograph from the Smith Creek streamgage. 

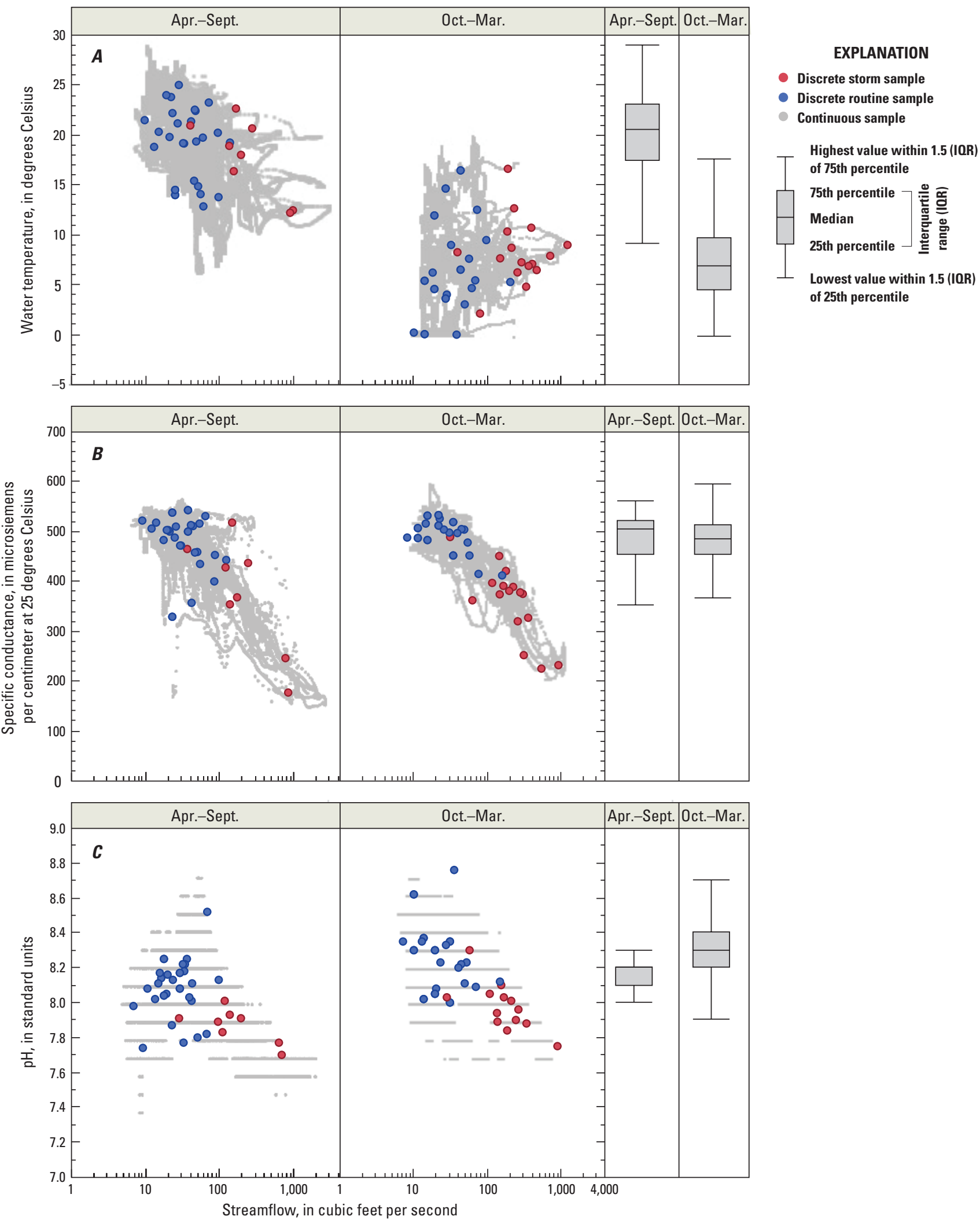

Figure 11. (A) Water temperature, $(B)$ specific conductance, and $(C) \mathrm{pH}$ data from continuous monitoring and discrete storm and routine samples for warm (April to September) and cool (October to March) seasons, Smith Creek streamgage, 2010-2013. 

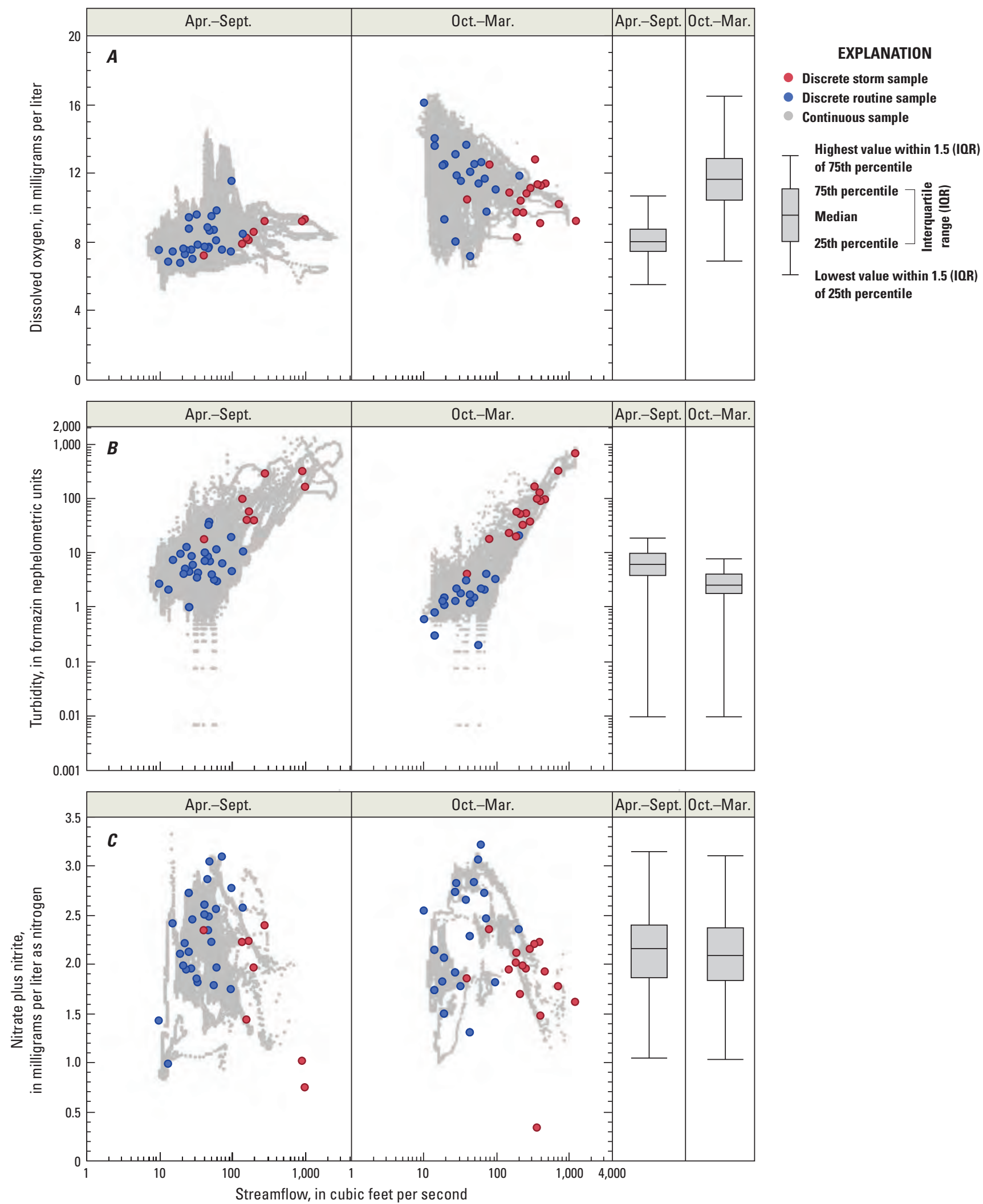

Figure 12. (A) Dissolved oxygen, $(B)$ turbidity, and $(C)$ nitrate data from continuous monitoring and discrete storm and routine samples for warm (April to September) and cool (October to March) seasons, Smith Creek streamgage. 


\section{Characterization of Discrete Water-Quality Data}

A large number of water-quality samples were collected during the study period, and many parameters were analyzed in each discrete water-quality sample collected. Systematic patterns in the discrete water-quality samples were explored by using cluster analysis and PCA because these tests offer rigorous approaches to investigate patterns in complex datasets.

A cluster analysis was run on the geochemical results for the 27 discrete samples for which a complete set of analyses was available. Variables that were obviously strongly correlated to flow, such as turbidity and suspended-sediment concentration (SSC), or season, such as water temperature, were excluded from this analysis to better explore the stream geochemistry and more subtle patterns in the data. Three clear clusters developed, representing seasonal and hydrologic variability (fig. 13). All of the Group 1 samples were collected during the cool season (October-March), and the Group 2 samples were all collected during the warm season (April-September). The Group 3 samples included only samples collected during the largest storm events during the monitoring period, and demonstrated strongly diluted majorion concentrations, which are generally indicative of groundwater sources being diluted by lower ionic strength runoff water. Discrete samples collected during some smaller storm events were assigned membership into Group 1 or Group 2,
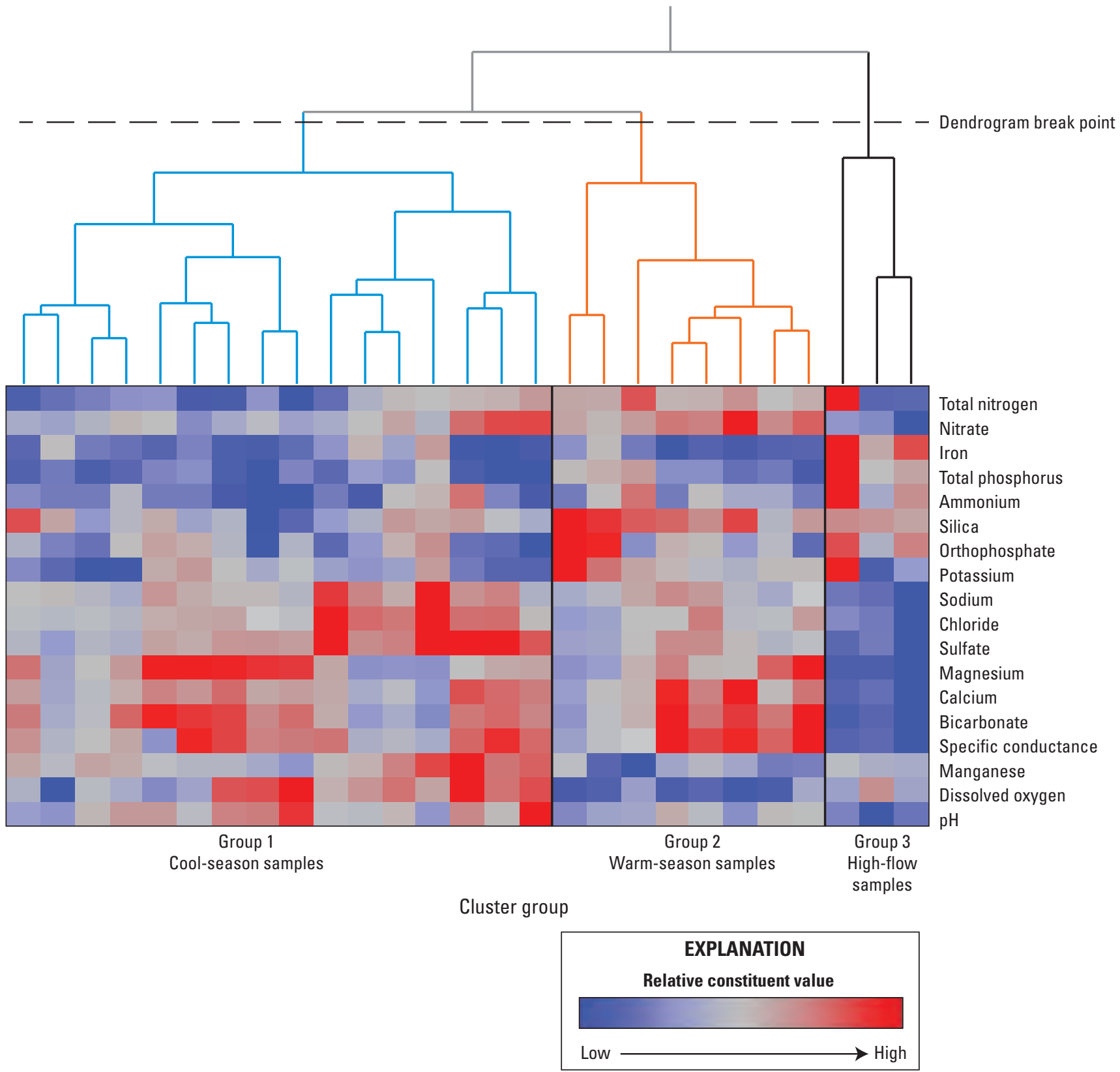

Figure 13. Discrete samples from the Smith Creek streamgage with a heat map of constituent values and the breakpoint used to produce three cluster groups, 2012-2013. 
depending on the season in which they were collected, likely indicating that during relatively small storms, the groundwater contributions and effects of seasonality continue to dominate the in-stream geochemistry. Runoff processes only dominated and changed the Smith Creek water chemistry during the largest storm events.

A PCA was run using all 27 discrete samples with complete analytical results to further explore the patterns in these discrete data. Again, water temperature, turbidity, and SSC were withheld from the analysis. Two principal components explained 58 percent of the variability in the data (table 9). The first component (explaining 39.6 percent of the data variability) had high positive loadings for $\mathrm{pH}$, specific conductance, calcium, magnesium, bicarbonate, and sulfate, with large negative loadings for TP and iron. Component 1 appears to be a traditional flow axis; at low flow, calcium, magnesium, bicarbonate, sulfate, $\mathrm{pH}$, and specific conductance are elevated, but concentrations of iron and TP are relatively low. At higher flows, and under runoff conditions, concentrations of iron and TP increase, but $\mathrm{pH}$, specific conductance, and concentrations of calcium, magnesium, and bicarbonate decrease because of dilution. This flow effect is clearly evident in a plot of component 1 versus flow, which demonstrated a strong negative relationship (fig. 14). Constituents load less strongly on the second component; however, more positive

Table 9. Loading of water-quality constituents collected at the Smith Creek streamgage on principal component axes 1 and 2.

[\%, percent; PC1, first principal components axis; PC2, second principal components axis; loadings with absolute value greater than 0.70 are shown in bold; those with absolute value less than $|0.40|$ are omitted]

\begin{tabular}{|c|c|c|}
\hline Constituent & $\begin{array}{c}\text { PC1 } \\
(39.6 \%)^{1}\end{array}$ & $\begin{array}{c}\text { PC2 } \\
(18.7 \%)^{1}\end{array}$ \\
\hline $\mathrm{pH}$ & 0.80 & \\
\hline Specific conductance & 0.78 & 0.42 \\
\hline Dissolved oxygen & 0.44 & -0.69 \\
\hline Bicarbonate & 0.76 & 0.45 \\
\hline Sulfate & 0.73 & \\
\hline Chloride & 0.66 & \\
\hline Calcium & 0.86 & 0.41 \\
\hline Magnesium & 0.73 & \\
\hline Sodium & 0.53 & \\
\hline Potassium & & 0.58 \\
\hline Nitrate-N & 0.52 & 0.55 \\
\hline Ammonium & -0.47 & \\
\hline Total nitrogen & & 0.63 \\
\hline Orthophosphate & -0.63 & \\
\hline Total phosphorus & -0.82 & \\
\hline Iron & -0.83 & \\
\hline Manganese & & -0.55 \\
\hline Silica & -0.46 & 0.68 \\
\hline
\end{tabular}

${ }^{1}$ Percent of overall variance explained. component 2 scores are associated with higher silica and TN concentrations, and lower component 2 scores are driven by concentrations of DO and manganese. A comparison of component 2 scores relative to the timing of sample collection confirmed that this second component is a seasonal axis, with greater component 2 scores during the warmer seasons and lower component 2 scores during the cooler seasons. The presence of a flow and a seasonal axis in discrete data like these is rather typical (Ator and others, 2004) and reflects that hydrology and seasonality contribute significantly to the variability of water quality in Smith Creek.

Because the cluster analysis and the PCA highlighted the seasonal and hydrologic variability of the parameters in this system, all analytes were subsequently tested individually for relationships to streamflow and seasonality (table 10; fig. 15). Large (Spearman's rho $>0.7$ ) significant positive relationships with flow are indicative of those constituents that are transported during wet weather and runoff conditions; large positive relationships with flow were observed for turbidity, SSC, and the calcium/magnesium ratio (table 10), and weaker (but still statistically significant) positive relationships were observed for TN, ammonium, orthophosphate, iron, and TP. Large (Spearman's rho <-0.7) inverse relationships with flow were observed for specific conductance, magnesium, and $\delta^{15} \mathrm{~N}$ of nitrate, while smaller inverse correlations were observed for $\mathrm{pH}$, bicarbonate, calcium, and $\delta^{18} \mathrm{O}$ of nitrate. These negative relationships are consistent with dilution of base flow by relatively lower ionic strength waters during storm events. Note that flow and nitrate did not have a statistically significant relationship, likely because of the relatively complex C-Q relationship observed in the continuous and discrete datasets (fig. 12). The general relationships between flow and various water-quality constituents are fairly typical (with the exception of nitrate). During storm events, sediment and particulate nitrogen and phosphorus concentrations typically increase and groundwater-derived constituents (such as calcium, magnesium, and bicarbonate) tend to decrease because the runoff from the landscape is relatively less concentrated in these constituents than the groundwater which has had considerably longer residence time and contact with bedrock containing these constituents. Non-significant C-Q relationships are provided in the appendix as supplemental material (fig. 1-1).

Statistically significant seasonal patterns existed for a number of monitored constituents (table 10). Water temperature, turbidity, orthophosphate, TP, SSC, and silica were higher during the warm season (fig. 15). Seasonal patterns in water temperature were expected and demonstrated previously with C-Q plots. Seasonally variable turbidity, TP, and sediment patterns were likely related to a greater availability of sediment for transport during the spring and summer, although greater algal production during warm seasons or more cattle wading into the streams and stirring up sediment cannot be excluded as contributing factors. The seasonally higher concentrations of orthophosphate and silica during warm weather periods were somewhat unexpected and the cause 


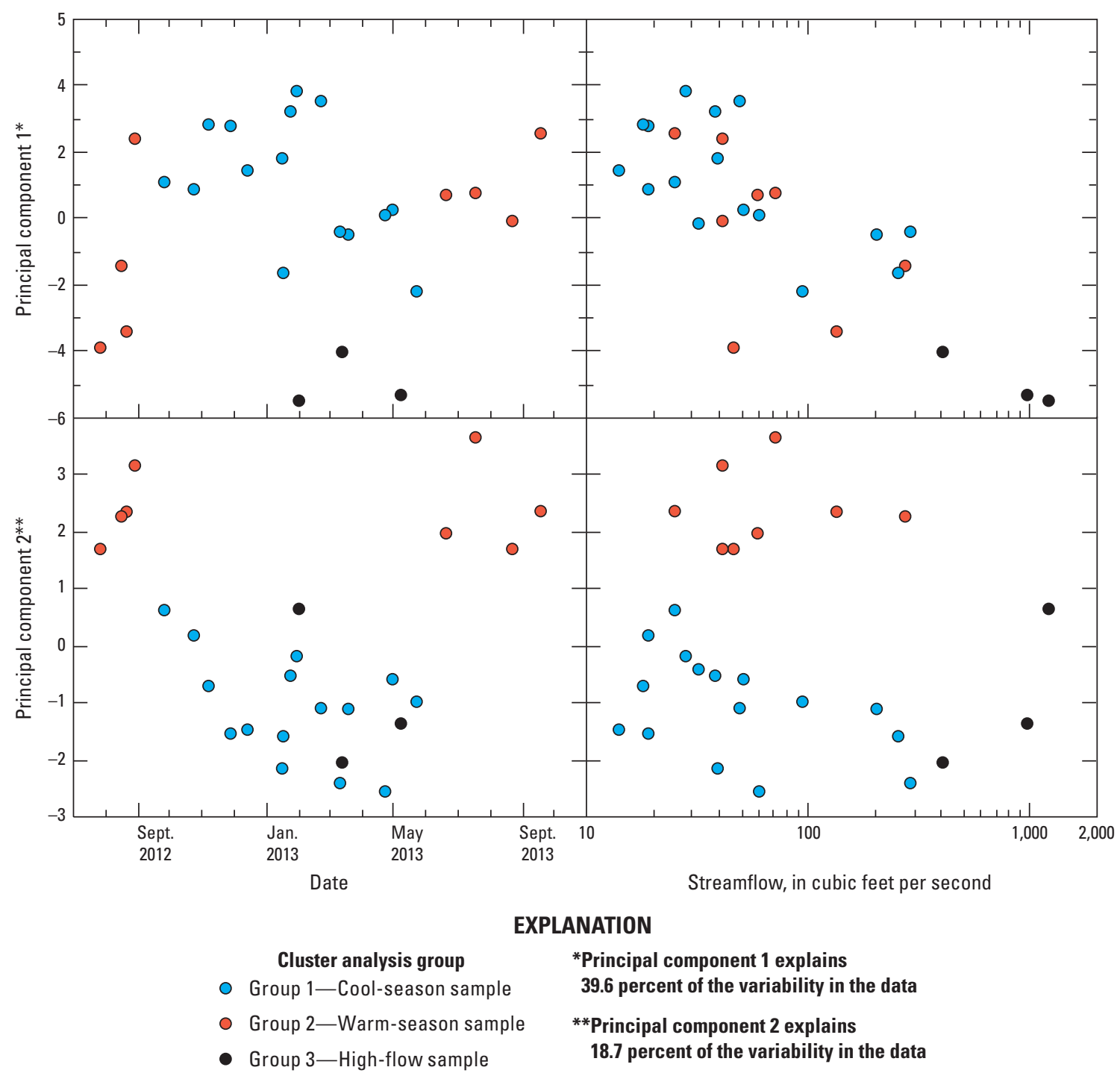

Figure 14. First two principal component axis scores for discrete samples from the Smith Creek streamgage along with time and streamflow, 2012-2013.

unresolved, although the silica patterns were likely partially related to temperature-driven silica solubility, as well as other factors. Levels of $\mathrm{pH}, \mathrm{DO}$, and sulfate were higher during the cool season (figs. 11, 12, and 16). The seasonally higher DO concentrations during cool periods were related to temperaturedriven solubility, as previously shown (fig. 12). Seasonally higher $\mathrm{pH}$ values during the cool season would be consistent with increased discharge of high-pH groundwater during the fall and winter, while the higher cool-season sulfate concentrations are likely related to soil storage during drier summer periods with release during wetter winter periods (Böhlke and Michel, 2009). Non-significant seasonal relationships are provided in the appendix as supplemental material (fig. 1-2).
The variability in the discrete nitrate isotope results is shown in figure 17 . The $\delta^{15} \mathrm{~N}$ values generally range from $+8 \%$ to $+14 \%$, while $\delta^{18} \mathrm{O}$ values generally range from $+3 \%$ to $+6 \%$. Routine samples generally demonstrate a positive correlation between $\delta^{15} \mathrm{~N}$ and $\delta^{18} \mathrm{O}$ values, consistent with varying amounts of biologic processing (denitrification, assimilation) within the Smith Creek watershed. Stormflow samples tend to have lower $\delta^{15} \mathrm{~N}$ and $\delta^{18} \mathrm{O}$ values than routine samples, indicating contributions of less-altered nitrate components during high flows. Nitrogen isotopes are likely indicative of manure or sewage sources of nitrogen; these possible sources will be further investigated in more detail later in the report. 
Table 10. Summary of hydrologic and seasonal correlations for discrete water-quality constituents collected at the Smith Creek streamgage.

[Results in bold are significant at $\alpha=0.05$; $n$, number of observations; APR, April; SEPT, September; OCT, October; MAR, March; <, less than]

\begin{tabular}{|c|c|c|c|c|c|c|c|}
\hline \multirow[b]{2}{*}{ Parameter } & \multicolumn{3}{|c|}{ Streamflow } & \multicolumn{4}{|c|}{ Season $^{1}$} \\
\hline & $\mathbf{n}$ & rho $^{2}$ & p-value ${ }^{2}$ & nAPR-SEPT & nOCT-MAR & p-value ${ }^{3}$ & $\begin{array}{c}\text { Season with } \\
\text { higher values }\end{array}$ \\
\hline Water temperature & 73 & -0.14 & 0.254 & 28 & 20 & $<0.001$ & APR-SEPT \\
\hline $\mathrm{pH}$ & 73 & -0.52 & $<0.001$ & 28 & 20 & 0.002 & OCT-MAR \\
\hline Specific conductance & 73 & -0.70 & $<0.001$ & 28 & 20 & 0.826 & \\
\hline Dissolved oxygen & 73 & 0.14 & 0.227 & 28 & 20 & $<0.001$ & OCT-MAR \\
\hline Sulfate & 30 & -0.23 & 0.225 & 12 & 8 & 0.003 & OCT-MAR \\
\hline Chloride & 30 & -0.34 & 0.068 & 12 & 8 & 0.097 & \\
\hline Bicarbonate & 30 & -0.68 & $<0.001$ & 12 & 8 & 0.969 & \\
\hline Calcium & 46 & -0.59 & $<0.001$ & 16 & 14 & 0.064 & \\
\hline Calcium/magnesium & 46 & 0.78 & $<0.001$ & 16 & 14 & 0.329 & \\
\hline Sodium/chloride & 30 & 0.35 & 0.055 & 12 & 8 & 0.375 & \\
\hline Nitrate-N & 73 & -0.09 & 0.468 & 28 & 20 & 0.908 & \\
\hline Total nitrogen & 73 & 0.27 & 0.023 & 25 & 17 & 0.828 & \\
\hline Ammonium & 72 & 0.39 & $<0.001$ & 28 & 19 & 0.124 & \\
\hline Orthophosphate & 73 & 0.25 & 0.030 & 28 & 20 & $<0.001$ & APR-SEPT \\
\hline Total phosphorus & 73 & 0.54 & $<0.001$ & 28 & 20 & $<0.001$ & APR-SEPT \\
\hline $\begin{array}{l}\text { Delta N-15 of nitrate, } \\
\text { per mil }\end{array}$ & 33 & -0.79 & $<0.001$ & 9 & 13 & 0.083 & \\
\hline Silica & 44 & 0.14 & 0.353 & 15 & 13 & $<0.001$ & APR-SEPT \\
\hline
\end{tabular}

'Only routine samples included in the Wilcoxon test of rank scores.

${ }^{2}$ rho is Spearman's rho; p-value is from Spearman's test for correlation.

${ }^{3} \mathrm{p}$-value is from the Wilcoxon test of rank scores. 

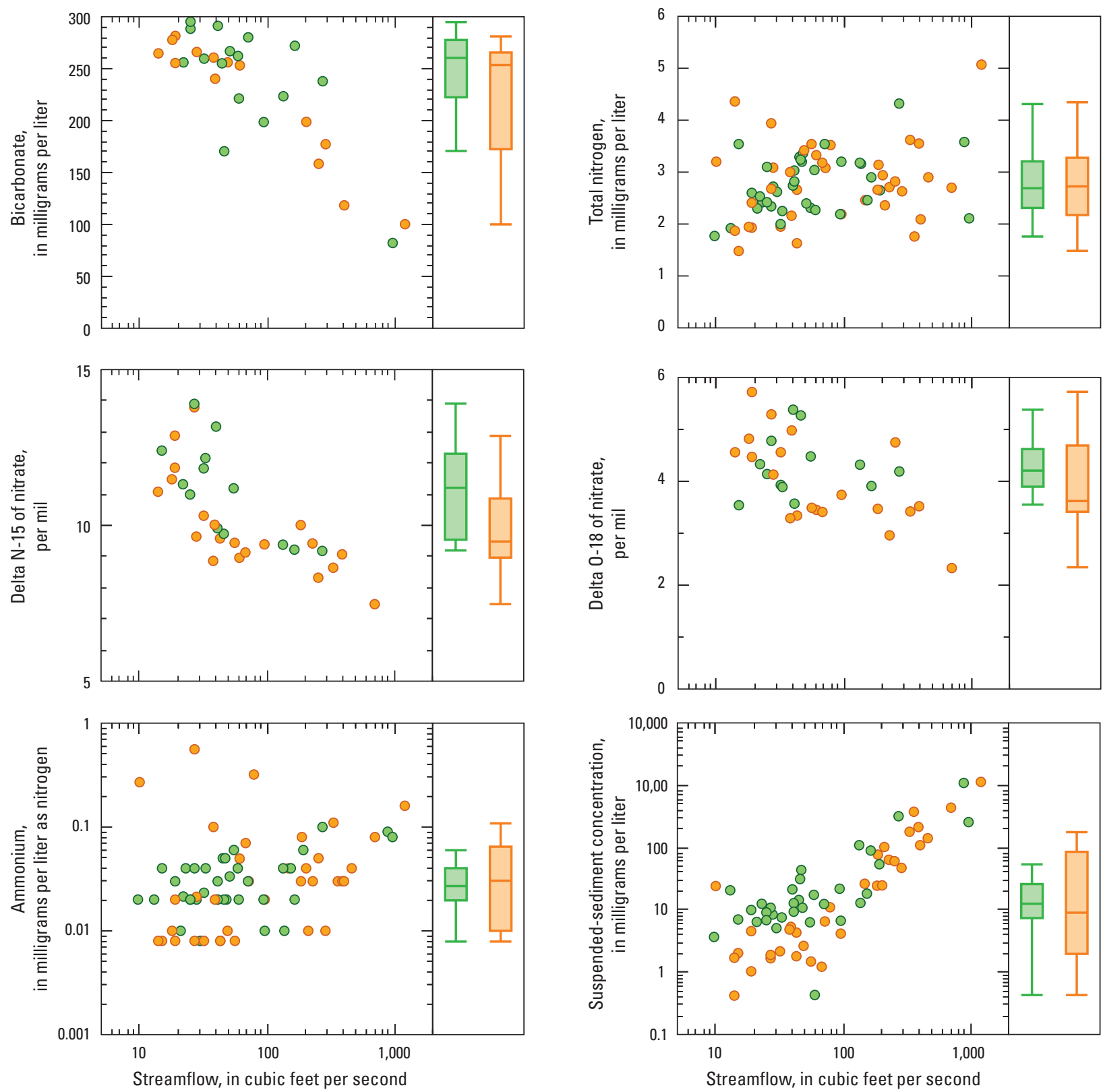

\section{EXPLANATION}

Season

○ ゆ April to September

○

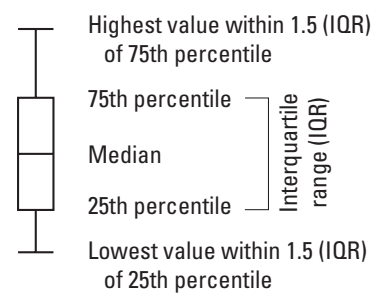

Figure 15. Concentration-discharge data for discrete samples from the Smith Creek streamgage by warm and cool season. 

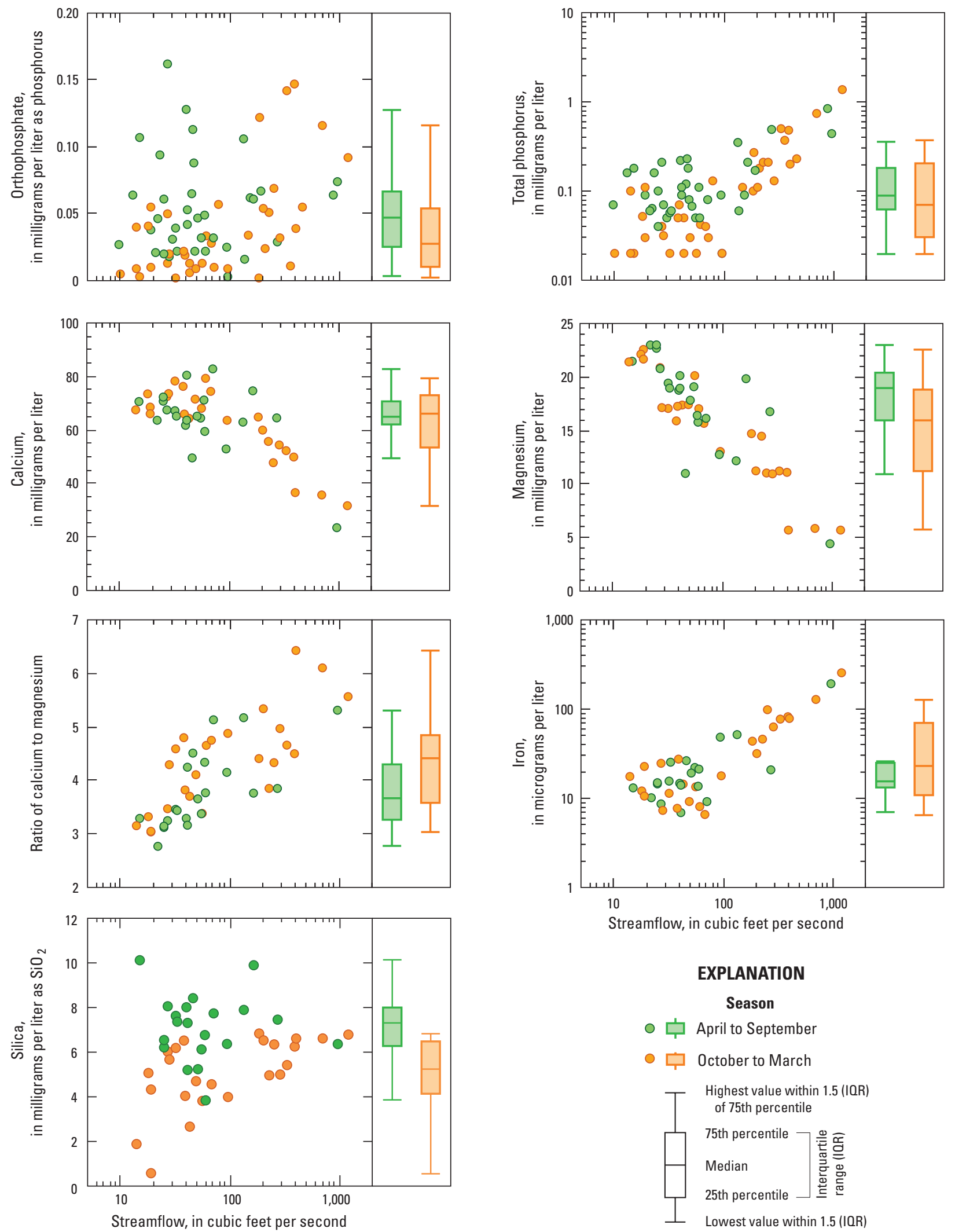

\section{EXPLANATION}

Season

○ April to September

○ October to March

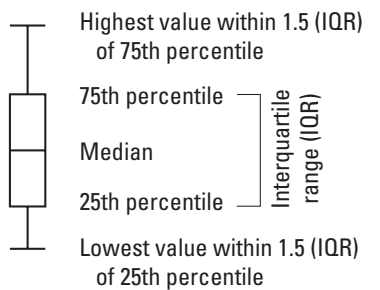

Figure 15. Concentration-discharge data for discrete samples from the Smith Creek streamgage by warm and cool season.-Continued 

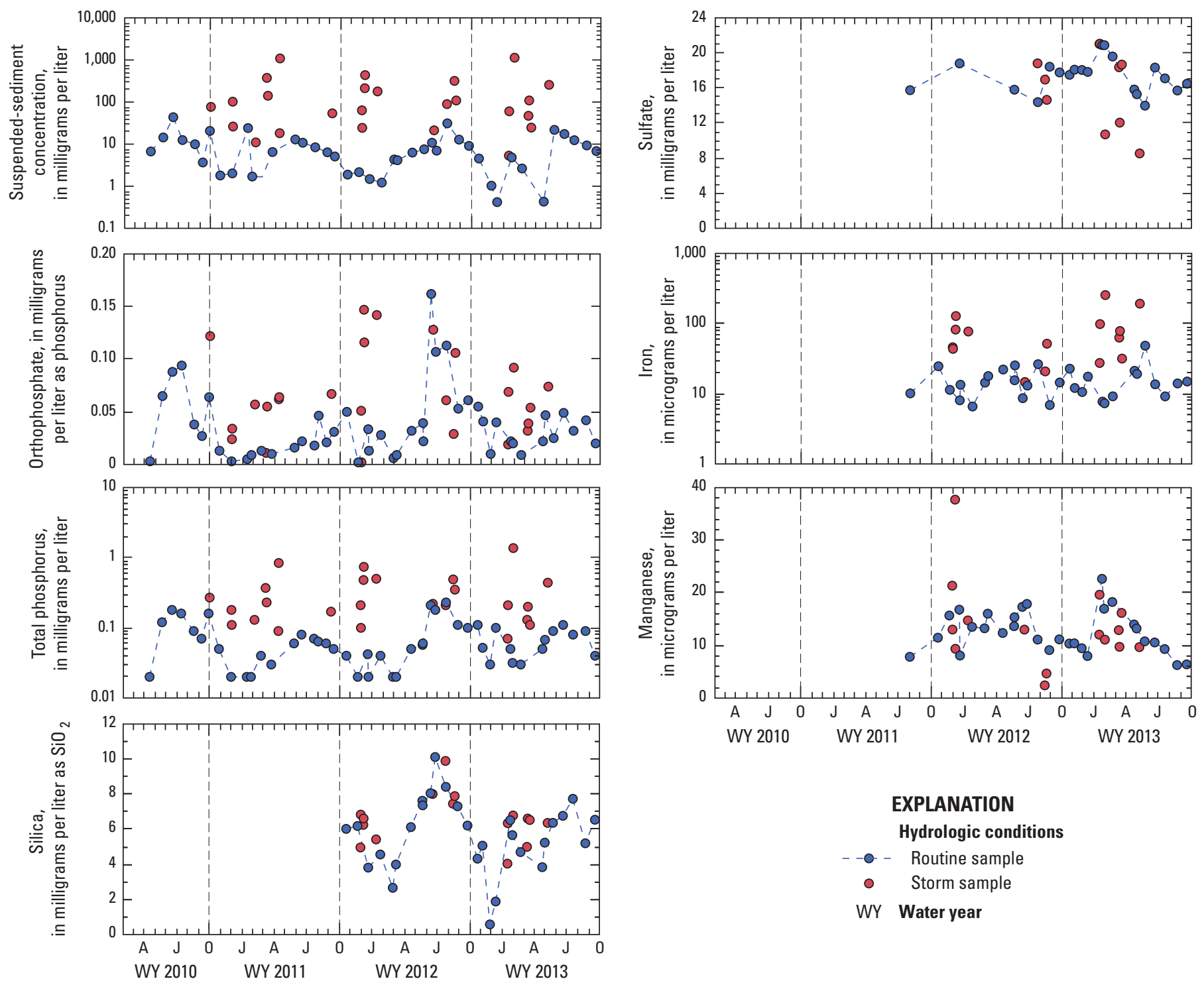

Figure 16. Concentrations of various constituents in discrete samples from the Smith Creek streamgage. 


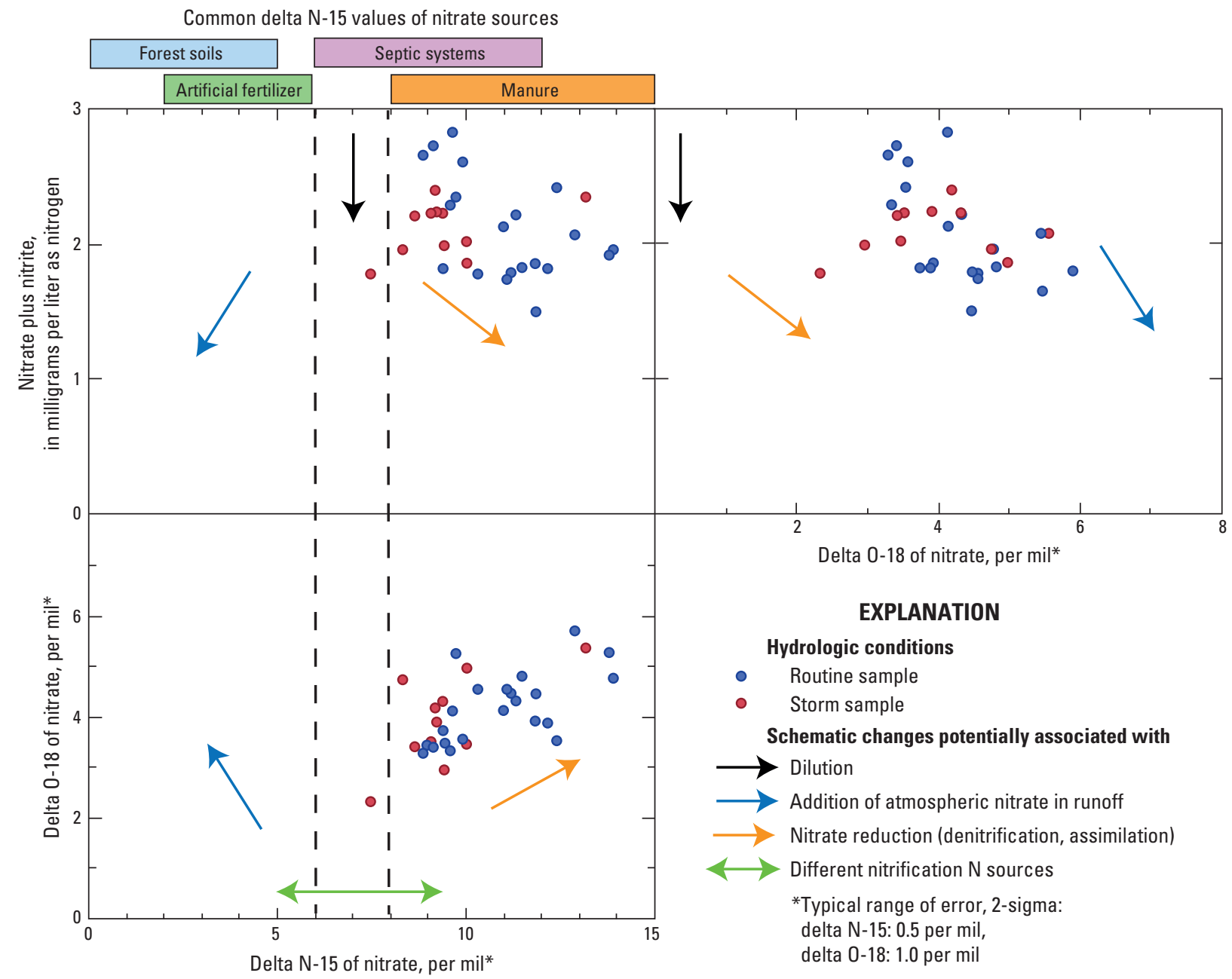

Figure 17. Variability in nitrate isotopes in discrete samples from the Smith Creek streamgage and potential causes for variability, 2011-2013.

\section{Surrogate Models for the Computation of Sediment and Nutrient Loads}

The discrete and continuous water-quality data were subsequently analyzed to explore the development of surrogate regression models to predict SSC and TN and TP concentrations. The development of these surrogate models is critical for the computation of constituent loads and an improved understanding of the watershed function.

\section{Model Development}

Standard USGS multiple linear regression methods were used to develop the best surrogate models (Helsel and Hirsch, 2002; Jastram and others, 2009; Rasmussen and others, 2009), and a detailed overview of the model selection process is offered in the Methods section. In addition to identifying the statistically best surrogate model, other commonly used model formulations were considered because these common formulations can provide continuity to other monitoring programs and could provide useful model inputs for other data analyses. The best models for the prediction of SSC and TN and TP concentrations, basic model diagnostics, and the other common model formulations were developed (table 11). For the best SSC, TN, and TP models, additional model diagnostics and information are presented in figures 18, 19, and 20. For each of the five models, a three-panel figure summarizes the model diagnostics using

- A plot of the observed versus the predicted concentrations,

- A plot of the observed and predicted concentrations relative to flow, and

- A plot of the residuals versus the predicted concentration.

In all five cases, the presented models are valid for the prediction of SSC, TP, and TN, but the models have subtle differences. For SSC, the best model included turbidity and flow terms, a classical model formulation. For prediction of $\mathrm{TN}$ concentrations, the strongest predictor always included the continuous nitrate data, likely because 70 to 80 percent of the nitrogen at the Smith Creek monitoring site occurs as nitrate. The best nitrate model included a flow-squared term, 
Table 11. Statistical results of the top-ranked suspended sediment, total nitrogen, and total phosphorus concentration estimation models for the Smith Creek streamgage with an alternative model presented for total nitrogen and total phosphorus.

[ln, natural logarithm; top-ranked models are listed in bold]

\begin{tabular}{|c|c|c|c|c|c|c|}
\hline $\begin{array}{c}\text { Explanatory } \\
\text { variables }\end{array}$ & $\begin{array}{c}\text { Model } \\
\text { coefficient }\end{array}$ & p-value & $\begin{array}{c}\text { Variance } \\
\text { inflation } \\
\text { factor }\end{array}$ & $\begin{array}{c}\text { Number of } \\
\text { observations }\end{array}$ & $\begin{array}{c}\text { Adjusted } \\
\text { coefficient of } \\
\text { determination }\end{array}$ & Mallows' Cp \\
\hline \multicolumn{7}{|c|}{ Suspended-sediment concentration } \\
\hline Intercept & 0.886 & 0.537 & & \multirow{3}{*}{67} & \multirow{3}{*}{0.833} & \multirow{3}{*}{5.23} \\
\hline $\ln ($ Flow $)$ & 0.135 & 0.332 & 3.42 & & & \\
\hline In(Turbidity) & 0.817 & $<0.001$ & 3.42 & & & \\
\hline \multicolumn{7}{|c|}{ Total nitrogen } \\
\hline Intercept & 0.056 & $<0.001$ & & \multirow{4}{*}{73} & \multirow{4}{*}{0.714} & \multirow{4}{*}{5.99} \\
\hline $\ln ($ Flow $)$ & 0.102 & $<0.001$ & 1.08 & & & \\
\hline $\ln (\text { Flow })^{2}$ & 0.062 & $<0.001$ & 1.33 & & & \\
\hline Nitrate-N & 0.418 & $<0.001$ & 1.42 & & & \\
\hline Intercept & -0.089 & 0.414 & & \multirow{3}{*}{73} & \multirow{3}{*}{0.602} & \multirow{3}{*}{6.84} \\
\hline $\ln ($ Flow $)$ & 0.092 & $<0.001$ & 1.06 & & & \\
\hline Nitrate-N & 0.331 & $<0.001$ & 1.06 & & & \\
\hline \multicolumn{7}{|c|}{ Total phosphorus } \\
\hline Intercept & 1.565 & 0.241 & & \multirow{4}{*}{73} & \multirow{4}{*}{0.816} & \multirow{4}{*}{2.94} \\
\hline $\ln ($ Flow $)$ & -0.238 & 0.004 & 3.44 & & & \\
\hline pH & -0.651 & 0.018 & 1.76 & & & \\
\hline In(Turbidity) & 0.563 & $<0.001$ & 4.07 & & & \\
\hline Intercept & -2.756 & $<0.001$ & & \multirow{3}{*}{73} & \multirow{3}{*}{0.803} & \multirow{3}{*}{6.76} \\
\hline $\ln$ (Flow) & -0.229 & 0.007 & 3.43 & & & \\
\hline $\ln$ (Turbidity) & 0.618 & $<0.001$ & 3.43 & & & \\
\hline
\end{tabular}

and because flow-squared models can have problems with load prediction (Moyer and others, 2012), also presented is a slightly less robust model for the prediction of TN that does not include a flow-squared term. For the prediction of TP concentrations, the best concentration model included flow and turbidity, as expected, but also included $\mathrm{pH}$ (with a negative coefficient), which seemed reasonable given that $\mathrm{pH}$ tended to decrease in Smith Creek during storm events and TP concentrations are highest during storm events. Because other published TP models sometimes do not commonly include a pH term (Jastram and others, 2009), an alternative TP concentration model is presented using flow and turbidity only as predictor variables.

\section{Interpretation of the Computed Loads}

After developing surrogate models for estimating SSC and concentrations of TN and TP, water-year loads of these constituents were computed by using the record of continuous flow (from the streamgage) and predicted water quality (from the regression equations presented above in table 11). Methods for the replacement of missing records are described in the Development of Surrogate Water-Quality Models and Computation of Loads section of the report. The USGS software program LOADEST was used for these computations because the computed load could be calculated with confidence intervals around the predicted load, which is necessary for comparisons between water years and sites.

The water-year SSC loads are presented in figure 21, along with the total flow for each complete water year. At a basic level, the total mass of sediment transported seems related to the total flow for a given year; however, annual runoff in 2012 was approximately 30 percent less than in 2011, but the sediment load in 2012 was approximately 60 percent less than in 2011, indicating that factors in addition to total annual flow (such as rainfall intensity, duration, and antecedent conditions) affect the amount of sediment transported. The mean annual sediment yield during 2011-2013 was 6,900 tons 

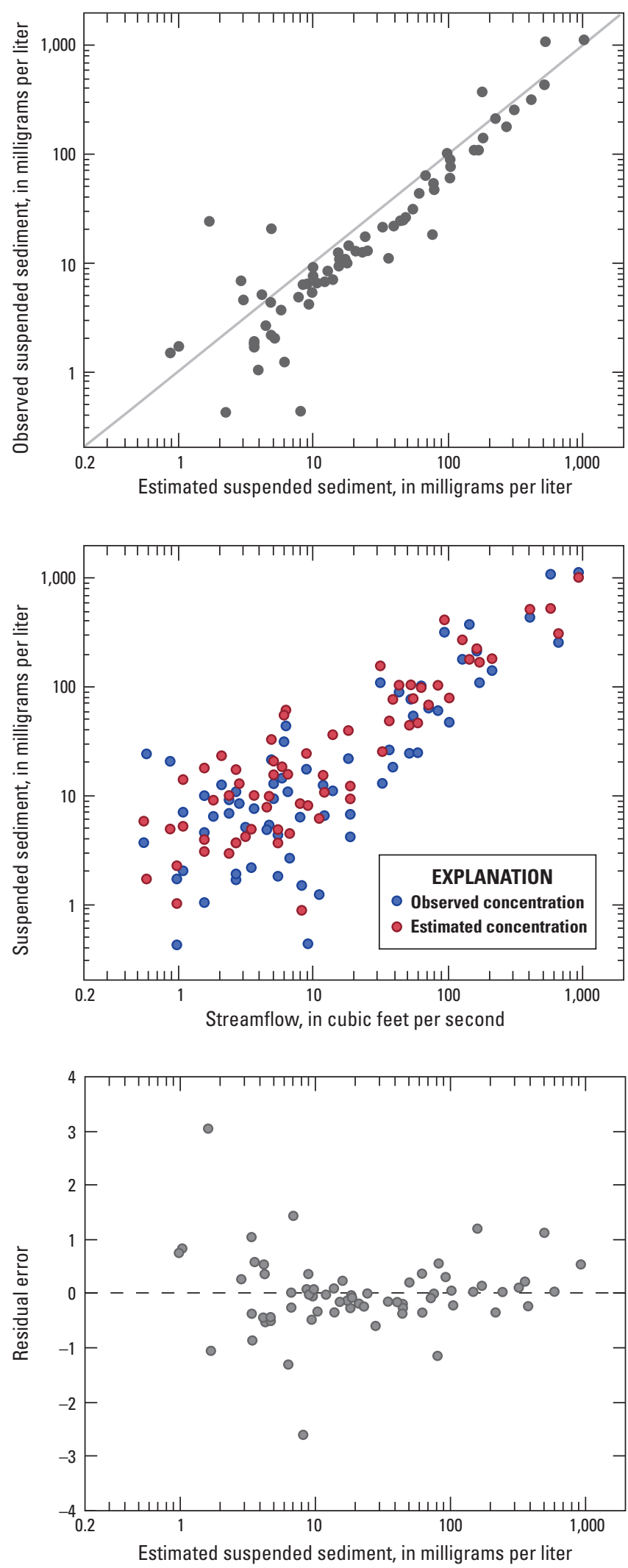

Figure 18. Observed and estimated values from the best suspended-sediment surrogate model for the Smith Creek streamgage and the residual plot of model predictions, 2010-2013. per year (ton/yr). Further insight into the sediment transport patterns is gained by looking at the cumulative sediment load for the entire monitoring period, as well as total flow and sediment load for each water year (fig. 22). Sediment loading within Smith Creek is highly episodic, with the eight largest observed storms generating nearly 90 percent of the estimated sediment load. In fact, three events during the spring of 2011 contributed nearly 50 percent of the Smith Creek sediment load, while the single largest storm contributed 30 percent of the sediment load during this 3.5 -year period. Although relatively similar streamflows occurred during 2011 and 2013 (fig. 8), substantially more sediment was transported in 2011, likely because of two large events in 2011, compared to numerous small events in 2013. Little sediment moved during 2012 because there were fewer large storm events. Sediment yields will be presented in the Comparison of WaterQuality Patterns Among Study Watersheds section to promote comparisons between sites.

Annual TN loading for Smith Creek in the 2013 water year was approximately 400,000 pounds (lb), which can be considered typical given that $2013 \mathrm{had}$ annual runoff totals that were close to the long-term mean at this site (fig. 23). Interestingly, the $\mathrm{TN}$ load accumulation (fig. 24) seems to occur more gradually and is less driven by episodic inputs than the SSC accumulation (fig. 22). This more gradual accumulation rate is likely related to the relatively elevated Smith Creek BFI and sustained groundwater contributions of nitrogen that support relatively steady nitrogen loading that is only occasionally augmented by significant stormflow events. Additional years of monitoring will be needed before comparing TN accumulation rates between water years.

The water-year TP loads are presented in figure 25 , along with the total flow for each complete water year. Given the typically strong association between sediment and phosphorus, the annual loading patterns for TP (fig. 26) look very similar to the loading plots for suspended-sediment load (fig. 22), with the greatest loading occurring during the wettest year. The mean annual total phosphorus yield from 2011 to 2013 was 21,390 pounds, which can be considered typical given that 2011-2013 had relatively typical hydrology. The eight largest storm events contributed the bulk of the sediment load; however, similar to the nitrogen accumulation plot, base-flow periods contribute materially to the annual loading. For example, nearly 10 percent of the total load was already delivered to Smith Creek prior to the three large storm events in the spring of 2011. In fact, during the relatively drier 2012 water year, approximately half of the TP was transported by Smith Creek during relatively low-flow periods. In short, the TP loadings are driven by storm events and base-flow contributions. 

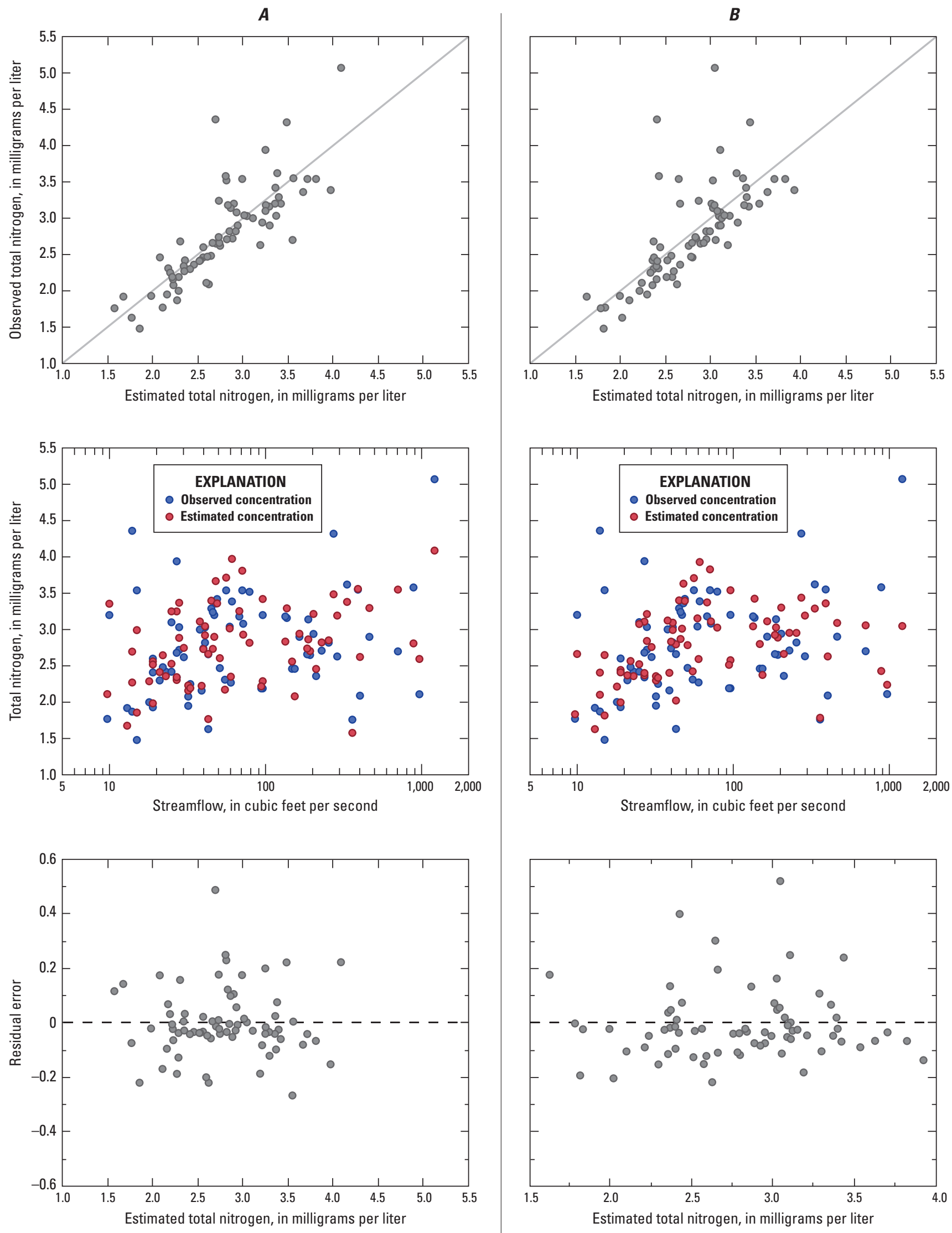

Figure 19. Observed and estimated concentrations of total nitrogen from the $(A)$ best and $(B)$ alternative surrogate models for the Smith Creek streamgage and the residual plot of model predictions, 2010-2013. 

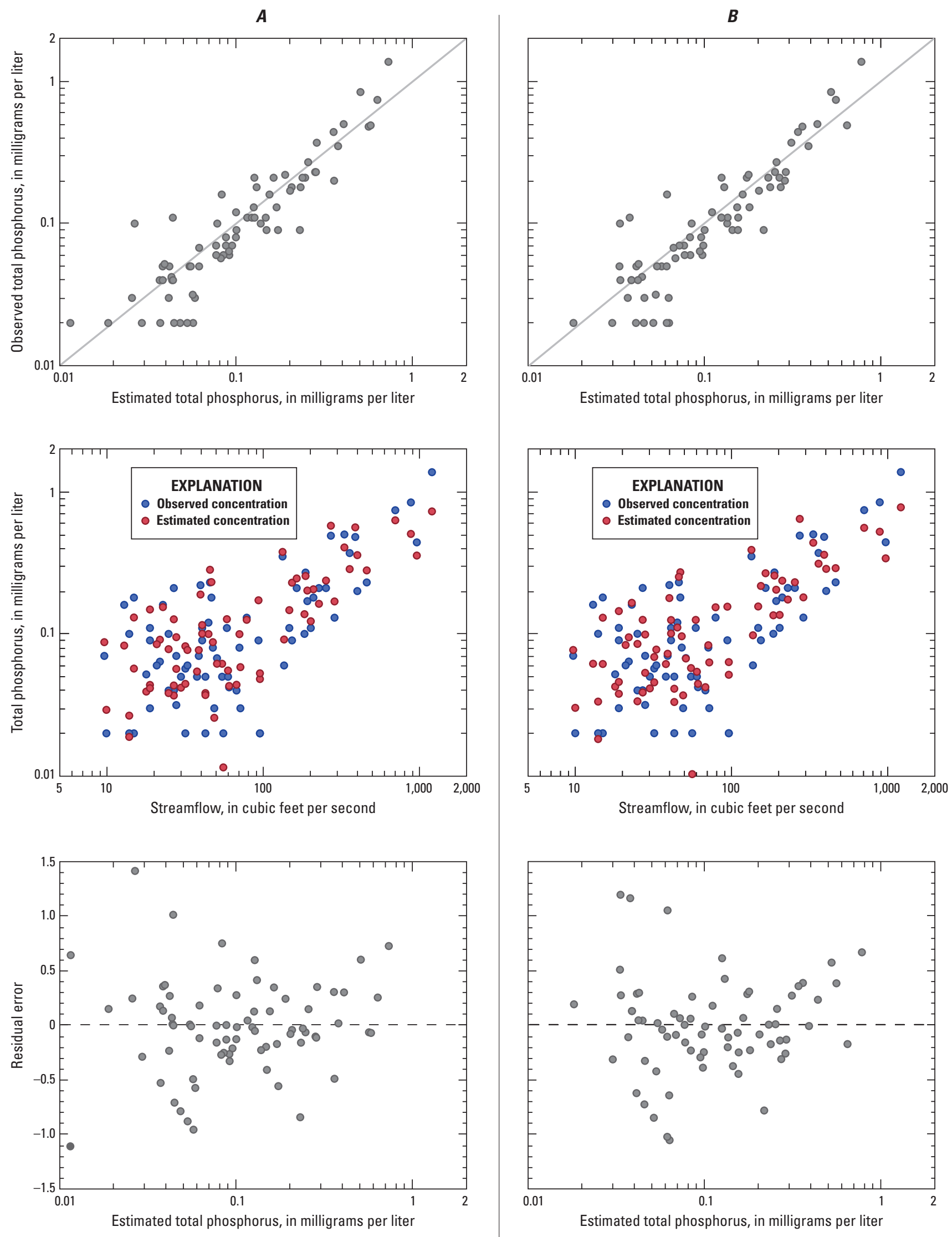

Figure 20. Observed and estimated concentrations of total phosphorus from the $(A)$ best and $(B)$ alternative surrogate models for the Smith Creek streamgage and the residual plot of model predictions, 2010-2013. 

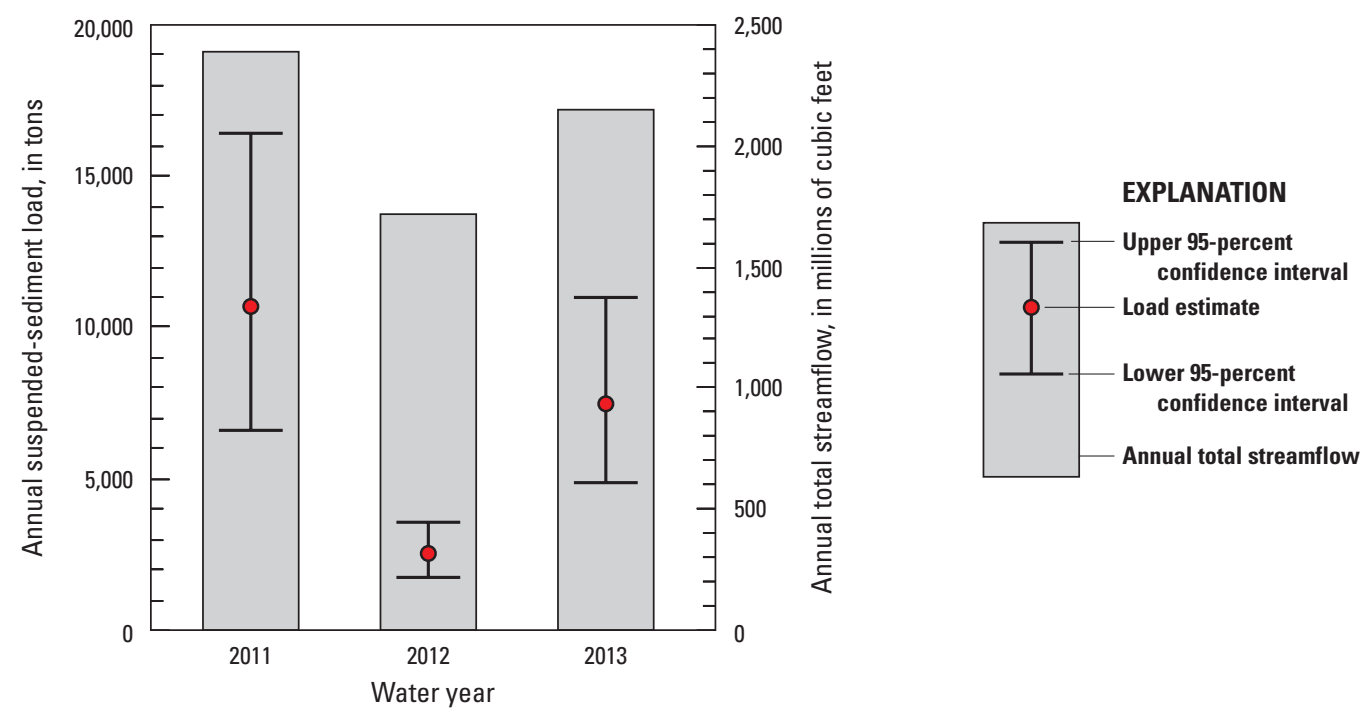

Figure 21. Suspended-sediment load and total annual streamflow at the Smith Creek streamgage for water years 2011 through 2013.

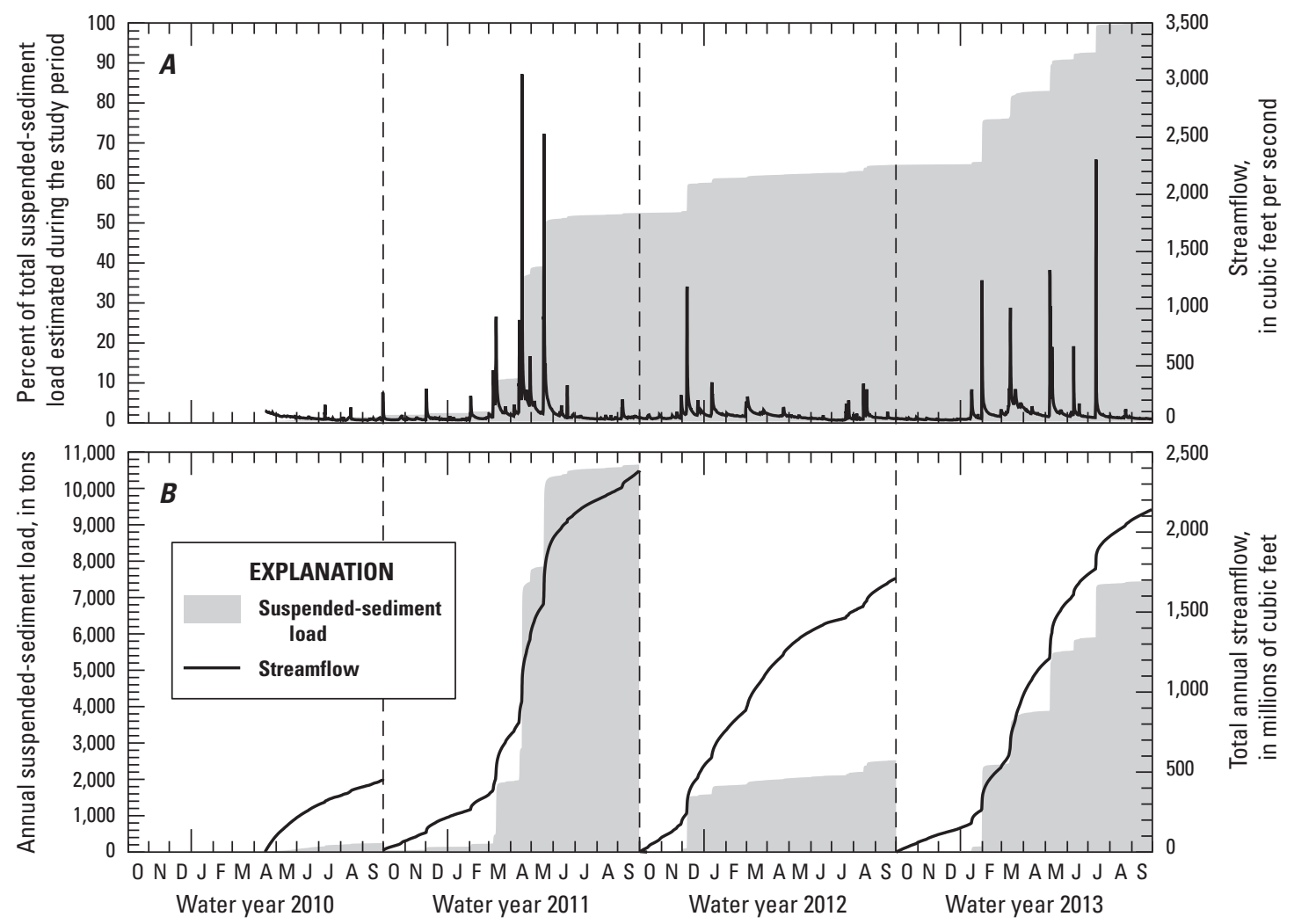

Figure 22. Suspended-sediment load at the Smith Creek streamgage for water years 2010 through 2013 along with $(A)$ the percentage of load accumulated and the hydrograph during the period of study and $(B)$ the accumulation of load and streamflow in each water year. 

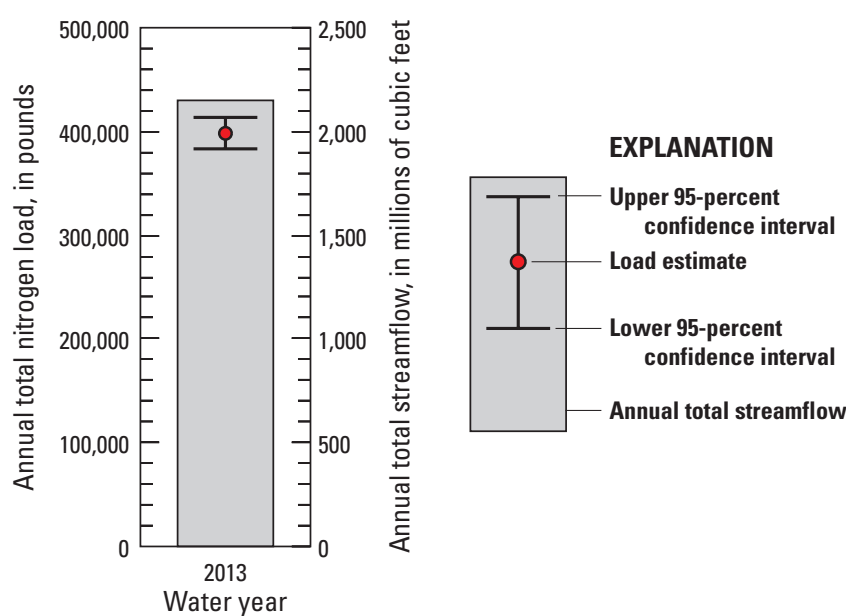

Figure 23. Total nitrogen load and total annual streamflow at the Smith Creek streamgage for the 2013 water year

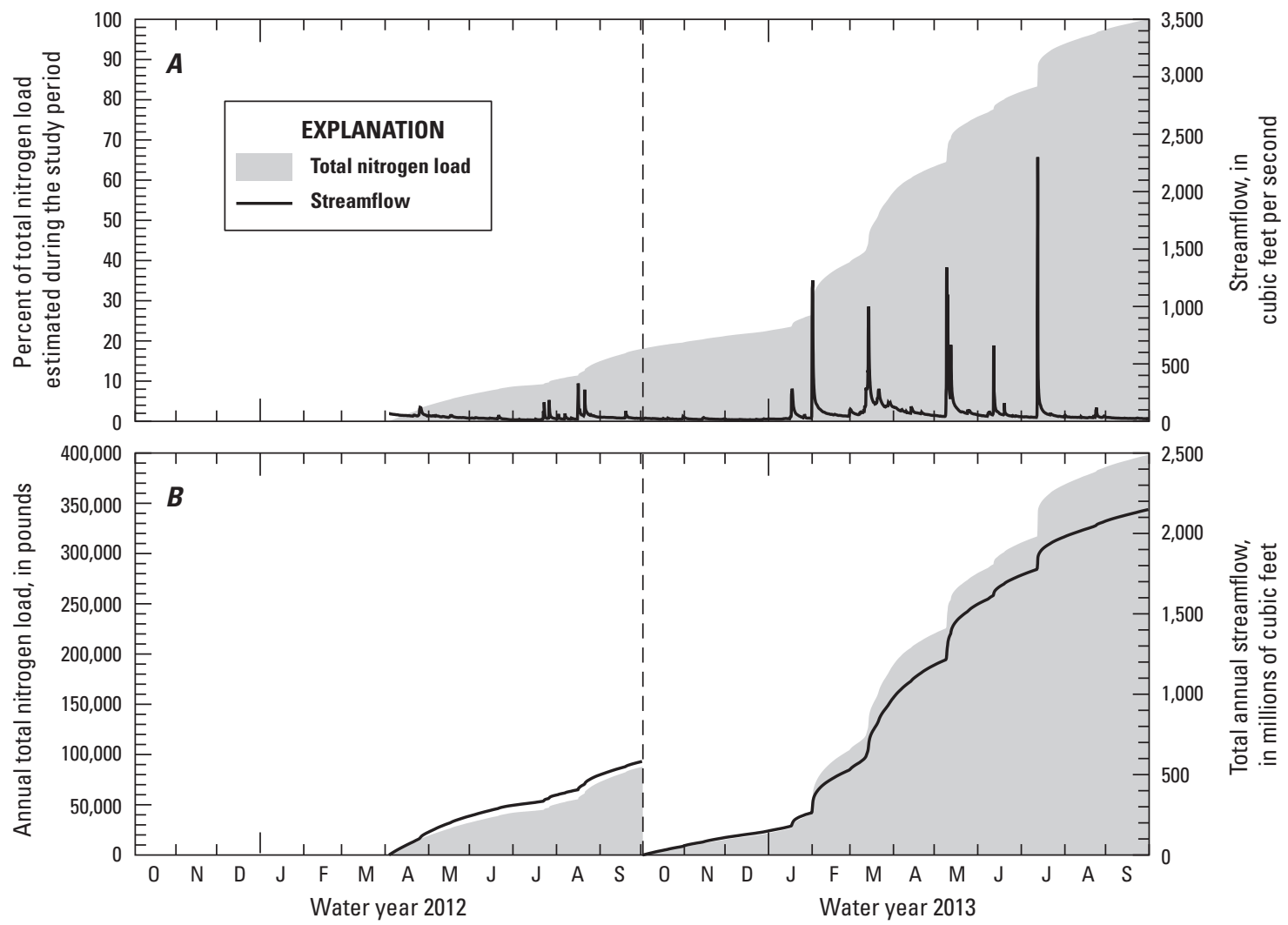

Figure 24. (A) The percentage of total nitrogen load accumulated and the hydrograph during the period of study and $(B)$ the accumulation of load and streamflow at the Smith Creek streamgage for water years 2012 and 2013. 

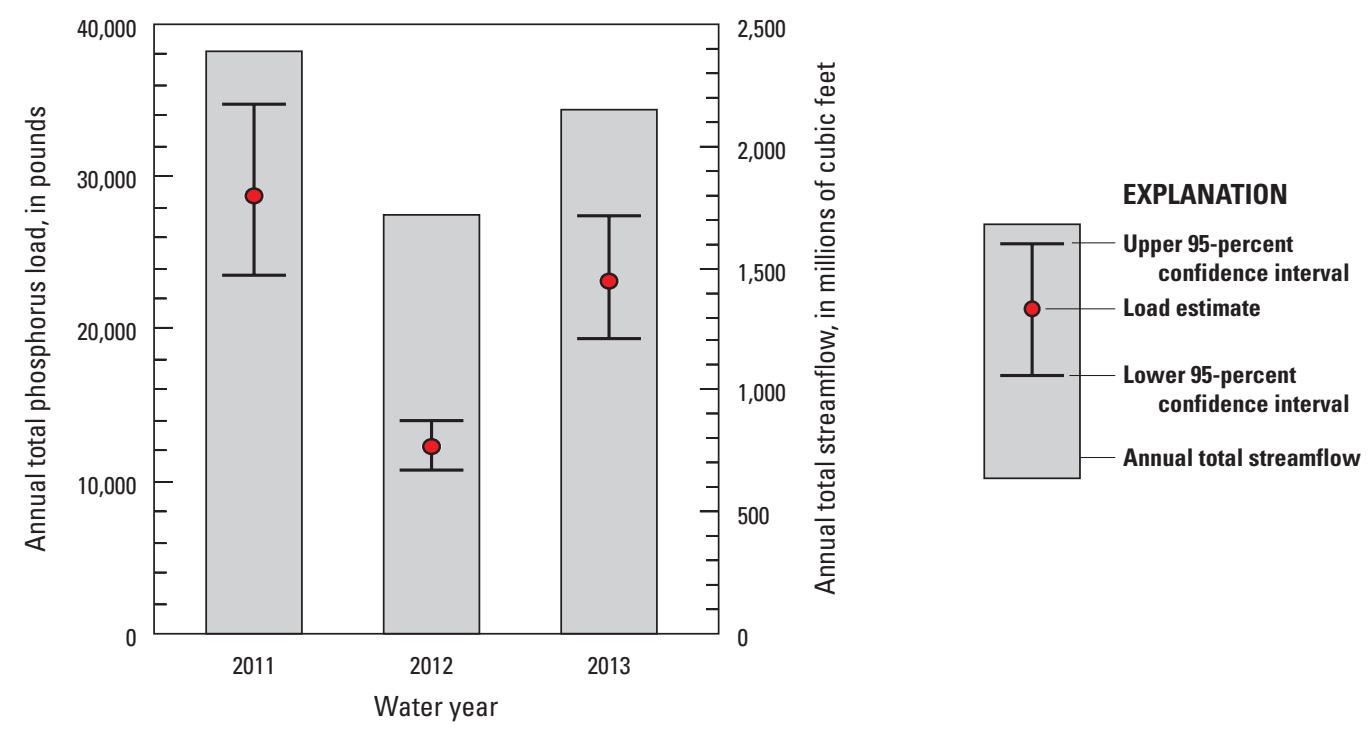

Figure 25. Total phosphorus load and total annual streamflow at the Smith Creek streamgage for water years 2011 through 2013.

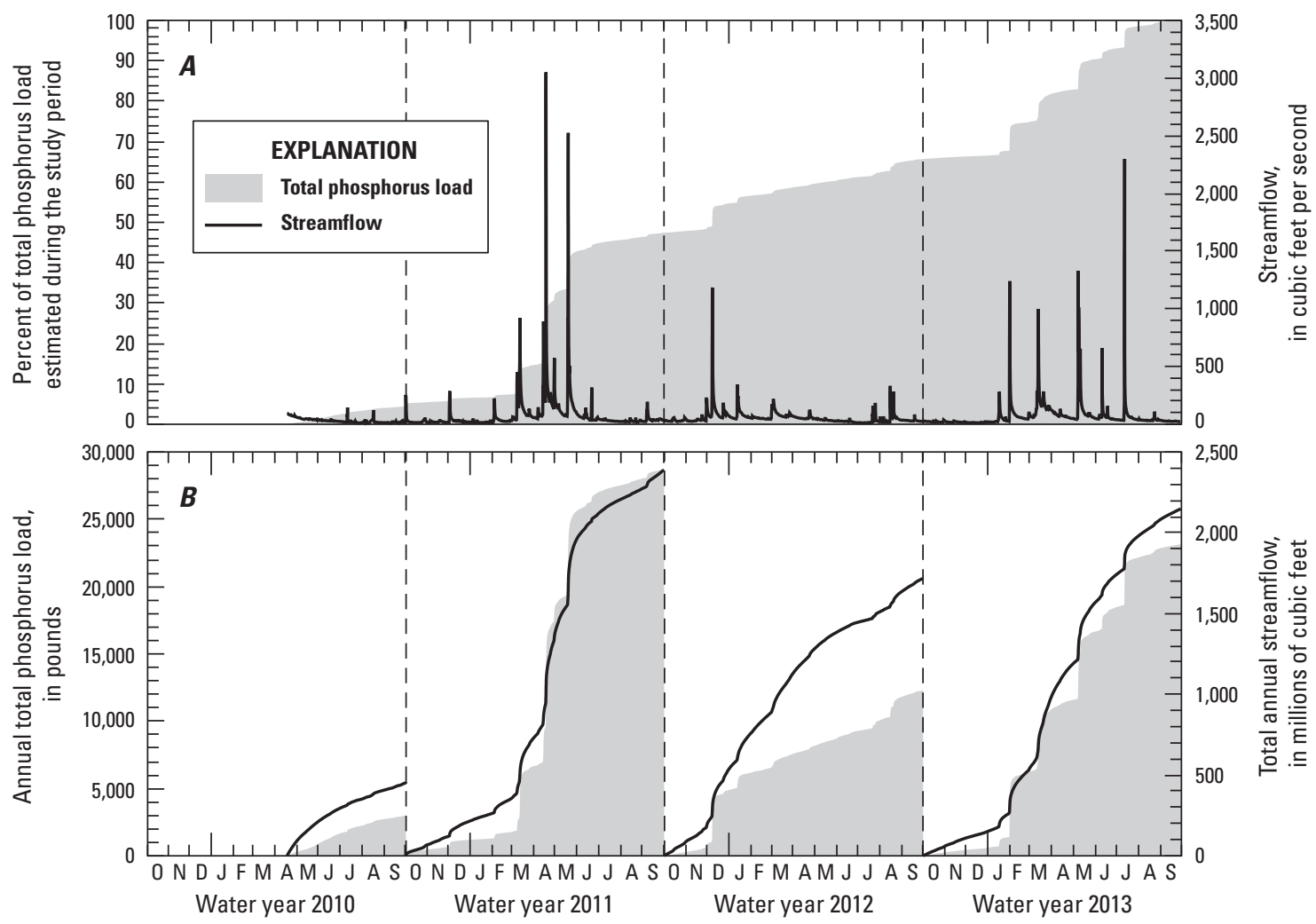

Figure 26. (A) The percentage of total phosphorus load accumulated and the hydrograph during the period of study and $(B)$ the accumulation of load and streamflow at the Smith Creek streamgage for water years 2010 through 2013. 


\section{Spatial Patterns in Water Quality}

A series of synoptic sampling events was performed to provide an understanding of the spatial patterns in water quality, as well as information related to sources, sinks, and transport processes for nutrients. For synoptic water-quality sampling, 38 sites were selected throughout the Smith Creek watershed; sites were selected to isolate various tributaries, major springs, and stream reaches. During a given synoptic sampling event, all sites were sampled during no more than a 36-hour period of stable base flow. By sampling all sites under steady flow conditions, a consistent understanding of the chemical and hydrologic spatial variability within the watershed can be developed. Four synoptic sampling events were performed within the Smith Creek watershed over a range of base-flow conditions (low base flow through high base flow), which resulted in slightly different hydrologic conditions being characterized by each synoptic event (fig. 27). During the relatively low-flow synoptic (August 2011), the flows in Smith Creek were largely generated within the upper part of the basin (by a drainage area approximately $43 \mathrm{mi}^{2}$ ), with the lower part of the watershed serving essentially as an aqueduct that conveyed the flows from the headwaters out of the basin, likely because the zero- and first-order streams on the eastern side of the watershed were not flowing under such dry conditions. Conversely, during the high base-flow synoptic sampling event (December 2011), the flow in Smith
Creek increased in the downstream direction, likely because all of the zero- and first-order streams on the eastern side of the watershed were flowing. During the intermediate flow conditions, it is likely that only some of the eastern watershed boundary tributaries were flowing, or that they were flowing at low levels.

A few synoptic-monitoring stations deserve special mention because their measured discharge relative to their topographically derived drainage area is unusual. The synoptic site located at the mouth of Dry Fork (site 9) generally has very low discharge, typically less than $1 \mathrm{ft}^{3} / \mathrm{s}$, even though it drains a basin that is slightly larger than $20 \mathrm{mi}^{2}$ (fig. 27). The prevalence of sinkholes within this subwatershed (fig. 2C) is hypothesized to result in substantial connectivity to groundwater and loss of streamflow and precipitation to groundwater recharge. Conversely, the Lacey Spring synoptic site (originally sampled as site 10 during the first three synoptic events and later approximately 1,000 feet upstream at site 42 during the fourth synoptic event) has a relatively small topographically derived drainage area, but a much larger than expected discharge value that commonly exceeds $10 \mathrm{ft}^{3} / \mathrm{s}$ (fig. 27). This relatively large discharge from Lacey Spring commonly represents almost half of the flow to Smith Creek in this headwater area, indicating that the waterquality composition of Lacey Spring will strongly affect that of Smith Creek.

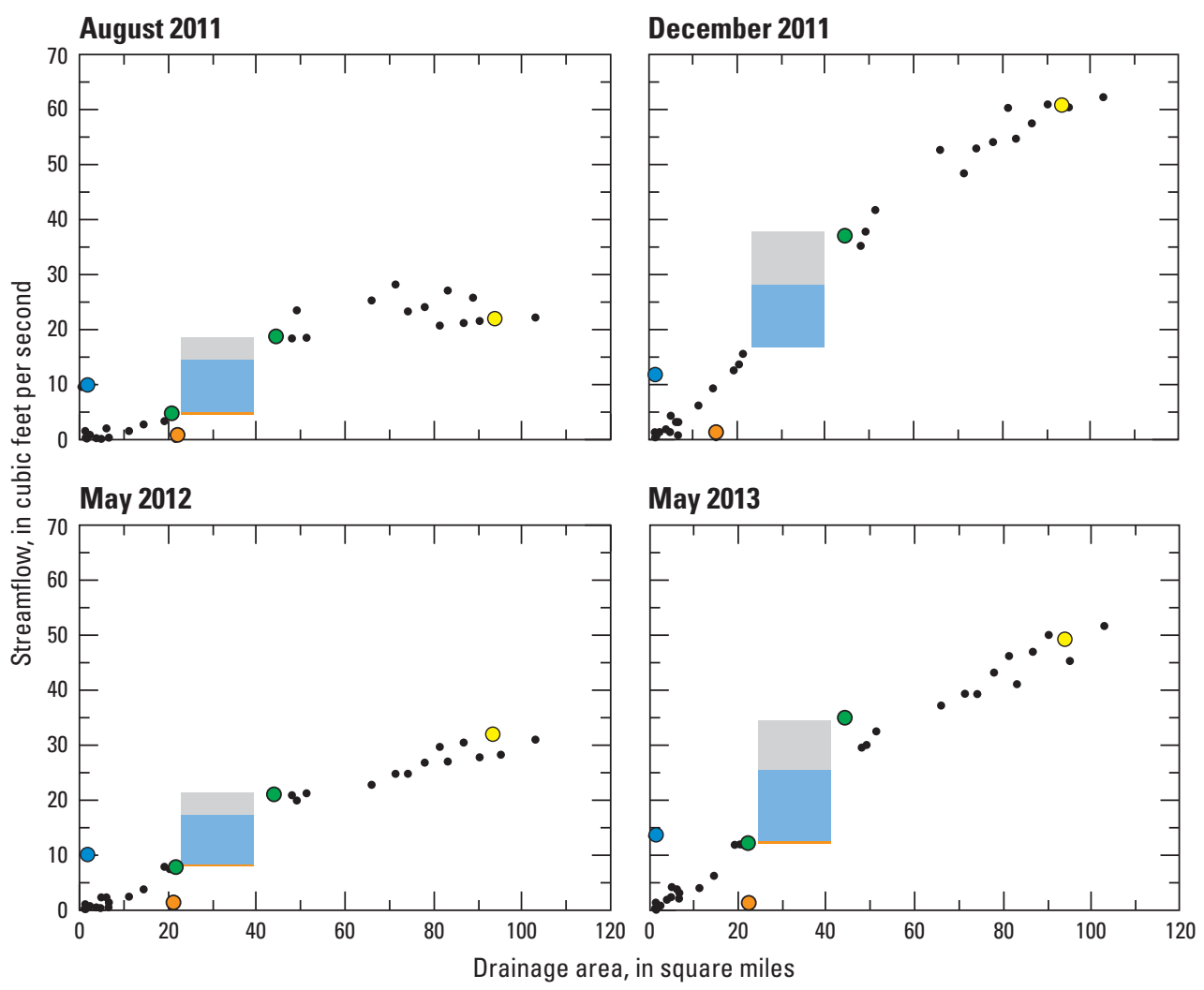

\begin{tabular}{c} 
EXPLANATION \\
Streamflow inputs between \\
site 8 and site 11 \\
From Dry Fork (site 9) \\
From Lacey spring (site 10) \\
Unaccounted for by synoptic \\
sampling locations \\
Synoptic sampling location \\
Smith Creek streamgage \\
(site 32) \\
D Dry Fork (site 9) \\
\hline$\quad$ Lacey spring (site 10) \\
Site 8 and site 11 \\
Other
\end{tabular}

Figure 27. Streamflow inputs and drainage area for samples collected during each synoptic sampling event between sites 8 and 11 in the Smith Creek watershed. 
Little evidence of direct groundwater discharge into the Smith Creek stream channel was observed during synoptic sampling, with the exception of the reach between Smith Creek stations 8 and 11, which consistently demonstrated an excess of flow at station 11 that cannot be accounted for by the flow at station 8 and the contributions from Dry Fork and Lacey Spring. Given that site 11 is near the bedrock contact between the upper carbonate section of the watershed and the lower shale portion of the watershed, groundwater is likely being forced into Smith Creek within this reach because of contrasting permeability along this bedrock contact. The amount of unmeasured flow entering Smith Creek between stations 8 and 11 seemed to vary with hydrologic conditions, with greater groundwater inputs during wetter synoptic sampling events. These unmeasured flow contributions were assumed to be direct discharges to Smith Creek, rather than an unmonitored spring or tributary, because subsequent in-stream temperature monitoring confirmed extensive discharge of relatively cool groundwater directly into the bottom of Smith Creek at many points in the vicinity of Lacey Spring (Kurt J. McCoy, U.S. Geological Survey, oral commun., 2014).

Strong variability in nitrogen concentrations and loads were observed throughout the Smith Creek Watershed during the synoptic sampling; however, consistent spatial patterns were observed between monitoring sites for all four synoptic events (figs. 28 and 29). TN concentrations were consistently low $(<0.5 \mathrm{mg} / \mathrm{L})$ for sites that drained the forested tributaries on the eastern edge of the watershed. Conversely, concentrations were commonly in the $5-8-\mathrm{mg} / \mathrm{L}$ range for the various springs in the headwaters of the watershed. In general, and for all four synoptic events, $\mathrm{TN}$ concentrations were highest in the headwaters of the basin and decreased in the downstream direction to values of $2-3 \mathrm{mg} / \mathrm{L}$ at the streamgage (fig. 28).

Although elevated TN concentrations occurred at the spring sites, measured discharge strongly affected the observed nitrogen loadings in the watershed. Several of the springs with elevated nitrogen concentrations had small discharge values, which resulted in relatively low loadings, whereas the discharge at Lacey Spring (sites 10 and 42), combined with moderate TN concentrations, resulted in dominant nitrogen loadings to Smith Creek (fig. 29). During the driest synoptic sampling event (August 2011), maximum stream loads occurred in the central part of the watershed (downstream of Lacey Spring and in the area of the confluence with War Branch); nitrogen loads decreased downstream of this location, likely because of in-stream processes such as uptake and denitrification. During wetter conditions similar to the December 2011 synoptic event, elevated nitrogen loadings were still contributed by Lacey Spring, but downstream of Lacey Spring, nitrogen concentrations decreased, and nitrogen loads continued to increase, likely because of relatively low nitrogen concentrations from the streams entering from the eastern edge of the watershed.

Phosphorus patterns in Smith Creek also demonstrated major spatial concentration and load patterns that were similar between synoptic sampling events (figs. 30 and 31). In general, low phosphorus concentrations were observed at the spring sites and the forested mountain sites. Relative to the low phosphorus concentrations in the headwaters, the monitoring site on Dry Fork (site 9) demonstrated slightly elevated phosphorus concentrations but insufficient discharge to be a major source of phosphorus. Phosphorus concentrations and loads appear to increase markedly in the lower part of Smith Creek, generally between stations 25 and 26, and these elevated loads persist throughout the remainder of the downstream part of Smith Creek.

The reach of Smith Creek between sites 25 and 26 was subsequently sampled at a much finer spatial resolution whereby water-quality samples were collected from all inflowing tributaries and point sources within the reach. Results of this water-quality sampling indicated that elevated phosphorus concentrations $(0.34 \mathrm{mg} / \mathrm{L})$ were being discharged from a permitted point source within this reach and that low concentrations $(0.003 \mathrm{mg} / \mathrm{L})$ of phosphorus were in the flowing tributaries. The sampled point source appears to be the cause of increased phosphorus loading in the lower part of Smith Creek. The discharge permit for this point source established limits for the release of flow, $\mathrm{pH}$, chemical/biological oxygen demand, suspended solids, E. coli, total residual chlorine, oil, and grease; however, because of the size of the point source discharge ( 0.30 million gallons per day or less), no limitation has been placed on the concentrations of released nutrients. 

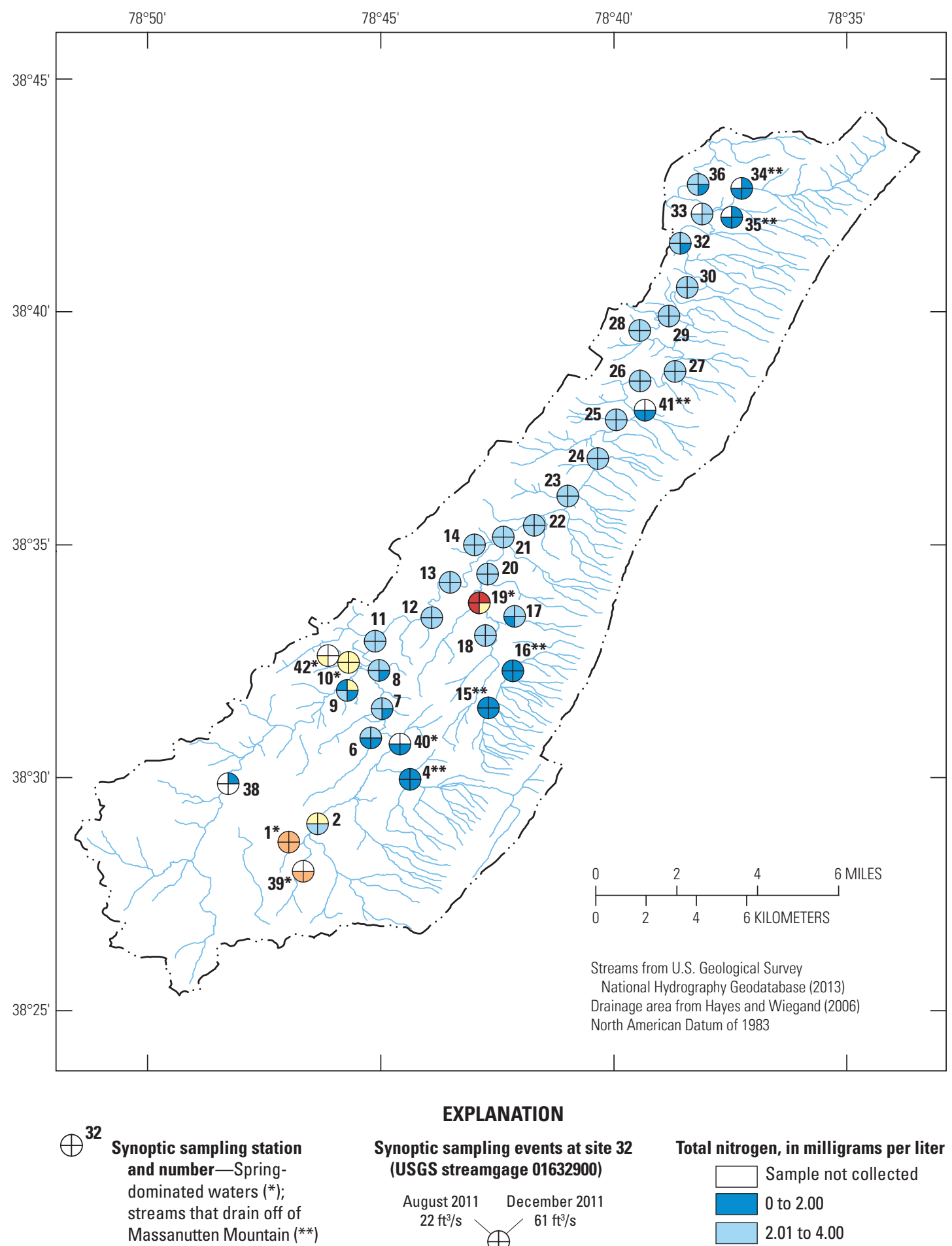

EXPLANATION

Synoptic sampling events at site 32 Total nitrogen, in milligrams per liter (USGS streamgage 01632900)

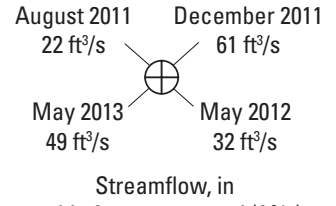

cubic feet per second $\left(\mathrm{ft}^{3} / \mathrm{s}\right)$

\begin{tabular}{l}
\hline Sample not collected \\
0 to 2.00 \\
2.01 to 4.00 \\
4.01 to 6.00 \\
6.01 to 8.00 \\
8.01 to 10.00
\end{tabular}

Figure 28. Monitoring locations, total nitrogen concentrations measured during each synoptic sampling event, and the stream network in the Smith Creek watershed. 


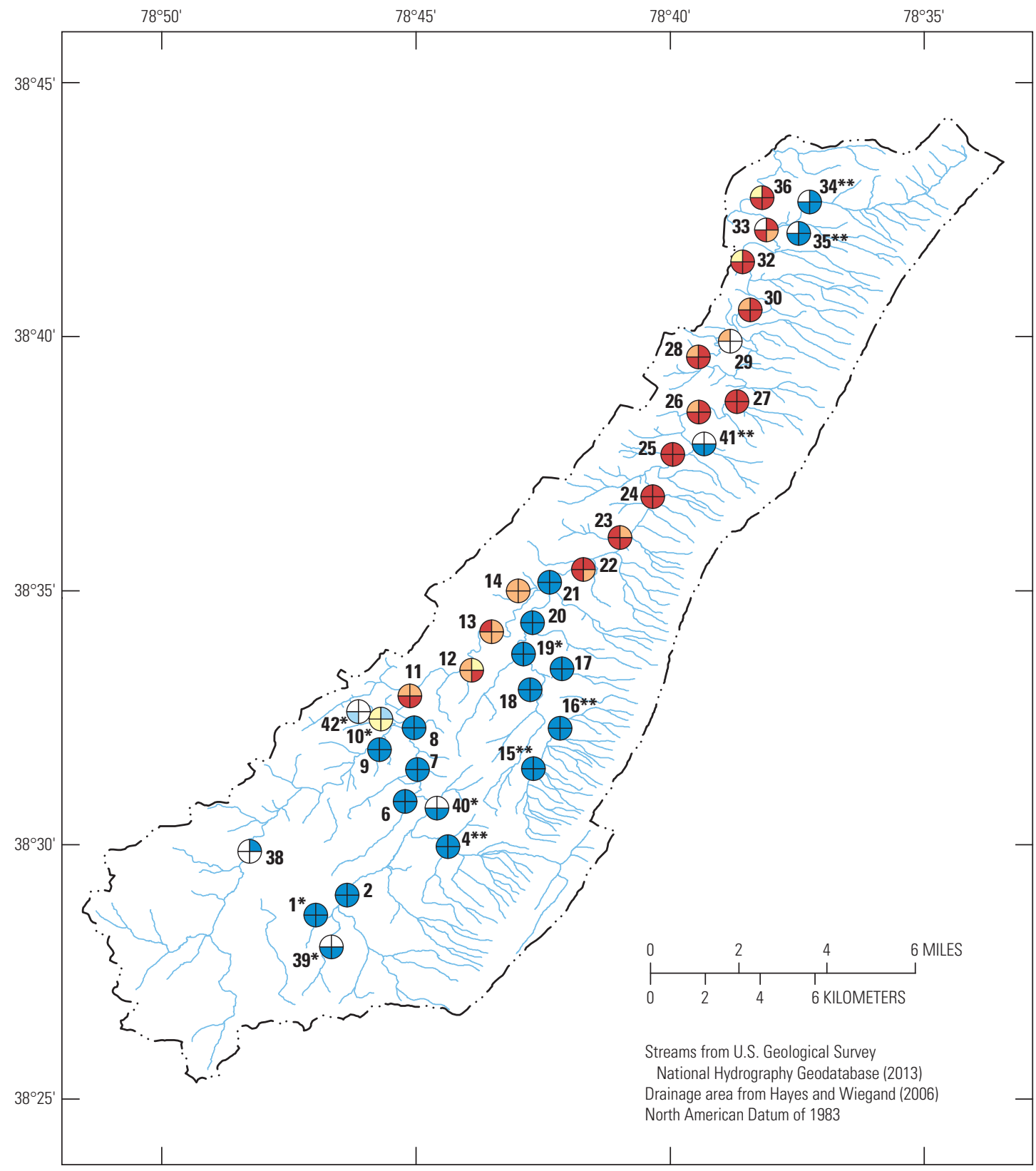

$\bigoplus^{32}$ Synoptic sampling station and number-Springdominated waters $(*)$; streams that drain off of Massanutten Mountain (**)
EXPLANATION

Synoptic sampling events at site 32 (USGS streamgage 01632900)

$$
\begin{aligned}
& \text { August } 2011 \text { December } 2011 \\
& 22 \mathrm{ft}^{3} / \mathrm{s} \quad 61 \mathrm{ft}^{3} / \mathrm{s} \\
& 506 \mathrm{lb} / \mathrm{day} \quad 1,199 \mathrm{lb} / \mathrm{day} \\
& \begin{array}{c}
\text { May 2013 } \\
49 \mathrm{ft}^{3} / \mathrm{s} \\
714 \mathrm{lb} / \mathrm{day}
\end{array} \begin{array}{c}
\text { May } 2012 \\
32 \mathrm{ft} / \mathrm{s} / \mathrm{l} / \mathrm{day}
\end{array} \\
& \text { Streamflow, in } \\
& \text { cubic feet per second }\left(\mathrm{ft}^{3} / \mathrm{s}\right) \\
& \text { and maximum total nitrogen load } \\
& \text { in pounds per day (lb/day) }
\end{aligned}
$$

Percent of maximum total nitrogen load by event

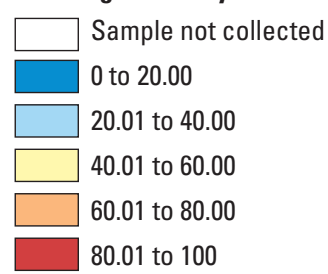

Figure 29. Monitoring locations, the percentage of the maximum total nitrogen load measured during each synoptic sampling event, and the stream network in the Smith Creek watershed. [Note that percentages are only valid for comparisons within a single synoptic event, not between synoptic events.] 

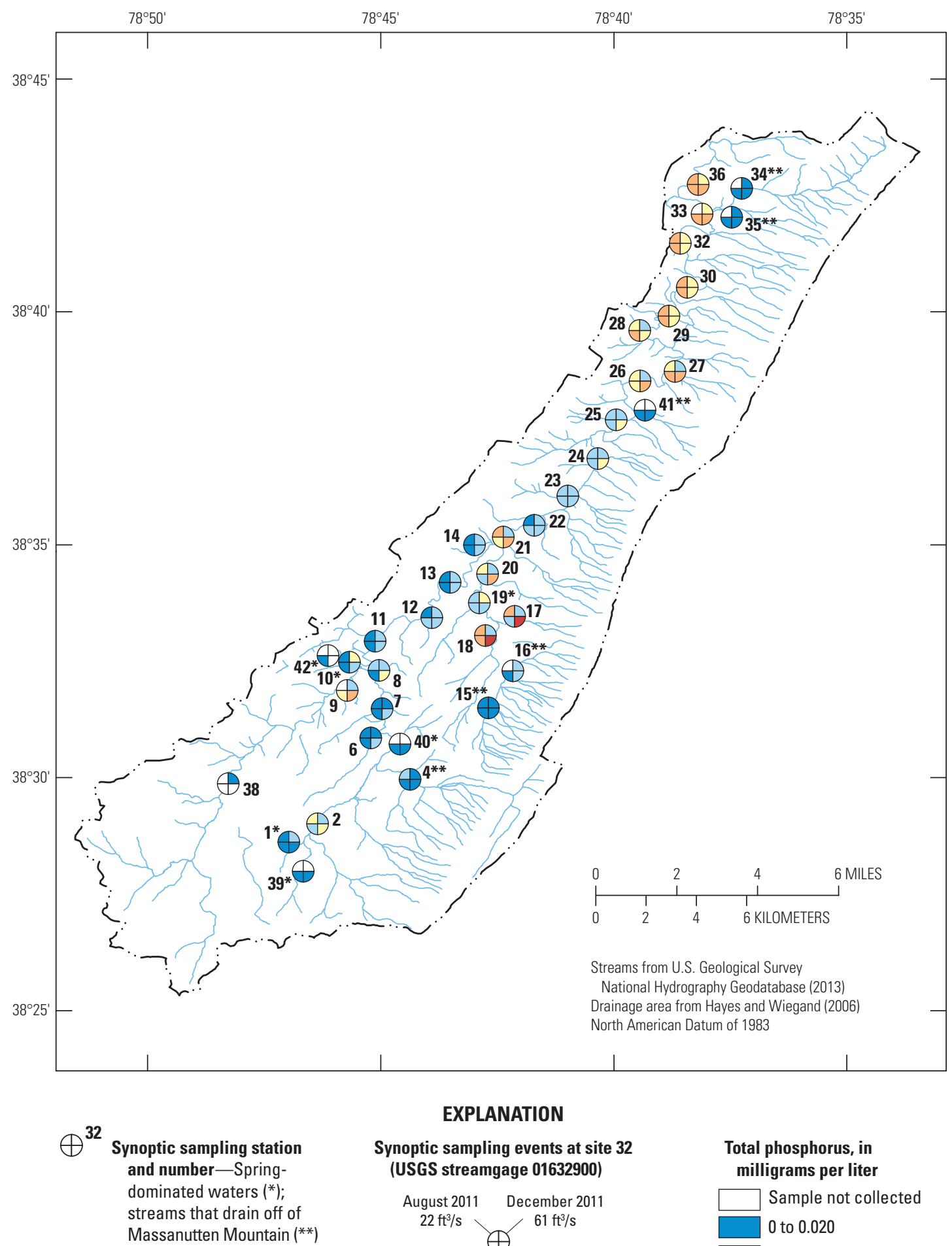

\section{EXPLANATION}

Synoptic sampling events at site 32 (USGS streamgage 01632900)

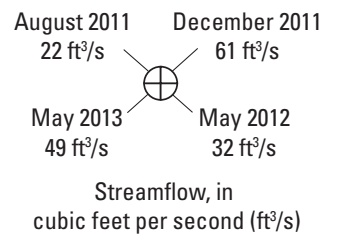

\begin{tabular}{|c|}
\hline $\begin{array}{l}\text { Total phosphorus, in } \\
\text { milligrams per liter }\end{array}$ \\
\hline Sample not collected \\
\hline 0 to 0.020 \\
\hline 0.021 to 0.040 \\
\hline 0.041 to 0.060 \\
\hline 0.061 to 0.080 \\
\hline 0.081 to 0.100 \\
\hline
\end{tabular}

Figure 30. Monitoring locations, the total phosphorus concentration measured during each synoptic sampling event, and the stream network in the Smith Creek watershed. 

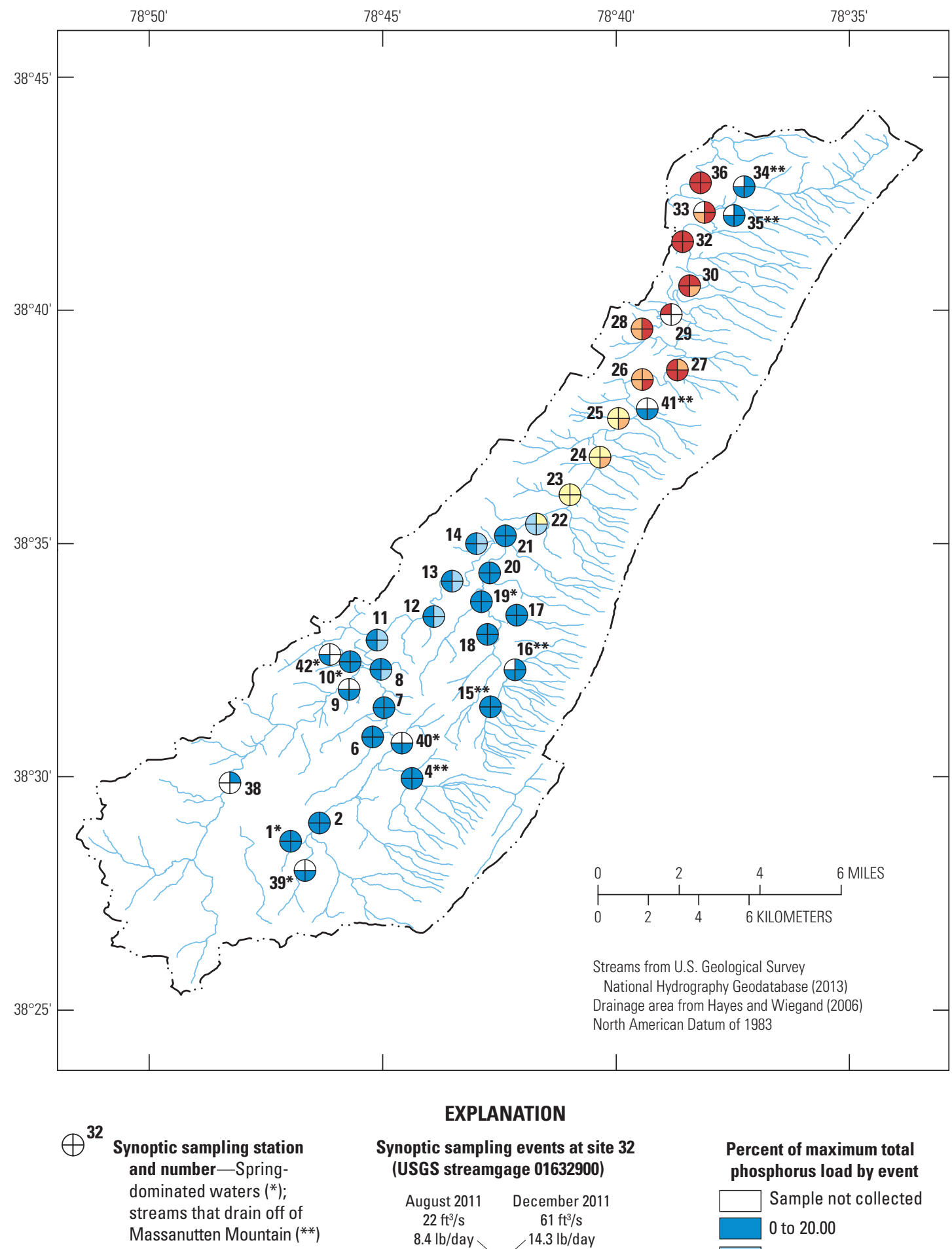

EXPLANATION

Synoptic sampling events at site 32 (USGS streamgage 01632900)

$$
\begin{aligned}
& \text { August } 2011 \text { December } 2011 \\
& 22 \mathrm{ft}^{3} / \mathrm{s} \quad 61 \mathrm{ft}^{3} / \mathrm{s} \\
& 8.4 \mathrm{lb} / \text { day } \quad 14.3 \mathrm{lb} / \text { day } \\
& \text { May 2013 } 2012 \\
& 49 \mathrm{ft}^{3} / \mathrm{s} \quad 32 \mathrm{ft}^{3} / \mathrm{s} \\
& 20.1 \mathrm{lb} / \text { day } \quad 10.4 \mathrm{lb} / \text { day } \\
& \text { Streamflow, in } \\
& \text { cubic feet per second }\left(\mathrm{ft}^{3} / \mathrm{s}\right) \\
& \text { and maximum total nitrogen load, } \\
& \text { in pounds per day (lb/day) }
\end{aligned}
$$

\begin{tabular}{|c|}
\hline Sample not collected \\
\hline 0 to 20.00 \\
\hline 20.01 to 40.00 \\
\hline 40.01 to 60.00 \\
\hline 60.01 to 80.00 \\
\hline 80.01 to 100 \\
\hline
\end{tabular}

Percent of maximum total phosphorus load by event

Figure 31. Monitoring locations, the maximum total phosphorus load measured during each synoptic sampling event, and the stream network in the Smith Creek watershed. [Note that percentages are only valid for comparisons within a single synoptic event, not between synoptic events.] 
Because of the general consistency in the synoptic nutrient concentrations at each monitoring site, compared to the between-site variability, the water-quality samples for all four synoptic events were analyzed by using a single cluster analysis to explore spatial patterns in the water quality that persisted between synoptic events. Four distinct clusters were formed, with each cluster representing a different "water type" within the Smith Creek watershed (fig. 32). These water types are identified and described below:

Cluster \#1 - Smith Creek type - This cluster included most sampling sites located on the mainstem of Smith Creek. The number of sampling locations included in this group across all sampling events suggests that the water quality of the Smith Creek main channel was relatively homogeneous, despite some unique conditions measured in the headwaters. The ionic strength of these waters was higher than that of the relatively dilute streams that flowed off of the eastern edge of the watershed (included in cluster \#4), but lower than the headwater springs (cluster \#2) and Dry Fork (cluster \#3). The conditions within this group were likely influenced by contact with the carbonate bedrock in the upper part of the watershed and subsequent mixing with the other water sources.

Cluster \#2 - Limestone springs type - This cluster included sites 39, 1, 19, 42, and 10, all associated with carbonate springs in the upper part of the Smith Creek watershed. Site 39 is the Smith Creek spring, and site 1 is located approximately $1,500 \mathrm{ft}$ downstream of the spring. Site 19 is an unnamed tributary that drains into War Branch. Site 42 is Lacey Spring, with site 10 located approximately $1,000 \mathrm{ft}$ below Lacey Spring. These sites were all characterized by elevated concentrations of calcium, magnesium, potassium, bicarbonate, and nitrogen, as well as elevated

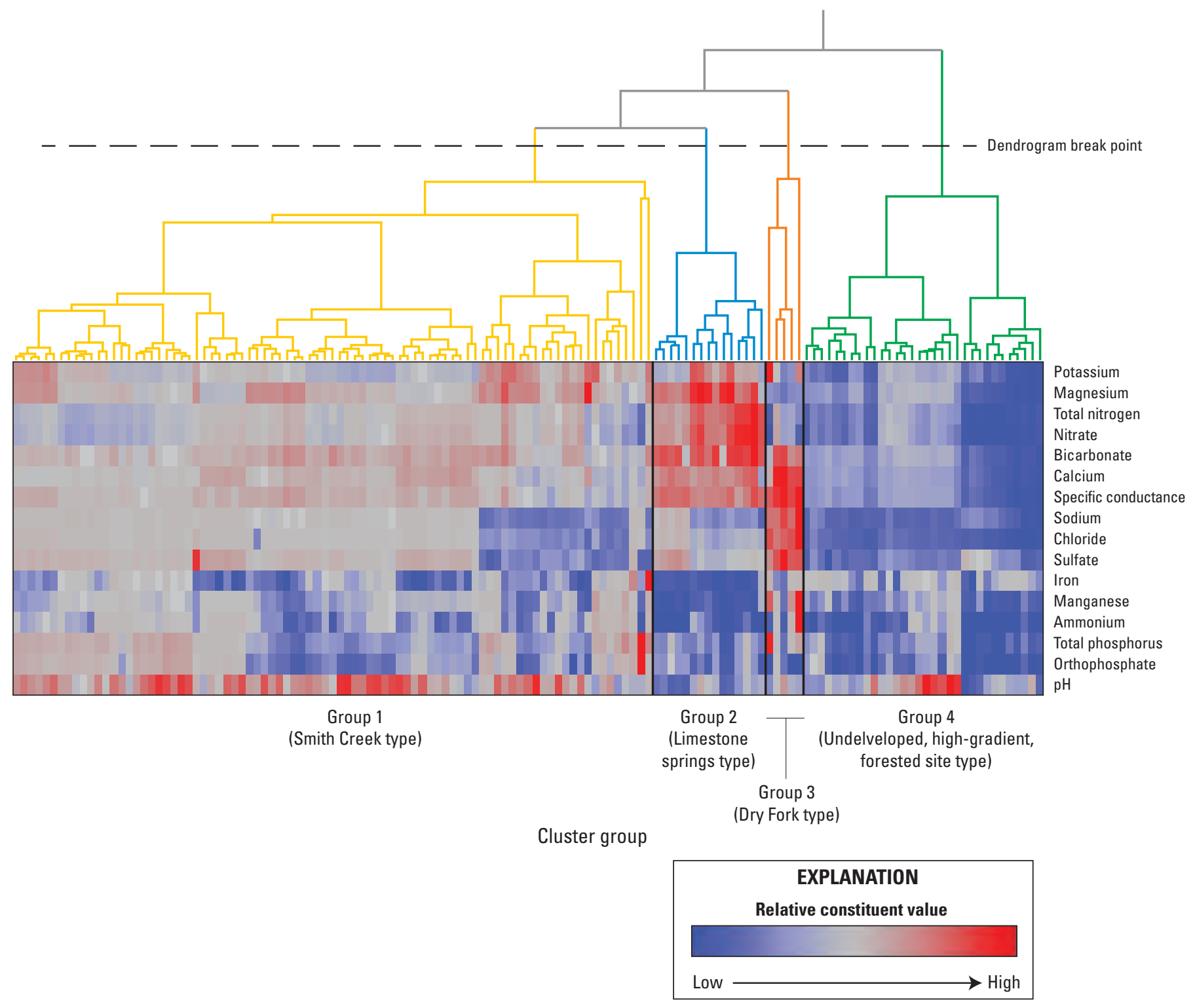

Figure 32. Samples collected from each synoptic event within the Smith Creek watershed with a heat map of constituent values and the breakpoint used to produce four cluster groups. 
specific conductance. Cluster \#2 was further characterized by low concentrations of phosphorus, ammonium, iron, and manganese, as well as low water temperatures. All of the previously described characteristics tend to be indicative of springs that issue from limestone and dolostone in the agricultural Shenandoah Valley (Nelms and Moberg, 2010). This cluster of sites included the sites with the highest nitrate concentrations in Smith Creek, and those sites with substantial flow were responsible for much of the nitrogen loading to Smith Creek.

Cluster \#3 - Dry Fork type - Aptly named, Dry Fork was frequently a series of disconnected pools, except for during wet periods. Water quality within the Dry Fork watershed was quite different from that of Smith Creek and was characterized by extremely elevated specific conductance, as well as elevated concentrations of sodium, chloride, sulfate, calcium, bicarbonate. Dry Fork has a high density of sinkholes (fig. 2C) in its watershed that likely contribute to its intermittent flow and create a rapid connection between the land surface and a deeper groundwater reservoir that fails to support sustained base flow during all but the wettest periods in Dry Fork. The reason for the elevated specific conductance and total dissolved solids in Dry Fork remains unresolved. Potentially contributing to the observed salt and high dissolved solids in the Dry Fork watershed is the fairly extensive network of roadways that includes Interstate 81 , Route 11 , and many other tertiary roadways that bisect the Dry Fork watershed (fig. 7). Salt application to roadways during the winter may be one source of this elevated salt concentration. Overall, Dry Fork contributed very little direct surface flow to Smith Creek during base flow, although the stream was active during rainfall periods. Still, further investigation into the water resources of Dry Fork may be warranted to better understand the unusual water quality and potential groundwater vulnerability in this watershed.

Cluster \#4 - Undeveloped, high-gradient, forested site type - This final cluster is composed of sites 4, 41, 34, 35, 15, and 16-all of which originated in the relatively undeveloped, high-gradient forested area along the eastern edge of the watershed. All sites in this cluster were characterized by low ionic strength waters with low nutrient concentrations, which generally confirms that the elevated nutrient concentrations in Smith Creek were likely related to anthropogenic activities or natural processes on the valley floor and not driven by atmospheric deposition or contributions from the forested areas.

While the cluster analysis demonstrated consistency among the site types, subtle mixing differences seem to be caused by varying hydrologic conditions (fig. 33). Note that because synoptic sites were added during the period of study, not all stations were sampled during all synoptic events. Overall, the spring sites and the forested mountain sites retained their membership during all events, but the chemistry of the stream sites downstream of these springs and mountain tributaries varied somewhat, with the greatest effects of the springs occurring during the driest period and the greatest effects of the mountain tributaries occurring during wetter periods. For example, during the August 2011 event, the bulk of the Smith Creek headwaters resembled the main channel of Smith Creek, while during the wettest event in December 2011, the headwater sites were most like the mountain streams, presumably because of increased flow from these mountain streams. Overall, the water quality within Smith Creek appeared to be a mixture of springs and mountain streams, with the relative mixture of the two water types driving the upper Smith Creek chemistry until the addition of the permitted point source, which supplied greater phosphorus concentrations and could have initiated greater in-stream processing.

The synoptic spatial sampling of the Smith Creek watershed demonstrated a complex hydrogeology and geochemistry. In general, most base flow was generated by groundwater discharge in the upper part of Smith Creek that lies above site 11. Within this upper part of the watershed, the contributions of flow from Lacey Spring (site 42) often dominate discharge. Groundwater with high total nitrogen concentrations was discharging from several headwater springs, and downstream effects of these springs were governed by the discharge of each spring; the greatest loads originated from Lacey Spring (site 42), and the lowest originated from site 19. Because of the high density of sinkholes, most of the water in the Dry Fork watershed was recharged to groundwater and contributed little direct flow to Smith Creek. Relatively dilute, nutrient-poor water was contributed from the forested eastern boundary, and little nitrogen was likely entering along the lower part of Smith Creek underlain by shale. In contrast, the limestone headwaters had low phosphorus concentrations and were a less dominant source of phosphorus to the watershed. Instead, a point source with high phosphorus concentrations discharged to Smith Creek between station 25 and 26. Further study of the nitrogen and phosphorus sources to Smith Creek could improve the understanding of the sources and transport processes (including lag times) associated with these constituents.

\section{Characterization of Nitrogen Sources}

Characterization of the primary nitrogen sources in the Smith Creek watershed can inform watershed-management decisions related to the implementation of conservation BMPs. In this section, nitrogen sources as indicated by nitrate isotopes and other data are compared to results of land-use and model-based nutrient-source evaluations.

The synoptic nitrate isotope results indicated several patterns and processes that affect the distribution and export loads of nitrate in the Smith Creek watershed (fig. 34). The lowest nitrate concentrations and $\delta^{15} \mathrm{~N}$ values were associated with sites draining undeveloped, high-gradient forested sites, while the highest nitrate concentrations and intermediate $\delta^{15} \mathrm{~N}$ values were associated with limestone springs. The nitrogen from the undeveloped high-gradient forested sites was likely from a combination of atmospheric and natural 


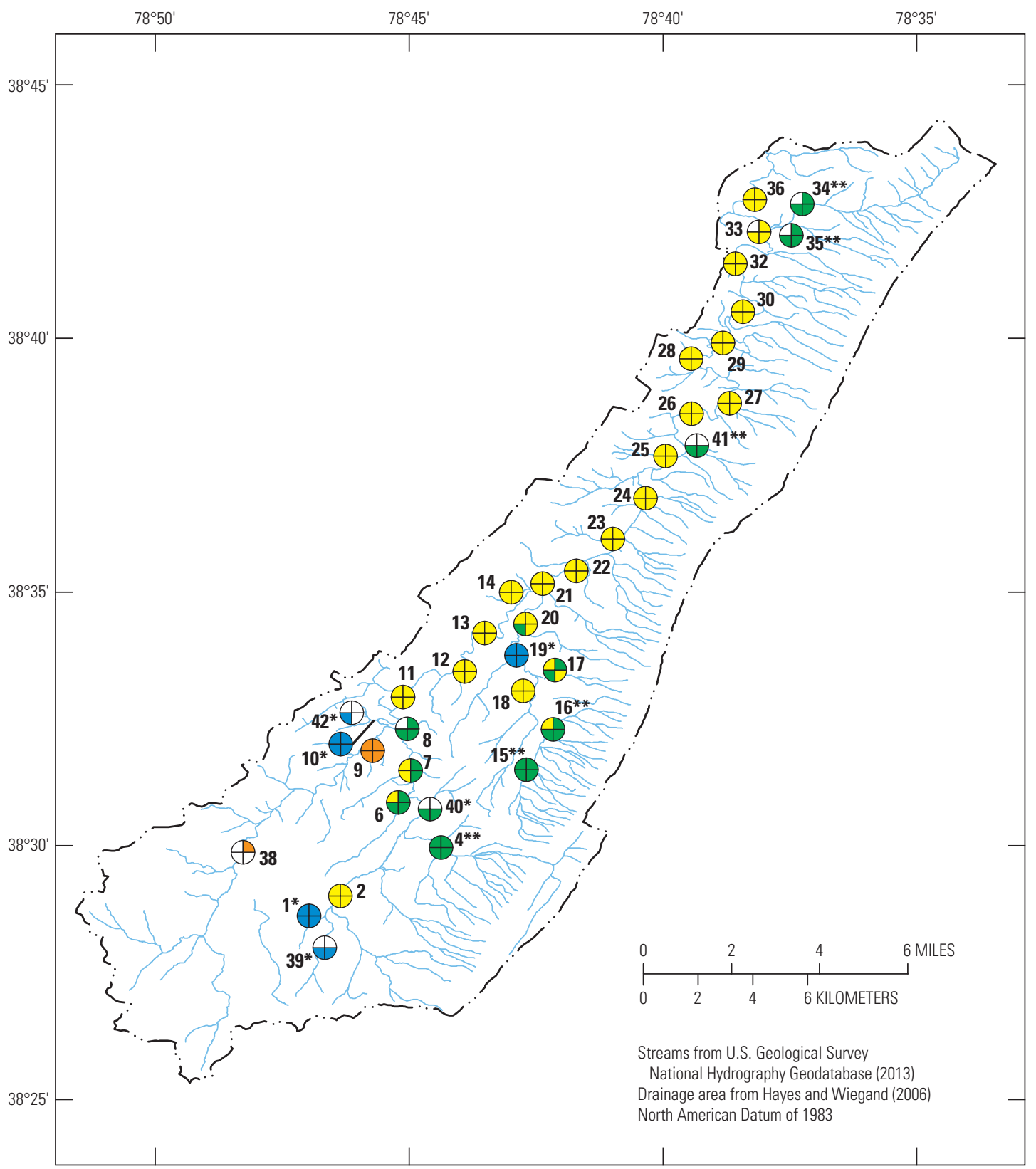

EXPLANATION

Synoptic sampling events at site 32 (USGS streamgage 01632900)

August 2011 December 2011

$22 \mathrm{ft}^{3} / \mathrm{s}$

May 2013

Streamflow, in

cubic feet per second $\left(\mathrm{ft}^{3} / \mathrm{s}\right)$

\section{Cluster group}

Sample not collected

Group 1-Smith Creek type

Group 2-Limestone springs type

Group 3-Dry Fork type

Group 4-Undeveloped, highgradient, forested site type

Figure 33. Synoptic sampling events at monitoring locations in the Smith Creek watershed as grouped in a cluster analysis. 


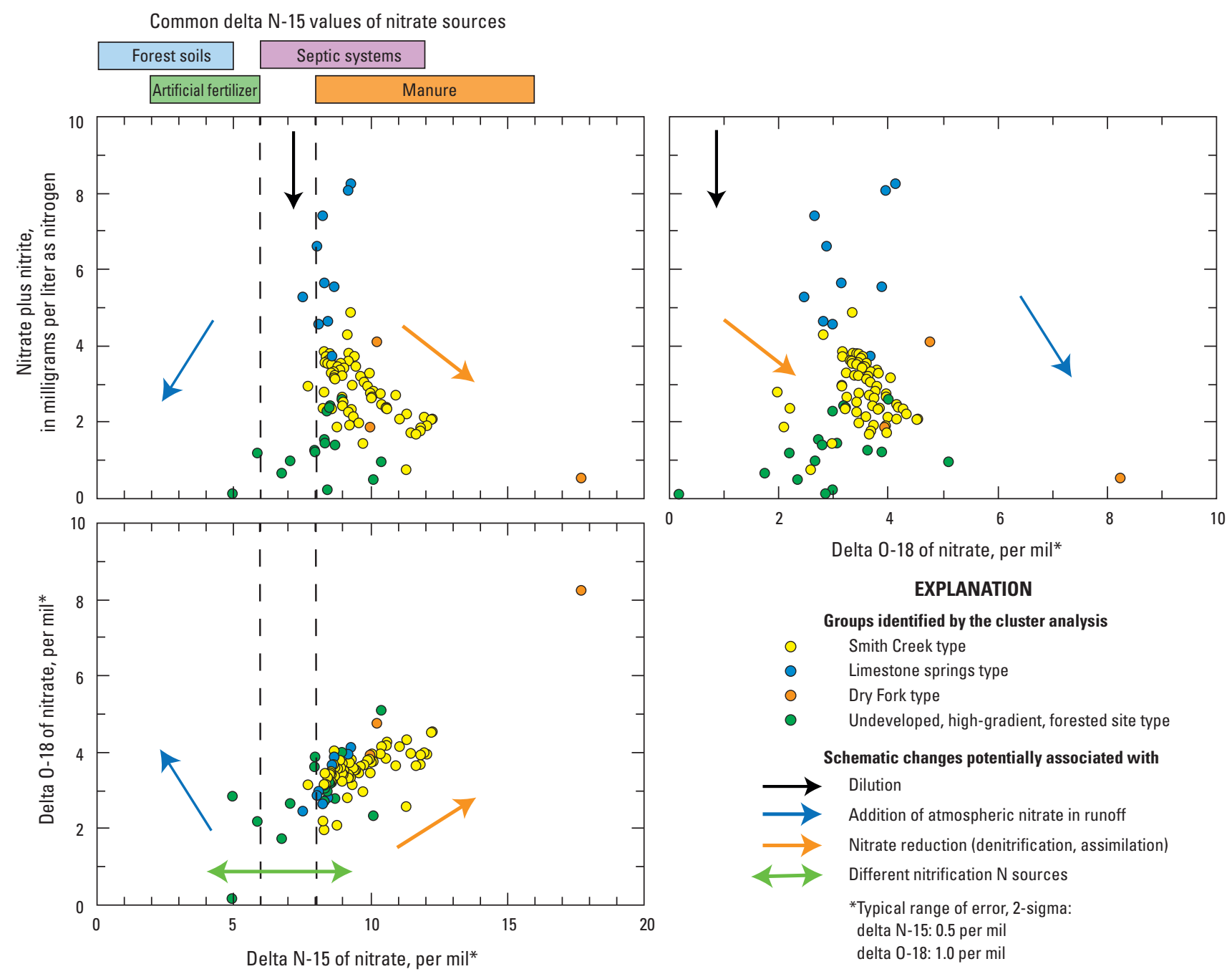

Figure 34. Nitrate isotope results from each synoptic sampling event within the Smith Creek watershed.

soil sources, but the nitrogen from the limestone springs was most consistent with manure-derived sources, although the possibility of mixed sources cannot be excluded. The median $\delta^{15} \mathrm{~N}$ value of nitrate from Lacey Spring $(8.4 \%$ ) was similar to reported values for nitrate in discharge from a small spring in the nearby Muddy Creek watershed (+8.6\%o $\pm 0.7 \%$ ) where the nitrate was interpreted to be largely derived from animal-rearing activities (Hyer and others, 2001; Lindsey and others, 2003).

Regardless of the nitrogen source(s), $\delta^{18} \mathrm{O}$ data indicate that nearly all of the nitrate exported from Smith Creek originated from within-watershed nitrification, and not as unreacted atmospheric or synthetic nitrate, which would have low $\delta^{15} \mathrm{~N}$ and high $\delta^{18} \mathrm{O}$ values (fig. 6 and associated text). Even during high-flow events, direct runoff of atmospheric nitrate generally was not sufficient to affect the isotopic composition of nitrate in total discharge. The main-stem Smith Creek sites were characterized by intermediate nitrate concentrations and by increasing $\delta^{15} \mathrm{~N}$ and $\delta^{18} \mathrm{O}$ values in the downstream direction. The downstream trends may have resulted from partial nitrate reduction in the stream channels or in downgradient discharging groundwater. The Dry Fork sites had variable nitrate concentrations and $\delta^{15} \mathrm{~N}$ and $\delta^{18} \mathrm{O}$ values, which indicated substantial biologic processing of the nitrate in some cases.

Land-use, fertilizer-use, and animal and human population census data were used to evaluate likely nitrogen sources within the Smith Creek watershed. Although a landuse analysis is informative about the sources and application of nutrients that are available for transport, it does not provide specific information regarding which sources of nitrogen are stored in the landscape and which are transported to the groundwater or stream system. Because most of the available datasets related to agricultural practices were developed and published at the county scale, the land-use nitrogen-source analysis was performed at the county scale. Results of a county-based analysis are only relevant to a given watershed of interest (in this case, Smith Creek) if land uses are similar in the basin of interest and the county. Fortunately for this analysis, land uses within the Smith Creek watershed and those of Rockingham and Shenandoah Counties (the Smith Creek watershed lies in both counties) are similar (fig. 35), 


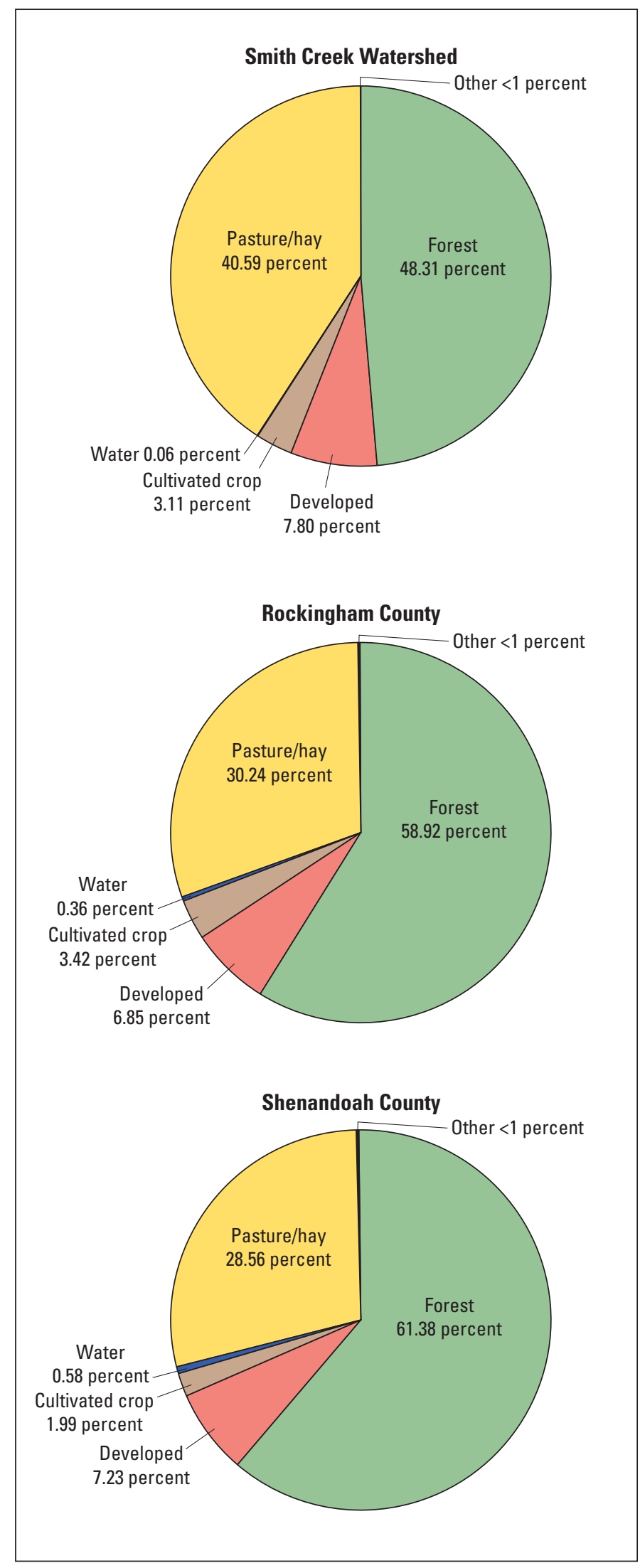

Figure 35. Percentages of land-use types from Homer and others (2015) within the Smith Creek watershed, Rockingham County and Shenandoah County, Virginia. and consequently the land-use-derived information on nitrogen sources in Rockingham and Shenandoah Counties is likely representative of the nitrogen sources in the Smith Creek watershed.

The land-use-derived sources of nitrogen to the land surface were computed for Rockingham and Shenandoah Counties from 1987 through approximately 2006 (fig. 36A). Within both counties, manure sources of nitrogen dominated and were followed by commercial inorganic fertilizer application and atmospheric deposition. The manure source (from agricultural livestock, dominated by poultry and cattle sources) was approximately four times the commercial inorganic fertilizer source in both counties. In both counties, the amount of nitrogen generated by sewage and septic waste, as well as by residential fertilizer, was small compared to other sources. While these land-use-derived source data indicate only the relative magnitudes of nitrogen inputs on the landscape and do not necessarily indicate which nitrogen sources were routed to the stream system, they appear to corroborate the nitrate isotope results, which indicate that manure was the dominant source of nitrogen exported from the watershed. Based on this analysis, reductions in nitrogen sources have not been observed within either county, to date (fig. 36A).

Watershed-scale nitrogen sources for Smith Creek also were evaluated by using results from a SPAtially Referenced Regressions On Watershed attributes (SPARROW) model with parameter values derived for the Chesapeake Bay watershed (Ator and others, 2011). Land-surface loading data used by SPARROW indicated that nitrogen loading from manure was approximately 2 times the nitrogen loading from crop fertilizer plus nitrogen fixation in the Smith Creek watershed for 2002 (fig. 37), similar to the land-use-derived pattern previously described (fig. 36B). However, when converted to percentages of nitrogen sources contributing to the TN export load of the stream, SPARROW model results indicated that nitrogen from manure was preferentially retained and nitrogen from fertilizer plus nitrogen fixation was preferentially exported, such that the nitrogen export load from manure was approximately 0.5 times the nitrogen export load from fertilizer plus nitrogen fixation, a factor of 4 reversal in the relative fluxes between input and output (table 12). This result would seem to be in conflict with the nitrate isotope data, which favor manure over fertilizer and nitrogen fixation as dominant source of nitrate- $\mathrm{N}$ exported from Smith Creek. The reasons for this apparent discrepancy are unclear, but some possible contributing factors based on the SPARROW model results are (1) nitrogen from fertilizer and nitrogen fixation assimilated into plants in pastureland largely was used as animal feed and converted to manure before being nitrified and exported as nitrate; (2) relative source coefficients (the model terms representing the fraction of applied source material that is transported to the stream) for nitrogen from manure and fertilizer plus nitrogen fixation derived from the SPARROW model for the whole Chesapeake Bay watershed were not accurate in the Smith Creek watershed because of local conditions of hydrogeology (karst) or land-use practices (open pasture). Some other 
A. Kilograms of nitrogen per year

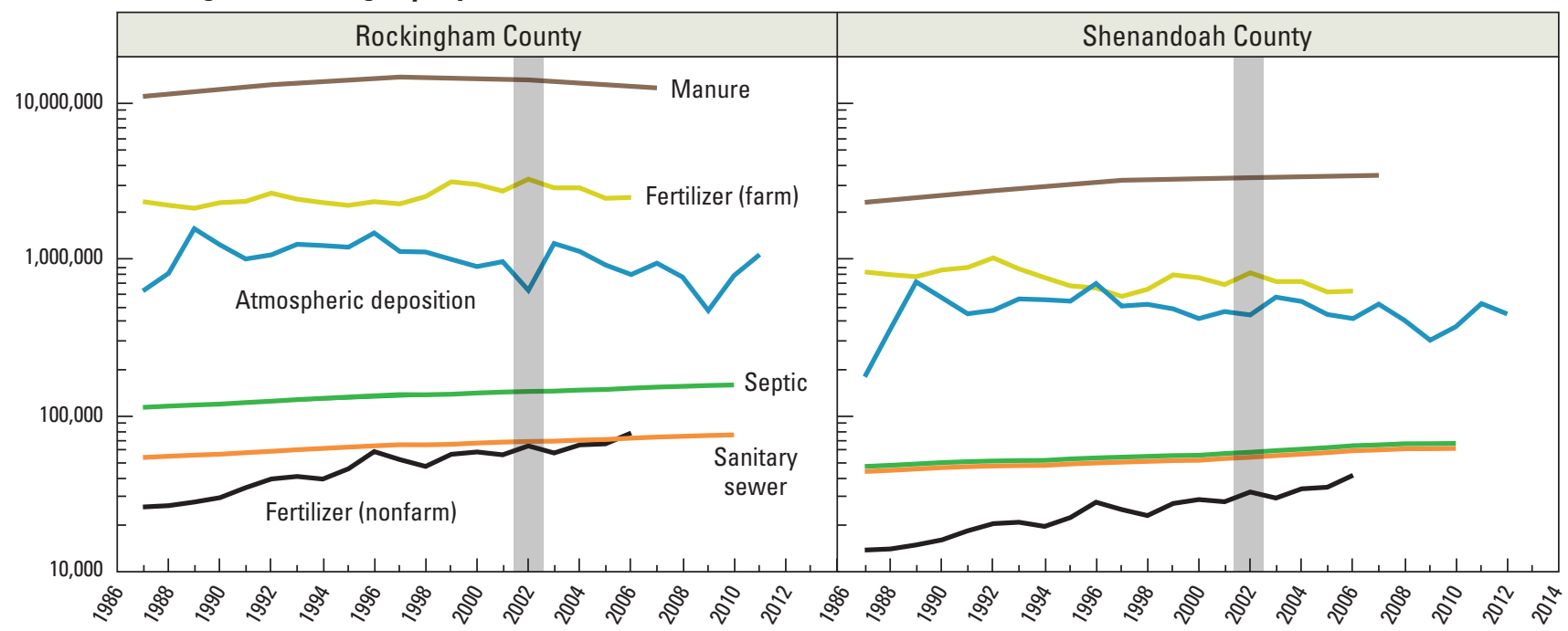

B. Nitrogen sources in 2002

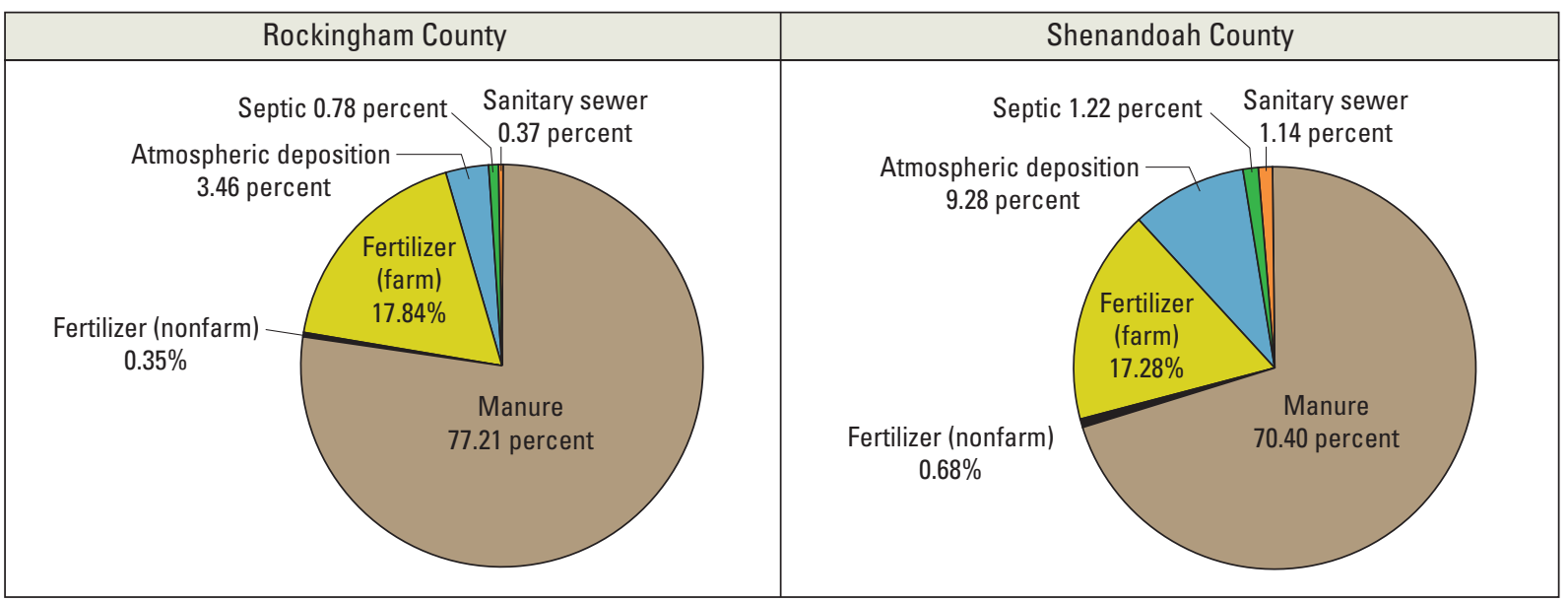

Figure 36. (A) Nitrogen sources for Rockingham County and Shenandoah County, Virginia, from 1987 to 2012 and $(B)$ nitrogen sources in 2002 for Rockingham County and Shenandoah County, Virginia.
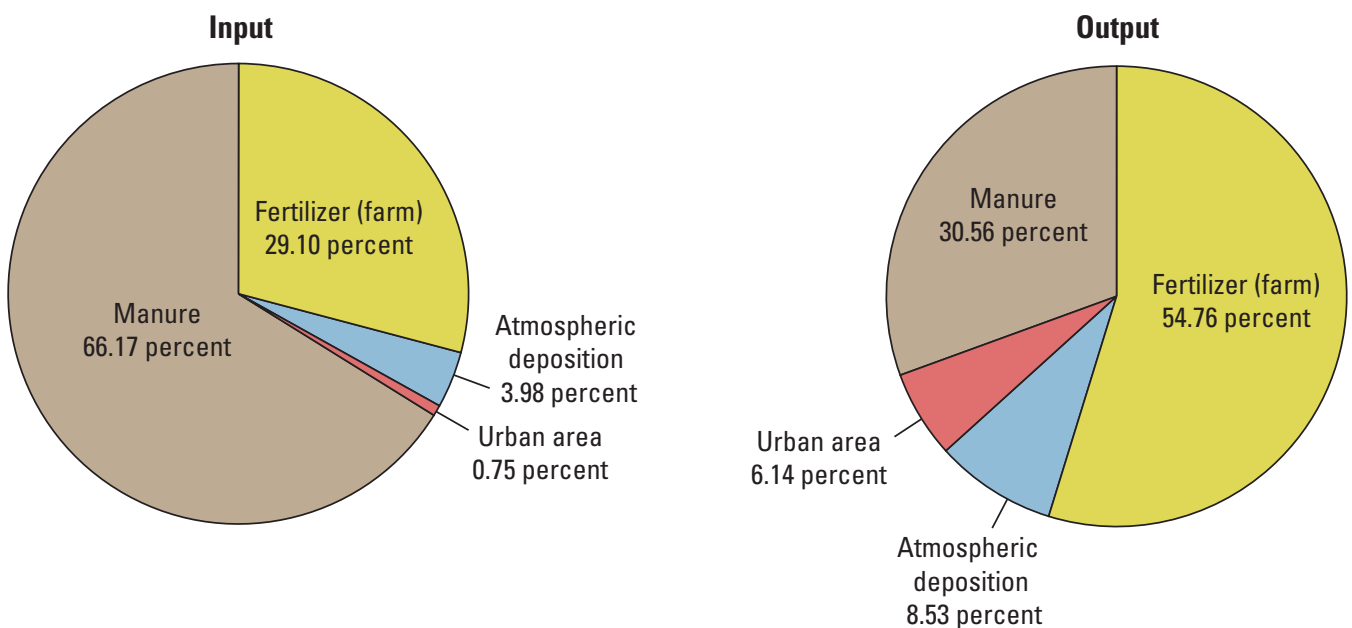

Figure 37. Percentages of input and output sources of total nitrogen for the Smith Creek watershed as generated by the 2002 Chesapeake Bay Total Nitrogen SPARROW model as described in Ator and others (2011). 
Table 12. Nitrogen delivery factors and source estimates identified by the SPARROW model for the Smith Creek watershed.

[HUCs, hydrologic unit codes; $\mathrm{kg} / \mathrm{yr}^{-1}$, kilogram per year; $\mathrm{km}^{2}$, square kilometer; $\left(\mathrm{kg} / \mathrm{km}^{-2}\right) / \mathrm{yr}^{-1}$, kilogram per square kilometer per year; \%, percent]

\begin{tabular}{|c|c|c|c|c|c|c|}
\hline \multirow[t]{3}{*}{ Number of 8-digit HUCs } & \multicolumn{6}{|c|}{ Nitrogen delivery factor ${ }^{1}$} \\
\hline & \multicolumn{2}{|c|}{ Minimum } & \multicolumn{2}{|c|}{ Median } & \multicolumn{2}{|c|}{ Maximum } \\
\hline & \multicolumn{2}{|c|}{0.553} & \multicolumn{2}{|c|}{0.701} & \multicolumn{2}{|c|}{0.875} \\
\hline \multirow{2}{*}{ Source explanatory variables } & \multirow{2}{*}{$\begin{array}{c}\text { Source } \\
\text { coefficient }^{\text {estimate }}{ }^{2}\end{array}$} & \multirow{2}{*}{ Units } & \multicolumn{2}{|c|}{ Inputs ${ }^{1}$} & \multicolumn{2}{|c|}{ Outputs' ${ }^{1}$} \\
\hline & & & Sum & $\%$ & Sum & $\%$ \\
\hline Point sources $\left(\mathrm{kg} / \mathrm{yr}^{-1}\right)$ & 0.774 & & - & 0.00 & - & 0.00 \\
\hline Crop fertilizer and fixation $\left(\mathrm{kg} / \mathrm{yr}^{-1}\right)$ & 0.237 & & 898,739 & 29.10 & 150,079 & 54.76 \\
\hline Manure $\left(\mathrm{kg} / \mathrm{yr}^{-1}\right)$ & 0.058 & & $2,043,675$ & 66.17 & 83,758 & 30.56 \\
\hline Atmospheric deposition $\left(\mathrm{kg} / \mathrm{yr}^{-1}\right)$ & 0.267 & & 122,814 & 3.98 & 23,387 & 8.53 \\
\hline $\operatorname{Urban}^{2}\left(\mathrm{~km}^{2}\right)$ & 1,090 & $\left(\mathrm{~kg} / \mathrm{km}^{-2}\right) / \mathrm{yr}^{-1}$ & 23,293 & 0.75 & 16,834 & 6.14 \\
\hline Total & & & $3,088,522$ & 100.00 & 274,059 & 100.00 \\
\hline
\end{tabular}

${ }^{1}$ Nitrogen delivery factors, input and output data calculated for 25 8-digit HUCs that encompass the Smith Creek watershed.

${ }^{2}$ Source coefficient data adopted from the Chesapeake Bay watershed total nitrogen model as reported in Ator and others (2011).

reported SPARROW models yielded source coefficient ratios for manure to fertilizer nitrogen that were similar to those listed in table 12 (for example, Preston and others, 2011, for the northeastern United States); however, other models yielded ratios closer to 1 (for example, Preston and Brakebill, 1999, for the Chesapeake Bay watershed; Alexander and others, 2000, 2008, for the Mississippi River Basin), in which cases the isotope data and model export loads would be more consistent. Alternatively, elevated $\delta^{15} \mathrm{~N}$ values may not be related to manure sources if mineralized soil and fertilizer $\mathrm{N}$ were isotopically fractionated more than usual in Smith
Creek watershed because calcareous (high $\mathrm{pH}$ ) soils promoted volatilization of ammonia prior to nitrification (Kreitler, 1975; Kreitler and others, 1978); however, high $\delta^{15} \mathrm{~N}$ values similar to those in Smith Creek have been reported for groundwater nitrate in other Chesapeake Bay subwatersheds containing pastures and confined animal feeding operations, not all of which have calcareous soils (Lindsey and others, 2003).

More detailed analysis of SPARROW input variables and regression results could reveal new insights about the relative transmission of nitrogen from manure and other sources from landscapes to streams. 


\section{Implementation of Conservation Practices and Water-Quality Response}

The designation of Smith Creek as an agricultural Showcase Watershed by USDA in 2010 and the subsequent commitment of implementation program funding to the Smith Creek watershed have substantially increased the implementation of conservation management actions over the past 5 years (table 13). Several State and Federal programs have been responsible for the increased level of conservation implementation, including cost-share and technical assistance from the NRCS, FSA, and Virginia Department of Conservation and Recreation (VADCR). The observed implementation intensity in Smith Creek is likely indicative of what can be achieved through concentrated grassroots local implementation efforts that are supported by these State and Federal programs.

Numerous Federal- and State-funded conservation practices have been implemented within Smith Creek to reduce the transport of sediment and nutrients (tables 13 through 15). In the Smith Creek watershed, 1,404 USDA-compliant agricultural conservation practices were implemented between 2007 and 2013 (table 13). The USDA provided cost-share for 431 of those practices using funds from the Chesapeake Bay Watershed Initiative (371 practices), Environmental Quality Incentives Program

Table 13. Number of USDA-compliant conservation practices implemented in water years 2007 through 2013 in the Smith Creek watershed, aggregated by sponsoring program.

[USDA, U.S. Department of Agriculture]

\begin{tabular}{|c|c|c|c|c|c|c|c|c|}
\hline Program & 2007 & 2008 & 2009 & 2010 & 2011 & 2012 & 2013 & Total \\
\hline Chesapeake Bay Watershed Initiative & 0 & 0 & 0 & 1 & 60 & 121 & 189 & 371 \\
\hline Environmental Quality Incentives Program & 7 & 3 & 9 & 10 & 7 & 5 & 14 & 55 \\
\hline Conservation Reserve Program ${ }^{1}$ & 2 & 0 & 2 & 0 & 0 & 0 & 0 & 4 \\
\hline Total USDA-funded practices & 9 & 4 & 11 & 11 & 67 & 126 & 203 & 431 \\
\hline Total practices & 292 & 66 & 99 & 117 & 202 & 312 & 316 & 1,404 \\
\hline
\end{tabular}

${ }^{1}$ Conservation Reserve Program and Conservation Reserve Enhancement Program practices administered by the USDA Farm Service Agency.

${ }_{2}^{2}$ Technical assistance and verification provided by the USDA Natural Resources Conservation Service, without federal cost-share funding.

Table 14. Implementation of USDA-compliant conservation practices within the Smith Creek watershed for water years 2007 through 2013.

[USDA, U.S. Department of Agriculture; — , values are privacy protected due to fewer than five customers participating]

\begin{tabular}{|c|c|c|c|c|c|c|c|c|c|c|c|}
\hline $\begin{array}{c}\text { Practice } \\
\text { code }^{1}\end{array}$ & Practice name & $\begin{array}{c}\text { Lifespan } \\
\text { (years) }\end{array}$ & Units & 2007 & 2008 & 2009 & 2010 & 2011 & 2012 & 2013 & $\begin{array}{c}\text { Aggregate } \\
\text { implementation: } \\
2007 \text { to } 2013^{2}\end{array}$ \\
\hline 328 & Conservation Crop Rotation & 1 & acres & 445 & - & - & - & - & 518 & 342 & 2,119 \\
\hline 340 & Cover Crop & 1 & acres & - & - & - & - & 735 & 736 & 1,494 & 3,878 \\
\hline 590 & Nutrient Management & 1 & acres & - & - & 659 & - & 1,473 & 728 & 1,026 & 4,842 \\
\hline 633 & Waste Recycling & 1 & acres & - & - & - & 632 & - & 417 & - & 1,239 \\
\hline 512 & Forage and Biomass Planting & 5 & acres & - & - & - & - & - & - & 84 & 122 \\
\hline 472 & Access Control & 10 & acres & - & - & - & - & - & - & 48 & 135 \\
\hline 561 & Heavy Use Area Protection & 10 & acres & - & - & - & - & - & 8 & - & 16 \\
\hline 382 & Fence & 20 & feet & - & - & - & - & 8,191 & 23,410 & 28,660 & 76,375 \\
\hline
\end{tabular}

${ }^{1}$ Practice codes from the U.S. Department of Agriculture, Natural Resources Conservation Service (2016).

\footnotetext{
${ }^{2}$ Aggregate implementation is greater than the sum of reported annual practices because privacy protections restrict the reporting of annual results for practices with fewer than five participating customers.
} 
Table 15. Implementation of state-funded conservation practices within the Smith Creek watershed for water years 2007 through 2014. The table does not include practices for which the NRCS provided funds or technical assistance.

[NRCS, Natural Resources Conservation Service; - , values are privacy protected due to fewer than five customers participating]

\begin{tabular}{|c|c|c|c|c|c|c|c|c|c|c|}
\hline $\begin{array}{l}\text { Practice } \\
\text { code }^{1}\end{array}$ & Practice name & Units & 2007 & 2008 & 2009 & 2010 & 2011 & 2012 & 2013 & $\begin{array}{c}\text { Aggregate } \\
\text { implementation: } \\
2007 \text { to } 2013^{2} \\
\end{array}$ \\
\hline NM-3B & $\begin{array}{l}\text { Manure Application to Corn Using } \\
\text { Pre-Application Nitrate Test }\end{array}$ & acres & - & 682 & - & 1,137 & - & - & - & 2,022 \\
\hline RB-1 & Septic Tank Pumpout & number & - & - & - & - & - & 6 & 41 & 47 \\
\hline RB-3 & Septic Tank System Repair & number & - & - & - & - & - & - & 5 & 6 \\
\hline SL-8B & $\begin{array}{l}\text { Small Grain Cover Crop for } \\
\text { Nutrient Management }\end{array}$ & acres & 1,170 & 1,063 & 839 & 616 & 140 & 571 & 879 & 5,278 \\
\hline SL-8H & Harvestable Cover Crop & acres & - & 802 & 432 & 570 & 471 & 521 & 678 & 3,474 \\
\hline WP-4 & Animal Waste Control Facility & number & - & - & - & - & - & - & 5 & 12 \\
\hline
\end{tabular}

${ }^{1}$ Practice codes from the Virginia Department of Conservation and Recreation (2016).

${ }^{2}$ For some practices, aggregate implementation is greater than the sum of reported annual practices because privacy protections restrict the reporting of annual results for practices with fewer than five participating customers.

(55 practices), and additional USDA programs (5 practices). For the remaining 973 conservation practices, the NRCS provided technical assistance, but funding was provided by non-Federal programs and (or) farmers.

The aggregated total of conservation practice implementations (new practices applied between October 2007 and September 2013) is reported by NRCS practice code in table 14 for all practices with five or more participating farmers. State-funded conservation practices are included in table 15. Sediment-control measures tended to include fencing of cattle out of streams and marginal pastureland, along with the creation of alternative watering facilities. From 2007 to 2013 , more than $75,000 \mathrm{ft}$ of fencing was installed in the Smith Creek watershed to reduce cattle access to sensitive areas and to reduce sediment transport. Nutrient-control measures tended to include the development of nutrient management plans, conservation crop rotation, and planting of cover crops, as well as excluding cattle from stream access.

Although intensive water-quality monitoring at the Smith Creek streamgage started for this project in 2010, historical water-quality monitoring data exist for the period 1979 through 2004, and these historical data were coupled with the recent monitoring data to provide an initial assessment of trends in water quality in Smith Creek. These data were included in a trend analysis using Weighted Regression on Time, Discharge and Season (WRTDS) to provide trends in concentration and load (http://cbrim.er.usgs.gov/). Results of this analysis of the Smith Creek nitrate data indicate that flow-normalized nitrate concentrations have increased from 1985 through 2014 at a rate of $0.01 \mathrm{mg} / \mathrm{L}$ per year. While this is a small rate of change, it indicates that nitrate concentrations in the watershed have increased, despite the implementation of conservation practices to date. Even though nitrate concentrations have increased over this time period, flow-normalized nitrate fluxes (loads) have actually decreased by approximately 0.1 percent per year. Overall, these trends are small and are generally difficult to discern in the time series of observed concentration data (fig. 38). Differences in trend between flow-normalized concentration patterns and flow-normalized flux patterns are fairly common in WRTDS analyses and occur whenever the changes in water chemistry vary with flow. In the case of Smith Creek, WRTDS model output data indicate that nitrate concentrations increased during low-flow conditions, causing the increasing trend in concentration, but the nitrate concentrations during high flows have decreased, resulting in decreasing nitrate loads. Increasing nitrate concentrations during low-flow conditions suggests that concentrations of nitrate in the groundwater discharged to Smith Creek are actually increasing over time. Increased nitrate concentrations in groundwater may be related to stable or increasing nitrogen sources in Rockingham and Shenandoah Counties (fig. 36A), as well as potential lag effects related to groundwater residence and transport times. Enhanced implementation of agricultural conservation practices and continued beneficial farm practices will continue to be needed to reduce nitrate concentrations in Smith Creek.

Recent results from a Conservation Effects Assessment Project (CEAP) in the Chesapeake Bay Region (U.S. Department of Agriculture, Natural Resources Conservation Service, 2013) suggested that while implementation of conservation practices across the Chesapeake Bay watershed is increasing, the following trends in other cultivated cropland management practices, evaluated from 2003-2006 to 2011, were less encouraging:

- Annual nitrogen application increased 10 percent on cultivated cropland, including a 13-percent increase in manure nitrogen application;

- Annual phosphorus application increased 6 percent on cultivated cropland, including an 11-percent increase in manure nitrogen application; and

- Manure application rates on cultivated cropland increased by 25 percent. 


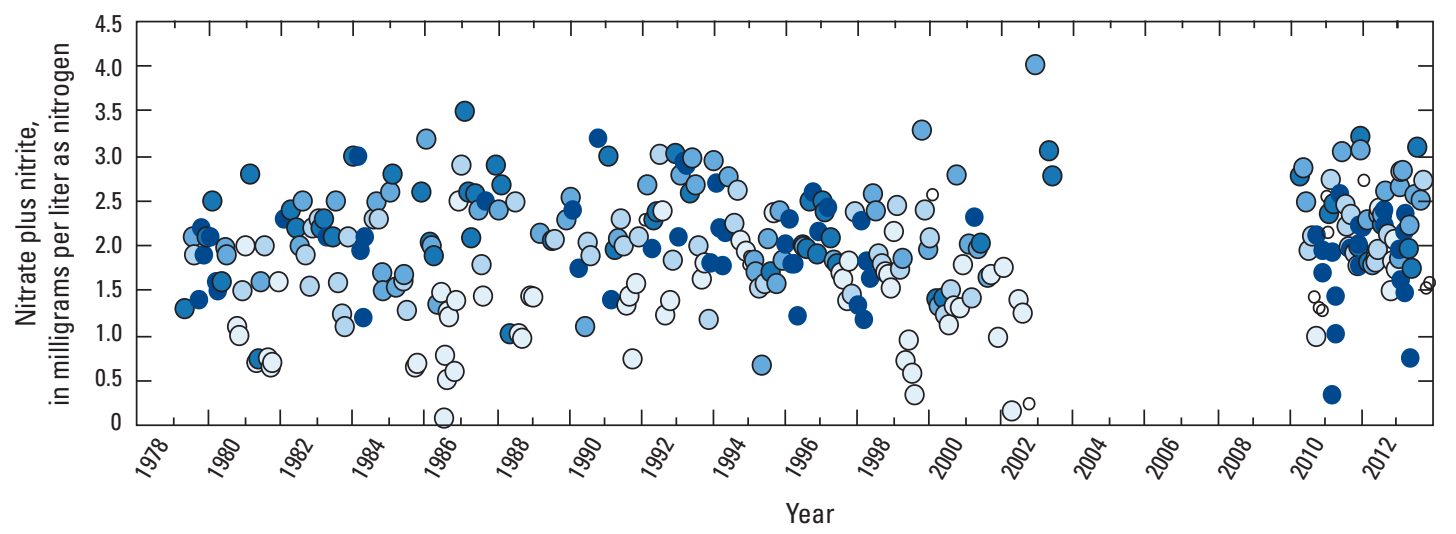

EXPLANATION

Percentage of values equal to or less than the maximum streamflow of 4,250 cubic feet per second (where small values represent low-flow samples)

○ 0 to 20

$0>20$ to 40

O $>40$ to 60

- $>60$ to 80

- $>80$ to 100

- Streamflow data not available

Figure 38. Nitrate concentrations from the Smith Creek streamgage for water years 1979 through 2013.

These increases in nutrient inputs are associated with increased agricultural intensification, including higher yields and greater numbers of animals. While these overall CEAP trends are not specific to Smith Creek, they may help to explain why nitrate concentrations were increasing in the watershed, despite the widespread implementation of conservation practices.

The cumulative effects of BMP implementation within the Smith Creek watershed were difficult to quantify because of the many different types of BMP practices, the location of each, potential lag times between implementation and full functionality of the practice, and the relative efficiency of each practice/installation. Future monitoring will measure the overall changes in watershed nutrient and sediment transport. Another way to develop an interim set of expectations is with the Chesapeake Bay Program's watershed model, by evaluating model output for model scenarios with and without the implementation of BMP practices. The results for the land-water segment that contains Smith Creek are presented in figure 39 (courtesy of the Chesapeake Bay Modeling Team, written commun., 2015, based on Watershed Model 5.3.2).

This modeling scenario projects that nitrate loads have decreased approximately 16 percent since 2007 and that overall, the reductions in nitrate loading to this segment of the model are driven by agricultural BMPs, with little changes in the other source categories. These model results are generally in conflict with the empirical water-quality data that indicate a general increase in nitrate concentrations, raising concerns regarding the application of certain watershed model assumptions within the Smith Creek watershed. Subsequent investigations will explore in more detail the possible reasons for the discrepancy between the watershed model and the observed water-quality data.

\section{Conceptual Watershed Model and Implications for Management Actions}

Cumulatively, the intensive and extensive monitoring elements provide a process-level understanding of the Smith Creek nutrient and sediment transport processes that are summarized as follows.

- Substantial hydrologic and seasonal variability in the water-quality conditions of Smith Creek were observed. Concentrations of constituents associated with groundwater discharge were generally highest during base flow and were diluted during stormflow. During stormflow, concentrations of particulate constituents increased. Common seasonal patterns in water-quality constituents were observed.

- No systematic seasonal pattern was observed for nitrate concentrations; instead, maximum concentrations occurred throughout the year when flow was about $70-80 \mathrm{ft}^{3} / \mathrm{s}$. Dilution by runoff commonly caused lower nitrate concentrations at flows greater than this, while biologic processing may have contributed to lower concentrations at discharges less than this.

- The dominant geographic source of nitrate discharge to Smith Creek appears to be headwater springs, while the primary source of the nitrogen is likely agricultural manure, followed by commercial fertilizer.

- Most of the phosphorus load in Smith Creek at base flow appears to enter the stream from a local source near the town of New Market; during wet-weather conditions, nonpoint sources seemed to dominate phosphorus input. 


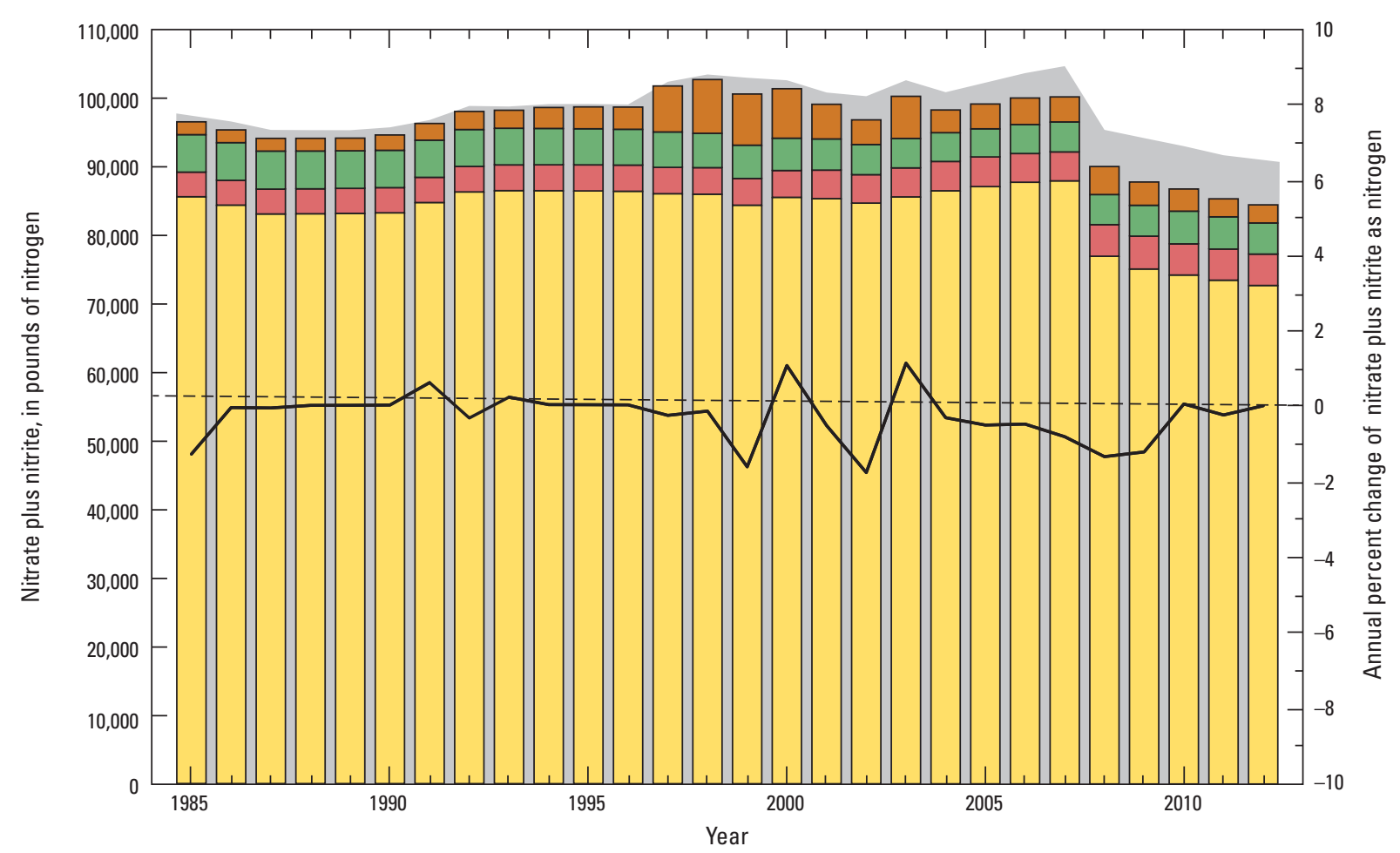

\section{EXPLANATION}

Pounds of nitrate plus nitrite as nitrogen from all sources with no best management practice implementation

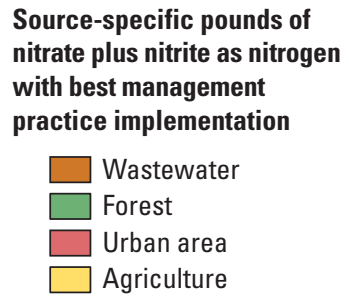

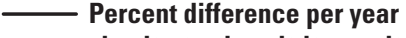
in nitrate plus nitrite as nitrogen predicted by implementation versus no implementation of best management practices

Figure 39. Nitrate loads estimated from the Chesapeake Bay watershed model for the model segment containing Smith Creek with and without best management practice implementation with input sources and the annual percentage difference of load attributed to implementation, 1985-2012.

- Tributaries draining the eastern forested edge of the watershed contributed relatively dilute, low ionic strength water that tended to dilute the composition of Smith Creek as it passed through the lower part of the watershed.

- During the driest, lowest flow conditions, springs provided the bulk of the water in Smith Creek; during wetter base-flow conditions, the eastern forested tributaries provided substantial flow to Smith Creek, and during wet weather events, various nonpoint sources contributed flow, sediment, and nutrients to Smith Creek.

- Implemented conservation practices increased substantially during 2007 through 2013 . The primary practices for the reduction of sediment and nutrient transport included exclusion of cattle from streams by using fencing, as well as the development of nutrient management plans and planting of cover crops.
- During 1985-2014, nitrate concentrations in Smith Creek increased at a rate of approximately $0.01 \mathrm{mg} / \mathrm{L}$ per year, despite the implementation of conservation practices. Increasing nitrate concentrations during low-flow conditions suggest that concentrations of nitrate in the groundwater discharged to Smith Creek are increasing over time.

The process-level understanding previously summarized is directly applicable to the development of effective conservation practices and is particularly important for informed management strategies. Decisions to manage the following constituents in the following ways are likely to generate the most efficient response.

- Management activities for nitrogen would likely be most effective in the upper part of the watershed in the areas that are underlain by karst geology. Management activities that reduce the amount of nitrogen transported to groundwater are important because subsequent groundwater discharge to the stream, 
particularly in the upper part of the watershed, appears to be driving the increasing concentrations of nitrate observed in Smith Creek.

- The development of nutrient management plans that address the application of manure, as well as commercial inorganic fertilizer, could be important for reducing the overall nitrogen loading to the basin.

- Managing these manure and commercial inorganic fertilizer inputs could have a corollary benefit of reducing phosphorus inputs because nonpoint-source phosphorus inputs seem to dominate the phosphorus transport at high flow.

- Managing phosphorus within the Smith Creek watershed will involve both point-source and nonpoint-source contributions. A single point source is generally responsible for the majority of the phosphorus transported by Smith Creek under base-flow conditions. Nonpoint sources are generally responsible for the majority of the phosphorus during wet-weather periods.

- While modifications to the timing and incorporation of fertilizer and manure could alter the transport of nitrogen and phosphorus within the system, a reduction in total nutrient loading to the watershed is ultimately needed to reduce nutrient export from the basin.

- The increased in-stream nitrate concentrations were likely a result of stable or increasing nitrogen sources within the watershed, although groundwater residence times and transport processes may also be important.

- The collection of empirical nutrient and geochemical water-quality data in the Smith Creek watershed were critical for better understanding of the nitrogen sources and temporal responses within the watershed and for reconciling regional model discrepancies for nitrogen sources (SPARROW results) and trends in water-quality data (Chesapeake Bay Watershed Model results). Given the potential for model discrepancies at smaller scales, the collection and analysis of field water-quality data remain the primary tool for evaluating basins of interest.

Ongoing USGS water-quality monitoring efforts will be directed towards the further understanding of the sources, sinks, and transport processes in Smith Creek, as well as the detection of water-quality change that can be directly related to the implementation of management actions. Because large changes in water quality take time and sufficient management of the landscape to actually affect the system, different study elements will be used to detect change in the basin.

- Nutrient and sediment monitoring at the streamgage will provide a long-term record of the quality of the water exiting the basin. With enough years of monitoring, a trend analysis on an expanded list of constituents can be performed to determine whether statistically significant trends exist. Generally, 10 years of data is considered sufficient to attempt a trend test. This is a classical approach for trend analysis; however, it is least sensitive to change because the intensive monitoring site is located well down in the watershed, miles below much of the interesting geochemistry and anticipated change.

- A continuous nitrate record is likely one of the best tools for determining whether the Smith Creek system is changing. With 15-minute interval, continuous data being collected, sufficient data are available to measure the change over time, rather than estimating this change with regression models, such as LOADEST and WRTDS. Furthermore, shifts in the nitrate $\mathrm{C}-\mathrm{Q}$ relationships might be an early indicator of water-quality change because the increased management of the watershed is likely to fundamentally change nutrient transport dynamics without actually changing the hydrology; hence, the $\mathrm{C}-\mathrm{Q}$ relationships might evolve over time with enhanced nutrient management.

- Ratios of various chemical tracers might produce indicators of change at an early stage because concentrations of some constituents are controlled largely by dissolution and reaction chemistry in aquifers, whereas others are more strongly related to land-use practices on the land surface. For example, implementation of sufficient nutrient management practices could drive changes in the ratios of nitrate to calcium and other constituents. With additional years of data collection, these patterns in constituent ratios will be evaluated.

- Direct monitoring of the headwater springs that contribute significant flows and elevated nitrogen concentrations represent an effective way to monitor changes in the chemistry and nutrient transport from the important agricultural sources to Smith Creek. 


\section{Upper Chester River Watershed Water-Quality Characterization}

\section{Lead Author: Judith M. Denver}

The Upper Chester River watershed includes the watershed area around several small nontidal tributaries that drain into the tidal portion of the Chester River (fig. 40). The study area was selected in 2010 as a Showcase Watershed by the USDA NRCS with the intent of targeting the area with intensive installation of BMPs aimed at improving water quality throughout the watershed. The USGS was charged with monitoring the long-term effects of this concentrated BMP implementation. Current (2015) monitoring includes an intensively gaged monitoring site on Chesterville Branch and 17 additional sites on Chesterville Branch and several other tributaries that were monitored during synoptic surveys of water quality (fig. 40). These data are supported by previous data collection and analyses from intensive studies of groundwater and surface-water quality, particularly by the USGS National Water-Quality Assessment (NAWQA), on the northern side of the Chester River (Böhlke and Denver, 1995; Shedlock and others, 1999; Ator and others, 2004).

\section{Streamflow and Water-Quality Characterization at the Intensive Monitoring Site}

Chesterville Branch, which drains approximately $6.12 \mathrm{mi}^{2}$, is the largest nontidal subwatershed of the Upper Chester River watershed (fig. 40). Land use is row-crop production in the southern part of the watershed; in the northern part, a large plant nursery covers about 40 percent of the total watershed area. This site has been monitored for flow and water quality intermittently since 1990, when samples were collected in 1990 and 1991 to support a NAWQA groundwater flow-path study and for routine monitoring and storm sampling from 1996 through 2001 as part of the Chesapeake Bay nontidal network. Stream gaging and sampling began again in July 2011 as part of the current study, with sampling during base-flow and storm conditions (fig. 41). Most of the studies of nutrient and sediment transport in the Bay area have been conducted in much larger watersheds, which makes studying a stream of this size somewhat unusual. Hydrogeologic setting and land use in the Chesterville Branch subwatershed are similar to those in large areas of the Eastern Shore that have not been monitored intensively. Results from the study in this watershed can be extended to understanding processes affecting nutrient and sediment transport in other similar small Coastal Plain watersheds in this area.

\section{Characterization of the Physical Hydrology}

Based on the base-flow index, about three-quarters of the flow to Chesterville Branch is from groundwater that continually discharges through the streambed, as is typical of most of the Coastal Plain (table 16). Base flow ranged from about $10 \mathrm{ft}^{3} / \mathrm{s}$ during winter months when the water table is generally highest and groundwater discharge is greatest to as low as $3 \mathrm{ft}^{3} / \mathrm{s}$ during dry periods, which generally occur in the late summer (fig. 41). Runoff is rapid during storms, and the stream returns to base-flow conditions within a relatively short time period because little water is retained in the floodplain of this small watershed. During the study period from July 2011 through September 2013, streamflow was below normal (as represented by median flow) at the beginning, increased to be above normal in the late summer and fall after a period of intensive storms, returned to normal in January 2012, and remained normal throughout the remainder of the study period (fig. 41). 


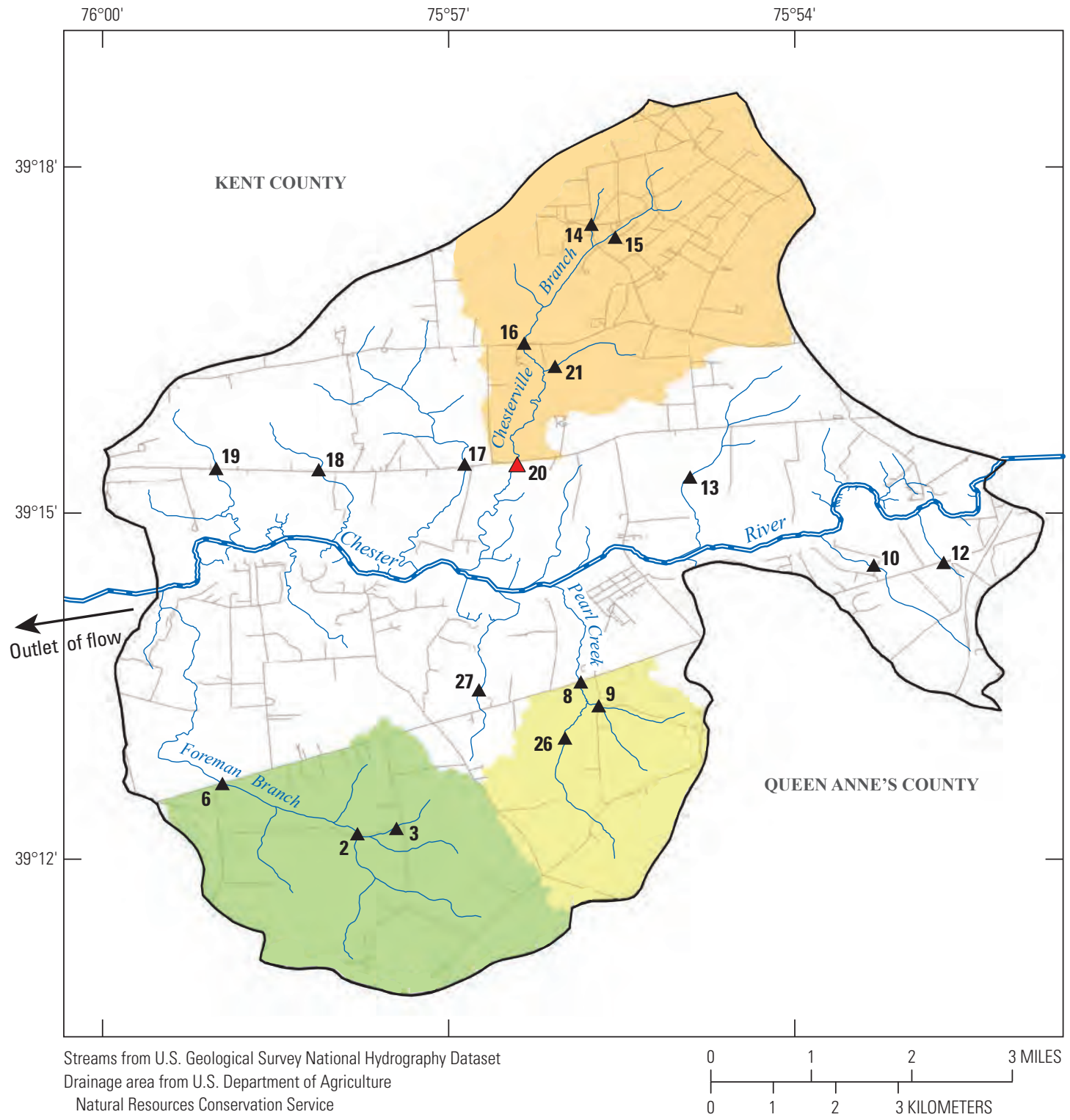

unpub data for HUC 020600020605,24

Roads are from U.S. Census Bureau TIGER/Line shapefiles (2015)

North American Datum of 1983

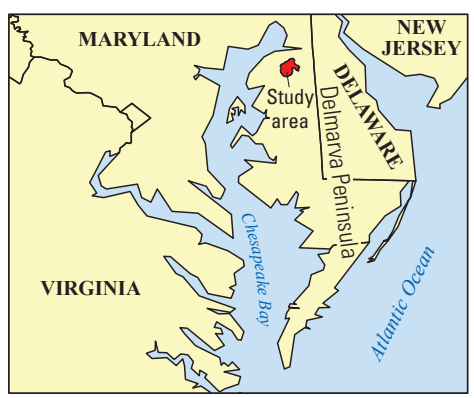

EXPLANATION

Watershed

Foreman Branch

Pearl Creek

Chesterville Branch

Upper Chester River (area $=36.54 \mathrm{mi}^{2}$ )
= Upper Chester River Tributary to Upper Chester River Monitoring station and identifier $\Delta_{\mathbf{2 0}} \quad$ USGS streamgage 01493112

$\Delta 21$ Synoptic sampling location and identifier

Figure 40. Monitoring stations, select subwatershed boundaries, and the stream network within the Upper Chester watershed, Maryland. 


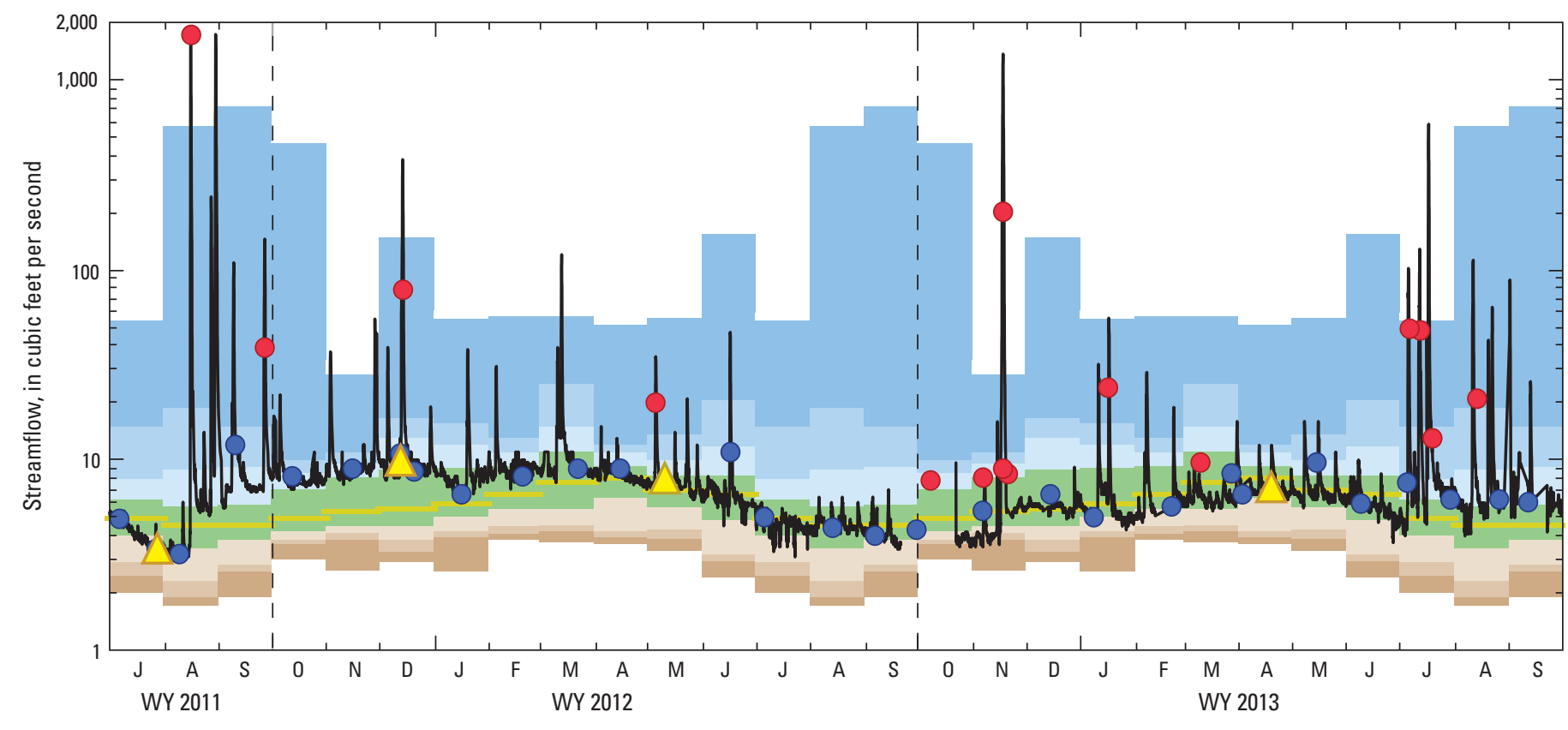

EXPLANATION

Monthly flow statistics - Historical daily flows from WY 1991 to WY 2013

Minimum daily flow to 5 th percentile 5th percentile to 10 th percentile 10th percentile to 25 th percentile 25th percentile to 75 th percentile 75th percentile to 90th percentile 90th percentile to 95th percentile 95th percentile to maximum daily flow Median flow

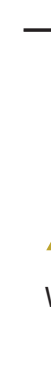

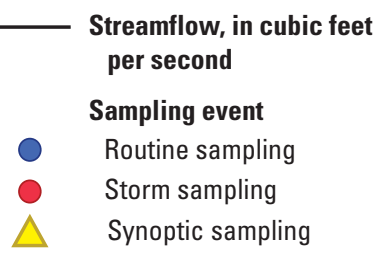

WY Water year

Figure 41. Chesterville Branch streamgage and quantiles that represent historical monthly flow data with the timing of various sampling events from July 2011 through September 2013 within the Upper Chester River watershed.

Table 16. Streamflow partitioning for streamgage station 01493112 in the Upper Chester River watershed.

$\left[\mathrm{mi}^{2}\right.$, square mile; $\mathrm{ft}^{3} / \mathrm{s}$, cubic foot per second; in/yr, inch per year; \%, percent; data were computed using the software package PART (Rutledge, 1998)]

\begin{tabular}{|c|c|c|c|c|c|c|c|}
\hline \multirow{2}{*}{ Watershed } & \multirow{2}{*}{$\begin{array}{l}\text { Drainage area } \\
\qquad\left(\mathrm{mi}^{2}\right)\end{array}$} & \multirow{2}{*}{ Period of record } & \multicolumn{2}{|c|}{$\begin{array}{c}\text { Mean } \\
\text { streamflow }\end{array}$} & \multicolumn{2}{|c|}{ Mean base flow } & \multirow{2}{*}{$\begin{array}{l}\text { Base-flow } \\
\text { index (\%) }\end{array}$} \\
\hline & & & $\mathrm{ft}^{3} / \mathrm{s}$ & in/yr & $\mathbf{f t}^{3} / \mathbf{s}$ & in/yr & \\
\hline \multirow{2}{*}{$\begin{array}{l}\text { Upper Chester } \\
\text { River }\end{array}$} & 6.12 & $1997-2001$ & 7.71 & 17.12 & 5.79 & 12.84 & 75.0 \\
\hline & & 2012-2013 & 8.64 & 19.17 & 6.23 & 13.83 & 72.1 \\
\hline
\end{tabular}




\section{Characterization of Continuous Water-Quality Data}

Continuous data collected at Chesterville Branch illustrate seasonal and diel patterns in water chemistry, as well as the effects of variations in streamflow (figs. 42 and 43). Water temperature ranged from $0{ }^{\circ} \mathrm{C}$ to about $25^{\circ} \mathrm{C}$ over the course of the study period (fig. 42). Concentrations of DO were highest in the cooler months and stayed above about $6 \mathrm{mg} / \mathrm{L}$ during base flow, reflecting a consistent input of DO in discharging groundwater or reaeration processes (fig. 42). The lowest DO concentrations occurred during the warmer months when biologic activity and the potential for DO to be affected by plant and microbial respiration was greatest. Also during the warmer months, streamflow is generally lowest on an annual basis, and a larger proportion of discharging groundwater is older, calcareous water that has relatively little DO (Böhlke and Denver, 1995). The amplitude of diel DO fluctuations reached about $5 \mathrm{mg} / \mathrm{L}$ in the spring when biologic activity increased, but was generally about $2 \mathrm{mg} / \mathrm{L}$ over the rest of the year (fig. 42).

Specific conductance, $\mathrm{pH}$, nitrate concentrations, and turbidity were strongly related to flow in Chesterville Branch (figs. 44 through 46). Nitrate concentrations and specific conductance decrease with increases in flow because runoff has much lower concentrations of constituents than the groundwater that makes up most of the stream base flow. As flow decreases, nitrate concentrations and specific conductance begin to increase until returning to base-flow levels. Previous studies in this area have shown that chemicals from agricultural sources, including nitrate, calcium, and magnesium, dominate water chemistry and contribute to the higher specific conductance in groundwater and base flow than in runoff (Böhlke and Denver, 1995; Shedlock, and others, 1999; Denver and others, 2014). Seasonal variations in specific conductance are minor during base flow, with the majority of change occurring during stormflow dilution (fig. 44). Stream water is circumneutral to slightly acidic, and $\mathrm{pH}$ decreases with runoff during storms. The $\mathrm{pH}$ also is related to seasonal changes in $\mathrm{DO}$ diel cycles, with the highest $\mathrm{pH}$ readings occurring during periods when the diel fluctuation of DO is greatest in the spring (figs. $42 B, 42 C, 44$, and 45 ).

Concentrations of nitrate ranged from about $8 \mathrm{mg} / \mathrm{L}$ as $\mathrm{N}$ to more than $10 \mathrm{mg} / \mathrm{L}$ as $\mathrm{N}$ in base flow during the study period (fig. 45). The median nitrate concentrations were higher during cooler months when base flow was greatest, indicating the potential for a larger proportion of young groundwater containing nitrate to enter the stream and also a lower potential for uptake of nitrate by aquatic plants and algae (fig. 45). Groundwater discharge to Chesterville Branch includes the nitrate-rich water from the unconfined surficial aquifer and older water from near the base of the surficial aquifer which is anoxic, had higher bicarbonate than water from the unconfined surficial aquifer, and did not contain nitrate (Böhlke and Denver, 1995). The contribution of older water from the deeper aquifer is greatest during the dry season when the water table is low (Ator and others, 2004).

Turbidity data did not have much seasonal difference during the study period with continuous data collection. The study period was limited, however, and does not represent a large number of storms (fig. 45). 


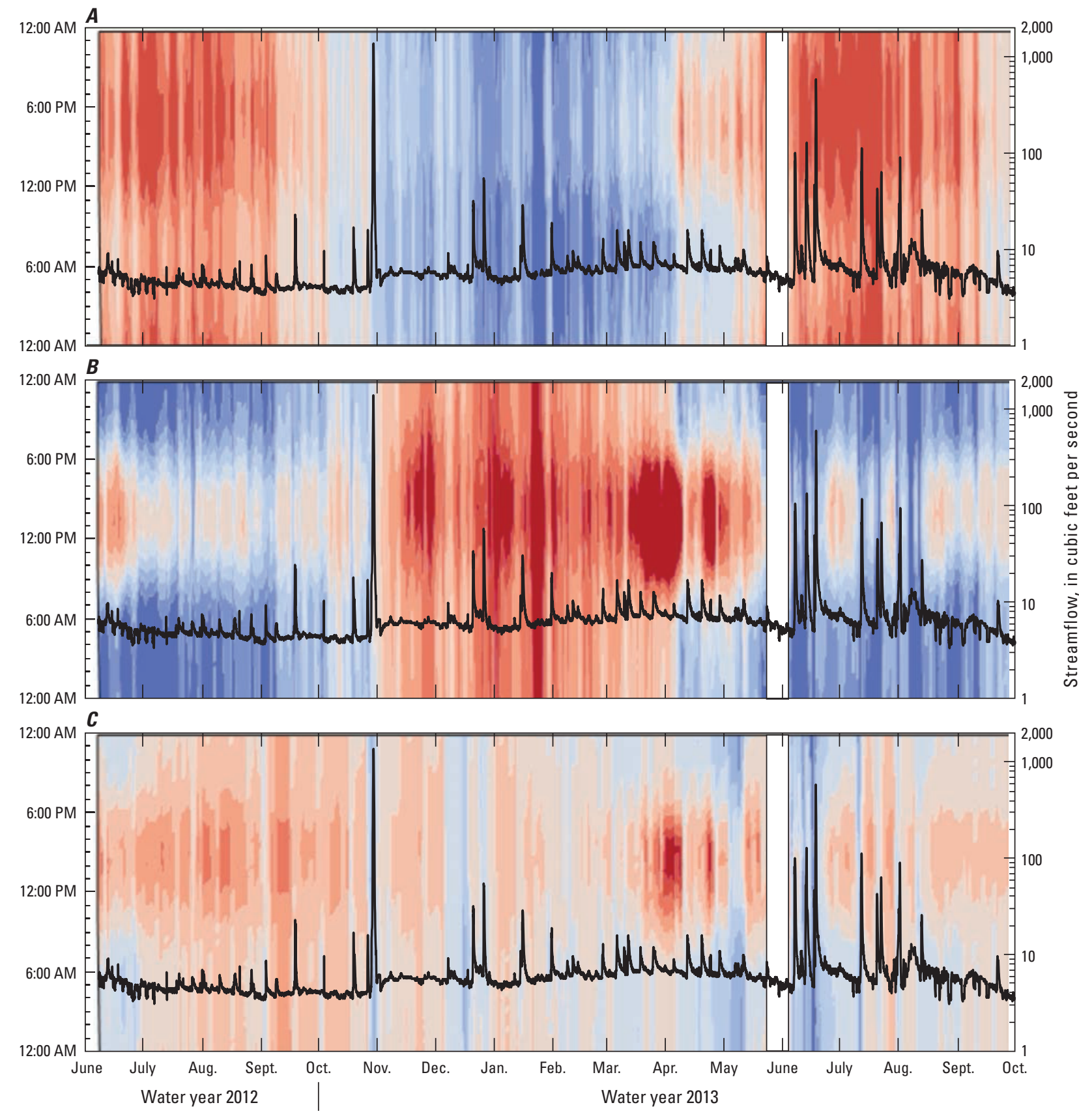

Figure 42. Continuous $(A)$ water temperature, $(B)$ dissolved oxygen, and $(C) \mathrm{pH}$ data with the hydrograph from the Chesterville Branch streamgage, 2012-2013.

\section{EXPLANATION}

Water temperature, in degrees Celsius

\begin{tabular}{|c|c|}
\hline 2.70 to 6.50 & 16.71 to 18.40 \\
\hline 6.51 to 8.00 & 18.41 to 19.60 \\
\hline 8.01 to 9.60 & 19.61 to 20.70 \\
\hline 9.61 to 11.70 & 20.71 to 26.30 \\
\hline 11.71 to 14.70 & 26.31 to 28.00 \\
\hline 14.71 to 16.70 & $\begin{array}{l}\text { Gap in data that } \\
\text { exceeds } 1 \text { week }\end{array}$ \\
\hline
\end{tabular}

Dissolved oxygen, in milligrams per liter

\begin{tabular}{|c|c|}
\hline 4.40 to 7.50 & 9.71 to 10.30 \\
\hline 7.51 to 7.90 & 10.31 to 10.90 \\
\hline 7.91 to 8.30 & 10.91 to 11.60 \\
\hline 8.31 to 8.70 & 11.61 to 12.00 \\
\hline 8.71 to 9.10 & 12.01 to 14.60 \\
\hline 9.11 to 9.70 & $\begin{array}{l}\text { Gap in data that } \\
\text { exceeds } 1 \text { week }\end{array}$ \\
\hline
\end{tabular}

— Streamflow, in cubic feet per second

$\mathrm{pH}$, in standard units

\begin{tabular}{|l|l|}
\hline 6.00 to 6.30 & 6.81 to 6.90 \\
\hline 6.31 to 6.40 & 6.91 to 7.00 \\
6.41 to 6.50 & 7.01 to 7.10 \\
6.51 to 6.60 & 7.11 to 7.20 \\
6.61 to 6.70 & 7.21 to 7.25 \\
\hline 6.71 to 6.80 & $\begin{array}{l}\text { Gap in data that } \\
\text { exceeds 1 week }\end{array}$ \\
\hline
\end{tabular}

- Streamflow, in cubic feet per second 

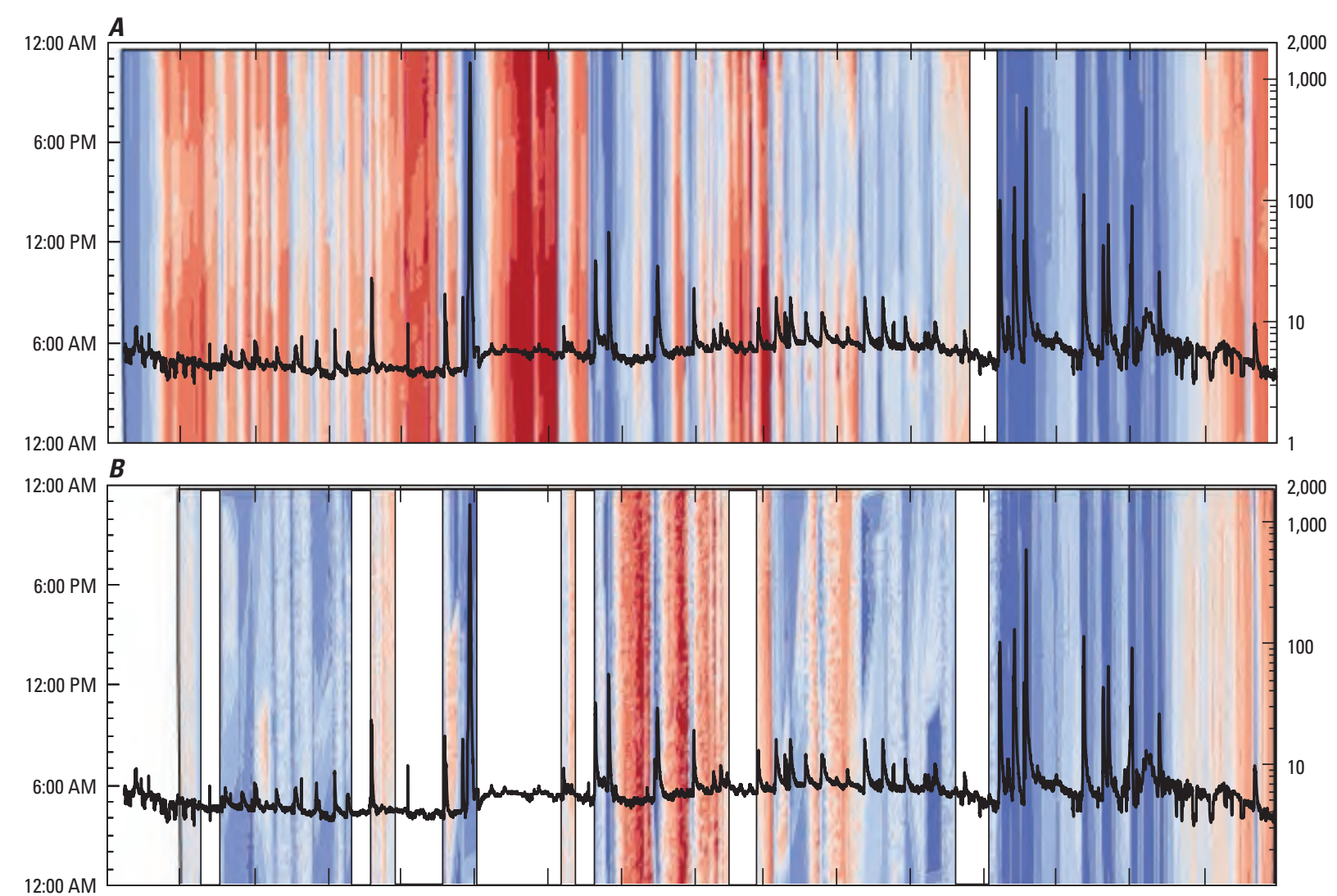

$12.00 \mathrm{AM}$

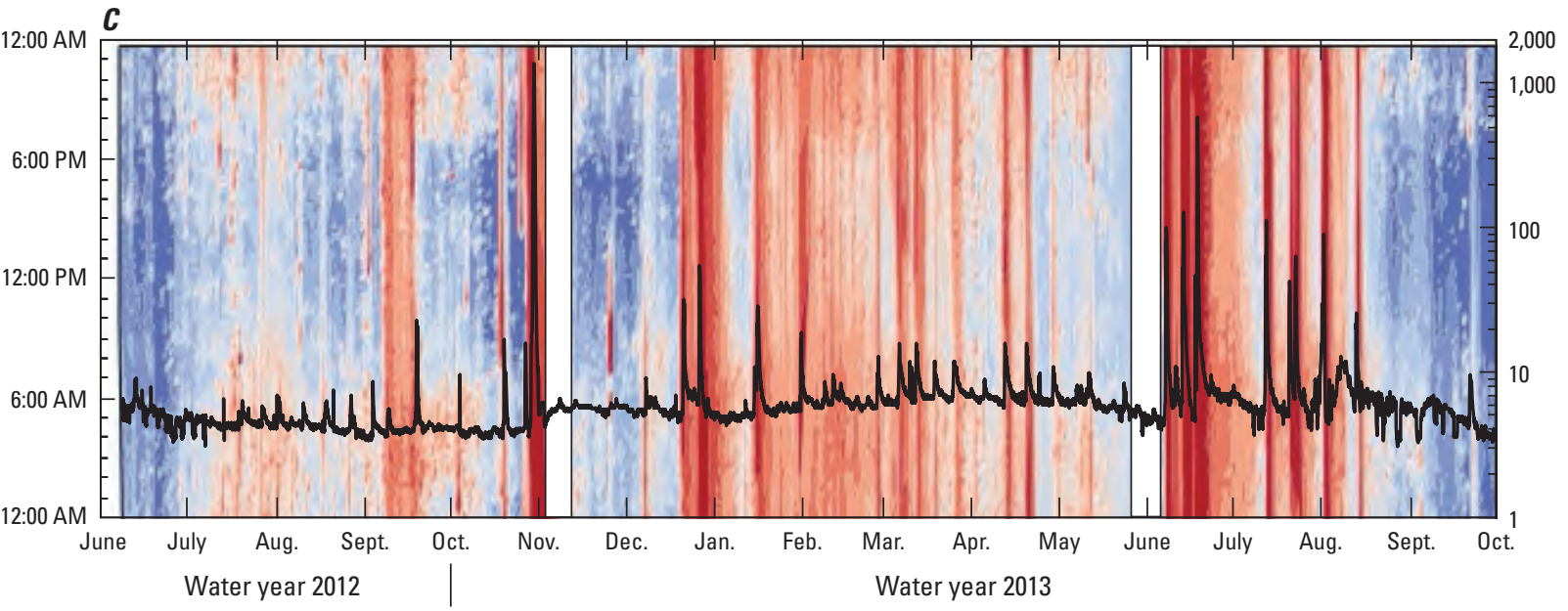

Figure 43. Continuous $(A)$ specific conductance, $(B)$ nitrate, and $(C)$ turbidity data with the hydrograph from the Chesterville Branch streamgage, 2012-2013.

\section{EXPLANATION}

Specific conductance, in microsiemens per centimeter at 25 degrees Celsius

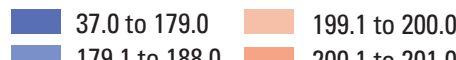

\begin{tabular}{l|l|l|l|l|}
179.1 to 188.0 & 200.1 to 201.0
\end{tabular}

188.1 to $193.0 \quad 201.1$ to 203.0

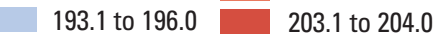

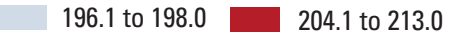

198.1 to $199.0 \square$ Gap in data that exceeds 1 week

- Streamflow, in cubic feet per second

Nitrate plus nitrite, in milligrams per liter as nitrogen

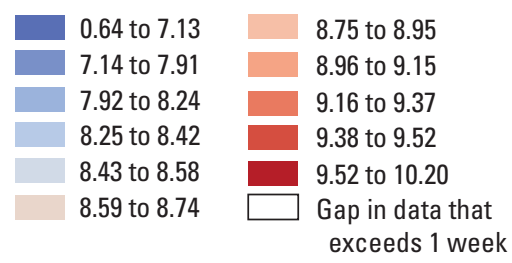

- Streamflow, in cubic feet per second

Turbidity, in formazin nephelometeric units

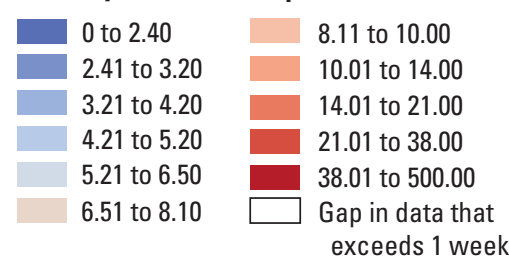

- Streamflow, in cubic feet per second 

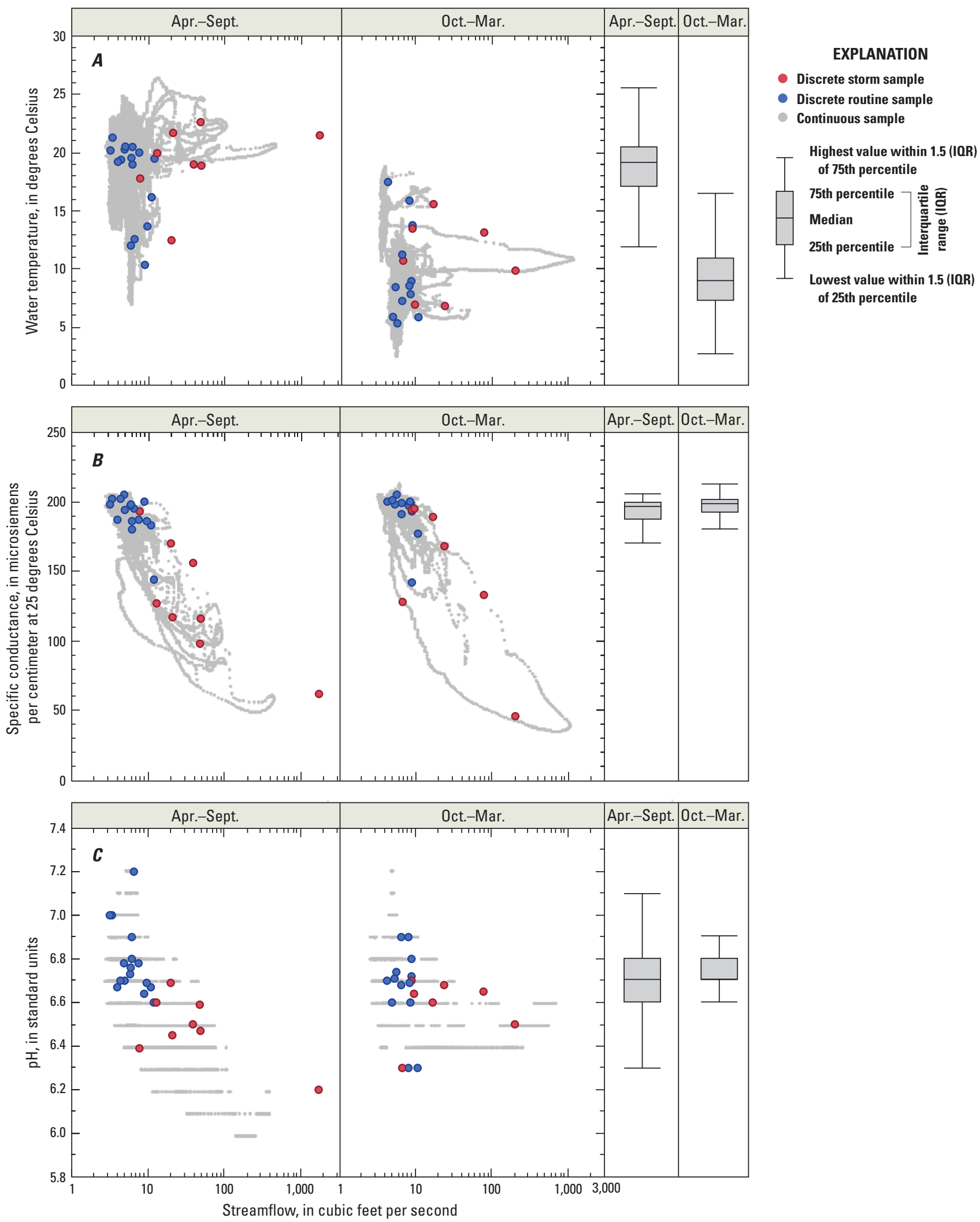

Figure 44. (A) Water temperature, $(B)$ specific conductance, and $(C) \mathrm{pH}$ data from continuous monitoring and discrete storm and routine samples for warm (April to September) and cool (October to March) seasons, Chesterville Branch streamgage, 2012-2013. 

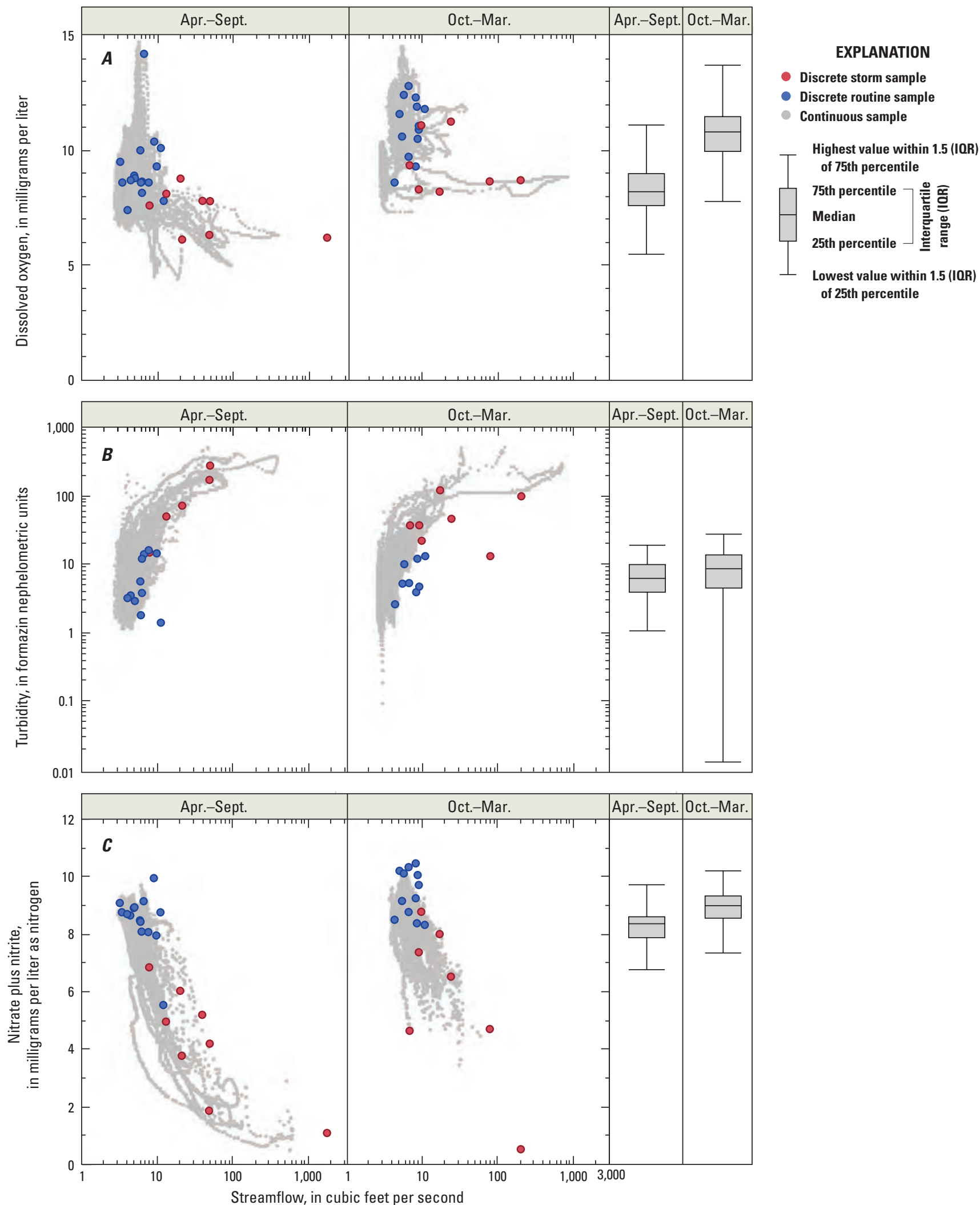

Figure 45. (A) Dissolved oxygen, $(B)$ turbidity, and $(C)$ nitrate data from continuous monitoring and discrete storm and routine samples for warm (April to September) and cool (October to March) seasons, Chesterville Branch streamgage, 2012-2013. 


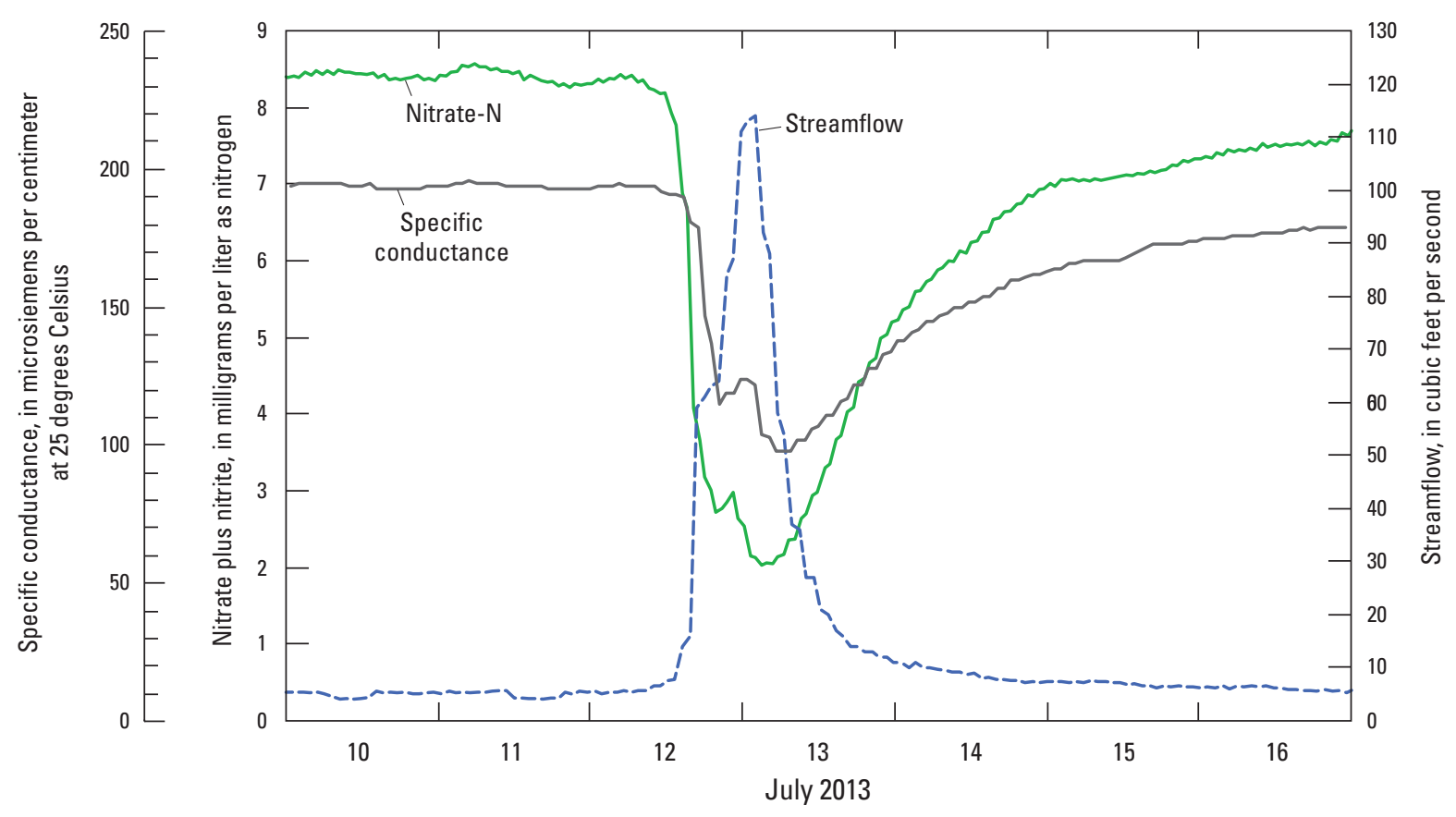

Figure 46. Chesterville Branch hydrograph, continuous nitrate concentrations, and continuous specific conductance data, July 10 through July 16, 2013.

\section{Characterization of Discrete Water-Quality Data}

Differences in water quality related to flow at Chesterville Branch are further supported by correlations between discrete water-quality data and streamflow (table 17). Constituents transported primarily in runoff or associated with near-stream processes, such as the degradation of organic matter and development of reducing conditions in floodplain areas and ponds, are positively correlated with flow. Constituents primarily associated with groundwater input are negatively correlated with flow. These relations, shown graphically on figure 47 and statistically in table 17 , are important to understanding nitrogen and phosphorus transport in Chesterville Branch. As flow increases, concentrations of ammonium, orthophosphate, and TP increase, but concentrations of nitrate and TN decrease. Concentrations of TP are considerably higher than those of orthophosphate, the dissolved form of phosphorus, because much of the phosphorus measured is in the particulate phase adsorbed onto sediment particles. Other constituents associated with overland flow include potassium, sulfate, iron, and manganese, which are likely contributed from near-stream areas with higher organic-matter content, and suspended sediment. In contrast, most of the TN in the stream is in the form of nitrate, which is dissolved in groundwater. Calcium and magnesium applied as lime commonly are correlated with nitrate in groundwater affected by agriculture on the Delmarva Peninsula (Shedlock and others, 1999) and also decrease as flow increases. Silica, dissolved in groundwater from aquifer sediments, also decreases as stream water is diluted by runoff, as do bicarbonate and $\mathrm{pH}$ as the stream water is diluted by the more acidic precipitation. Non-significant C-Q relationships are provided in the appendix as supplemental material (fig. 1-3).
Seasonal differences also are evident in discrete samples collected during base flow (table 17). Many of these differences are related to seasonal changes in biologic activity that affects the uptake and release of chemical constituents in the stream and near-stream areas. Processes associated with redox reactions are evident in the trends in concentrations of bicarbonate and sulfate during base-flow conditions (represented by routine samples) over time (table 17; fig. 48). In the spring, sulfate is high and bicarbonate is low, with the reverse occurring in autumn months. The pattern is likely related to processes occurring in highly eutrophic ponds with heavy algal growth and other aquatic vegetation that are located in the watershed upgradient of the sampling site - the largest of which is behind a dam in the stream channel. Similar patterns were seen in a study of eutrophic ponds by Mann (1958), who found that sulfate derived from sulfides produced by organic decay in anaerobic pond bottom sediments in winter and early spring was reduced when the ponds became anoxic in the later spring and summer. Lower concentrations of bicarbonate in the cool season could be partly due to removal of carbon dioxide from the water during photosynthesis and also to the formation of sulfuric acid when the sulfide oxidizes in water (Mann, 1958). These processes could also affect concentrations of manganese which is redox sensitive and more mobile in more acidic conditions (Millaleo and others, 2010) and shows a similar seasonal pattern as sulfate (table 17). The effects of anoxic conditions during the warmer months are also indicated by higher concentrations of dissolved orthophosphate released from exchange sites on streambed or near-stream sediments (table 17). Despite the effect of these ponds on redox-sensitive species, nitrate concentrations do not appear to respond to these processes, possibly because 
Table 17. Summary of hydrologic and seasonal correlations for discrete water-quality constituents collected at the Chesterville Branch streamgage.

[Results in bold are significant at $\alpha=0.05$; n, number of observations; APR, April; SEPT, September; OCT, October; MAR, March; <, less than]

\begin{tabular}{|c|c|c|c|c|c|c|c|}
\hline \multirow[b]{2}{*}{ Parameter } & \multicolumn{3}{|c|}{ Streamflow } & \multicolumn{4}{|c|}{ Season $^{3}$} \\
\hline & $\mathbf{n}$ & rho ${ }^{1}$ & p-value ${ }^{1}$ & nAPR-SEPT & nOCT-MAR & p-value ${ }^{2}$ & $\begin{array}{l}\text { Season with } \\
\text { higher values }\end{array}$ \\
\hline $\begin{array}{l}\text { Suspended-sediment } \\
\text { concentration }\end{array}$ & 41 & 0.73 & $<0.001$ & 14 & 11 & 0.545 & \\
\hline Total phosphorus & 45 & 0.72 & $<0.001$ & 16 & 12 & 0.417 & \\
\hline Ammonium & 45 & 0.52 & $<0.001$ & 16 & 12 & 0.659 & \\
\hline Manganese & 32 & 0.51 & 0.003 & 11 & 10 & 0.002 & OCT-MAR \\
\hline Orthophosphate & 45 & 0.50 & $<0.001$ & 16 & 12 & 0.031 & APR-SEPT \\
\hline Potassium & 32 & 0.47 & 0.007 & 11 & 10 & 0.860 & \\
\hline $\begin{array}{l}\text { Delta N-15 of nitrate, } \\
\text { per mil }\end{array}$ & 35 & 0.13 & 0.459 & 11 & 10 & 0.048 & APR-SEPT \\
\hline Sodium/chloride & 32 & 0.07 & 0.697 & 11 & 10 & 0.038 & APR-SEPT \\
\hline Calcium & 32 & -0.81 & $<0.001$ & 11 & 10 & 0.916 & \\
\hline Calcium/magnesium & 32 & -0.78 & $<0.001$ & 11 & 10 & 0.170 & \\
\hline Specific conductance & 47 & -0.69 & $<0.001$ & 18 & 13 & 0.388 & \\
\hline Nitrate-N & 45 & -0.62 & $<0.001$ & 17 & 12 & 0.020 & OCT-MAR \\
\hline Silica & 32 & -0.61 & $<0.001$ & 11 & 10 & 0.699 & \\
\hline Water temperature & 47 & -0.07 & -0.623 & 18 & 13 & $<0.001$ & APR-SEPT \\
\hline Magnesium & 32 & -0.05 & 0.778 & 11 & 10 & 0.008 & OCT-MAR \\
\hline
\end{tabular}



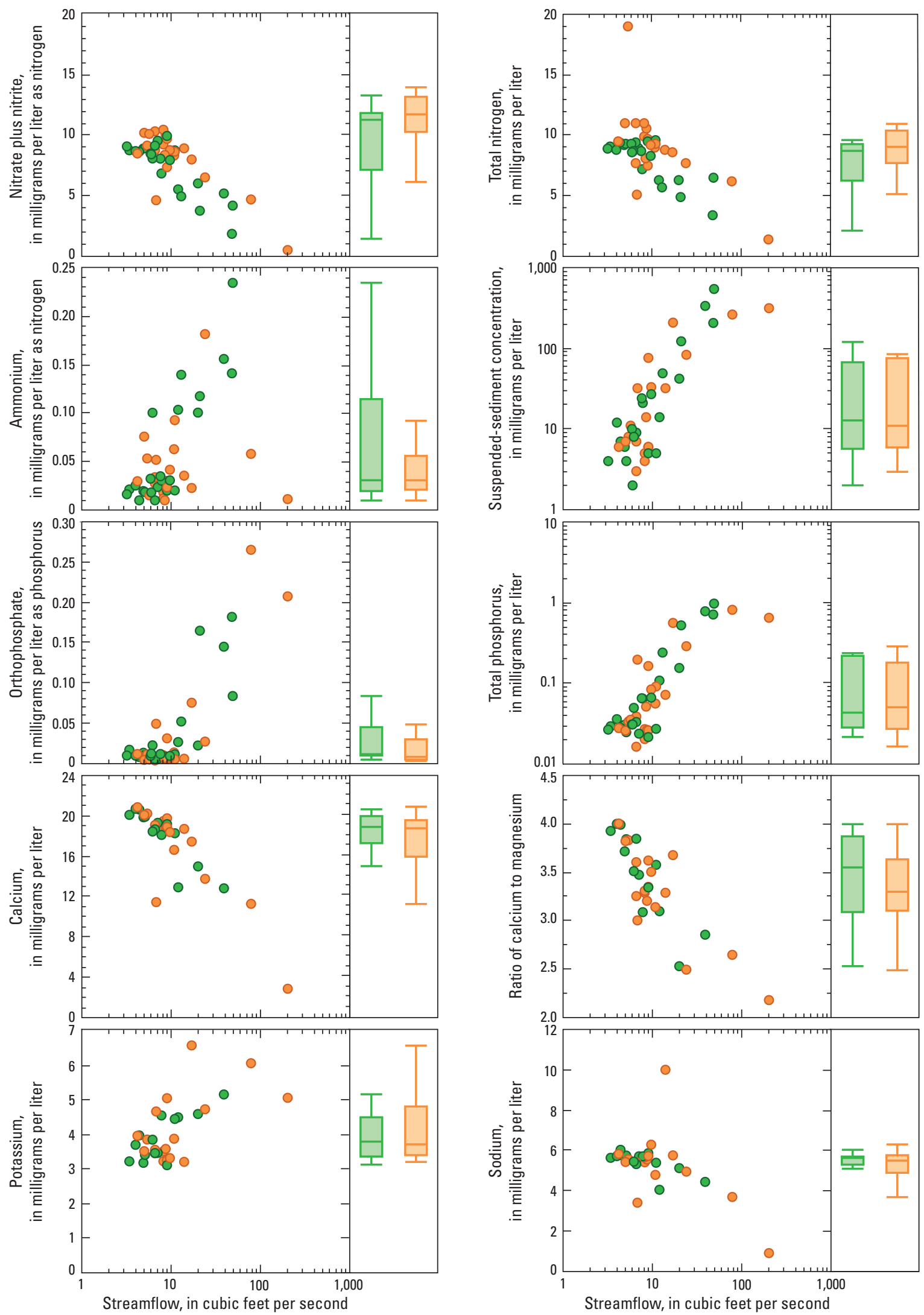

Figure 47. Concentration-discharge data for discrete samples from the Chesterville Branch streamgage by warm and cool seasons, 2011-2013. 

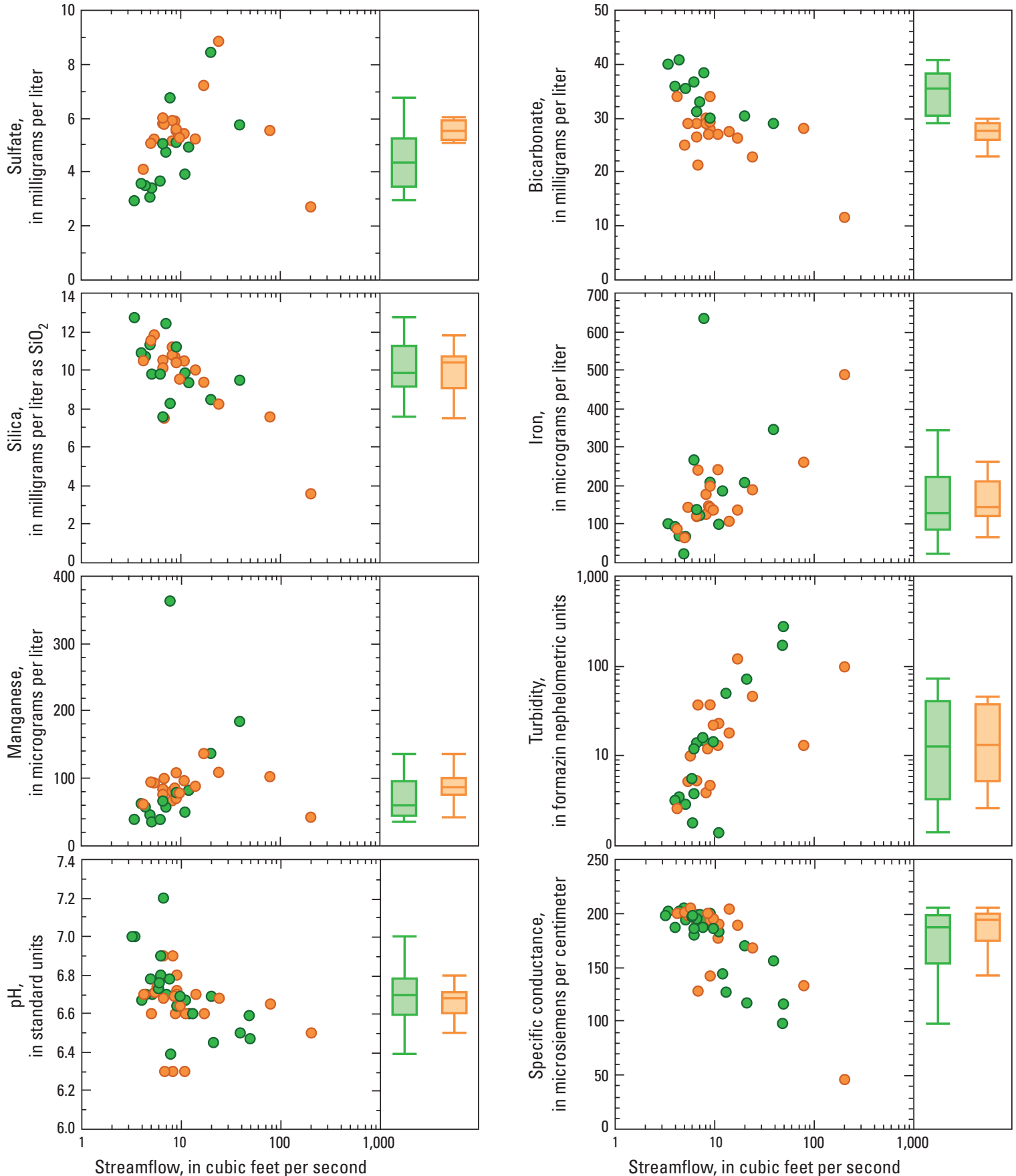

EXPLANATION

Season

- $\square$ April to September

- $\square$ October to March

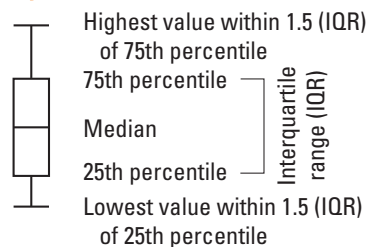

Figure 47. Concentration-discharge data for discrete samples from the Chesterville Branch streamgage by warm and cool seasons, 2011-2013.-Continued 

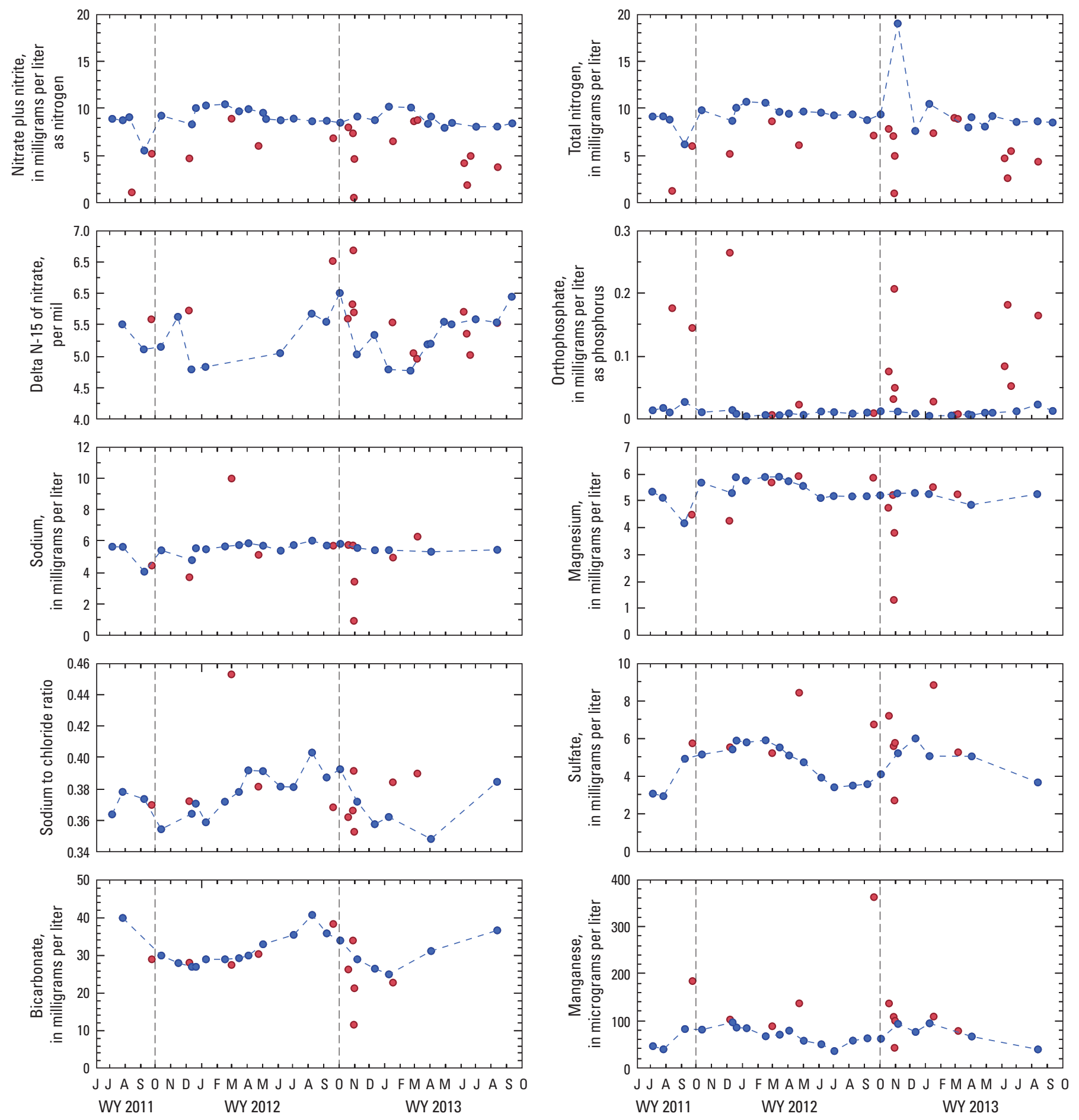

\footnotetext{
EXPLANATION

Hydrologic conditions

- - Routine sample

- Storm sample

WY Water year
}

Figure 48. Concentrations of various constituents in discrete samples from the Chesterville Branch streamgage, $2011-2013$. 
of the high concentrations of nitrate in the stream. Other ions contributed from groundwater that are not affected by redox reactions in ponds and the near-stream area, including silica, calcium, sodium, potassium, and chloride, do not show significant seasonal fluctuations in base flow because groundwater containing these constituents is continuously discharged throughout the year (fig. 1-4).

Nutrient concentrations and nitrate isotopes also show seasonal trends, though variations are relatively small compared to trends in the other watersheds in this study (table 17 and fig. 48). Overall, $\delta^{15} \mathrm{~N}$ values were consistent with artificial fertilizer as a major source of excess nitrogen. Some degree of uptake and (or) denitrification is indicated during the warmer months by slight increases in $\delta^{15} \mathrm{~N}$ (figs. 48 and 49) and increases in $\delta^{18} \mathrm{O}$ of nitrate (fig. 49). The high concentrations of nitrate in base flow at Chesterville Branch likely dampen observation of the effects of near-stream or in-stream denitrification and uptake at this site, compared to what might be seen at a site with low nitrate inputs. High-flow events that caused substantial dilution of nitrate and other major constituents in the Chesterville Branch caused little or no change in values of $\delta^{15} \mathrm{~N}$ or $\delta^{18} \mathrm{O}$ of nitrate (table 17). This result is consistent with the relatively low concentration of atmospheric nitrate in precipitation compared to the much higher concentration of agricultural nitrate in the base flow. Some of the change in nitrate concentrations also may be

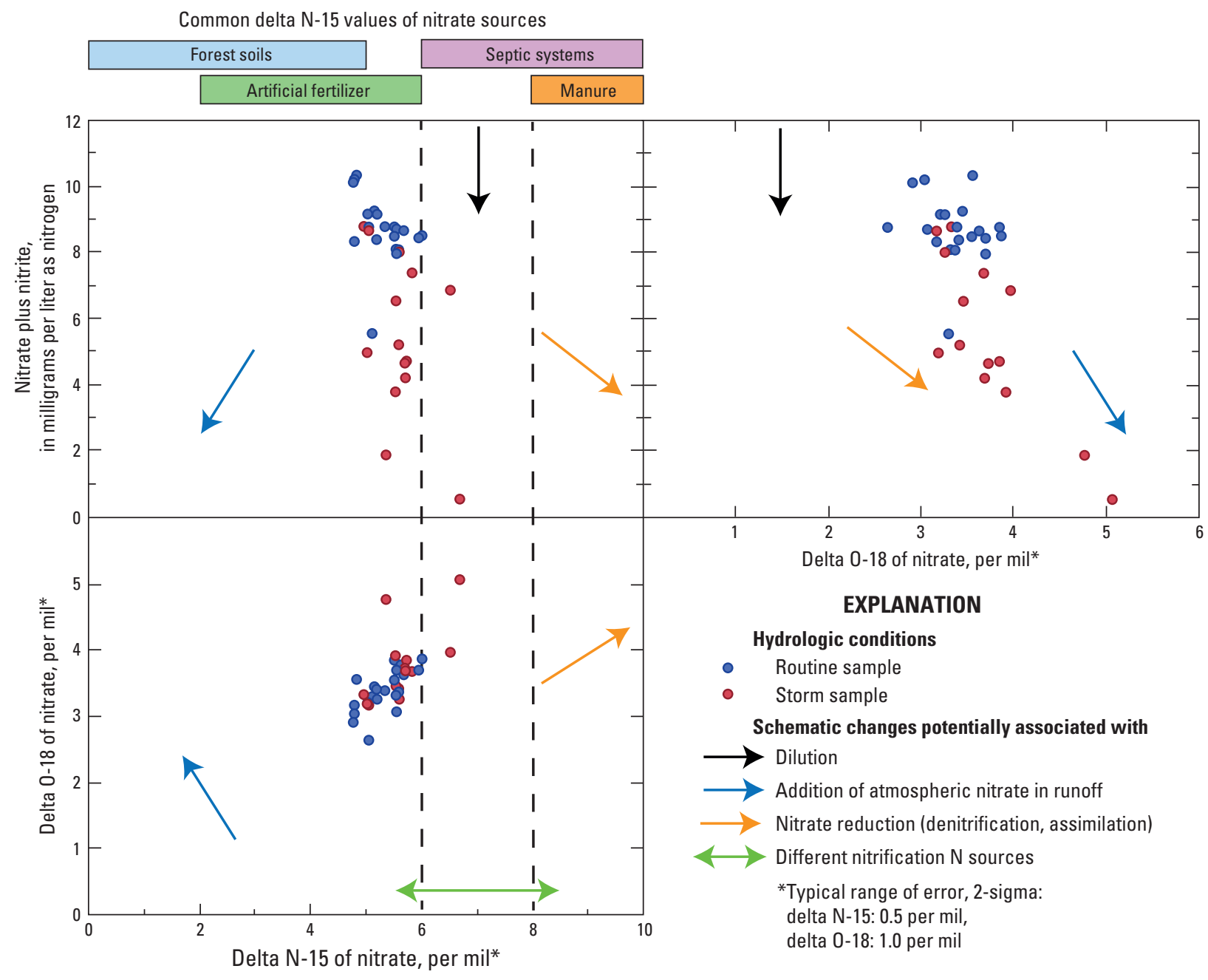

Figure 49. Variability in nitrate isotopes in discrete samples from the Chesterville Branch streamgage and potential causes for variability, 2011-2013. 
related to proportionally less young groundwater containing higher concentrations of nitrate and magnesium from agricultural sources discharging to Chesterville Branch in the warmer months when the water table is typically lowest.

Cluster and PCA of geochemical parameters also clearly illustrate the strong differences in water chemistry related to flow and season in the discrete samples from Chesterville Branch (table 18; figs. 50 and 51). The two clusters containing multiple samples are related to flow regime (fig. 50): base flow (cluster 1) is related to groundwater inputs, and high flow (cluster 2) is related to rapid overland runoff. A third cluster comprises one very dilute high-flow sample (fig. 50). Further analysis of these data using PCA developed from the same discrete dataset with the plotted points colored by their assigned cluster (fig. 51) shows similar patterns as seen in the Spearman's test and the cluster analysis. The first principal components axis relates to flow and shows the strong relationship of chemicals transported in groundwater (44.2 percent of the variance explained; during base flow, +) and high flows (in runoff, -). The second principal components axis appears to relate to seasonal variability in base-flow samples. These results are similar to those seen in a PCA based on earlier data collected at this site, where 47 percent of the variance in the data was explained by flow and 15 percent was attributed to seasonal variations in water chemistry (Ator and others, 2004).

Table 18. Loading of water-quality constituents collected at the Chesterville Branch streamgage on principal component axes 1 and 2.

$[\%$, percent; $\mathrm{PC} 1$, first principal components axis; $\mathrm{PC} 2$, second principal components axis; loadings with absolute value greater than 0.70 are shown in bold; those with absolute value less than $|0.40|$ are omitted]

\begin{tabular}{lcc}
\hline \multicolumn{1}{c}{ Constituent } & $\begin{array}{c}\text { PC1 } \\
(\mathbf{4 4 . 2 \%})^{\mathbf{1}}\end{array}$ & $\begin{array}{c}\text { PC2 } \\
(\mathbf{1 7 . 5 \%})^{1}\end{array}$ \\
\hline $\mathrm{pH}$ & 0.51 & \\
Specific conductance & $\mathbf{0 . 8 4}$ & $\mathbf{0 . 7 2}$ \\
Dissolved oxygen & & -0.59 \\
Bicarbonate & 0.41 & $\mathbf{0 . 7 5}$ \\
Sulfate & & \\
Chloride & 0.48 & \\
Calcium & $\mathbf{0 . 8 2}$ & 0.69 \\
Magnesium & & \\
Sodium & 0.61 & \\
Potassium & $-\mathbf{0 . 8 3}$ & \\
Nitrate-N & $\mathbf{0 . 8 9}$ & 0.42 \\
Ammonium & -0.43 & \\
Total nitrogen & $\mathbf{0 . 8 3}$ & -0.40 \\
Orthophosphate & $-\mathbf{0 . 8 0}$ & \\
Total phosphorus & $-\mathbf{0 . 9 0}$ & \\
Iron & $-\mathbf{0 . 7 1}$ & \\
Manganese & -0.51 & \\
Silica & $\mathbf{0 . 7 7}$ & \\
\hline
\end{tabular}

${ }^{1}$ Percent of overall variance explained. 


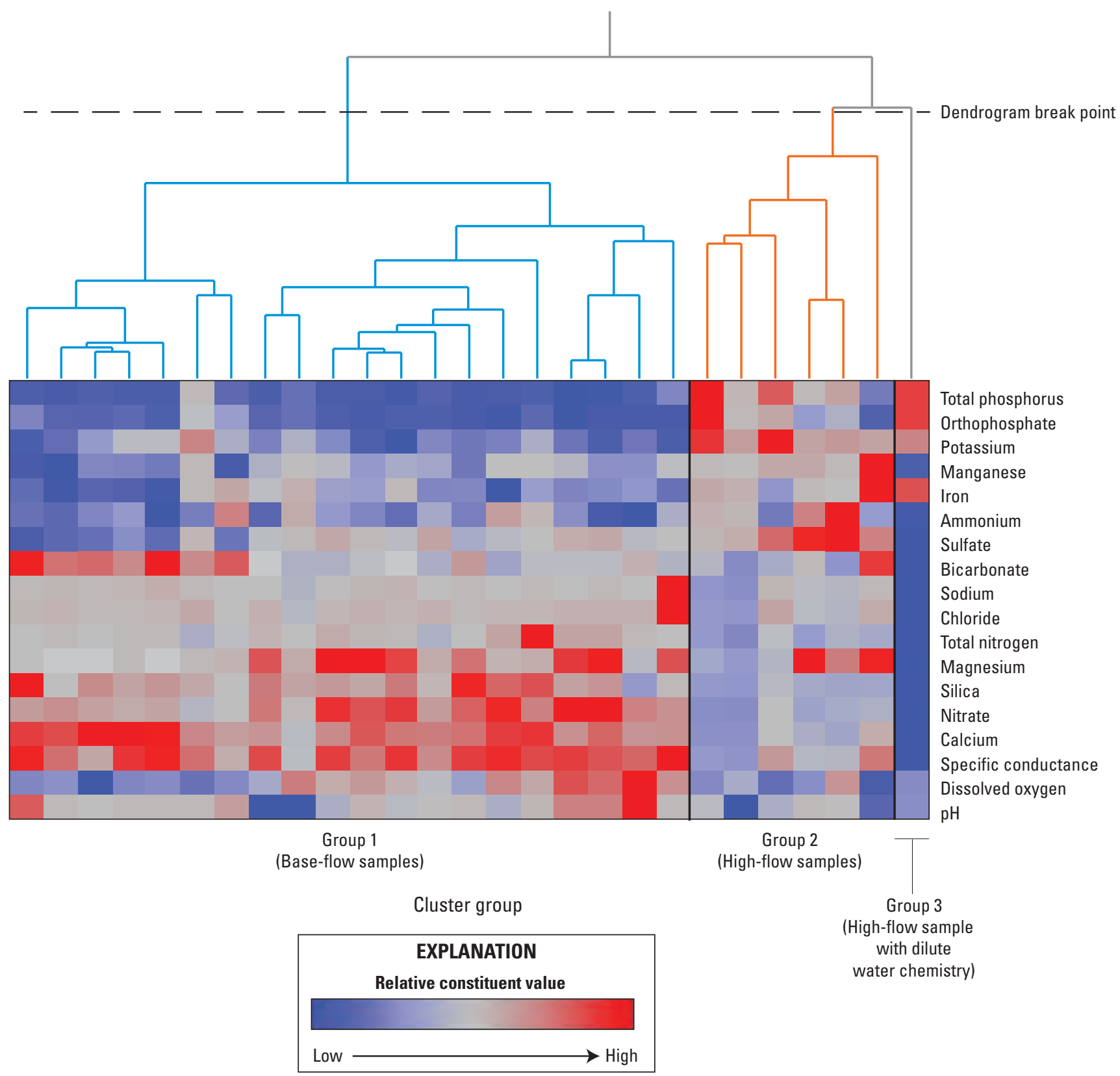

Figure 50. Discrete samples from the Chesterville Branch streamgage with a heat map of constituent values and the breakpoint used to produce three cluster groups, 2011-2013. 


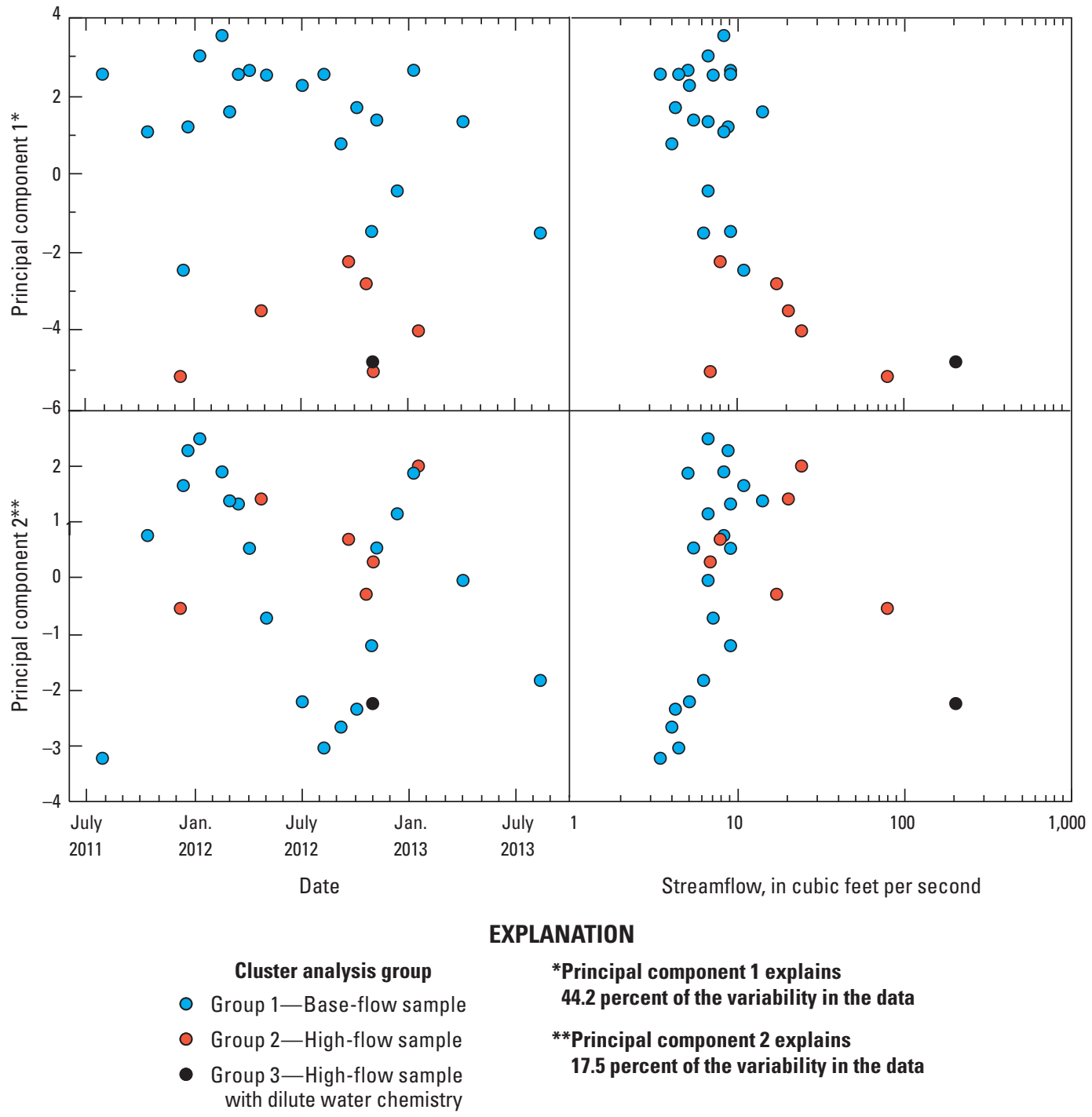

Figure 51. First two principal component axis scores for discrete samples from the Chesterville Branch streamgage along with time and streamflow, 2011-2013. 


\section{Surrogate Models for the Computation of Sediment and Nutrient Loads}

The discrete and continuous water-quality data were subsequently analyzed to explore the development of surrogate regression models to predict SSC and TN and TP concentrations. The development of these surrogate models is critical to the computation of constituent loads and an improved understanding of the watershed function.

\section{Model Development}

Predictions of SSC, TN, and TP were explored by using surrogate regression models of the discrete and continuous water-quality data. For each constituent, the strongest predictive model (as indicated by lowest Mallows' Cp) and model diagnostics are presented (table 19; figs. 52 through 54).
For SSC and TP, alternative model forms are presented that contain only flow and turbidity as explanatory variables. Flow and turbidity were significant in both suspended-sediment models, as would be expected, but the addition of DO, which had a negative relation to flow and turbidity, improved the predictions in the best model. Continuous data from this site indicate that DO decreases during high-flow events when sediment is transported (fig. 45). Both of the phosphorus models included flow and turbidity, and as with suspended sediment, the addition of DO improved the model. In this case, DO had a greater significance (lower p-value) than in the SSC model, which could be related to the potential for more transport of phosphorus from parts of the stream channel and ponds with reducing conditions during high-flow events. For the TN model, nitrate was the most important predictor, which is expected because nitrate makes up approximately 90 percent of the total nitrogen concentration during base flow.

Table 19. Details of the top-ranked suspended sediment, total nitrogen, and total phosphorus concentration estimation models for the Chesterville Branch streamgage with an alternative model presented for each constituent.

[ln, natural logarithm; top-ranked models are listed in bold; <, less than]

\begin{tabular}{|c|c|c|c|c|c|c|}
\hline Explanatory variables & $\begin{array}{c}\text { Model } \\
\text { coefficient }\end{array}$ & p-value & $\begin{array}{c}\text { Variance inflation } \\
\text { factor }\end{array}$ & $\begin{array}{c}\text { Number of } \\
\text { observations }\end{array}$ & $\begin{array}{c}\text { Adjusted } \\
\text { coefficient of } \\
\text { determination }\end{array}$ & Mallows' Cp \\
\hline \multicolumn{7}{|c|}{ Suspended-sediment concentration } \\
\hline Intercept & 2.192 & 0.005 & & \multirow{4}{*}{30} & \multirow{4}{*}{0.951} & \multirow{4}{*}{7.08} \\
\hline $\ln ($ Flow $)$ & 0.315 & 0.007 & 2.42 & & & \\
\hline Dissolved oxygen & -0.100 & 0.005 & 1.11 & & & \\
\hline In(Turbidity) & 0.790 & $<0.001$ & 2.47 & & & \\
\hline Intercept & 0.132 & 0.506 & & \multirow{3}{*}{30} & \multirow{3}{*}{0.936} & \multirow{3}{*}{15.37} \\
\hline $\ln$ (Flow) & 0.335 & 0.011 & 2.41 & & & \\
\hline $\ln$ (Turbidity) & 0.823 & $<0.001$ & 2.41 & & & \\
\hline \multicolumn{7}{|c|}{ Total nitrogen } \\
\hline Intercept & 0.683 & $<0.001$ & & \multirow{3}{*}{31} & \multirow{3}{*}{0.973} & \multirow{3}{*}{4.11} \\
\hline $\ln ($ Flow $)$ & 0.046 & 0.058 & 3.05 & & & \\
\hline $\ln ($ Nitrate-N) & 0.723 & $<0.001$ & 3.05 & & & \\
\hline \multicolumn{7}{|c|}{ Total phosphorus } \\
\hline Intercept & -2.455 & $<0.001$ & & \multirow{4}{*}{32} & \multirow{4}{*}{0.959} & \multirow{4}{*}{2.09} \\
\hline $\ln ($ Flow $)$ & 0.316 & $<0.001$ & 2.41 & & & \\
\hline Dissolved oxygen & -0.145 & $<0.001$ & 1.11 & & & \\
\hline In(Turbidity) & 0.592 & $<0.001$ & 2.46 & & & \\
\hline Intercept & -5.013 & $<0.001$ & & \multirow{3}{*}{32} & \multirow{3}{*}{0.907} & \multirow{3}{*}{4.48} \\
\hline $\ln ($ Flow $)$ & 0.344 & 0.007 & 2.40 & & & \\
\hline $\ln$ (Turbidity) & 0.639 & $<0.001$ & 2.40 & & & \\
\hline
\end{tabular}



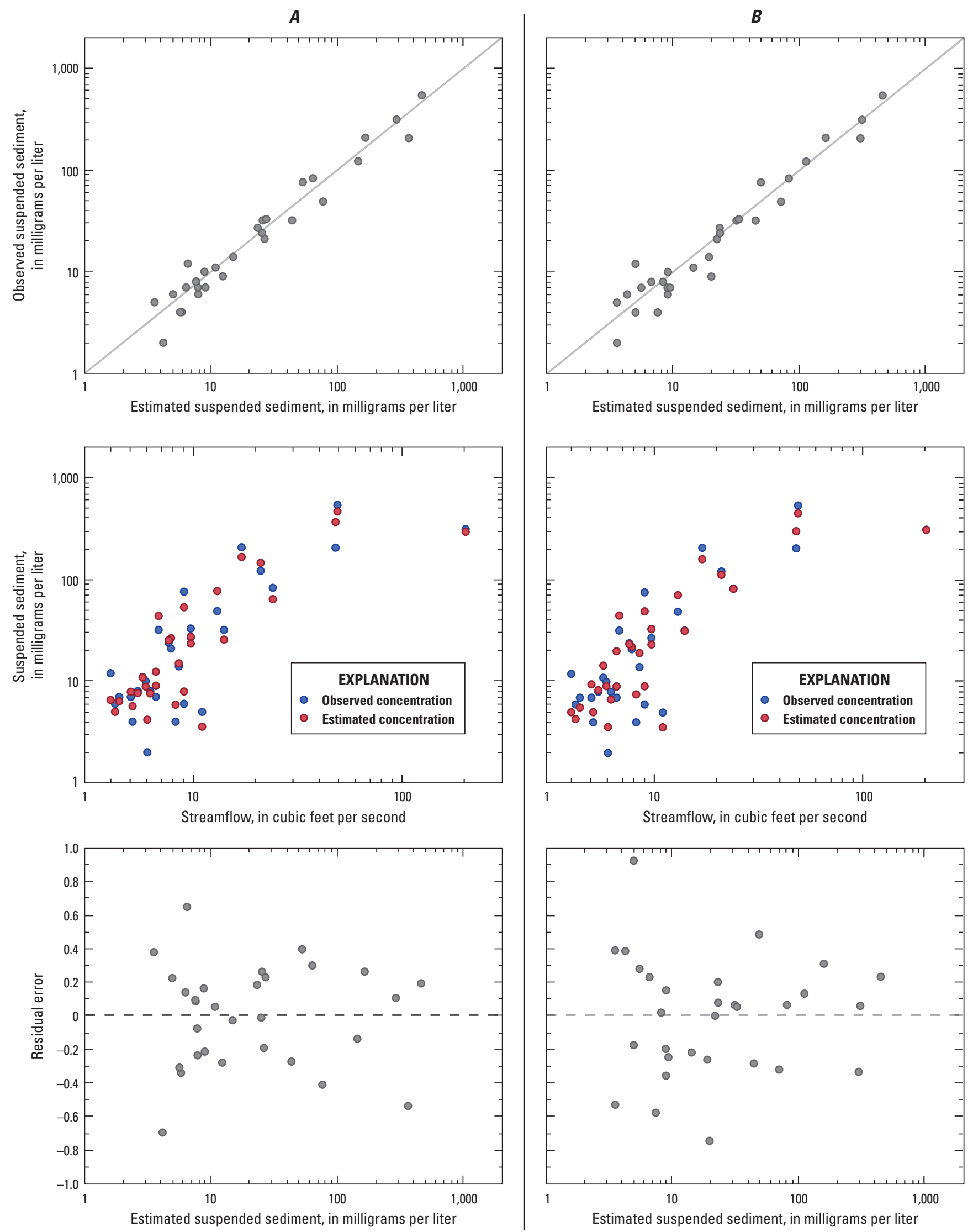

Figure 52. Observed and estimated values from the $(A)$ best and $(B)$ alternative suspended-sediment surrogate models for the Chesterville Branch streamgage and the residual plot of model predictions, 2012-2013. 

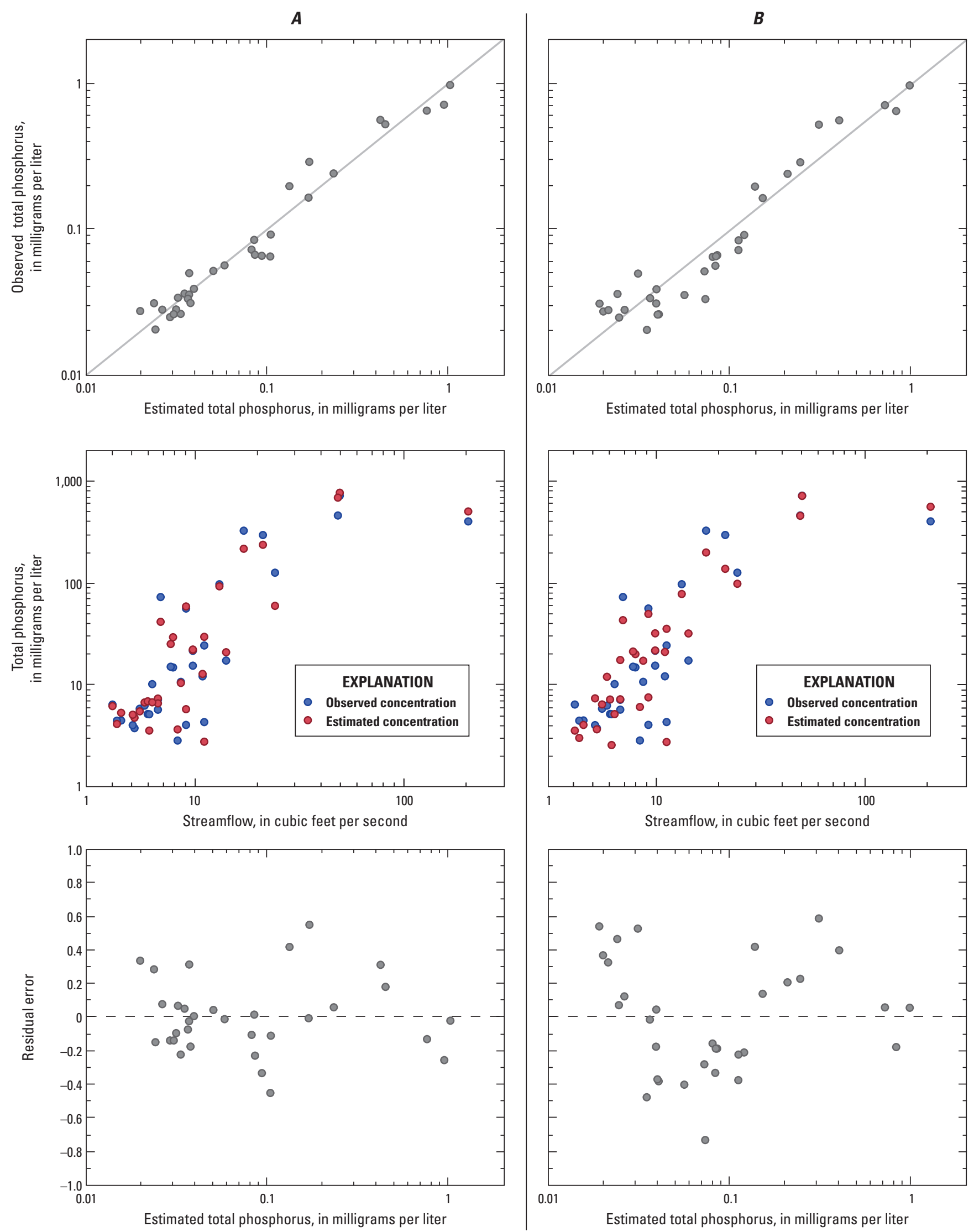

Figure 53. Observed and estimated values from the $(A)$ best and $(B)$ alternative total phosphorus surrogate models for the Chesterville Branch streamgage and the residual plot of model predictions, 2012-2013. 

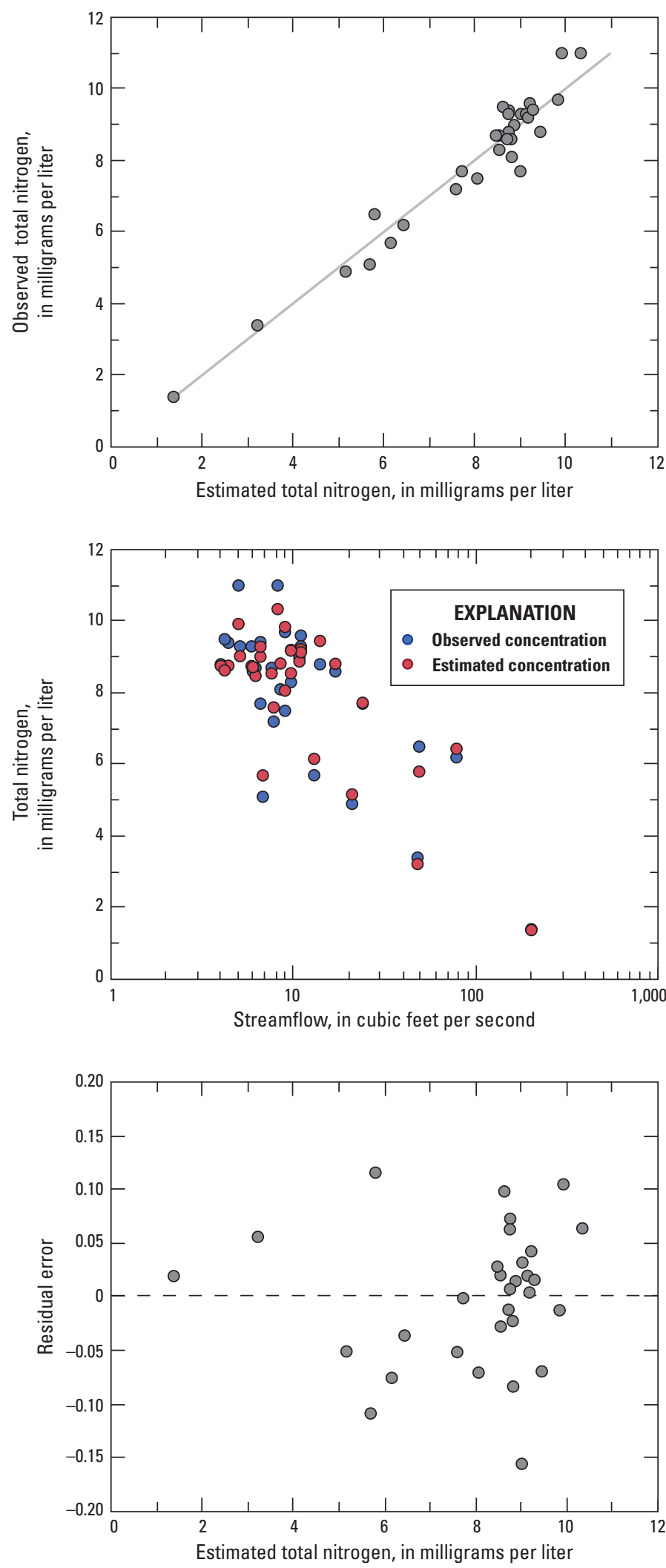

Figure 54. Observed and estimated values from the best total nitrogen surrogate model for the Chesterville Branch streamgage and the residual plot of model predictions, 2012-2013.

\section{Interpretation of the Computed Loads}

After developing surrogate models for estimating concentrations of suspended sediment, TN, and TP, water-year loads of these constituents were computed by using the record of continuous flow (from the streamgage) and predicted water quality (from the regression equations presented above). Methods for the replacement of missing records were described in the Development of Surrogate Water-Quality Models and Computation of Loads section of this report. The USGS software program LOADEST was used for these computations because the computed load could be calculated with confidence intervals around the predicted load, which was needed for comparisons between water years and sites.

The annual sediment load for the 2013 water year was estimated to be about 2,600 tons (fig. 55). The greatest loads were episodic and occurred during the two highest flows, particularly during one major storm early in the 2013 water year that contributed more than 65 percent of the total load; otherwise, the sediment load was minor during the smaller high-flow events (fig. 56).

About 13,000 lb of phosphorus entered Chesterville Branch during the 2013 water year (fig. 57). The greatest loads of TP also occurred during major storm events, and the pattern in load accumulation was almost identical to that of SSC (fig. 58).

The estimated load of TN during the 2013 water year was about 140,000 lb (fig. 59). TN, most of which comes from input of groundwater containing nitrate, had a constant input during most of the year, rather than large episodic event-related inputs as seen with SSC and TP. The major storm that contributed the majority of SSC and TP loads to Chesterville Branch (about 70 percent and 65 percent, respectively) contributed about 20 percent of the TN load; otherwise, the total load increased relatively steadily during the remainder of the year as nitrate in groundwater continuously entered the stream (fig. 60). Compared to the other study watersheds, intermittent fouling of the nitrate sensor resulted in a greater frequency of missing data that were replaced for the computation of TN loads. 


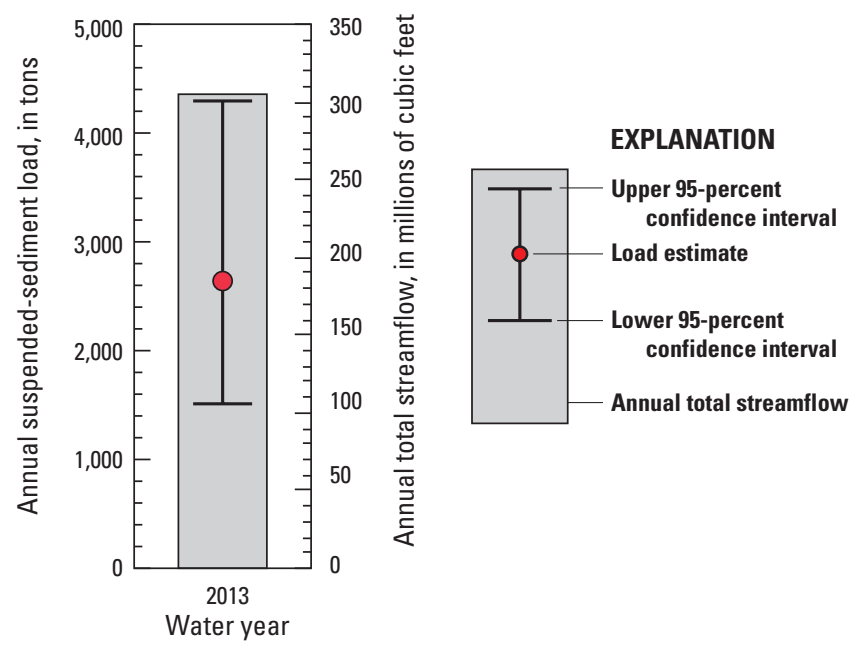

Figure 55. Suspended-sediment load and total annual streamflow at the Chesterville Branch streamgage for the 2013 water year.

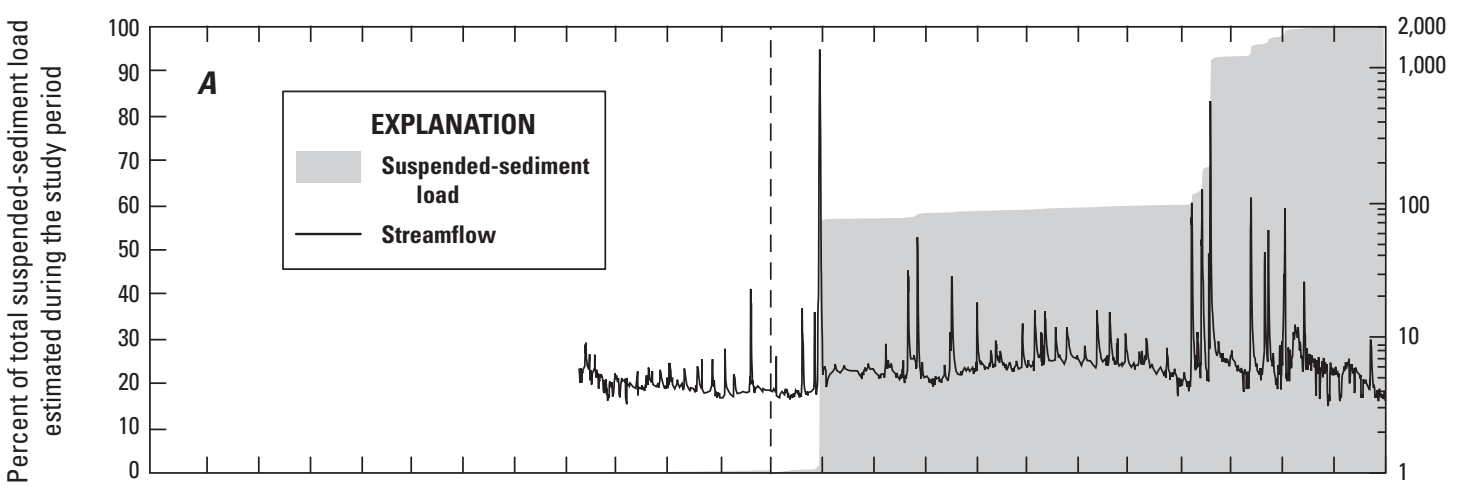

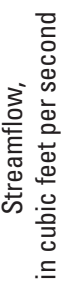

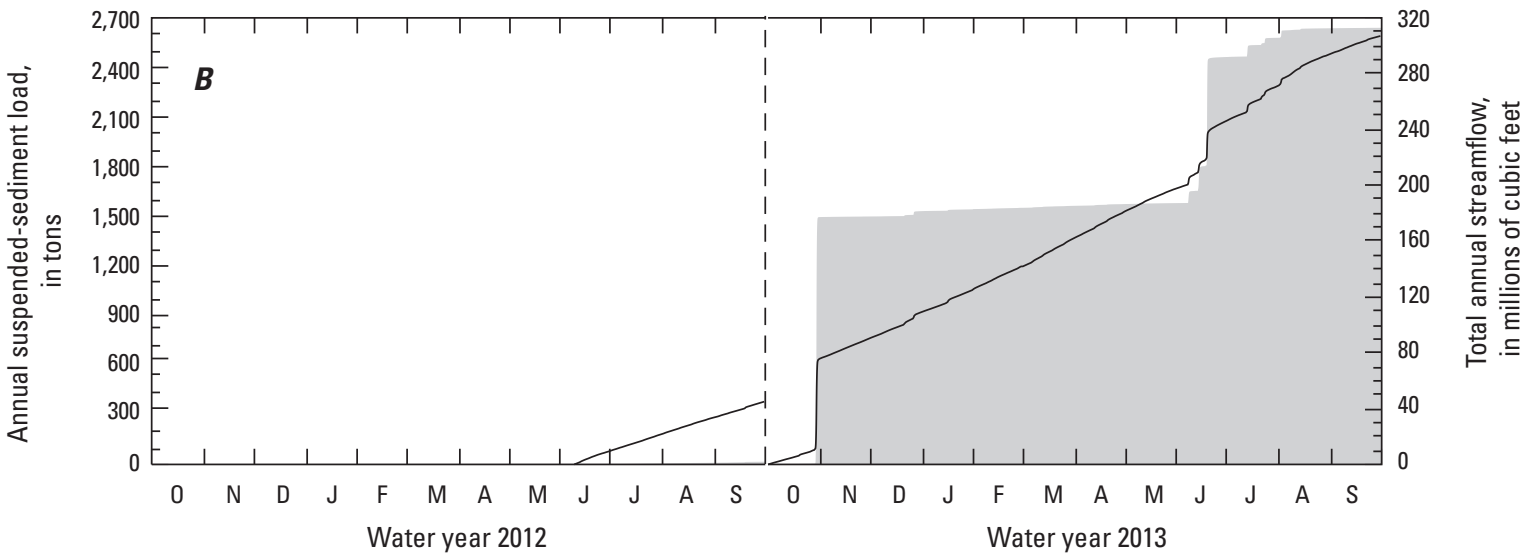

Figure 56. Suspended-sediment load at the Chesterville Branch streamgage for water years 2012 and 2013 along with $(A)$ the percentage of load accumulated and the hydrograph during the period of study and $(B)$ the accumulation of load and streamflow in each water year. 

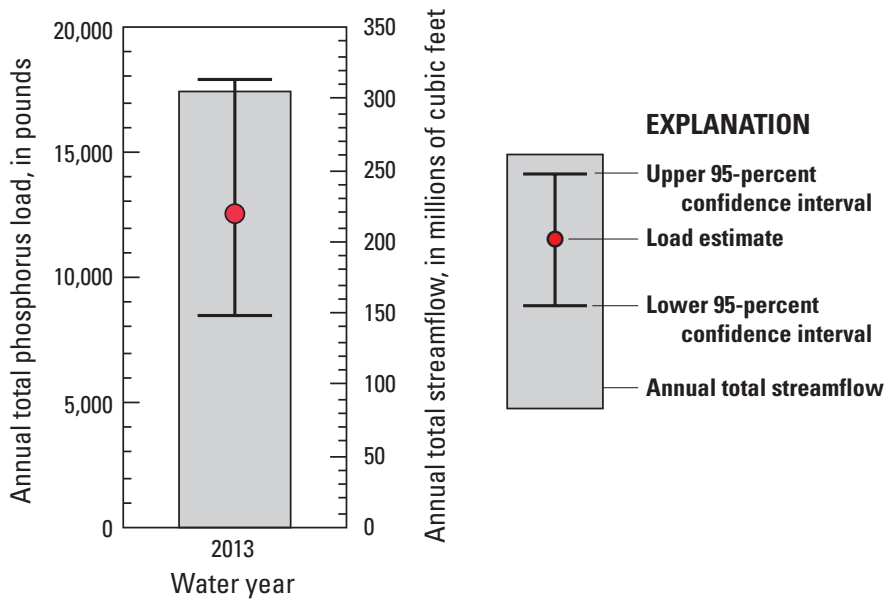

Figure 57. Total phosphorus load and total annual streamflow at the Chesterville Branch streamgage for the 2013 water year.
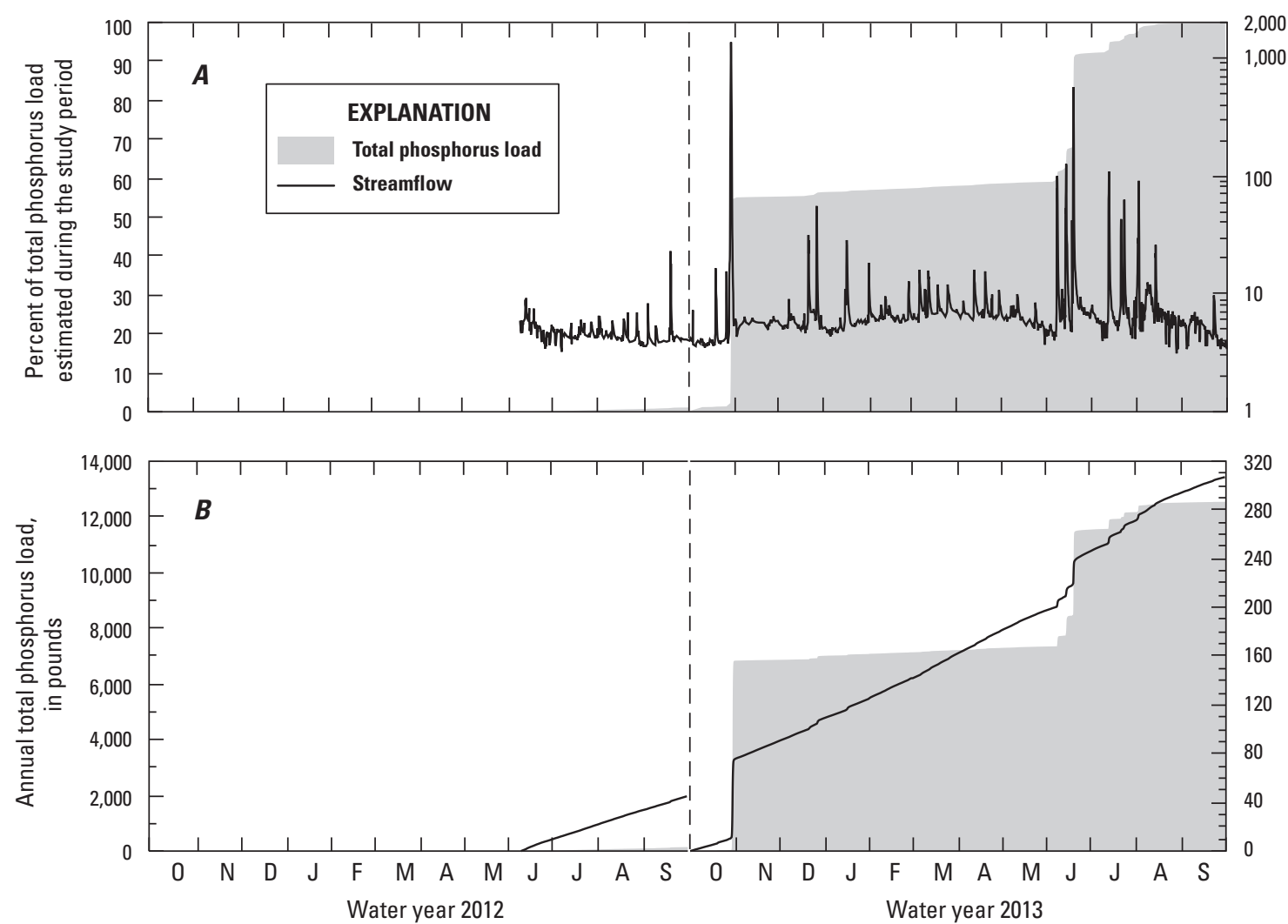

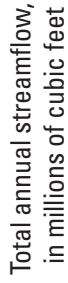

Figure 58. (A) The percentage of total phosphorus load accumulated and the hydrograph during the period of study and $(B)$ the accumulation of load and streamflow at the Chesterville Branch streamgage for water years 2012 and 2013. 


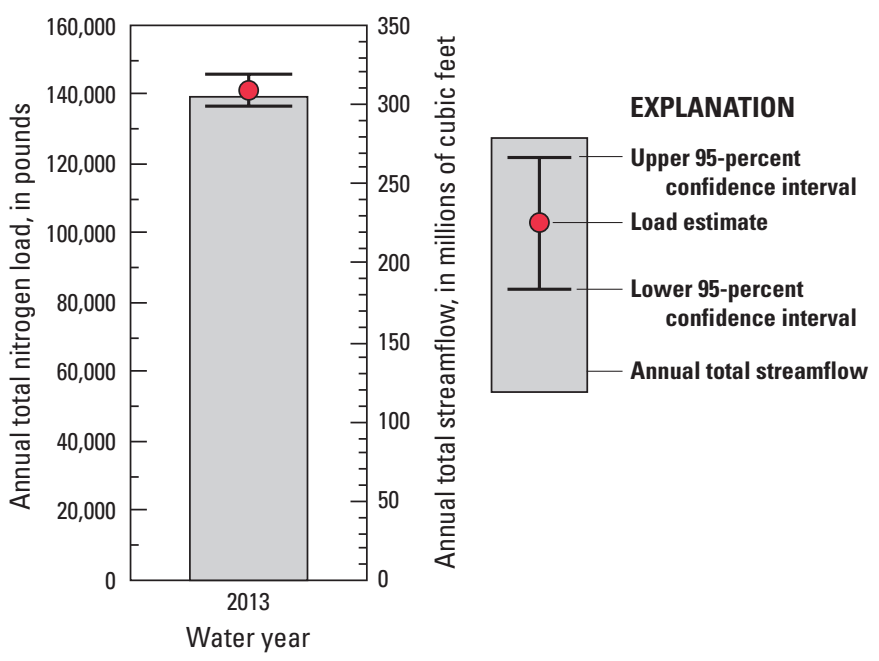

Figure 59. Total nitrogen load and annual total streamflow at the Chesterville Branch streamgage for the 2013 water year.

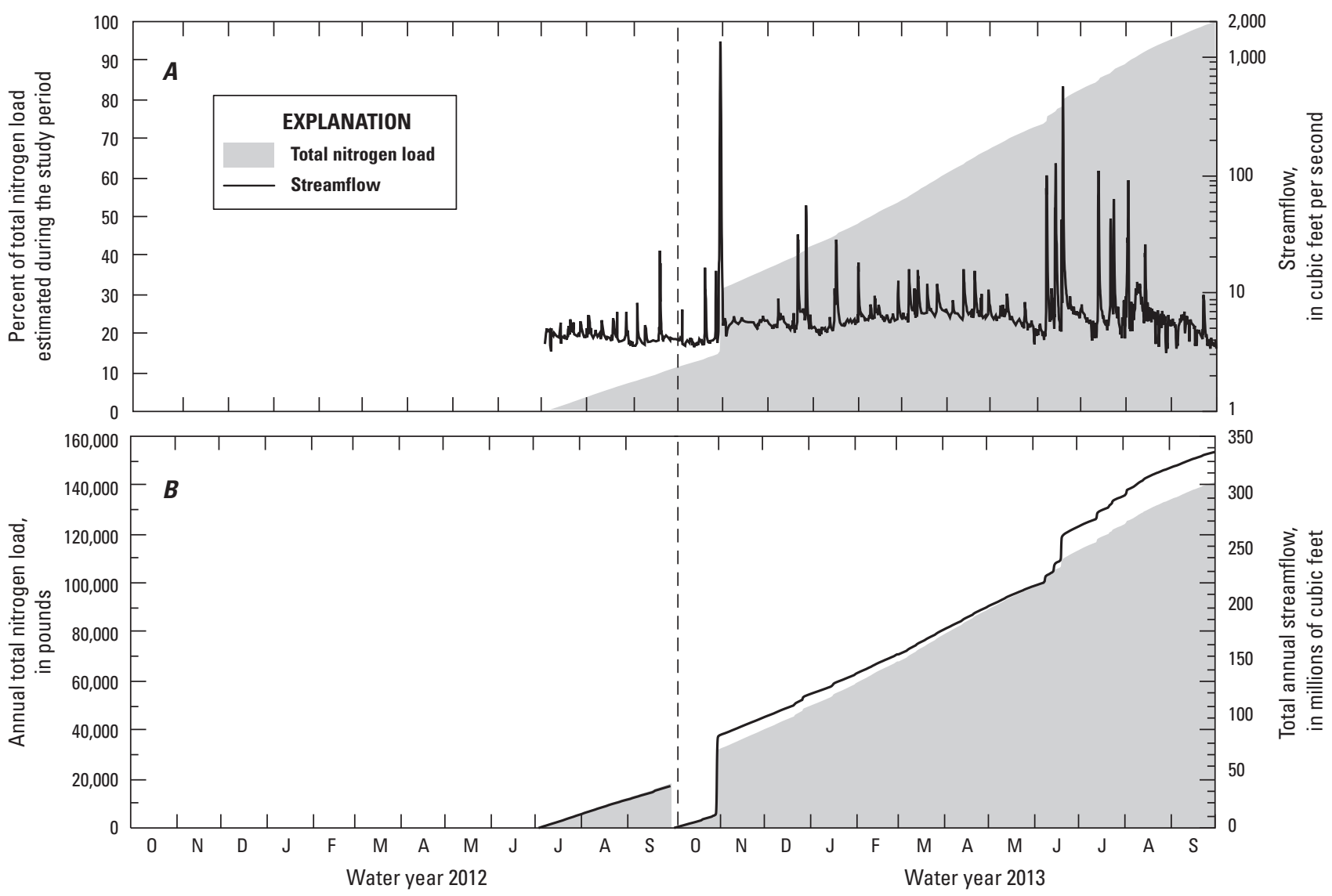

Figure 60. $(A)$ The percentage of total nitrogen load accumulated and the hydrograph during the period of study and $(B)$ the accumulation of load and streamflow at the Chesterville Branch streamgage for water years 2012 and 2013. 


\section{Spatial Patterns in Water Quality}

Water-quality samples were collected during base-flow conditions at 18 individual sites throughout the watershed in a synoptic manner (all sites were sampled within a short timeframe) 4 times during the study period (fig. 61). The sampled locations include multiple sites on the three main tributariesChesterville Branch (6.12 $\left.\mathrm{mi}^{2}\right)$, Foreman Branch (5.27 $\left.\mathrm{mi}^{2}\right)$, and Pearl Creek (3.08 $\mathrm{mi}^{2}$ ) — and single sites on seven smaller tributaries. These sampling events were intended to provide an understanding of the spatial patterns in water quality and the processes controlling the transport of nutrients throughout the watershed. Sampling occurred during a range of hydrologic conditions from very low summer base flow (July 2011) to high winter base flow (December 2011) and intermediate spring base flow (May 2012 and April 2013; fig. 61).

Nitrogen concentrations in stream water varied across the watershed between sampling locations and between the different sampling events (fig. 62) and were affected by differences in the amounts of agricultural land use in each subwatershed and hydrogeologic conditions. In the absence of agricultural or other anthropogenic effects, the predominance of highly weathered sediments composed mostly of quartz and other silicate minerals that are resistant to weathering results in groundwater that generally has a specific conductance less than $100 \mu \mathrm{S} / \mathrm{cm}$ (Denver, 1989; Hamilton and others, 1993).
In water affected by agriculture, calcium and magnesium from lime, nitrate and chloride from nitrogen-based fertilizer and manure, and potassium and chloride from potash fertilizer $(\mathrm{KCl})$ are the predominant ions; specific conductance also is elevated above natural conditions. Water of this type is common across the Delmarva Peninsula in areas with agricultural land use (Shedlock and others, 1999; Debrewer and others, 2007).

As agricultural inputs increase, the amounts of agricultural chemicals in groundwater also increase. In the Upper Chester River watershed, this is illustrated in water chemistry from the three major subwatersheds - Chesterville Branch, Foreman Branch, and Pearl Creek (fig. 63). Base-flow water quality in Chesterville Branch and Foreman Branch, which have about 82 percent and 61 percent of agricultural land use, respectively, is affected by ions from agricultural fertilizers and manure. The soils and surficial aquifer sediments are well drained and oxic in most of the watershed, thus contributing to the formation of nitrate in the soil zone and the transport of nitrate and other soluble fertilizer components (including calcium, magnesium, potassium, and chloride) through groundwater to streams. More than 90 percent of the $\mathrm{TN}$ in Chesterville Branch and Foreman Branch is nitrate that originates in groundwater. During base-flow conditions in December 2011, concentrations of total nitrogen in the most downstream sites were about $8 \mathrm{mg} / \mathrm{L}$ in Chesterville Branch and about $5 \mathrm{mg} / \mathrm{L}$ in Foreman Branch (fig. 62). Chesterville

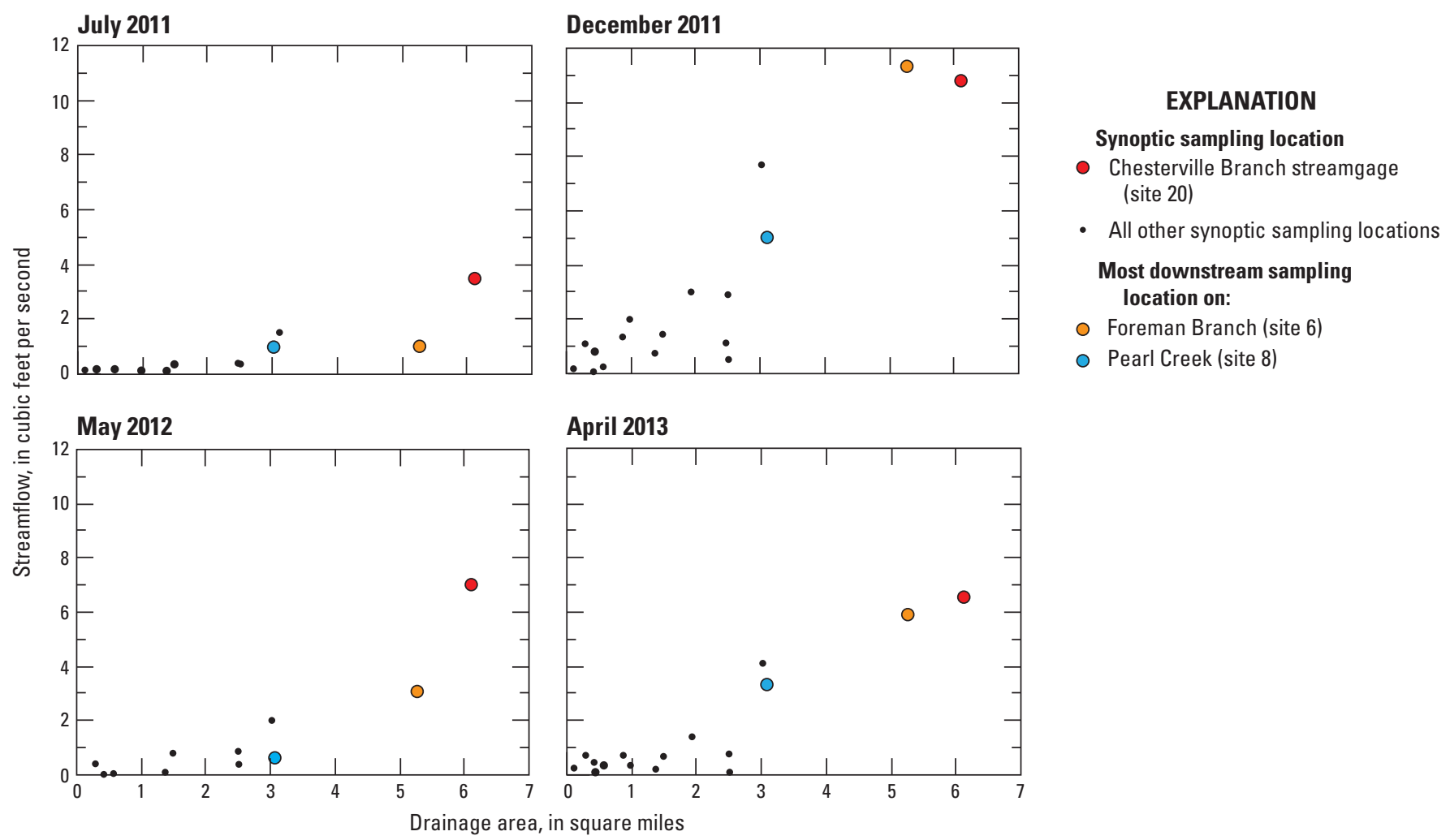

Figure 61. Streamflow and drainage area for samples collected from the Upper Chester River watershed during each synoptic event. 

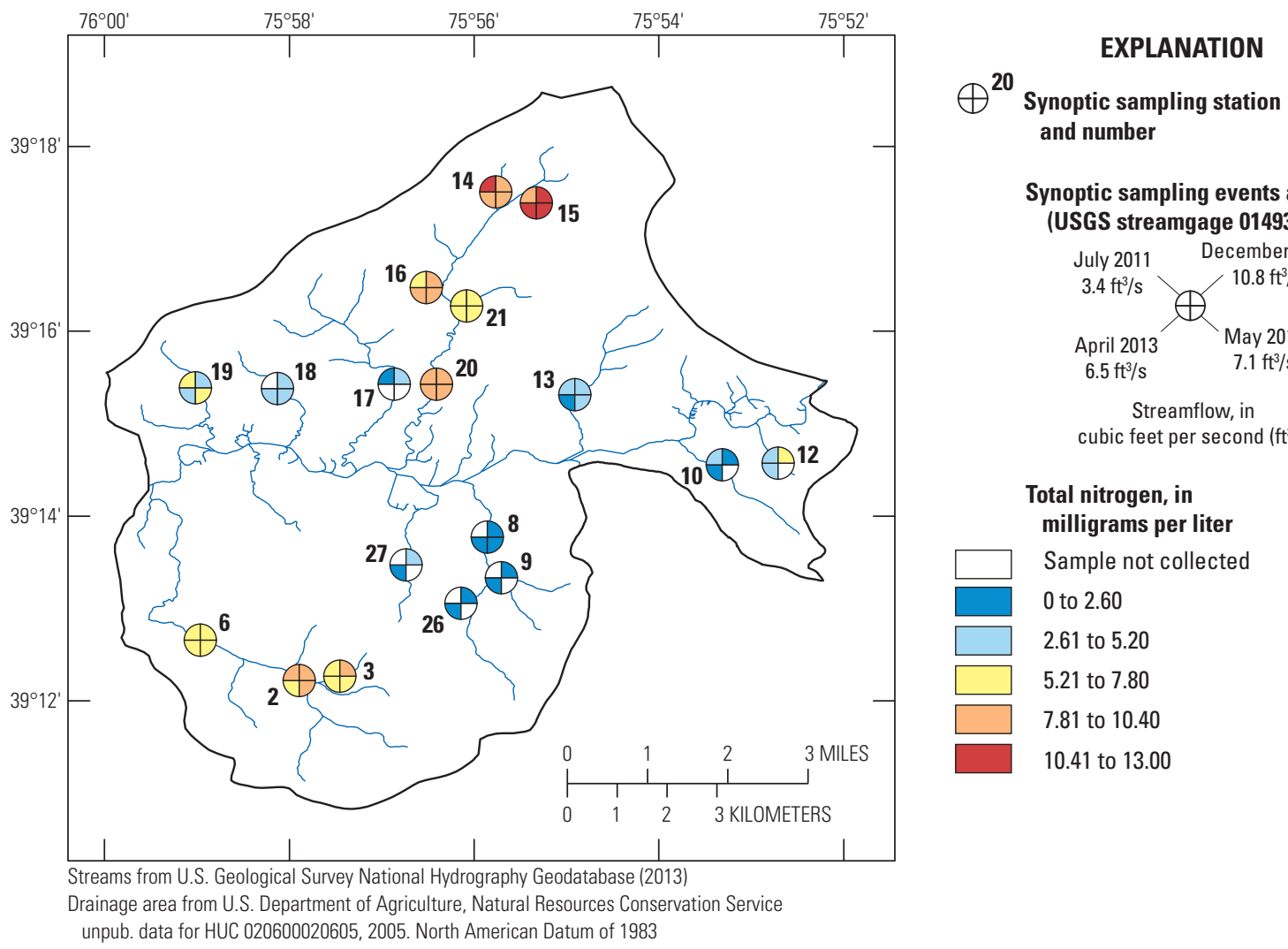

Synoptic sampling events at site 20 (USGS streamgage 01493112)

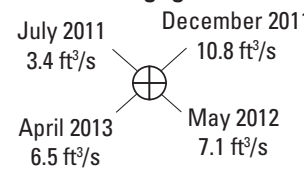

Streamflow, in cubic feet per second $\left(\mathrm{ft}^{3} / \mathrm{s}\right)$

Total nitrogen, in milligrams per liter

$\square$ Sample not collected

0 to 2.60

2.61 to 5.20

5.21 to 7.80

7.81 to 10.40

10.41 to 13.00

Figure 62. Monitoring locations, total nitrogen concentrations measured during each synoptic sampling event, and the stream network in the Upper Chester River watershed.

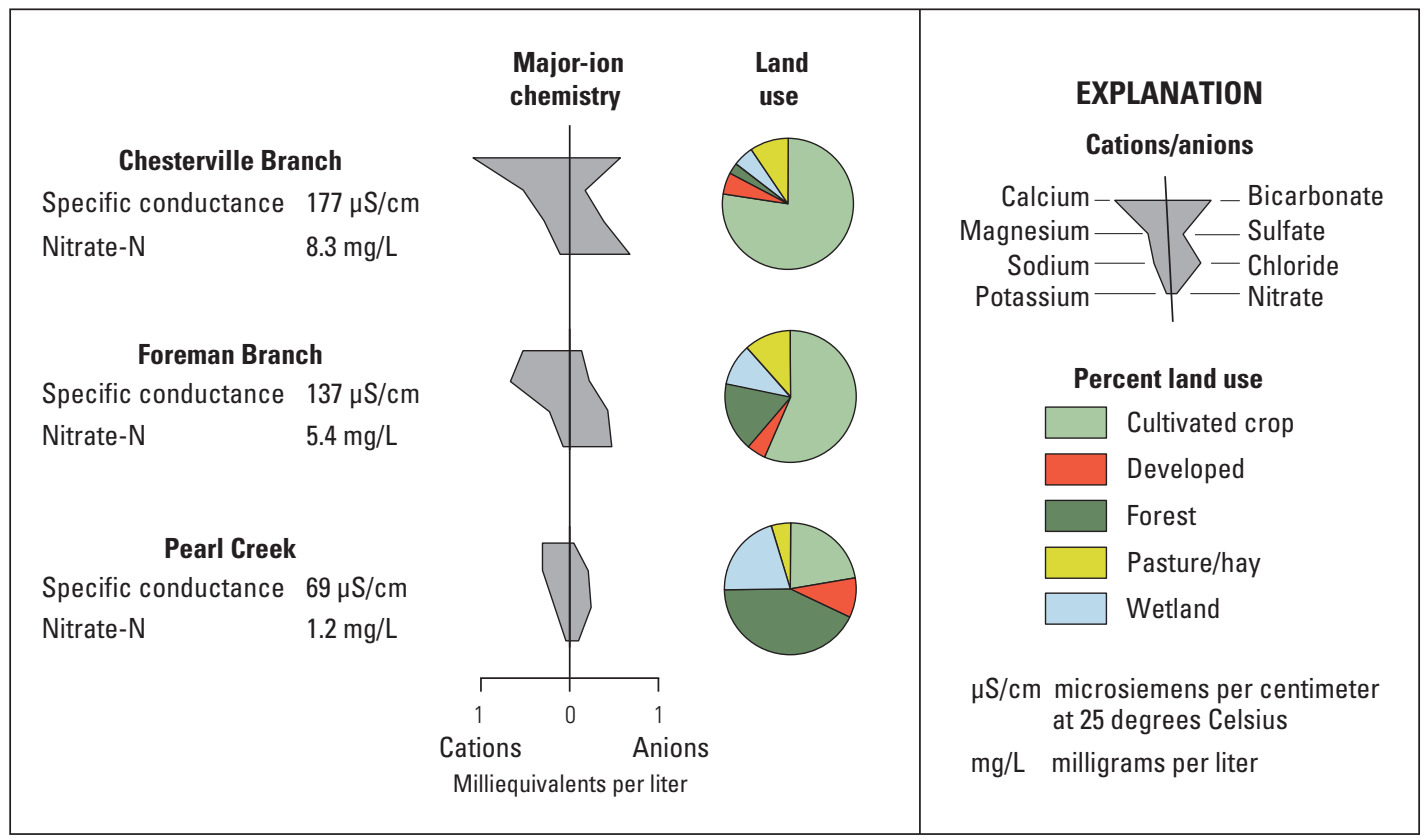

Figure 63. Major-ion chemistry from the December 2011 synoptic sampling event and pie charts representing percentages of land use within the Chesterville Branch, Foreman Branch, and Pearl Creek subwatersheds. 
Branch, which has the highest concentrations of nitrate in the part of the Upper Chester River watershed studied, also has a higher percentage of agricultural land use, including a large nursery in its headwaters, than Foreman Branch where some of the headwaters areas are forested, which would contribute little nitrate to the stream (fig. 63). Nitrogen loadings are also greatest in these two streams compared to other small streams in the Upper Chester River watershed because of the combination of higher flows and higher concentrations of nitrogen (fig. 64). While Chesterville Branch consistently contributes the highest loads to the Chester River, loads from Foreman Branch are more variable over time, and were particularly low during July 2011, the driest period sampled.

The Pearl Creek subwatershed has generally poorly drained soils, a thinner surficial aquifer, and less agricultural land use than the Chesterville Branch and Foreman Branch subwatersheds. Nitrate concentrations are about $1 \mathrm{mg} / \mathrm{L}$, and water is more dilute and similar to water in areas without anthropogenic effects (specific conductance less than $100 \mu \mathrm{S} / \mathrm{cm}$ ) than water in the other major branches where agriculture dominates (fig. 63). Nitrogen load is similarly low, with nitrate composing about 75 percent of the TN load. Although calcium and magnesium are still the major cations, sulfate and chloride are the major anions instead of nitrate as in the other streams (fig. 63). During low-flow conditions, such as observed in July 2011, Pearl Creek can go dry.

Concentrations of nitrogen in the smaller watersheds with single sampling sites were usually lower than those in Chesterville Branch and Foreman Branch. When combined with very low flows, concentrations of nitrogen had relatively insignificant loadings on an individual basis (figs. 62 and 64).

TP concentrations during base flow at the synoptic sites ranged from below detection $(0.004 \mathrm{mg} / \mathrm{L})$ to about $0.2 \mathrm{mg} / \mathrm{L}$ (fig. 65). Concentrations were greatest on the northern side of the Upper Chester River where there is more relief and a greater opportunity for phosphorus transport during runoff from agricultural fields. The highest concentrations were present in small tributaries, but because of low flows, loads were relatively small compared to loads in streams with higher flows, such as Chesterville Branch and Foreman Branch, even though concentrations in Foreman Branch also were relatively low (figs. 65 and 66). The synoptic samples were collected during base flow when phosphorus transport from the land surface was minimal. Higher concentrations under low baseflow conditions could indicate the release of phosphorus from anoxic sediments in the streambed or ponds.

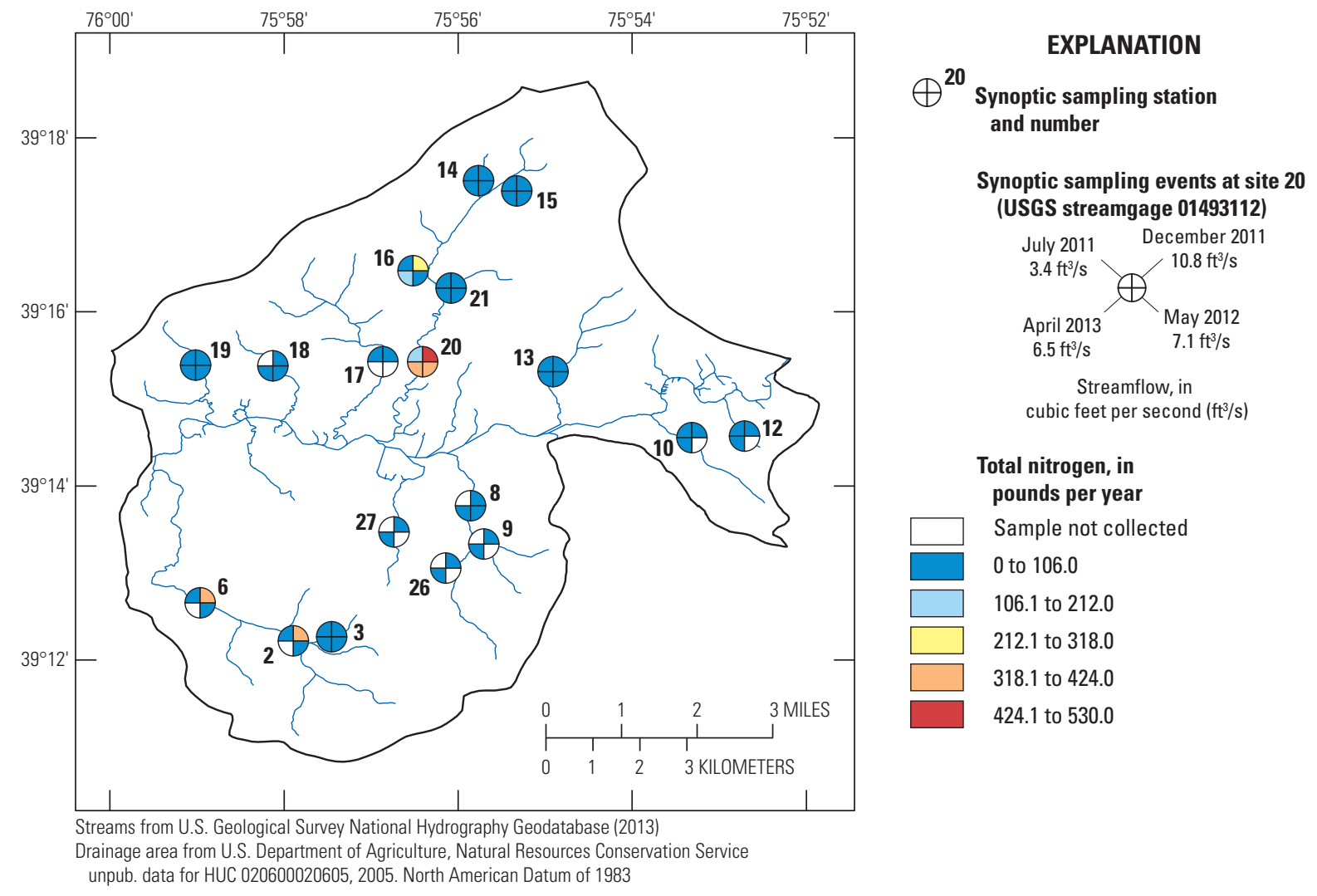

Figure 64. Monitoring locations, total nitrogen load measured during each synoptic sampling event, and the stream network in the Upper Chester River watershed. 


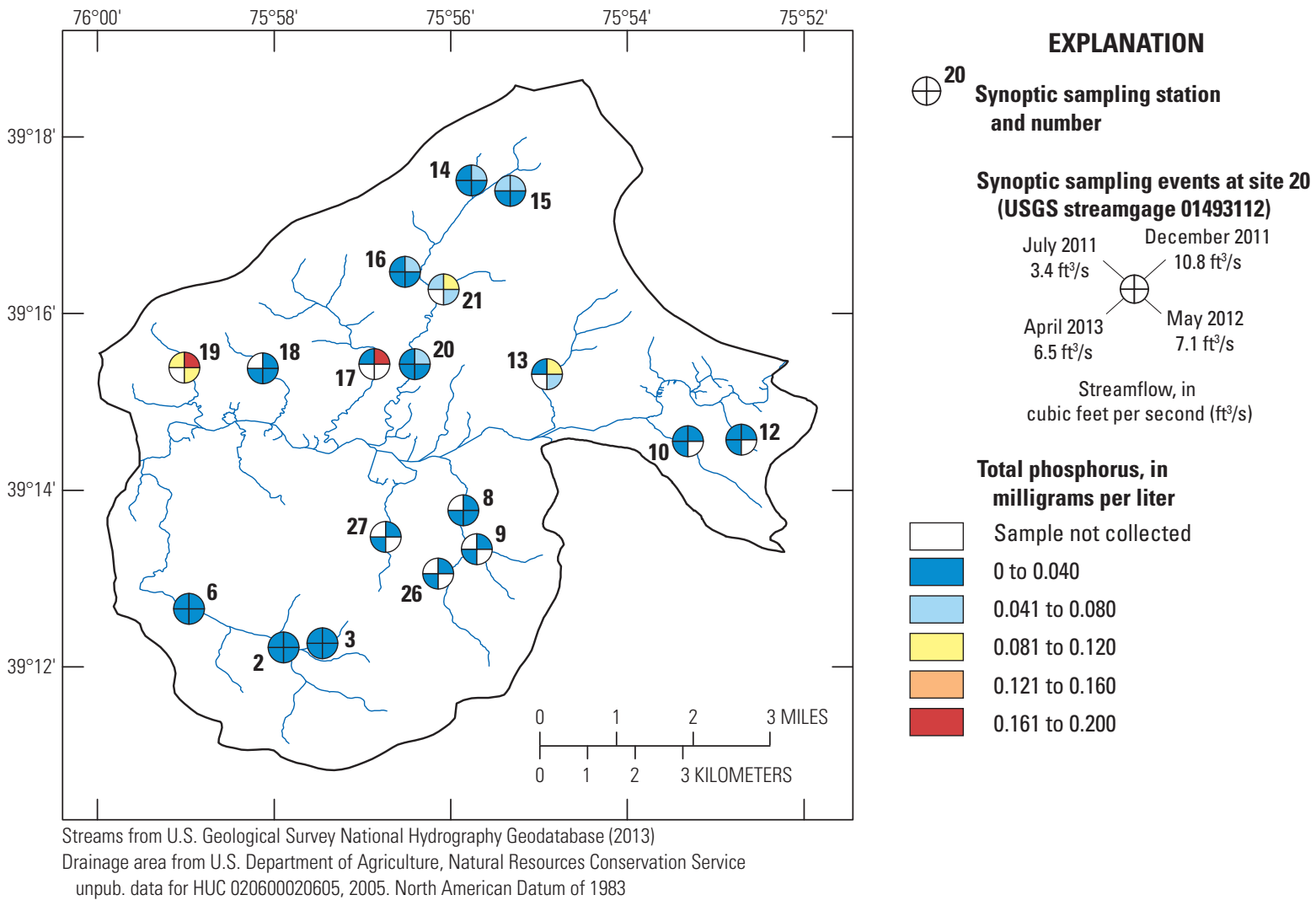

Figure 65. Monitoring locations, the total phosphorus concentration measured during each synoptic sampling event, and the stream network in the Upper Chester River watershed.

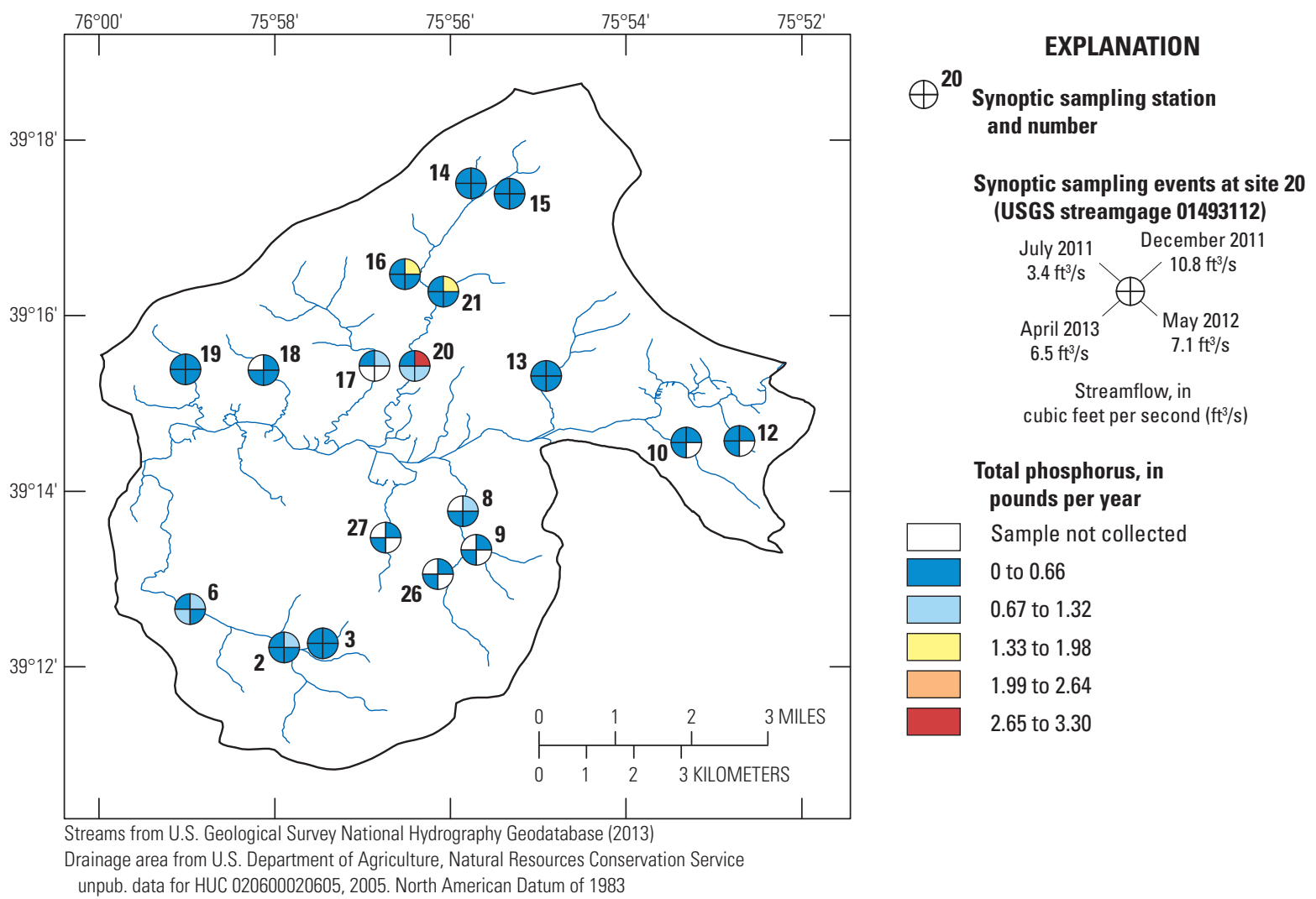

Figure 66. Monitoring locations, the total phosphorus load measured during each synoptic sampling event, and the stream network in the Upper Chester River watershed. 
Cluster analysis of the data from the synoptic sampling events was used to group the small watersheds into four groups with similar water-quality characteristics and to explore spatial patterns in nitrate and phosphorus across the landscape in the Upper Chester River watershed (fig. 67). This analysis brings out several features of the watershed that are not evident by looking only at nutrient concentrations and also helps to further explain the differences among Chesterville Branch, Foreman Branch, and Pearl Creek.

Cluster 1 includes the majority of samples from Chesterville Branch and from Foreman Branch (fig. 68). This cluster represents water affected by agriculture with dominantly oxic conditions leading to higher nitrate concentrations, as seen in the higher cluster loadings (red and pink) with the constituents contributed from agriculture including nitrate, calcium, magnesium, and potassium than in the other clusters (fig. 67).
The difference in calcium and bicarbonate loadings between some samples in Cluster 1 is likely related to the hydrogeologic differences above and below the Upper Chester River. There is a greater influence of deeper calcareous groundwater discharge into Chesterville Branch on the northern side of the river than into Foreman Branch on the southern side.

Cluster 2 represents samples from the northern side of the Upper Chester River with high phosphorus loadings during one or more synoptic sampling events (fig. 68). Elevated loadings of ammonium, manganese, and iron in the water samples from this group indicate that anoxic conditions are likely controlling the presence of higher loadings of dissolved phosphorus. The tributaries that contribute phosphorus include some of the smallest tributaries with agricultural land use.

Cluster 3 contains samples from one site with high sodium chloride, a condition that most likely originates from a nearby

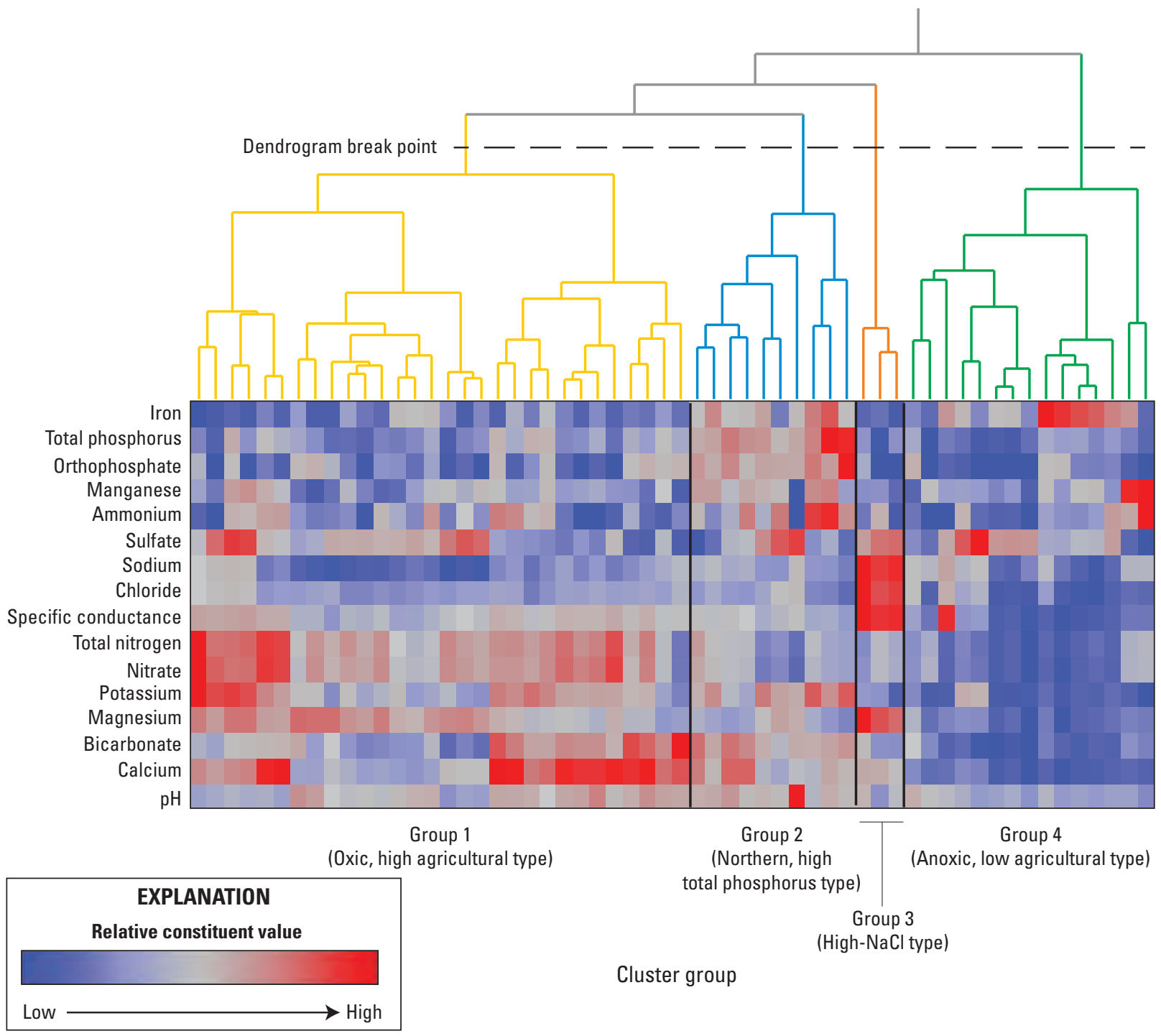

Figure 67. Samples collected from each synoptic event within the Upper Chester River watershed with a heat map of constituent values and the breakpoint used to produce four cluster groups. 


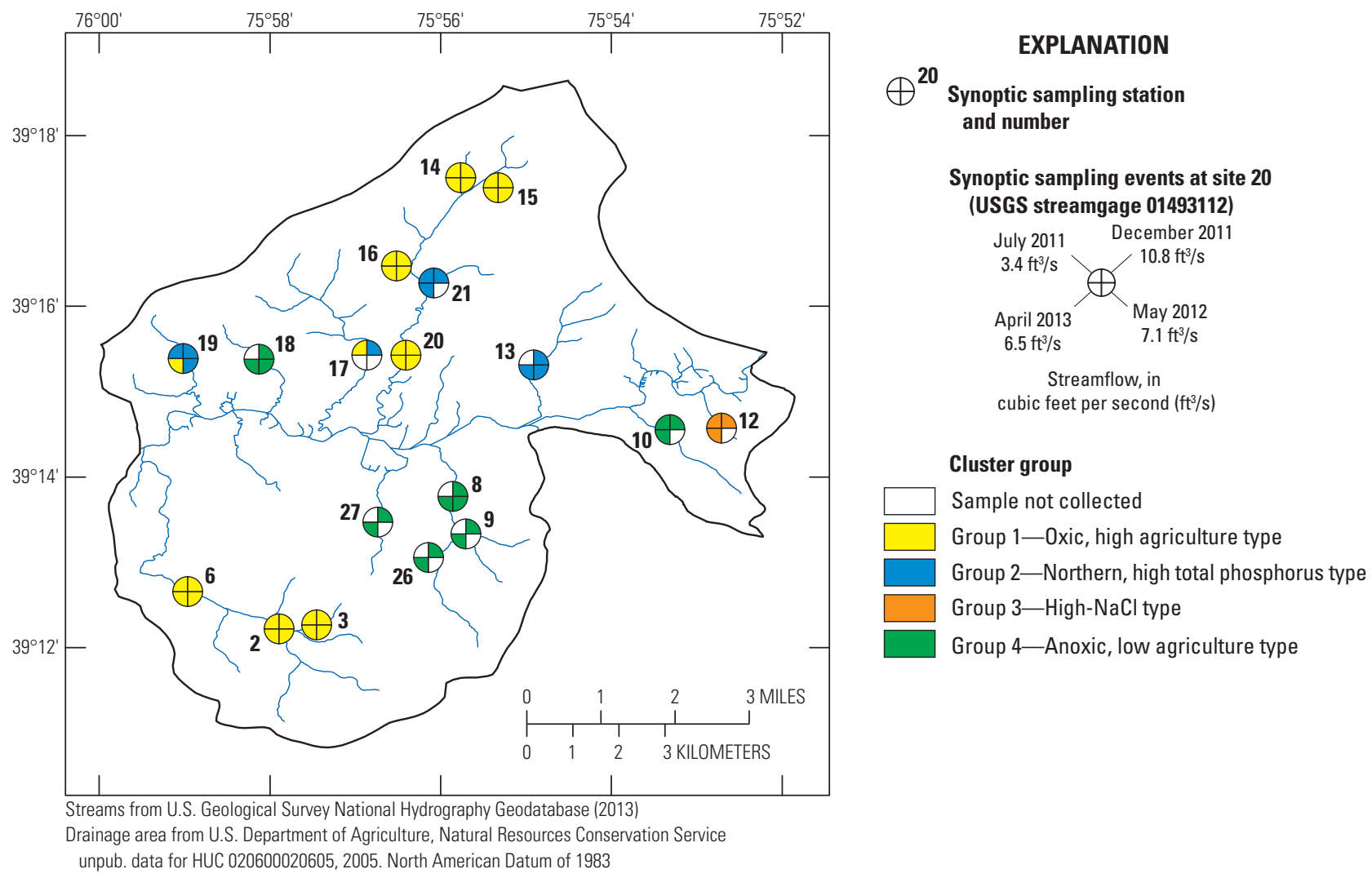

Figure 68. Monitoring locations as identified in a cluster analysis for each synoptic sampling event and the stream network of the Upper Chester River watershed.

road. This sampling location has relatively little anthropogenic additions of agricultural constituents to affect water chemistry.

Cluster 4 represents waters where the effects of anoxic conditions can be seen in higher loadings of constituents such as iron, phosphorus, ammonium, sulfate, and manganese and lower loadings of chemicals typically associated with agricultural additions of fertilizer and lime (such as nitrate, magnesium, and calcium) (fig. 67). This cluster includes all samples from Pearl Creek, the other major tributary in the Upper Chester River study area (fig. 68).

With some exceptions, $\delta^{15} \mathrm{~N}$ and $\delta^{18} \mathrm{O}$ values of nitrate at the Upper Chester River watershed sites cluster around mean values of 5 per mil (\%o) and $3 \%$, respectively (fig. 69). Whereas most samples plotted in a tight cluster near the low end of the range, a few samples had relatively high $\delta^{15} \mathrm{~N}$ and $\delta^{18} \mathrm{O}$ values that may indicate nitrate reduction (denitrification, assimilation). Excepting samples with relatively high $\delta^{18} \mathrm{O}$ values, the median $\delta^{18} \mathrm{O}$ value indicates that nitrification of reduced $\mathrm{N}$ was the dominant source of nitrate. The $\delta^{15} \mathrm{~N}$ data are similar to those reported previously for nitrate in groundwater recharged beneath fertilized agricultural land in this region (Böhlke and Denver, 1995; Böhlke, 2003).

Despite high nitrate concentrations and association of nitrate with other constituents attributed to agricultural fertilizer applications, $\delta^{15} \mathrm{~N}$ values of nitrate in recharge generally were higher than $\delta^{15} \mathrm{~N}$ values of major fertilizers used on crops. A $\delta^{15} \mathrm{~N}$ shift of about $+4 \%$ o $\pm 2 \%$ from fertilizer to nitrate recharged beneath fertilized fields may be attributed to isotopic fractionation between fertilizer loading and recharge; fractionation can occur, for example, by ammonia volatilization, uptake by plants and soil microbiota, loss of nitrogen gas, nitrous oxide, and other gases during nitrification or denitrification in soils. Thus, Upper Chester River nitrate $\delta^{15} \mathrm{~N}$ values can be explained by the dominance of a fractionated "fertilized agriculture" source of nitrate. Elevated $\delta^{15} \mathrm{~N}$ and $\delta^{18} \mathrm{O}$ values were occasionally detected in samples from different parts of the watershed, most commonly from Pearl Creek. Variations in isotope values indicating nitrate loss could be related to variable seasonal flow conditions and uptake or to anoxia in ponds in near-stream areas associated with the small watersheds. 


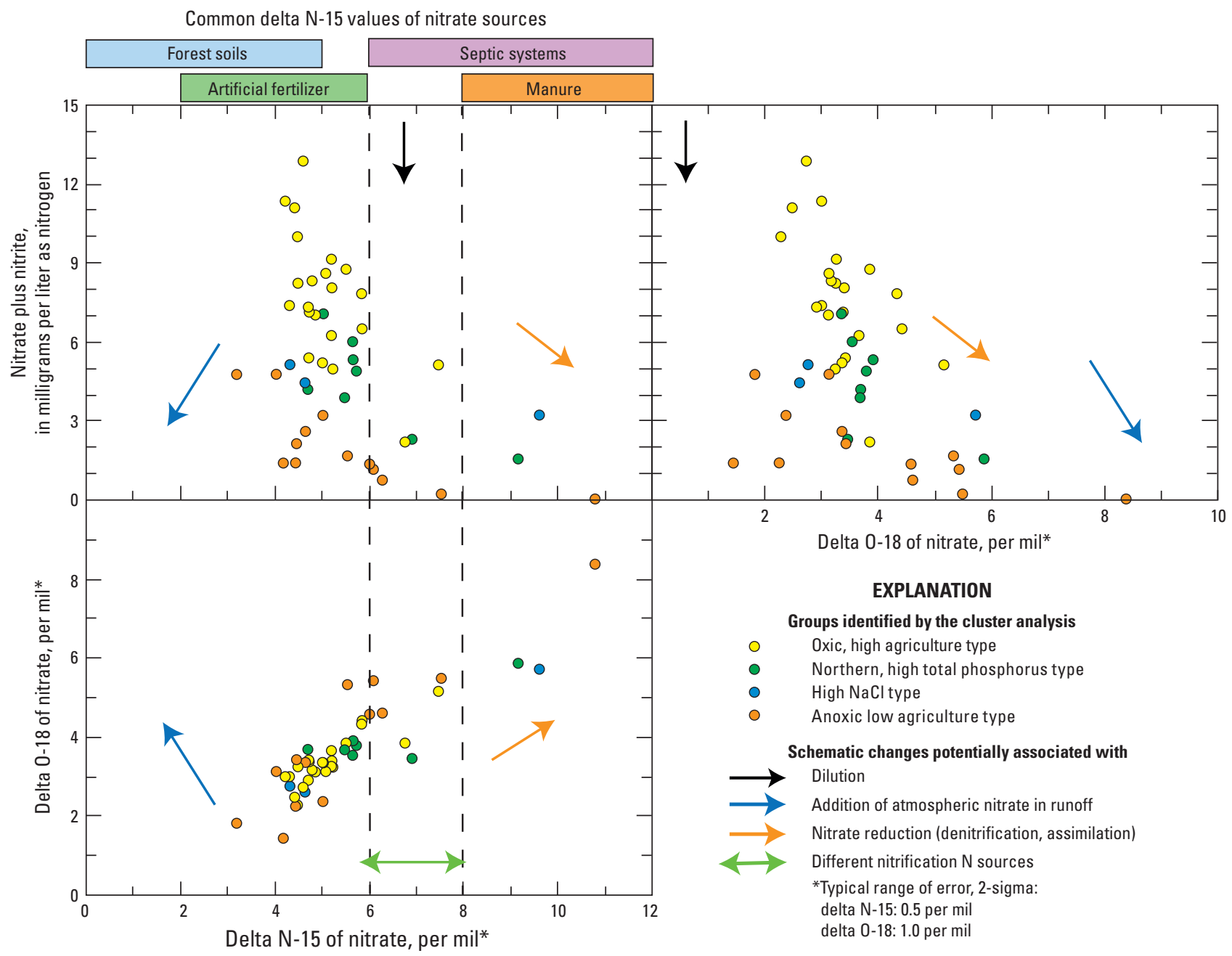

Figure 69. Nitrate isotope results from each synoptic sampling event within the Upper Chester River watershed. 


\section{Characterization of Nitrogen Sources}

Fifty-four percent of the land area of the Upper Chester River watershed is cultivated cropland, and about 10 percent is pasture, making agricultural activities the major human land use in the area (fig. 70). Also, a large plant nursery on the northern side of the watershed covers about 7 percent of the land area. Forests cover 13.35 percent of the area, with most of the forested areas located adjacent to streams. Many forested areas are also wetlands ( 10.75 percent of the area) located in riparian zones (fig. $3 A$ ). The subwatersheds with the most intensive agricultural land use are on the northern side of the Upper Chester River in Kent County, Maryland, and subwatersheds with a greater amount of forested land are on the southeastern side of the river in Queen Anne's County, Maryland. Overall, however, the Upper Chester River study area has a similar land-use distribution to that of both counties (fig. 70).

Land-use nitrogen-source analysis indicates that nitrogen additions to cropland and the watershed as a whole are primarily through inorganic fertilizers (fig. 71). This observation is supported by isotopes of nitrogen from samples in this area that are consistent with an inorganic fertilizer source (fig. 69). Manure is the second most commonly added source of nitrogen, although its estimated use is an order of magnitude less than that of fertilizer in this area (fig. 71). In 2015, local sources of manure have been limited to only a few poultry producers and small dairy operations. Manure application is greater in southern parts of the Delmarva Peninsula closer to areas with concentrated poultry production. SPARROW model input data attribute almost 80 percent of the nitrogen sources in the Upper Chester River watershed to fertilizer and fixation of atmospheric nitrogen by legumes (fig. 72) (Wieczorek and LaMotte, 2010a,b,c,d). The amount of biologic nitrogen fixation, mostly by soybeans, which is the major nitrogen-fixing crop in this area, has not been quantified locally; however, estimates of nitrogen added by fixation of soybeans range from 15 to 60 pounds per acre (lb/acre) (Killpack and Buchholz, 1993).

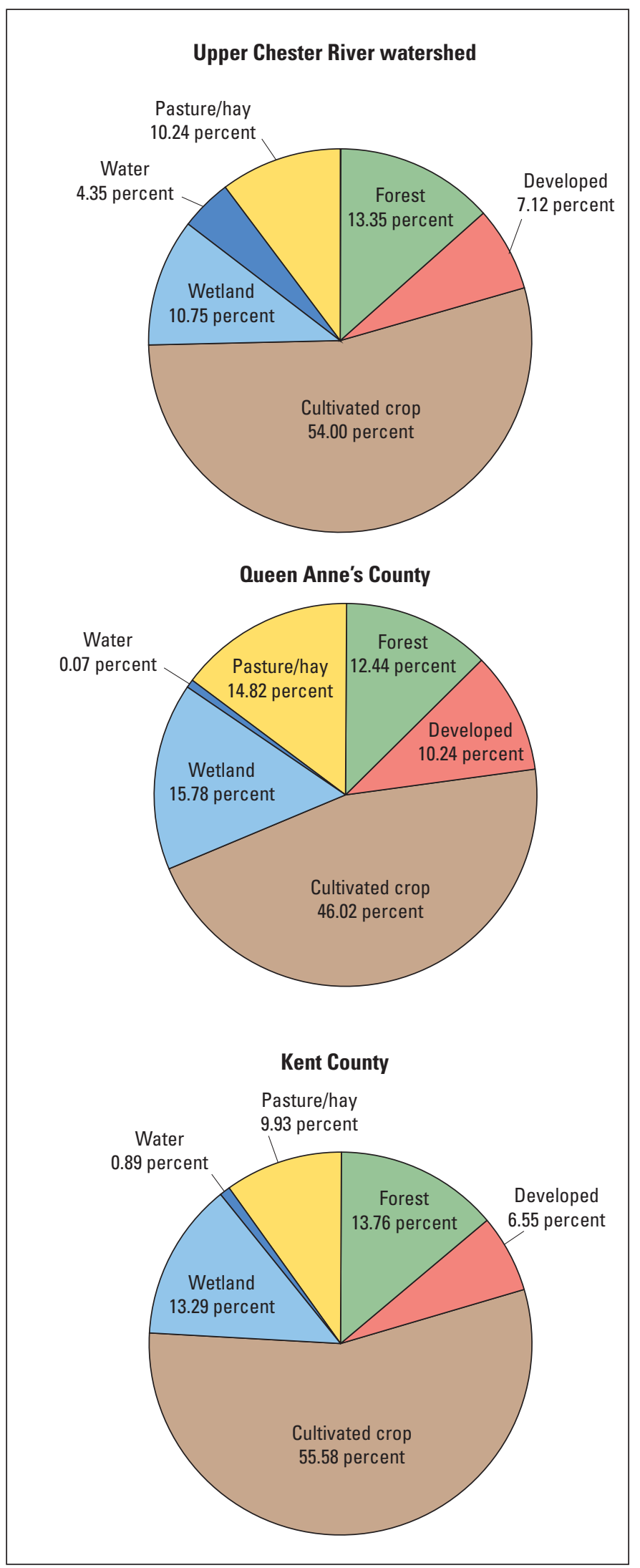

Figure 70. Percentages of land-use types from Homer and others (2015) within the Upper Chester River watershed, Queen Anne's County, and Kent County, Maryland. 


\section{A. Kilograms of nitrogen per year}

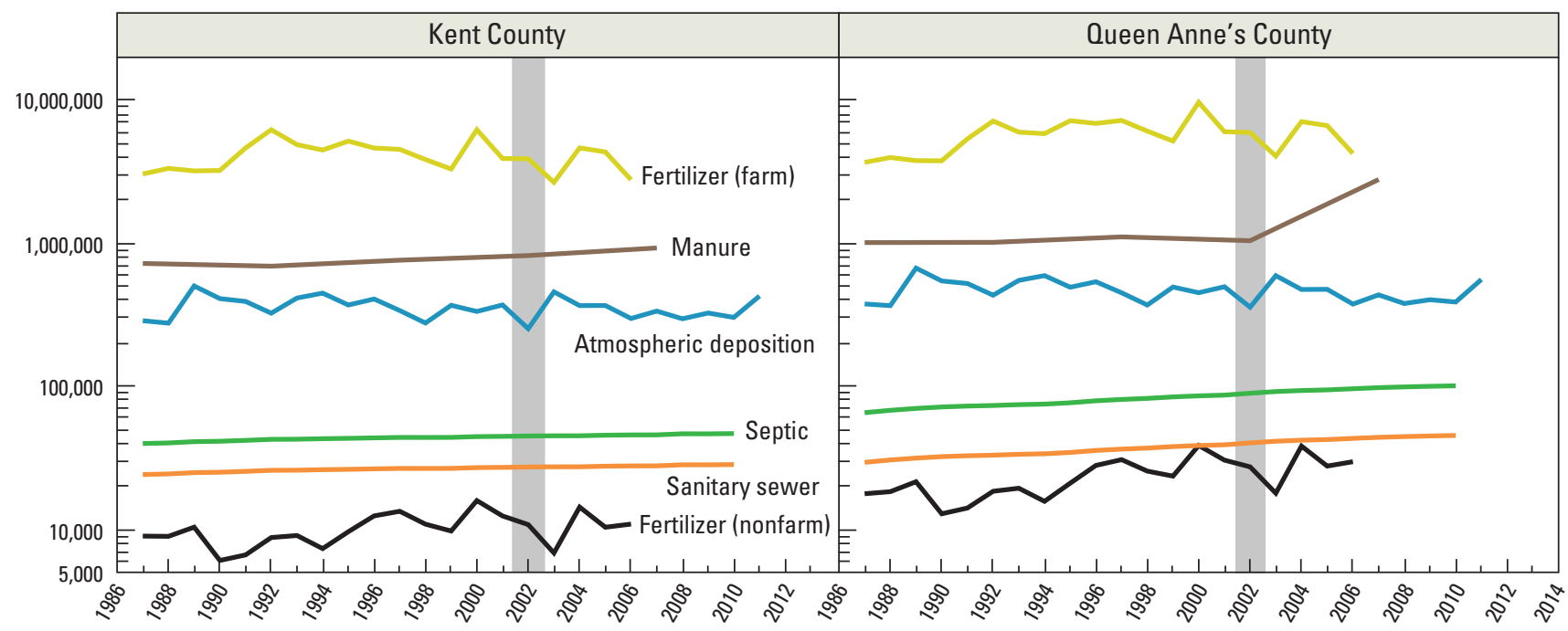

B. Nitrogen sources in 2002

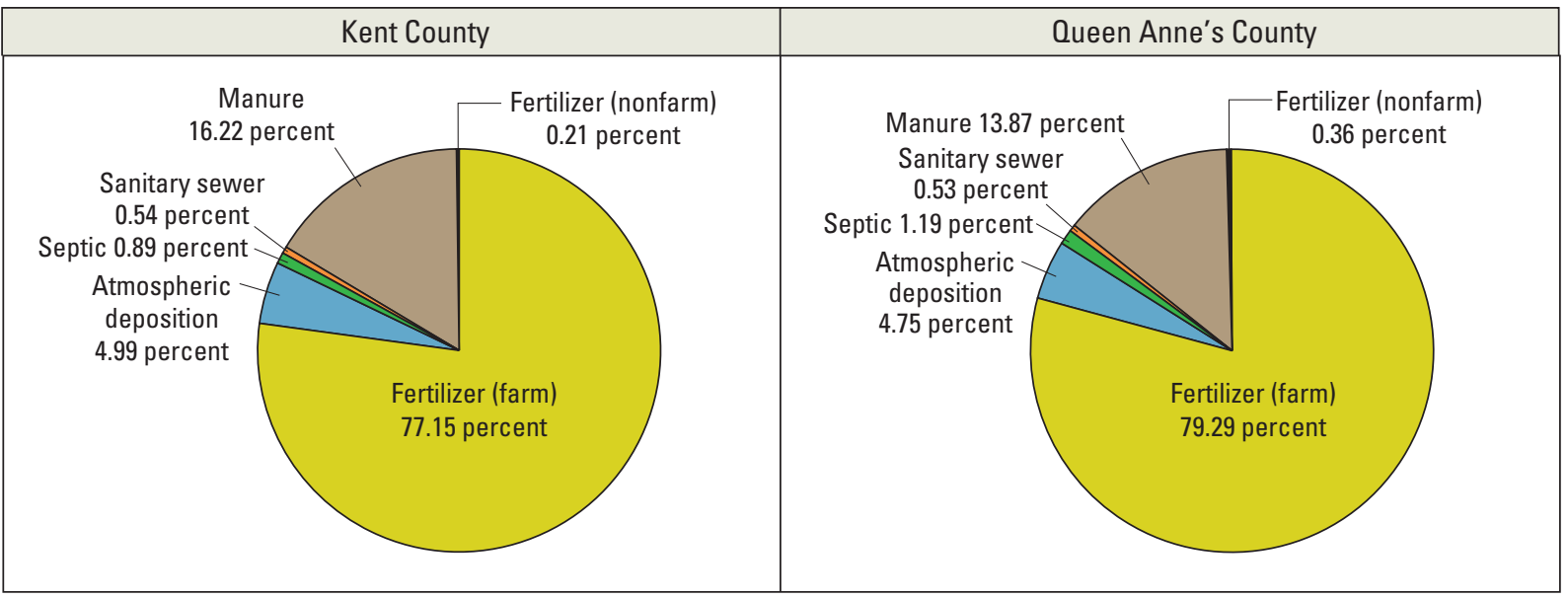

Figure 71. (A) Nitrogen sources for Kent County and Queen Anne's County, Maryland, from 1987 to 2012, and $(B)$ nitrogen sources in 2002 for Kent County and Queen Anne's County, Maryland.
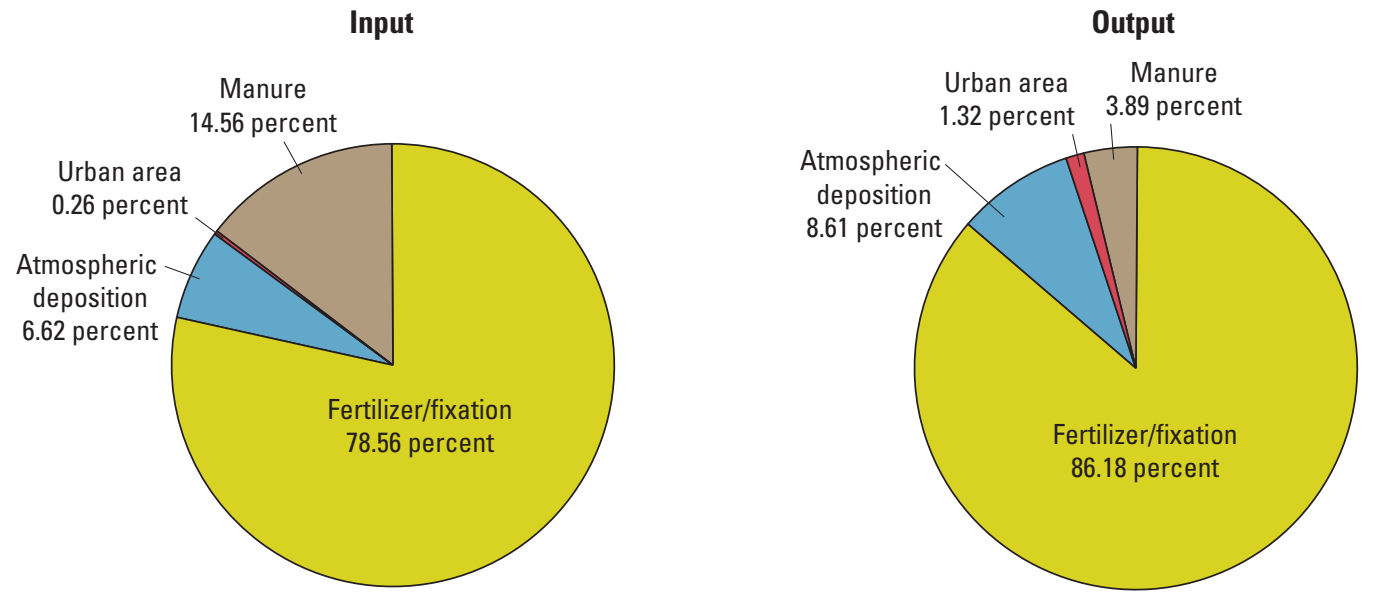

Figure 72. Percentages of input and output sources of total nitrogen for the Upper Chester River watershed as generated by the 2002 Chesapeake Bay Total Nitrogen SPARROW model. 


\section{Implementation of Conservation Practices and Water-Quality Response}

In the Upper Chester River watershed, 1,194 USDAcompliant agricultural conservation practices were implemented between 2007 and 2013 (table 20). The NRCS provided cost-share for 363 of those practices using funds from the Chesapeake Bay Watershed Initiative (254 practices), Environmental Quality Incentives Program (70 practices), Conservation Reserve Program (95 practices) and additional USDA programs (25 practices). For the remaining 750 conservation practices, the NRCS provided technical assistance, and funding was provided by non-Federal programs and (or) farmers. The aggregated total of conservation practice implementation (new practices applied between October 2007 and September 2013) is reported by NRCS practice code in table 21 for all practices with five or more participating farmers. Additional practices were implemented through the Maryland Agricultural Cost-Share (MACS) Program, other State programs, and voluntary practices implemented by farmers (table 22). The overall implementation of conservation practices increased substantially over this time period, especially after 2010 when the area was targeted as a Showcase Watershed by the USDA. The most frequently used practices oriented to nutrient and sediment control included cover crops, nutrient management, conservation crop rotation, conservation tillage, and residue and tillage management (tables 21 and 22).

Table 20. Number of USDA-compliant conservation practices implemented in water years 2007 through 2013 in the Upper Chester River watershed, aggregated by sponsoring program.

[USDA, U.S. Department of Agriculture]

\begin{tabular}{|c|c|c|c|c|c|c|c|c|}
\hline Program & 2007 & 2008 & 2009 & 2010 & 2011 & 2012 & 2013 & Total \\
\hline Chesapeake Bay Watershed Initiative & 0 & 0 & 0 & 24 & 115 & 79 & 36 & 254 \\
\hline Environmental Quality Incentives Program & 1 & 30 & 4 & 1 & 31 & 1 & 2 & 70 \\
\hline Conservation Security Program & 0 & 0 & 0 & 12 & 0 & 0 & 0 & 12 \\
\hline Conservation Reserve Program ${ }^{1}$ & 16 & 16 & 14 & 21 & 7 & 12 & 9 & 95 \\
\hline Wildlife Habitat Incentives Program & 1 & 0 & 1 & 2 & 1 & 2 & 0 & 7 \\
\hline Agricultural Management Assistance & 4 & 0 & 2 & 0 & 0 & 0 & 0 & 6 \\
\hline Total USDA-funded practices & 22 & 46 & 21 & 60 & 154 & 94 & 47 & 444 \\
\hline Conservation Technical Assistance ${ }^{2}$ & 161 & 74 & 96 & 150 & 46 & 182 & 41 & 750 \\
\hline Total practices & 183 & 120 & 117 & 210 & 200 & 276 & 88 & 1,194 \\
\hline
\end{tabular}

${ }^{1}$ Conservation Reserve Program and Conservation Reserve Enhancement Program practices administered by the USDA Farm Service Agency.

${ }^{2}$ Technical assistance and verification provided by the USDA Natural Resources Conservation Service, without federal cost-share funding.

Table 21. Implementation of USDA-compliant conservation practices within the Upper Chester River watershed for water years 2007 through 2013.

[USDA, U.S. Department of Agriculture; - , values are privacy protected due to fewer than five customers participating; the most frequently implemented practices oriented toward controlling nutrients and sediment are listed in bold]

\begin{tabular}{|c|c|c|c|c|c|c|c|c|c|c|c|}
\hline $\begin{array}{l}\text { Practice } \\
\text { code }\end{array}$ & Practice name & $\begin{array}{l}\text { Lifespan } \\
\text { (years) }\end{array}$ & Units & 2007 & 2008 & 2009 & 2010 & 2011 & 2012 & 2013 & $\begin{array}{c}\text { Aggregate } \\
\text { implementation: } \\
2007 \text { to } 2013^{1}\end{array}$ \\
\hline 2340 & Cover Crop & 1 & acres & 1,211 & 732 & - & 646 & 2,774 & 2,647 & - & 8,170 \\
\hline 2590 & Nutrient Management & 1 & acres & 766 & - & 152 & 1,790 & - & 685 & - & 4,125 \\
\hline 2328 & Conservation Crop Rotation & 1 & acres & - & - & - & 1,936 & - & 1,243 & - & 4,747 \\
\hline${ }^{2} 595$ & Integrated Pest Management & 1 & acres & 551 & - & - & 891 & - & - & - & 1,746 \\
\hline${ }^{2} 645$ & $\begin{array}{l}\text { Upland Wildlife Habitat } \\
\text { Management }\end{array}$ & 1 & acres & 412 & - & 494 & - & - & - & - & 1,451 \\
\hline 2329 & $\begin{array}{l}\text { Residue and Tillage } \\
\text { Management, No-Till }\end{array}$ & 1 & acres & - & - & - & - & - & 663 & - & 1,839 \\
\hline${ }^{3} \mathrm{CP} 21$ & Filter Strips & 10 & acres & 19 & 30 & 56 & 69 & 37 & 76 & 127 & 414 \\
\hline
\end{tabular}

${ }^{1}$ Aggregate implementation is greater than the sum of reported annual practices because privacy protections restrict the reporting of annual results for practices with fewer than five participating customers.

${ }^{2}$ Practice codes from the U.S. Department of Agriculture, Natural Resources Conservation Service (2016).

${ }^{3}$ Conservation reserve practice codes from the U.S. Department of Agriculture, Farm Service Agency (2016). 
Table 22. Implementation of conservation practices sponsored by state programs or adopted on a voluntary basis within the Upper Chester River watershed for water years 2007 through 2013. The table does not include practices for which the NRCS provided funds or technical assistance.

[MACS, Maryland Agricultural Water Quality Cost Share; USDA, U.S. Department of Agriculture; NRCS, Natural Resources Conservation Service; the most frequently implemented practices oriented toward controlling nutrients and sediment are listed in bold; - , values are privacy protected due to fewer than five customers participating]

\begin{tabular}{ccccccccccc}
\hline $\begin{array}{l}\text { NRCS } \\
\text { code }\end{array}$ & Practice description & Units & 2007 & 2008 & 2009 & 2010 & 2011 & 2012 & 2013 & $\begin{array}{c}\text { Aggregate implementation: } \\
\text { 2007 to 20132 }\end{array}$ \\
\hline $\mathbf{3 4 0}$ & Cover Crop-MACS & acres & $\mathbf{3 , 0 3 2}$ & $\mathbf{2 , 7 1 8}$ & $\mathbf{2 , 6 7 4}$ & $\mathbf{4 , 7 9 6}$ & $\mathbf{1 , 6 5 2}$ & $\mathbf{4 , 3 9 8}$ & $\mathbf{1 , 4 5 8}$ & $\mathbf{2 0 , 7 2 8}$ \\
412 & Grassed Waterway & acres & - & 9 & 7 & - & - & - & 8 & 26 \\
\hline
\end{tabular}

${ }^{1}$ Maryland Department of Agriculture uses identical codes to the USDA NRCS to track the implementation of State-supported conservation practices.

${ }^{2}$ Aggregate implementation is greater than the sum of reported annual practices because privacy protections restrict the reporting of annual results for practices with fewer than five participating customers.

A “farm assessment survey" covering 87 percent of the agricultural land in the watershed was conducted between December 2010 and March 2011 as part of the USDA-led Showcase Watershed effort (Maryland Department of Agriculture, 2011). Results of the assessment indicated that 97 percent of the acreage was covered by a nutrient management plan and 89 percent of cropland acreage was regularly planted in cover crop (when feasible due to crop rotations and weather). These frequently implemented practices are among the most important to limiting nutrient transport to streams. Nutrient management is intended to help farmers determine the amount, placement, and timing of plant nutrients to obtain optimum yields and minimize the risk of surface-water and groundwater pollution. Cover crops, when planted in newly harvested fields, recycle unused plant nutrients remaining in the soil from previous summer crops, protect the field against wind and water erosion, and reduce leaching of nitrate to groundwater (U.S. Department of Agriculture, Natural Resources Conservation Service, 2013).

The time series of observed nitrate concentrations in Chesterville Branch indicates that, overall, nitrate concentrations have been increasing (fig. 73), despite the implementation of conservation practices to date. Waterquality monitoring at the streamgage started for this project in 2010 coupled with historical water-quality monitoring data for the period 1996 through 2002 provide an initial assessment of trends in water quality in Chesterville Branch. Because the streamgage was discontinued between 2002 and 2011, insufficient data are available to perform a trend analysis using Weighted Regression on Time, Discharge, and Season (Moyer and others, 2012). Increasing nitrate concentrations may still be occurring because of the time period required for water carrying nitrate to move through the groundwater system and discharge to the stream. Nitrate concentrations in groundwater have increased over time, especially since the early 1970s, in response to increases in nitrogen applications at the land surface (Böhlke and Denver, 1995; Debrewer and others, 2007). Since that time, the groundwater carrying higher concentrations of nitrate has reached Chesterville Branch causing nitrate concentrations in the stream to increase. The timeframe of increased implementation of practices intended to reduce nitrate in groundwater may not be sufficient yet to see any changes in stream quality that result from those practices, or even to evaluate if they will result in significant change.

Recent results from a CEAP report in the Chesapeake Bay Region (U.S. Department of Agriculture, Natural Resources Conservation Service, 2013) suggest that while implementation of conservation practices across the basin is increasing, trends in other cropland management practices, evaluated from 2003-2006 to 2011 were less encouraging:

- Annual nitrogen application increased 10 percent on cultivated cropland, including a 9-percent increase in commercial fertilizer application;

- Annual phosphorus application increased 6 percent on cultivated cropland, including a 5-percent increase in commercial fertilizer application; and

- Appropriate nitrogen application rate on all crops in rotation decreased 9 percent from 32 percent to 23 percent of cropped acres.

These increases in nutrient inputs are associated with increased agricultural intensification, including higher yields and greater number of animals. While these overall CEAP trends are not specific to Chesterville Branch, they may help to explain why nitrate concentrations are increasing in the basin, despite the widespread implementation of conservation practices.

The implementation and continuation of widespread conservation practices in the Upper Chester River watershed could have long-term benefits to farming and water-quality in this area. The current Chesapeake Bay model estimates a 9-percent decrease between 2007 and 2012 in overall delivery of nitrate to the model segment containing Chesterville Branch (source: Chesapeake Bay Modeling Team, written commun., 2015, based on Watershed Model 5.3.2) (fig. 74). As mentioned previously, the time period of monitoring has not been sufficient for changes that may be occurring to be measured in surface water. In addition, groundwater, the major source of nitrate to streams and the first place changes would be seen, is not currently monitored; therefore, no direct 


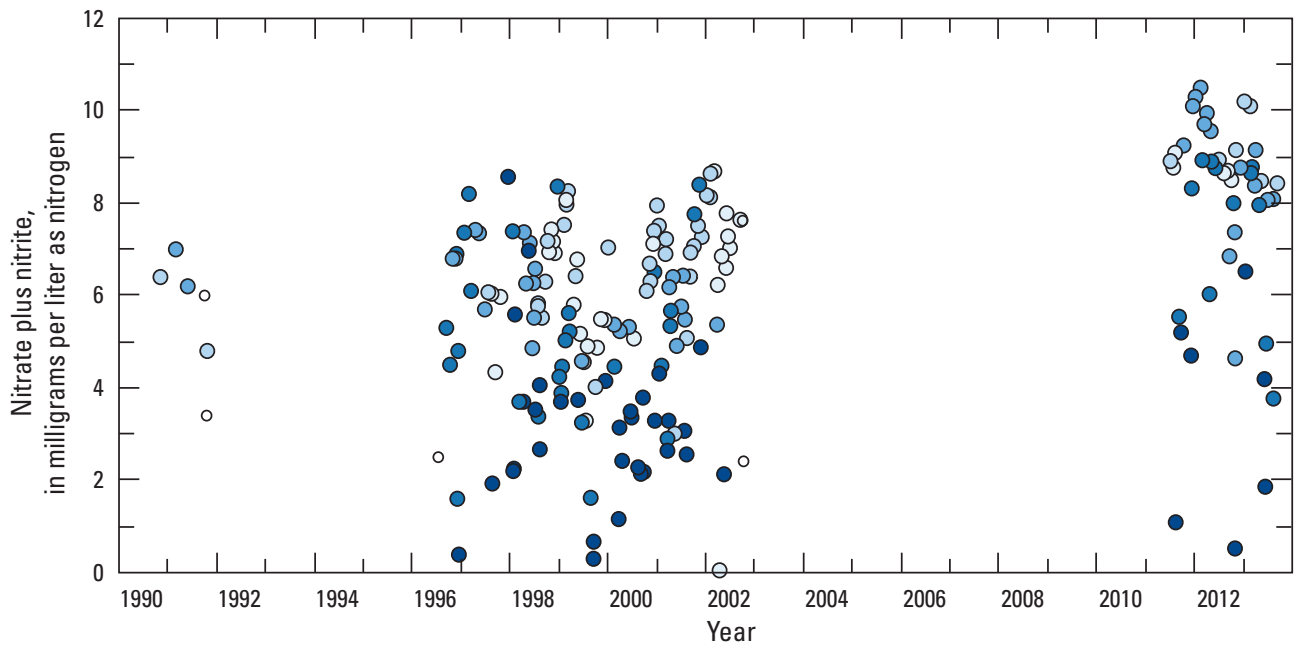

\section{EXPLANATION}

Percentage of values equal to or less than the maximum streamflow of 1,730 cubic feet per second (where small values represent low flow samples)

○ 0 to 20

$0>20$ to 40

$0>40$ to 60

$0>60$ to 80

- $>80$ to 100

- Streamflow data not available

Figure 73. Nitrate concentrations from the Chesterville Branch streamgage between 1990 and 2013.

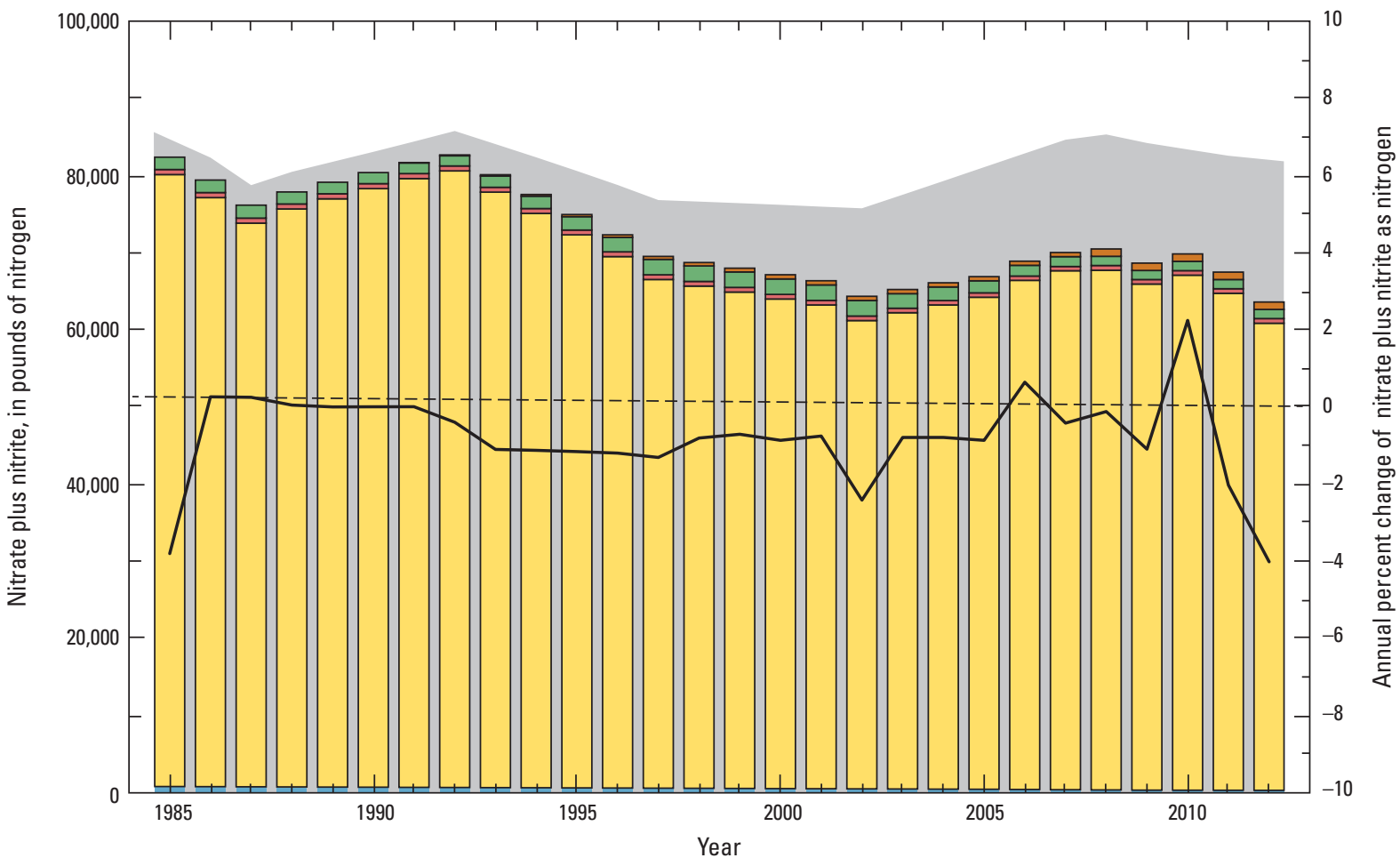

EXPLANATION

Pounds of nitrate plus nitrite as nitrogen from all sources with no best management practice implementation

Source-specific pounds of
nitrate plus nitrite as nitrogen
with best management
practice implementation
$\square$ Wastewater
$\square$ Forest
$\square$ Urban area
$\square$ Agriculture
$\square$ Atmospheric deposition

Figure 74. Nitrate load estimated from the Chesapeake Bay watershed model for the model segment containing Chesterville Branch with and without best management practice implementation with input sources and the annual percentage difference of load attributed to implementation, 1985-2012. 
data support estimates of nutrient reduction in the current Chesapeake Bay model. Previous estimates of the apparent ages of groundwater in the surficial aquifer discharging to Chesterville Branch ranged from relatively young near the water table to between 30 and 50 years at deeper depths in the aquifer and at discharge sites (Böhlke and Denver, 1995; Denver and others, 2010). According to a recent groundwater flow model for the Delmarva Peninsula, the median age of groundwater discharging to Chesterville Branch is about 25 years (Sanford, Pope, and others, 2012), similar to that derived previously from local groundwater dating (Böhlke and Denver, 1995). Less than 20 percent of the groundwater discharging to streams recharged the groundwater system within the last 10 years, the time period when most cover crops and nutrient management plans have been implemented. Continued long-term monitoring of surface water and groundwater could help to verify any improvement to water quality related to agricultural conservation practices.

\section{Conceptual Watershed Model and Implications for Management Actions}

Cumulatively, the intensive monitoring at Chesterville Branch and extensive monitoring throughout the watershed combine to provide a process-level understanding of nutrient and sediment transport in the Upper Chester River watershed. These processes are summarized as follows:

- Intensive data collected at Chesterville Branch indicate that constituents associated with groundwater dominated water chemistry during base flow and were diluted during stormflow. Nitrate ranged from 8 to about $11 \mathrm{mg} / \mathrm{L}$ as $\mathrm{N}$ during base flow all year, with the lowest concentrations during the summer when biologic uptake is greatest and the highest concentrations in the colder months. Dissolved oxygen also was lower during the summer, but still above $5 \mathrm{mg} / \mathrm{L}$, the level of concern for aquatic life, because of the continuous discharge of oxic groundwater into the stream.

- The predominant sources of nitrogen and phosphorus in the Upper Chester River watershed are inorganic fertilizers and nitrogen fixation by legume crops. Manure is also a source of these nutrients, but it is not as widely used as in other parts of the Delmarva Peninsula. Total nitrogen in streams is predominantly in the form of nitrate from groundwater. Ratios of nitrogen and oxygen isotopes of nitrate also identify inorganic fertilizer and nitrogen fixation as the primary sources of nitrogen in this watershed.

- Nitrate concentrations have increased in Chesterville Branch since the early 1990s. This increase is associated with an increase of nitrogen use in this watershed over time that resulted in increases in concentrations of nitrate in groundwater that has been discharging to the stream over time. The median age of groundwater discharging to Chesterville Branch is about 25 years, and the effects of conservation practices implemented in the last 10 years to more effectively utilize nitrogen applied to cropland, which should reduce nitrate leaching to groundwater, are not yet great enough or of long enough duration to be evident in stream water quality.

- In 2013, more than 90 percent of the phosphorus in Chesterville Branch entered the stream during two large storms with runoff. Concentrations of dissolved phosphorus were much lower during storms than those of TP, indicating that most of the phosphorus in streams was transported while attached to soil particles.

- Phosphorus is typically low or below detection in Chesterville Branch and other small tributaries during base-flow conditions with concentrations of TP ranging from below detection to about $0.2 \mathrm{mg} / \mathrm{L}$. Some of the small tributaries on the northern side of the Upper Chester River had higher concentrations of phosphorus than those on the southern side. Sites with higher phosphorus also had more dissolved iron and ammonium than in other tributaries - conditions indicative of reducing conditions where phosphorus is more readily dissolved in water.

- Variability associated with hydrogeologic conditions was observed in base-flow water-quality conditions from samples collected throughout the Upper Chester River watershed. Concentrations of nitrate entering the small subwatersheds of the Upper Chester River watershed were greatest in the two largest streams, Chesterville Branch and Foreman Branch. The watersheds for these streams have predominantly agricultural land use and are underlain by thick sandy surficial aquifer sediments through which nitrate is transported to streams relatively unaltered. In the Pearl Creek subwatershed, the third largest subwatershed, soil and aquifer sediments are not as well drained, and the surficial aquifer is thin. Land use is a mix of forest, wetland, and agriculture. Nitrate leaving Pearl Creek is about $1 \mathrm{mg} / \mathrm{L}$ as $\mathrm{N}$. In addition, because the aquifer is very thin, Pearl Creek can be ephemeral under certain low-flow conditions.

Knowledge gained from process-level understanding is important for the development of the most effective conservation management practices and informed decisionmaking. Decisions to manage the nutrients by considering their modes of transport in the environment are likely to have the greatest positive effect on water quality:

- Managing nitrogen in surface water will require a decrease in the amount of nitrate reaching groundwater. Ways to accomplish this reduction include reduced application of nitrogen fertilizer on crop land and expanded use of cover crops that retain nitrogen in the 
soil zone for use by the next crop. The effectiveness of cover crops, however, varies with the species planted, previous crop, the method and date of planting, and soil types. Because most nitrogen reaching streams is nitrate from groundwater, practices that limit runoff and soil losses, while effective at limiting nitrogen in runoff, may actually cause more infiltration of nitrogen to groundwater and may have little overall effect on nitrate concentrations in streams.

- Understanding subsurface flow paths is important to determining the effectiveness of management practices such as riparian buffers intended to increase the likelihood of nitrogen losses through denitrification. In areas of the Upper Chester River watershed with a thick sandy aquifer, nitrate in groundwater can bypass these areas and discharge relatively unaltered to streams.

- Changes in management actions today that affect nitrogen concentrations will take several years or decades to be fully realized in streams because most nitrogen is from groundwater sources and it will take time for water currently recharging the system to reach local streams.

- Developing and following nutrient management plans that address the amounts and timing of fertilizer application customized to meet crop needs can substantially reduce nutrient applications to crops in excess of plant needs.

- Phosphorus transport during high-flow events can be limited by practices that limit soil erosion, including conservation tillage, riparian buffers, grassed waterways, and sediment-control ponds. Reduction of phosphorus use to the minimum required for crop production will also reduce phosphorus storage in soils over time.

- Because of the large stores of phosphorus currently in soils and streambed sediments, reductions in phosphorus available for transport, particularly during large storms, will also take many years to be realized.

- The collection of empirical nutrient and geochemical water-quality data in the Upper Chester River watershed was critical for better understanding the nitrogen sources and temporal responses within the basin, and for verifying regional model performance (SPARROW results) and assessing trends in water-quality data (Chesapeake Bay Watershed Model results).

Ongoing USGS water-quality monitoring efforts will be directed towards improved understanding of nutrient sources and transport processes in the Upper Chester River watershed, as well as the detection of water-quality change that can be directly related to the implementation of management actions. Large changes in water quality take time and sufficient implementation of conservation management practices on the landscape to be fully realized in water quality. To accomplish this goal, monitoring of both surface water and groundwater for trends is needed. Ongoing monitoring in Chesterville Branch and the small watersheds located throughout the Upper Chester River watershed is intended to continue to help meet this goal.

- Monitoring of nutrients and sediment at the streamgage on Chesterville Branch will provide a long-term record of water quality with respect to changes in nutrient management practices. With sufficient data, an expanded trend analysis can be performed to determine whether statistically significant trends exist. Previous surface-water monitoring has shown nitrate has increased from a high of about $9 \mathrm{mg} / \mathrm{L}$ as N in 1997 to about $11 \mathrm{mg} / \mathrm{L}$ in 2013. A similar amount of time may be needed to see the effects of changes in management practices that began in the last 10 years.

- The continuous nitrate record at Chesterville Branch is likely one of the best tools for determining whether water quality is changing in Chesterville Branch. With 15-minute interval, continuous data, sufficient data can be collected to measure change over time, rather than estimating it with regression models such as LOADEST and WRTDS. Furthermore, shifts in the relationship between nitrate and flow might be an early indicator of change because increased nutrient management in the watershed will change the transport of nutrients without changing hydrology. Even though it will take several decades for the entire groundwater system that contributes to Chesterville Branch to show the effect of current management practices, gradual changes in the relationship between flow and nitrate may be seen sooner in water that travels along shorter flow paths.

- Monitoring the current network of small tributaries to the Upper Chester River began in 2011 and will continue on a yearly basis during high base-flow conditions in the spring to provide a long-term record of water quality in small first-order streams so that trends can be studied on a watershed basis.

- If conservation practices implemented in the Upper Chester River watershed are improving groundwater quality, monitoring of shallow groundwater over time could show changes in nitrate concentrations in recently recharged groundwater long before those changes are observed in the streams and would also be an indicator of how much change to expect. Development of a network of monitoring wells associated with selected tributaries to the Upper Chester River would be needed to accomplish this. 


\section{Conewago Creek Watershed Water-Quality Characterization}

\author{
Lead Author: Michael J. Langland
}

In June 2010, the Conewago Creek watershed was named a Showcase Watershed by the USDA. The USGS employed an upstream/downstream monitoring strategy by building and operating one streamflow station near the middle of the watershed and another near the outlet into the Susquehanna River (fig. 75). The intensity of land-based management practices and water-quality data-collection activities within the basin was increased when the monitoring sites were funded and instrumented as part of the Chesapeake Bay Program Nontidal Network.

\section{Streamflow and Water-Quality Characterization at the Intensive Monitoring Site}

Monthly water-quality sampling, continuous water-quality monitoring for field parameters, and wetweather (storm) monitoring were initiated in January 2012 at the upstream site and in June 2011 at the downstream site. The timeline associated with the collection of different water-resources data in the Conewago Creek watershed is summarized in figure 76. High-flow synoptic sampling of an additional 12 sites occurred in May 2012.

\section{Characterization of the Physical Hydrology}

No long-term hydrologic record is available in the Conewago Creek watershed. The hydrologic record is limited to complete water years for 2012 and 2013 and indicates a wide range in instantaneous flows from lows of 1.5 and $4.7 \mathrm{ft}^{3} / \mathrm{s}$ to highs of 776 and $9,610 \mathrm{ft}^{3} / \mathrm{s}$ at the upstream and downstream sites, respectively (fig. 76). The maximum downstream flow occurred during one notable storm event on September 7, 2011, shortly after the downstream gage was built, when more than 9 inches of rain fell in the watershed. The hydrographical record was examined by using the hydrograph separation software package, PART, to compute a BFI for the watershed over multiple time periods (Rutledge, 1998). The BFI represents the ratio of the total base-flow volume to the total flow volume for a given year and is indicative of whether a given stream is dominated by groundwater discharge or direct runoff during storms. The results indicate a BFI of 54.9 percent for the upstream site and 43.1 percent for the downstream site for the 2012-2013 water years (table 23). Approximately 43 percent of the Conewago Creek flow exited the watershed as base flow during the study period. This suggests that Conewago Creek hydrology is dominated by stormflow discharge rather than groundwater discharge, which is characteristic of underlying geology dominated by less permeable mudstone, and sandstone with volcanic (diabase) intrusions instead of more permeable carbonate rock (fig. 4B). The influence of more carbonate rock on the BFI from below the upstream site to the downstream site was not observed, likely due to having only 2 years of record. 


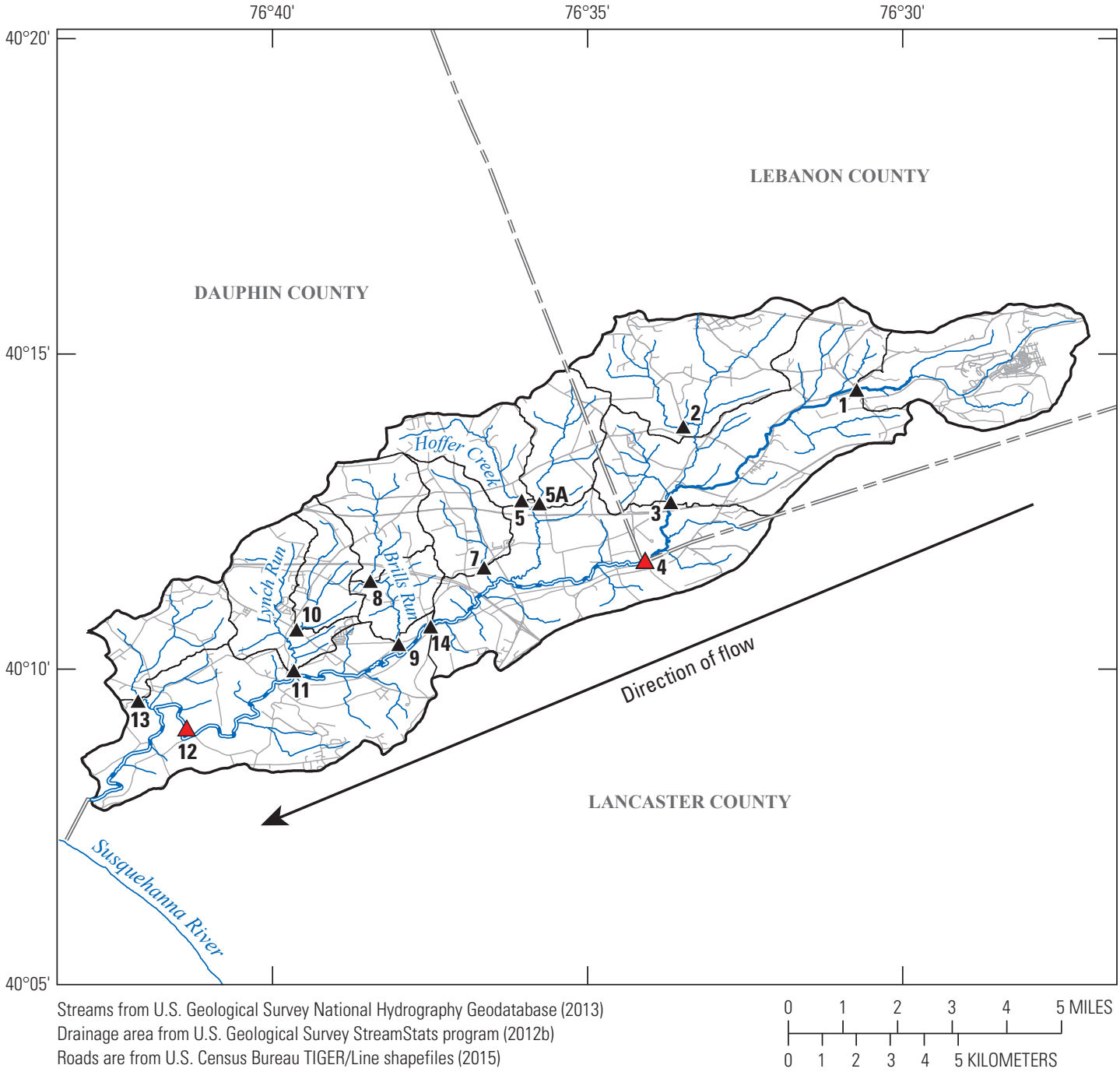

North American Datum of 1983

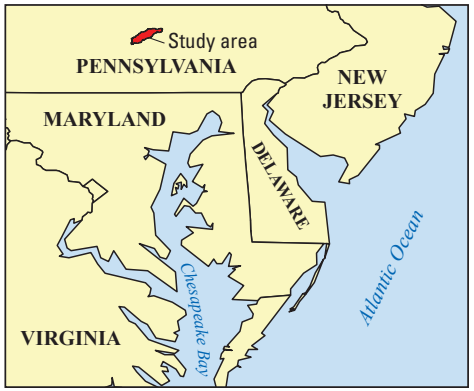

EXPLANATION

Watershed boundary

Conewago Creek (area $=52.53 \mathrm{mi}^{2}$ )

Subwatershed

Conewago Creek

Tributary to Conewago Creek $\triangle_{4}$ Monitoring station and identifier

12-USGS streamgage Falmouth (01573710)

4-USGS streamgage Bellaire (01573695)

$\Delta_{21}$ Synoptic sampling location and identifier

Figure 75. Stream network, monitoring stations, subwatershed boundaries, and sampling locations within the Conewago Creek watershed, Pennsylvania. 


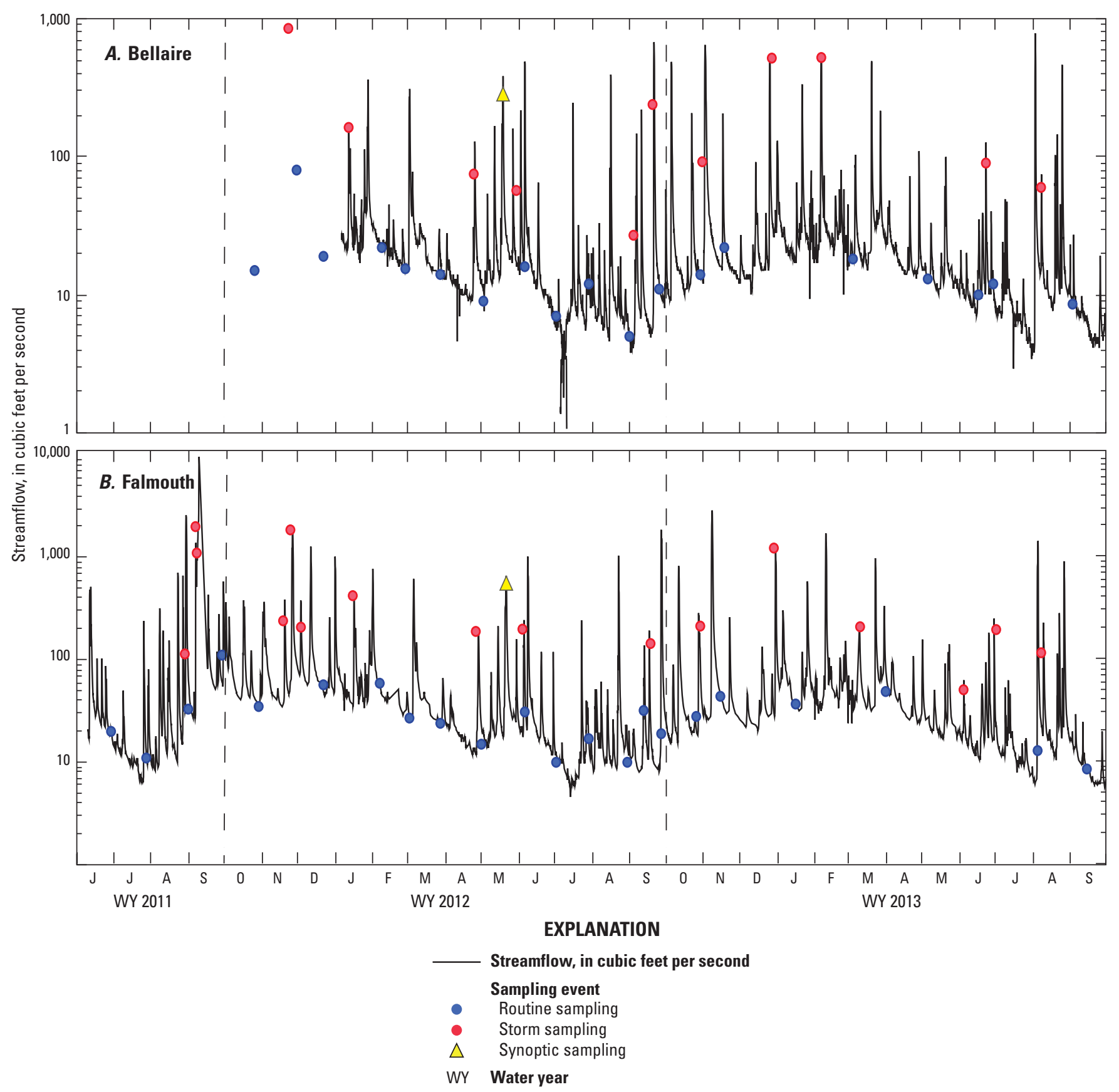

Figure 76. (A) Conewago Creek Bellaire and $(B)$ Conewago Creek Falmouth streamgages with the timing of various sampling events. 
Table 23. Streamflow partitioning for streamgage stations 01573695 and 01573710 in the Conewago Creek watershed.

$\left[\mathrm{mi}^{2}\right.$, square miles; $\mathrm{ft}^{3} / \mathrm{s}$, cubic foot per second; in/yr, inch per year; \%, percent; data were computed using the software package PART (Rutledge, 1998)]

\begin{tabular}{|c|c|c|c|c|c|c|c|}
\hline \multirow{2}{*}{ Watershed } & \multirow{2}{*}{$\begin{array}{c}\text { Drainage area } \\
\left(\mathrm{mi}^{2}\right)\end{array}$} & \multirow{2}{*}{$\begin{array}{l}\text { Period of } \\
\text { record }\end{array}$} & \multicolumn{2}{|c|}{ Mean streamflow } & \multicolumn{2}{|c|}{ Mean base flow } & \multirow{2}{*}{$\begin{array}{l}\text { Base-flow } \\
\text { index (\%) }\end{array}$} \\
\hline & & & $\mathrm{ft}^{3} / \mathrm{s}$ & in/yr & $\mathrm{ft}^{3} / \mathrm{s}$ & in/yr & \\
\hline Conewago Creek Bellaire & 20.5 & 2013-2013 & 26.14 & 17.32 & 14.35 & 9.51 & 54.9 \\
\hline Conewago Creek Falmouth & 47.3 & 2012-2013 & 60.06 & 17.25 & 25.89 & 7.44 & 43.1 \\
\hline
\end{tabular}

\section{Characterization of Continuous Water-Quality Data}

The temporal variability in the continuously monitored water-quality constituents is presented for the monitoring period as multidimensional contour plots in figures 77 and 78 . Seasonal, diel, and flow-driven fluctuations in most of the continuously monitored constituents were observed at both monitoring locations.

Water temperature had some of the strongest seasonality, with summertime temperatures commonly reaching greater than $20^{\circ} \mathrm{C}$ and wintertime temperatures falling below $5^{\circ} \mathrm{C}$. A slight increase in average temperature $\left(0.5^{\circ} \mathrm{C}\right)$ is noted between the upstream and downstream monitoring locations in the summer months, and the reverse happened in the winter months. This can be attributed to a greater amount of forest canopy (shading) above the upstream site in the summer and greater exposure to colder air at the downstream site in winter.

Specific conductance values were generally about $250 \mu \mathrm{S} / \mathrm{cm}$ at the upstream location and $300 \mu \mathrm{S} / \mathrm{cm}$ at the downstream location. The higher conductance values are likely influenced by some thin carbonate rock layers present in the lower half of the watershed. Specific conductance is inversely related to streamflow, with the highest specific conductance levels observed during relatively low-flow periods and the lowest levels observed during stormflow periods due to dilution from overland runoff and precipitation with lower specific conductance.

Hydrologic variability in the continuously monitored constituents was explored by using a series of concentrationdischarge plots (known as C-Q plots) that were subset into two classifications - warm periods (April-September) and cool periods (October-March). For this assessment, the continuously monitored parameters (temperature and specific conductivity) were combined with discrete water-quality samples collected within the same timeframe. Seasonal characterization for each of the continuously monitored parameters was based on the C-Q plot and seasonal boxplots (figs. 79 and 80). Water temperature indicated the most seasonality, with greater temperatures observed during the April-September warmer seasons. Specific conductance values showed little seasonal variability, with both seasons demonstrating substantial dilution during elevated flow conditions. 


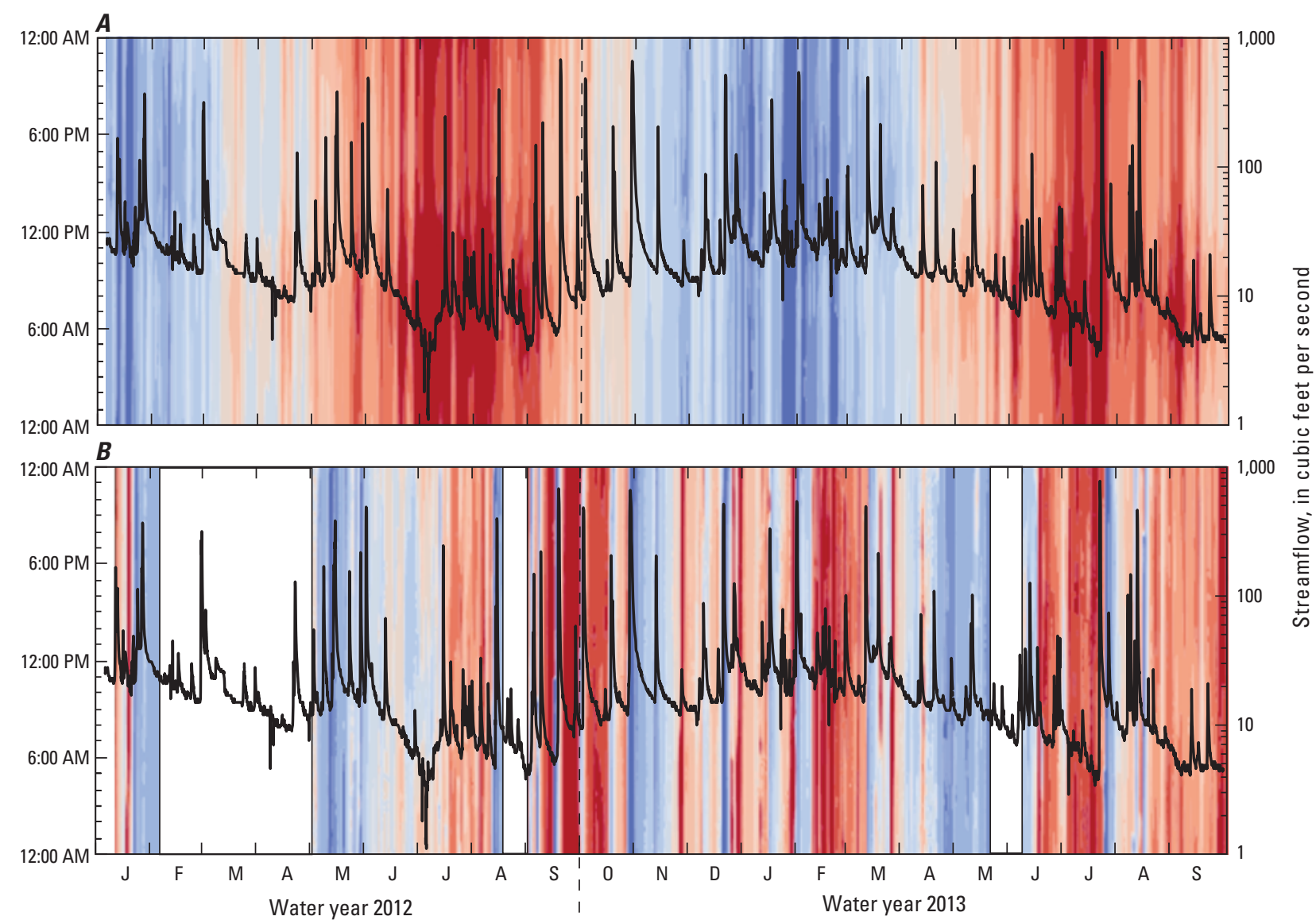

EXPLANATION

Water temperature, in degrees Celsius

\begin{tabular}{ll}
0 to $1.30 \quad 14.71$ to 17.10 \\
\hline
\end{tabular}

131 to $250 \quad 17.11$ to 19.50

$\begin{array}{ll}1.31 \text { to } 2.50 & 17.11 \text { to } 19.50 \\ 2.51 \text { to } & 19.51 \text { to } 21.70\end{array}$

4.21 to $6.60 \quad 21.71$ to 23.40

6.61 to $11.40 \quad 23.41$ to 30.90

11.41 to 14.70

— Streamflow, in cubic feet per second

Specific conductance, in microsiemens per centimeter at 25 degrees Celsius

86.0 to $203.0 \quad 254.1$ to 261.0 203.1 to $216.0 \quad 261.1$ to 269.0

216.1 to $231.0 \quad 269.1$ to 275.0

231.1 to 241.0

241.1 to $247.0 \square 283.1$ to 486.0

247.1 to $254.0 \square$ Gap in data that exceeds 1 week

- Streamflow, in cubic feet per second

Figure 77. Continuous $(A)$ water temperature and $(B)$ specific conductance data with the hydrograph from the Conewago Creek Bellaire streamgage, 2012-2013. 

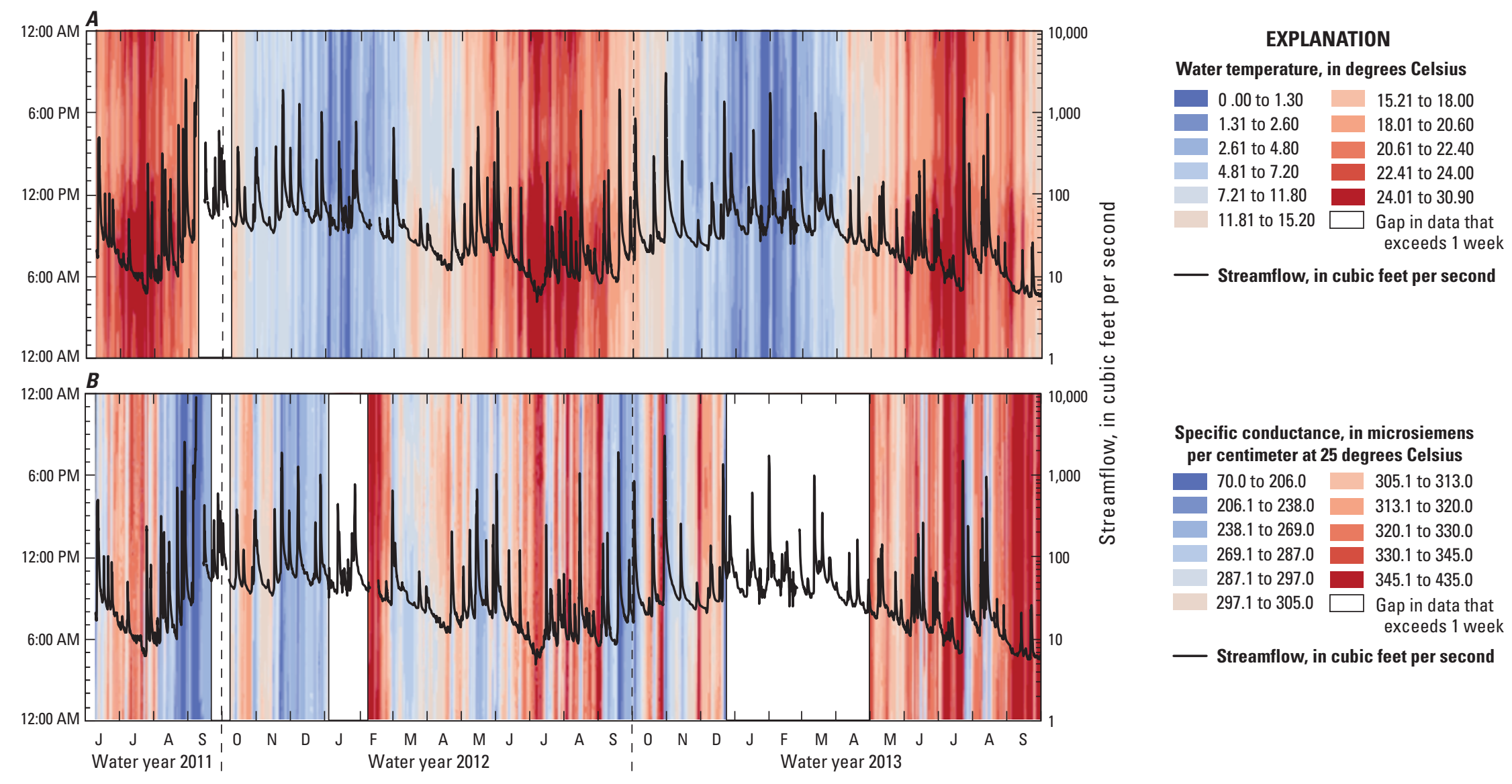

Figure 78. Continuous $(A)$ water temperature and $(B)$ specific conductance data with the hydrograph from the Conewago Creek Falmouth streamgage, 2011-2013. 

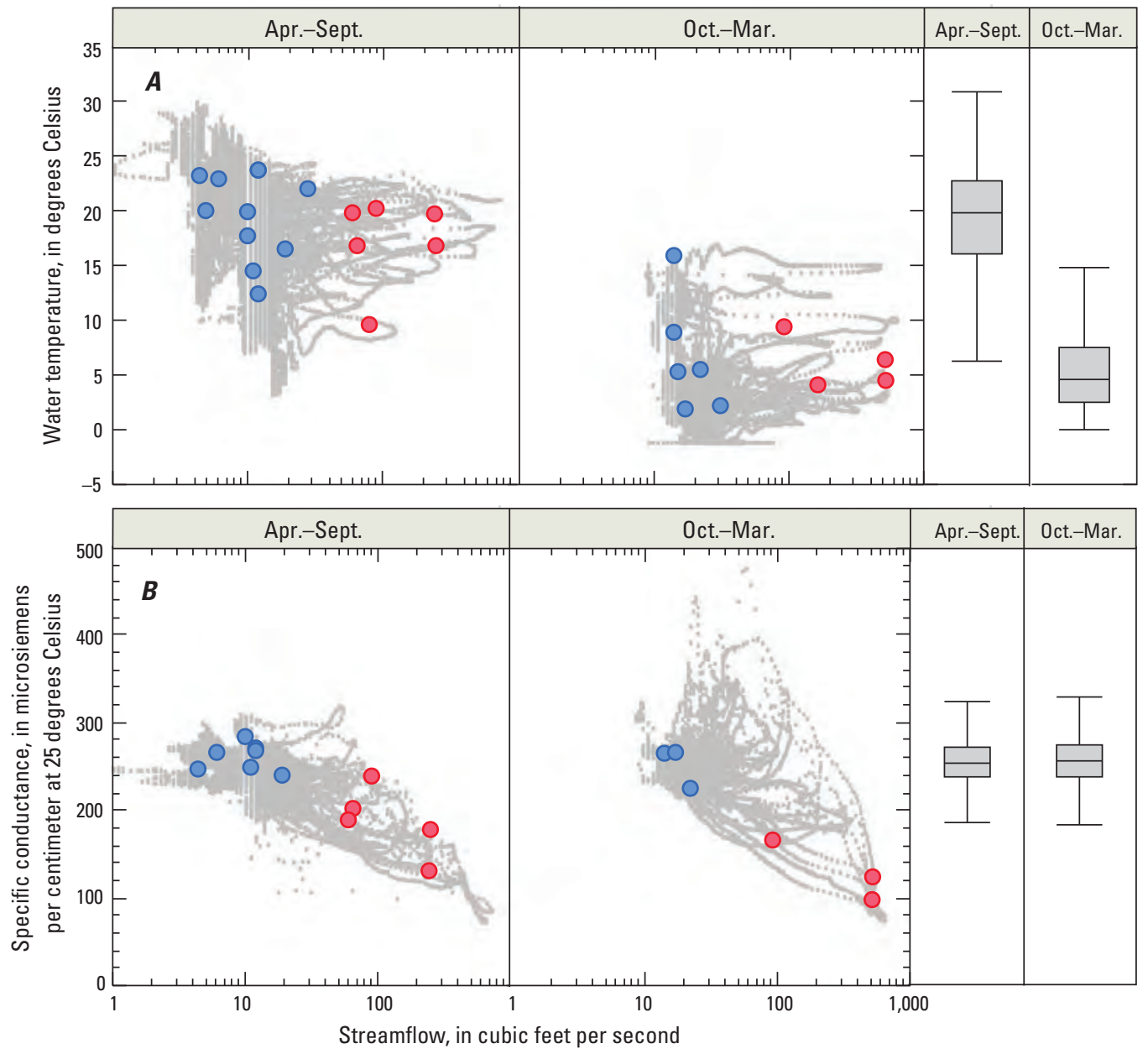

Figure 79. (A) Water temperature and $(B)$ specific conductance data from continuous monitoring and discrete storm and routine samples for warm (April to September) and cool (October to March) seasons, Conewago Creek Bellaire streamgage, 2012-2013.

\section{EXPLANATION}

- Discrete storm sample

O Discrete routine sample

- Continuous sample

Highest value within 1.5 (IOR) of 75th percentile

75th percentile

Median

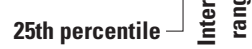

Lowest value within 1.5 (IOR) of 25 th percentile 

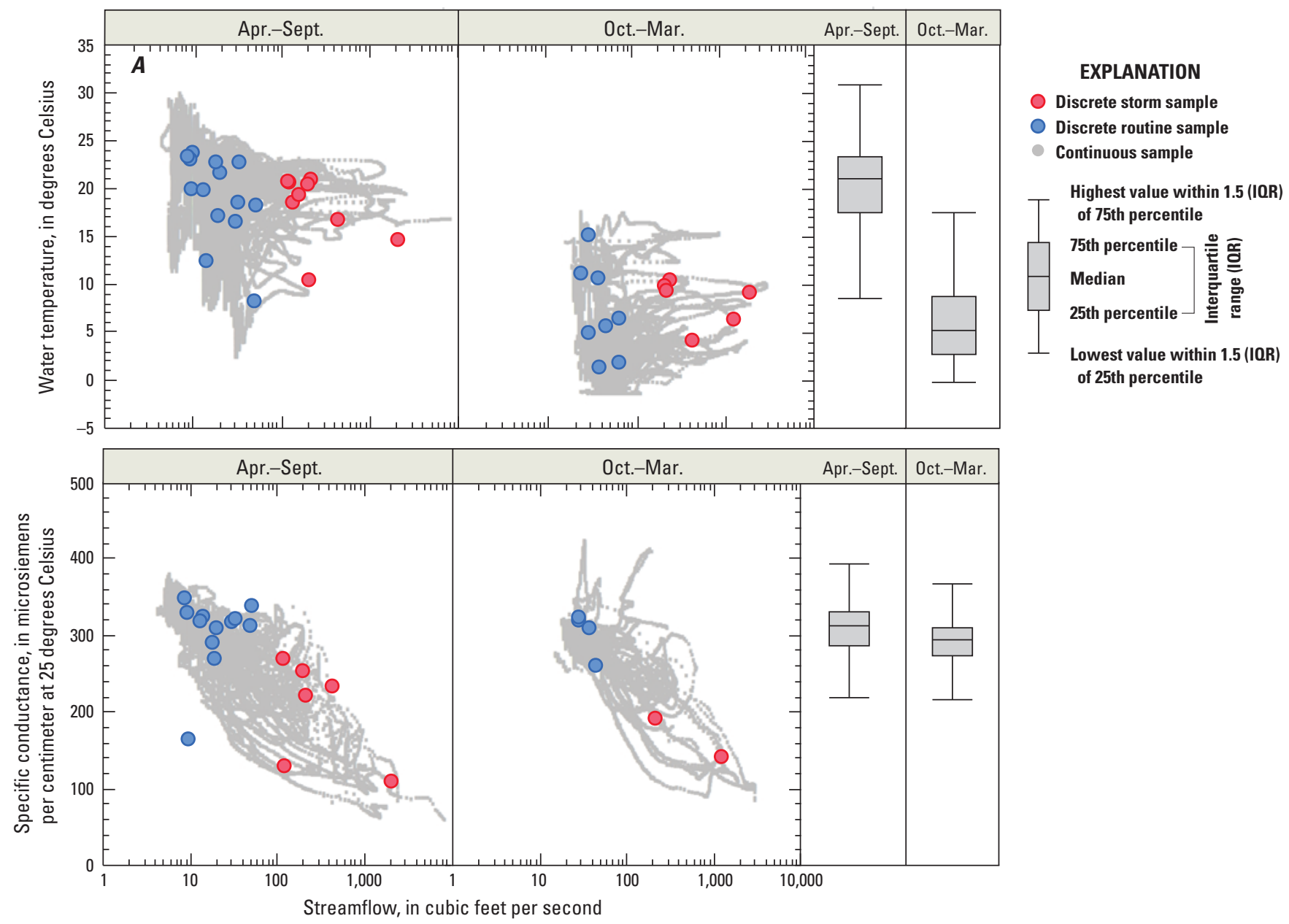

Figure 80. (A) Water temperature and $(B)$ specific conductance data from continuous monitoring and discrete storm and routine samples for warm (April to September) and cool (October to March) seasons, Conewago Creek Falmouth streamgage, 2011-2013.

\section{Characterization of Discrete Water-Quality Data}

A total of 85 water-quality samples were collected at the monitoring sites during the study period, and field and laboratory parameters were analyzed from each discrete water-quality sample collected. Systematic patterns in the discrete water-quality samples were explored by using simple statistics, cluster analysis, and PCA because these tests offer additional insights in complex water-quality datasets.

Similar to the continuous water-quality data, the discrete water-quality data demonstrated temporal variations that are likely related to flow, seasonality, temperature, nutrient uptake, and natural in-stream processes. A slight seasonal pattern in 2012 and 2013 is observed in the discharge data associated with water-quality sampling with elevated flow levels in late winter and lower flow levels in late summer. Because the annual flows were similar in 2012 and 2013, a longer monitoring period that would include more hydrologic variability is likely needed to provide additional information on seasonal patterns.

Simple statistics based on constituent concentrations (maximum, minimum, and mean) for the upstream (Bellaire) and downstream (Falmouth) monitoring locations are presented in tables 24 and 25, respectively. Based on a comparable dataset of 38 samples from each monitoring location, nearly every constituent increased in mean concentration between the two sites. The largest increase was in flow. The increases in mean concentrations from upstream to downstream are predominantly related to drainage area (flow) and land use. Areas upstream of the upstream monitoring gage have a greater percentage of land classified as forest, less agricultural land, and minimal developed land (fig. 4A). The downstream watershed contains less forest, with more agricultural and urban land (fig. 4A). All of the impaired tributaries are below the upstream monitoring location.

Conewago Creek $\mathrm{pH}$ ranged from 7.0 to 8.9 , averaging 7.7 and 7.8 at the upstream and downstream monitoring locations, respectively (tables 24 and 25). The $\mathrm{pH}$ levels indicate some dilution by more acidic runoff during stormflow. At each location, the difference between the storm and non-storm samples was about 1 standard unit, which represents a ten-fold change in acidity.

DO ranged from about $5 \mathrm{mg} / \mathrm{L}$ to $16 \mathrm{mg} / \mathrm{L}$ with a mean about $10 \mathrm{mg} / \mathrm{L}$ at each of the monitoring locations (tables 24 and 25). Some variation is indicated between storm and non-storm samples, but correlations between DO and flow, temperature, or nutrient data were statistically insignificant. 
Table 24. Summary statistics for discrete water-quality constituents collected at the Conewago Creek Bellaire streamgage with a comparison between storm and base-flow samples.

[USGS, U.S. Geological Survey; n, number; deg C, degrees Celsius; mg/L, milligram per liter; N, nitrogen; $\mathrm{P}$, phosphorus; $\mathrm{CaCO}_{3}$, calcium carbonate; $\mu \mathrm{g} / \mathrm{L}$, microgram per liter; $\%$, percent; $<$, less than; $\mathrm{mm}$, millimeter; $\mu \mathrm{S} / \mathrm{cm}$, microsiemens per centimeter; $\mathrm{ft}^{3} / \mathrm{s}$, cubic foot per second; - , no samples collected]

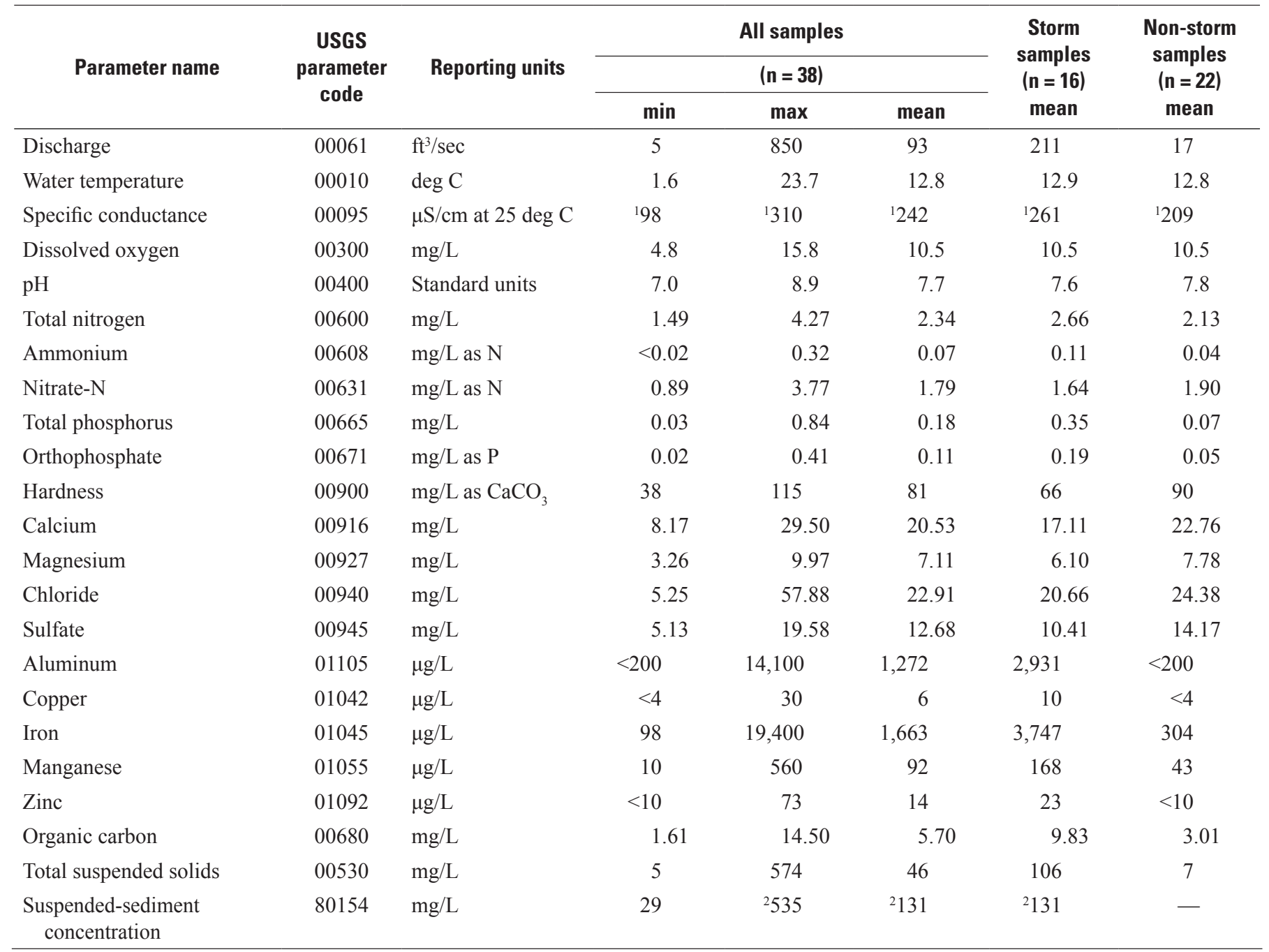

${ }^{1}$ Statistics for specific conductance are based on 33 total samples, 14 storm samples, and 19 non-storm samples.

${ }^{2}$ Statistics for suspended-sediment concentration are based on 14 total samples, 14 storm samples, and 0 non-storm samples. 
Table 25. Summary statistics for discrete water-quality constituents collected at the Conewago Creek Falmouth streamgage with a comparison between storm and base-flow samples.

[USGS, U.S. Geological Survey; n, number; deg C, degrees Celsius; mg/L, milligram per liter; N, nitrogen; P, phosphorus; $\mathrm{CaCO}_{3}$, calcium carbonate; $\mu \mathrm{g} / \mathrm{L}$, microgram per liter; $\%$, percent; $<$, less than; $\mathrm{mm}$, millimeter; $\mu \mathrm{S} / \mathrm{cm}$, microsiemens per centimeter; $\mathrm{ft}^{3} / \mathrm{s}$, cubic foot per second; - , no samples collected]

\begin{tabular}{|c|c|c|c|c|c|c|c|}
\hline \multirow{3}{*}{ Parameter name } & \multirow{3}{*}{$\begin{array}{c}\text { USGS } \\
\text { parameter } \\
\text { code }\end{array}$} & \multirow{3}{*}{ Reporting units } & \multicolumn{3}{|c|}{ All Samples } & \multirow{3}{*}{$\begin{array}{c}\text { Storm } \\
\text { samples } \\
(\mathbf{n}=18) \\
\text { mean }\end{array}$} & \multirow{3}{*}{$\begin{array}{c}\text { Non-storm } \\
\text { samples } \\
(\mathrm{n}=\mathbf{2 8}) \\
\text { mean }\end{array}$} \\
\hline & & & \multicolumn{3}{|c|}{$(n=46)$} & & \\
\hline & & & Min & Max & Mean & & \\
\hline Discharge & 00061 & $\mathrm{ft}^{3} / \mathrm{sec}$ & 9 & 1,990 & 243 & 562 & 39 \\
\hline Water temperature & 00010 & $\operatorname{deg} \mathrm{C}$ & 1.5 & 23.9 & 14.2 & 14.0 & 14.3 \\
\hline Specific conductance & 00095 & $\mu \mathrm{S} / \mathrm{cm}$ at $25 \operatorname{deg} \mathrm{C}$ & ${ }^{1} 110$ & ${ }^{1} 388$ & ${ }^{1} 269.3$ & ${ }^{1} 222.6$ & ${ }^{1} 298$ \\
\hline $\mathrm{pH}$ & 00400 & Standard units & 7.0 & 8.5 & 7.8 & 7.7 & 7.7 \\
\hline Total nitrogen & 00600 & $\mathrm{mg} / \mathrm{L}$ & 1.18 & 8.40 & 3.28 & 3.68 & 3.03 \\
\hline Ammonium & 00608 & $\mathrm{mg} / \mathrm{L}$ as $\mathrm{N}$ & $<0.02$ & 1.37 & 0.12 & 0.25 & 0.03 \\
\hline Nitrate-N & 00631 & $\mathrm{mg} / \mathrm{L}$ as $\mathrm{N}$ & 0.44 & 4.83 & 2.54 & 2.27 & 2.70 \\
\hline Calcium & 00916 & $\mathrm{mg} / \mathrm{L}$ & 6.79 & 30.50 & 24.48 & 19.94 & 27.40 \\
\hline Magnesium & 00927 & $\mathrm{mg} / \mathrm{L}$ & 1.74 & 10.80 & 8.32 & 6.71 & 9.35 \\
\hline Chloride & 00940 & $\mathrm{mg} / \mathrm{L}$ & 2.37 & 60.40 & 24.41 & 19.38 & 27.64 \\
\hline Sulfate & 00945 & $\mathrm{mg} / \mathrm{L}$ & 3.76 & 21.10 & 14.88 & 11.33 & 17.16 \\
\hline Aluminum & 01105 & $\mu \mathrm{g} / \mathrm{L}$ & $<200$ & 10,500 & 1,255 & 2,848 & 232 \\
\hline Copper & 01042 & $\mu \mathrm{g} / \mathrm{L}$ & $<4$ & 67 & 8 & 13 & 4 \\
\hline Iron & 01045 & $\mu \mathrm{g} / \mathrm{L}$ & 54 & 11,700 & 1,474 & 3,318 & 289 \\
\hline Manganese & 01055 & $\mu \mathrm{g} / \mathrm{L}$ & $<10$ & 550 & 76 & 153 & 27 \\
\hline Zinc & 01092 & $\mu \mathrm{g} / \mathrm{L}$ & $<10$ & 142 & 22 & 33 & 15 \\
\hline
\end{tabular}

${ }^{1}$ Statistics for specific conductance are based on 42 total samples, 16 storm samples, and 26 non-storm samples.

${ }^{2}$ Statistics for suspended-sediment concentration are based on 14 total samples, 14 storm samples, and 0 non-storm samples.

Based on the observation that mean concentrations increased downstream, a cluster analysis was run on the geochemical results for the 74 discrete samples for which a complete set of analyses was available (fig. 81). Variables that are strongly correlated to flow (such as sediment) or season (such as water temperature) were excluded from this analysis to better examine the stream geochemistry and provide information on subtle patterns in the data. Four cluster groups resulted, representing both site locations and hydrologic variability (fig. 82). All the Group 1 and the Group 2 samples were collected during low- to medium-flow conditions at each monitoring location. Groups 1 and 2 represent nearly each site, exclusively. Group 3 included the samples collected at the highest flows during the monitoring period and demonstrated strongly diluted major-ion (calcium, magnesium, and chloride) and iron and manganese concentrations. Group 4 represents the samples collected at "elevated" flow, a transition from lower flows to the highest sampled flows. Group 4 samples had the highest concentrations of particulate-associated constituents (iron, manganese, TN, and TP), and during "elevated" flows, water quality in Conewago Creek showed the greatest change in concentration. This response is likely due to the rapid transport of particulate-associated constituents that become diluted at the highest flows (Group 3) due to supply limitation.

A PCA was run using all 74 discrete samples collected at the two monitoring locations with complete analytical results to further explore the patterns in discrete concentration data. Similar to the cluster analysis, water temperature and sediment were withheld from the analysis. Two principal components 


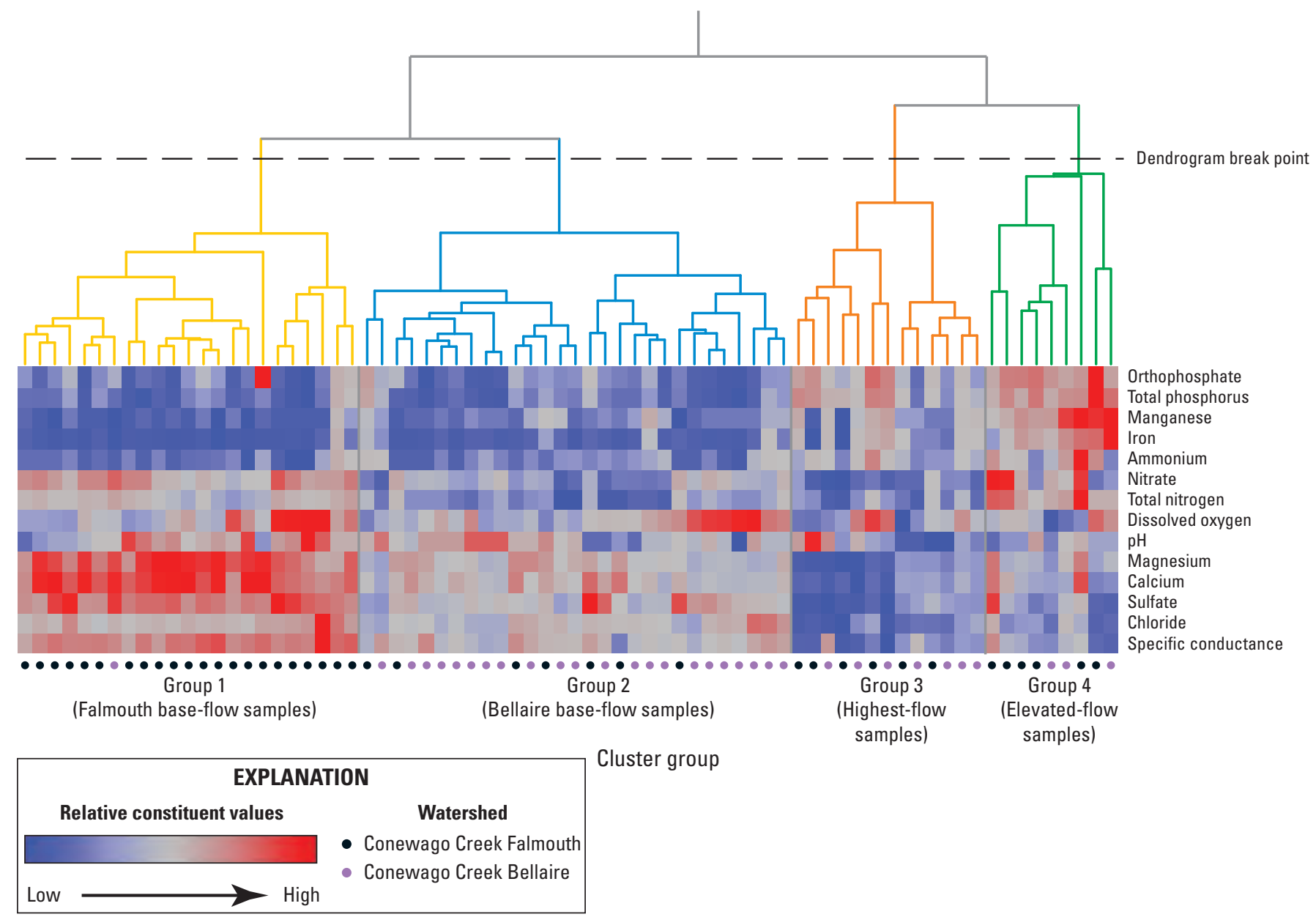

Figure 81. Discrete samples from the Conewago Creek Bellaire and Falmouth streamgages with a heat map of constituent values and the breakpoint used to produce four cluster groups, 2011-2013.

(the first and second principal components axes) explained 66 percent of the variability in the data (table 26). The first component explained 48.5 percent of the data variability and had high positive axis loadings for specific conductance, sulfate, chloride, calcium, magnesium, and nitrate, with large negative axis loadings for TP, ammonium, orthophosphate, iron, and manganese. The first principal components axis is a flow axis; at low flow, calcium, magnesium, sulfate, and specific conductance are elevated, while concentrations of iron and TP are relatively low. At higher flows and under runoff conditions, concentrations of iron, magnesium, and TP increase. The second principal components axis explains less variability (17.7 percent); however, the occurrence of
$\mathrm{TN}$ and dissolved nitrate (primary species of TN) suggests an additional influence other than flow. An examination of the second principal components axis over time suggests the cycling of nitrogen does not follow a traditional seasonal pattern with higher nitrogen concentrations in the fall and winter due to less biologic uptake. Some weak seasonal patterns are evident during base-flow conditions at each location. As previously mentioned, the data record may not be long enough to detect a persistent seasonal signature. The presence of a flow and a seasonal (although weak) signature in the discrete data is typical of most stream systems and indicates that hydrology and seasonality both contribute to water-quality variability in Conewago Creek. 


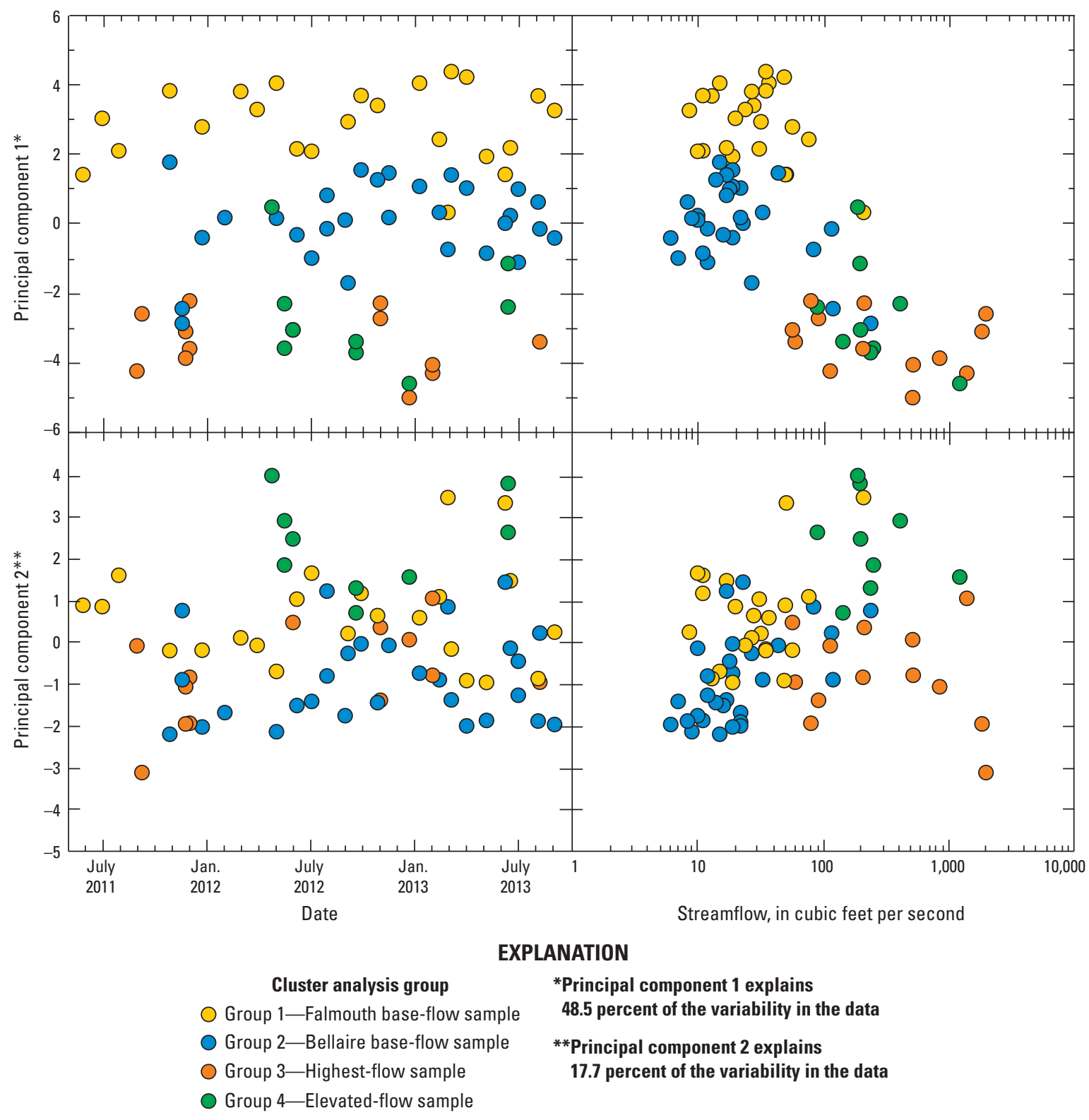

Figure 82. First two principal component axis scores for discrete samples from the Conewago Creek Bellaire and Falmouth streamgages along with time and streamflow, 2011-2013. 
Table 26. Loading of water-quality constituents collected at the Conewago Creek Bellaire and Falmouth streamgages on principal component axes 1 and 2.

$[\%$, percent; PC1, first principal components axis; PC2, second principal components axis; loadings with absolute value greater than 0.70 are shown in bold; those with absolute value less than $|0.40|$ are omitted]

\begin{tabular}{|c|c|c|}
\hline Parameter & $\begin{array}{c}\text { PC1 } \\
(48.5 \%)^{1}\end{array}$ & $\begin{array}{c}\text { PC2 } \\
(17.7 \%)^{1}\end{array}$ \\
\hline \multicolumn{3}{|l|}{$\mathrm{pH}$} \\
\hline Specific conductance & 0.82 & \\
\hline \multicolumn{3}{|l|}{ Dissolved oxygen } \\
\hline Sulfate & 0.89 & \\
\hline Chloride & 0.74 & \\
\hline Calcium & 0.87 & \\
\hline Magnesium & 0.87 & \\
\hline Nitrate-N & 0.67 & 0.56 \\
\hline Ammonium & -0.73 & \\
\hline Total nitrogen & & 0.82 \\
\hline Orthophosphate & -0.62 & 0.61 \\
\hline Total phosphorus & -0.73 & 0.54 \\
\hline Iron & -0.76 & 0.44 \\
\hline Manganese & -0.76 & \\
\hline
\end{tabular}

${ }^{1}$ Percent of overall variance explained. 
The cluster analysis and the PCA indicated correlations with flow, and to a lesser extent, the seasonal variability of the parameters in Conewago Creek; therefore, many constituents were tested individually for relationships to flow and seasonality (tables 27 and 28). Highly correlated (termed large, Spearman's rho >0.7) significant positive relations with flow are indicative of constituents that are transported during higher flow and runoff conditions. Large positive relations with flow were observed for iron at the upstream location (table 27), while smaller but still statistically significant positive relationships were observed at both sites for TP, orthophosphate, ammonium, manganese, and iron (at the downstream site) (table 28). Large (Spearman's rho <-0.7) inverse relationships with flow were observed for two ions (calcium and magnesium) at both locations, while moderate inverse correlations were observed for specific conductance, sulfate, chloride, and water temperature (tables 27 and 28). These negative relationships are consistent with dilution of streamflow by lower ionic strength waters (rainfall) during storm events. Total nitrogen results indicate significant positive correlations with flow at the upstream location and non-significant correlations at the downstream location, most likely due to less variability in flow and concentration at the upstream location.

The general relations between flow and various water-quality constituents exhibited in the data for Conewago Creek (fig. 83) are typical of many streams in the Piedmont
Physiographic Province, where sediments and particulate nitrogen and phosphorus concentrations typically increase during storm events, while groundwater-derived constituents (such as calcium, magnesium, chloride, and sulfate), which are more prominent during lower flows, tend to decrease during storms. Groundwater-derived streamflow has a longer residence time and contact with bedrock, resulting in water with a higher concentration of major ions. Dilution occurs when rainfall-derived runoff from the landscape mixes with groundwater-derived streamflow with higher concentrations of major ions. Non-significant seasonal relationships are provided in the appendix as supplemental material (fig. 1-5).

Statistically significant seasonal patterns exist for only a few of the monitored constituents (fig. 84). The most significant seasonal patterns occurred in the warm season (April-September) for water temperature at both locations. At the upstream station, $\mathrm{TN}$ and nitrate concentrations increased in the cool season (October-March), and TP and orthophosphate concentrations increased in the warm season. At the downstream station, nitrate increased in the cool season, whereas orthophosphate increased in the warm season. Seasonal patterns in water temperature were expected and demonstrated previously with C-Q plots. Many of the remaining constituents showed insignificant seasonal patterns, which may be the result of a short data record; a longer monitoring record could result in clearer seasonal patterns (fig. 1-6).

Table 27. Summary of hydrologic and seasonal correlations for discrete water-quality constituents collected at the Conewago Creek Bellaire streamgage.

[results in bold are significant at $\alpha=0.05$; n, number of observations; APR, April; SEPT, September; OCT, October; MAR, March; <, less than]

\begin{tabular}{|c|c|c|c|c|c|c|c|}
\hline \multirow[b]{2}{*}{ Parameter } & \multicolumn{3}{|c|}{ Streamflow } & \multicolumn{4}{|c|}{ Season ${ }^{1}$} \\
\hline & $\mathbf{n}$ & rho $^{2}$ & p-value ${ }^{2}$ & nAPR-SEPT & nOCT-MAR & $p$-value ${ }^{3}$ & $\begin{array}{c}\text { Season with } \\
\text { higher values }\end{array}$ \\
\hline Water temperature & 38 & -0.35 & 0.032 & 12 & 11 & $<0.001$ & APR-SEPT \\
\hline $\mathrm{pH}$ & 38 & -0.18 & 0.271 & 12 & 11 & 0.156 & \\
\hline Specific conductance & 34 & -0.33 & 0.063 & 11 & 9 & 0.703 & \\
\hline Dissolved oxygen & 38 & -0.02 & 0.906 & 12 & 11 & 0.479 & \\
\hline Sulfate & 38 & -0.47 & 0.0031 & 12 & 11 & 0.310 & \\
\hline Chloride & 38 & -0.43 & 0.007 & 12 & 11 & 0.372 & \\
\hline Calcium & 38 & -0.81 & $<0.001$ & 12 & 11 & 0.124 & \\
\hline Magnesium & 38 & -0.80 & $<0.001$ & 12 & 11 & 0.079 & \\
\hline Calcium/magnesium & 38 & -0.15 & 0.382 & 12 & 11 & 0.018 & \\
\hline Nitrate-N & 38 & -0.13 & 0.421 & 12 & 11 & 0.018 & OCT-MAR \\
\hline Ammonium & 38 & 0.56 & $<0.001$ & 12 & 11 & 0.616 & \\
\hline Total nitrogen & 38 & 0.41 & 0.011 & 12 & 11 & 0.011 & OCT-MAR \\
\hline Orthophosphate & 38 & 0.61 & $<0.001$ & 12 & 11 & 0.013 & APR-SEPT \\
\hline Total phosphorus & 38 & 0.65 & $<0.001$ & 12 & 11 & 0.010 & APR-SEPT \\
\hline Iron & 38 & 0.81 & $<0.001$ & 12 & 11 & 0.829 & \\
\hline Manganese & 38 & 0.63 & $<0.001$ & 12 & 11 & 0.175 & \\
\hline
\end{tabular}

${ }^{1}$ Only routine samples included in the Wilcoxon test of rank scores.

${ }^{2}$ rho is Spearman's rho; p-value is from Spearman's test for correlation.

${ }^{3} \mathrm{p}$-value is from the Wilcoxon test of rank scores. 
Table 28. Summary of hydrologic and seasonal correlations for discrete water-quality constituents collected at the Conewago Creek Falmouth streamgage.

[results in bold are significant at $\alpha=0.05$; n, number of observations; APR, April; SEPT, September; OCT, October; MAR, March; <, less than]

\begin{tabular}{|c|c|c|c|c|c|c|c|}
\hline \multirow[b]{2}{*}{ Parameter } & \multicolumn{3}{|c|}{ Streamflow } & \multicolumn{4}{|c|}{ Season ${ }^{1}$} \\
\hline & $\mathbf{n}$ & rho $^{2}$ & p-value ${ }^{2}$ & nAPR-SEPT & nOCT-MAR & p-value ${ }^{3}$ & $\begin{array}{c}\text { Season with } \\
\text { higher values }\end{array}$ \\
\hline Water temperature & 46 & -0.45 & 0.002 & 17 & 11 & $<0.001$ & APR-SEPT \\
\hline $\mathrm{pH}$ & 46 & -0.12 & 0.439 & 17 & 11 & 0.126 & \\
\hline Specific conductance & 42 & -0.57 & $<0.001$ & 16 & 10 & 1.000 & \\
\hline Dissolved oxygen & 46 & -0.17 & 0.273 & 17 & 11 & 0.747 & \\
\hline Sulfate & 46 & -0.61 & $<0.001$ & 17 & 11 & 0.204 & \\
\hline Chloride & 46 & -0.51 & 0.000 & 17 & 11 & 0.742 & \\
\hline Calcium & 46 & -0.73 & $<0.001$ & 17 & 11 & 0.410 & \\
\hline Magnesium & 46 & -0.78 & $<0.001$ & 17 & 11 & 0.540 & \\
\hline Calcium/magnesium & 46 & 0.29 & 0.051 & 17 & 11 & 0.888 & \\
\hline Nitrate-N & 46 & -0.18 & 0.235 & 17 & 11 & 0.029 & OCT-MAR \\
\hline Ammonium & 45 & 0.62 & $<0.001$ & 16 & 11 & 0.745 & \\
\hline Total nitrogen & 46 & 0.18 & 0.235 & 17 & 11 & 0.063 & \\
\hline Orthophosphate & 46 & 0.49 & 0.001 & 17 & 11 & 0.043 & APR-SEPT \\
\hline Total phosphorus & 46 & 0.66 & $<0.001$ & 17 & 11 & 0.070 & \\
\hline Iron & 46 & 0.48 & 0.001 & 17 & 11 & 0.925 & \\
\hline Manganese & 46 & 0.38 & 0.01 & 17 & 11 & 0.094 & \\
\hline
\end{tabular}

${ }^{1}$ Only routine samples included in the Wilcoxon test of rank scores.

${ }^{2}$ rho is Spearman's rho; p-value is from Spearman's test for correlation.

${ }^{3} \mathrm{p}$-value is from the Wilcoxon test of rank scores. 

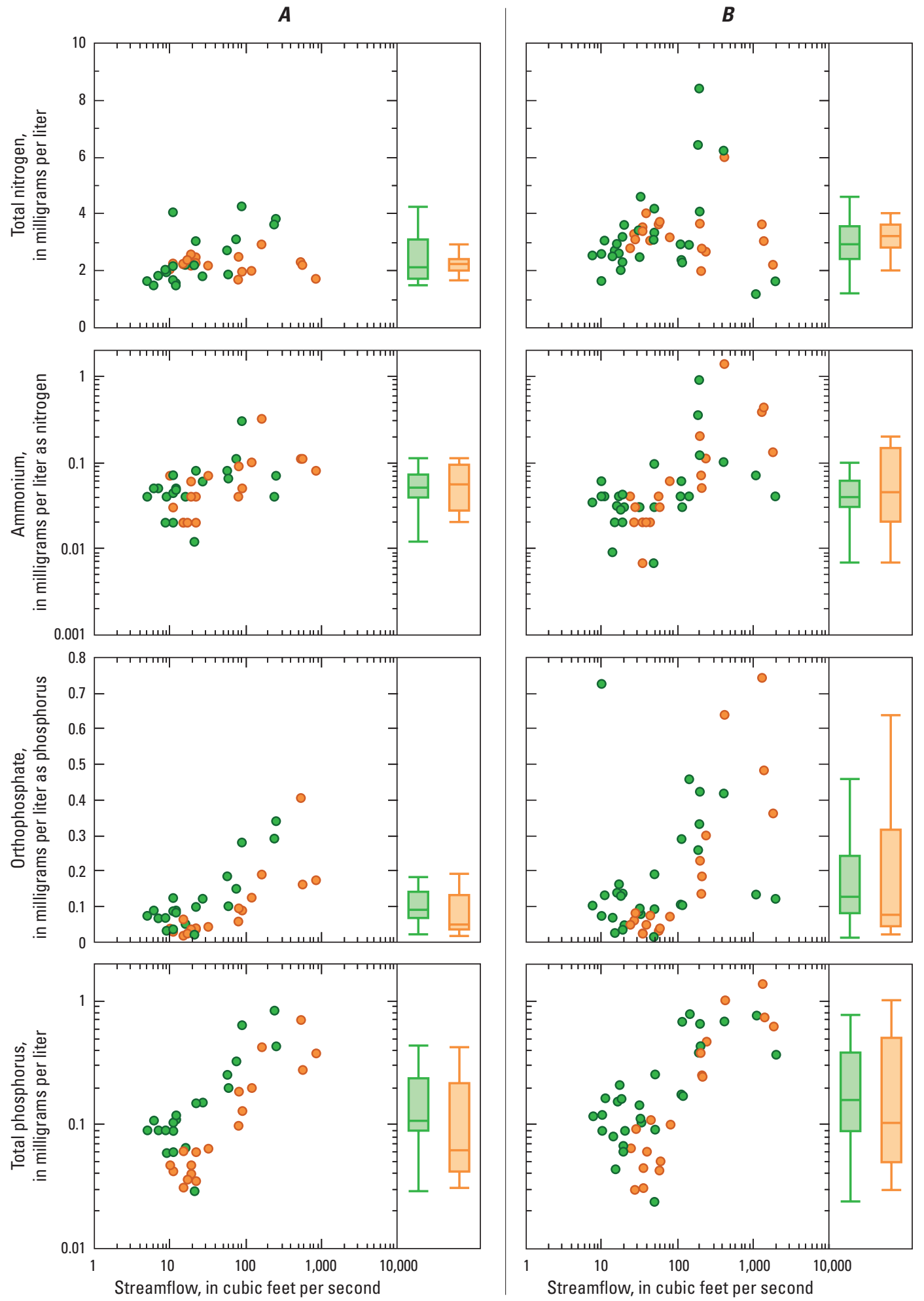

Figure 83. Concentration-discharge data for discrete samples from the Conewago Creek $(A)$ Bellaire and $(B)$ Falmouth streamgages by warm (April to September) and cool (October to March) seasons. 

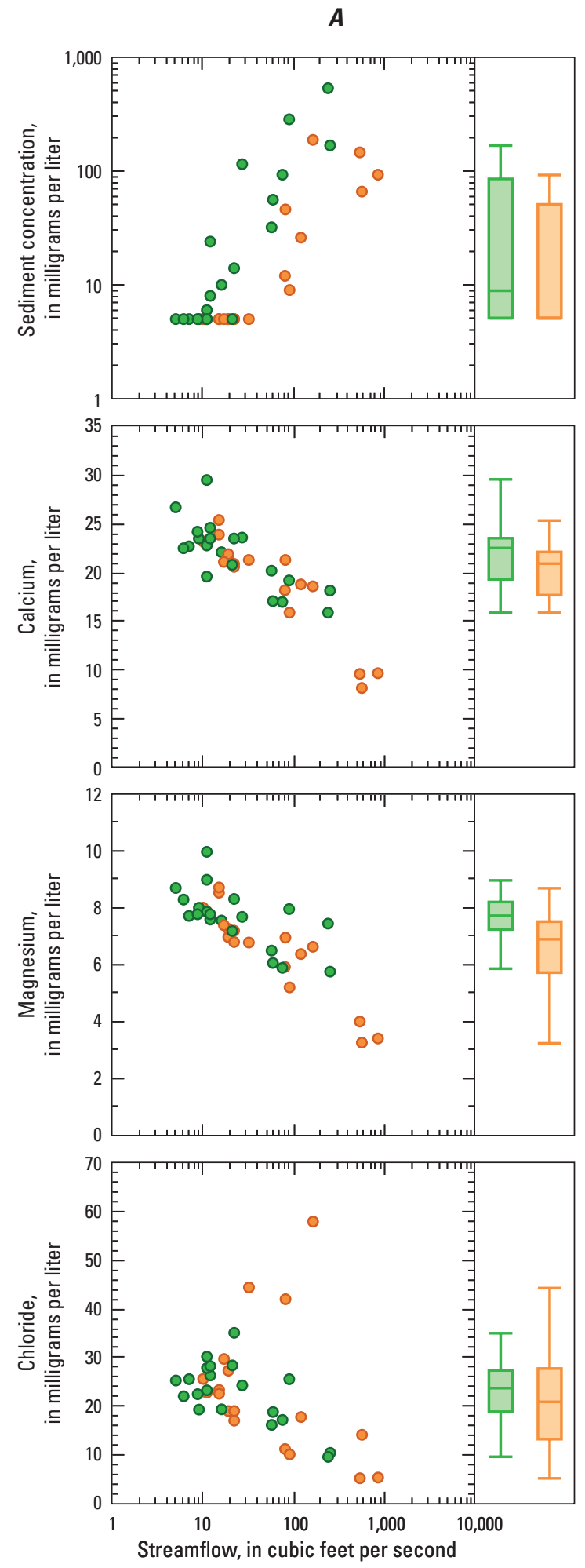
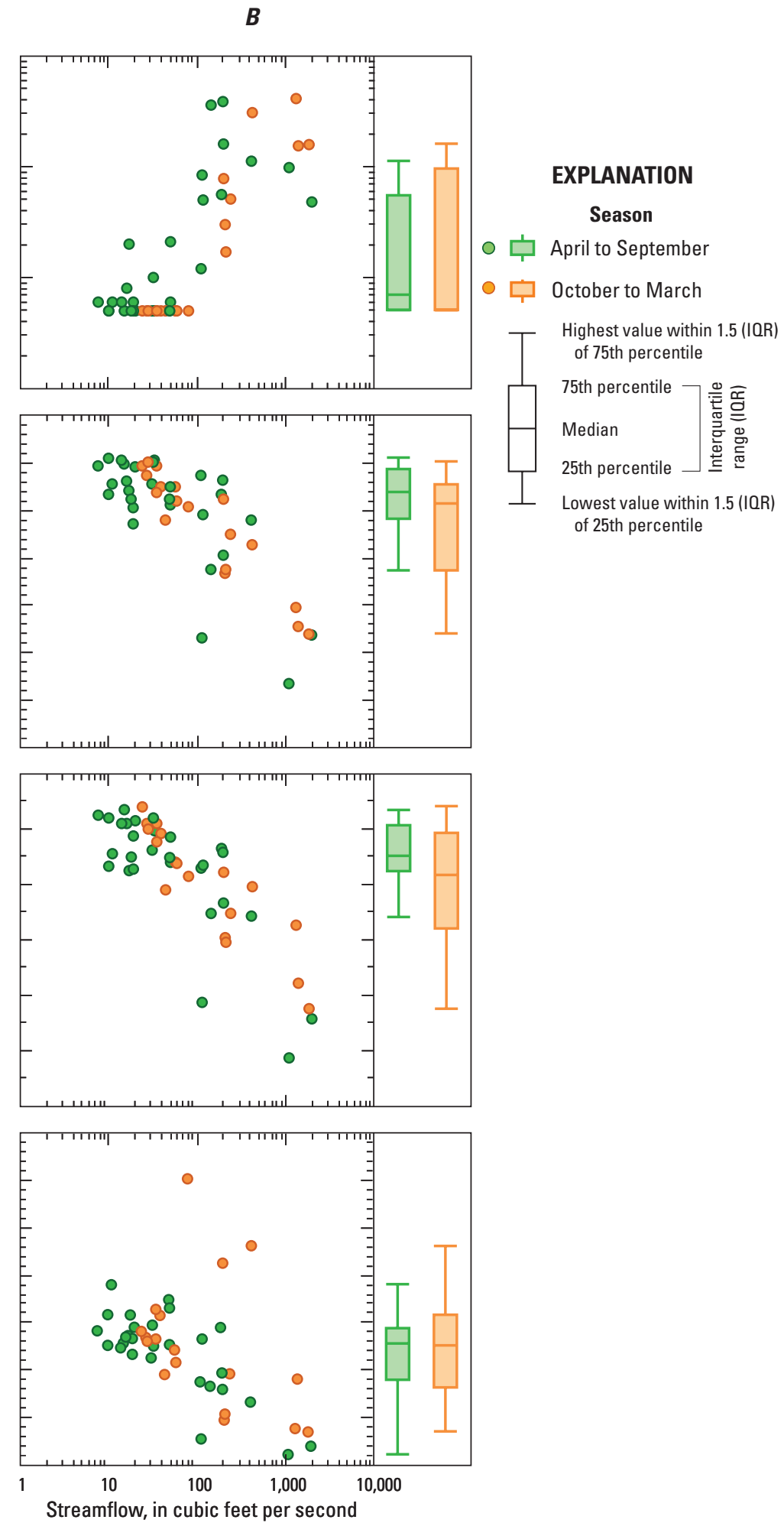

Figure 83. Concentration-discharge data for discrete samples from the Conewago Creek $(A)$ Bellaire and $(B)$ Falmouth streamgages by warm (April to September) and cool (October to March) seasons.-Continued 

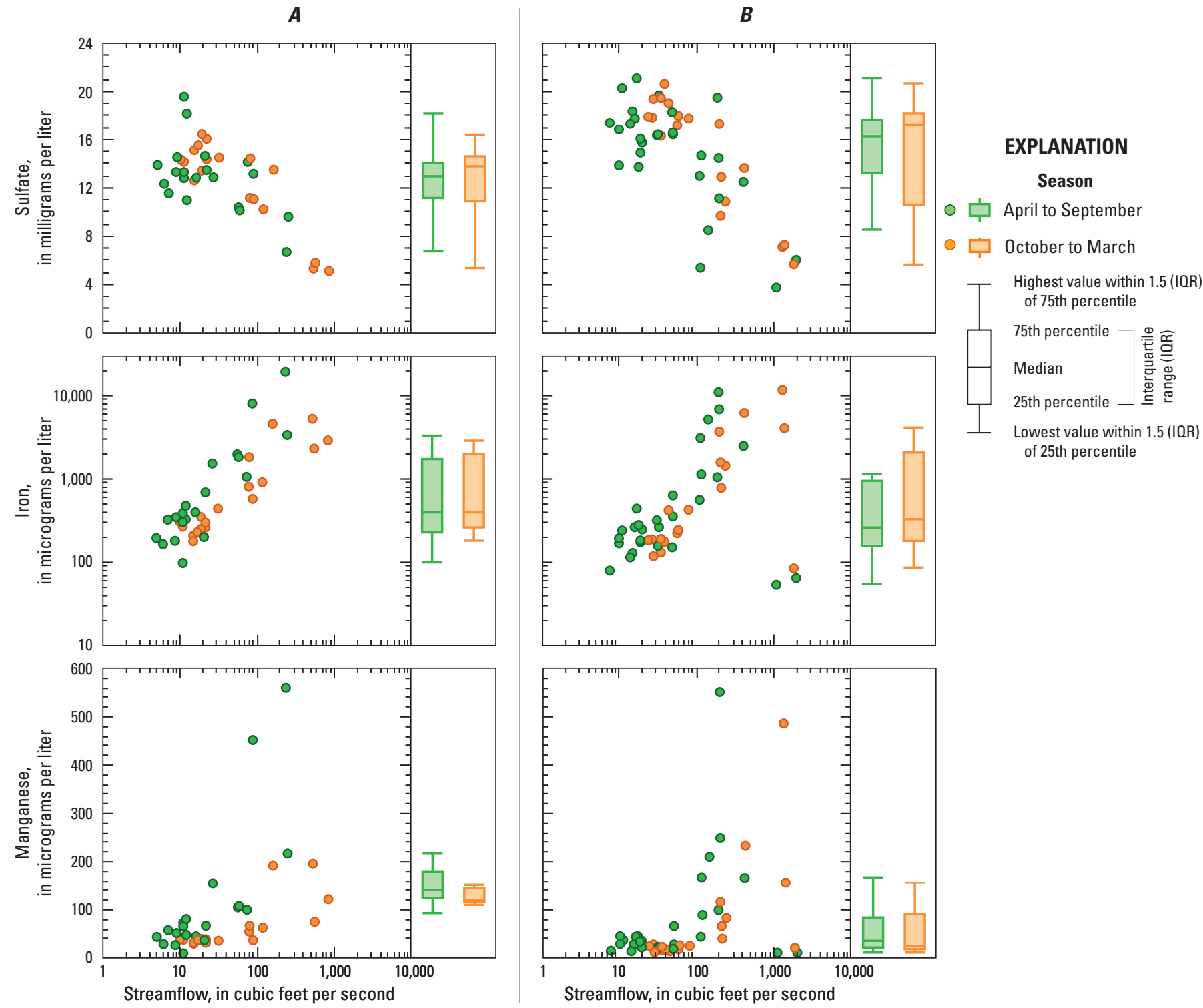

Figure 83. Concentration-discharge data for discrete samples from the Conewago Creek $(A)$ Bellaire and (B) Falmouth streamgages by warm (April to September) and cool (October to March) seasons.-Continued 

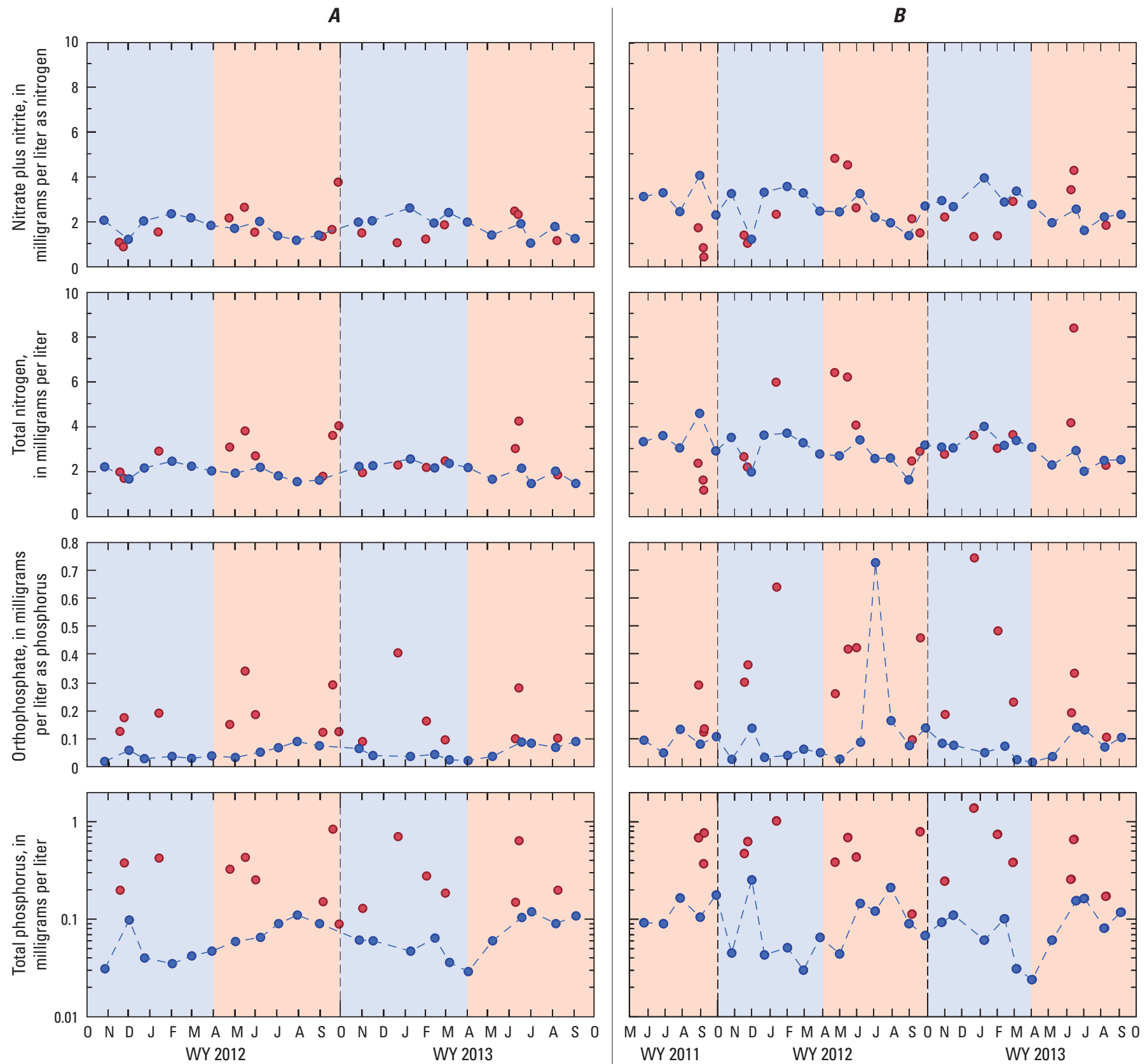

EXPLANATION

$\begin{array}{lc}\text { Season } & \text { Hydologic conditions } \\ \text { "Warm" (April to September) } & --- \text { Routine sample } \\ \text { "Cool" (October to March) } & \bullet \quad \text { Storm sample } \\ & \text { WY Water year }\end{array}$

Figure 84. Concentrations of various constituents in discrete samples from the Conewago Creek $(A) \operatorname{Bellaire}$ and $(B)$ Falmouth streamgages. 


\section{Surrogate Models for the Computation of Sediment and Nutrient Loads}

The discrete and continuous water-quality data were subsequently analyzed to explore the development of surrogate regression models to predict total sediment concentration (TSC) and TN and TP concentrations. The development of these surrogate models is critical to the computation of constituent loads and an improved understanding of the watershed function.

\section{Model Development}

Sediment samples from Conewago Creek were analyzed at two different labs depending on flow conditions. During low to medium flows, the sediment samples were analyzed for total suspended solids (TSS) at the PADEP laboratory. Samples collected during high flows were analyzed for SSC at the USGS Sediment Laboratory in Kentucky. Previous studies have examined the bias between TSS and SSC samples collected concurrently and concluded that total sediment load is under-predicted based on TSS alone (Gray and others, 2000). The TSS and SSC records were combined (concatenated) into a new variable, referred to as total sediment concentration (TSC) for load estimation.

Standard USGS multiple linear regression methods were used to develop the best surrogate models (Helsel and Hirsch, 2002; Jastram and others, 2009; Rasmussen and others, 2009), and a detailed overview of the model selection process is presented in the Study Approach and Methods section. The best regression model prediction of TSC and TN and TP concentrations, as well as basic model diagnostics, is presented in table 29 . Figures 85,86 , and 87 present observed versus predicted concentrations, observed and predicted concentrations relative to flow, and residuals versus the predicted concentrations for the best TSC, TN, and TP models at the upstream and downstream sites.

Table 29. Details of the top-ranked suspended sediment, total nitrogen, and total phosphorus concentration estimation models for the Conewago Creek Bellaire and Falmouth streamgages.

[dtime, decimal time; $<$, less than; ln, natural logarithm]

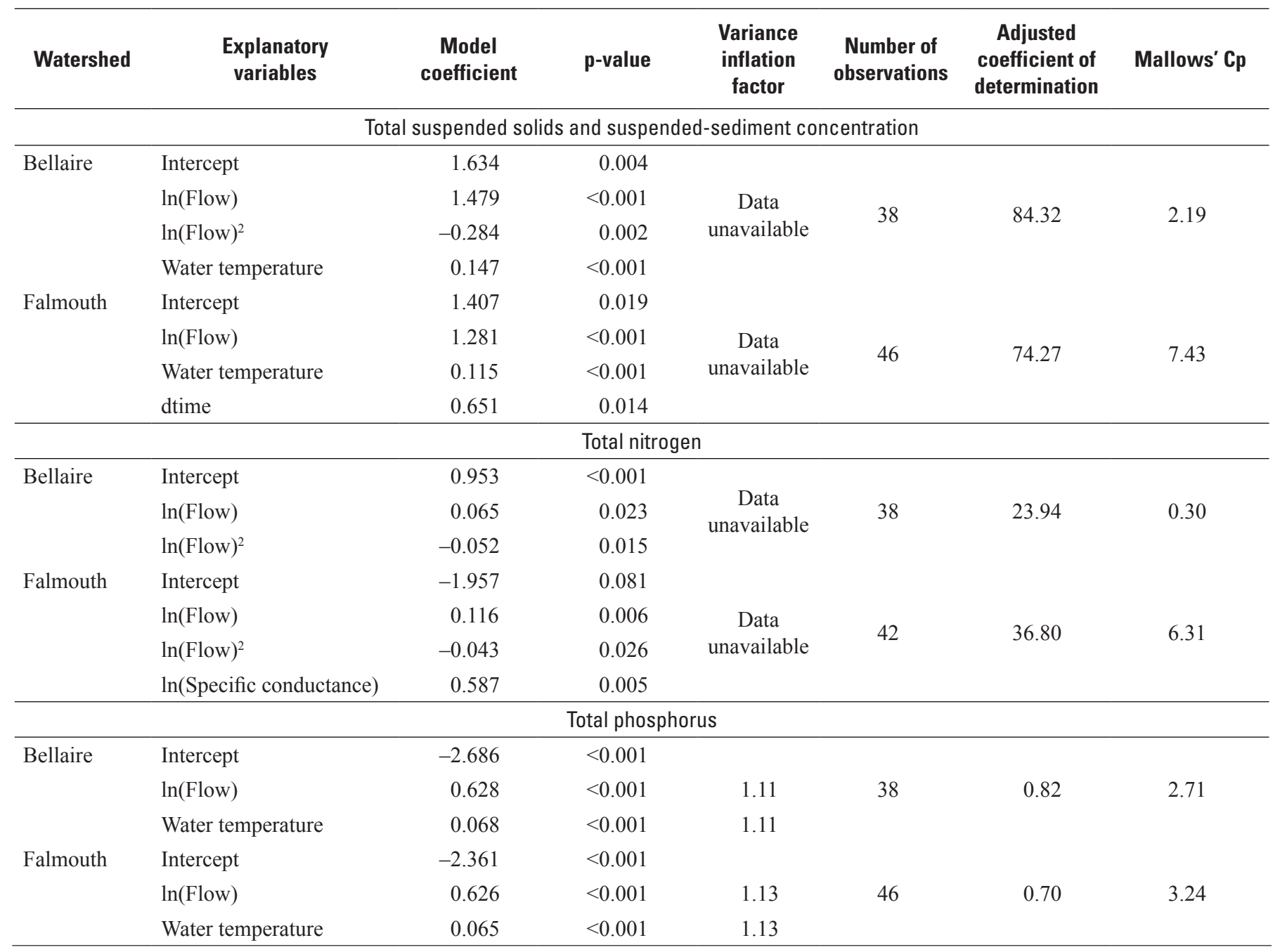



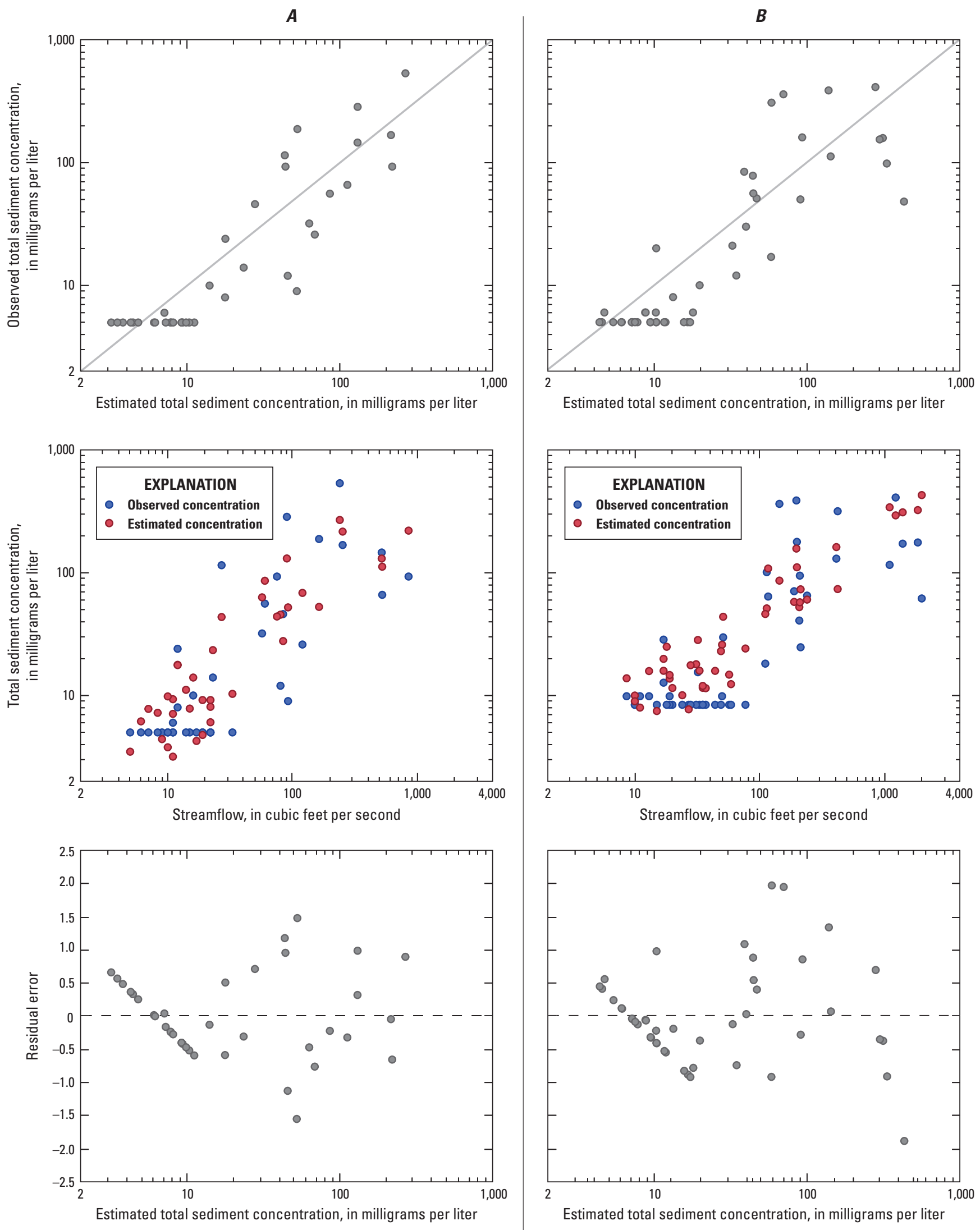

Figure 85. Observed and estimated values from the best suspended-sediment surrogate models for the Conewago Creek $(A)$ Bellaire and $(B)$ Falmouth streamgages, the observed and estimated values along with streamflow, and the residual plot of model predictions. 

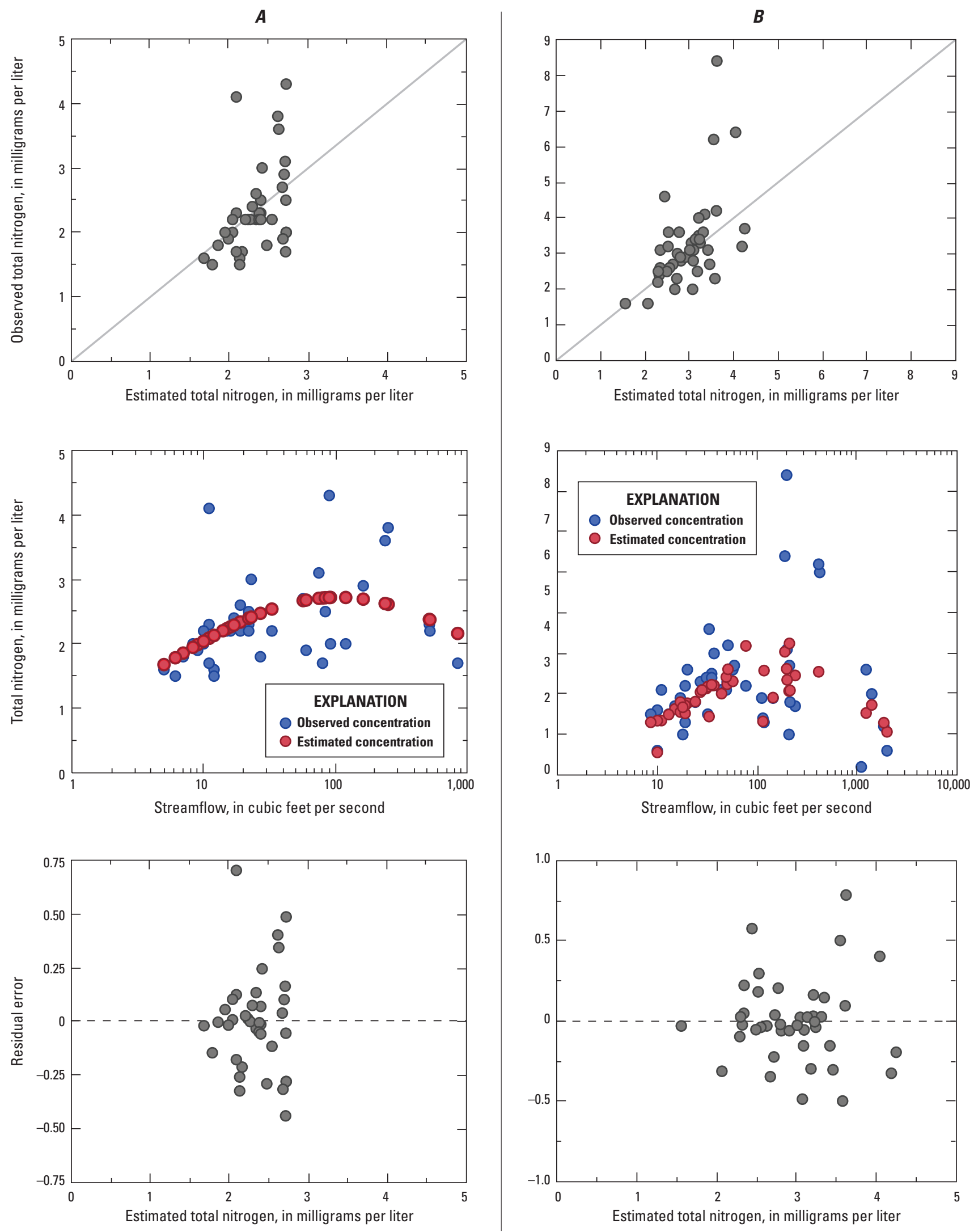

Figure 86. Observed and estimated values from the best total nitrogen surrogate models for the Conewago Creek $(A)$ Bellaire and $(B)$ Falmouth streamgages, the observed and estimated values along with streamflow, and the residual plot of model predictions. 

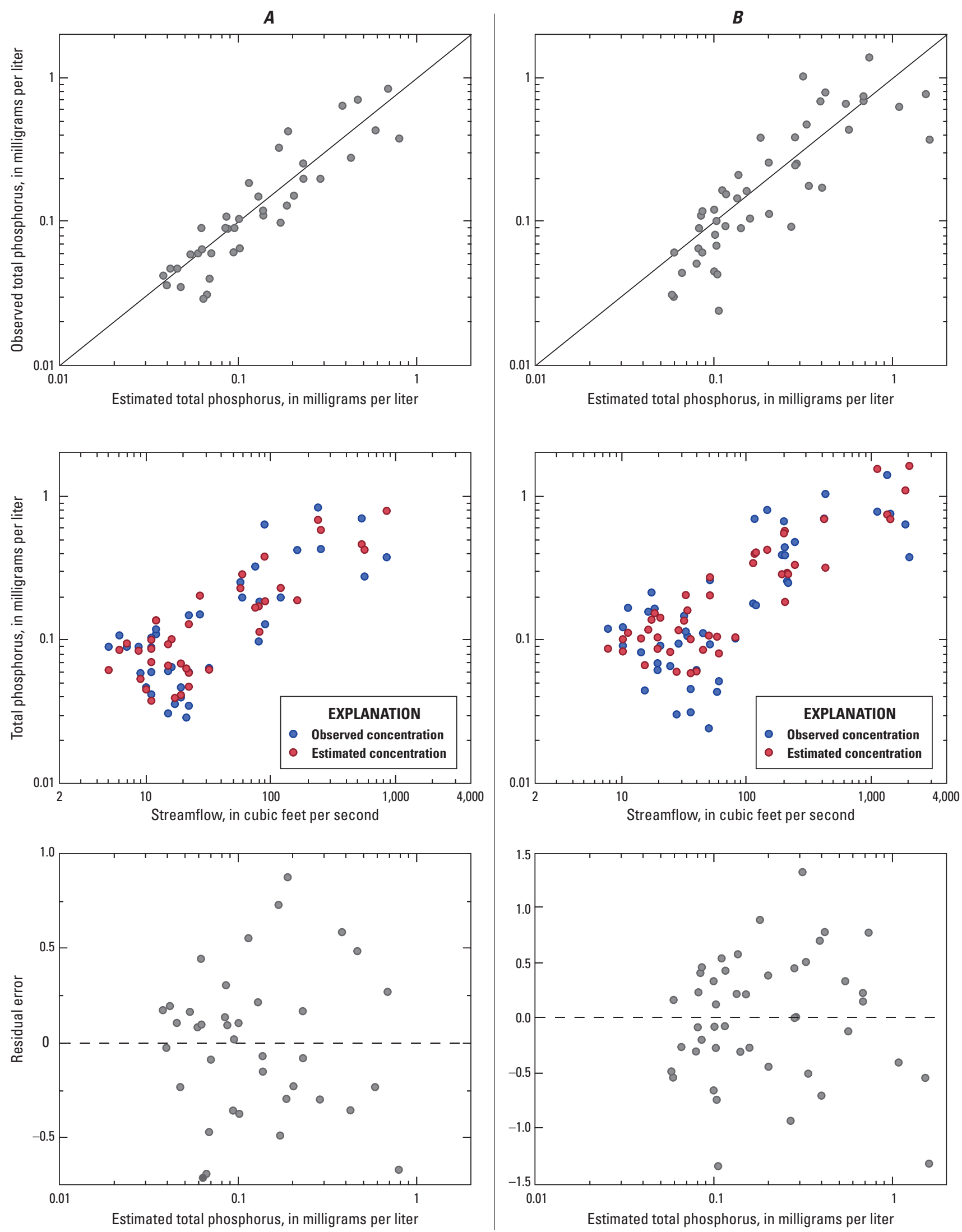

Figure 87. Observed and estimated values from the best total phosphorus surrogate models for the Conewago Creek $(A)$ Bellaire and $(B)$ Falmouth streamgages, the observed and estimated values along with streamflow, and the residual plot of model predictions. 
The best sediment models included flow and water temperature at the upstream site, and flow, water temperature, and time at the downstream site. At the downstream site (Falmouth location), the model diagnostics indicate the possibility of slight overprediction of load at the highest flows (predicted values higher than observed values). Continued sampling and the addition of continuous turbidity data could improve this regression model. For the prediction of TN, the Bellaire model contains only flow and flow-squared terms, while the Falmouth model includes flow, flow squared and specific conductance. Both models explained relatively little of the variability in the TN concentrations. The deployment of a continuous nitrate monitor could help improve TN predictions. The best prediction models for TP concentrations included flow and water temperature and accounted for at least 70 percent of the variability in TP at each of the sites.

\section{Interpretation of the Computed Loads}

After developing surrogate models for estimating concentrations of total sediment, TN, and TP, water-year loads of these constituents were computed using the record of continuous flow (from the streamgages) and predicted water quality (from the regression equations presented above). Methods for the replacement of missing records are provided in the Development of Surrogate Water-Quality Models and Computation of Loads section of this report. The USGS software program LOADEST was used for daily load computations with estimation of error between computed and predicted loads.

The water-year total sediment loads are presented in figure 88, along with the total annual flow. The 2013 Bellaire sediment load was approximately 2,800 tons, while the Falmouth sediment loads were 9,900 tons in 2012 and 18,900 tons in 2013. Generally, the total mass of sediment transported is highly related to the total flow in a given year; however, factors in addition to total annual flow (such as rainfall intensity, duration, season, and antecedent conditions) can affect the amount of sediment transported. For example, the accumulated total flows in 2012 and 2013 at the downstream location are nearly the same; however, the 2013 annual sediment load is nearly double that of 2012 .

Sediment loadings within Conewago Creek are highly episodic, with the majority of the sediment transported in only a few events (figs. 89 and 90). In 2013, at the upstream location, approximately 60 percent of the sediment load was transported in three high-flow events (fig. 89), and the downstream location had approximately 80 percent transported in the same three high-flow events (fig. 90). Based on the 2013 data, approximately 15 percent of the sediment load originated from above the upstream monitoring location, which composes approximately 43 percent of the monitored Conewago Creek watershed. Conversely, 85 percent of sediment load was transported from the remaining 57 percent of the downstream Conewago Creek watershed (fig. 90). This disproportionate amount of transported sediment is likely caused by the land-use distribution of more forest land in the upper headwaters and more agricultural and mixed land uses in the lower part of the watershed (fig. 4A).

Annual TN loads were not estimated because of poor model performance and results of model diagnostics. Additional discrete monitoring in conjunction with a continuous nitrate sensor (a surrogate for $\mathrm{TN}$ ), could produce a better model and more robust predictions.

The water-year TP loads are presented in figure 91, along with the total flow for each water year. Note that 2012 was a partial monitoring year at the upstream site. As reported earlier, the annual flows in 2012 and 2013 were nearly the same; however, unlike total sediment loads, the TP loads were only slightly higher in 2013 with an additional 3,200 pounds transported. A total of 51,500 pounds was transported past the downstream monitoring location during the 2013 water year (fig. 91). The cumulative loading plot for TP is similar to that of sediment, with the three largest storm events in 2013 transporting the majority ( 75 percent) of the TP load (fig. 92 and 93). Based on the 2013 data, approximately 25 percent of the TP load originated from above the upstream monitoring location. Similar to the total sediment loads, a disproportionate amount of TP load (75 percent of TP load; 57 percent of the watershed) was mobilized between the upstream and downstream monitoring locations.

In summary, the sediment and TP loadings were largely driven by storm events, but base-flow contributions were still substantial. More management actions targeting minimizing effects of the high-flow events by keeping more water on the landscape (terracing) and more runoff-control structures, in addition to streambank stabilization, could help reduce sediment and TP loads. 

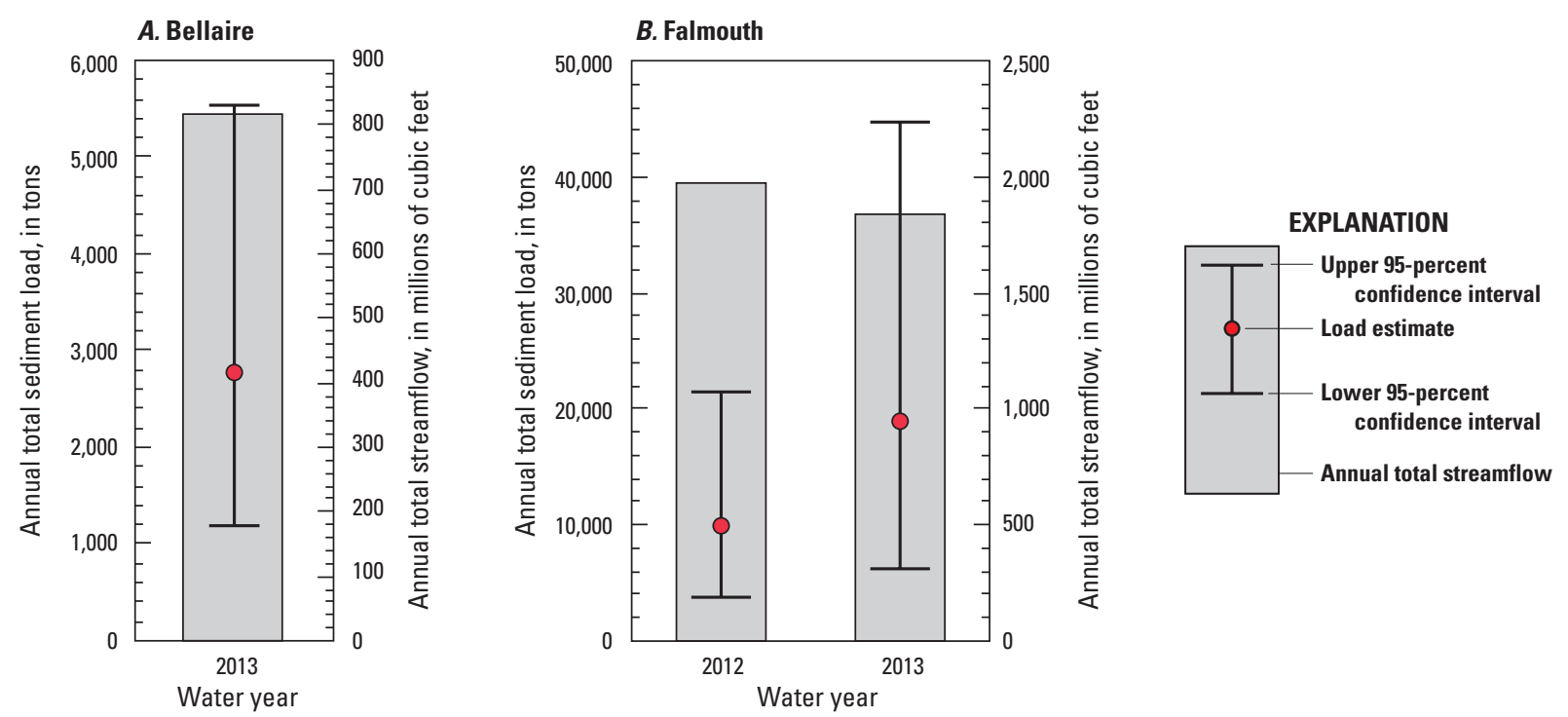

Figure 88. Total sediment load and total annual streamflow at the Conewago Creek $(A)$ Bellaire and $(B)$ Falmouth streamgages for water years 2012 and 2013.
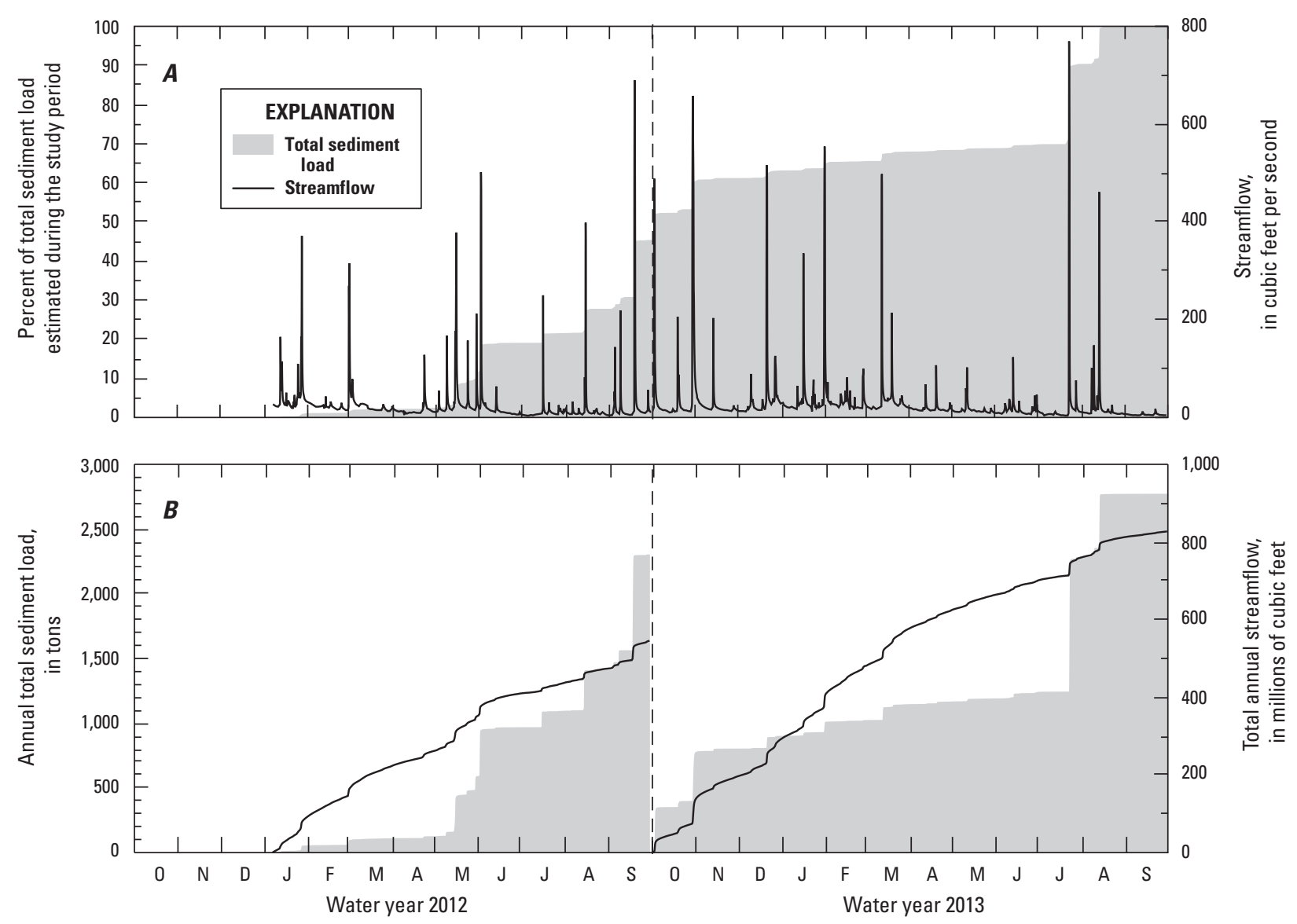

Figure 89. Total sediment load at the Conewago Creek Bellaire streamgage for water years 2012 and 2013 along with $(A)$ the percentage of load accumulated and the hydrograph during the period of study and $(B)$ the accumulation of load and streamflow in each water year. 


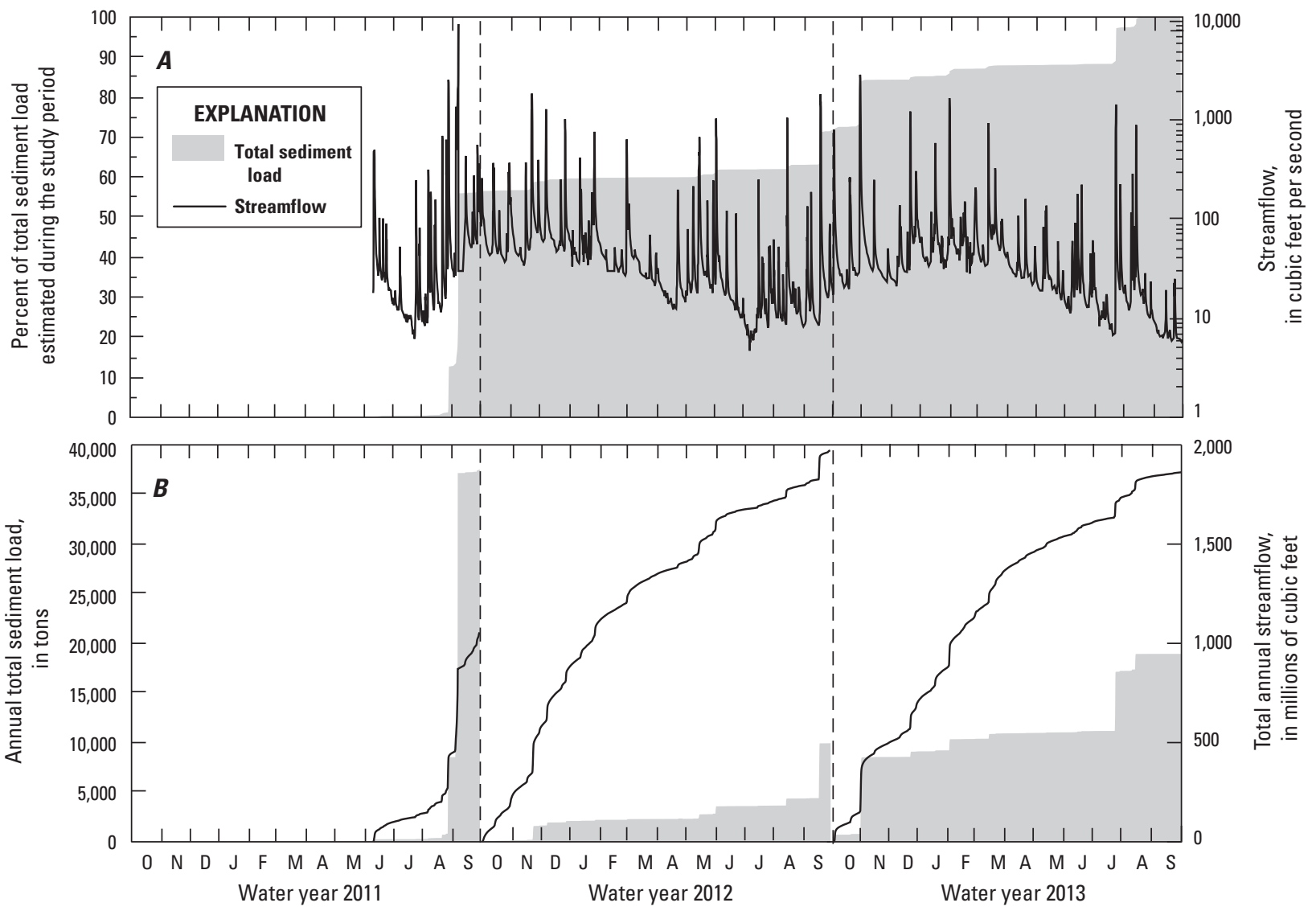

Figure 90. Total sediment load at the Conewago Creek Falmouth streamgage for water years 2011 through 2013 along with $(A)$ the percentage of load accumulated and the hydrograph during the period of study and $(B)$ the accumulation of load and streamflow in each water year. 

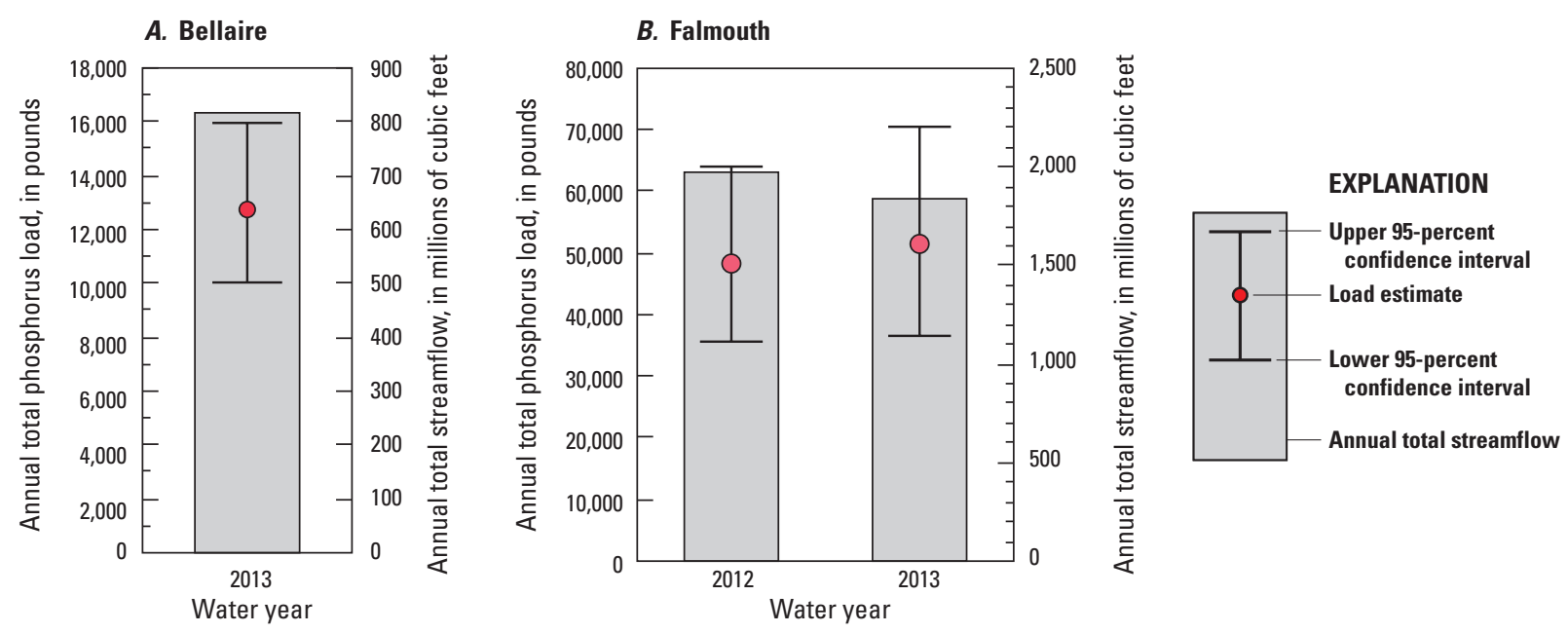

Figure 91. Total phosphorus load and total annual streamflow at the Conewago Creek $(A)$ Bellaire and $(B)$ Falmouth streamgages for the 2012 and 2013 water years.

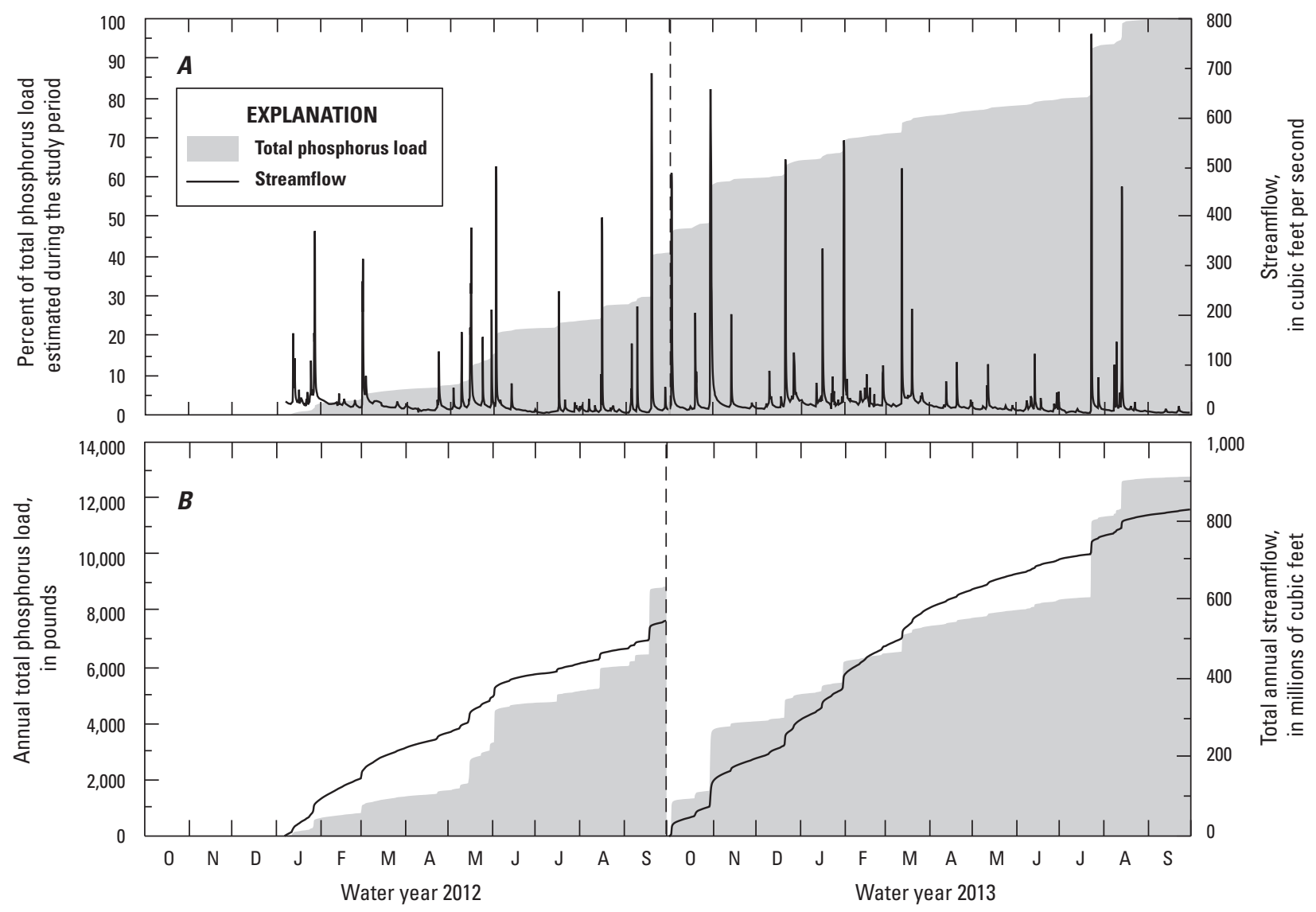

Figure 92. Total phosphorus load at the Conewago Creek Bellaire streamgage for water years 2012 and 2013 along with $(A)$ the percentage of load accumulated and the hydrograph during the period of study and $(B)$ the accumulation of load and streamflow in each water year. 


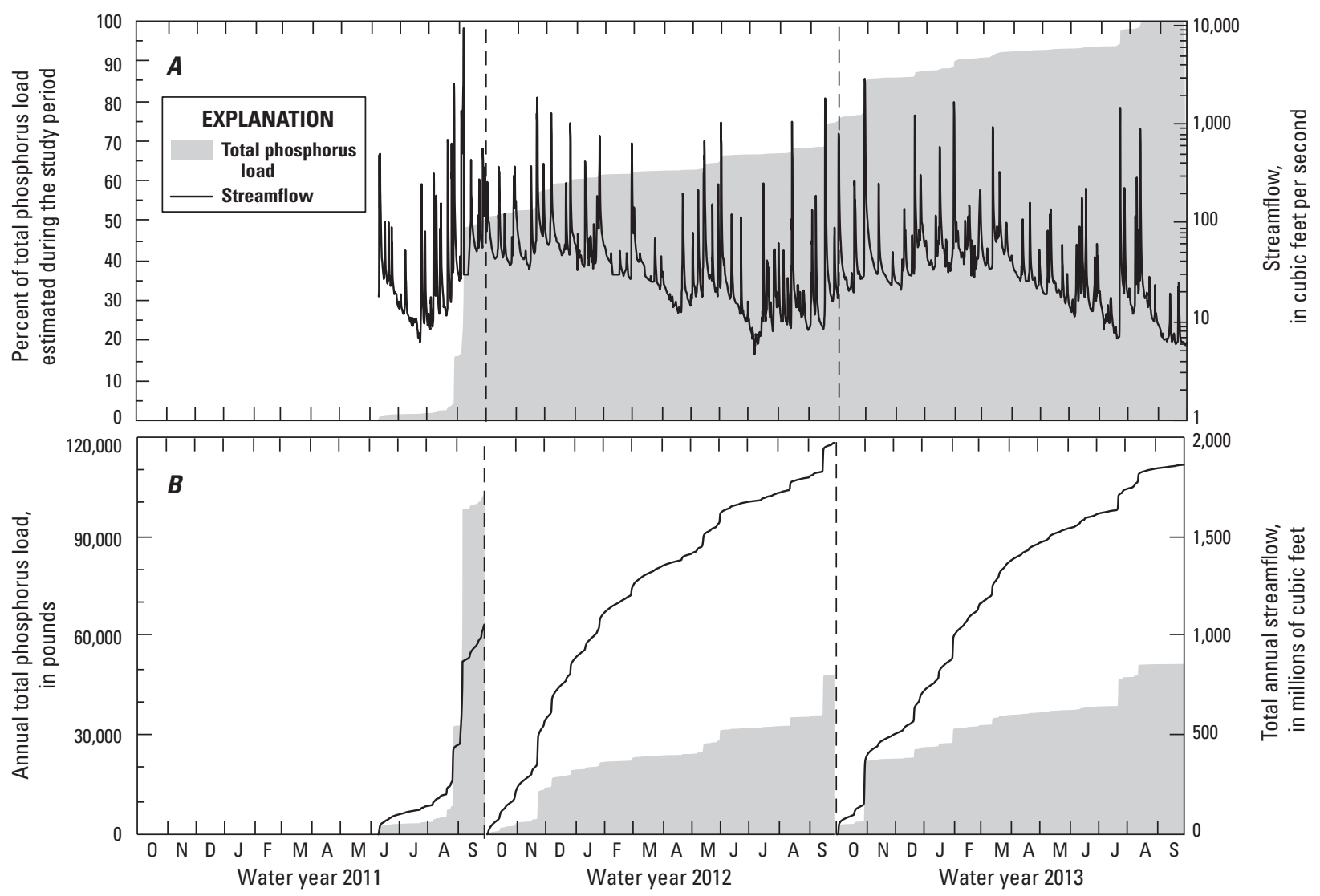

Figure 93. Total phosphorus load at the Conewago Creek Falmouth streamgage for water years 2011 through 2013 along with $(A)$ the percentage of load accumulated and the hydrograph during the period of study and $(B)$ the accumulation of load and streamflow in each water year. 


\section{Spatial Patterns in Water Quality}

In addition to routine sample collection at the two monitoring locations, 14 locations (including the 2 monitoring locations) were sampled during 1 high-flow synoptic event in Conewago Creek (fig. 94). The purpose of the sampling was to provide information (a snapshot) of the chemical and hydrologic spatial variability within the watershed, as well as provide information related to sources and transport processes for nutrients and sediments. Sites were selected to isolate various tributaries and stream reaches. Each of the major subwatersheds had at least one location (many had two), and four locations were on the mainstem of Conewago Creek. The high-flow synoptic sampling was conducted on May 15, 2012, following a watershed-wide 1.5 - to 2 -inch rainfall event. All sites were sampled within a 3-hour period. At each location, field measurements were recorded and discharge was measured at locations where conditions were safe. At four locations, discharge was estimated by using drainage ratios. Significant variability in discharge and in nitrogen, phosphorus, and sediment concentrations were observed in the Conewago Creek watershed during the high-flow synoptic sampling (table 30). Discharges ranged from 11 to $412 \mathrm{ft}^{3} / \mathrm{s}$, and not surprisingly, were highly dependent on drainage area. TN concentrations ranged from 2.16 to $11.7 \mathrm{mg} / \mathrm{L}$ (the highest observed in Conewago Creek during the study period), TP concentrations ranged from 0.11 to $1.59 \mathrm{mg} / \mathrm{L}$, and SSC ranged from 57 to $250 \mathrm{mg} / \mathrm{L}$.

Mean nutrient concentrations were lower (TN $3.34 \mathrm{mg} / \mathrm{L}$ and TP $0.37 \mathrm{mg} / \mathrm{L}$ ) for sites that drain the mainly forested tributaries (sites 1, 2, and 3) above the upstream monitoring location (site 4) and were higher downstream (TN $6.0 \mathrm{mg} / \mathrm{L}$ and TP $0.78 \mathrm{mg} / \mathrm{L}$ ). Average SSCs were about equal above and below the upstream monitoring locations. Expectations were that sediment concentrations would be higher downstream, similar to the TP concentration patterns. The lower than expected sediment concentrations could have been the result of missing peak sediment concentrations on several tributaries downstream.

Differences in nutrient and sediment concentrations and loads by subwatershed for the high-flow synoptic sampling are shown in figure 94 . TN has a general pattern of increasing concentrations and loads downstream as shown by the stream-reach line color and stream-reach thickness between monitoring sites. The TN concentration at site 9 (Brills Run) was $11.7 \mathrm{mg} / \mathrm{L}$ (fig. 94A; table 30), nearly double the next highest TN concentration. The area above this site is dominated by agricultural activities (42 percent). The second highest TN concentration occurred at site 10 (Lynch Run), which coincides with dense multiple land uses. A trailer park, residential homes, and small businesses dominate the western side of Lynch Run, and agriculture and a golf course dominate the eastern side of Lynch Run. Based on the daily flow, approximately 14,500 pounds of TN were discharged from the Conewago Creek watershed on May 15, 2012 (fig. 94A).

The pattern of increasing TP concentrations and load patterns downstream is similar to that exhibited by TN (fig. 94B). The lowest phosphorus concentrations were generally observed at sites with greater percentages of forested land. Based on the daily flow, approximately 1,500 pounds of TP were discharged from the Conewago Creek watershed on May 15, 2012 (fig. 94B).

Sediment concentration and load patterns differed from the TP patterns (fig. 94C). Out of the five sites with the highest sediment concentrations, only one also had one of the highest TP concentrations (site 5A). Because TP is bound to sediment, a closer correspondence in spatial patterns was expected. The highest concentrations of sediment did occur in the agricultural basins. Figure 94 does suggest some sediment deposition in the lowest area of the basin based on the measured load at site 12 . Based on the daily flow, approximately 124 tons of sediment were discharged from the Conewago Creek watershed (site 12) on May 15, 2012 (fig. 94C). 

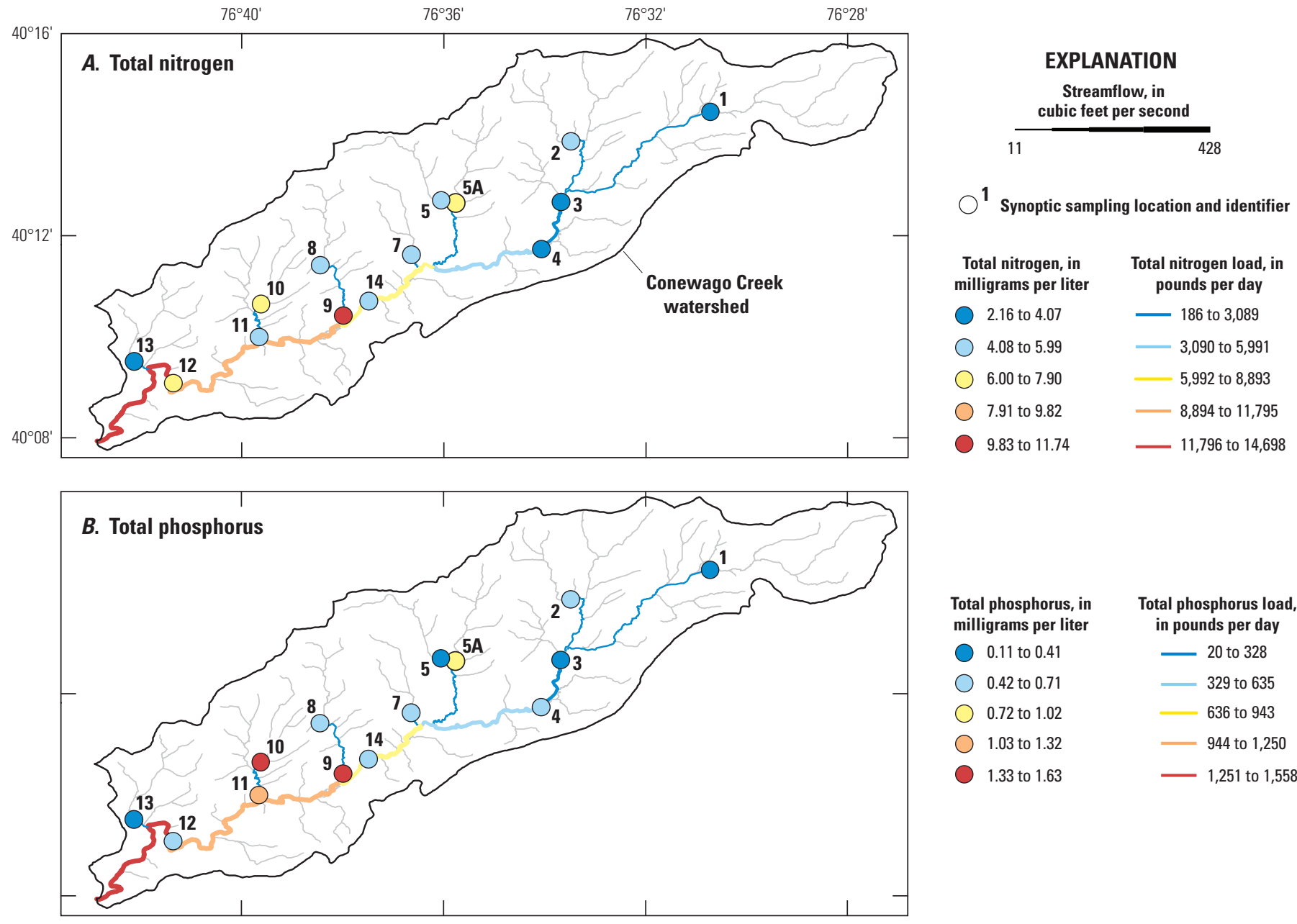

Total phosphorus, in milligrams per liter

Total phosphorus load,

milligrams per

in pounds per day

0.42 to 0.71

— 20 to 328

0.72 to 1.02

329 to 635

1.03 to 1.32

636 to 943

1.33 to 1.63

— 944 to 1,250

1,251 to 1,558

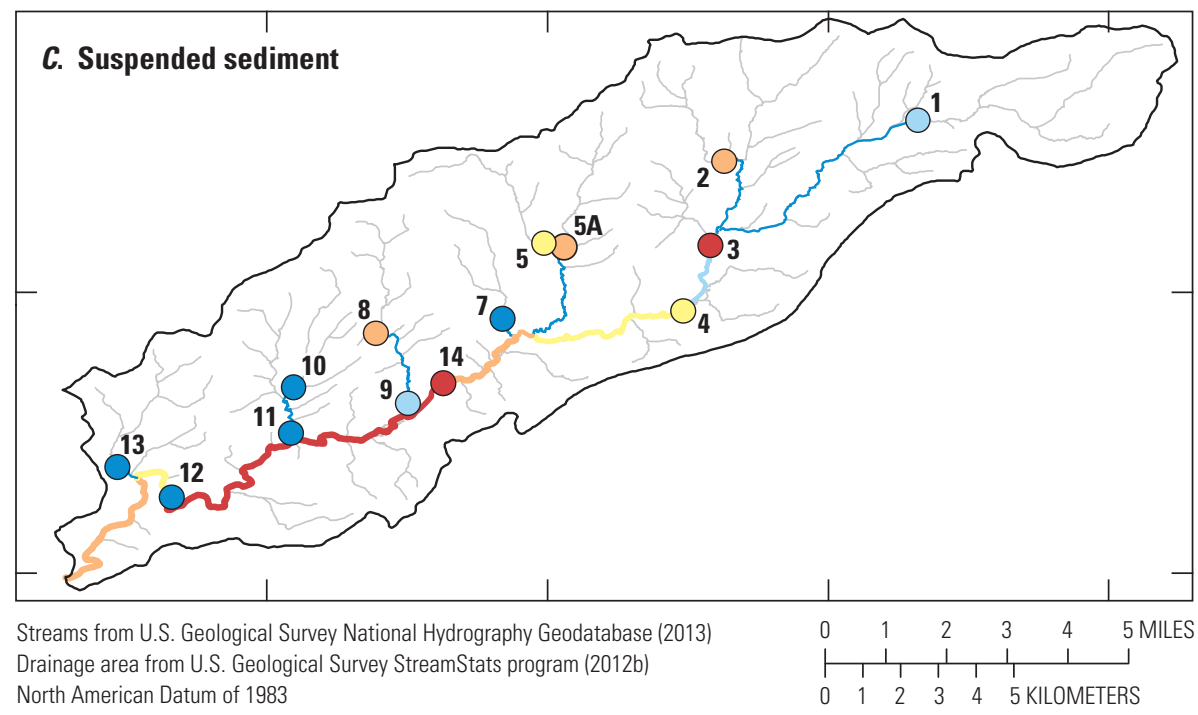

Suspended sediment, in milligrams per liter

Suspended-sediment load, in tons per day

57 to $96 \quad 3$ to 44

○ 97 to 134

45 to 85

135 to 173

86 to 126

- 174 to 211

127 to 167

212 to 250

168 to 209

Figure 94. Instantaneous $(A)$ total nitrogen, $(B)$ total phosphorus, and $(C)$ suspended-sediment concentrations and loads at the Conewago Creek watershed monitoring locations, May 15, 2012. 
Table 30. Station information, sampling time, and water-quality results from the high-flow synoptic samples collected in the Conewago Creek watershed.

[USGS, U.S. Geological Survey; $\mathrm{ft}^{3} / \mathrm{s}$, cubic foot per second; mg/L, milligram per liter; mi² ${ }^{2}$ square mile; SSC, suspended-sediment concentration]

\begin{tabular}{|c|c|c|c|c|c|c|c|c|c|c|}
\hline Station ID & $\begin{array}{l}\text { USGS } \\
\text { local } \\
\text { ID }\end{array}$ & USGS site name & $\begin{array}{l}\text { Drainage } \\
\text { area } \\
\left(\mathrm{mi}^{2}\right)\end{array}$ & $\begin{array}{l}\text { Mainstem or } \\
\text { subwatershed }\end{array}$ & Time & $\begin{array}{l}\text { Discharge } \\
\qquad\left(\mathrm{ft}^{3} / \mathrm{s}\right)\end{array}$ & $\begin{array}{c}\text { Total } \\
\text { nitrogen } \\
\text { (mg/L) }\end{array}$ & $\begin{array}{l}\text { Nitrate-N } \\
\text { (mg/L) }\end{array}$ & $\begin{array}{c}\text { Total } \\
\text { phosphorus } \\
\text { (mg/L) }\end{array}$ & $\begin{array}{c}\text { SSC } \\
\text { (mg/L) }\end{array}$ \\
\hline 01573680 & 2 & $\begin{array}{l}\text { Unnamed tributary to Little } \\
\text { Conewago Creek near } \\
\text { Upper Lawn, PA }\end{array}$ & 5.15 & $\begin{array}{l}\text { Upper } \\
\text { Conewago } \\
\text { Creek }\end{array}$ & $9: 45$ & 29 & 4.38 & 2.76 & 0.60 & 193 \\
\hline 01573690 & 3 & $\begin{array}{l}\text { Conewago Creek near } \\
\text { Lawn, PA }\end{array}$ & 18.1 & Mainstem & $10: 50$ & 119 & 3.47 & 2.19 & 0.40 & 225 \\
\hline 01573695 & 4 & $\begin{array}{l}\text { Conewago Cr near Bel- } \\
\text { laire, PA }\end{array}$ & 20.5 & Mainstem & $11: 30$ & 252 & 3.83 & 2.65 & 0.43 & 168 \\
\hline 01573702 & 5 & $\begin{array}{l}\text { Hoffer Creek near Bellaire, } \\
\text { PA }\end{array}$ & 2.25 & Hoffer Run & $12: 15$ & 22 & 5.59 & 4.27 & 0.36 & 158 \\
\hline 01573705 & 14 & $\begin{array}{l}\text { Conewago } \mathrm{Ck} \text { at Aberdeen } \\
\text { Mills, } \mathrm{Pa}\end{array}$ & 33 & Mainstem & $8: 30$ & 280 & 4.69 & 3.82 & 0.48 & 250 \\
\hline 01573706 & 8 & $\begin{array}{l}\text { Brills Run near Deodate, } \\
\text { PA }\end{array}$ & 2.32 & Brills Run & $9: 50$ & 32 & 5.00 & 3.15 & 0.57 & 199 \\
\hline 01573707 & 9 & $\begin{array}{l}\text { Brills Run near Elizabeth- } \\
\text { town, PA }\end{array}$ & 3.61 & Brills Run & $9: 10$ & 50 & 11.70 & 9.57 & 1.59 & 126 \\
\hline 01573708 & 10 & $\begin{array}{l}\text { Lynch Run at Londonderry } \\
\text { Township, PA }\end{array}$ & 1.58 & Lynch Run & $10: 45$ & 24 & 7.25 & 4.83 & 1.42 & 96 \\
\hline
\end{tabular}




\section{Characterization of Nitrogen Sources}

Knowledge of the primary nitrogen sources in the Conewago Creek watershed is critical for making informed watershed-management decisions regarding BMP implementation. To explore the likely sources of the nitrogen observed in Conewago Creek, two different approaches were used: (1) an analysis of land-use and agricultural census data, and (2) SPARROW model results. A better understanding of nitrogen sources in Conewago Creek might make it easier to more effectively target the locations of agricultural conservation practices to provide the highest return on investment.

Compiled agricultural practices and land-use data can provide evidence of the nitrogen sources within a given region. While an analysis of agricultural practices and land-use data cannot provide detailed information regarding nitrogen storage and potential transport to groundwater or surface water, the analysis can provide information about the sources of material that are available for transport. Because most of the available datasets related to agricultural practices were developed at the county scale, the land-use nitrogen-source analysis was also performed at the county scale. Results of a county-based source analysis are only relevant to a given watershed of interest (Conewago Creek) if land uses are similar in the basin of interest and the county. The NLCD land use for Conewago Creek was compared to the land use of Lebanon and Dauphin Counties (fig. 95). As expected, the Conewago Creek watershed has a mix of both counties' land uses, with some percentages of categories closely matching those of each county. For example, the category of cultivated crop is more indicative of Lebanon County, and the category of forest is more indicative of Dauphin County. This corresponds to the geographical locations of each county. Areas above the Conewago Creek upstream monitoring location are dominated by forest and are nearly all in Lebanon County, but the cultivated areas are located most often in Dauphin County.
The land-use-derived sources of nitrogen applied to the land surface were similar in Dauphin and Lebanon Counties from 1987 through approximately 2006 (fig. 96A; results for 2002 displayed in fig. 96B). Within both counties, manure sources of nitrogen dominate, followed by a mixture of other sources, including agricultural fertilizer usage, atmospheric deposition, sanitary sewage, septic waste, and nonfarm fertilizer. While these land-use-derived source data provide information on the relative magnitude of the nitrogen inputs on the landscape, the data do not provide information on the amount routed to the stream system.

Watershed-scale nitrogen sources for Conewago Creek were further evaluated by using the output from the SPARROW model with parameters derived for the Chesapeake Bay watershed (Ator and others, 2011). The SPARROW model's relative sources of nitrogen input and output source data are shown in figure 97. The output represents the percentage of the total nitrogen reaching the stream, by source. Within the Conewago Creek watershed, the primary sources of in-stream nitrogen are from fertilizer and fixation, with lesser contributions from manure, atmospheric deposition, and urban sources (fig. 97). These results are in broad agreement with the county land-use data that indicated agricultural sources are dominant, followed by atmospheric and urban sources. Similar to observations from the Smith Creek watershed, as watershed inputs were converted to fractions of $\mathrm{N}$ sources contributing to the TN export load of the stream, SPARROW model results indicated that $\mathrm{N}$ from manure was preferentially retained and $\mathrm{N}$ from fertilizer plus nitrogen fixation was preferentially exported, resulting in a factor of 4 reversal in the relative fluxes between input and export. The dominant sources of in-stream nitrogen in Conewago Creek are likely a combination of manure as well as fertilizer plus nitrogen fixation; further investigation could provide more resolution regarding the dominant nitrogen source. 


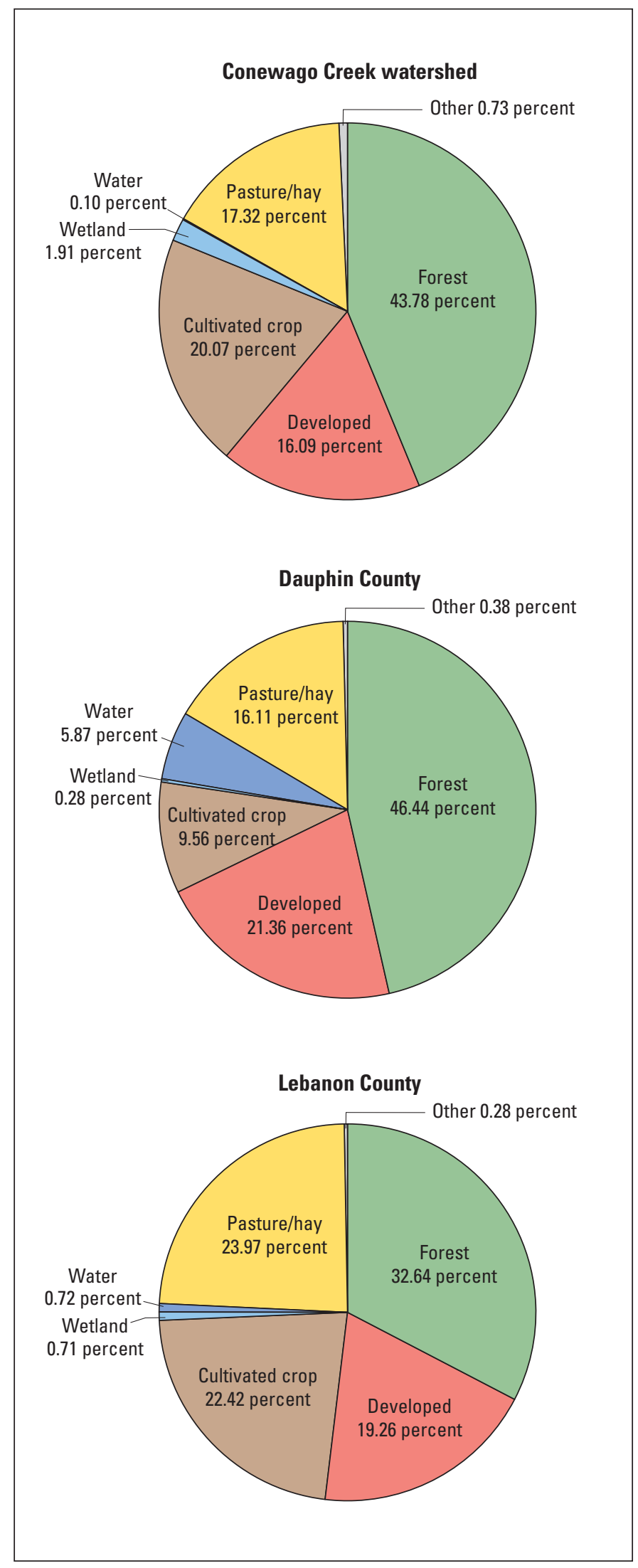

Figure 95. Percentages of land-use types from Homer and others (2015) within the Conewago Creek watershed, Dauphin County, and Lebanon County. 


\section{A. Kilograms of nitrogen per year}

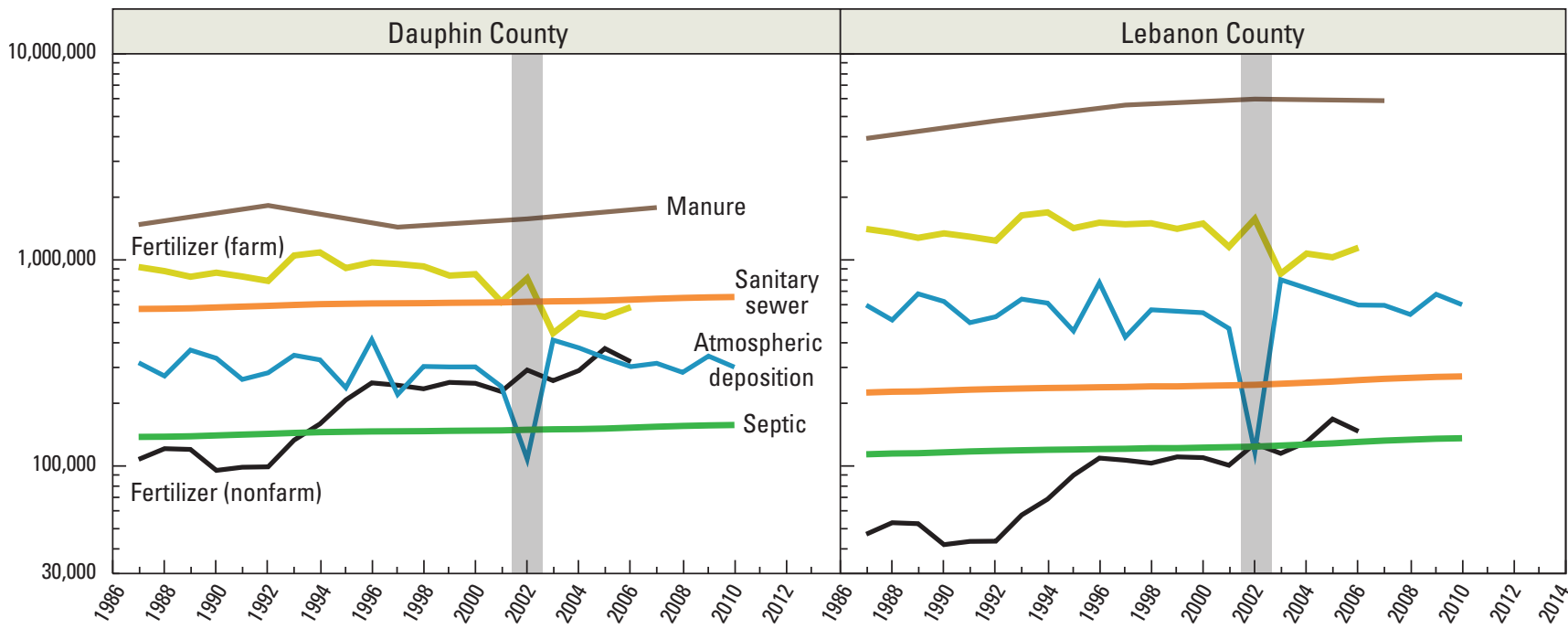

B. Nitrogen sources in 2002

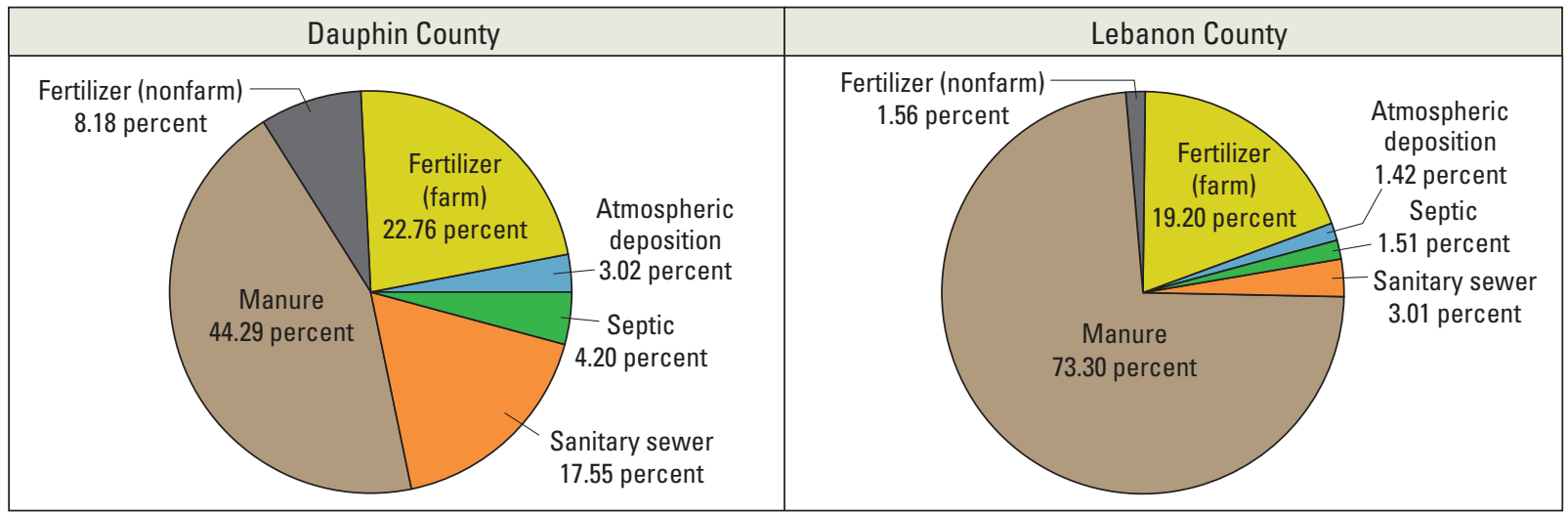

Figure 96. (A) Nitrogen sources for Dauphin County and Lebanon County from 1987 to 2012 and $(B)$ nitrogen sources in 2002 for Dauphin County and Lebanon County, Pennsylvania.
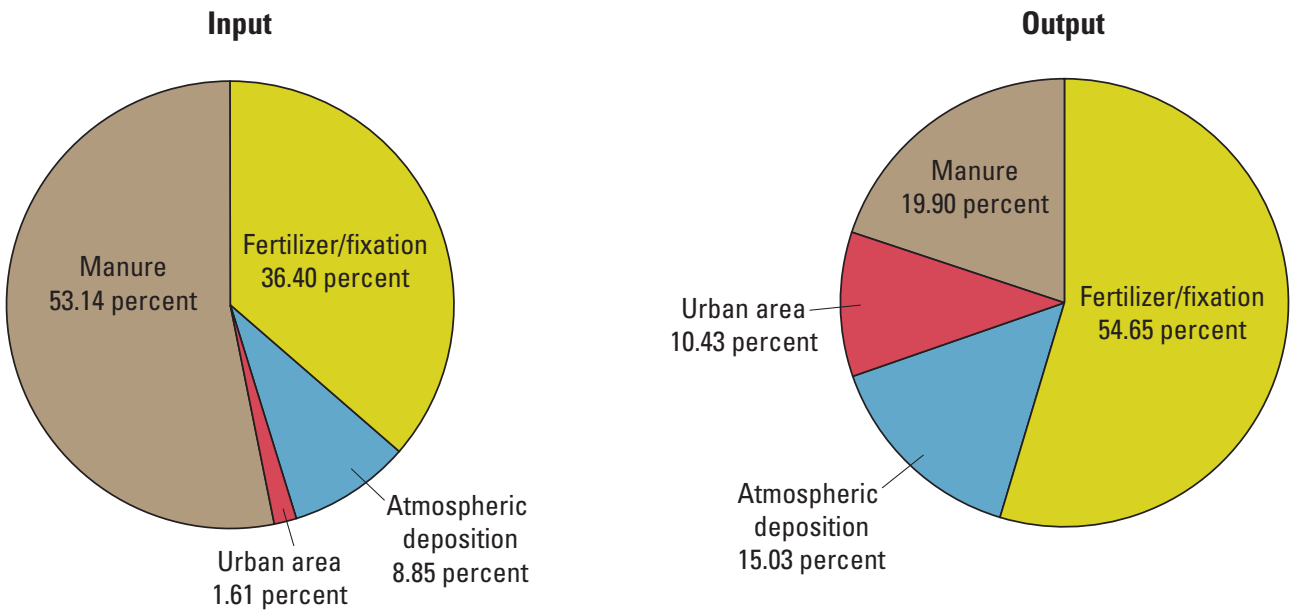

Figure 97. Percentages of input and output sources of total nitrogen for the Conewago Creek watershed as generated by the 2002 Chesapeake Bay Total Nitrogen SPARROW model. 


\section{Implementation of Conservation Practices and Water-Quality Response}

The designation of Conewago Creek as an agricultural Showcase Watershed by USDA, and the subsequent commitment of program funding to the Conewago Creek watershed resulted in increased implementation of conservation management actions from 2009 to 2013 (table 31). Several Federal and State programs have been responsible for the increased level of conservation implementation, including cost-share and technical assistance from the NRCS, the FSA, and the EPA Section 319 Nonpoint Source Management Program. Implementation efforts in the Conewago Creek watershed are indicative of what can be done through local, communitybased support for these programs. An extensive outreach effort by the Conewago Creek watershed group helped to coordinate efforts. During the last 5 years, representatives from the USDA, NRCS, and local conservation districts have visited nearlzy all of the farmers within the Conewago Creek watershed to conduct surveys, discuss farm management, and plan possible implementation of conservation practices.

In the Conewago Creek watershed, 682 USDA-compliant agricultural conservation practices were implemented between 2009 and 2013 (table 31). The USDA provided cost-share for 198 of those practices using funds from the Chesapeake Bay Watershed Initiative (131 practices), Environmental Quality Incentives Program (60 practices), and additional USDA programs (7 practices). For the remaining 484 conservation practices, the NRCS provided technical assistance but funding was provided by non-Federal programs and (or) farmers. While the total number of conservation practices implemented per year recorded in the USDA database remained relatively steady at around 100 per year, the designation of the Conewago Creek watershed as a Showcase Watershed led to yearly increases in USDA cost-shared conservation implementation, from 9 in 2009 to 47 in 2013, through the Chesapeake Bay Watershed Initiative.

The aggregated total of conservation practice implementations (new practices applied between October 2007 and September 2013) is reported by NRCS practice code in table 32 for all practices with five or more participating farmers. State-funded conservation practices sponsored by the EPA Section 319 Nonpoint Source Management Program are included in table 33. Common practices implemented included grassed waterways, residue and tillage management, nutrient management, conservation crop rotation, terraces, and construction related to water control. Crop residue and tillage management affect sediment transport from the land surface, and nutrient management and crop rotation affect nitrogen and phosphorus by controlling applications to the field and enhancing nutrient uptake. Because no historical water-quality data exist for either Conewago Creek monitoring station, trends in water quality cannot be evaluated until about 10 years of data collection is completed.

The cumulative effects of all the BMP implementation within the Conewago Creek watershed are difficult to quantify because of the many different types of BMP practices, the location of each practice, potential lag times between implementation and full functionality of the practice, and the relative efficiency of each practice/installation. Factors such as location, lifespan, number of conservation practices, and amount of land affected by the practice all influence downstream water quality. Another important factor in detecting changes in water quality related to conservation implementation is the time lag from implementation of a practice to a measurable resultant change. The lag could be years to decades depending on the constituent (nitrogen, phosphorus, or sediment) and primary delivery source (groundwater or surface water). Further water-quality monitoring could measure the overall changes in Conewago Creek nutrient and sediment transport.

Table 31. Number of USDA-compliant conservation practices implemented in water years 2007 through 2013 in the Conewago Creek watershed, aggregated by sponsoring program.

[USDA, U.S. Department of Agriculture]

\begin{tabular}{|c|c|c|c|c|c|c|c|c|}
\hline Chesapeake Bay Watershed Initiative & 0 & 0 & 3 & 28 & 28 & 34 & 38 & 131 \\
\hline Environmental Quality Incentives Program & 17 & 5 & 6 & 17 & 7 & 1 & 7 & 60 \\
\hline Conservation Stewardship Program & 0 & 0 & 0 & 0 & 3 & 0 & 2 & 5 \\
\hline Total USDA-funded practices & 17 & 7 & 9 & 45 & 38 & 35 & 47 & 198 \\
\hline Conservation Technical Assistance ${ }^{2}$ & 114 & 43 & 101 & 45 & 84 & 51 & 46 & 484 \\
\hline Total practices & 131 & 50 & 110 & 90 & 122 & 86 & 93 & 682 \\
\hline
\end{tabular}

${ }^{1}$ Conservation Reserve Program and Conservation Reserve Enhancement Program practices administered by the USDA Farm Service Agency.

${ }^{2}$ Technical assistance and verification provided by the USDA Natural Resources Conservation Service, without federal cost-share funding. 
Table 32. Implementation of USDA-compliant conservation practices within the Conewago Creek watershed for water years 2007 through 2013.

[-, values are privacy protected due to fewer than five customers participating]

\begin{tabular}{|c|c|c|c|c|c|c|c|c|c|c|c|}
\hline $\begin{array}{l}\text { Practice } \\
\text { code }^{1}\end{array}$ & Practice name & $\begin{array}{l}\text { Lifespan } \\
\text { (years) }\end{array}$ & Units & 2007 & 2008 & 2009 & 2010 & 2011 & 2012 & 2013 & $\begin{array}{c}\text { Aggregate } \\
\text { implementation: } \\
2007 \text { to } 2013^{2}\end{array}$ \\
\hline 329 & $\begin{array}{l}\text { Residue and Tillage } \\
\text { Management, No-Till }\end{array}$ & 1 & acres & - & - & - & 864 & 453 & 304 & - & 2,160 \\
\hline 620 & Underground Outlet & 20 & feet & - & - & - & - & 7,773 & - & - & 17,487 \\
\hline 590 & Nutrient Management & 1 & acres & 535 & - & - & - & 一 & - & - & 1,379 \\
\hline 600 & Terrace & 10 & feet & - & - & - & - & 19,912 & - & - & 32,377 \\
\hline 606 & Subsurface Drain & 20 & feet & - & - & - & - & 6,418 & - & - & 20,961 \\
\hline
\end{tabular}

${ }^{1}$ Practice codes from the U.S. Department of Agriculture, Natural Resources Conservation Service (2016).

${ }^{2}$ Aggregate implementation is greater than the sum of reported annual practices because privacy protections restrict the reporting of annual results for practices with fewer than five participating customers.

Table 33. Implementation of State-level conservation practices sponsored by the EPA Section 319 Nonpoint Source Management Program within the Conewago Creek watershed.

[EPA, U.S. Environmental Protection Agency]

\begin{tabular}{|c|c|c|}
\hline Practice name & Units & Amount \\
\hline Access Road & feet & 218 \\
\hline Animal Trails and Walkways & feet & 4,799 \\
\hline Diversion & acres & 424 \\
\hline Grassed Waterway & acres & 11 \\
\hline Grazing Planned Systems & acres & 29 \\
\hline Heavy Use Area Protection & acres & 0 \\
\hline Nutrient Management & acres & 660 \\
\hline Riparian Forest Buffer & acres & 18 \\
\hline Stream Channel Stabilization & feet & 4,840 \\
\hline Stream Exclusion with Grazing Land Management & feet & 6,310 \\
\hline Stream Habitat Improvement and Management & feet & 3,370 \\
\hline Streambank and Shoreline Protection & feet & 9,680 \\
\hline Terrace & feet & 12,425 \\
\hline Waste Storage Facility & number & 2 \\
\hline Wetland Restoration & acres & 16 \\
\hline
\end{tabular}


One way to develop an interim set of expectations for future improvements in water quality is with the Chesapeake Bay Program's watershed model. Evaluating model output for model scenarios with and without the implementation of BMPs provides an indication of expected improvement in the watershed. The results for the land-water segments that contain Conewago Creek are presented in figures 98 and 99 (source: Chesapeake Bay Modeling Team, written commun., 2015, based on Watershed Model 5.3.2). Despite the implementation of BMPs, these modeling scenarios project that the nitrate load has increased since 2007 and is primarily driven by increases in wastewater sources. Between 1985 and 2012, agricultural sources of nitrate have decreased in the land-river segment that contains the entire Conewago Creek watershed (fig. 99).

Results from a recent CEAP report in the Chesapeake Bay Region (U.S. Department of Agriculture, Natural Resources Conservation Service, 2013) indicate that while implementation of conservation practices across the basin is increasing, trends in other cropland management practices that were evaluated from 2003-2006 to 2011 were less encouraging.

- Annual nitrogen application increased 10 percent on cultivated cropland, including a 9-percent increase in commercial fertilizer application and a 13-percent increase in manure nitrogen application.

- Annual phosphorus application increased 6 percent on cultivated cropland, including a 5-percent increase in commercial fertilizer application and an 11-percent increase in manure nitrogen application.

- Manure application rates on cultivated cropland increased by 25 percent.

- Use of appropriate nitrogen application rate on all crops in rotation decreased 9 percent from 32 percent to 23 percent of cropped acres.

These increases in nutrient inputs are associated with increased agricultural intensification, including higher yields and greater numbers of animals. These overall CEAP trends are not specific to Conewago Creek; however, they do reflect regional trends occurring in Chesapeake Bay agricultural practices. If the increases in commercial fertilizer applications are similar in Conewago Creek from farms and other land uses, then expectations for water-quality change will be further delayed and harder to detect, despite the widespread implementation of conservation practices.

\section{Conceptual Watershed Model and Implications for Management Actions}

The intensive and extensive monitoring components combine to provide a process-level understanding of the Conewago Creek watershed. Major nutrient and sediment characterizations and transport processes are summarized below as follows:

- The geology of the watershed is a complex mix of sedimentary rocks with diabase intrusions. The more resistant sandstones are in the upper watershed, and softer, finer textured mudstones are in the middle and lower watershed. About 57 percent of the streamflow leaving the watershed is from runoff.

- Land use is strongly associated with geology. Agricultural land use dominates the areas underlain by sandstone and mudstone, and forested land use dominates the areas underlain by diabase.

- Extensive hydrologic and, to a lesser extent, seasonal variability in the water-quality conditions of Conewago Creek were observed at the upstream and downstream locations. Constituents associated with groundwater discharge (calcium, magnesium, and chloride) were generally greatest during base flow and were diluted during stormflow. During stormflow, particulate constituents (metals, total nutrients, and sediment) increased. Seasonal patterns in water temperature, specific conductance, and other water-quality constituents were observed.

- Mean concentrations of nearly every measured constituent increased from upstream to downstream, indicative of the changing land uses.

- Sediment loads are highly episodic; the majority of the sediment is transported in only a few high-flow events. Phosphorus transport is usually similar to sediment transport because of its affinity to attach to sediment; however, while phosphorus transport was elevated in high-flow events, it was not as closely related to sediment.

- Two approaches were used to examine nitrogen inputs into Conewago Creek - county-level agricultural land-use and census data and SPARROW model data. As expected, the county-level data represented the two counties composing most of the watershed. The three leading inputs were agriculture manure, commercial fertilizer, and atmospheric deposition. The SPARROW model was also used to discern primary sources of instream nitrogen. The primary sources of instream nitrogen are commercial fertilizer and fixation, manure, and atmospheric deposition.

The process-level understanding is directly applicable in developing the most effective conservation practices and plans by providing useful results to managers for informed decisionmaking. Managing the following constituents in the following ways could generate the greatest benefit.

- Management activities for nitrogen will likely be most effective in the middle part of the watershed in the areas that tend to have the greater amount of agricultural land. 


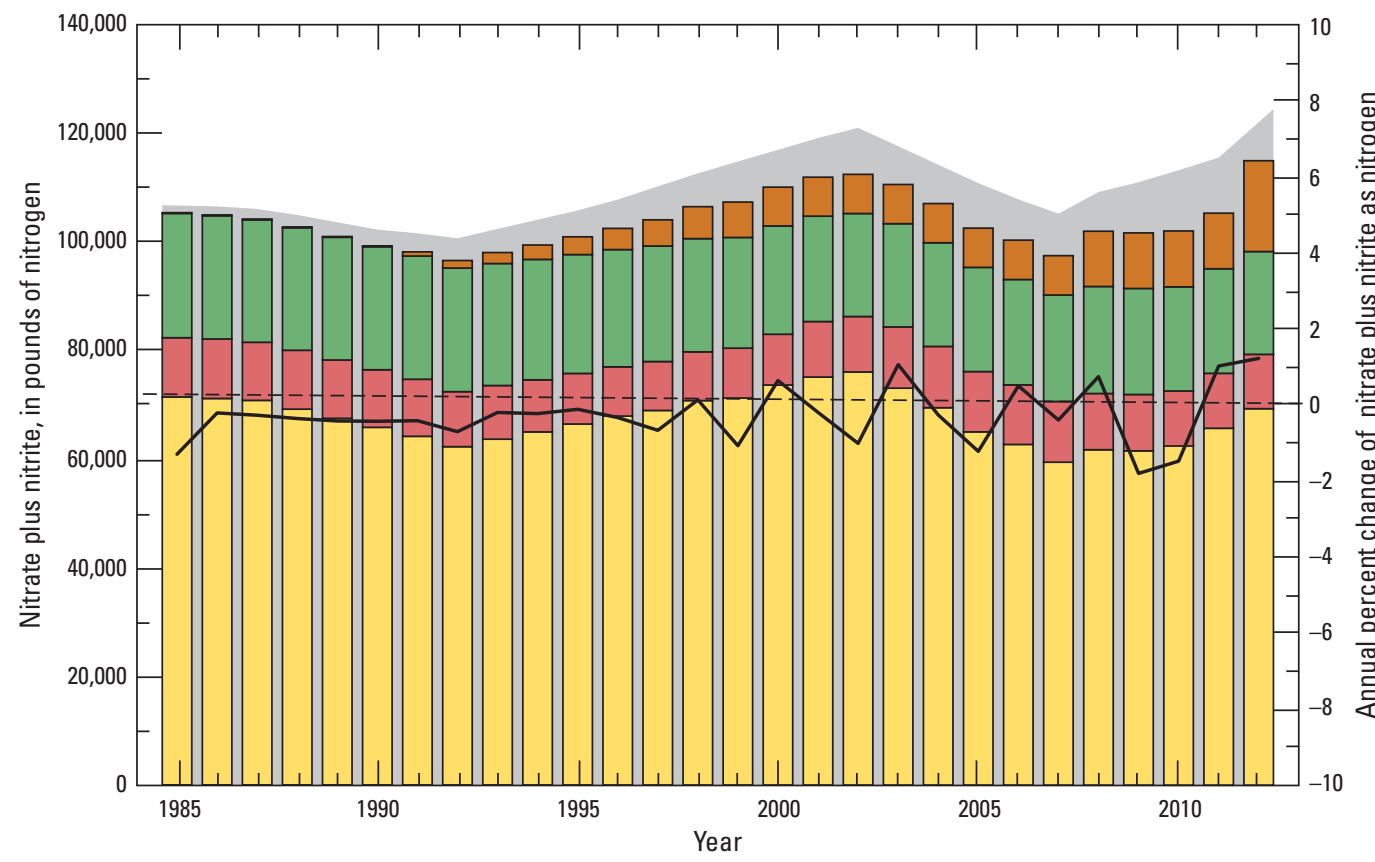

\section{EXPLANATION}

Pounds of nitrate plus nitrite as nitrogen from all sources with no best management practice implementation

Source-specific pounds of nitrate plus nitrite as nitrogen with best management practice implementation

$\square$ Wastewater

$\square$ Forest

$\square$ Urban area

$\square$ Agriculture

Percent difference per year in nitrate plus nitrite as nitrogen predicted by implementation versus no implementation of best management practices

Figure 98. Nitrate loads estimated from the Chesapeake Bay watershed model for the Conewago Creek Bellaire land-river segment with and without best management practice (BMP) implementation with input sources and the annual percentage difference of load attributed to BMP implementation, 1985-2012.

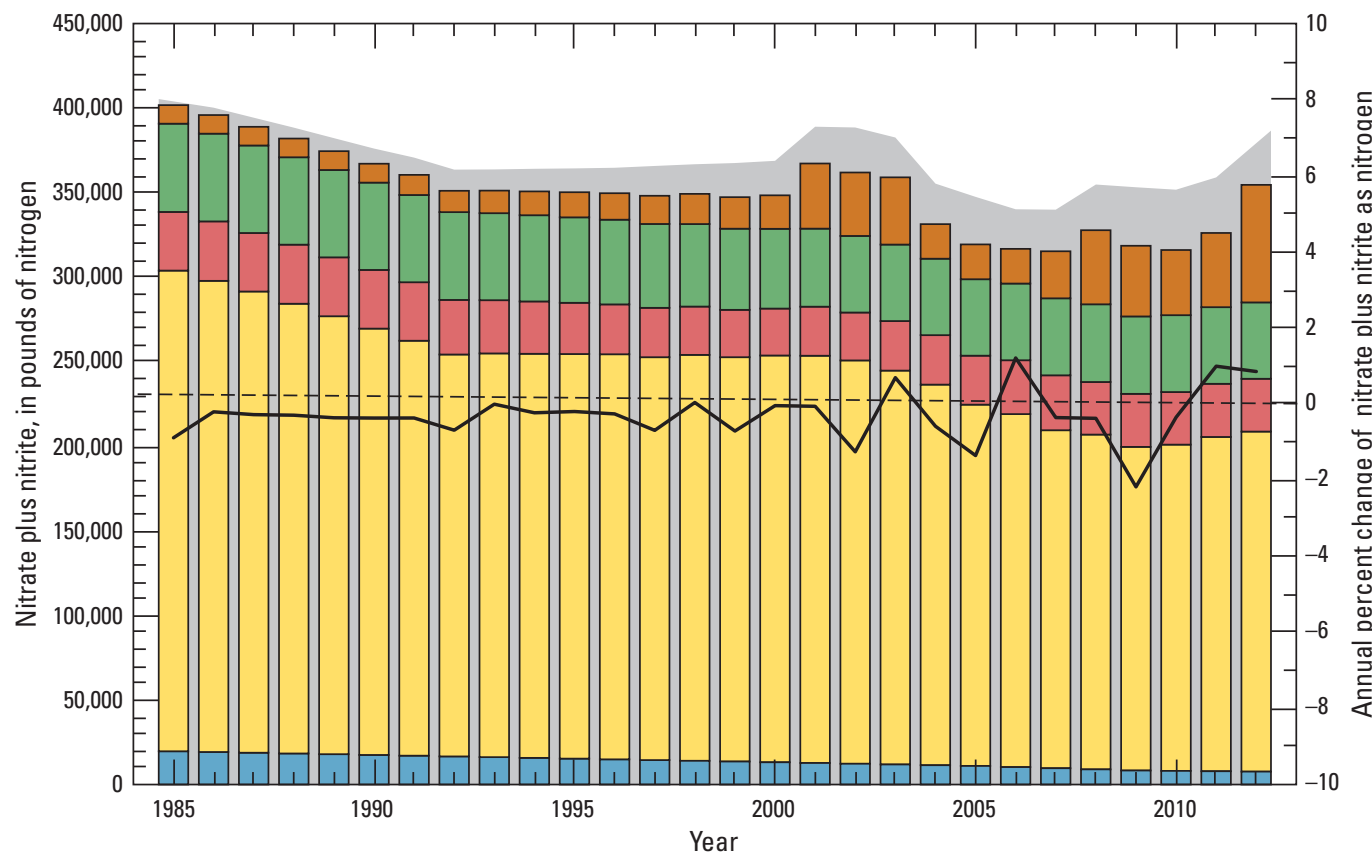

\section{EXPLANATION}

Pounds of nitrate plus nitrite as nitrogen from all sources with no best management practice implementation

Source-specific pounds of nitrate plus nitrite as nitrogen with best management practice implementation

$\square$ Wastewater

$\square$ Forest

$\square$ Urban area

$\square$ Agriculture

Atmospheric deposition

Percent difference per year in nitrate plus nitrite as nitrogen predicted by implementation versus no implementation of best management practices

Figure 99. Nitrate loads estimated from the Chesapeake Bay watershed model for the Conewago Creek Falmouth land-river segment with and without best management practice (BMP) implementation with input sources and the annual percentage difference of load attributed to BMP implementation, 1985-2012. 
- The development of nutrient management plans that address especially the application of manures, as well as commercial fertilizer should be important for reducing the overall nitrogen loading to the basin.

- Managing these manure and fertilizer inputs should have a corollary benefit of reducing phosphorus inputs because nonpoint-source phosphorus inputs seem to dominate the phosphorus transport.

- While modifications to the timing and incorporation of fertilizer and manure could alter the transport of nitrogen and phosphorus within the system, ultimately a reduction in nutrient loading is needed to reduce nutrient export from the watershed.

- Many of the streams are impaired by sediment. Erosion and sediment controls are needed to improve the health of the streams and similar to nutrients and also to reduce sediment load exported from the watershed.

- The collection of empirical nutrient and geochemical water-quality data in the Conewago Creek watershed was critical for better understanding the nitrogen sources and temporal responses within the basin, for verifying regional model performance (SPARROW results), and for assessing trends in water-quality data (Chesapeake Bay Watershed Model results).
Ongoing USGS water-quality monitoring efforts will be directed towards the further understanding of the sources, sinks, and transport processes in Conewago Creek, as well as the detection of water-quality change that can be related to the implementation of management actions. Large changes in water quality take time and sufficient management of the landscape to actually affect the system; a number of different study elements will be used to help detect future change in the basin.

- Nutrient and sediment monitoring at the streamgages will provide a long-term record of the water quality in the basin. With sufficient data, trend analysis can be performed to determine whether a statistically significant trend exists, and comparisons from upstream to downstream can be further evaluated.

- The addition of a continuous nitrate monitor and a longer monitoring period will permit the estimation of a TN load. To investigate in-stream nitrate dynamics such as stream respiration and diel cycles, nitrate sensor data collected at a 15-minute interval are necessary.

- Changes in the nutrient and sediment concentration compared to flow relation might be an early indicator of water-quality change because increased management in the watershed is likely to produce a change in nutrient transport dynamics with minimal effects on hydrology. In other words, concentration and flow relations might evolve over time with continued and enhanced management. 


\section{Difficult Run Watershed Water-Quality Characterization}

\section{Lead Author: James S. Webber}

Water quality was characterized within the Difficult Run watershed through the use of a streamgage, site 30 , located near the outlet of the basin and by extensive synoptic sampling at 35 sites throughout the basin (fig. 100). The synoptic sites were selected to characterize the water-chemical variability in the tributaries and upstream section of Difficult Run. Various stream orders, land-use activities, and surrounding hydrologic features were captured by the network of synoptic locations.

\section{Streamflow and Water-Quality Characterization at the Intensive Monitoring Site}

The intensive Difficult Run monitoring location is located approximately eight-tenths of a mile above the confluence of Difficult Run with the Potomac River (station 01646000). Discrete sample collection began at this site in July 2011, and continuous water-quality monitoring began in October 2012. A streamgage has been in operation at this location since 1935, which allows the findings and hydrologic conditions of this study period to be placed into a historical context. This section presents an overview and characterization of the physical hydrology and water-chemistry data from the various sampling activities at this location.

\section{Characterization of the Physical Hydrology}

The hydrology of Difficult Run during the sample period and the long-term record of flow is presented in figure 101. Seasonal variation in flow followed historical patterns, with elevated base flows of about $50 \mathrm{ft}^{3} / \mathrm{s}$ in early- to mid-spring followed by a decrease through late summer. Historical flows during summer were between 5 and $15 \mathrm{ft}^{3} / \mathrm{s}$, which coincide with the conditions measured during this study. The total volume of water transported in water years 2011, 2012, and 2013 was higher than the historical median annual total streamflow of 1,200 million $\mathrm{ft}^{3}$ (fig. 102). Total annual discharge is mostly controlled by precipitation quantity and intensity. A comparison of annual rainfall totals at two weather stations adjacent to the Difficult Run watershed demonstrates that total precipitation was greater in 2013 than historical averages (table 34). Precipitation during 2012 was below longterm averages and was only higher in 2011 at the Dalecarlia Reservoir station. Rainfall intensity resulting from Tropical Storm Lee was mostly responsible for the large total discharge in 2011. Annual instantaneous flow peaked at $17,000 \mathrm{ft}^{3} / \mathrm{s}$ in September 2011, and the substantial effect of that storm event on streamflow is seen in the cumulative annual streamflow (fig. 101). By contrast, maximum annual instantaneous flows were 2,100 ft $\mathrm{ft}^{3} / \mathrm{s}$ in 2012 and 2,650 ft $\mathrm{ft}^{3} / \mathrm{s}$ in 2013 .

The influences of storm-related flows in the basin can be described by using the hydrograph separation tool, PART. The results indicate that 42.4 percent of the streamflow left the basin as base flow during the study period (table 35), which means that a majority of flow can be attributed to storm runoff. This is consistent with a traditional conceptual model of streamflow generation in an urban basin where imperviousness is known to cause an increased frequency, magnitude, and duration of extreme flow events (McMahon and others, 2003). A shift in historical flow records occurred in this basin following the development of Reston, Virginia, in the mid-1960s that resulted in greater mean annual peak discharges (Hupp and others, 2013). This continued development of the watershed is reflected in a lower BFI, 50.8 percent from 1990-2010, compared to the long-term historical value of 57.9 percent (table 35). 


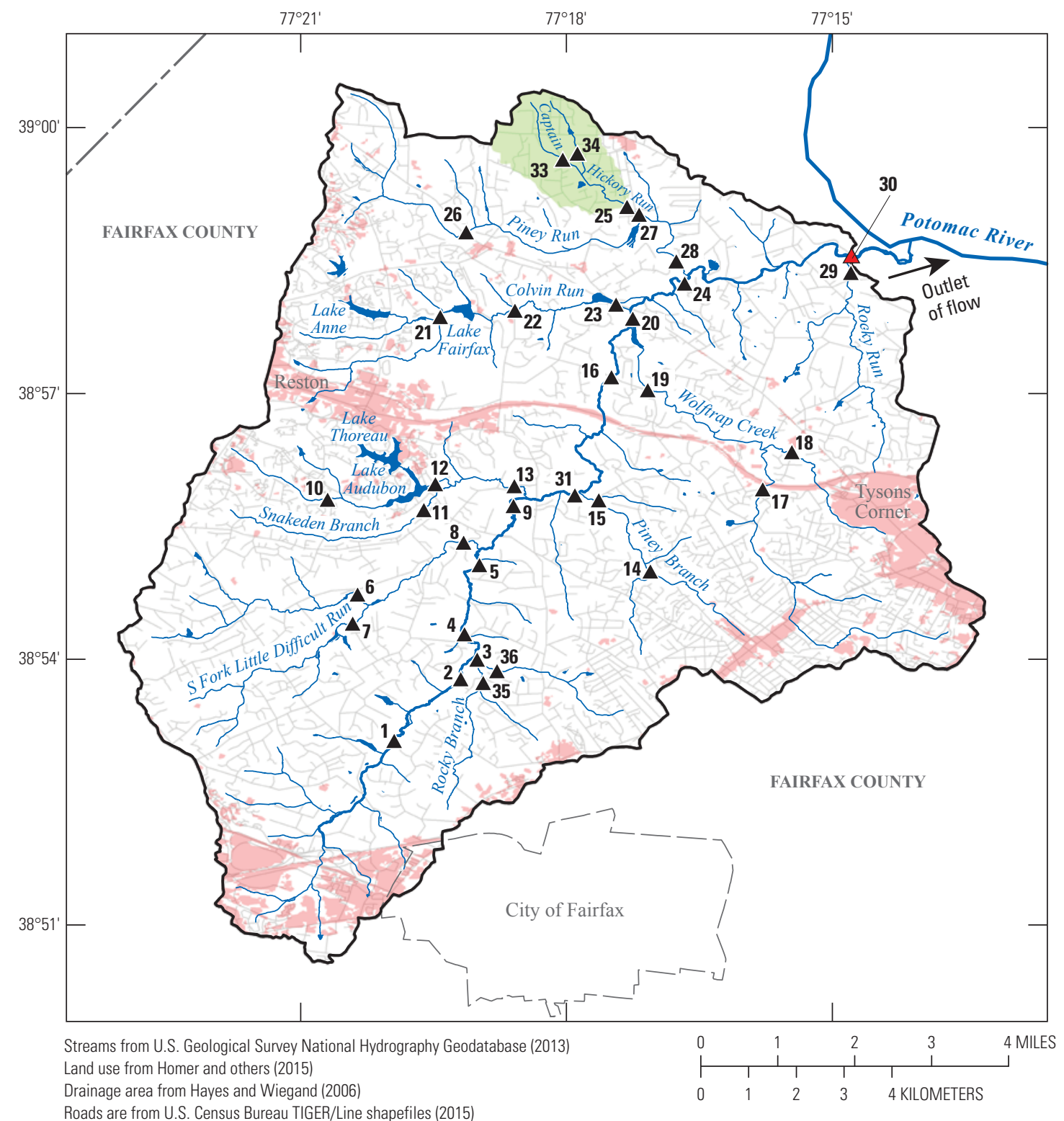

Roads are from U.S. Census Bureau TIGER/Line shapefiles (2015)

North American Datum of 1983
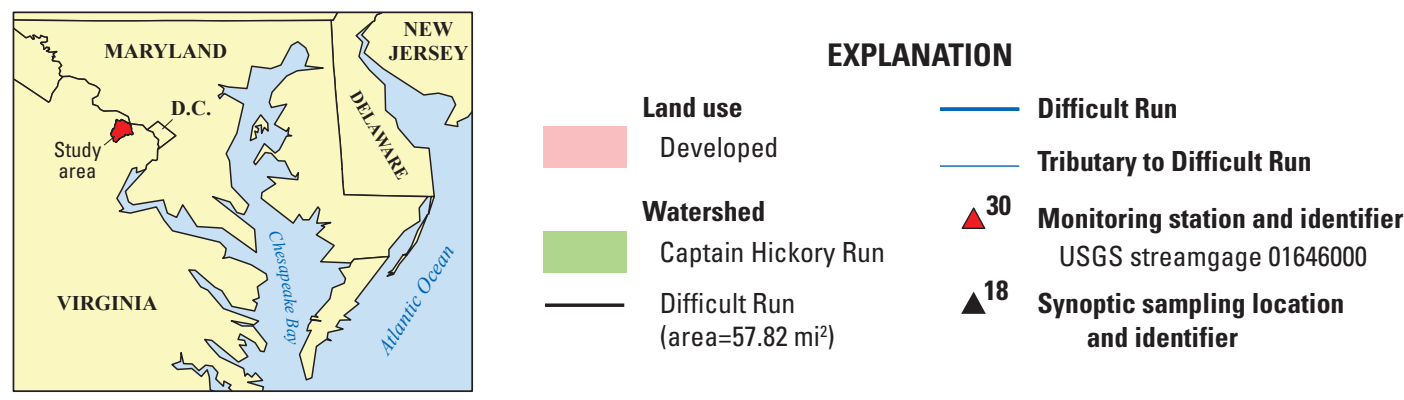

Figure 100. Monitoring stations and the stream network within the Difficult Run watershed, Virginia. 


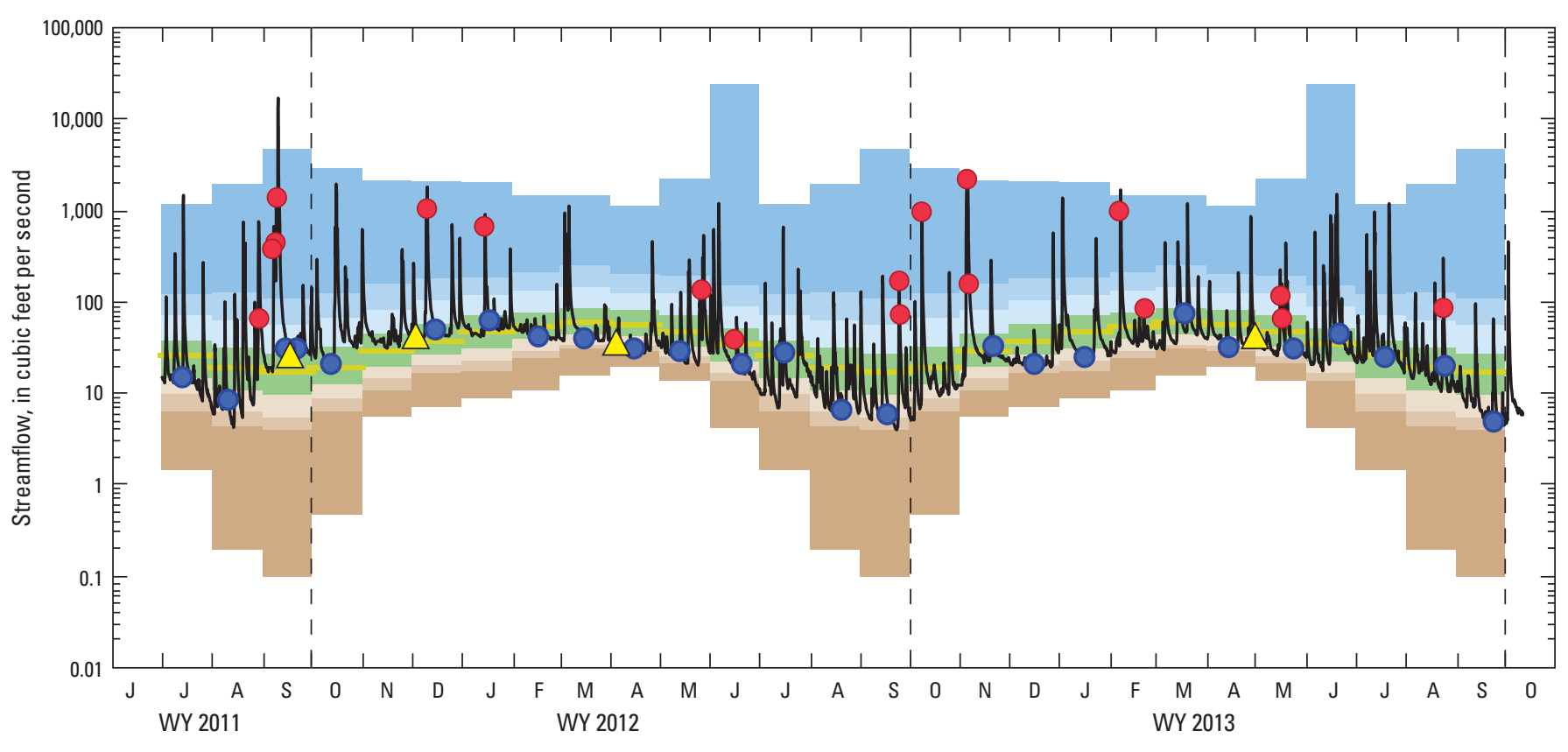

EXPLANATION

Monthly flow statistics - Historical daily flows from WY 1935 to WY 2013

Minimum daily flow to 5 th percentile 5th percentile to 10th percentile 10th percentile to 25th percentile 25th percentile to 75 th percentile 75th percentile to 90th percentile 90th percentile to 95th percentile

95th percentile to maximum daily flow Median flow

\section{Streamflow, in cubic feet per second}

Sampling event

- Routine sampling

- Storm sampling

$\triangle \quad$ Synoptic sampling

WY Water year

Figure 101. Difficult Run streamgage and quantiles that represent historical monthly flow data with the timing of various sampling events from June 2011 through September 2013 within the Difficult Run watershed.

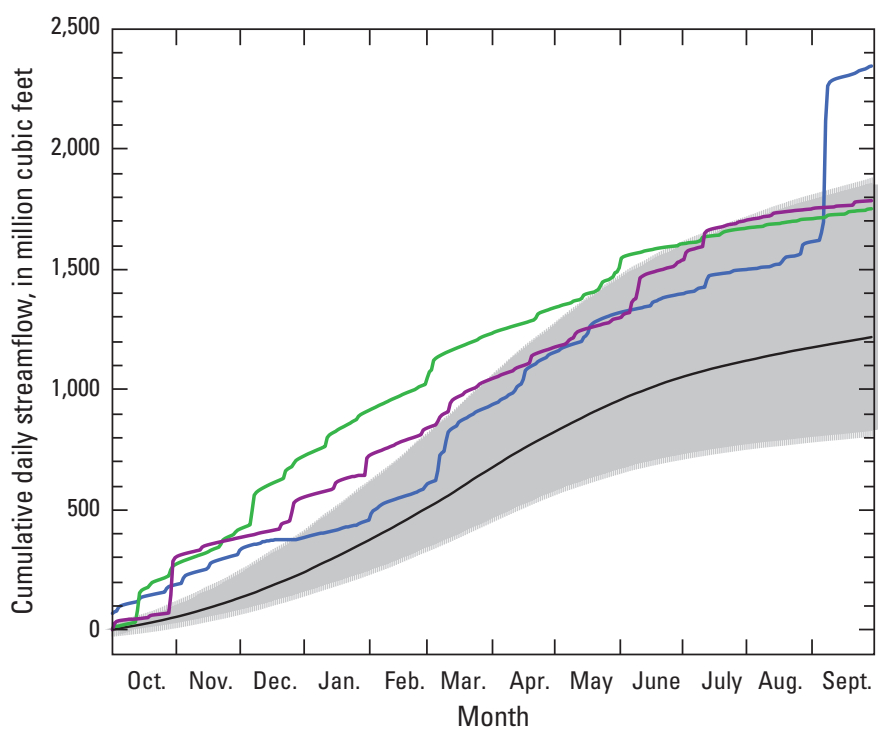

\section{EXPLANATION}

Historical streamflow

75th quantile of observed values

Median of

observed values

25th quantile of observed values
Water year

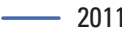

2012

Figure 102. Cumulative daily streamflow values from the Difficult Run streamgage for water years 2011 through 2013 with the median, 75th quantile, and 25th quantile of daily streamflow values observed from water years 1935 through 2010. 
Table 34. Rainfall data from two NOAA weather monitoring stations including average precipitation for two historical time periods and total precipitation for water years 2011 through 2013.

[numbers in bold indicate water years that were greater than the historical averages]

\begin{tabular}{lccc}
\hline \multirow{2}{*}{ Weather station } & Water year & \multicolumn{2}{c}{ Annual precipitation (inches) } \\
\cline { 3 - 4 } & $1949-2010$ & Mean & Total \\
\hline & $1990-2010$ & 43.3 & - \\
Dalecarlia Reservoir & $\mathbf{2 0 1 1}$ & 45.9 & $\mathbf{4 8 . 6}$ \\
& 2012 & - & 38.0 \\
& $\mathbf{2 0 1 3}$ & - & $\mathbf{5 0 . 4}$ \\
\hline & $1964-2010$ & 41.3 & - \\
\hline & $1990-2010$ & 40.3 & - \\
& 2011 & - & 39.7 \\
& 2012 & - & 35.7 \\
\hline
\end{tabular}

Table 35. Streamflow partitioning for streamgage station 01646000 in the Difficult Run watershed.

$\left[\mathrm{mi}^{2}\right.$, square mile; $\mathrm{ft} / \mathrm{s}$, cubic foot per second; in/yr, inch per year; \%, percent; data were computed using the software package PART (Rutledge, 1998)]

\begin{tabular}{|c|c|c|c|c|c|c|c|}
\hline Watershed & $\begin{array}{l}\text { Drainage area } \\
\qquad\left(\mathrm{mi}^{2}\right)\end{array}$ & $\begin{array}{l}\text { Period of } \\
\text { record }\end{array}$ & \multicolumn{2}{|c|}{ Mean streamflow } & \multicolumn{2}{|c|}{ Mean base flow } & $\begin{array}{l}\text { Base-flow } \\
\text { index (\%) }\end{array}$ \\
\hline \multirow[t]{3}{*}{ Difficult Run } & 57.8 & 1936-2010 & 62.51 & 14.69 & 36.22 & 8.51 & 57.9 \\
\hline & & 1936-1965 & 53.6 & 12.56 & 35.98 & 8.46 & 67.1 \\
\hline & & 1990-2010 & 71.13 & 16.72 & 36.16 & 8.50 & 50.8 \\
\hline
\end{tabular}




\section{Characterization of Continuous Water-Quality Data}

Continuous data collected at the streamgage demonstrated seasonal and hydrologic variability in a number of parameters that are presented in the contour plots in figures 103 and 104 and in C-Q plots separated by "warm" (April through September) and "cool" (October through March) seasons in figures 105 and 106.

DO solubility varies inversely with water temperature; consequently, observed concentrations of DO are inversely related to the water temperature. Water temperatures peaked at about $27^{\circ} \mathrm{C}$ in the summer and decreased to below $5{ }^{\circ} \mathrm{C}$ in the winter. DO concentrations were lowest in July and August with most measurements about $7 \mathrm{mg} / \mathrm{L}$, and concentrations increased in the winter to a maximum of $15 \mathrm{mg} / \mathrm{L}$. These constituents followed a diel cycle that is driven by light availability. Photosynthetic production of oxygen occurred during the day, resulting in peak concentrations in early to mid-afternoon and minimums during the early morning. This diel pattern was interrupted during periods of stormflow. Temperature and DO responded inconsistently to increased flows, but some inferences were made during the largest events. High flows had a neutralizing influence on water temperature, with relatively cooler water added during warm months and warmer precipitation added during cooler periods. Large events appeared to have no effect on DO during warm periods when concentrations were already low, but concentrations decreased during cool months with the addition of relatively warmer stormwater.

Specific conductance exhibited a relationship with flow that appears to be influenced by the application of road salts. These chloride-based compounds are applied during the winter months and caused a spike in conductivity values when they were delivered to the stream. Evidence for this pattern was seen in the varying seasonal response to flow. Conductivity values in early spring months (represented by the October through March season in fig. 105) peaked during large storm events and then quickly subsided. The maximum conductivity measurement of $2,660 \mu \mathrm{S} / \mathrm{cm}$ was recorded during this period. These findings are consistent with previous work done in the basin and suggest that the chloride concentrations associated with periods of peak conductivity could negatively affect aquatic health (Jastram, 2014). A more typical dilution response is exhibited outside of these early spring months.

Most of the $\mathrm{pH}$ values were between 7.0 and 7.5 standard units, the expected range of $\mathrm{pH}$ in natural waters that are unaffected by pollution (Hem, 1985). Values of $\mathrm{pH}$ had a negative relation with streamflow that was likely caused by the addition of relatively acidic rainfall and storm runoff. Values of $\mathrm{pH}$ of up to 8.0 were observed during base-flow conditions in late April and early May. The uptake of carbon dioxide by aquatic organisms during the growing season likely caused these increased values (Hem, 1985). The effect of biologic processing also was seen in the diel cycling of $\mathrm{pH}$.

Turbidity is a measure of the cloudiness of water and is directly related to the amount and composition of sediment in the water column. This parameter was directly correlated with streamflow and displayed no obvious seasonal patterns. Values greater than 300 FNU were commonly observed during storm events, and readings less than 5 FNU were typical for periods of base flow.

Nitrate concentrations generally ranged between 0.5 and $2.0 \mathrm{mg} / \mathrm{L}$ and demonstrated a seasonally dependent flow response. The average nitrate concentration between October and March was $1.46 \mathrm{mg} / \mathrm{L}$ and was $1.17 \mathrm{mg} / \mathrm{L}$ for April through September. Lower concentrations during the growing season may be related to low-flow conditions, combined with denitrification or biologic uptake in the watershed or within the stream network. A decrease in biologic processing within the streams and watershed during the cooler months could explain the increased in-stream nitrate concentrations during these months. Nitrate demonstrated a strong dilution response during high-flow events during the cooler months that was less evident during the growing season when base-flow concentrations were lower. 


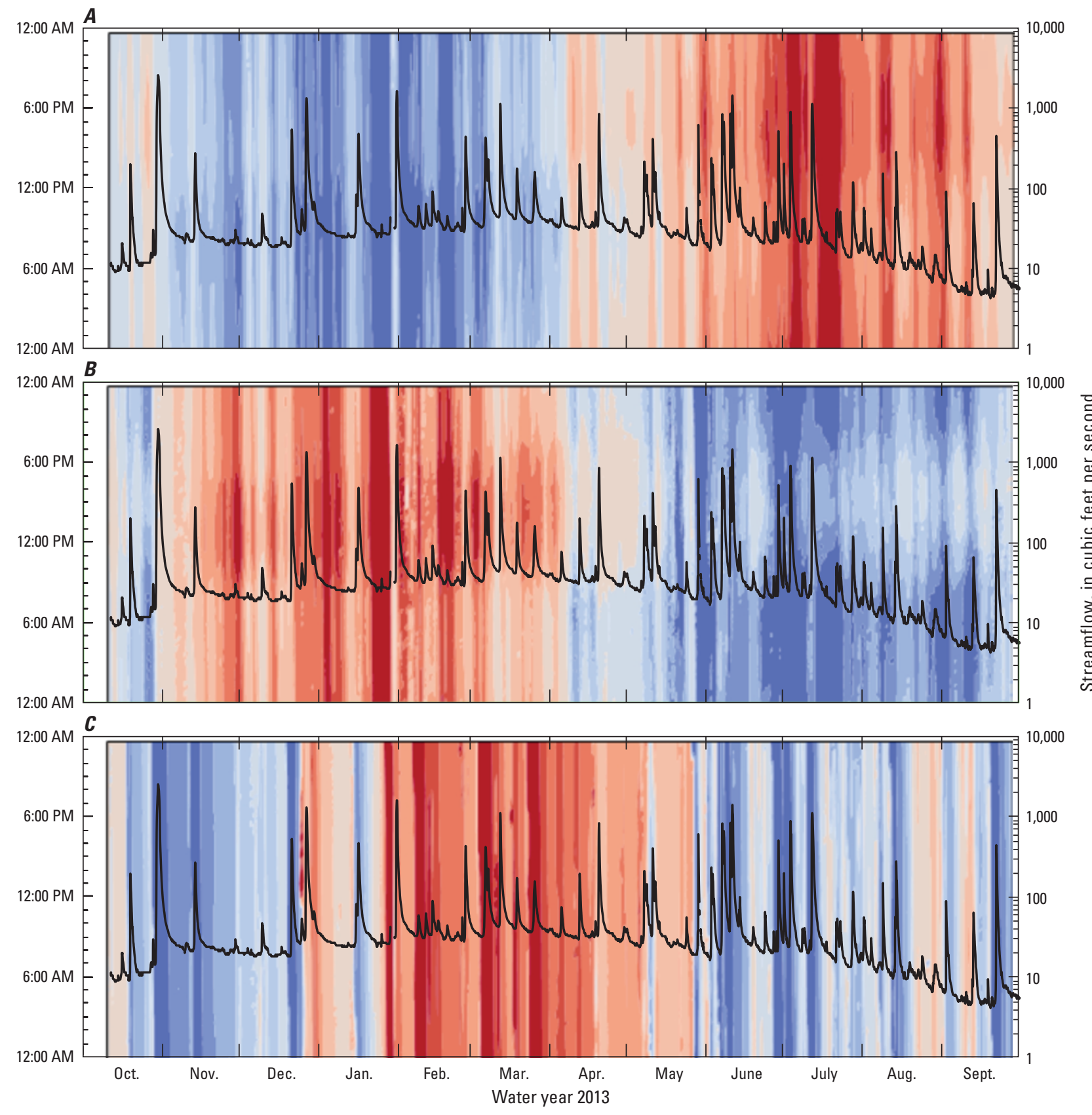

EXPLANATION

Water temperature, in degrees Celsius

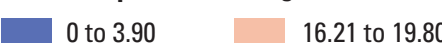

3.91 to $5.40 \quad 19.81$ to 21.60

5.41 to 7.10

7.11 to 9.00

21.61 to 23.20

21.61 to 23.20
23.21 to 24.30

24.31 to 28.20

- Streamflow, in cubic feet per second

Dissolved oxygen, in milligrams per liter

5.30 to $7.70 \quad 11.21$ to 11.90

\begin{tabular}{l|l}
7.71 to 8.10 & 11.91 to 12.40
\end{tabular}

7.71 to 8.10
8.11 to 8.50

8.51 to 9.00

9.01 to 9.70

11.91 to 12.40
12.41 to 12.90

12.91 to 13.30

9.71 to 11.20

- Streamflow, in cubic feet per second

Specific conductance, in microsiemens per centimeter at 25 degrees Celsius

\begin{tabular}{ll|l}
68.0 to 177.0 & 245.1 to 262.0
\end{tabular} \begin{tabular}{ll}
177.1 to $201.0 \quad 262.1$ to 291.0 \\
\hline
\end{tabular} \begin{tabular}{|l|l|}
201.1 to 215.0 & 291.1 to 344.0
\end{tabular} 215.1 to $223.0 \quad 344.1$ to 400.0 223.1 to $233.0 \quad 400.1$ to $2,660.0$

233.1 to 245.0

— Streamflow, in cubic feet per second

Figure 103. Continuous $(A)$ water temperature, $(B)$ dissolved oxygen, and $(C)$ specific conductance data with the hydrograph from the Difficult Run streamgage, 2013 water year. 

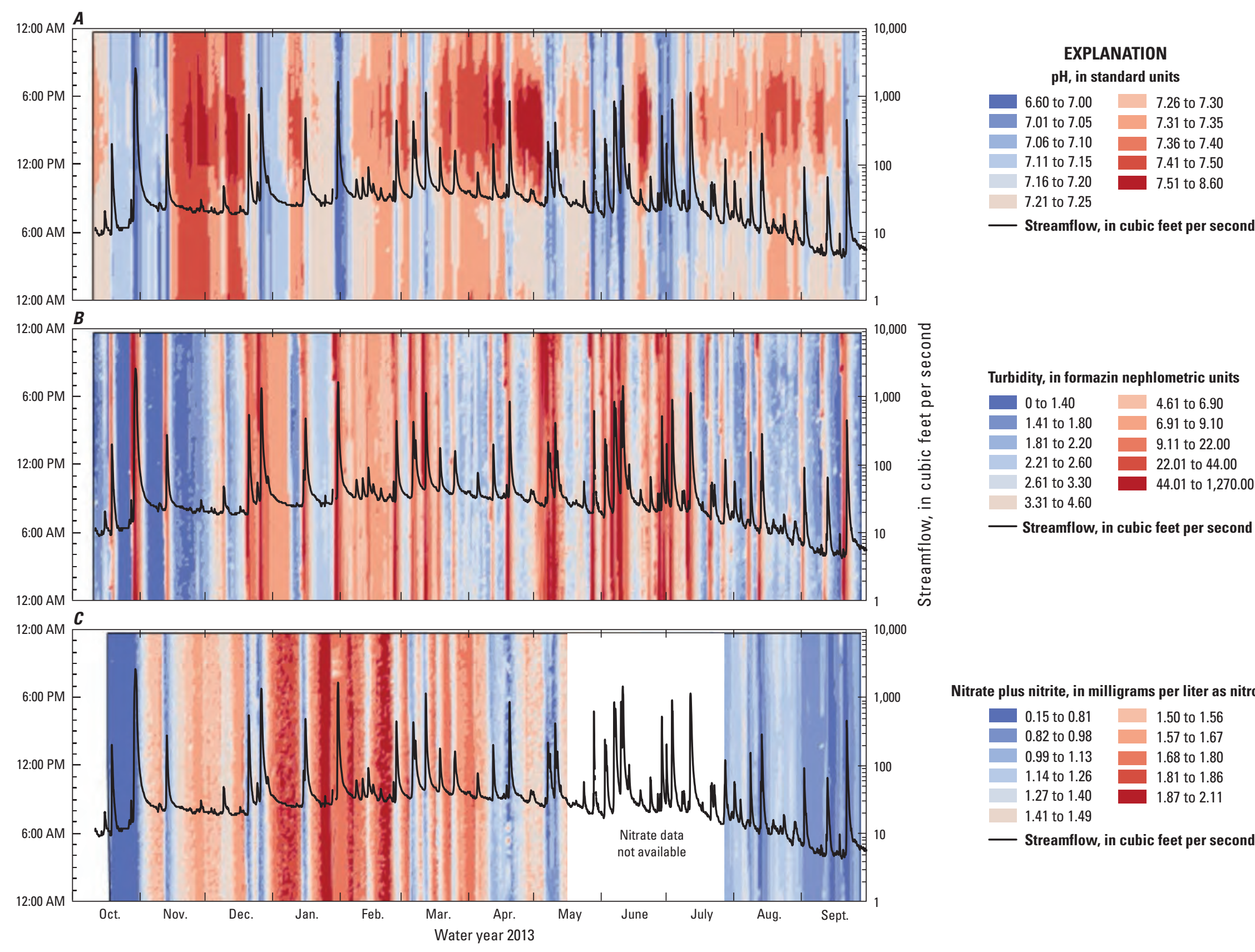

Turbidity, in formazin nephlometric units

\begin{tabular}{l|l}
0 to 1.40 & 4.61 to 6.90
\end{tabular}

1.41 to 1.80

1.81 to 2.20

2.21 to 2.60

2.61 to 3.30

3.31 to 4.60

- Streamflow, in cubic feet per second

Nitrate plus nitrite, in milligrams per liter as nitrogen

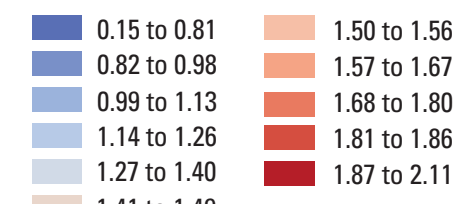

1.41 to 1.49

4.61 to 6.90
6.91 to 9.10

9.11 to 22.00

22.01 to 44.00

44.01 to $1,270.00$

Figure 104. Continuous $(A) \mathrm{pH},(B)$ turbidity, and $(C)$ nitrate data with the hydrograph from the Difficult Run streamgage, 2013 water year. 

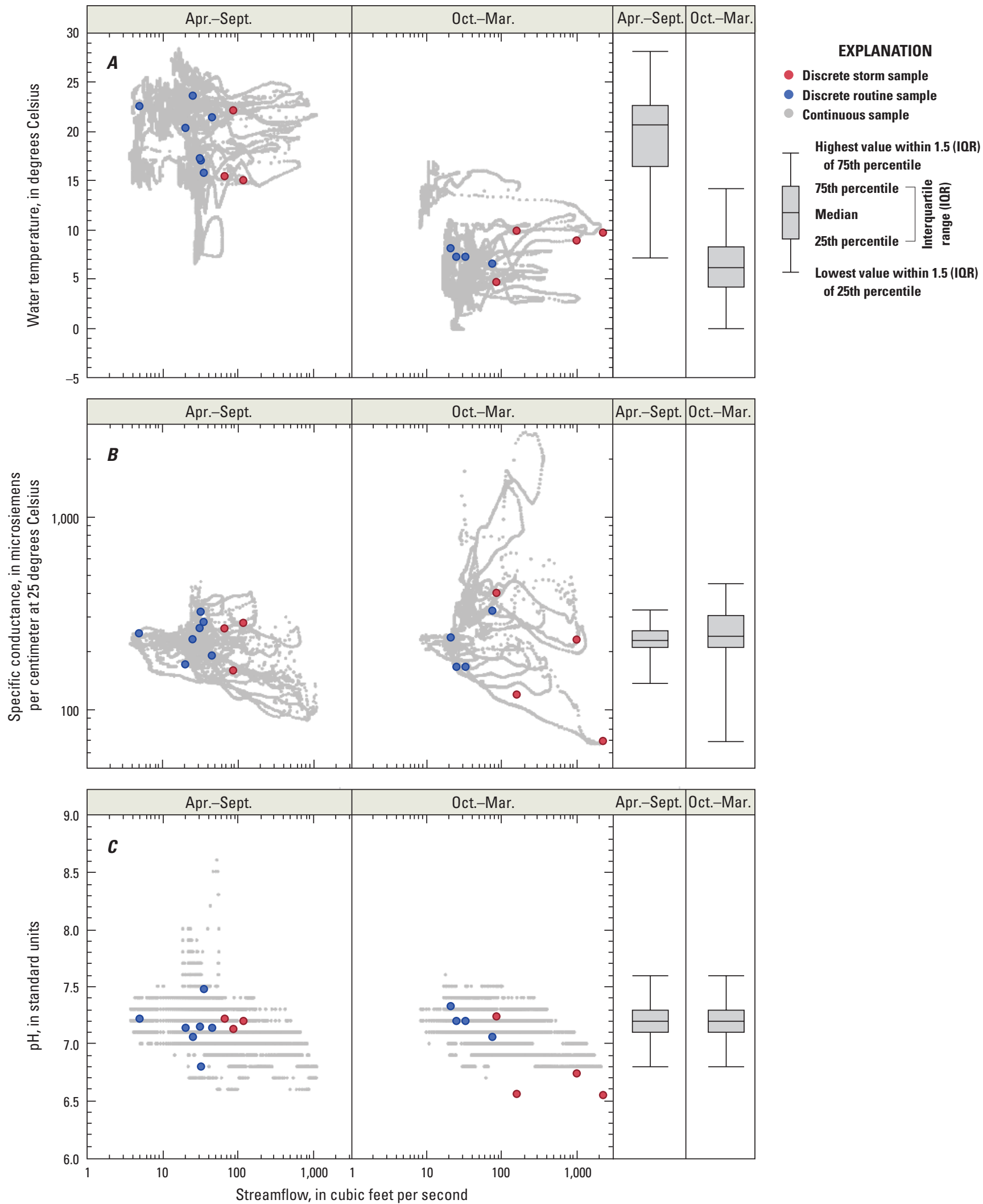

Figure 105. $(A)$ Water temperature, $(B)$ specific conductance, and $(C) \mathrm{pH}$ data from continuous monitoring and discrete storm and routine samples for warm (April to September) and cool (October to March) seasons, Difficult Run streamgage, 2012-2013. 


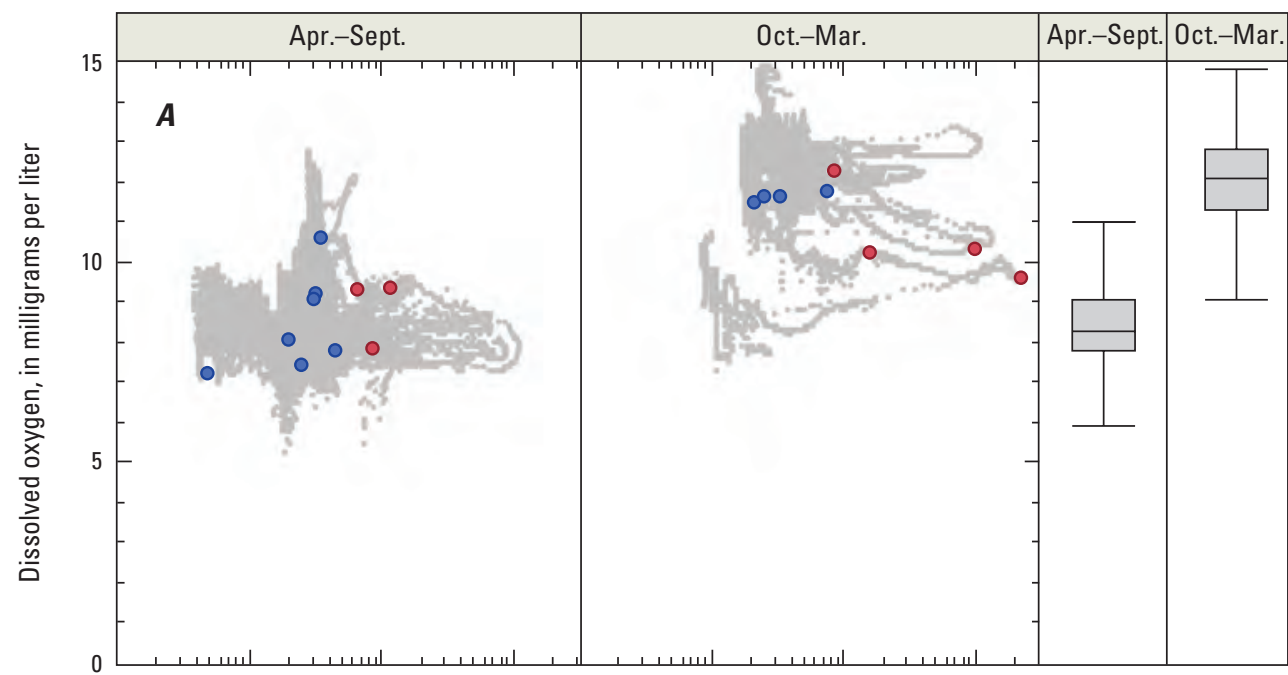

EXPLANATION

- Discrete storm sample

Discrete routine sample

- Continuous sample

Highest value within 1.5 (IOR) of 75 th percentile

75th percentile 7 을 똥

Median

25th percentile $\triangle$ 힐

L Lowest value within 1.5 (IOR) of 25th percentile
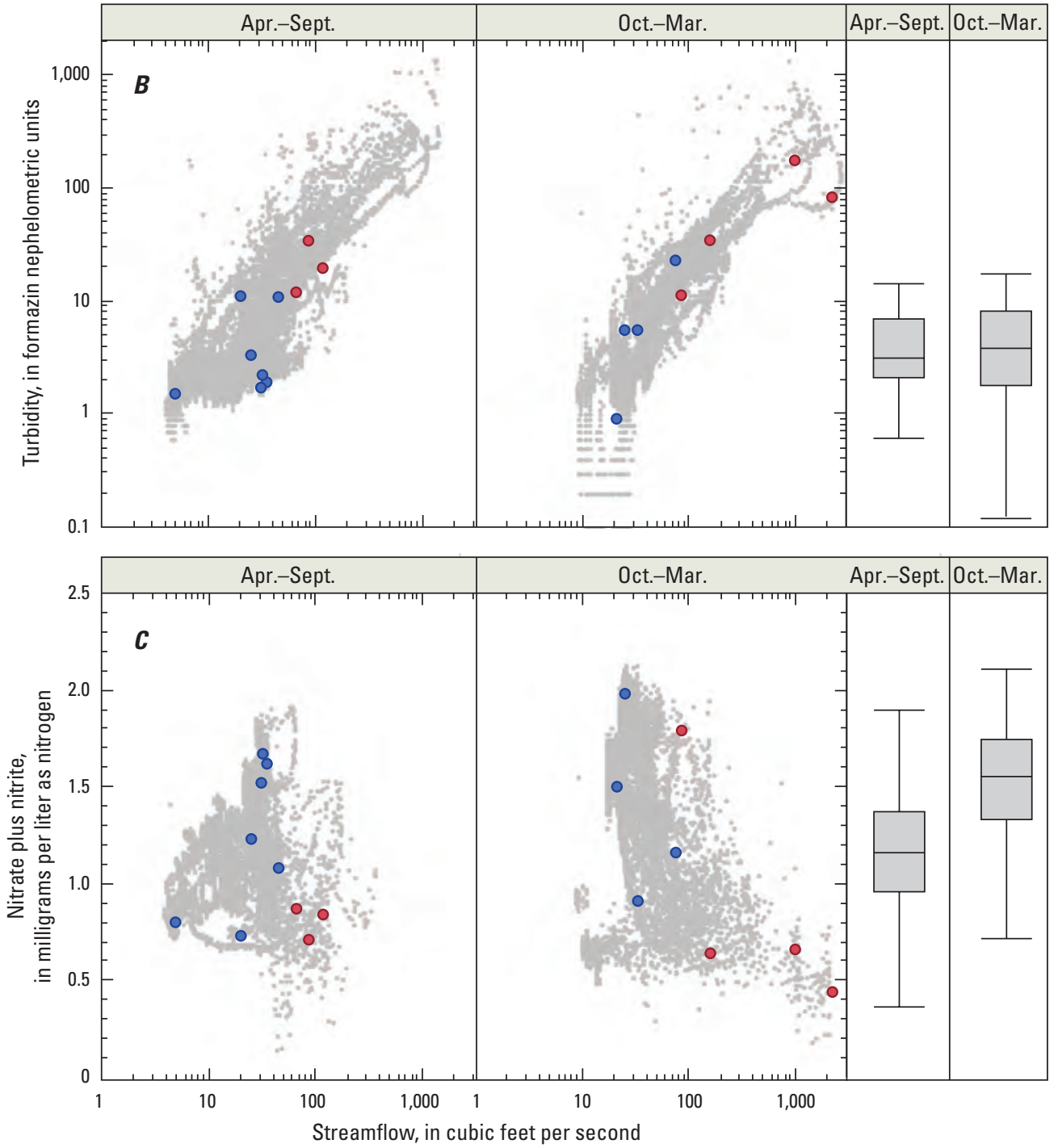

Figure 106. (A) Dissolved oxygen, $(B)$ turbidity, and $(C)$ nitrate data from continuous monitoring and discrete storm and routine samples for warm (April to September) and cool (October to March) seasons, Difficult Run streamgage, 2012-2013. 


\section{Characterization of Discrete Water-Quality Data}

Discrete samples and targeted stormflow samples were analyzed for a broad suite of water-quality parameters. Cluster analysis and PCA were used to identify patterns in water-quality constituents that could be attributed to changes in flow or seasonality. All possible C-Q and temporal plots are provided in the appendix and those of interest are discussed below.

Three groups were identified from the cluster analysis of 25 discrete samples (fig. 107). Seven of the eight samples assigned to group 1 were collected between December and May. In general, these cool-season samples had higher values of nitrate, TN, DO, conductivity, sodium, and chloride than the other two groups. These characteristics coincide with cooler stream water that has limited biologic activity and is influenced by the runoff of high conductivity road salts. The 14 samples assigned to group 2 were collected between May and November. These samples were more dilute and had lower nitrogen concentrations than those in group 1 and represent the influence of the growing season on the in-stream water chemistry. The remaining four samples were collected when streamflow was greater than $150 \mathrm{ft}^{3} / \mathrm{s}$ and represent a dilution response to stormflow. These samples had the lowest specific conductance values and the highest TP concentrations of the 25 discrete samples.

The amount of variability explained by streamflow and seasonality was quantified by using a PCA. The first principal components axis demonstrated that a large portion (48.5 percent) of this variability could be attributed to streamflow. This axis had a strong, negative correlation with flow, and the parameter loadings indicated a dilution response
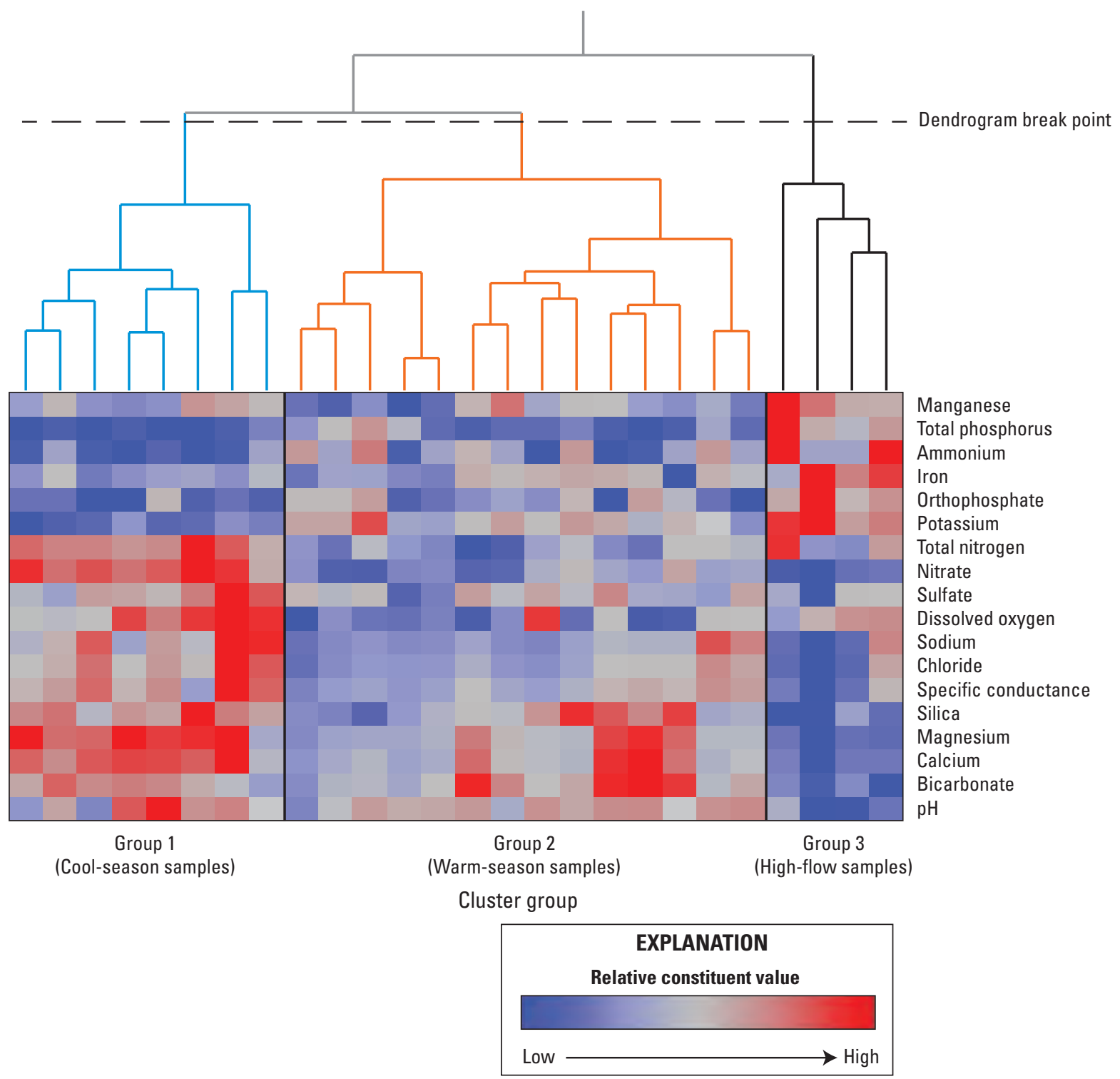

Figure 107. Discrete samples from the Difficult Run streamgage with a heat map of constituent values and the breakpoint used to produce three cluster groups, 2012-2013. 
(table 36; fig. 108). Constituents with strong, positive loadings had a negative relation with flow and included magnesium, calcium, nitrate, specific conductance, chloride, sodium, and silica. Parameters with strong, negative loadings increased with flow and included potassium and TP.

The second principal components axis accounted for only 13 percent of the variability within the dataset and represented the effects of seasonality. The sinusoidal relationship between this axis and the timing of sample collection demonstrated that higher axis scores were assigned during cooler months and lower values during warmer months. DO concentrations had the strongest positive relationship on this axis, which indicates higher concentrations during cooler seasons. Most parameters loaded weakly on this axis, which suggests that they do not experience seasonal variations.

The significance $(\mathrm{p}<0.05)$ of streamflow correlations and seasonal differences were calculated for individual parameters

Table 36. Loading of water-quality constituents collected at the Difficult Run streamgage on principal component axes 1 and 2.

[\%, percent; PC1, first principal components axis; PC2, second principal components axis; loadings with absolute value greater than 0.70 are shown in bold; those with absolute value less than $|0.40|$ are omitted]

\begin{tabular}{|c|c|c|}
\hline Constituent & $\begin{array}{c}\text { PC1 } \\
(48.5 \%)^{1}\end{array}$ & $\begin{array}{c}\text { PC2 } \\
(13.7 \%)^{1}\end{array}$ \\
\hline $\mathrm{pH}$ & 0.66 & \\
\hline Specific conductance & 0.81 & \\
\hline Dissolved oxygen & & 0.72 \\
\hline Bicarbonate & 0.67 & -0.58 \\
\hline Sulfate & 0.54 & \\
\hline Chloride & 0.78 & 0.41 \\
\hline Calcium & 0.90 & \\
\hline Magnesium & 0.91 & \\
\hline Sodium & 0.76 & 0.43 \\
\hline Potassium & -0.83 & \\
\hline Nitrate-N & 0.88 & \\
\hline Ammonium & -0.58 & \\
\hline Total nitrogen & 0.44 & 0.61 \\
\hline Orthophosphate & -0.69 & \\
\hline Total phosphorus & -0.87 & \\
\hline \multicolumn{3}{|l|}{ Iron } \\
\hline Manganese & & 0.51 \\
\hline Silica & 0.77 & \\
\hline
\end{tabular}

${ }^{1}$ Percent of overall variance explained. based on the importance that these effects have on in-stream water chemistry (table 37 ). These relationships are characteristic of a stormflow-dominated, urbanized watershed. The significant negative relations between flow and bicarbonate, calcium, magnesium, and silica represent a dilution response to storm events (fig. 109). The concentrations of these groundwater-derived constituents were higher during base-flow conditions because the stream water has been in contact with bedrock longer than water contributed from overland flow. Specific conductance is a representation of the ionic strength of water and had a weaker negative relation with flow due to the varied response of sodium and chloride. Sodium and chloride concentrations had no significant relations with flow because the dilution response demonstrated by these constituents is interrupted in winter and early spring. Sodium-chloride salts are commonly used to deice roads, and they cause a spike in conductivity when they enter streams during these seasons. Turbidity and suspended-sediment concentrations had significant positive relations with flow, which is expected with these correlated parameters that represent the mobilization of streambed and streambank material (table 37). Total phosphorus sorbs to the surface of minerals and displays a similar relationship with flow as turbidity (fig. 109) (Hem, 1985). Orthophosphate is the biologically available form of phosphorus, and its concentrations had a significant positive correlation to flow. This constituent can be transported from groundwater, but concentrations were likely from overland runoff. Ammonium concentrations respond similarly to streamflow and had a positive significant correlation with orthophosphate concentrations. Nitrate concentrations have a significant negative relation with streamflow, and the nature of this response is described in the previous discussion about the characterization of continuous water-quality data (fig. 106). Non-significant C-Q relationships are provided in the appendix as supplemental material (fig. 1-7).

Water temperature, DO, nitrate, ammonium, orthophosphate, $\delta^{15} \mathrm{~N}$, and manganese demonstrated a significant $(\mathrm{p}<0.05)$ difference between seasons (table 37$)$. Water temperature and DO patterns were described in the previous section, Characterization of Continuous Water-Quality Data (figs. 105 and 106). Nitrate concentrations were significantly higher in the cool season during relatively high base-flow conditions; biologic activity and uptake processes during warmer months result in reduced concentrations (fig. 110). The seasonality displayed by orthophosphate concentrations may be a dilution response related to higher base flows in October through March. Manganese concentrations were significantly lower during the warm season because it can be accumulated by aquatic vegetation for metabolic use (Hem, 1985).

Seasonally variable $\delta^{15} \mathrm{~N}$ values are likely related to in-stream and (or) watershed nutrient processing resulting in elevated $\delta^{15} \mathrm{~N}$ values during warmer periods and lower values during cooler, less biologically active periods (fig. 110). Nonsignificant seasonal relationships are provided in the appendix as supplemental material (fig. 1-8). 


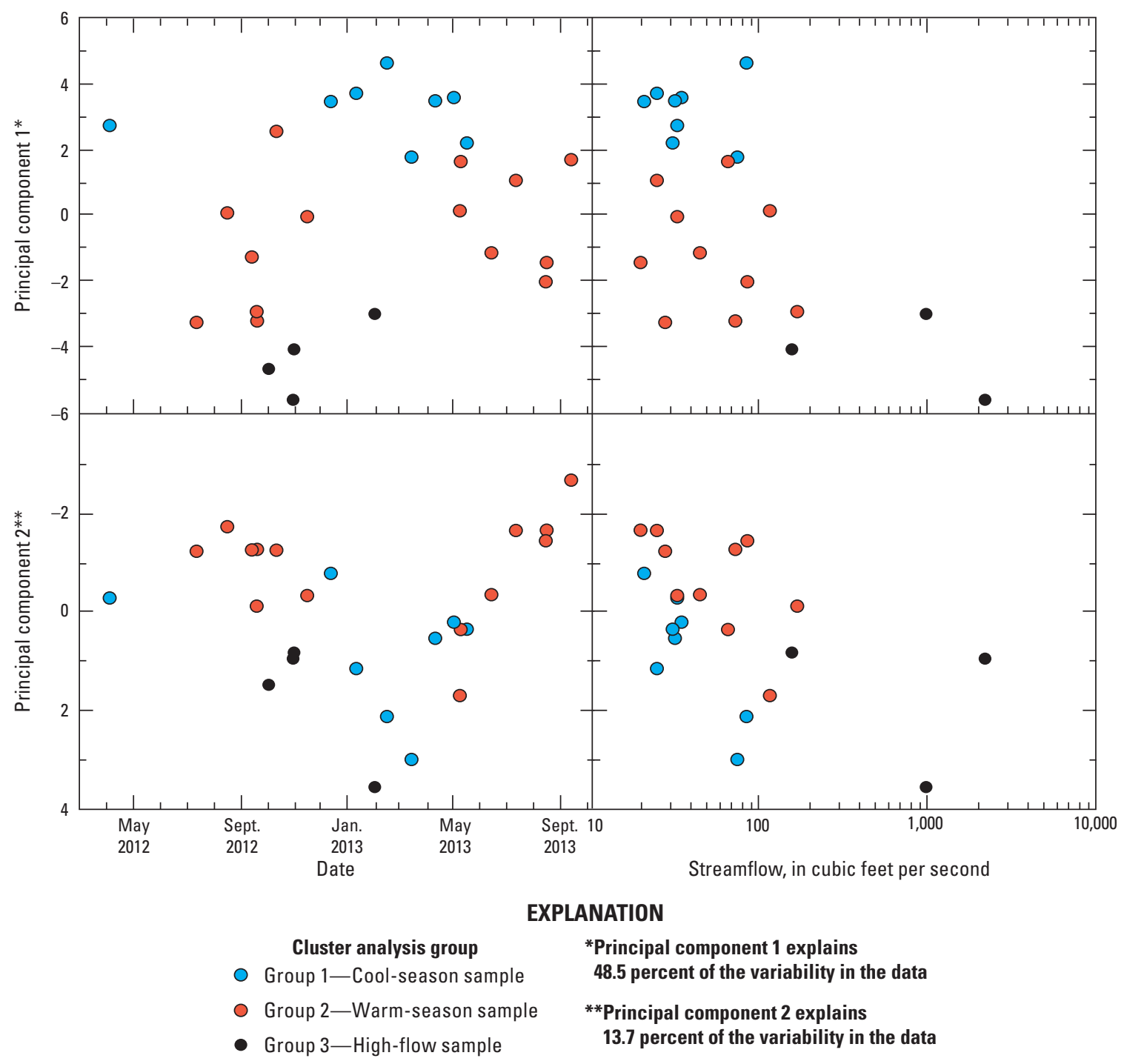

Figure 108. First two principal component axis scores for discrete samples from the Difficult Run streamgage along with time and streamflow, 2012-2013. 
Table 37. Summary of hydrologic and seasonal correlations for discrete water-quality constituents collected at the Difficult Run streamgage.

$[<$, less than; results in bold are significant at $\alpha=0.05$; n, number of observations; APR, April; SEPT, September; OCT, October; MAR, March $]$

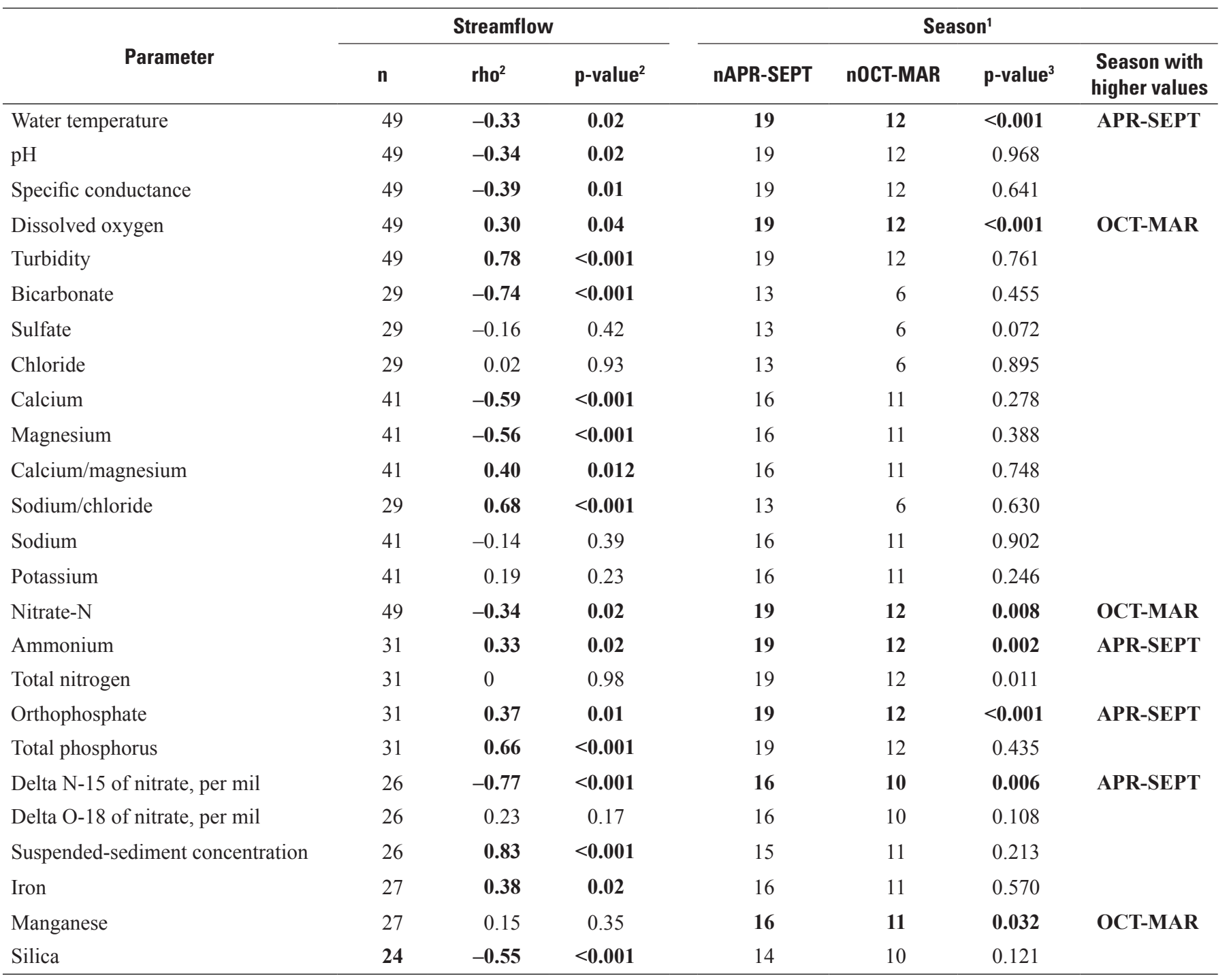

${ }^{1}$ Only routine samples included in the Wilcoxon test of rank scores.

${ }^{2}$ rho is Spearman's rho; p-value is from Spearman's test for correlation.

${ }^{3} \mathrm{p}$-value is from the Wilcoxon test of rank scores. 

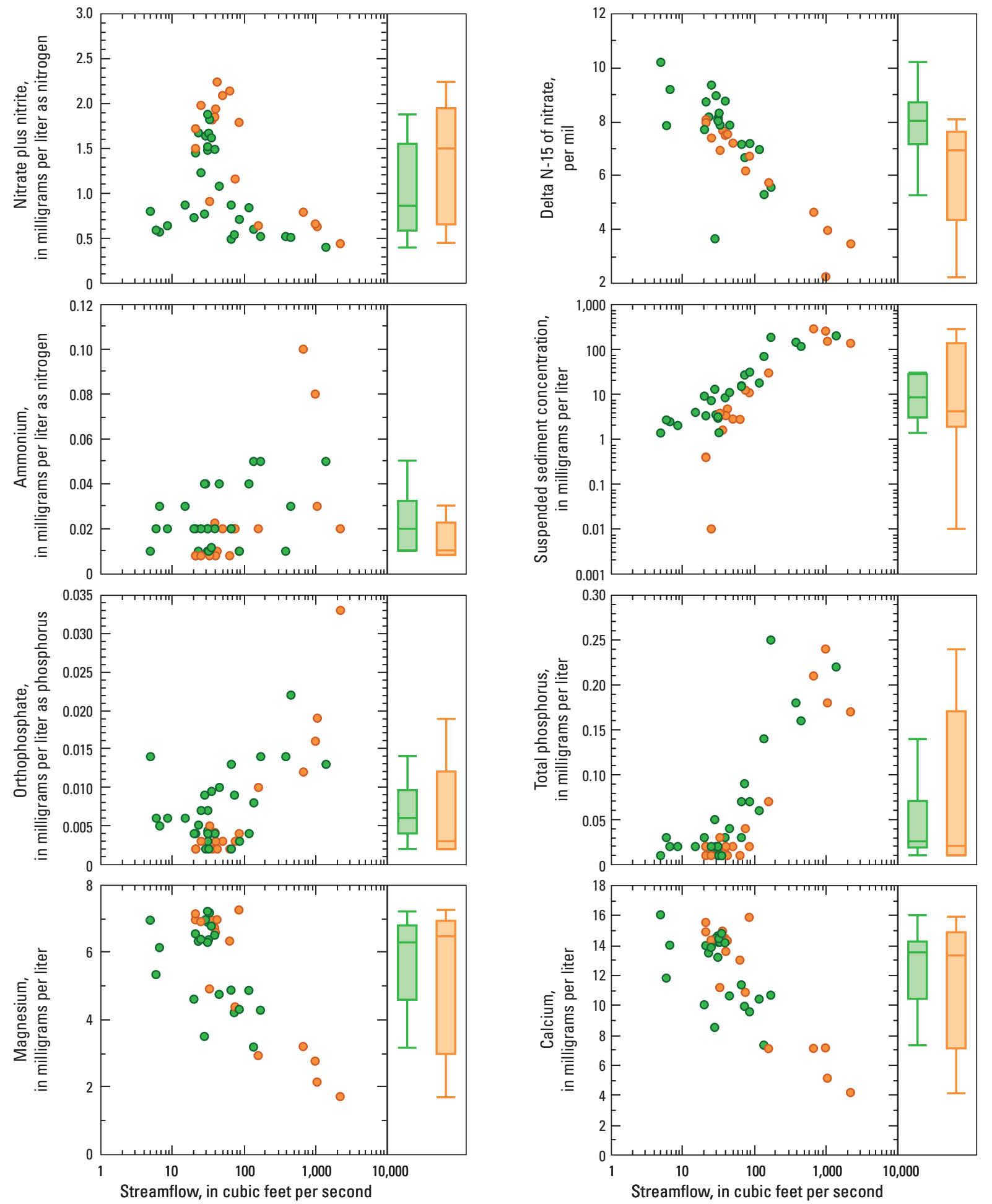

Figure 109. Concentration-discharge data for discrete samples from the Difficult Run streamgage by warm (April to September) and cool (October to March) seasons, 2011-2013. 

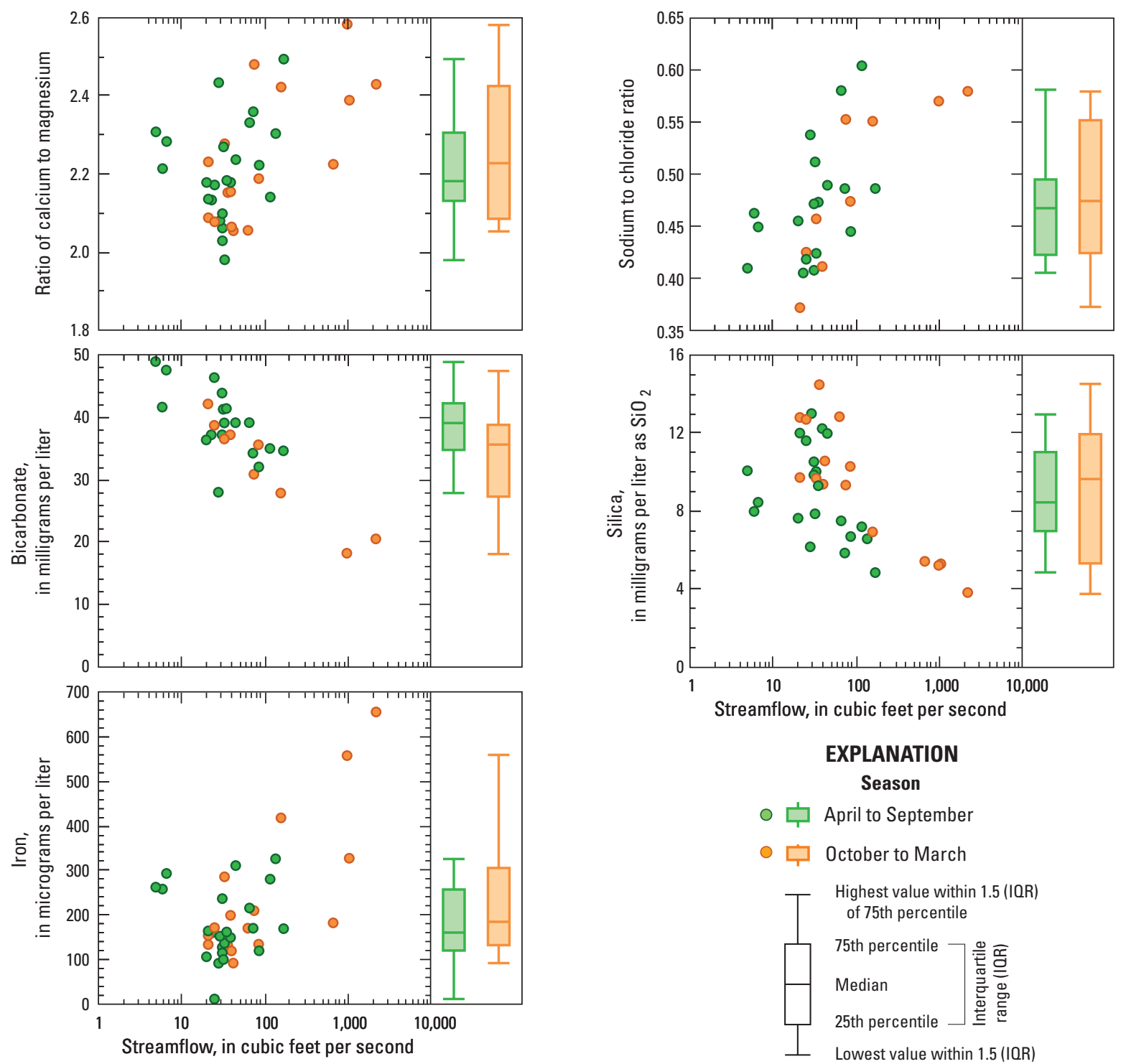

EXPLANATION

Season

○ ゆ April to September

- $\square_{\text {October to March }}$

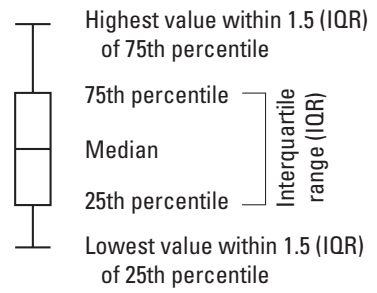

Figure 109. Graphs showing concentration-discharge data for discrete samples from the Difficult Run streamgage by warm (April to September) and cool (October to March) seasons, 2011-2013. - Continued 

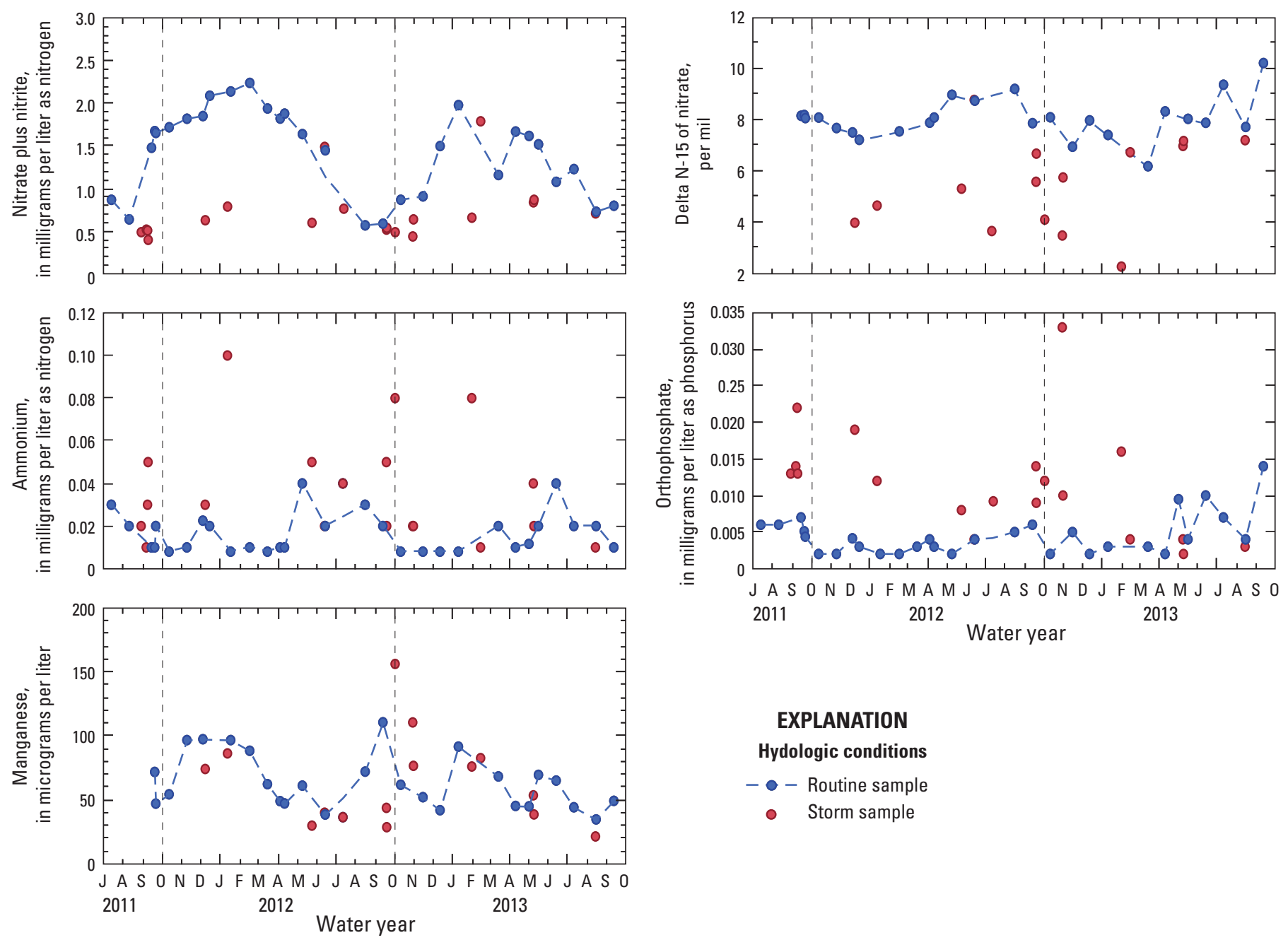

\section{EXPLANATION \\ Hydologic conditions \\ - $\bullet$ - Routine sample \\ - Storm sample}

Figure 110. Concentrations of various constituents in discrete samples from the Difficult Run streamgage, 2011-2013. 
The isotopic composition of nitrate in Difficult Run at the streamgage was variable at seasonal and event time scales (fig. 111). The $\delta^{15} \mathrm{~N}$ values ranged from about $+2 \%$ to $+10 \%$, and $\delta^{18} \mathrm{O}$ values ranged from about $+2 \%$ to $+18 \%$. Routine (base-flow) samples had relatively uniform isotopic composition; minor variations exhibited a weak pattern of positively correlated $\delta^{15} \mathrm{~N}$ and $\delta^{18} \mathrm{O}$ values, with higher values typically associated with relatively low nitrate concentrations in summer and fall seasons. These subdued patterns are qualitatively consistent with isotopic fractionation caused by partial nitrate reduction that was more pronounced during seasonal low-flow periods of older groundwater discharge and more in-stream biologic activity. In contrast, stormflow samples typically had lower nitrate concentrations, lower $\delta^{15} \mathrm{~N}$ values, and higher $\delta^{18} \mathrm{O}$ values than routine (base-flow) samples, indicating contributions of unaltered atmospheric nitrate in precipitation runoff during high-flow events.
Although precipitation runoff generally had lower nitrate concentrations than stream water, and therefore generally diluted stream nitrate concentrations, the distinctive isotopic composition of atmospheric nitrate could be detected in the diluted mixtures. The stream sample with the highest nitrate $\delta^{18} \mathrm{O}$ value ( $+18 \%$ ), when compared to the base-flow stream value $(+3 \%)$ and typical atmospheric value $(+75 \%)$, would be consistent with approximately 20 percent of new precipitation nitrate in the sample. In samples least likely to have been affected by either nitrate reduction or precipitation runoff, values of $\delta^{15} \mathrm{~N}$ were about +7 to $+8 \%$, and $\delta^{18} \mathrm{O}$ values were about around $+3 \%$, respectively. Those values are consistent with nitrification as the source of the base-flow nitrate, with some mixture of organic sources of the nitrified nitrogen, as discussed subsequently in the Characterization of Nitrogen Sources section of this report.

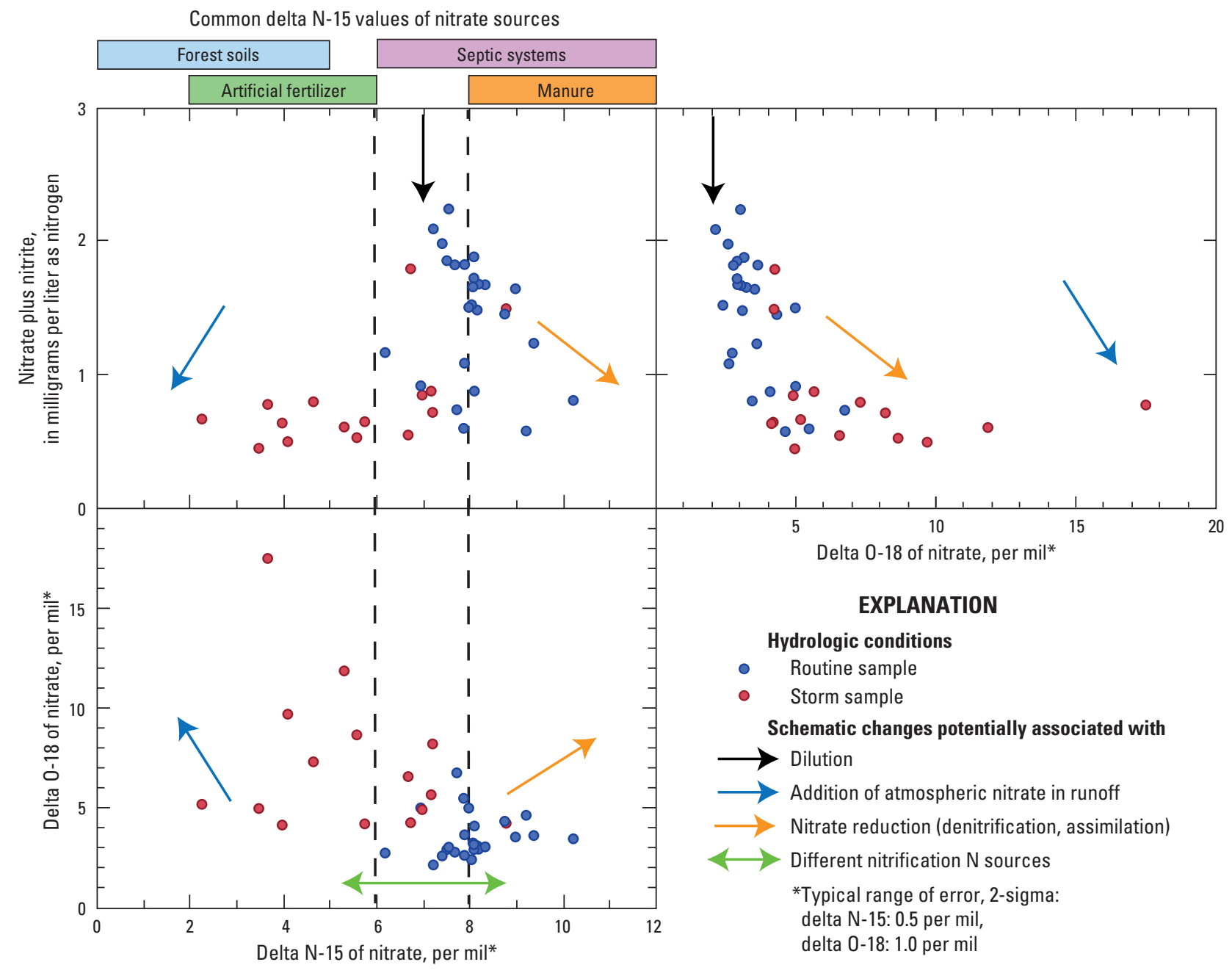

Figure 111. Variability in nitrate isotopes in discrete samples from the Difficult Run streamgage and potential causes for variability, 2011-2013. 


\section{Surrogate Models for the Computation of Sediment and Nutrient Loads}

The discrete and continuous water-quality data were subsequently analyzed to explore the development of surrogate regression models to predict SSC and TN and TP concentrations. The development of these surrogate models is critical to the computation of constituent loads and an improved understanding of the watershed function.

\section{Model Development}

Standard USGS multiple linear-regression methods were used to develop the best surrogate models (Helsel and Hirsch, 2002; Jastram and others, 2009; Rasmussen and others, 2009); a detailed overview of the model selection process is offered in the Development of Surrogate WaterQuality Models and Computation of Loads section of this report. For Difficult Run, relatively common load model formulations were observed to provide the strongest predictive models for SSC and TN and TP concentrations; consequently, no other common model formulations are presented (table 38; figs. 112-114).

For SSC, the best model included turbidity and flow terms, which is a typical surrogate model formulation SSC. For prediction of TN concentrations, the best predictor always included the continuous nitrate data, which was expected because the vast majority of the nitrogen in Difficult Run was in the form of nitrate at the intensive monitoring site. The best nitrate model also included a significant flow term, indicating that TN transport in Difficult Run was best predicted by a nitrate concentration component and a flow component. For the prediction of TP concentrations, the best concentration model included flow and turbidity, which is a common surrogate model formulation for TP (Jastram and others, 2009).

\section{Interpretation of the Computed Loads}

After developing surrogate models for estimating concentrations of suspended sediment, TN, and TP, 2013 water-year loads of these constituents were computed by using the record of continuous flow (from the streamgage) and predicted water quality (from the regression equations in table 38). Because the continuous water-quality monitors at Difficult Run were not installed until early October 2012, only the loads for the 2013 water year are presented. Methods for the replacement of missing records are provided in the Development of Surrogate Water-Quality Models and Computation of Loads section of this report. The USGS software program LOADEST was used for these computations because the computed load can be calculated with confidence intervals around the predicted load, which is needed for comparisons between water years and sites.

The 2013 water-year SSC load is presented in figure 115, along with the total flow for the water year. Because the hydrology during the 2013 water year was fairly typical, the surrogate SSC loads computed for the 2013 water year are likely fairly typical for the Difficult Run watershed. The total sediment load is estimated to be just over 8,000 tons of sediment during the water year. Normalizing the Difficult Run loads to the watershed area (to compute a sediment yield) results in a sediment yield of approximately 143 tons per square mile (tons $/ \mathrm{mi}^{2}$ ), which is almost a factor of 4 less than the 546-tons $/ \mathrm{mi}^{2}$ sediment-loading rates that have been documented for headwater streams in Fairfax County, Virginia (Jastram, 2014, based on an average of sediment-loading rates from USGS stations 01645762 and 01645704). The reduced sediment export rates measured at the downstream Difficult Run site (relative to the headwater site studies by Jastram, 2014) are likely related to deposition of eroded

Table 38. Details of the top-ranked suspended sediment, total nitrogen, and total phosphorus concentration estimation models for the Difficult Run streamgage.

$[<$, less than; ln, natural logarithm]

\begin{tabular}{|c|c|c|c|c|c|c|}
\hline $\begin{array}{l}\text { Explanatory } \\
\text { variables }\end{array}$ & $\begin{array}{c}\text { Model } \\
\text { coefficient }\end{array}$ & $\mathrm{p}$-value & $\begin{array}{c}\text { Variance } \\
\text { inflation factor }\end{array}$ & $\begin{array}{c}\text { Number of } \\
\text { observations }\end{array}$ & $\begin{array}{l}\text { Adjusted coefficient } \\
\text { of determination }\end{array}$ & Mallows' $\mathrm{Cp}$ \\
\hline \multicolumn{7}{|c|}{ Suspended-sediment concentration } \\
\hline Intercept & 0.070 & 0.025 & & & & \\
\hline $\ln$ (Flow) & 0.223 & 0.194 & 4.49 & 42 & 0.848 & 16.55 \\
\hline $\ln$ (Turbidity) & 0.952 & $<0.001$ & 4.49 & & & \\
\hline \multicolumn{7}{|c|}{ Total nitrogen } \\
\hline Intercept & -0.143 & $<0.001$ & & & & \\
\hline $\ln$ (Flow) & 0.098 & $<0.001$ & 1.17 & 42 & 0.867 & 9.71 \\
\hline Nitrate-N & 0.525 & $<0.001$ & 1.17 & & & \\
\hline \multicolumn{7}{|c|}{ Total phosphorus } \\
\hline Intercept & -4.841 & $<0.001$ & & & & \\
\hline $\ln$ (Flow) & 0.005 & 0.954 & 4.49 & 42 & 0.882 & 39.84 \\
\hline $\ln$ (Turbidity) & 0.649 & $<0.001$ & 4.49 & & & \\
\hline
\end{tabular}



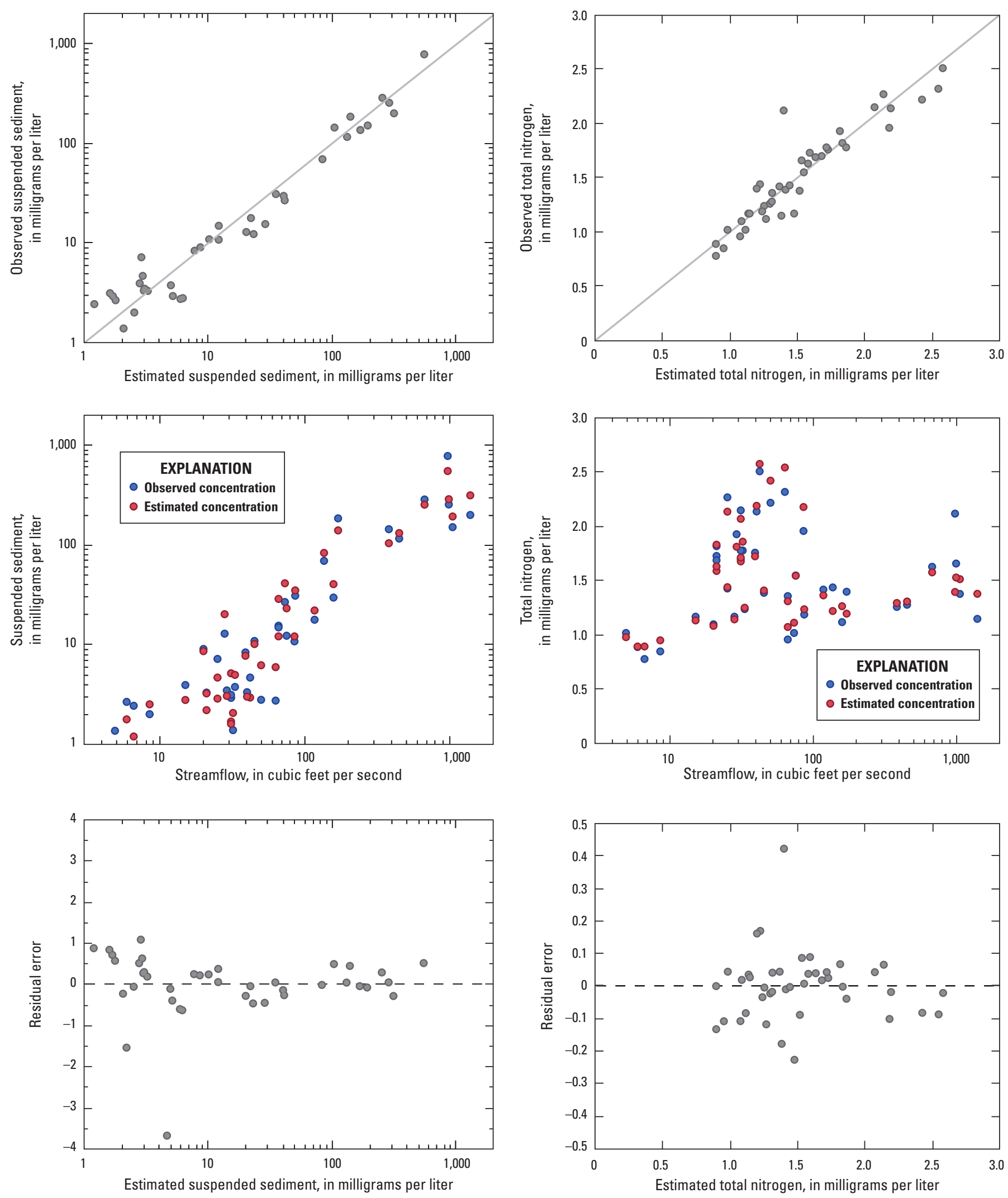

Figure 112. Observed and estimated values from the best suspended-sediment surrogate model for the Difficult Run streamgage and the residual plot of model predictions, 2011-2013.

Figure 113. Observed and estimated values from the best total nitrogen surrogate model for the Difficult Run streamgage and the residual plot of model predictions, 2011-2013. 

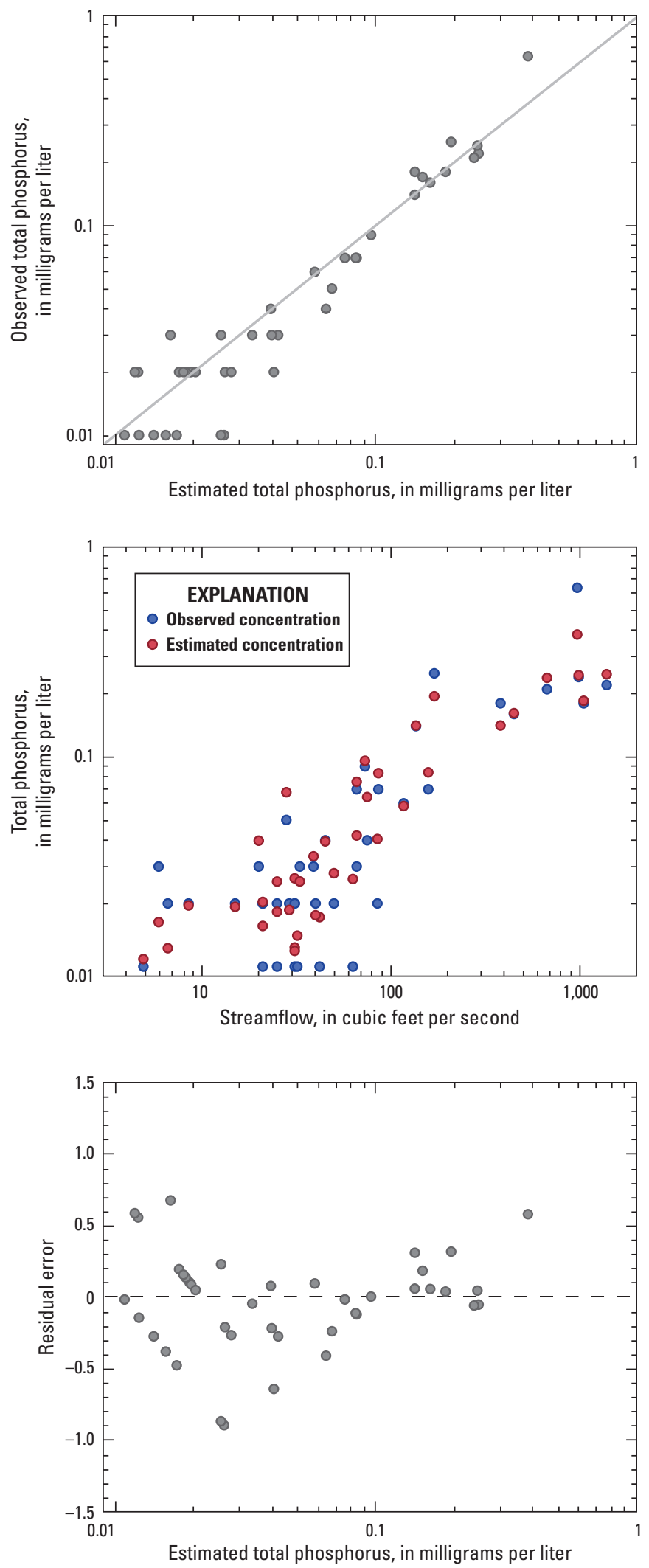

Figure 114. Observed and estimated values from the best total phosphorus surrogate model for the Difficult Run streamgage and the residual plot of model predictions, 2011-2013. sediment on the well-developed floodplains in the lower part of the watershed (Noe and others, 2013). Sediment loading within Difficult Run was highly episodic, with the seven largest storms generating nearly 95 percent of the estimated sediment load (fig. 116). The largest storm event (October 2012) generated more than 20 percent of the annual sediment load. Additional years of data will be required before comparisons between water years can be made to better understand intra-annual variability.

The 2013 water-year TN load for Difficult Run is presented in figure 117 along with the total flow for the water year. Because the hydrology during the 2013 water year was fairly typical, the surrogate TN loads computed for the 2013 water year were likely fairly typical for the Difficult Run watershed, and the annual total nitrogen loading for Difficult Run is approximately $140,000 \mathrm{lb} / \mathrm{yr}$. This estimated load is based on 288 days of the water year because the site was brought online on October 19 and 2 months of nitrate data were unavailable between May and July due to instrumentation fouling. This fouling was a result of increased turbidity caused by frequent stormflows that blocked the optic window on the nitrate monitor. Streamflow exceeded the 95 percent percentile of $153 \mathrm{ft}^{3} / \mathrm{s}$ eight times during this period, with a peak flow of $1,470 \mathrm{ft}^{3} / \mathrm{s}$ on June 11 . Based on previously measured high-flow events, the 2013 TN load may be underpredicted by about 10 percent due to this lapse in data collection. The collection of quality data through high-flow events was improved with the addition of a wiper system in July 2013. The 2013 nitrogen load can be normalized by basin area to compute a yield of approximately 2,500 pounds per square mile $\left(\mathrm{lb} / \mathrm{mi}^{2}\right)$ of nitrogen, which is substantially less than the median yield of $5,700 \mathrm{lb} / \mathrm{mi}^{2}$ that was observed in the headwater streams of Fairfax County by Jastram (2014), theoretically because of spatial variations in Difficult Run nitrogen sources, as well as in-stream processing and stream interaction with floodplains during storms (Noe and others, 2013). Interestingly, the TN load accumulation seemed to occur more gradually and is less driven by episodic inputs than the SSC accumulation (fig. 118). This more gradual accumulation rate is likely caused by the persistent nitrogen loading that occurred during base-flow conditions that support relatively steady nitrogen loading that is only occasionally altered by significant flow events. Additional years of monitoring will be needed before total nitrogen loading rates between water years can be compared. 

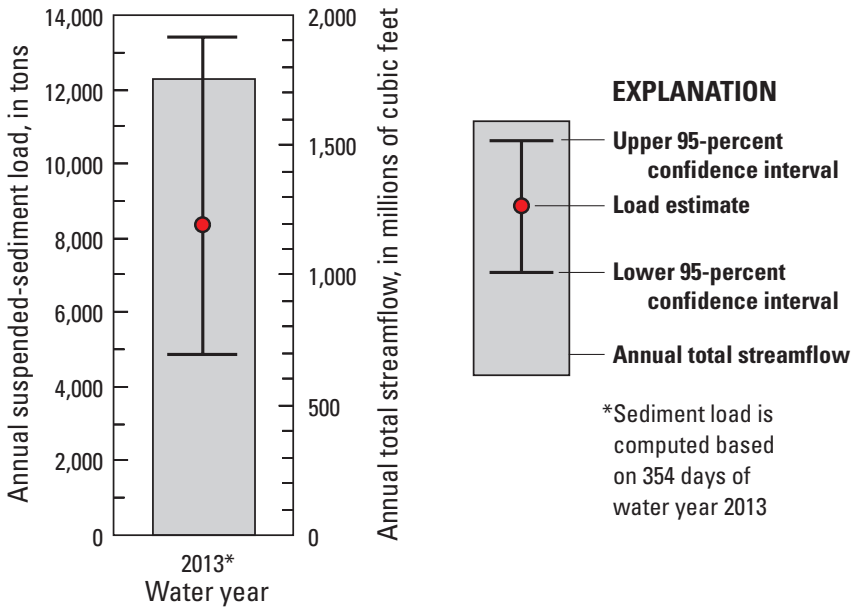

Figure 115. Suspended-sediment load and total annual streamflow at the Difficult Run streamgage for the 2013 water year.
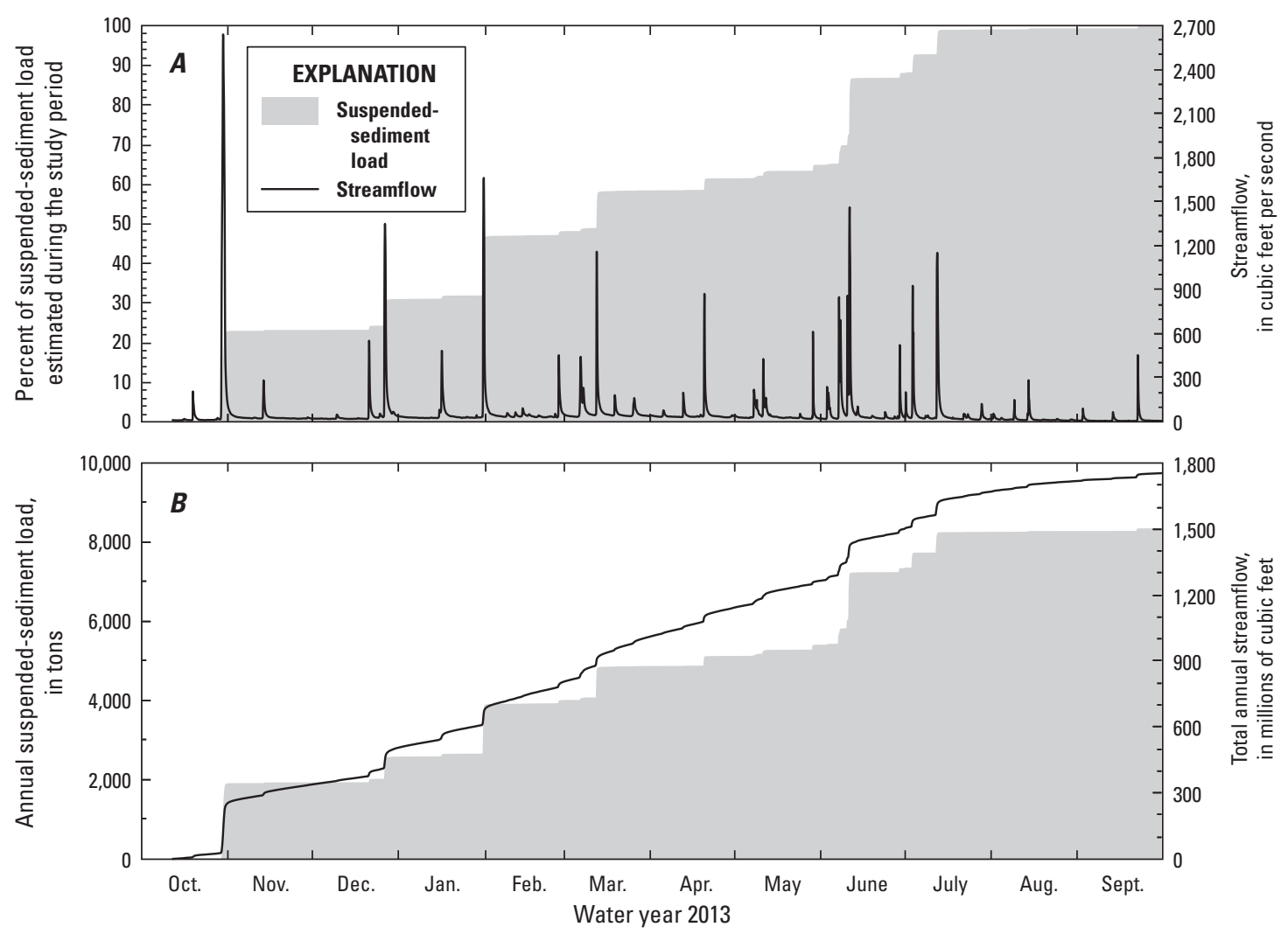

Figure 116. $(A)$ The estimated percentage of suspended-sediment load accumulated and the hydrograph during the period of study and $(B)$ the accumulation of load and streamflow at the Difficult Run streamgage for the 2013 water year. 


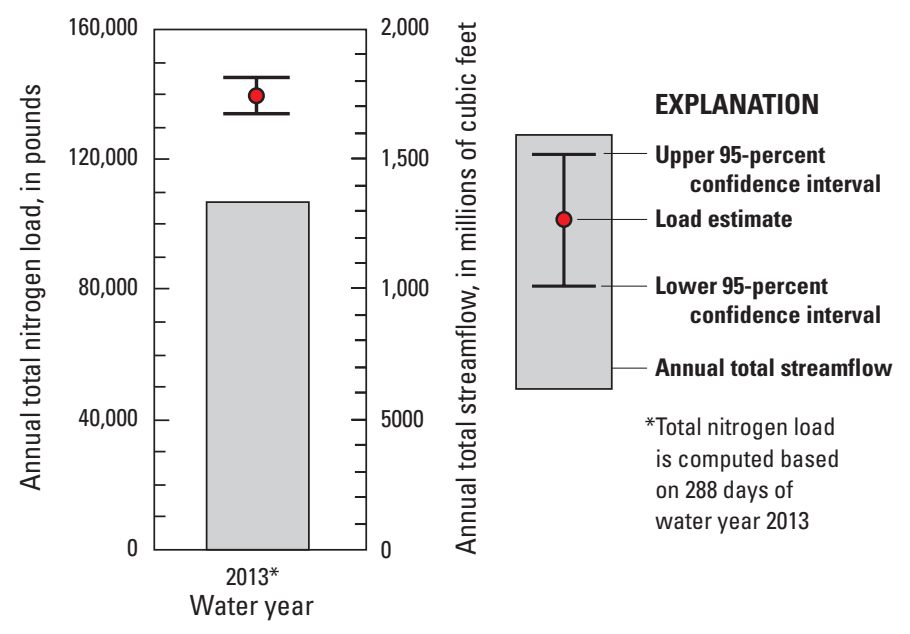

Figure 117. Total nitrogen load and total annual streamflow at the Difficult Run streamgage for the 2013 water year.
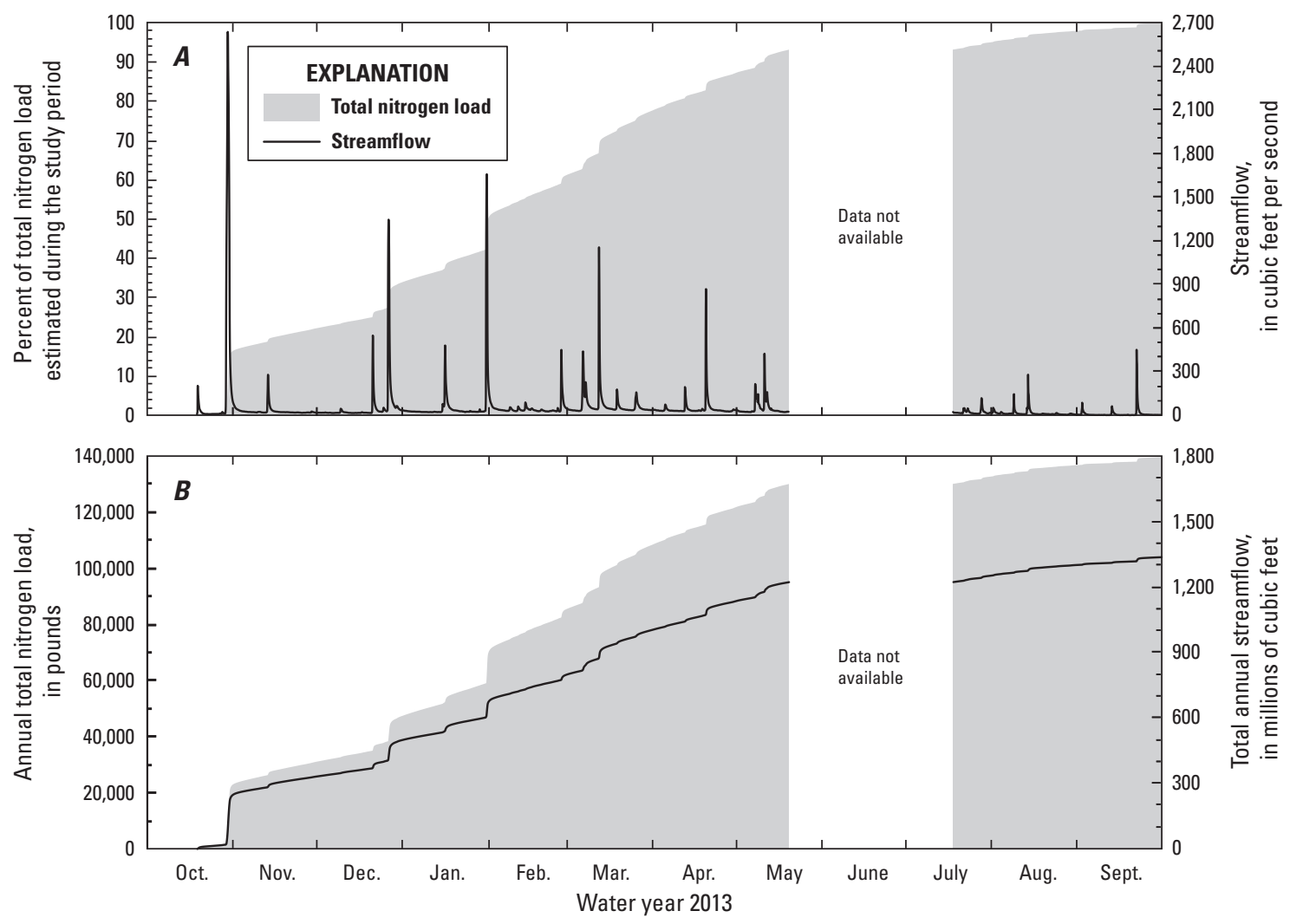

Figure 118. $(A)$ The estimated percentage of total nitrogen load accumulated and the hydrograph during the study period and $(B)$ the accumulation of load and streamflow at the Difficult Run streamgage for the 2013 water year. 
The 2013 water-year TP load is presented in figure 119 , along with the total flow for the water year. Given the typical discharge associated with 2013, the typical TP load for Difficult Run is estimated to be about $14,000 \mathrm{lb} / \mathrm{yr}$. Relative to the headwater contributions throughout Fairfax County (Jastram, 2014), the Difficult Run TP yield at the downstream gage $\left(250 \mathrm{lb} / \mathrm{mi}^{2}\right)$ is much less than the typical headwater yields (median of $485 \mathrm{lb} / \mathrm{mi}^{2}$, based on an average of USGS stations 01645762 and 01645704 ), likely because of variations in Difficult Run erosion rates and floodplain-deposition patterns, as well as in-stream processing. The cumulative loading plot (fig. 120) for TP is similar to that of suspended sediment, likely because much of the phosphorus is moving in association with sediment. Unlike Smith Creek, which demonstrates a base-flow loading of phosphorus, nearly all the TP loading in Difficult Run occurs in association with storm events and not during base-flow conditions.
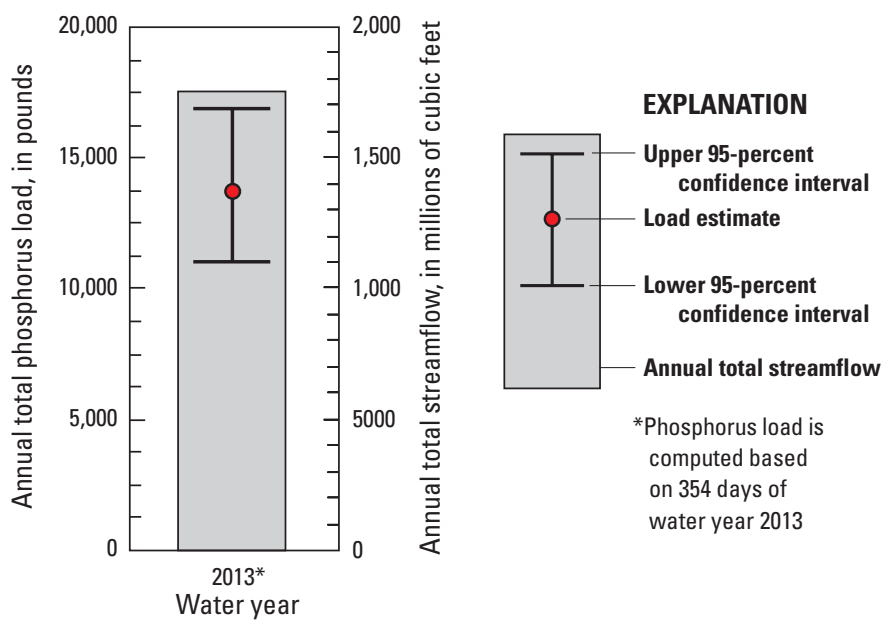

Figure 119. Total phosphorus load and total annual streamflow at the Difficult Run streamgage for the 2013 water year.
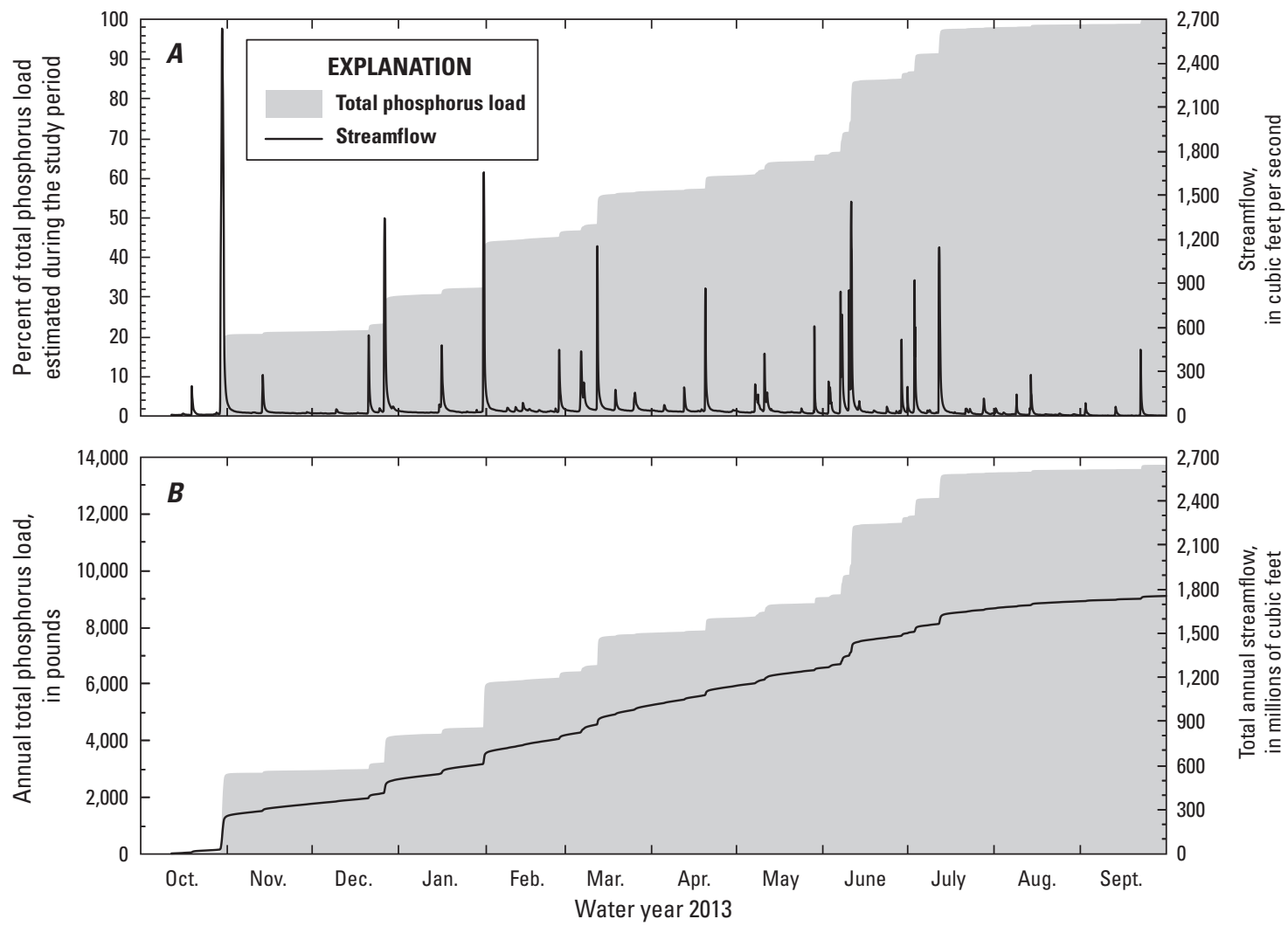

Figure 120. (A) The estimated percentage of total phosphorus load accumulated and the hydrograph during the period of study and $(B)$ the accumulation of load and streamflow at the Difficult Run streamgage for the 2013 water year. 


\section{Spatial Patterns in Water Quality}

Synoptic sampling throughout the Difficult Run watershed was completed in September 2011, December 2011, April 2012, and May 2013 during base-flow conditions. The relative wetness of the basin varied during these events, with the highest flows measured in December 2011 and lowest flows in September 2011 (fig. 121). Flow increased in the downstream direction with the addition of each contributing tributary, and the gain in streamflow between sampling stations was directly proportional to drainage area in all but the driest event.

Streamflow measurements were higher than expected at some headwater sites following a localized rain event during the September 2011 synoptic sampling. Opportunities to perform such time-intensive sampling during base-flow conditions were limited, and water-chemistry results from this synoptic sampling were rigorously reviewed for any potential biases. Six headwater sites with disproportionately high discharges were removed from the basin-wide load analyses because they misrepresented the spatial base-flow patterns of nitrogen and phosphorus accumulation. These samples were excluded because their ratio of discharge to drainage area was higher than the $95^{\text {th }}$ percentile of samples from all events (fig. 122). These six samples were included in all other analyses because the majority of their water-chemistry results were minimally affected. Large-scale spatial patterns and a conceptual understanding of basin processes were still achieved from sampling after this rain event.
In general, total nitrogen loads increased downstream along the main channel of Difficult Run and ranged from $216 \mathrm{lb} /$ day during the driest synoptic sampling event of September 2011 to $463 \mathrm{lb} /$ day during the wettest synoptic sampling event of December 2011 (fig. 123). TN concentrations remained relatively constant along the stream channel (fig. 124), indicating that nitrogen loads were mostly controlled by changes in flow. Loads were highest at the streamgage, site 30 , during all events (fig. 123). This is the most downstream sampling location that had the highest streamflow. Loads from sampled tributaries were comparatively low, but some locations, such as Captain Hickory Run (sites 27, 25, 33, and 34), had elevated total nitrogen concentrations (fig. 124).

TP loads also accumulated along the Difficult Run main channel and ranged from to $1.8 \mathrm{lb} /$ day during the driest synoptic sampling event of September 2011 to $2.7 \mathrm{lb} /$ day during the wettest event of December 2011 (fig. 125). Phosphorus concentrations were generally less than $0.02 \mathrm{mg} / \mathrm{L}$, but elevated concentrations occurred occasionally in some tributaries (fig. 126). Phosphorus was significantly correlated $(\mathrm{p}<0.05)$ with turbidity measurements, so these elevated concentrations were likely influenced by the quantity of sediment present during sampling. Sites with elevated TP concentrations were variable between events, but low flows resulted in loads that were consistently small at these sites. 


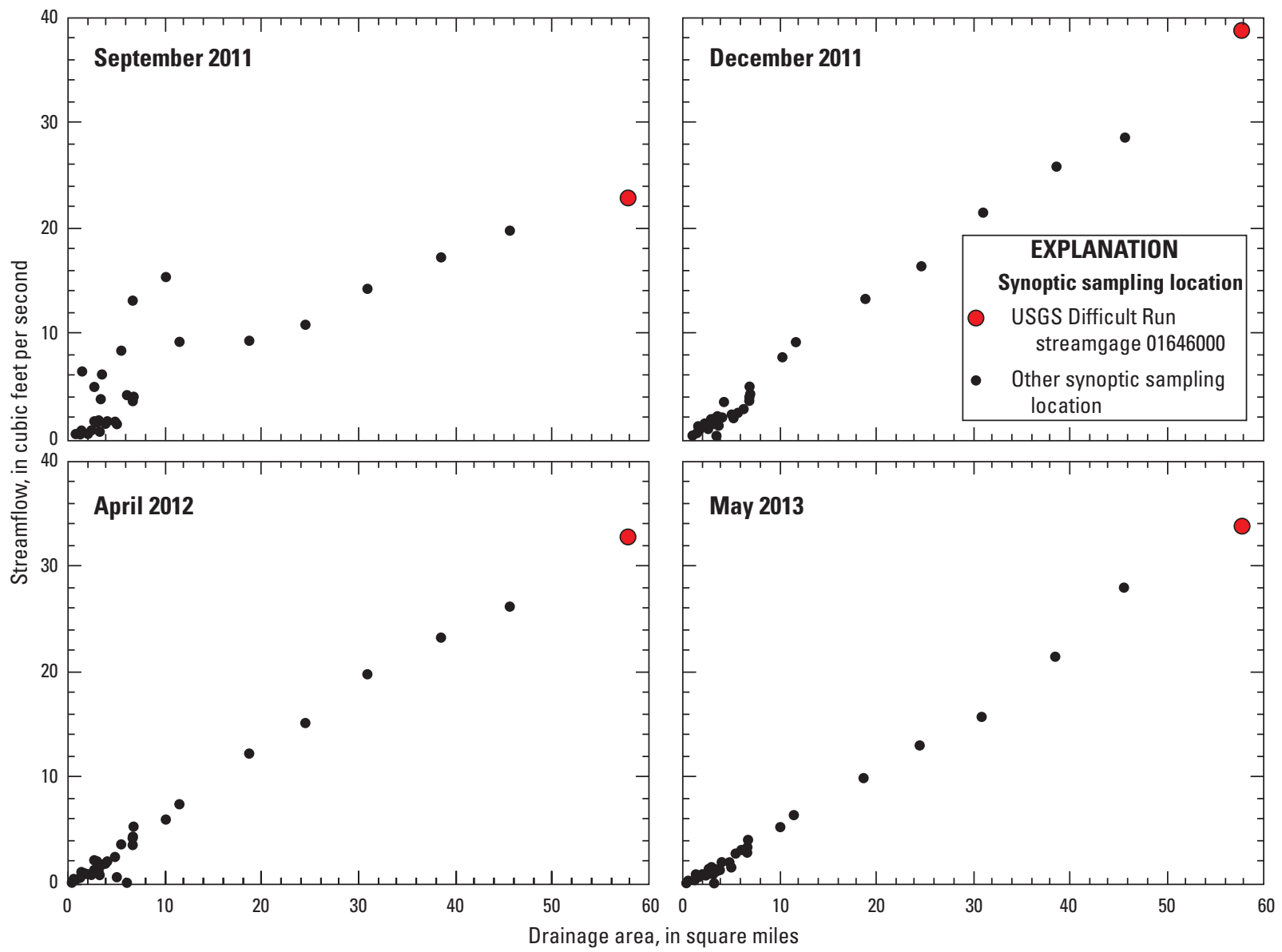

Figure 121. Streamflow and drainage area for samples collected from the Difficult Run watershed during each synoptic event.

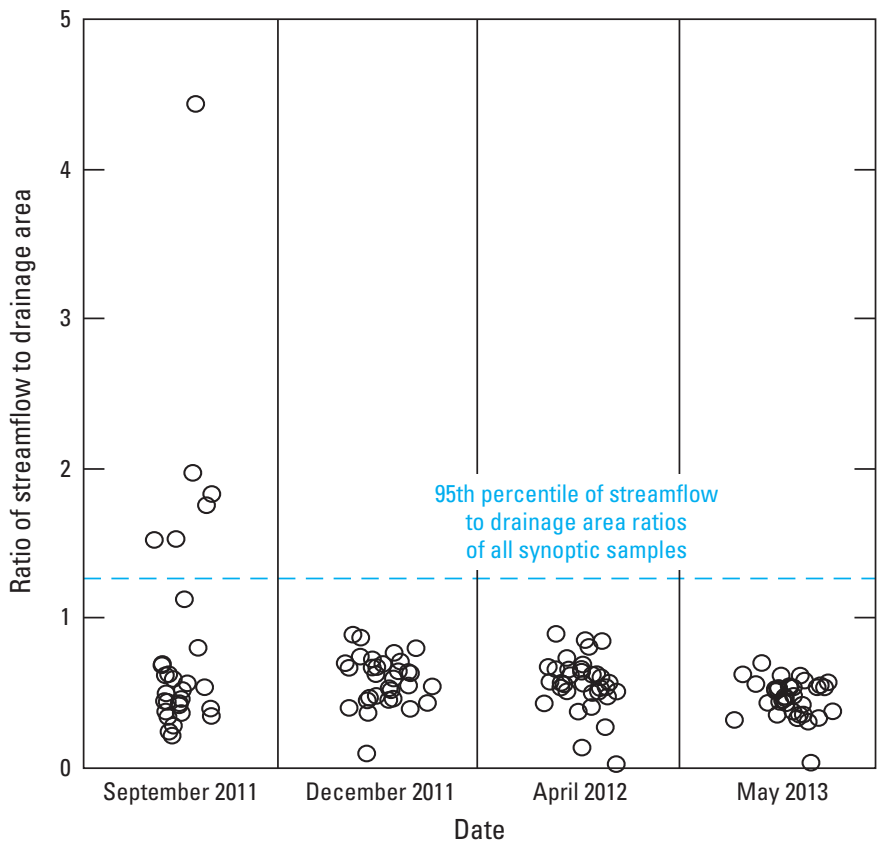

Figure 122. Ratio of streamflow to drainage area for each monitoring location during the synoptic sampling events in the Difficult Run watershed. 

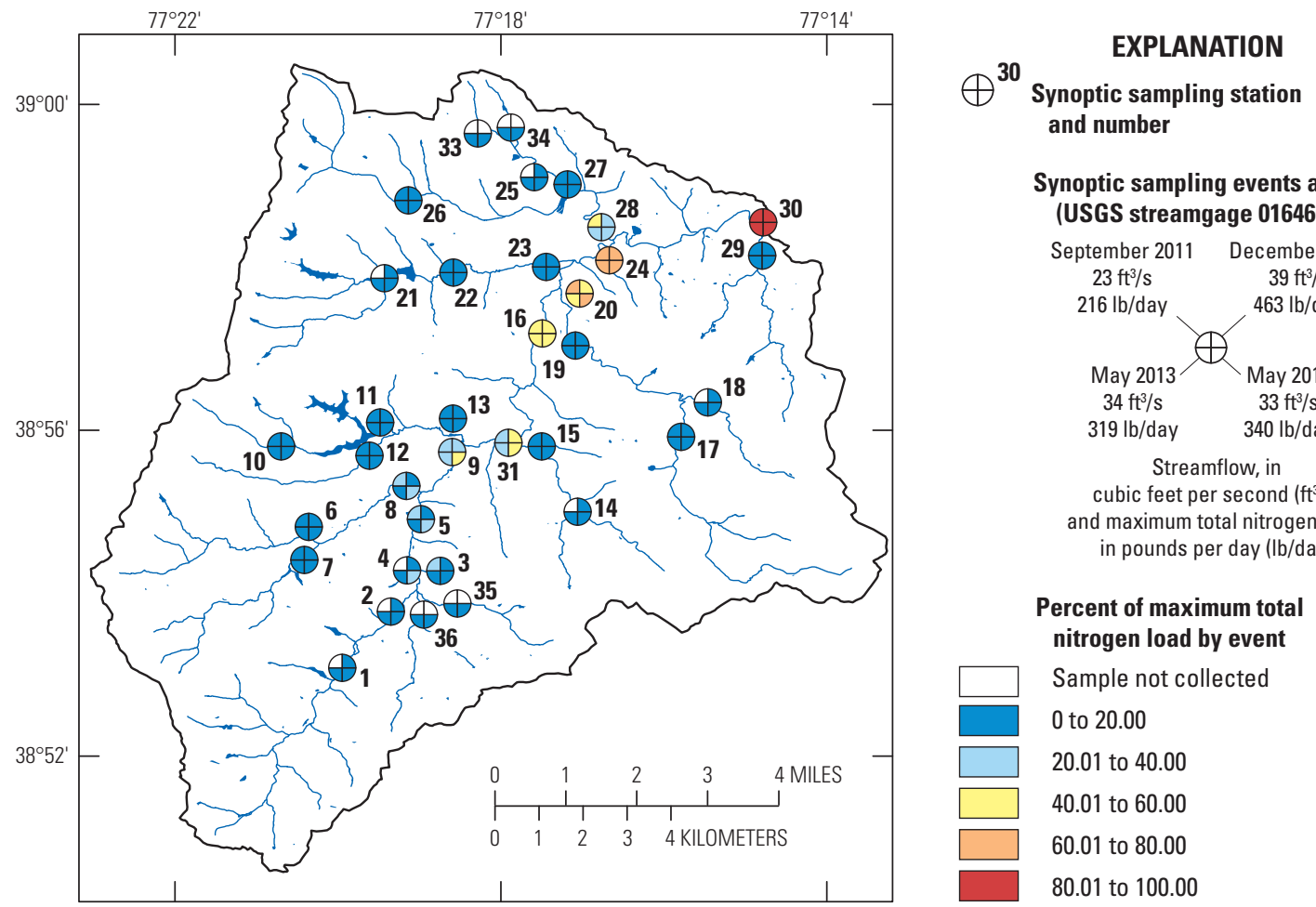
Synoptic sampling events at site 30 (USGS streamgage 01646000)
September 2011 December 2011

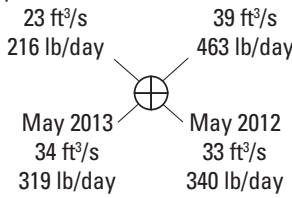 Streamflow, in cubic feet per second $\left(\mathrm{ft}^{3} / \mathrm{s}\right)$ and maximum total nitrogen load, in pounds per day (lb/day)

\section{Percent of maximum total} nitrogen load by event

Sample not collected

0 to 20.00

20.01 to 40.00

40.01 to 60.00

60.01 to 80.00

80.01 to 100.00

Streams from U.S. Geological Survey National Hydrography Geodatabase (2013)

Drainage area from Hayes and Wiegand (2006)

North American Datum of 1983

Figure 123. Monitoring locations, the percentage of the maximum total nitrogen load measured during each synoptic sampling event, and the streamflow network in the Difficult Run watershed.
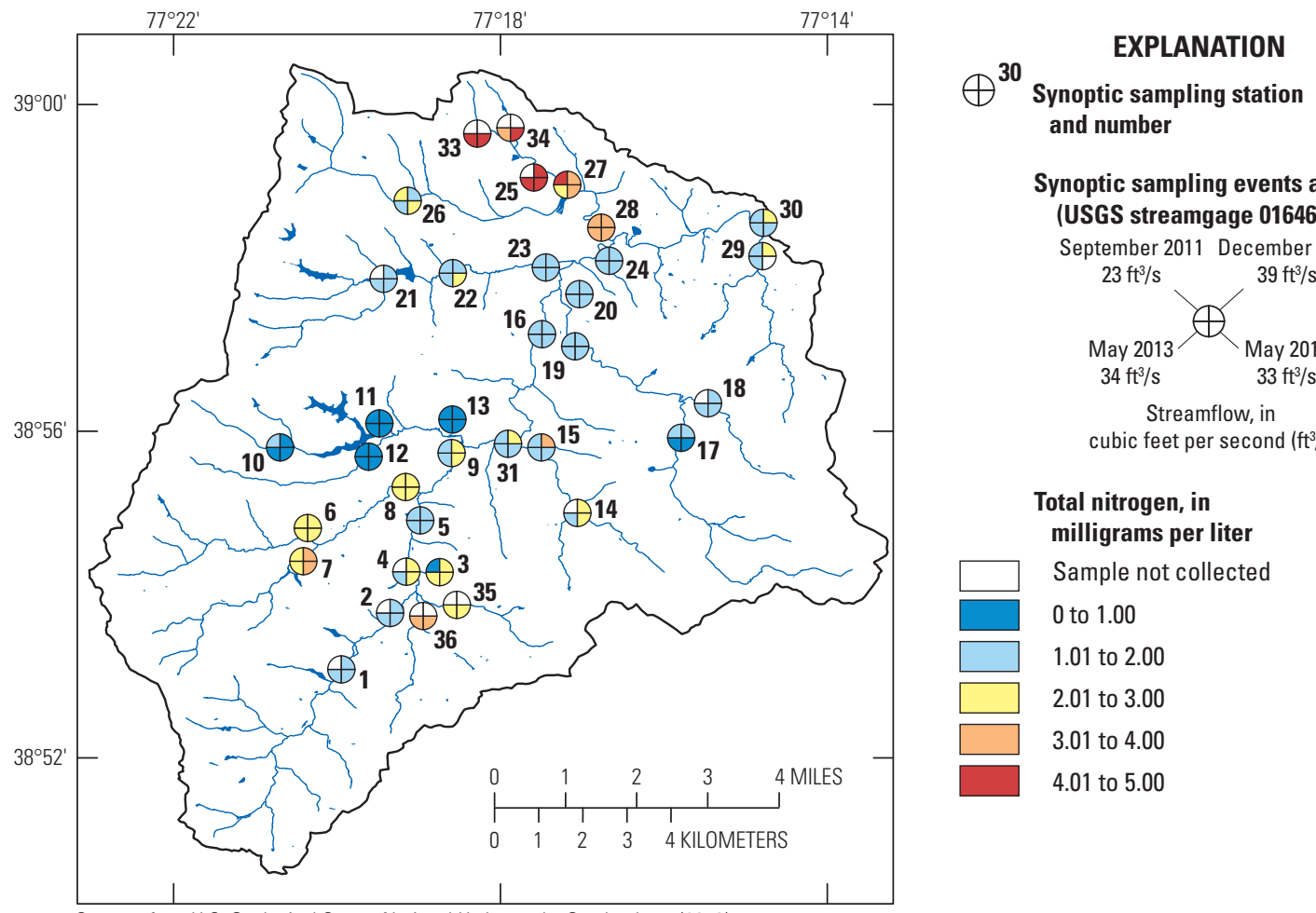

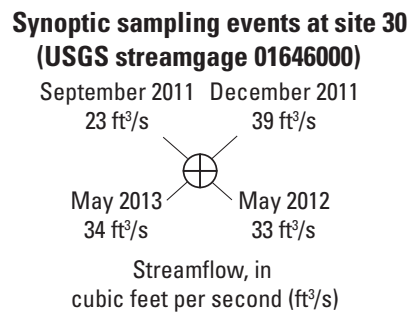

Total nitrogen, in milligrams per liter Sample not collected 0 to 1.00

1.01 to 2.00

2.01 to 3.00

3.01 to 4.00

4.01 to 5.00

Streams from U.S. Geological Survey National Hydrography Geodatabase (2013) Drainage area from Hayes and Wiegand (2006) North American Datum of 1983

Figure 124. Monitoring locations, the total nitrogen concentration measured during each synoptic sampling event, and the streamflow network in the Difficult Run watershed. 

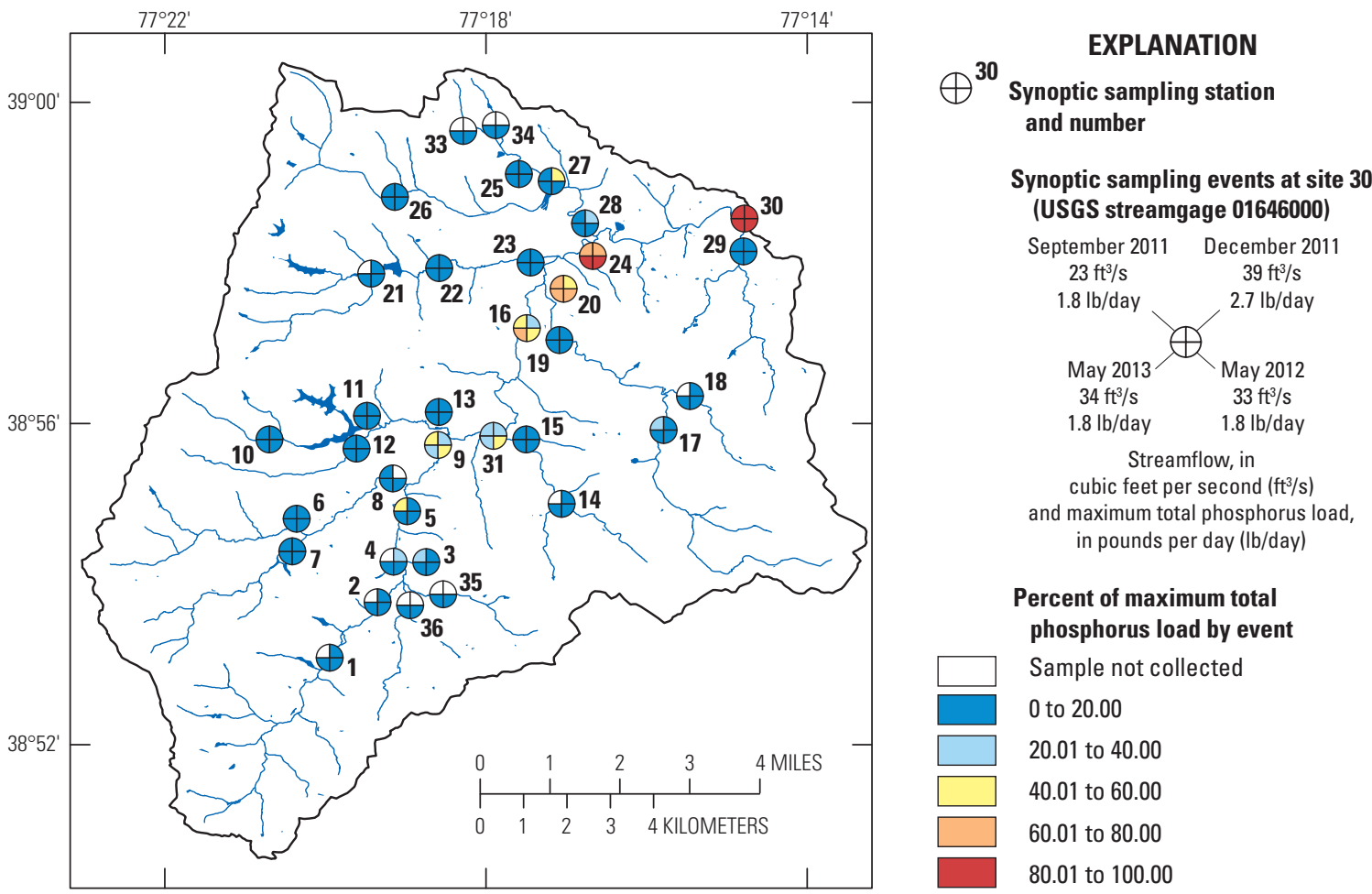

Streams from U.S. Geological Survey National Hydrography Geodatabase (2013)

Drainage area from Hayes and Wiegand (2006)

North American Datum of 1983

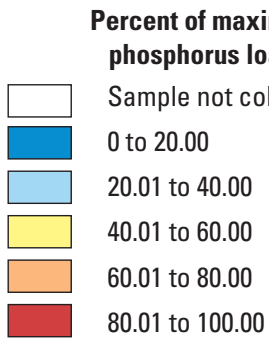

Figure 125. Monitoring locations, the percentage of the maximum total phosphorus load measured during each synoptic sampling event, and the streamflow network in the Difficult Run watershed.
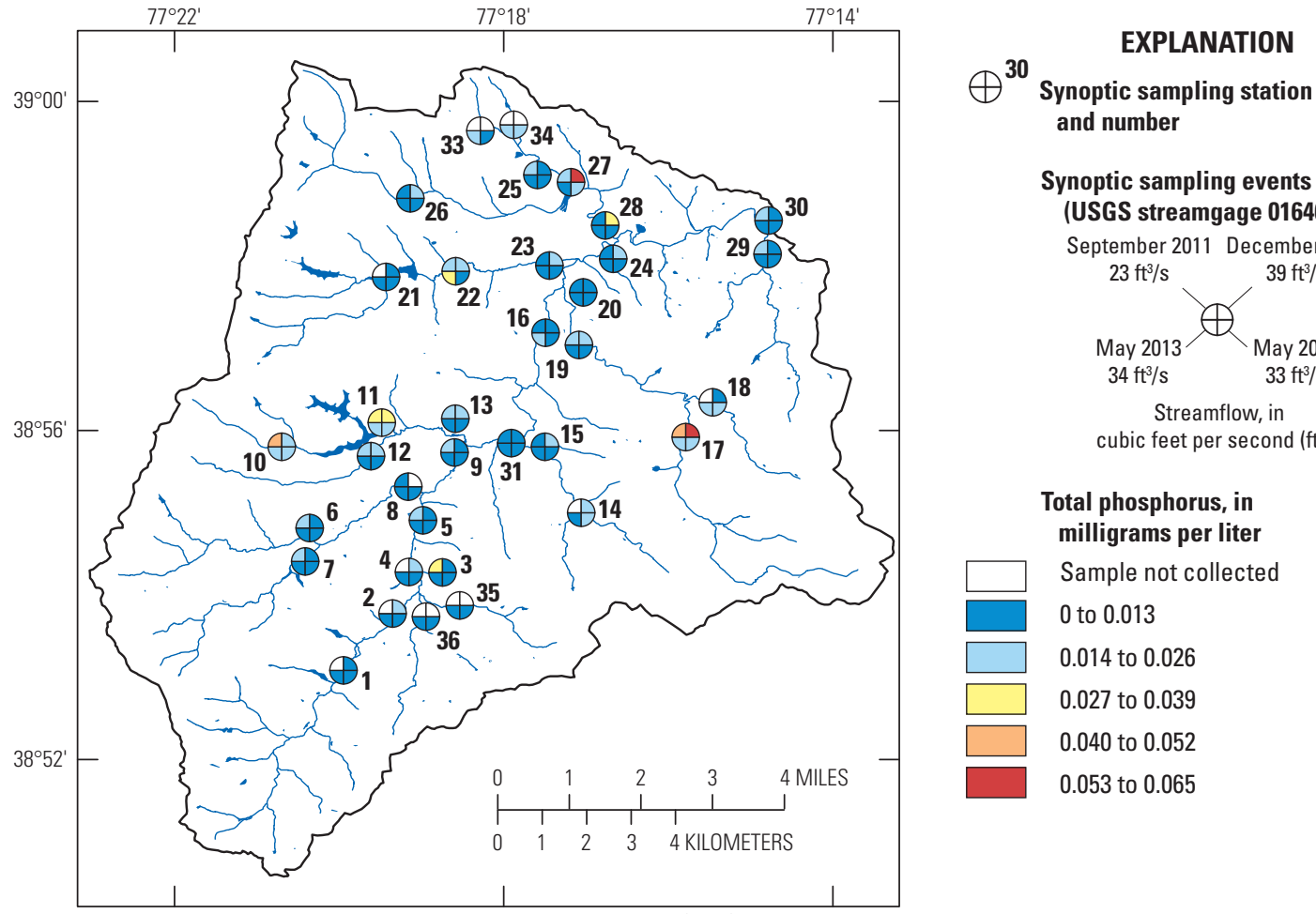

Synoptic sampling events at site 30 (USGS streamgage 01646000)

September 2011 December 2011

$23 \mathrm{ft}^{3} / \mathrm{s}$

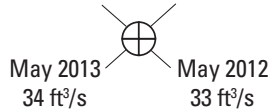

$34 \mathrm{ft}^{3} / \mathrm{s} \quad 33 \mathrm{ft}^{3} / \mathrm{s}$

Streamflow, in

cubic feet per second $\left(\mathrm{ft}^{3} / \mathrm{s}\right)$

Total phosphorus, in milligrams per liter

Sample not collected

0 to 0.013

0.014 to 0.026

0.027 to 0.039

0.040 to 0.052

0.053 to 0.065

Streams from U.S. Geological Survey National Hydrography Geodatabase (2013)

Drainage area from Hayes and Wiegand (2006)

North American Datum of 1983

Figure 126. Monitoring locations, the total phosphorus concentration measured during each synoptic sampling event, and the streamflow network in the Difficult Run watershed. 
Water-quality samples from all four synoptic events were analyzed by using a single cluster analysis (fig. 127). Four groups were identified, and the relative geochemical composition of each group is characterized below. The interpretation of the resulting groups of sites provided a better understanding of spatial water-quality patterns throughout the Difficult Run watershed.

Cluster \#1 - Difficult Run Type - The largest group identified from the cluster analysis contained 76 of the 129 samples (fig. 127). Samples within this group are represented by stations along the Difficult Run stream channel in the upper and lower parts of the watershed (fig. 128). Water-quality patterns are variable in the headwaters of the watershed, but these patterns are masked in the well mixed and homogeneous flows of the main channel. This homogenization effect is likely amplified by the lack of topographic or geologic variability in the watershed. The remaining cluster groups capture the variability in the headwater sampling stations.
Cluster \#2 - High Nitrate Type - Membership within the second cluster was assigned to all Captain Hickory Run and Little Difficult Run sampling locations (fig. 128). These stations are distinguished by elevated nitrate concentrations that are in contrast to an otherwise dilute water chemistry (fig. 127). Because these subwatersheds are characterized by low-density and estate-residential land uses (Jastram, 2014), the elevated nitrate concentrations were unexpected and may be the result of wastewater inputs (from septic systems) or increased fertilizer application rates on these larger lots (see the Characterization of Nitrogen Sources section, below, for further information). The less pronounced urban effect on these streams is likely reflected in dilute water chemistry; Captain Hickory Run and Little Difficult Run have relatively low levels of sodium, chloride, and specific conductance.

Cluster \#3 - Low Nitrate Type - Five sampling stations were assigned membership to the third cluster group (fig. 127). This group had relatively dilute nitrate concentrations and more variable measures of TP, iron, ammonium, and

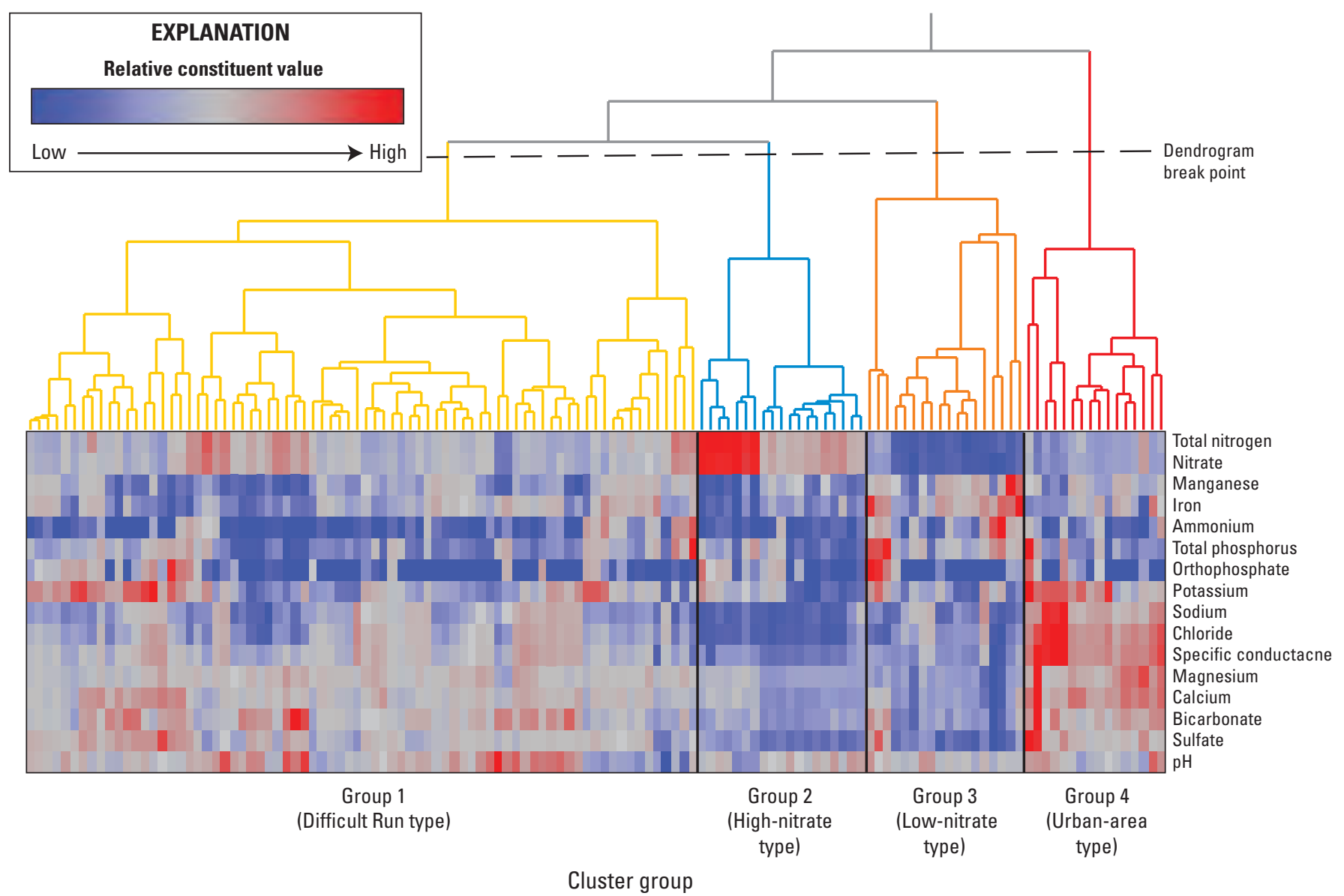

Figure 127. Samples collected from each synoptic event within the Difficult Run watershed with a heat map of constituent values and the breakpoint used to produce four cluster groups. 


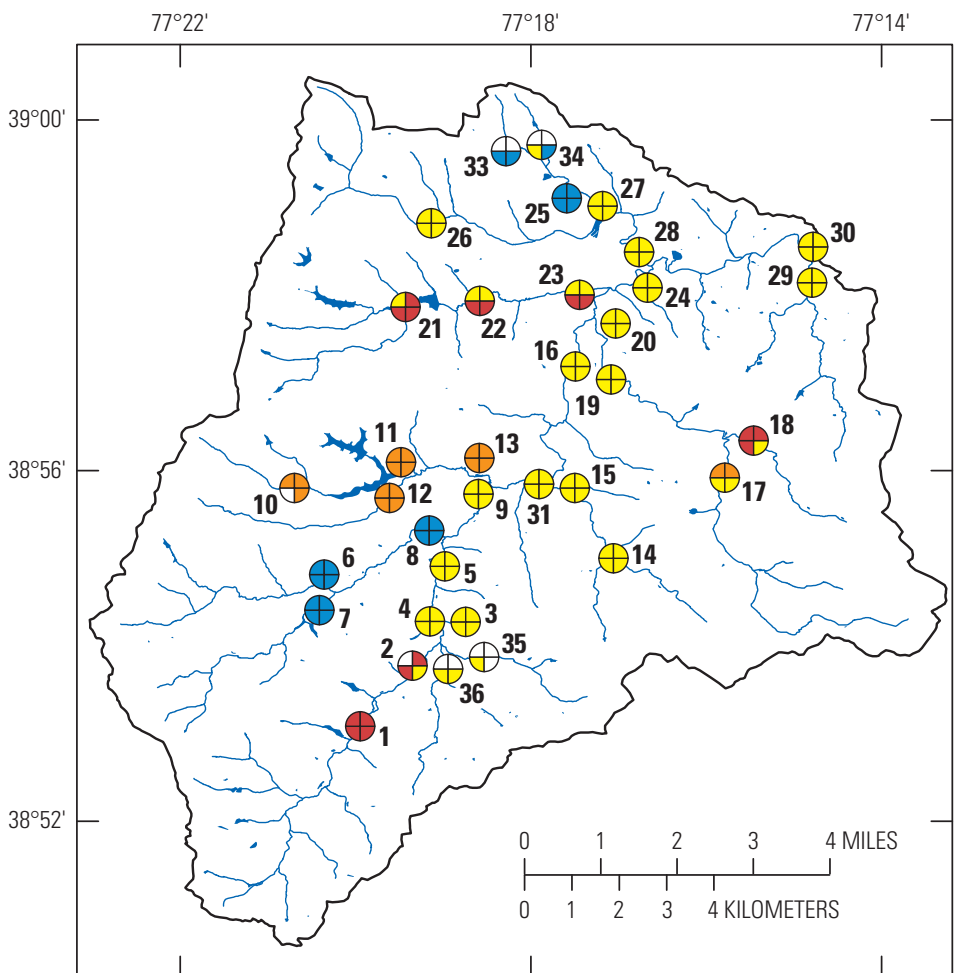

Streams from U.S. Geological Survey National Hydrography Geodatabase (2013) Drainage area from Hayes and Wiegand (2006) North American Datum of 1983

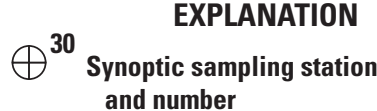

and number

Synoptic sampling events at site 30 (USGS streamgage 01646000)

September 2011 December 2011

$23 \mathrm{ft}^{3} / \mathrm{s}$ $39 \mathrm{ft}^{3} / \mathrm{s}$

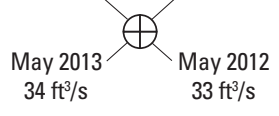

Streamflow, in

cubic feet per second $\left(\mathrm{ft}^{3} / \mathrm{s}\right)$

Cluster group

Sample not collected

Group 1-Difficult Run type

Group 2-High nitrate type

Group 3-Low nitrate type

Group 4-Urban area type

Figure 128. Synoptic sampling events at monitoring locations in the Difficult Run watershed as grouped in a cluster analysis.

manganese than the other groups. Curiously, all synoptic sampling sites within Snakeden Branch were contained within this cluster, indicating that this watershed had lower nitrogen inputs or watershed processes that favored uptake and denitrification processes. Lower nitrogen inputs to this watershed could be related to the extensive amounts of stream manipulation and restoration within this watershed that may have enhanced conditions for nitrogen loss within the watershed, as well as other watershed factors (wastewater infrastructure, for example) that could reduce nitrogen inputs to these subwatersheds.
Cluster \#4 - Urban Area Type - These sites are distinguished by high specific conductivities and appear to be related to the imperviousness of the surrounding region (figs. 127 and 128). Sampling stations within this group are located within the headwaters of the watershed and are immediately downstream of Fairfax City, Tysons Corner, and Reston. The high sodium and chloride concentrations in samples from sites within this group are likely caused by runoff of deicing salts applied to the dense roadway network. 


\section{Characterization of Nitrogen Sources}

Characterization of the primary nitrogen sources in the Difficult Run watershed is important for making informed watershed-management decisions related to the implementation of BMPs. Nitrate concentration and isotope data were evaluated in combination with land-use data and model-based estimates to determine likely sources of surface-water nitrate. Based on the overall assessment, elevated nitrate concentrations appear to be caused by high septic system density in some Difficult Run subwatersheds.

The highest observed TN and nitrate concentrations were at sites 25, 33, and 34, which are within the Captain Hickory Run subwatershed (fig. 124). The Captain Hickory Run subwatershed is predominantly characterized by low-intensity residential (32 percent of watershed) and estate residential (47 percent of watershed) land uses and has the lowest population density of all subwatersheds within Difficult Run (Jastram, 2014; U.S. Census Bureau, 2012). Lot sizes within the Captain Hickory Run subwatershed are generally larger than those in other watersheds in Difficult Run, and this area has no sewage infrastructure in this area because all houses are served by septic systems. Subsequent analyses were performed to explore whether elevated nitrate concentrations in Captain Hickory Run and other Difficult Run subwatersheds were likely related to the presence of septic systems, or were possibly caused by excessive use of commercial fertilizers on lawns.

Spatial nitrate concentration patterns in Difficult Run correlated well with the presence of septic systems throughout the watershed (fig. 129), with higher concentrations of nitrate observed in areas that are served by septic systems. Subsequent analyses incorporating data from Difficult Run and other watersheds within Fairfax County (Jastram, 2014) demonstrated a statistically significant positive relation ( $p$-value $<0.0001$ ) between watershed nitrate concentrations and the septic system density (fig. 130). In-stream nitrate concentrations increase steadily with increasing septic density, but concentrations appeared to sharply increase once septic density exceeded 100 units per square mile, indicating that wastewater leachate from septic systems may be a substantial source of nitrate in these suburban streams. Monthly waterquality data from two subwatersheds outside of the sanitary sewer service area, Captain Hickory Run (site 25) and Little Difficult Run (site 6), were available for seasonal analysis as part of another water-quality project (Jastram, 2014). Nitrate concentrations exhibited no statistically significant seasonal pattern at either of these sites; for example, no evidence was found for seasonally elevated concentrations that might have been caused by runoff from excessive lawn fertilization in the spring or fall (fig. 131). Instead, during wet weather, the concentrations of nitrate in both streams generally decreased, which is a pattern more consistent with dilution of a groundwater source during storms.

The synoptic nitrate isotope results demonstrate a broad range of values and a number of patterns and processes to provide a basic understanding of the nitrogen sources within the Difficult Run watershed (fig. 132). Sites with relatively high nitrate concentrations typically had $\delta^{15} \mathrm{~N}$ values from $+7 \%$ to $+9 \%$, similar to those commonly attributed to sewage or septic system sources, although more complex mixtures including nitrate derived from other sources cannot be excluded. Nitrate isotope data generally do not indicate major fractionating losses along the main stream channel; $\delta^{18} \mathrm{O}$ values were relatively constant and similar to biogenic source values except during some high-flow events. The sites with the lowest nitrate concentrations also generally had relatively low $\delta^{15} \mathrm{~N}$ values, which may indicate recycled atmospheric and soil sources of nitrate and, in some cases, nitrate formed in upstream lakes. Only modest amounts of biologic processing are apparent in the data, because the greatest $\delta^{15} \mathrm{~N}$ values are generally not associated with elevated $\delta^{18} \mathrm{O}$ values. A statistically significant ( $\mathrm{p}$-value $\left.=0.0002\right)$ positive correlation was found between nitrate concentrations and $\delta^{15} \mathrm{~N}$ values - a pattern that would be more consistent with varying excess contributions from wastewater rather than from commercial lawn fertilizers (fig. 132). Furthermore, a positive correlation between the density of septic systems and $\delta^{15} \mathrm{~N}$ values supports an interpretation of excess contributions from wastewater (fig. 133). Some of the lowest nitrate $\delta^{18} \mathrm{O}$ values $(<2 \%$ ) were from Captain Hickory Run. Some studies indicate that $\delta^{18} \mathrm{O}$ of nitrate values from septic systems may be slightly lower than $\delta^{18} \mathrm{O}$ of nitrate values formed in soils, possibly because of rapid reactions and the presence of transient intermediate species in septic system drain fields (for example, Hinkle and others, 2008). Previous studies also indicate $\delta^{15} \mathrm{~N}$ values of $+7 \%$ (similar to Captain Hickory Run) are common for nitrate from septic systems (see figure 6 and associated references in the Interpretation of Nitrate Isotopes section of this report).

A mass-balance computation of nitrogen sources in the Captain Hickory Run watershed was prepared by using U.S. Census data, Fairfax County land-use data, and numerous publications that focus on septic and fertilizer leachate (table 39). While various assumptions related to application rates and leachate amounts were required, the mass-balance computation indicates that the mass of nitrogen available for export from potential septic system leachate could be approximately an order of magnitude greater than the mass of nitrogen expected to be available from inorganic fertilizer applications. Even though input loading of nitrogen to the watershed was generally similar between septic systems and fertilizer application in this mass-balance calculation, most of the fertilizer nitrogen presumably was assimilated by plants and cycled in soils, whereas nitrogen in septic system recharge was delivered to streams relatively efficiently in the absence of groundwater denitrification.

Historical land use within the Captain Hickory watershed has not always been low-density residential, which could affect present-day nitrate concentrations. Legacy land use included the presence of cattle farms in some areas, which could be a persistent source of nitrate leaching from soils 


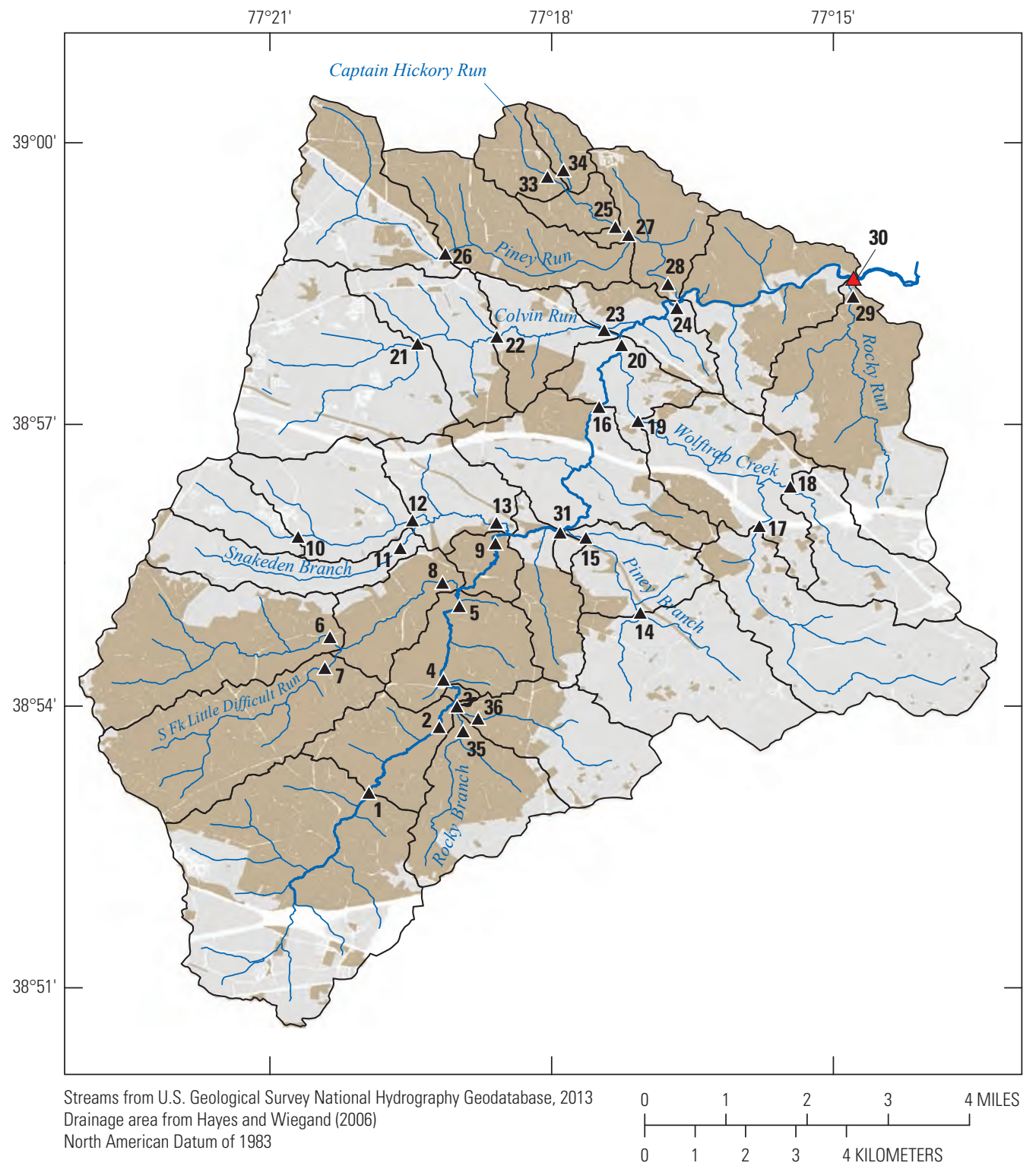

\section{EXPLANATION}

Septic/sewage coverage

(from Fairfax County GIS Branch, unpub. data, 2014)

Parcel not served by sewer

Parcel served by sewer
Difficult Run

Tributary to Difficult Run

Subwatershed boundary
$\triangle^{30}$ Monitoring site and identifier USGS streamgage 01646000
$\Delta^{18}$ Synoptic sampling location and identifier

Figure 129. Streamflow network, watershed boundaries of each monitoring location, and county-level tax parcels served and not served by sewage infrastructure in the Difficult Run watershed. 


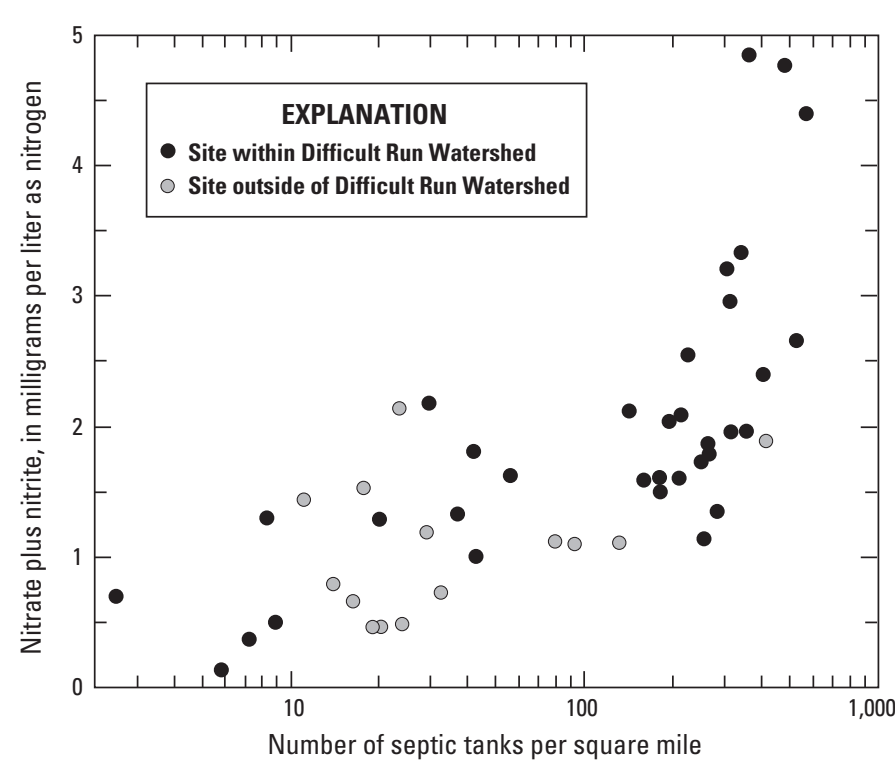

Figure 130. Median nitrate concentration results from synoptic sampling events within the Difficult Run watershed and from additional U.S. Geological Survey base-flow monitoring in Fairfax County compared to the septic tank density within the drainage area of each monitoring location. or in groundwater; however, most of the basin transitioned from agricultural to residential land use during the 1970s and 1980s, and legacy land use from 30+ years ago is considered relatively unlikely to be the primary driver of nitrate patterns or sources within the watershed.

Dominant nitrogen sources indicated by land-use-based estimates and nitrate isotopes were compared with results from the SPARROW Chesapeake Bay TN model (fig. 134). According to the model, urban sources contributed the most nitrogen to the watershed, followed by atmospheric deposition. The category of urban sources can include inputs from residential fertilizer, septic systems, leaky sewer lines, and local deposition from automobiles (Ator and others, 2011). Because these sources were not differentiated in the SPARROW model, however, the relative importance of different urban sources that might affect the isotopic composition of exported nitrate in stream base flow, such as wastewater or lawn fertilizer, could not be resolved from the model.

Earlier studies (Heisig, 2000; Burns and others, 2005; Landers and Ankcorn, 2008) have demonstrated that an increased density of septic systems within unsewered communities can result in hydrologic and chemical alteration to downstream receiving waters. The potential contribution of nitrate from septic systems to the Chesapeake Bay itself, however, has generally not been well understood.

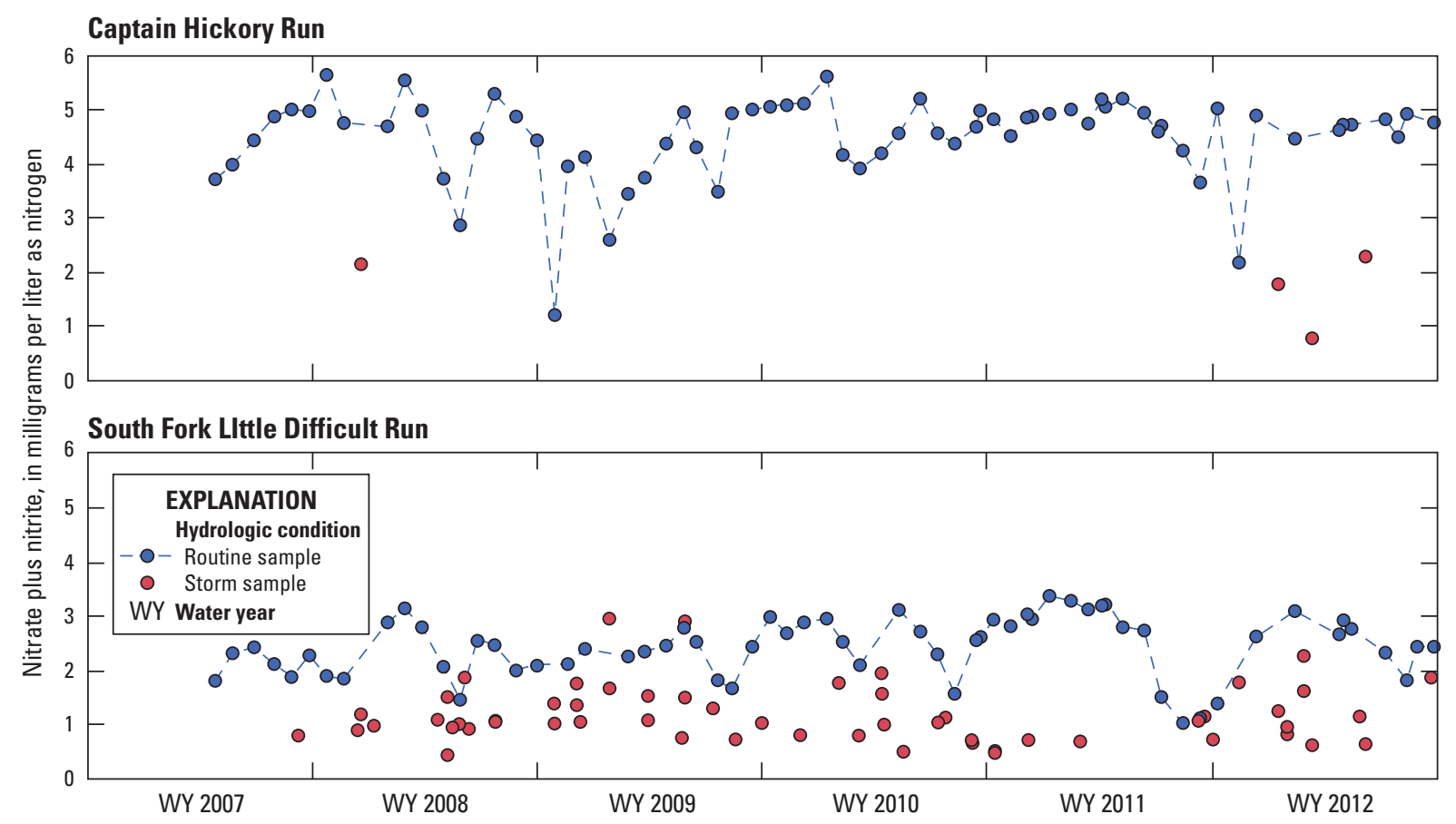

Figure 131. Nitrate concentrations by hydrologic event from Captain Hickory Run (site number 25) and South Fork Little Difficult Run (site number 7) for water years 2007 through 2012. 


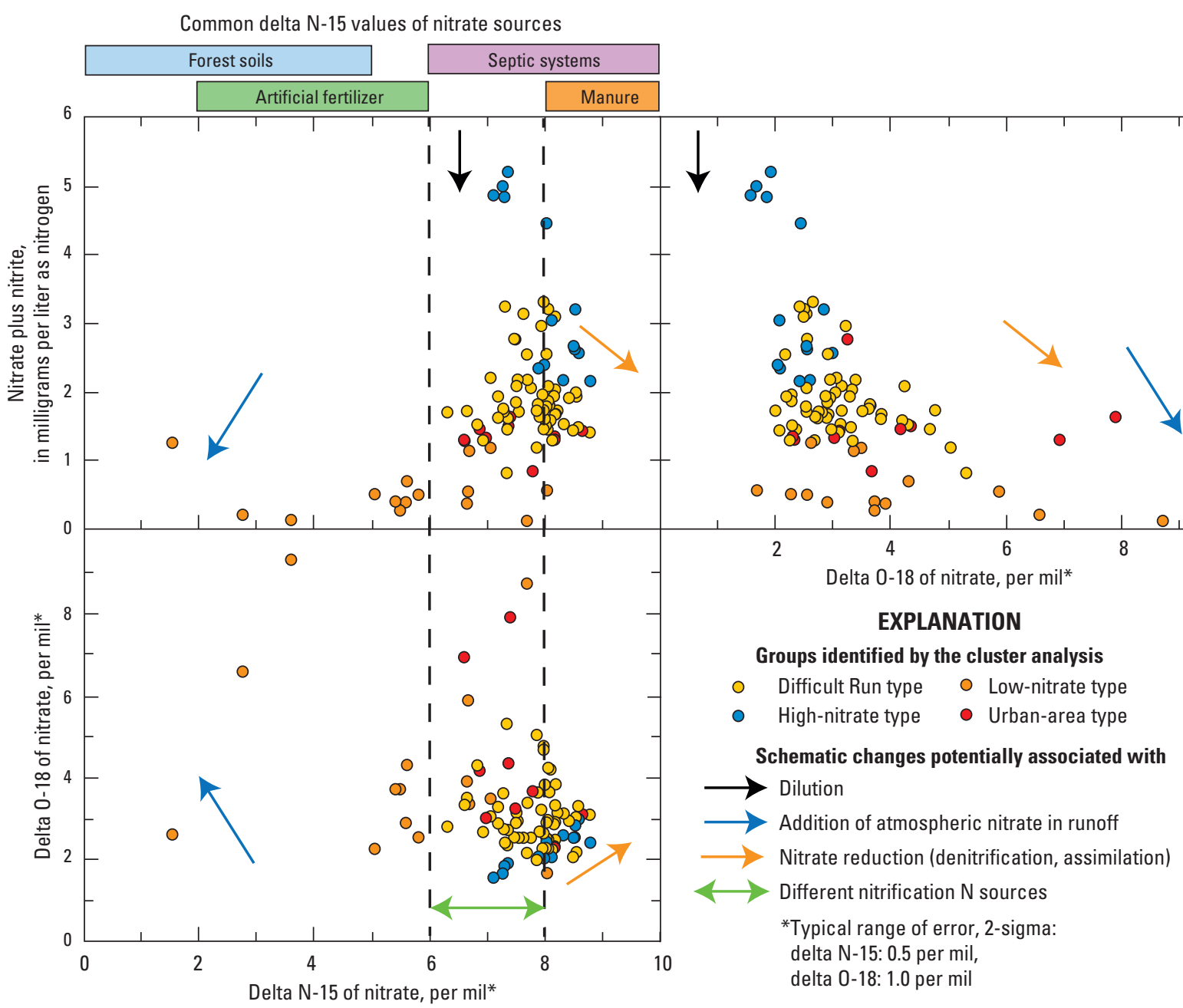

Figure 132. Nitrate isotope results from each synoptic sampling event within the Difficult Run watershed.
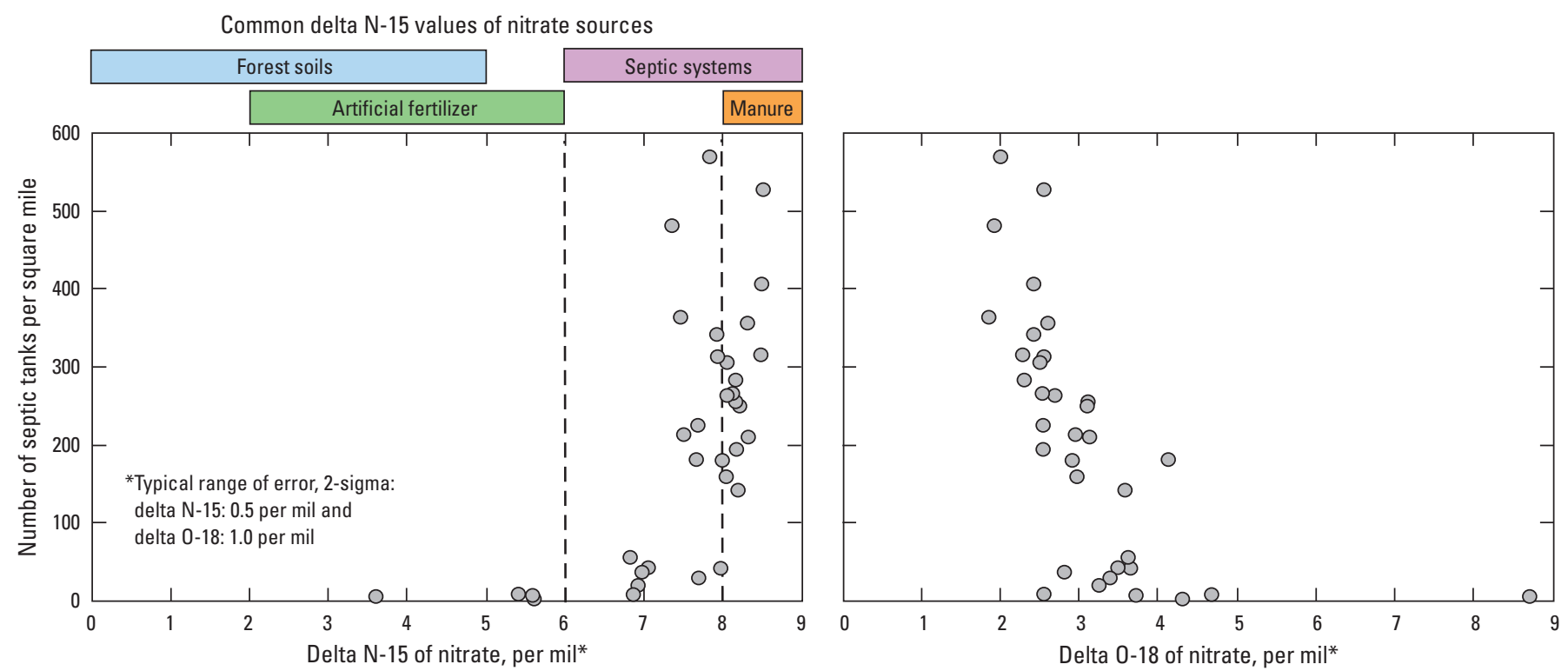

Figure 133. Median nitrate isotope results from synoptic sampling events within the Difficult Run watershed compared to the septic tank density within the drainage area of each monitoring location with dashed lines indicating literature values of nitrate sources. 
Table 39. Estimated annual nitrate loads contributed by septic system leachate and residential fertilizer application at the Captain Hickory Run monitoring location (01645940).

[TN, total nitrogen; lb, pound; yr, year; $\mathrm{mi}^{2}$, square mile; \%, percent]

\begin{tabular}{|c|c|c|c|c|c|c|c|}
\hline \multirow{2}{*}{ Population ${ }^{1}$} & \multirow{2}{*}{$\begin{array}{c}\text { Number of septic } \\
\text { systems }^{2}\end{array}$} & \multirow{2}{*}{$\begin{array}{l}\text { Septic system TN } \\
\text { loading rate at } \\
\text { the edge of the } \\
\text { drainfield } \\
(\mathrm{lb} / \text { person } / \mathrm{yr})^{3}\end{array}$} & \multirow{2}{*}{$\begin{array}{l}\text { Residential area } \\
\qquad\left(\mathrm{mi}^{2}\right)^{4}\end{array}$} & \multirow{2}{*}{$\begin{array}{c}\text { Fertilizer } \\
\text { application rate } \\
\left(\mid \mathrm{b} / \mathrm{yr} / \mathrm{mi}^{2}\right)^{5}\end{array}$} & \multirow{2}{*}{$\begin{array}{c}\begin{array}{c}\text { Percent of } \\
\text { fertilizer } \\
\text { nitrogen leached } \\
\text { from turfgrass } \\
(\%)^{6}\end{array}\end{array}$} & \multicolumn{2}{|c|}{$\begin{array}{c}\text { Annual TN load } \\
(\mathrm{lb} / \mathrm{yr})\end{array}$} \\
\hline & & & & & & Septic ${ }^{7}$ & Fertilizer $^{8}$ \\
\hline 1,724 & 668 & 9.33 & 1.14 & 15,560 & 10 & 16,085 & 1,774 \\
\hline
\end{tabular}

${ }^{1}$ U.S. Census Bureau, 2012.

${ }^{2}$ Fairfax County GIS Branch, unpub. data, 2014.

${ }^{3}$ Maizel and others, 1997.

${ }^{4}$ Fairfax County Stormwater Planning Division, 2007.

${ }^{5}$ Law and others, 2004.

${ }^{6}$ Petrovic, 2008.

${ }^{7}$ Computed as the population $(1,724)$ multiplied by the septic TN loading rate at the edge of the drainfield $(9.33)$.

${ }^{8}$ Computed as the residential area (1.14) multiplied by the fertilizer application rate $(15,560)$ and the fertilizer leachate rate $(10$ percent).
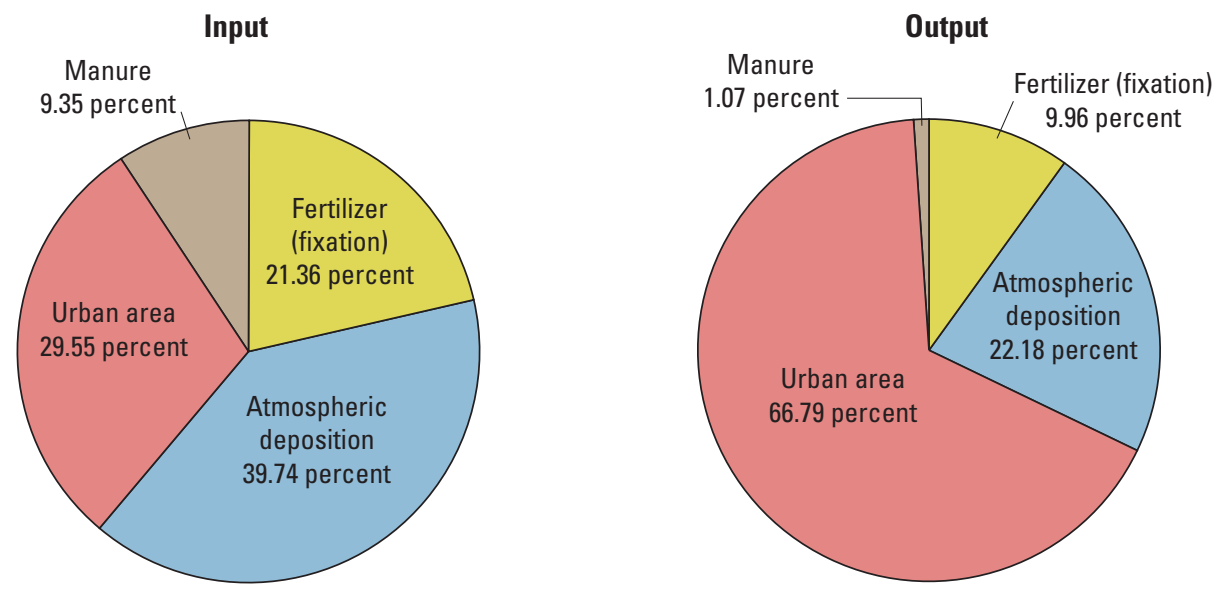

Figure 134. Percentages of input and output sources of total nitrogen for the Difficult Run watershed as generated by the 2002 Chesapeake Bay Total Nitrogen SPARROW model.

\section{Implementation of Conservation Practices and Water-Quality Response}

Implementation of conservation practices within the Difficult Run watershed has increased from 2007 to 2014 (table 40), with stream restoration becoming one of the principal implementation activities within the watershed. In theory, stream restoration should reduce sediment and nutrient export from the watershed by reducing streambank erosion, enhancing denitrification processes, and improving the connectivity between the stream and the floodplain. Other implementation practices were also used during the last 6 years to reduce stormwater runoff and transport of sediment and nutrients.

Although intensive water-quality monitoring at the streamgage started for this project in 2010 , historical water-quality monitoring data exist for the period 1972 through 2007, and these historical data were coupled with the recent monitoring data to provide an initial assessment of trends in water quality in Difficult Run. These data were included in a trend analysis using Weighted Regression on Time, Discharge and Season (WRTDS) to provide trends in concentration and load (http://cbrim.er.usgs.gov/). Analysis of the Difficult Run nitrate data using WRTDS indicated that overall nitrate concentrations have increased from 1985 through 2014 at a rate of approximately $0.02 \mathrm{mg} / \mathrm{L}$ per year. Flow normalized nitrate fluxes over this same period have increased by approximately 2.8 percent per year. While this is a rather small rate of change, it indicates that nitrate concentrations and in-stream loads have increased, which is evident in the time series of observed concentration data (fig. 135). Enhanced implementation of conservation practices could be necessary to reduce nitrate concentrations in Difficult Run. 
Table 40. The classes/types of conservation practices that were implemented in the Difficult Run watershed for water years 2009 through 2014.

\begin{tabular}{|c|c|c|c|c|c|c|}
\hline Practice type & 2009 & 2010 & 2011 & 2012 & 2013 & 2014 \\
\hline Stream Restoration & & 1 & & 1 & 1 & 5 \\
\hline Extended Detention Pond & 2 & 1 & & & 1 & \\
\hline Soil Compost Amendment & 2 & & & 2 & & 2 \\
\hline Bioretention & 3 & & & & & 1 \\
\hline Permeable Pavement & 1 & & & 1 & & \\
\hline Constructed Wetland & & & & 2 & 1 & 2 \\
\hline Infiltration & & & & 2 & & \\
\hline Dry Swale & & & & 1 & & \\
\hline
\end{tabular}

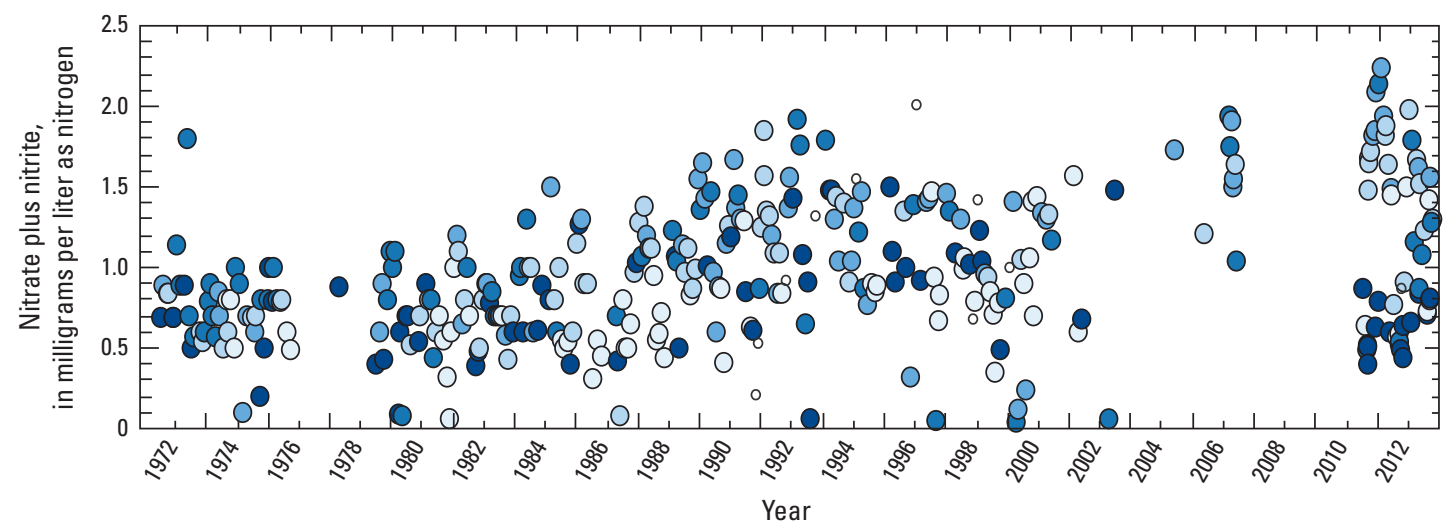

\section{EXPLANATION}

Percentage of values equal to or less than the maximum streamflow of 3,900 cubic feet per second (where small values represent low-flow samples)

○ 0 to 20

$0>20$ to 40

$0>40$ to 60

O $>60$ to 80

- $>80$ to 100

- Streamflow data not available

Figure 135. Nitrate concentrations for the Difficult Run watershed water years 1972 through 2013.

The cumulative effects of all the BMP implementation within the Difficult Run watershed are difficult to quantify because of the many different types of BMP practices, the location of each, potential lag times between implementation and full functionality of the practice, and the relative efficiency of each practice/installation. Future monitoring will be designed to measure the overall changes in watershed nutrient and sediment transport. An interim set of expectations was developed by using the Chesapeake Bay Program's watershed model to evaluating model output for model scenarios with and without the implementation of BMP practices. The results for the land-water segment that contain Difficult Run are presented in figure 136 (source: Chesapeake Bay Modeling Team, written commun., 2015, based on Watershed Model 5.3.2). The model results indicate that the implementation of BMPs has been responsible for a 1 to 2 percent annual change in nitrate, with a reduction of approximately 15 percent between 1985 and 2012. This annual rate of change would be difficult to detect in a short-term study, but could be detected through a long-term water-quality monitoring program.

\section{Conceptual Watershed Model and Implications for Management Actions}

Intensive monitoring of a downstream gage and extensive sampling throughout the basin has provided an overview of nutrient processing, seasonal dynamics, and spatial water-quality patterns within the Difficult Run watershed. These findings can inform future management actions related to controlling nutrient and sediment sources. Some of the more pertinent findings are summarized below to highlight their significance in our understanding of the watershed.

- A majority of the total flow in Difficult Run occurs as stormflow. The prominence of high-flow events is likely influenced by the degree of imperviousness of the watershed, which magnifies the effect of overland runoff on water quality.

- Most atmospheric nitrate was cycled through biota before being transported to the stream; however, direct runoff of atmospheric nitrate during storm events was more evident in Difficult Run than in the other watersheds, partly because base-flow nitrate concentrations were relatively low and partly because of enhanced runoff from urbanized parts of the watershed.

- The runoff of deicing salts applied to the dense road network has a seasonal effect on the water quality of the basin. Specific conductance values often spike during late winter and early spring storms because of increased concentrations of chloride. Previous work has demonstrated the effect of this process and has suggested that elevated chloride concentrations could negatively affect aquatic health (Jastram, 2014). 


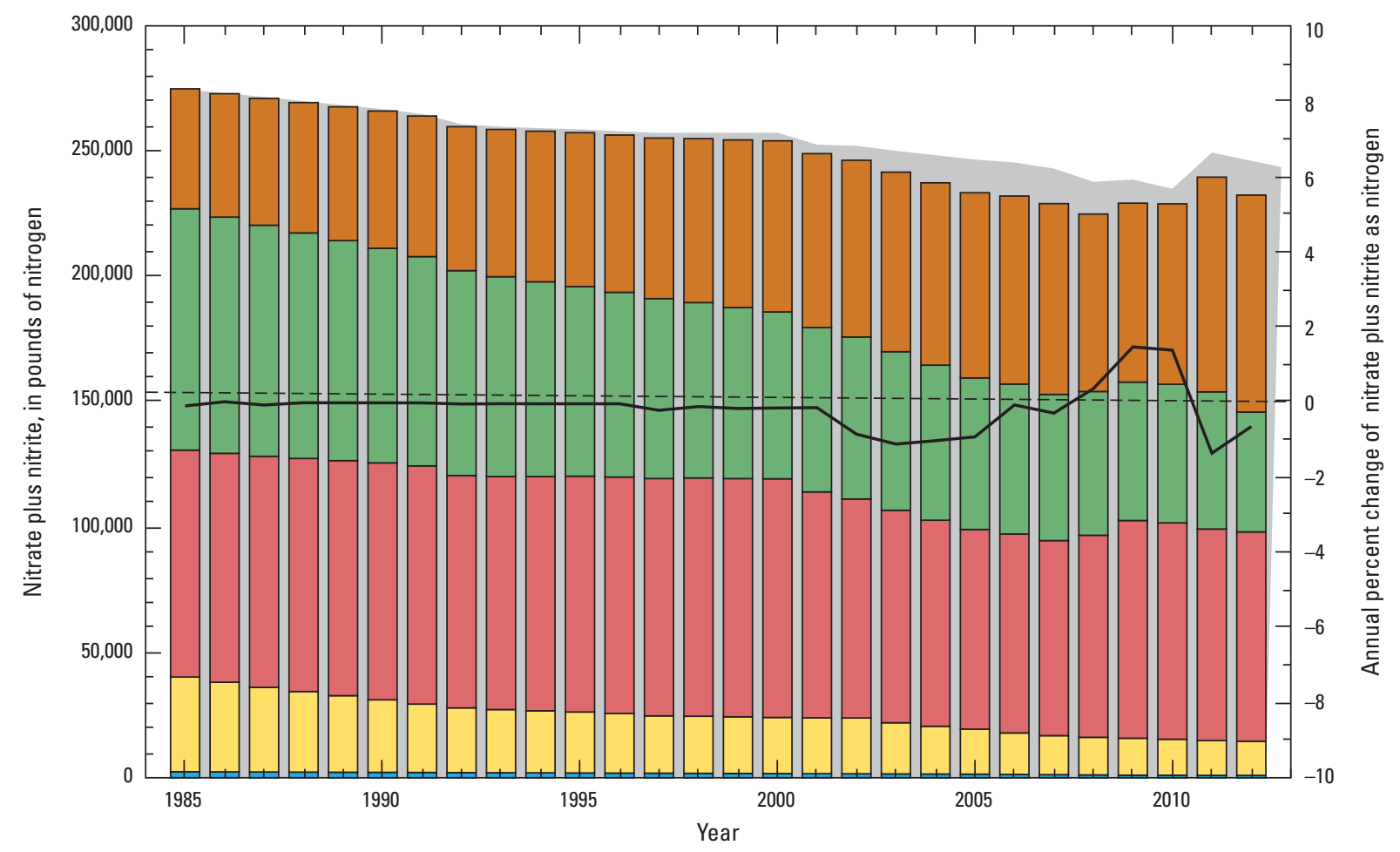

EXPLANATION

Pounds of nitrate plus nitrite as nitrogen from all sources with no best management practice implementation

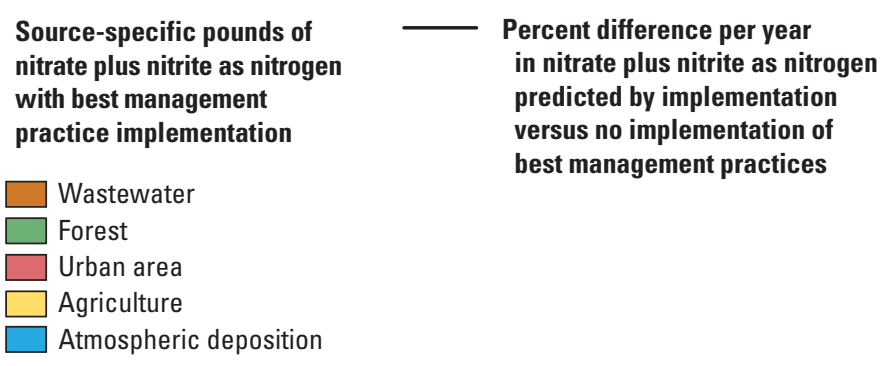

Figure 136. Nitrate loads estimated from the Chesapeake Bay watershed model for the Difficult Run land-river segment with and without best management practice implementation with input sources and the annual percentage difference of load attributed to implementation, 1985-2012. 
- Continuous nitrate data display a seasonal pattern that likely results from a combination of biologic in-stream and watershed processing, as well as changes in groundwater inputs.

- Suspended-sediment loading was highly episodic; 95 percent of the load was generated by the seven largest storms. This pattern is similar to the loads for headwater sites within the basin (Jastram, 2014). The sediment yield at the streamgage was almost a factor of 2 less than the yields measured at upstream sites, which indicates significant deposition of sediment on the Difficult Run floodplain, as described by Schenk and others (2013).

- TN loads accumulated steadily throughout the water year, indicating a persistent source during base-flow conditions. Annual nitrogen yields at the streamgage are less than those in the headwaters, which may be a result of biologic processing, variations in spatial sources, and interaction with the floodplain.

- TP accumulation patterns mirrored the episodic nature of suspended sediment and annual yields that are higher in the headwaters than the downstream monitoring location at site 30 . Some spatial processing and floodplain deposition are likely responsible for this downstream reduction in load.

- The Captain Hickory Run subwatershed had high nitrate and TN concentrations during all sampling events. These concentrations are likely affected by elevated density of septic systems contributing to groundwater discharge of nitrate, though other nitrogen sources also may contribute.

- The unique chemical composition of some headwater sampling locations was almost entirely diluted along the main channel of Difficult Run, resulting in relatively homogenous conditions throughout the majority of the basin.

- The largest water-quality variations were attributed to surrounding land-use or hydrologic features. Sites directly downstream of urban areas had the highest measures of conductivity, which are likely related to the application of road salts.

- Land-use-based assumptions, nitrate isotopes, and SPARROW modeling results suggest that a mix of sources, including septic system leachate, atmospheric deposition, and commercial fertilizer application, may be significant sources of nitrogen within the basin.

This process-level understanding is directly applicable in the development of the most effective conservation practices and provides some insight for informed decisionmaking. Decisions to manage the following constituents in the following ways could generate the most efficient results.
- Management activities for nitrogen would likely be most effective by the ongoing maintenance of septic systems, the management of fertilizer applications, and the possible expansion of the sanitary-sewer infrastructure.

- For the management of sediment and phosphorus, most loading occurs during the few relatively large storm events that occur each year; management strategies that target these few large events are critical.

- The collection of empirical nutrient and geochemical water-quality data in the Difficult Run watershed were critical for better understanding the nitrogen sources and temporal responses within the basin and for assessing trends in water-quality data (Chesapeake Bay Watershed Model results).

Ongoing USGS water-quality monitoring efforts will be directed towards the further understanding of the sources, sinks, and transport processes in Difficult Run, as well as the detection of water-quality change that can be directly related to the implementation of management actions. Because large changes in water quality take time and sufficient management of the landscape to actually affect the system, a number of methods could be used to detect change in the basin.

- Nutrient and sediment monitoring at the streamgage could provide a long-term record of the water quality that is leaving the basin. With sufficient data, expanded trend analyses can be performed to determine whether statistically significant trends exist for more constituents.

- The continuous nitrate, turbidity, and specific conductance records are likely some of the best tools for determining whether the Difficult Run system is changing. With 15-minute-interval data, change can be measured over time, rather than estimated with regressions models such as LOADEST and WRTDS. Furthermore, shifts in the nitrate C-Q relationships might be an early indicator of water-quality change because increased management of the watershed is likely to fundamentally change nutrient transport dynamics without necessarily changing the hydrology much; hence, the C-Q relationships might evolve over time and with enhanced management.

- Ratios of various chemical tracers might produce indicators of change at an early stage because the concentrations of some constituents are determined more by dissolution and reaction chemistry in the aquifers and others by nutrient management practices within the basin. For example, implementation of BMPs might result in changes in ratios of nitrate to calcium or other ions in base flow or runoff.

- Control of direct surface runoff from urban areas might be detected by a reduction in the frequency or magnitude of high- $\delta^{18} \mathrm{O}$ nitrate peaks during precipitation events. 


\section{Comparison of Water-Quality Patterns Among Study Watersheds}

Comparison of water-quality patterns among the four study watersheds provides an opportunity to explore similarities and differences among these watersheds that provide a range of land uses and hydrogeology.

Continuous water-quality data were collected at the streamgage(s) within each watershed, and these continuous water-quality data demonstrate a range of patterns (figs. 137 through 139). The greatest specific conductance values were from the predominantly agricultural sites during low-flow conditions, with subsequent dilution occurring during higher flows (fig. 137). Within the agricultural basins, the greatest conductance values were observed in the Smith Creek watershed, followed by the Conewago Creek watersheds, likely because of the carbonate bedrock that underlies parts of both watersheds. Lower conductance values were generally observed in the Chesterville Branch watershed, which yields lesser conductance from weathering. At the predominantly urbanized Difficult Run watershed, specific conductance sometimes decreased during higher flows, but more often increased. During the cooler season, in particular, a limited number of elevated Difficult Run specific conductance values were observed during higher flow periods, which seems to be attributable to the runoff of roadway salts and the generally higher roadway density in this watershed, relative to the other watersheds.

Data from continuous nitrate monitors demonstrate tremendous variability between water-quality sites (fig. 138). Chesterville Branch nitrate values fluctuate the most among the three monitored sites, ranging from almost $10 \mathrm{mg} / \mathrm{L}$ during low-flow periods to $1 \mathrm{mg} / \mathrm{L}$ during wet-weather periods, when nitrate from groundwater is diluted with event runoff. Smith Creek and Difficult Run nitrate concentrations are much less than those in Chesterville Branch and therefore have less variability. In contrast to the dilution response observed in Chesterville Branch, however, maximum nitrate concentrations at Smith Creek and Difficult Run were generally reached during intermediate flow conditions, with lower concentrations of nitrate observed during relatively low and high flows.

Lower concentrations during high flows are attributed to dilution during storm events. Lower concentrations during low flow in Smith Creek and Difficult Run are likely related to in-stream uptake and loss of nitrate during relatively low-flow conditions, as well as to potential shifts in the contributions of groundwater from different aquifer sources. The high concentrations of nitrate in base flow at Chesterville Branch likely dampen observation of the effects of near-stream or in-stream denitrification and uptake at this site, compared to what might be seen at a site with low nitrate inputs.

Relatively similar patterns in DO concentrations were observed in Smith Creek, Difficult Run, and Chesterville
Branch (fig. 139). All three watersheds displayed higher DO concentrations during the winter months, which is related to the increased solubility of oxygen in cooler water. All three sites showed relatively similar variability in DO concentrations over the monitoring period (about $7 \mathrm{mg} / \mathrm{L}$ ), and concentrations remained above $4 \mathrm{mg} / \mathrm{L}$ for all streams.

For further comparison between watersheds, the discrete water-quality data collected at the streamgage(s) in each watershed have been summarized (fig. 140; table 41). While a similar distribution of observed values is evident for water temperature and DO concentrations (fig. 140), the other monitored constituents show more variability, even for the two water-quality monitoring stations in Conewago Creek. These differences were explored by using cluster analyses.

Cluster analyses indicate more between-basin variability than within-basin variability in water quality among the study watersheds, with some interesting patterns. Four of the six major clusters tended to be dominated by water-quality samples from a single watershed (fig. 141). Group 1 included nearly all the samples from the Smith Creek watershed and was characterized as having relatively high $\mathrm{pH}$, specific conductance, calcium, magnesium, and sulfate levels (fig. 141). Groups 2 and 3 included nearly all the water-quality samples from the two monitoring sites in Conewago Creek, as well as a pair of higher flow samples from Smith Creek (figs. 141 and 142). Group 2 was characterized as having higher phosphorus concentrations and were generally associated with higher flows. Group 3 was characterized by elevated sulfate concentrations, as well as $\mathrm{pH}$, specific conductance, calcium, and magnesium levels that are slightly less than those in group 1. Given that Conewago Creek is partially underlain by carbonate rocks, but to a lesser extent than Smith Creek, this cluster makes sense. Group 4 contains high-flow samples from all watersheds, as well as a few Difficult Run base-flow samples, and is characterized by relatively dilute water chemistry. The Difficult Run base-flow samples in group 4 tended to be collected during the summer months and had lower chloride concentrations. Group 5 includes only samples from Difficult Run, and are generally characterized as having elevated chloride (figs. 141 and 142). Group 6 contains only samples from Chesterville Branch and is characterized by elevated nitrogen concentrations in samples collected during low- and intermediate-flow conditions (figs. 141 and 142).

Given extensive plans for implementation of BMPs across all four watersheds, as well as the somewhat varied nitrogen and phosphorus patterns among these basins and during different flow conditions, patterns in dissolved and total nutrients were examined. Theoretically, the effects of implemented BMP practices might first appear as subtle shifts in the ratios of certain nutrient constituents, rather than as statistically significant changes in loads or nutrient concentrations. The current findings provide a baseline to compare to future water-quality patterns at these sites. The highest 
nitrogen concentrations were observed in Chesterville Branch (up to $10 \mathrm{mg} / \mathrm{L}$ ), with the remaining four monitoring sites having relatively similar nitrogen concentrations that range from 1 to $4 \mathrm{mg} / \mathrm{L}$ (fig. 143). For all five monitoring sites, the vast majority of the low-flow TN was present as nitrate, which is almost entirely contributed by discharging groundwater, with nitrate composing an incrementally smaller proportion of the TN as flow and runoff increased (fig. 143). Orthophosphate and TP concentrations were more variable than those of TN; lower phosphorus concentrations overall were observed at Difficult Run and Smith Creek, relative to those at either Chesterville Branch or the Conewago Creek monitoring stations (fig. 144). During low-flow conditions, much of the TP was present as orthophosphate, but during higher flow conditions, TP was dominated by particulate or dissolved organic forms (fig. 144). Subsequent research could further explain phosphorus sources in these watersheds.

Nitrate isotope data for samples collected in Smith Creek, Difficult Run, and Chesterville Branch indicated variations in the proportions of nitrate sources and the relative effects of biogeochemical processes (fig. 145). Nitrate $\delta^{15} \mathrm{~N}$ values were largely consistent with commercial fertilizer inputs at Chesterville Branch, predominantly manure inputs at Smith Creek, and mixtures including domestic wastewater at Difficult Run. Nitrate $\delta^{18} \mathrm{O}$ values indicate that almost all of the nitrate exported from these watersheds was produced by nitrification, regardless of the source of nitrogen. Exceptions to this were most evident in Difficult Run, where nitrate commonly exhibited substantial isotopic variations during stormflow that were consistent with contributions of new atmospheric nitrate in runoff (high $\delta^{18} \mathrm{O}$, low $\delta^{15} \mathrm{~N}$ ). In comparison to the other watersheds, more frequent detections of atmospheric nitrate contributions in Difficult Run can be attributed to (1) a relatively large amount of impervious surface and stormwater engineering features that routed precipitation rapidly to streams and minimized contact with biogeochemically active soils, and (2) base-flow nitrate concentrations that were relatively low, so atmospheric nitrate was a relatively large fraction of the total nitrate during stormflow. Chesterville Branch nitrate exhibited relatively little isotopic variability at high flow, despite large variations in concentration. In this case, nitrate discharging from groundwater was diluted by precipitation runoff, but because of the high concentrations of nitrate from groundwater, atmospheric nitrate in the runoff was not a substantial fraction of the diluted stream mixtures. Smith Creek nitrate exhibited moderate isotopic variability, including a shift to lower $\delta^{15} \mathrm{~N}$ values during stormflow periods (some combination of shallow groundwater flowpaths and ephemeral contributions from high-elevation forested watersheds) and a tendency towards slightly higher $\delta^{15} \mathrm{~N}$ and $\delta^{18} \mathrm{O}$ values during low-flow periods that may indicate partial nitrate reduction in the stream channel or variations in groundwater flow paths contributing to discharge. Isotopic results from the spatial synoptic sampling events (fig. 146) supported the observations associated with the temporal discrete samples and revealed more variability related to local source-specific signatures from different parts of each watershed.

The 2013 water year sediment and nutrient loads for each basin were converted to yields to allow among-basin comparisons. Unexpectedly, sediment yields (fig. 147) were greatest for Chesterville Branch, while the lowest sediment yield was observed in Smith Creek, with Difficult Run and Conewago Creek basins having intermediate yield. In contrast to these results, Gellis and others (2009) documented relatively high sediment yields from the Piedmont Physiographic Province and relatively low sediment yields from the Coastal Plain Physiographic Province. Elevated sediment yields in Chesterville Branch may be related to basin scale and land use, as this is a relatively small headwater basin that is similar to the small headwater streams described by Jastram (2014), tremendous sediment erosion may come from the headwaters of this system. The upper one-third of the Chesterville Branch watershed is an active nursery, and activities related to this land-use practice could be increasing the sediment concentrations in a way that is not representative of other small Coastal Plain watersheds. As described earlier, the Difficult Run sediment yield was approximately 25 percent of what is mobilized from the Difficult Run headwaters (Jastram, 2014; J.D. Jastram, U.S. Geological Survey, oral commun., 2014), highlighting that much of the sediment that is liberated from the Difficult Run headwaters ends up in storage (either on the floodplains or in the stream channel) and is not immediately exported from the watershed (Noe and others, 2013). The Conewago Creek sediment yields had large uncertainties associated with them, but a source of sediment lower in the watershed was indicated that increased the sediment load from the watershed. The collection of additional water-quality data in future years could be used to refine the surrogate sediment models and to reduce the confidence intervals associated with these estimates.

TN loads were computed for all watersheds except Conewago Creek (fig. 148). Chesterville Branch yielded the most nitrogen, and Difficult Run yielded the least nitrogen, consistent with the relative differences in nitrate and TN concentrations. Despite the dramatically different land uses and geology in the Smith Creek and Difficult Run watersheds, their TN yields were relatively similar. Additional years of data would be needed to see if these patterns are consistent over time.

TP yields (fig. 149) were greatest for Chesterville Branch, intermediate for Conewago Creek, and lowest for Smith Creek and Difficult Run. Similar to the sediment patterns observed in Conewago Creek, phosphorus yields were greater at Falmouth and smaller at Bellaire, indicating the presence of a phosphorus source lower in the watershed that increased the phosphorus load from the basin. Because these yields were computed for a single year of data, climatological variability may be responsible for some of the relative differences between sites. 


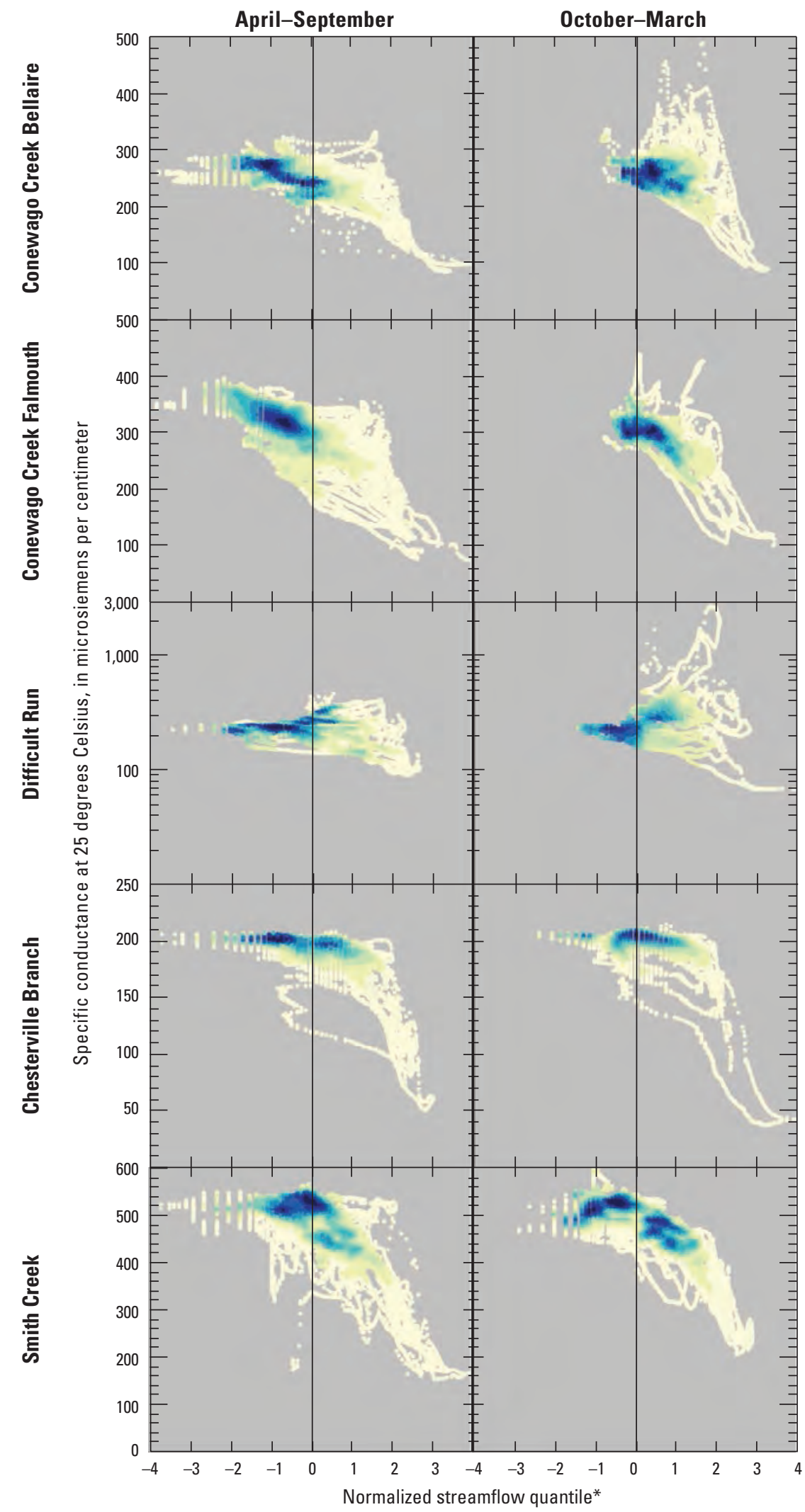

\section{EXPLANATION}

Percent of measured values

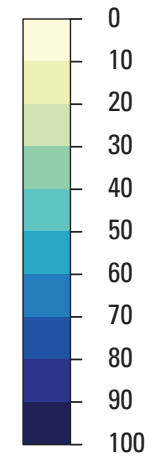

* One normalized quantile equates to one standard deviation

Figure 137. Continuous specific conductance data compared to normalized streamflow quantiles measured at the Conewago Creek Bellaire and Falmouth, Smith Creek, Chesterville Branch, and Difficult Run streamgages with colored bands that represent the density of data points for a "warm" (April through September) and "cool" (October through March) season. 


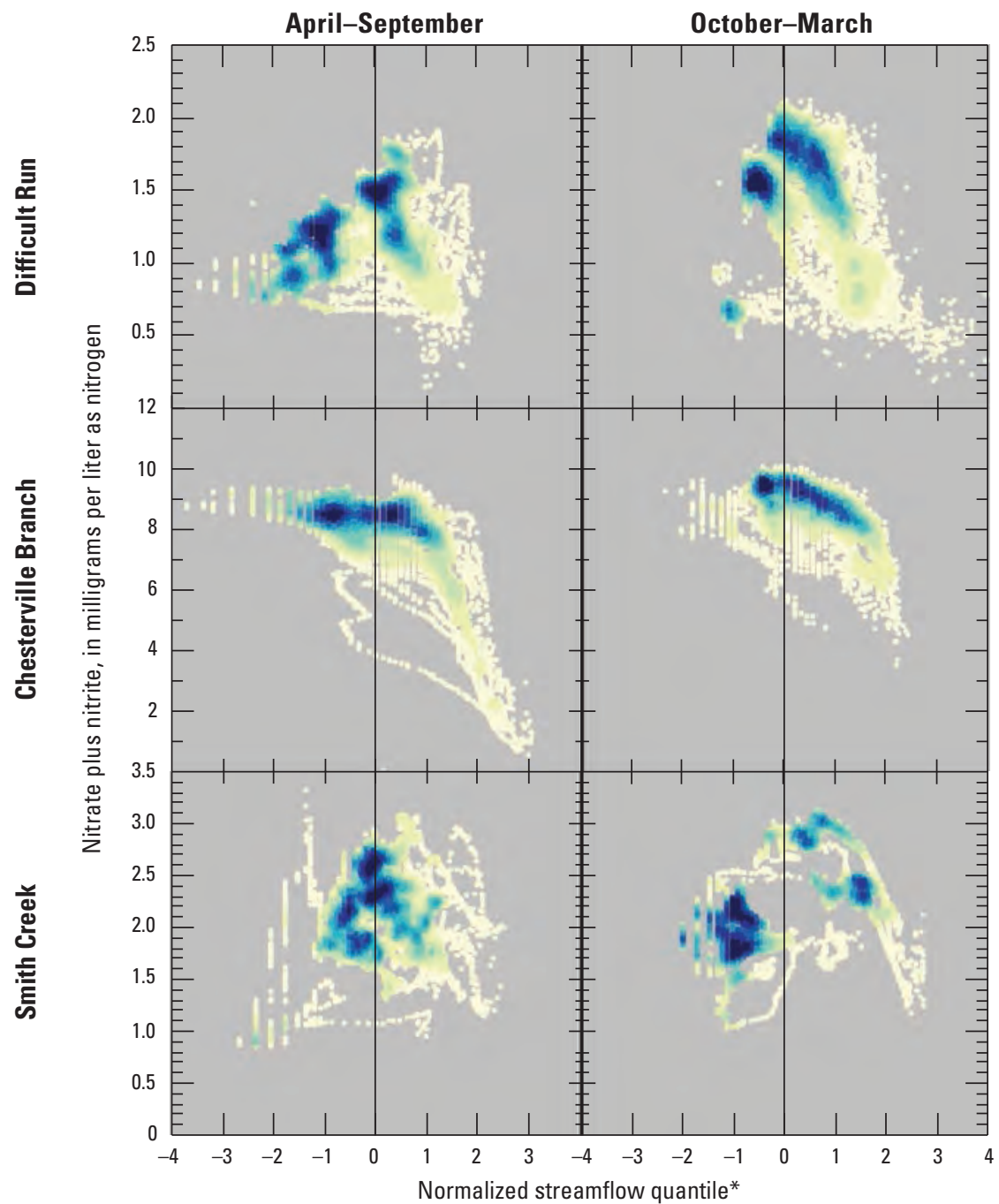

\section{EXPLANATION}

Percent of measured values

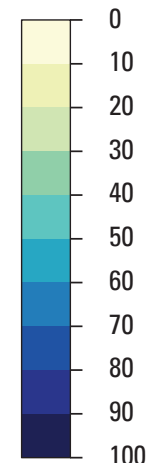

*ne normalized quantile equates to one standard deviation

Figure 138. Continuous nitrate data compared to normalized streamflow quantiles measured th the Smith Creek, Chesterville Branch, and Difficult Run streamgages with colored bands that represent the density of data points for a "warm" (April through September) and "cool" (October through March) season. 


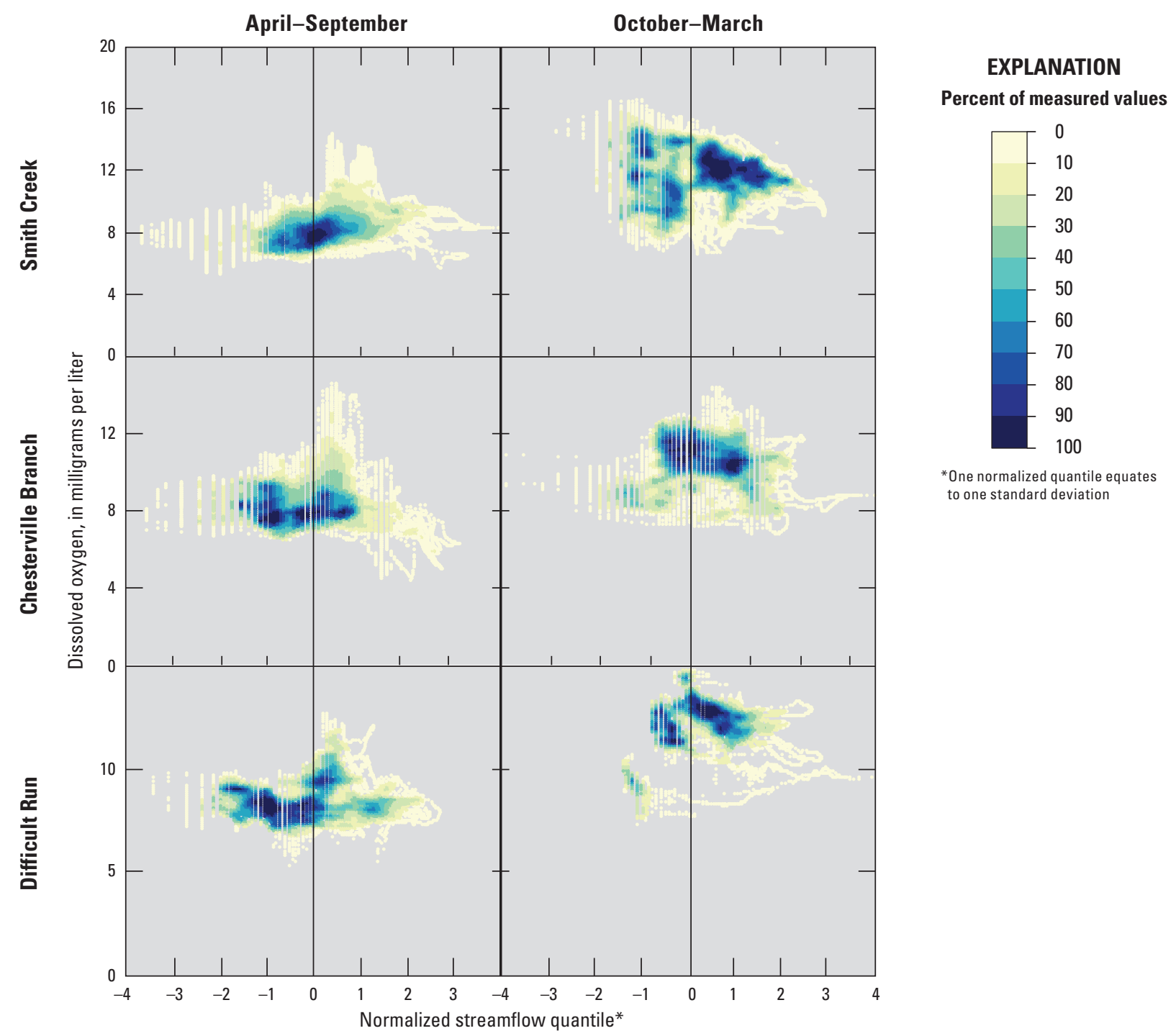

Figure 139. Continuous dissolved oxygen data compared to normalized streamflow quantiles measured at the Smith Creek, Chesterville Branch, and Difficult Run streamgages with colored bands that represent the density of data points for a "warm" (April through September) and "cool" (October through March) season. 

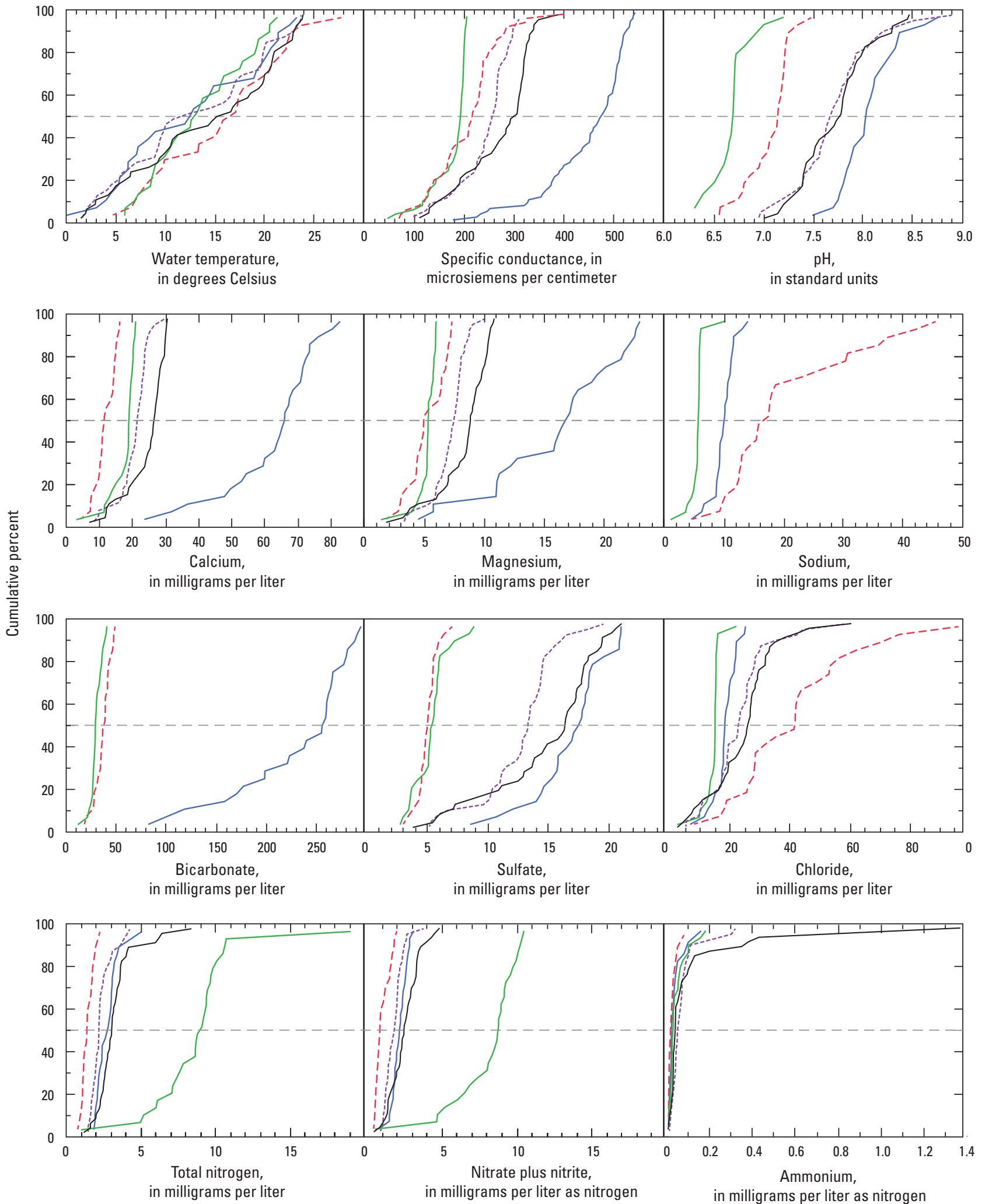

Figure 140. Cumulative distribution of various water-quality constituents collected from the Smith Creek, Conewago Creek Bellaire and Falmouth, Chesterville Branch, and Difficult Run streamgages. 

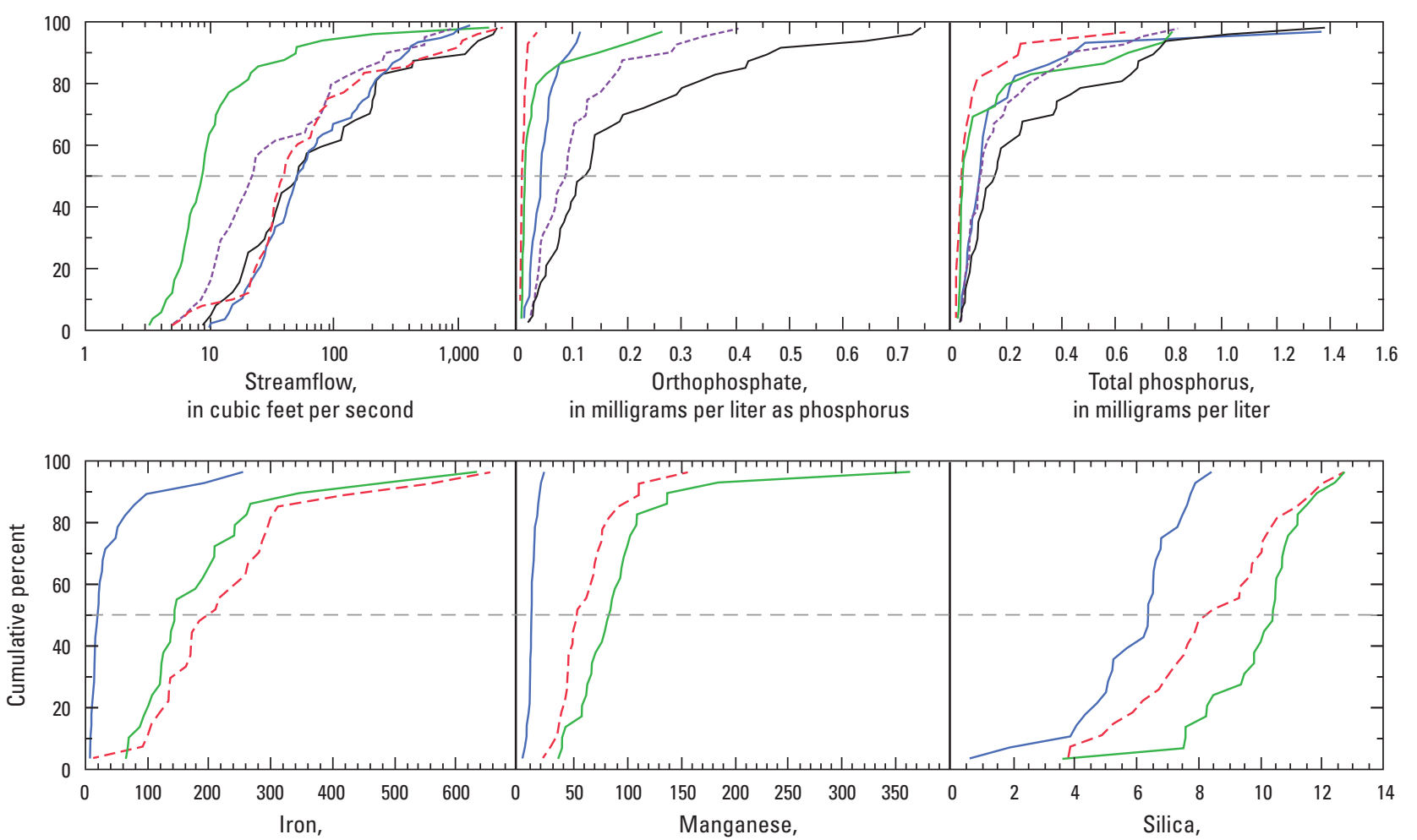

in micrograms per liter in micrograms per liter

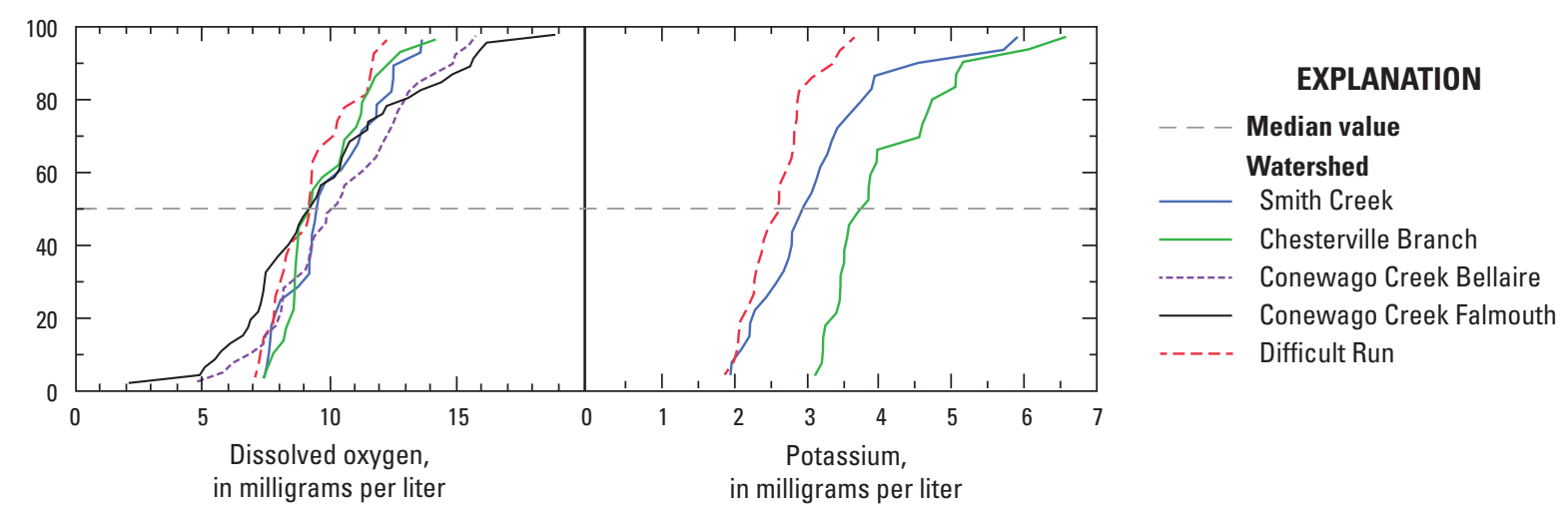

Figure 140. Cumulative distribution of various water-quality constituents collected from the Smith Creek, Conewago Creek Bellaire and Falmouth, Chesterville Branch, and Difficult Run streamgages.-Continued 
Table 41. Median concentrations of select discrete water-quality constituents at the Smith Creek, Difficult Run, Chesterville Branch, and Conewago Creek streamgages.

[deg C, degrees Celsius; mg/L, milligram per liter; $\mu \mathrm{S} / \mathrm{cm}$, microsiemens per centimeter; —, parameters not collected]

\begin{tabular}{|c|c|c|c|c|c|c|}
\hline Parameter & Reporting units & Smith Creek & Difficult Run & $\begin{array}{c}\text { Chesterville } \\
\text { Branch }\end{array}$ & $\begin{array}{c}\text { Conewago Creek } \\
\text { Bellaire }\end{array}$ & $\begin{array}{c}\text { Conewago } \\
\text { Creek } \\
\text { Falmouth }\end{array}$ \\
\hline Water temperature & $\operatorname{deg} \mathrm{C}$ & 12.46 & 16.44 & 12.89 & 11.60 & 15.20 \\
\hline $\mathrm{pH}$ & Standard units & 8.03 & 7.14 & 6.69 & 7.67 & 7.78 \\
\hline Specific conductance & $\mu \mathrm{S} / \mathrm{cm}$ at $25 \operatorname{deg} \mathrm{C}$ & 472.0 & 222.5 & 194.0 & 256.0 & 299.5 \\
\hline Dissolved oxygen & $\mathrm{mg} / \mathrm{L}$ & 9.50 & 9.21 & 9.20 & 10.10 & 9.20 \\
\hline Calcium & $\mathrm{mg} / \mathrm{L}$ & 65.95 & 11.29 & 18.80 & 21.30 & 26.20 \\
\hline Magnesium & $\mathrm{mg} / \mathrm{L}$ & 16.76 & 4.90 & 5.27 & 7.42 & 8.80 \\
\hline Sodium & $\mathrm{mg} / \mathrm{L}$ & 9.94 & 16.56 & 5.56 & - & - \\
\hline Potassium & $\mathrm{mg} / \mathrm{L}$ & 2.96 & 2.61 & 3.78 & - & - \\
\hline Bicarbonate & $\mathrm{mg} / \mathrm{L}$ & 256.06 & 37.62 & 29.15 & - & - \\
\hline Sulfate & $\mathrm{mg} / \mathrm{L}$ & 17.50 & 4.97 & 5.33 & 13.31 & 16.38 \\
\hline Chloride & $\mathrm{mg} / \mathrm{L}$ & 18.21 & 41.47 & 14.97 & 22.70 & 25.80 \\
\hline Nitrate-N & $\mathrm{mg} / \mathrm{L}$ & 2.16 & 0.86 & 8.73 & 1.82 & 2.46 \\
\hline Ammonium & $\mathrm{mg} / \mathrm{L}$ & 0.02 & 0.02 & 0.03 & 0.05 & 0.04 \\
\hline Total nitrogen & $\mathrm{mg} / \mathrm{L}$ & 2.82 & 1.40 & 8.94 & 2.20 & 3.06 \\
\hline Orthophosphate & $\mathrm{mg} / \mathrm{L}$ & 0.04 & 0.01 & 0.01 & 0.09 & 0.12 \\
\hline Total phosphorus & $\mathrm{mg} / \mathrm{L}$ & 0.10 & 0.03 & 0.03 & 0.10 & 0.16 \\
\hline Iron & $\mu \mathrm{g} / \mathrm{L}$ & 19.2 & 197.0 & 143.8 & 392.5 & 265.0 \\
\hline Manganese & $\mu \mathrm{g} / \mathrm{L}$ & 10.79 & 52.90 & 82.77 & 53.50 & 28.00 \\
\hline Silica & $\mathrm{mg} / \mathrm{L}$ & 6.36 & 8.23 & 10.40 & - & - \\
\hline
\end{tabular}




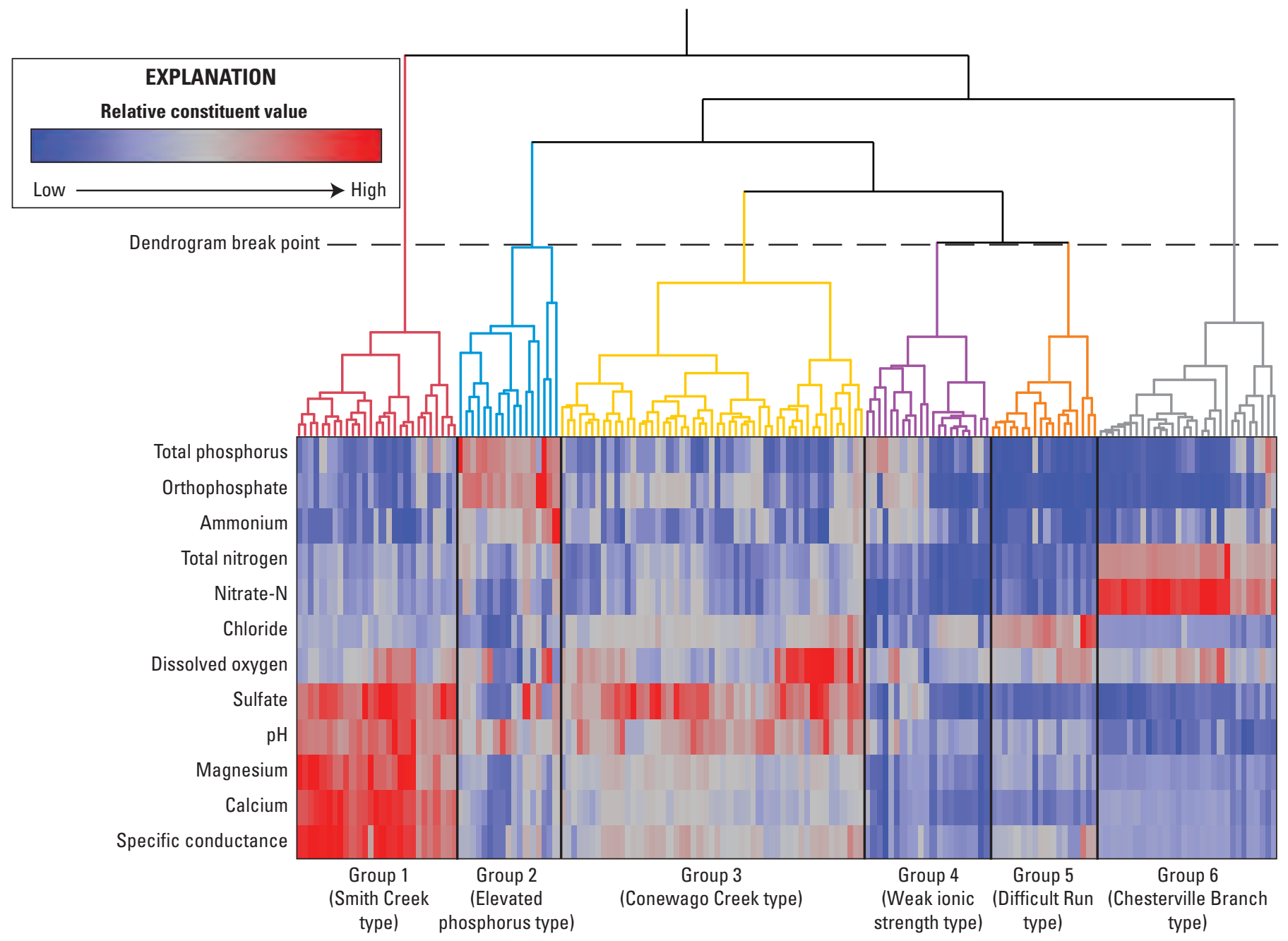

Figure 141. Discrete samples collected from the Smith Creek, Conewago Creek Bellaire and Falmouth, Chesterville Branch, and Difficult Run streamgages with a heat map of constituent values and the breakpoint used to produce five clusters.

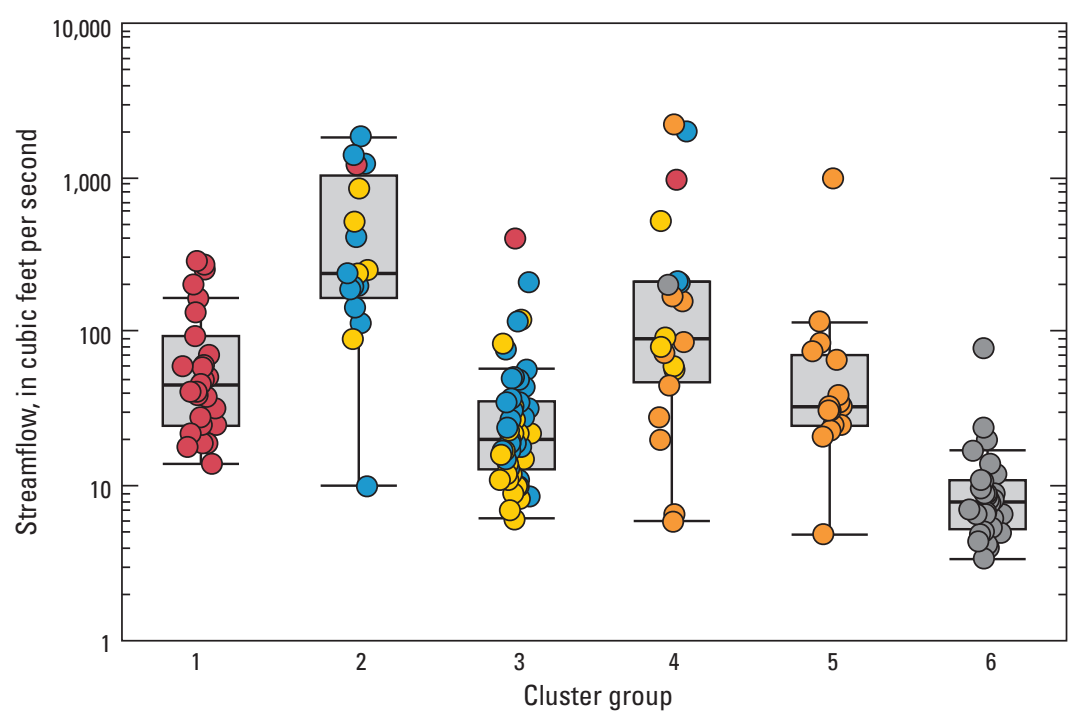

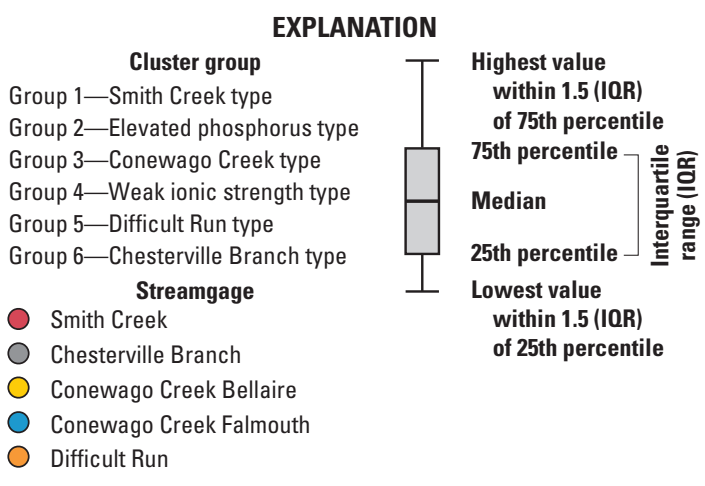

Figure 142. Streamflow for the five groups identified in a cluster analysis along with individual samples from the Smith Creek, Conewago Creek Bellaire and Falmouth, Upper Chester River, and Difficult Run watersheds. 

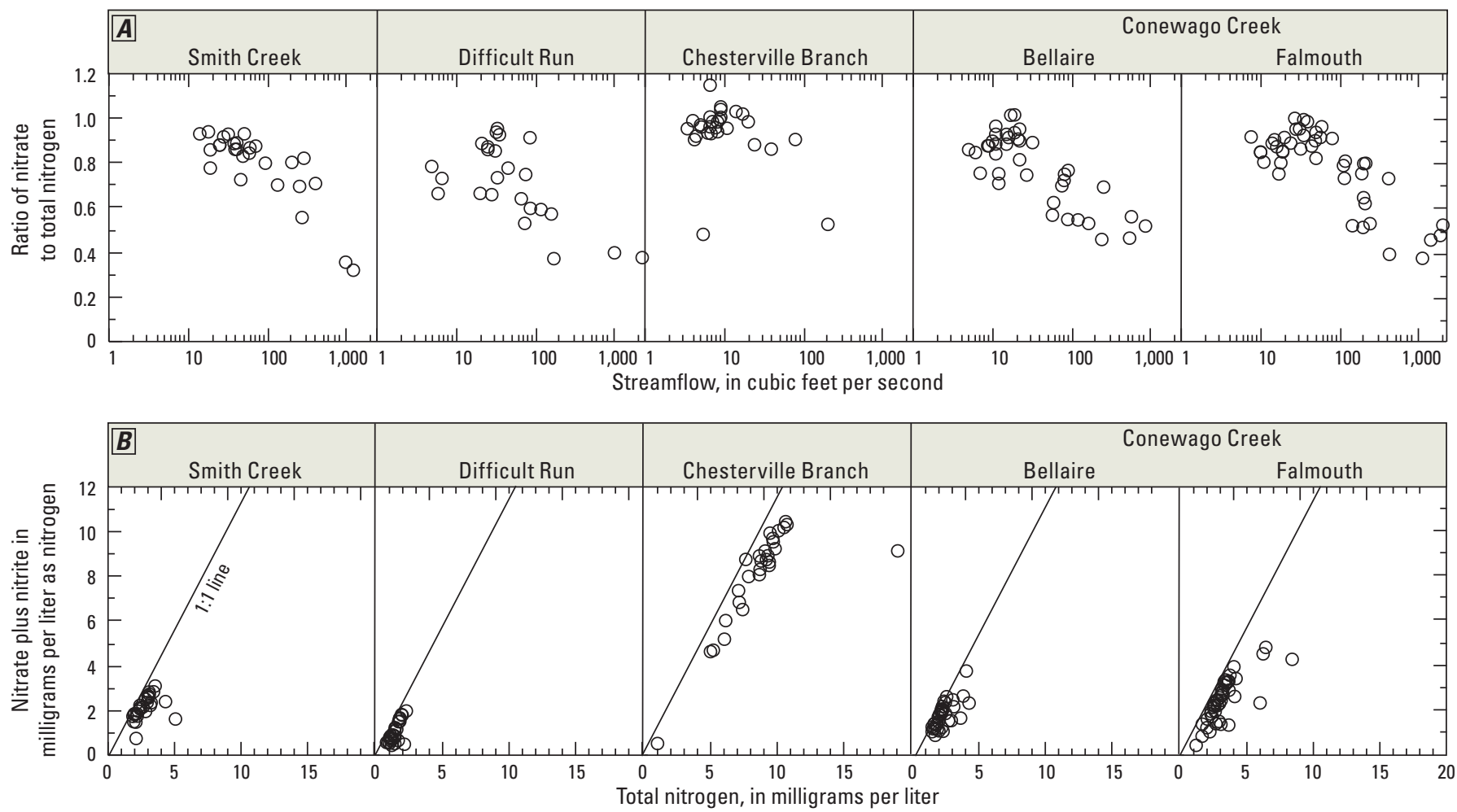

Figure 143. Discrete data from the Smith Creek, Difficult Run, Chesterville Branch, and Conewago Creek Bellaire and Falmouth streamgages representing $(A)$ the ratio of nitrate to total nitrogen compared to streamflow and $(B)$ nitrate compared to total nitrogen concentrations, 2010 through 2013.
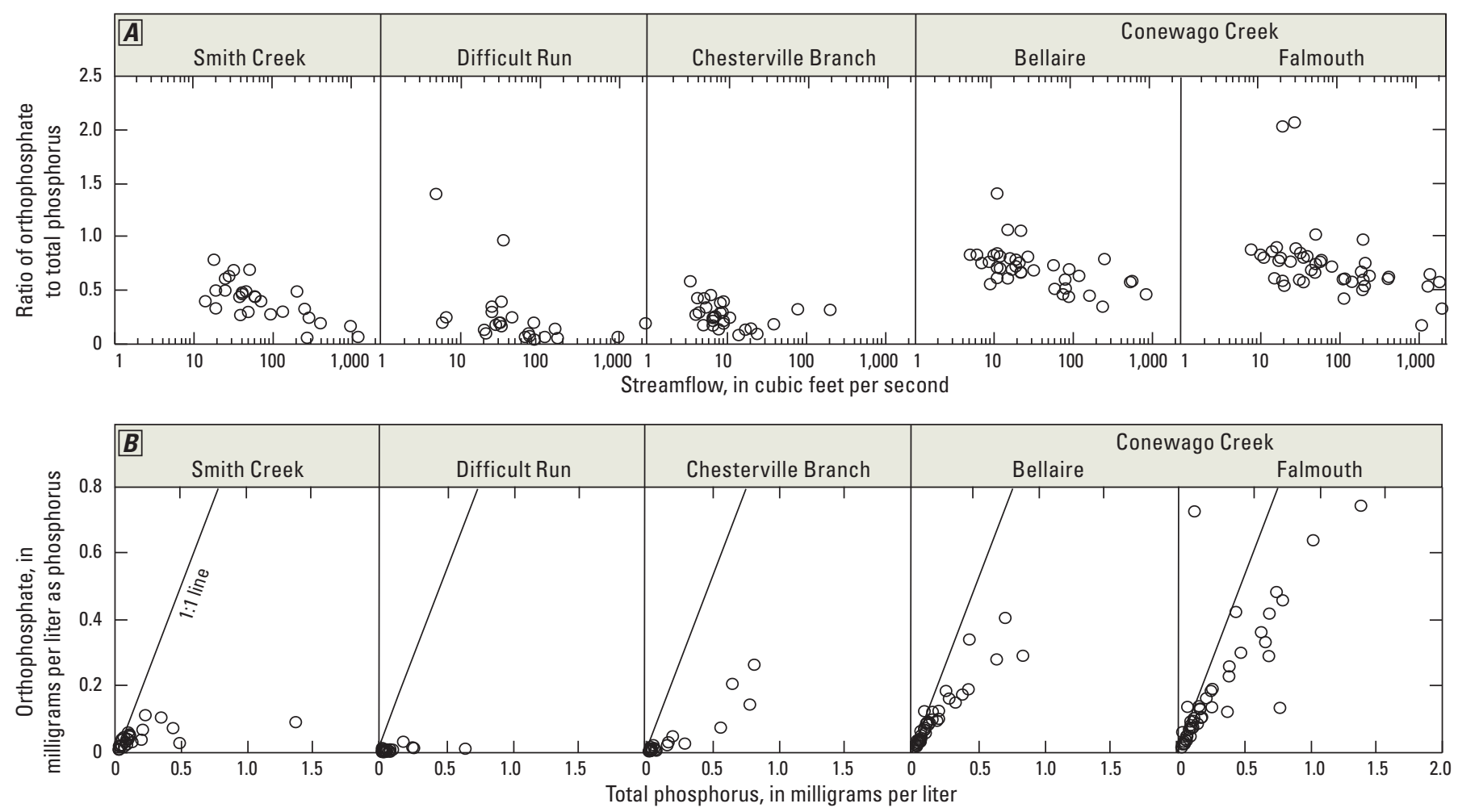

Figure 144. Discrete data from the Smith Creek, Difficult Run, Chesterville Branch, and Conewago Creek Bellaire and Falmouth streamgages representing $(A)$ the ratio of orthophosphate to total phosphorus compared to streamflow and (B) orthophosphate compared to total phosphorus concentrations, 2010 through 2013 


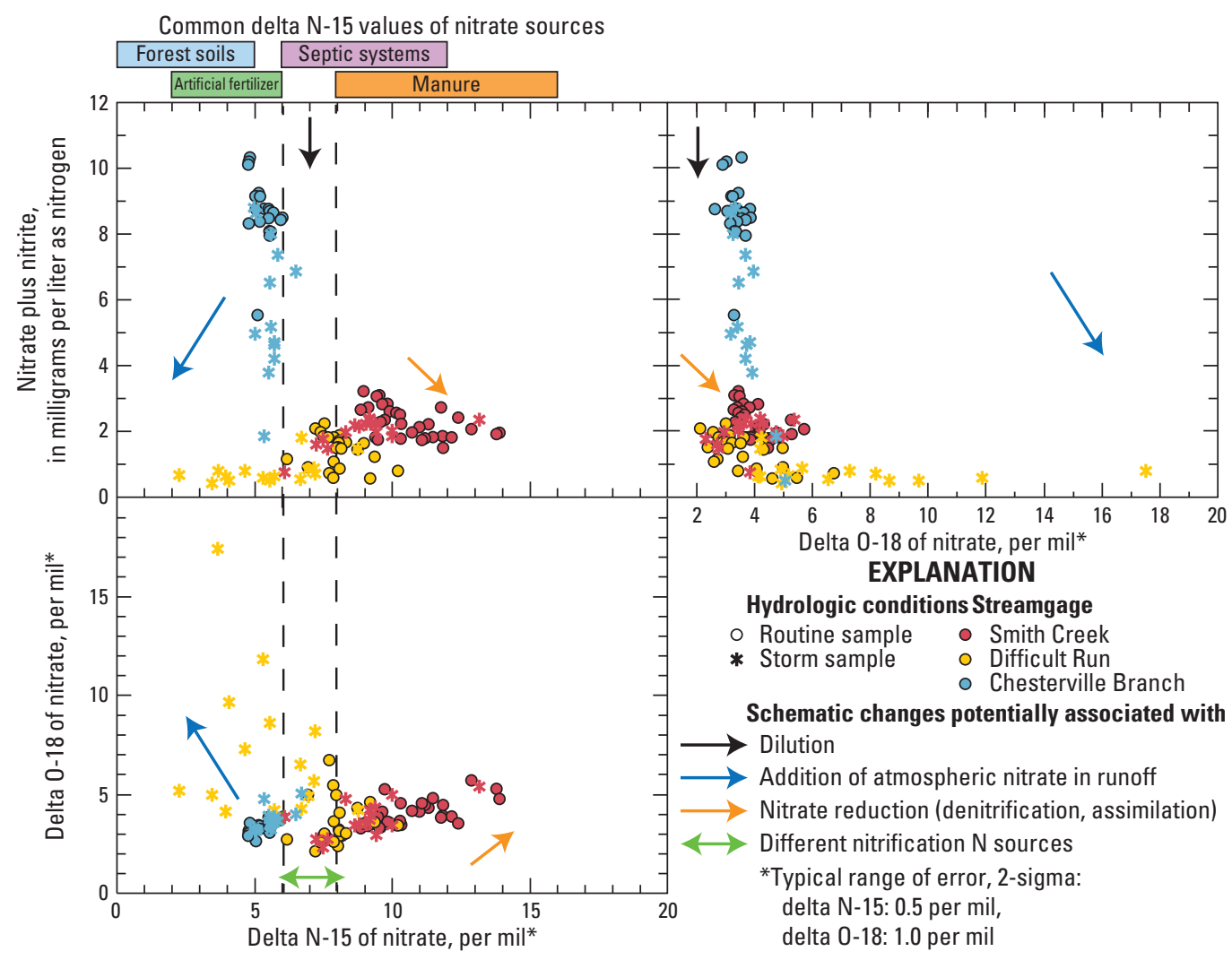

Figure 145. Discrete data from the Smith Creek, Difficult Run, and Chesterville Branch streamgages, and the relationships between $\delta^{15} \mathrm{~N}, \delta^{18} 0$, and nitrate results.

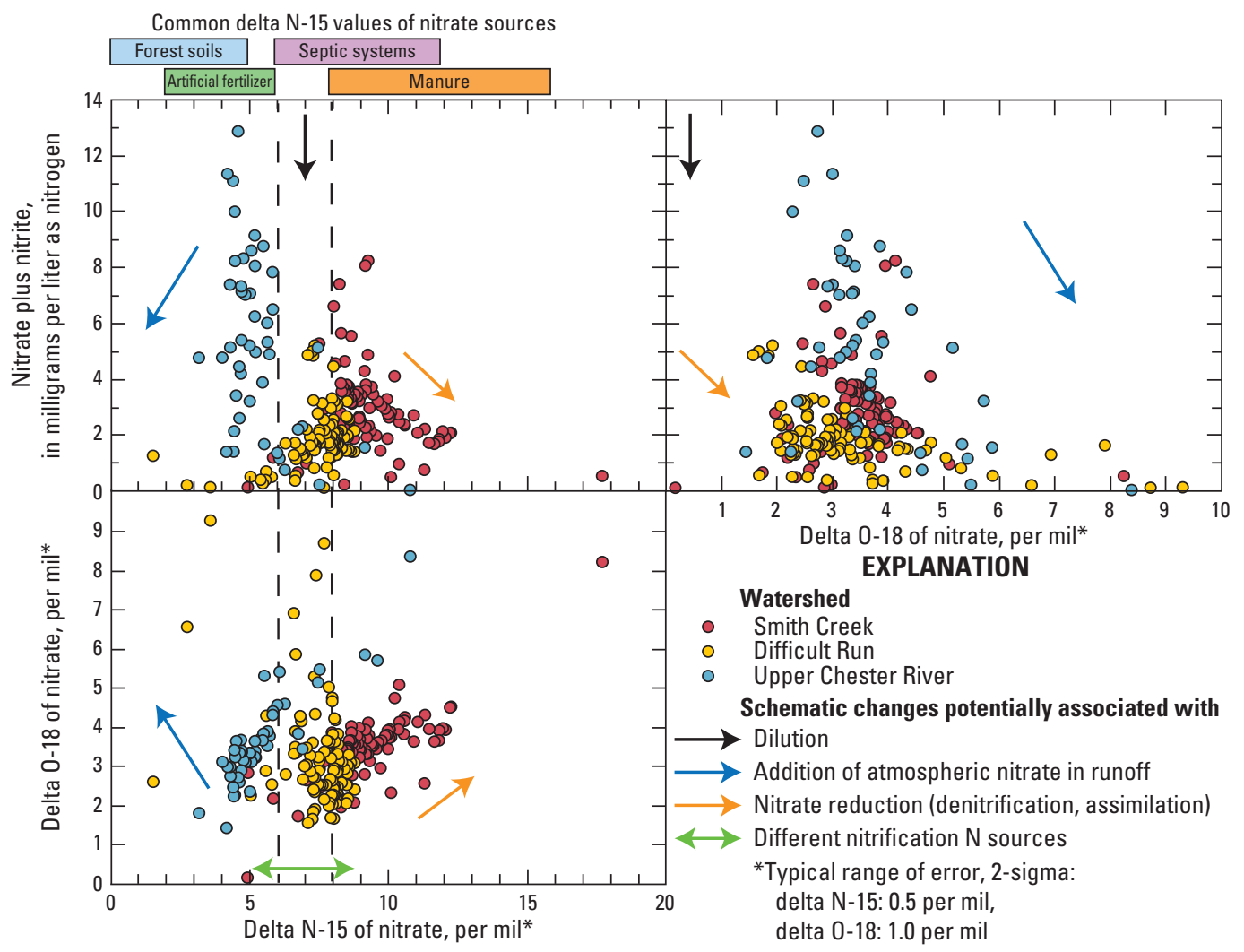

Figure 146. Data from the Smith Creek, Difficult Run, and Upper Chester River watersheds from each synoptic sampling event and the relationships between $\delta^{15} \mathrm{~N}, \delta^{18} 0$, and nitrate results. 

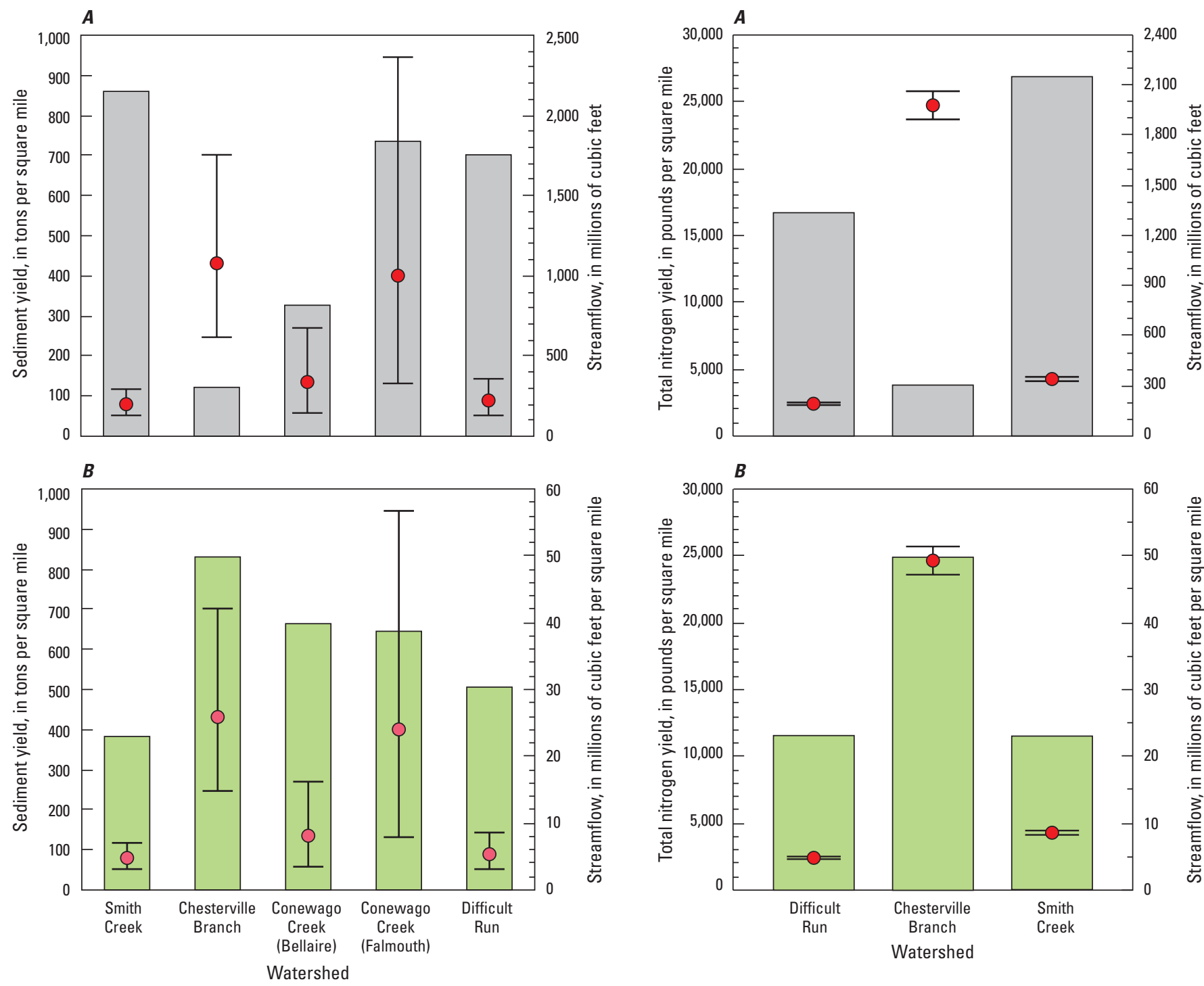

\section{EXPLANATION}

Total streamflow

In millions of cubic feet

In millions of cubic feet per square mile

T-Upper 95 percentile confidence interval

- Yield estimate

$\perp$ - Lower 95 percentile confidence interval

Figure 147. (A) The suspended-sediment yield and total annual streamflow and $(B)$ the suspended-sediment yield and streamflow yield for the 2013 water year from the Smith Creek, Chesterville Branch, Conewago Creek Bellaire and Falmouth, and Difficult Run streamgages.

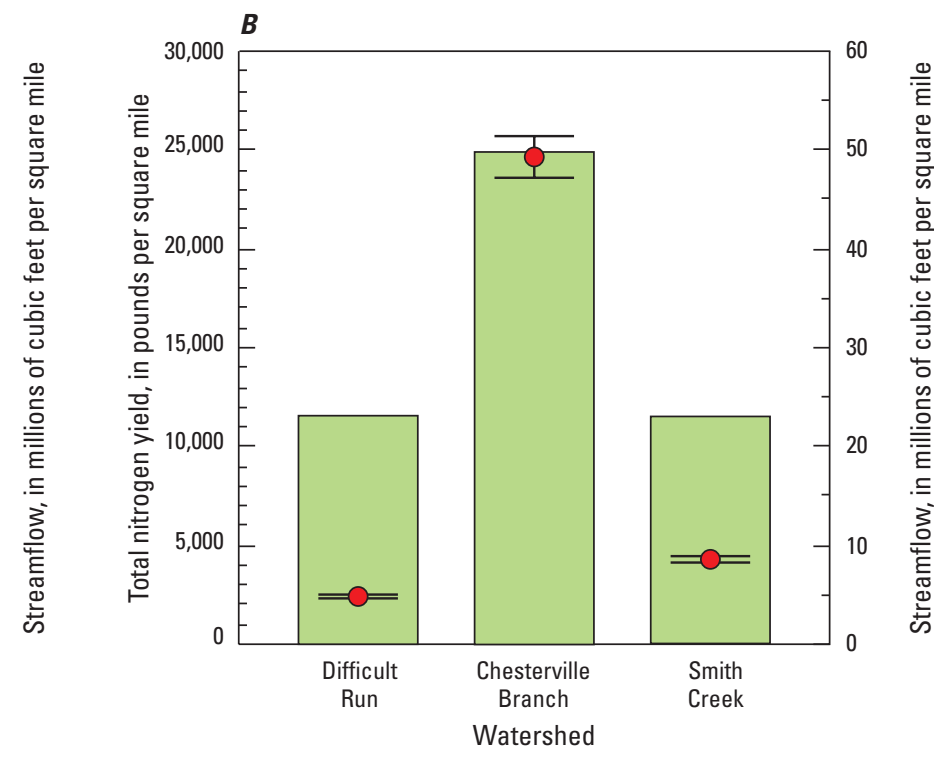

\section{EXPLANATION}

Total streamflow

In millions of cubic feet

In millions of cubic feet per square mile

- Upper 95 percentile confidence interva

- Yield estimate

L - Lower 95 percentile confidence interval

Figure 148. (A) Total nitrogen yield and total annual streamflow and $(B)$ the total nitrogen yield and streamflow yield for the 2013 water year from the Smith Creek, Chesterville Branch, and Difficult Run streamgages. 

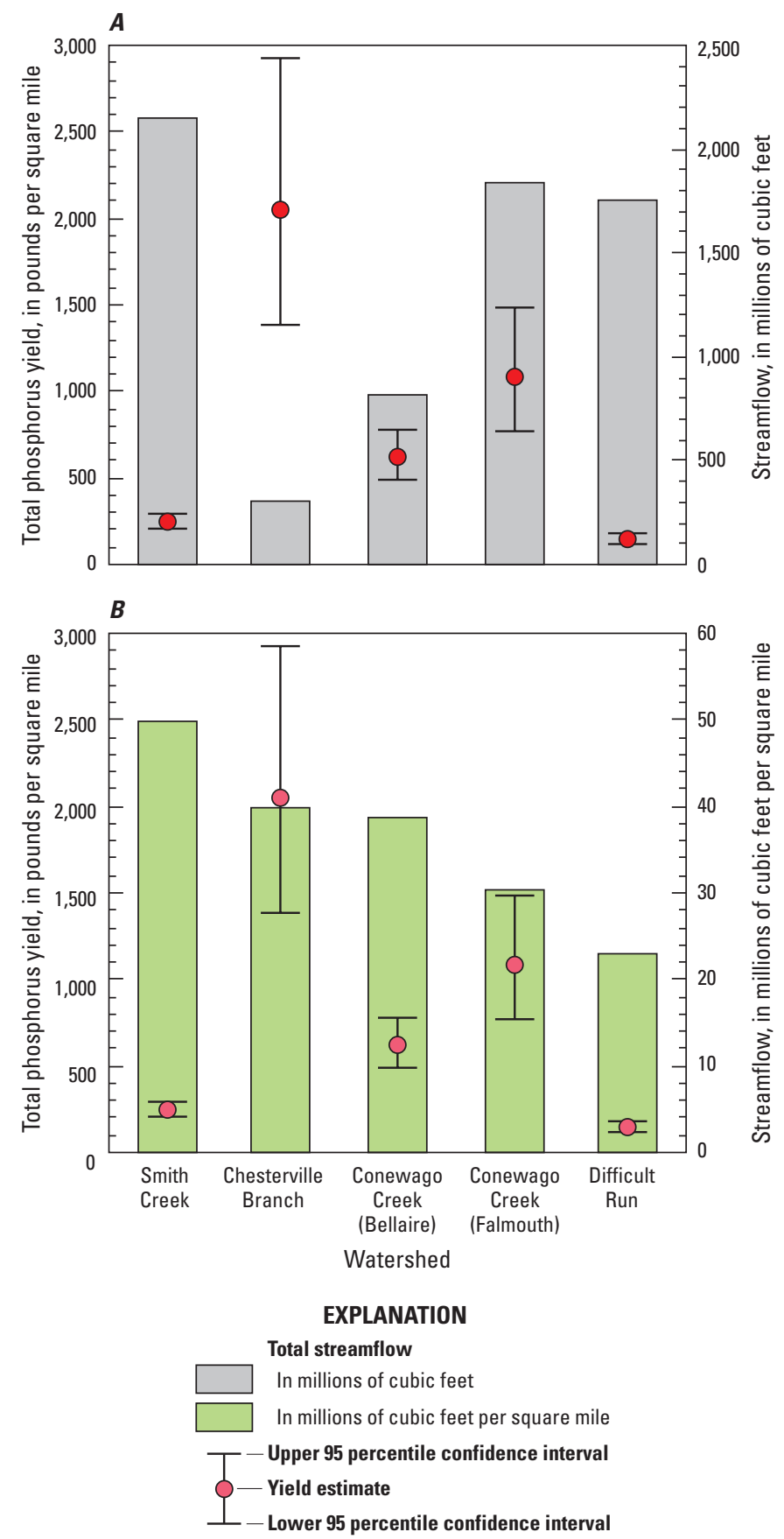

Figure 149. (A) Total phosphorus yield and total annual streamflow and $(B)$ the total phosphorus yield and streamflow yield for the 2013 water year from the Smith Creek, Chesterville Branch, Conewago Creek Bellaire and Falmouth, and Difficult Run streamgages

\section{Future Directions}

This report on the results of the small watershed studies in Smith Creek, Upper Chester River, Conewago Creek, and Difficult Run describes the first 3 years of data collection in these watersheds and contributes to understanding baseline conditions in these four watersheds. The report also begins to characterize the sources, sinks, and transport processes of sediment and nutrients in these watersheds. Future work may focus on the following areas of study:

1. Expand studies to improve understanding of sources, sinks, and transport processes in these watersheds. Improved understanding of sediment and nutrient sources and transport processes could lead to improved recommendations for implementation of the most beneficial BMPs as well as improved monitoring strategies to detect responses of water quality to BMPs. This expanded source and transport work will include such activities as (1) age dating of groundwater resources, (2) shallow groundwater monitoring, and (3) increased use of other geochemical tracers, including isotopes, emerging contaminants, and endocrine-disrupting chemicals.

2. Improve understanding of the effects of the implementation of conservation practices across these watersheds. While the BMPs that have been applied across the landscape to date can be characterized by type and quantity, the tools for characterizing how these actions should affect water quality are rather weak and are commonly limited to evaluations of watershed models with and without conservation practices.

3. Continue core water-quality monitoring and synoptic sampling in these watersheds to maintain a network that is capable of detecting and characterizing long-term improvements in water quality that result from the implementation of conservation practices. All five discrete water-quality monitoring sites described in this report currently are included in the Chesapeake Bay Nontidal Network, and therefore, trends in water-quality constituents will be computed as soon as sufficient data are available. The presence of the synoptic station network provides an additional trend-detection network that might be more sensitive than the five streamgages for the detection of water-quality improvements because the synopticmonitoring sites represent smaller subwatersheds that might be subjected to particularly intense local BMP implementation; therefore, these smaller synoptic sites could respond to BMP implementation sooner than the streamgage monitoring sites.

4. Finally, in an effort to better understand how activities on the landscape affect water quality, and ultimately ecological health, within these watersheds, a relatively new initiative has begun within these basins. Since 2014, the small watershed water-quality team and the fishhealth team of the USGS Chesapeake Bay Program have 
been collaborating to coordinate traditional water-quality nutrient and sediment monitoring with enhanced spatial and temporal monitoring of hormone activity (estrogenicity, androgenicity, glucocorticoid) in an effort to better understand the human and environmental factors that drive potential endocrine disruption in the environment. Detailed characterization of water quality, hydrogeology, and nutrient sources that has already been initiated within the small watershed basins will strengthen the interpretation of these data.

\section{Summary and Conclusions}

In 2010, the U.S. Geological Survey partnered with the U.S. Environmental Protection Agency and the U.S. Department of Agriculture to initiate water-quality monitoring in four diverse small watersheds that were targeted for increased implementation of conservation practices. The objective of this study was to investigate spatial and temporal variations in water chemistry and suspended sediment in these four watersheds that represent a range of land-use patterns and underlying geology to (1) characterize current water-quality conditions in these watersheds, and (2) identify the dominant sources, sinks, and transport processes in each watershed. The results of monitoring performed from April 2010 through September 2013 are discussed by watershed.

\section{Smith Creek Watershed}

Smith Creek is a $105.39-\mathrm{mi}^{2}$ watershed within the Shenandoah Valley that drains to the North Fork Shenandoah River. The long-term Smith Creek base-flow index is 72.3 percent, indicating that Smith Creek streamflow is dominated by groundwater discharge rather than stormwater runoff. A series of cluster and principal components analyses demonstrated that the majority of the variability in Smith Creek water quality could be attributed to hydrologic and seasonal variability. Statistically significant positive correlations with flow were observed for turbidity, suspended sediments, total nitrogen, ammonium, orthophosphate, iron, total phosphorus, and the ratio of calcium to magnesium concentrations. Statistically significant inverse correlations with flow were observed for specific conductance, magnesium, $\delta^{15} \mathrm{~N}$ of nitrate, $\delta^{18} \mathrm{O}$ of nitrate, $\mathrm{pH}$, bicarbonate, and calcium. Of particular note, flow and nitrate were not significantly correlated, likely because of the relatively complex concentration-discharge relationship observed in continuous and discrete datasets. Statistically significant seasonal patterns were observed for numerous water-quality constituents. Water temperature, orthophosphate, total phosphorus, turbidity, suspended-sediment concentration, and silica were higher during the warm season than during the cool season, and dissolved oxygen, $\mathrm{pH}$, and sulfate were higher during the cool season. Surrogate-regression models were developed to compute sediment and nutrient loads in Smith Creek using the continuous water-quality monitors.
The Smith Creek in-stream sediment load was approximately 6,900 tons per year, with nearly 90 percent of the sediment load over the 3-year study period contributed during the eight largest storm events of that period. The Smith Creek phosphorus load was approximately 21,000 pounds per year, with the majority of the load contributed during stormflow periods, although a substantial phosphorus load still occurred during base-flow conditions. Smith Creek total nitrogen load was about 400,000 pounds per year, with total nitrogen accumulation less dominated by stormflow contributions and strongly affected by base-flow export of nitrogen from the watershed.

Extensive water-quality monitoring throughout the Smith Creek watershed revealed how a complex geology and hydrology interact to result in variable water chemistry throughout the Smith Creek watershed. During relatively dry and low base-flow periods, much of the discharge in Smith Creek was contributed by a single dominant spring - Lacey Spring. During wetter base-flow periods, the flows in Smith Creek were largely generated by a mixture of headwater springs and forested mountain tributaries with very different geochemical composition. The headwater springs were generally underlain by carbonate bedrock and were characterized as having relatively high nitrate, specific conductance, calcium, and magnesium, as well as relatively low concentrations of phosphorus, ammonium, iron, and manganese. The undeveloped, high-gradient, forested mountain sites were generally characterized by low ionic strength waters with low nutrient concentrations. Analysis of the nitrate isotope data generally indicates that the nitrogen from the limestone springs was largely consistent with manure-derived sources (cattle and poultry), although the possibility of other mixed sources cannot be excluded. The nitrogen from the undeveloped, highgradient, forested mountain sites was consistent with atmospheric and natural soil sources of nitrogen. Land-use data indicate that manure sources of nitrogen dominated the input of nitrogen to the watershed. Phosphorus sources were less well studied. The presence of a single point-source discharge in the watershed near the town of New Market contributed the majority of the phosphorus to Smith Creek under base-flow conditions, but nonpoint sources of phosphorus dominated the loading to Smith Creek during stormflow periods.

Implementation of conservation practices increased in the Smith Creek watershed during the study period, and even though a broad range of practice types were implemented, the most common practices included stream fencing (for cattle exclusion), the development of nutrient management plans, conservation crop rotation, and the planting of cover crops. While the implementation of these conservation practices is encouraging, results indicate small increases in nitrate concentrations at the streamgage during the past several decades, concurrent with small decreases in nitrate fluxes. The cumulative effect of these practices may not be detected in the Smith Creek water quality for many years, and the magnitude of the effect of these conservation practices in Smith Creek will depend largely on whether nutrient loading (of manure and commercial fertilizer) is reduced over time. 


\section{Upper Chester River Watershed}

The Upper Chester River watershed includes the 36.54-square-mile $\left(\mathrm{mi}^{2}\right)$ watershed area around several nontidal tributaries that drain into the tidal Chester River. The streamgage is on Chesterville Branch, the largest nontidal tributary (approximately $6.12 \mathrm{mi}^{2}$ ) and the site for continuous water-quality monitoring during this project. The base-flow index at Chesterville Branch is about 72 percent and indicates that, as in most of the Coastal Plain, groundwater is the greatest contributor to streamflow. As such, more than 90 percent of the nitrogen in the stream is in the form of nitrate from groundwater. Continuous and discrete data collected at Chesterville Branch show the effects of streamflow and season on water quality. Significant positive correlations with flow were observed for ammonium, orthophosphate, total phosphorus, sediment, and turbidity as runoff carried these constituents from the land surface into Chesterville Branch. Other constituents that increased significantly with flow include potassium, sulfate, iron, and manganese, which were likely contributed from near-stream areas and ponds with higher organic-matter content. Total nitrogen, $\mathrm{pH}$, and specific conductance, along with chemical constituents associated with groundwater inputs including nitrate, calcium, silica, bicarbonate, ratio of calcium to magnesium, and sodium, were negatively correlated with flow because concentrations of these constituents were diluted by runoff.

Seasonal differences in water chemistry most likely related to increased biologic effects on the uptake and release of chemicals in the stream and near-stream areas also were observed. Water temperature, orthophosphate, $\delta^{15} \mathrm{~N}$ of nitrate, bicarbonate, ratio of sodium to chloride, and sodium were higher during the warm season, and dissolved oxygen, total nitrogen, nitrate, magnesium, sulfate, and manganese were higher during the cool season.

Surrogate regression models developed by using continuous water-quality data showed that the annual sediment load for the 2013 water year to be about 2,600 tons, with more than 90 percent of the sediment contributed during two storms. The total phosphorus load in 2013 water year was about 13,000 pounds, with more than 90 percent of the load contributed during the same two storms. The load of total nitrogen in the 2013 water year, about 140,000 pounds, accumulated steadily throughout the year as nitrate in groundwater continuously discharged into the stream. The same two large storms that contributed 90 percent of the suspended-sediment and total phosphorus load only contributed about 20 percent of the annual total nitrogen load.

Extensive water-quality monitoring of stream base flow throughout the Upper Chester River watershed identified how differences in land use and hydrogeology affect water chemistry. In parts of the watershed with well-drained soil and thick sandy aquifer sediments, concentrations of nitrate and other chemicals associated with fertilizer and lime application increased in streams as agricultural land use increased. More than 90 percent of the nitrogen in streams from these areas was in the form of nitrate, and concentrations ranged from about 6 to 10 milligrams per liter as nitrogen in the two largest tributaries. Stream nitrate concentrations were about 1 milligram per liter as nitrogen where soils were more poorly drained, the surficial aquifer sediments were thinner, and forests and wetlands were more widespread than agriculture. Nitrogen and oxygen isotopes of nitrate were consistent with soil nitrification in areas receiving large quantities of excess nitrogen from artificial fertilizers or atmospheric nitrogen fixation. Some denitrification was indicated by the isotopic signatures in water from the poorly drained streams. An analysis of land-use data and SPARROW modeling input data attribute almost 90 percent of the nitrogen sources in the Upper Chester River watershed to inorganic fertilizer and nitrogen fixation of atmospheric nitrogen by legumes, which agrees with the isotopic signature of nitrate in this watershed. Local sources of manure are limited in this area. Total phosphorus concentrations during base flow ranged from below detection to about 0.2 milligram per liter. Phosphorus concentrations present in streams during base-flow conditions were generally low compared to concentrations measured during storms because most phosphorus transport occurs as phosphorus attached to sediment particles during runoff. Because manure is not widely used in this area, the probable major source of phosphorus is fertilizer.

The implementation of conservation practices in the Upper Chester River watershed increased substantially during the study period. Out of the 1,194 USDA-compliant practices that were implemented, the most frequently used practices were oriented towards nutrient and sediment control, including cover crops, nutrient management planning, conservation crop rotation, conservation tillage, and irrigation management. The current Chesapeake Bay model for this area estimates that implementation of best management practices has caused a 9-percent decrease in overall delivery of nitrate to the Upper Chester River since 1985. Because most nitrogen travels through the groundwater system for years to decades before being discharged to streams, the time period of monitoring was not sufficient to see the effects of these practices on water quality. The magnitude of the effect that may eventually be detected depends on the degree to which leaching of nitrate into the groundwater system is reduced over time. Loadings of phosphorus and sediment are primarily transported during large runoff events and are difficult to control and analyze for trends because of their timing and episodic nature.

\section{Conewago Creek Watershed}

Conewago Creek has two monitoring locations-one near the middle of the 47-square-mile watershed, and the other near the outlet just upstream of the Susquehanna River. The base-flow index was 43.1 percent for 2012-2013, indicating that on average, approximately 57 percent of the streamflow in Conewago Creek exited the watershed as stormflow, which suggests that stormwater runoff was greater than groundwater discharge (base flow). A series of cluster and principal 
components analyses demonstrated that the majority of the variability in the Conewago Creek water quality could be attributed to hydrologic and seasonal variability. Statistically significant positive correlations with flow were observed for total nitrogen (at the upstream site only), ammonium, total phosphorus, orthophosphate, iron, and manganese. Statistically significant inverse correlations with flow were observed for water temperature, specific conductance (at the downstream site only), sulfate, chloride, calcium, and magnesium. The only difference between the monitoring locations was that flow and total nitrogen were not statistically significantly correlated at the downstream site. Statistically significant seasonal patterns were observed for several water-quality constituents. Water temperature, phosphorus (upstream site only), and orthophosphate were higher during the warm season than during the cool season, and nitrate nitrogen and TN (upstream site only) were higher during the cool season.

Surrogate regression models were developed to compute sediment and nutrient loads in Conewago Creek by using the continuous water-quality monitors and water-quality samples. Conewago Creek sediment load was approximately 9,900 tons in 2012 and 18,900 tons in 2013 , with nearly 80 percent of the sediment load in 2013 contributed by the three largest storm events. Annual total nitrogen loads could not be estimated due to poor model performance. Additional monitoring or a continuous nitrate sensor might improve future estimates of TN loads. Conewago Creek phosphorus loads were approximately 50,000 pounds in 2012 and 2013.

Combining data from one high-flow synoptic sampling event with the data from routine sampling revealed how the geology and hydrology interact to result in variable water chemistry throughout the Conewago Creek watershed. The areas above the upstream gage in the headwaters are generally underlain by forested non-carbonate bedrock and are characterized by low nitrate, specific conductance, calcium, and magnesium, as well as low concentrations of phosphorus, ammonium, iron, and manganese. The more developed, agricultural areas below the upstream site are generally characterized by higher ionic strength waters with higher nutrient and metal concentrations. An analysis of land-use data and SPARROW modeling data indicates that manure sources of nitrogen dominate the input of nitrogen to the watershed.

Implementation of conservation practices increased in the Conewago Creek watershed during the study period, and while a broad range of practice types were implemented, the most common practices included residue and tillage management (no-till with cover crops), nutrient management, terracing, and stream fencing (for animal exclusion or bank restoration). While the implementation of these conservation practices is encouraging, the cumulative effect of these practices may not be detected in Conewago Creek water quality for years. The magnitude of the effect of these conservation practices depends largely on whether or not nutrient loading (manure and commercial fertilizer) is reduced and if sedimentmanagement activities are intensified over time.

\section{Difficult Run Watershed}

The Difficult Run watershed is a $57.82-\mathrm{mi}^{2}$ watershed that drains to the Potomac River. The long-term Difficult Run base-flow index was 57.9 percent, indicating that approximately 58 percent of the flow left the watershed as base flow and 42 percent as stormflow; however, with continued development and urbanization of the watershed, the base-flow index has decreased to 50.8 percent during the last 20 years. This base-flow index was smaller than those of the other study watersheds with long-term streamflow data, likely because the Difficult Run watershed is mostly underlain by crystalline Piedmont metamorphic rocks and has a relatively large proportion of impervious urban land cover. A series of cluster and principal components analyses indicated that most of the variability in Difficult Run water quality could be attributed to hydrologic variability and seasonality. Statistically significant positive correlations with flow were observed for turbidity, dissolved oxygen, suspended sediments, ammonium, orthophosphate, iron, and total phosphorus. Statistically significant inverse correlations with flow were observed for water temperature, $\mathrm{pH}$, specific conductance, bicarbonate, calcium, magnesium, nitrate, $\delta^{15} \mathrm{~N}$ of nitrate, and silica. Statistically significant seasonal patterns were observed for numerous water-quality constituents. Water temperature, ammonium, orthophosphate, and $\delta^{15} \mathrm{~N}$ of nitrate were higher during the warm season, and dissolved oxygen, nitrate, and manganese were higher during the cool season. Surrogate regression models were developed to compute sediment and nutrient loading rates. The Difficult Run sediment load was approximately 8,000 tons per year, with greater than 95 percent of the sediment load in the 2013 water year contributed by the seven largest storm events. The phosphorus load in Difficult Run was approximately 14,000 pounds per year, with the majority of the load contributed during stormflow periods. The total nitrogen load in Difficult Run is estimated to have been approximately 140,000 pounds per year, with total nitrogen accumulation less dominated by stormflow contributions than that of phosphorus and strongly affected by base-flow export of nitrogen from the basin.

Extensive water-quality monitoring throughout the Difficult Run watershed revealed relatively uniform generation of flow per unit of watershed area, as well as spatial clusters in water quality that appear to be strongly related to land-use activities. One cluster of monitoring sites is composed of stations with elevated nitrate concentrations. The elevated nitrate concentrations are inversely correlated with population density and positively correlated with septic system density within each subwatershed. The majority of the elevated nitrate concentrations for sites in this cluster may have resulted from nitrate leaching by septic systems, whereas homeowner fertilizer usage in these lower density subwatersheds was less likely to be the principal source of nitrate. Nitrate isotope data, temporal patterns in the water-quality data, mass-balance computations, and a separate land-use analysis all generally indicate that leachate from septic systems was the most likely source of the elevated nitrate. Another water-quality 
cluster is composed of sites with relatively low nitrogen concentrations, and these sites are generally clustered in areas that are served by city sewer lines and have had significant stream restoration activities. A third cluster drained the areas with the highest imperviousness and consisted of sites with strongly elevated specific conductance, chloride, and sodium, which were likely caused by a combination of road salting and other anthropogenic sources draining these urbanized areas in the watershed. A fourth water-quality cluster represents a mixture of water sources and had water quality similar to that at the Difficult Run streamgage. Nitrate isotope data indicate variations in the proportions of different sources. Implementation of conservation practices increased in the Difficult Run watershed during the study period, and while a broad range of practice types were implemented, the most common practices included stream restoration. While the implementation of these conservation practices is encouraging, the cumulative effect of these practices likely will not be detected in the Difficult Run water quality for years.

\section{References Cited}

Alexander, R.B., Smith, R.A., and Schwarz, G.E., 2000, Effect of stream channel size on the delivery of nitrogen to the Gulf of Mexico: Nature, v. 403, p. 759-761.

Alexander, R.B., Smith, R.A., Schwarz, G.E., Boyer, E.W., Nolan, J.V., and Brakebill, J.W., 2008, Differences in phosphorus and nitrogen delivery to the Gulf of Mexico from the Mississippi River Basin: Environmental Science \& Technology, v. 42 , no. 3 , p. $822-830$.

Amberger, A., and Schmidt, H.L., 1987, Natürliche Isotopengehalte von Nitrat als Indikatoren für dessen Herkunft: Geochimica et Cosmochimica Acta, v. 51, p. 2699-2705.

Amundsen, R., Austin, A.T., Schuur, E.A.G., Yoo, K., Matzek, V., Kendall, C., Uebersax, A., Brenner, D., and Baisden, W.T., 2003, Global patterns of the isotopic composition of soil and plant nitrogen: Global Biogeochemical Cycles, v. 17 , no. 1 , p. 31-1-31-10.

Aravena, R., Evans, M.L., and Cherry, J.A., 1993, Stable isotopes of oxygen and nitrogen in source identification of nitrate from septic systems: Ground Water, v. 31, p. $180-186$.

Ator, S.W., Brakebill, J.W., and Blomquist, J.D., 2011, Sources, fate, and transport of nitrogen and phosphorus in the Chesapeake Bay watershed-An empirical model: U.S. Geological Survey Scientific Investigations Report 2011-5167, 27 p.

Ator, S.W., Denver, J.M., Brayton, M.J., 2004, Hydrologic and geochemical controls on pesticide and nutrient transport to two streams on the Delmarva Peninsula: U.S. Geological Survey Scientific Investigations Report 2004-5051, 34 p.
Böhlke, J.K., 2002, Groundwater recharge and agricultural contamination: Hydrogeology Journal, v. 10, p. 153-179.

Böhlke, J.K., 2003, Sources, transport, and reaction of nitrate in ground water, in Lindsey, B.D., Phillips, Scott, Donnelly, C.A., Speiran, G.K., Plummer, L.N., Böhlke, J.K., Focazio, M.J., Burton, W.C., and Busenberg, Eurybiades, Residence times and nitrate transport in ground water discharging to streams in the Chesapeake Bay watershed: U.S. Geological Survey Water-Resources Investigations Report 2003-4035, p. 25-39.

Böhlke, J.K., and Denver, J.M., 1995, Combined use of groundwater dating, chemical, and isotopic analyses to resolve the history and fate of nitrate contamination in two agricultural watersheds, Atlantic Coastal Plain, Maryland: Water Resources Research, v. 31, no. 9, p. 2319-2339.

Böhlke, J.K., and Michel, R.L., 2009, Contrasting residence times and fluxes of water and sulfate in two small forested watersheds in Virginia, USA: Science of the Total Environment, v. 407, p. 4363-4377.

Böhlke, J.K., Mroczkowski, S.J., and Coplen, T.B., 2003, Oxygen isotopes in nitrate- - New reference materials for ${ }^{18} \mathrm{O}:{ }^{17} \mathrm{O}:{ }^{16} \mathrm{O}$ measurements and observations on nitrate-water equilibration: Rapid Communications in Mass Spectrometry, v. 17, no. 16, p. 1835-1846.

Böhlke, J.K., Smith, R.L., and Miller, D.N., 2006, Ammonium transport and reaction in contaminated ground waterApplication of isotopic tracers and isotope fractionation studies: Water Resources Research, v. 42, p. 1-19, accessed December 11, 2015, at http://onlinelibrary.wiley.com/ doi/10.1029/2005WR004349/abstract.

Böhlke, J.K., Wanty, R., Tuttle, M., Delin, G., and Landon, M., 2002, Denitrification in the recharge area and discharge area of a transient agricultural nitrate plume in a glacial outwash sand aquifer, Minnesota: Water Resources Research, v. 38, no. 7, p. 1-26.

Böttcher, J., Strebel, O., Voerkelius, S., and Schmidt, H.-L., 1990, Using isotope fractionation of nitrate-nitrogen and nitrate-oxygen for evaluation of microbial denitrification in a sandy aquifer: Journal of Hydrology, v. 114, p. 413-424.

Burns, D.A., Vitvar, T., McDonnell, J., Hassett, J., Duncan, J., and Kendall, C., 2005, Effects of suburban development on runoff generation in the Croton River basin, New York, USA: Journal of Hydrology, v. 311, p. 266-281.

Burton, G.A., Jr., and Pitt, R.E., 2002, Stormwater effects handbook-A toolbox for watershed managers, scientists, and engineers: Boca Raton, Fla., Lewis Publishers, 911 p.

Casciotti, K.L., Sigman, D.M., Hastings, M., Böhlke, J.K., and Hilkert, A., 2002, Measurement of the oxygen isotopic composition of nitrate in seawater and freshwater using the denitrifier method: Analytical Chemistry, v. 74, p. 4905-4912. 
Clune, J.W., and Denver, J.M., 2012, Residence time, chemical and isotopic analysis of nitrate in the groundwater and surface water of a small agricultural watershed in the Coastal Plain, Bucks Branch, Sussex County, Delaware: U.S. Geological Survey Scientific Investigations Report 2012-5235, 15 p.

Coplen, T.B., Böhlke, J.K., and Casciotti, K.L., 2004, Using dual-bacterial denitrification to improve $\mathrm{d}^{15} \mathrm{~N}$ determinations of nitrates containing mass-independent ${ }^{17} \mathrm{O}$ : Rapid Communications in Mass Spectrometry, v. 18, p. 245-250.

Corsi, S.R., Horwatich, J.A., Rutter, T.D., and Bannerman, R.T., 2013, Effects of best-management practices in Bower Creek in the East River priority watershed, Wisconsin, 1991-2009: U.S. Geological Survey Scientific Investigations Report 2012-5217, 21 p.

Debrewer, L.M., Ator, S.W., and Denver, J.M., 2007, Factors affecting spatial and temporal variability in nutrient and pesticide concentrations in the surficial aquifer on the Delmarva Peninsula: U.S. Geological Survey Scientific Investigations Report 2005-5257, 44 p.

Denver, J.M., 1989, Effects of agricultural practices and septic-system effluent on the quality of water in the unconfined aquifer system in parts of eastern Sussex County, Delaware: Delaware Geological Survey Report of Investigations No. 45, 66 p.

Denver, J.M., Tesoriero, A.J., and Barbaro, J.R., 2010, Trends and transformation of nutrients and pesticides in a coastal plain aquifer system, United States: Journal of Environmental Quality, v. 39, no. 1, p. 154-167.

Dicken, C.L., Nicholson, S.W., Horton, J.D., Kinney, S.A., Gunther, Gregory, Foose, M.P., and Mueller, J.A.L., 2005, Preliminary integrated geologic map databases for the United States-Delaware, Maryland, New York, Pennsylvania, and Virginia: U.S. Geological Survey Open-File Report 2005-1325 [unpaginated].

Fairfax County Stormwater Planning Division, 2007, Fairfax County generalized current land use-Revision 2.

Federal Leadership Committee for the Chesapeake Bay, 2010, Protecting and Restoring a National Treasure, accessed January 13, 2016, at http://executiveorder. chesapeakebay.net/.

Feminella, J.W., and Walsh, C.J., 2005, Urbanization and stream ecology — An introduction to the series: Journal of the North American Benthological Society, v. 24, no. 3, p. 585-587.

Fenneman, N.M., and Johnson, D.W., 1946, Physical divisions of the United States: U.S. Geological Survey, scale 1:7,000,000.
Fogg, G.E., Rolston, D.E., Decker, D.L., Louie, D.T., and Grismer, M.E., 1998, Spatial variation in nitrogen isotope values beneath nitrate contamination sources: Ground Water, v. 36, p. 418-426.

Gellis, A.C., Hupp, C.R., Pavich, M.J., Landwehr, J.M., Banks, W.S.L., Hubbard, B.E., Langland, M.J., Ritchie, J.C., and Reuter, J.M., 2009, Sources, transport, and storage of sediment in the Chesapeake Bay watershed: U.S. Geological Survey Scientific Investigations Report 2008-5186, $95 \mathrm{p}$.

Granger, J., Sigman, D.M., Lehmann, M.F., and Tortell, P.D., 2008, Nitrogen and oxygen isotope fractionation during dissimilatory nitrate reduction by denitrifying bacteria: Limnology and Oceanography, v. 53, p. 2533-2545.

Granger, J., Sigman, D.M., Needoba, J.A., and Harrison, P.J., 2004, Coupled nitrogen and oxygen isotope fractionation of nitrate during assimilation by cultures of marine phytoplankton: Limnology and Oceanography, v. 49, p. 1763-1773.

Gray, J.R., Glysson, G.D., Turcios, L.M., and Schwarz, G.E., 2000, Comparability of suspended-sediment concentration and total suspended solids data: U.S. Geological Survey Water-Resources Investigations Report 00-4191, 14 p.

Groffman, P.M., Altabet, M.A., Bohlke, J.K., Butterbach-Bahl, K., David, M.B., Firestone, M.K., Giblin, A.E., Kana, T.M., Nielsen, L.P., and Voytek, M.A., 2006, Methods for measuring denitrification-Diverse approaches to a difficult problem: Ecological Applications, v. 16, p. 2091-2122.

Gronberg, J.M., and Spahr, N.E., 2012, County-level estimates of nitrogen and phosphorus from commercial fertilizer for the conterminous United States, 1987-2006: U.S. Geological Survey Scientific Investigations Report 2012-5207, 20 p.

Guler, C., Geoffrey, D.T., McCray, J.E., and Turner, A.K., 2002, Evaluation of graphical and multivariate statistical methods for classification of water chemistry data: Hydrogeology Journal, v. 10, p. 455-474.

Hamilton, P.A., Denver, J.M., Phillips, P.J., and Shedlock, R.J., 1993, Water-quality assessment of the Delmarva Peninsula, Delaware, Maryland, and Virginia-Effects of agricultural activities on, and distribution of, nitrate and other inorganic constituents in the surficial aquifer: U.S. Geological Survey Open-File Report 93-40, 87 p.

Handley, L.L., Austin, A.T., Robinson, D., Scrimgeour, C.M., Raven, J.A., Heaton, T.H.E., Schmidt, S., and Stewart, G.R., 1999, The ${ }^{15} \mathrm{~N}$ natural abundance $\left(\delta^{15} \mathrm{~N}\right)$ of ecosystem samples reflects measures of water availability: Australian Journal of Plant Physiology, v. 26, p. 185-199. 
Hayes, D.C., and Wiegand, Ute, 2006, Drainage area of selected streams in Virginia: U.S. Geological Survey OpenFile Report 2006-1308, 51 p.

Heaton, T.H.E., 1986, Isotopic studies of nitrogen pollution in the hydrosphere and atmosphere-A review: Chemical Geology: Isotope Geoscience Section, v. 59, p. 87-102.

Heisig, P., 2000, Effects of residential and agricultural land uses on the chemical quality of small streams in the Croton Watershed, southeastern New York: U.S. Geological Survey Water-Resources Investigation Report 99-4173, 15 p.

Helsel, D.R., and Hirsch, R.M., 2002, Statistical methods in water resources: U.S. Geological Survey Techniques of Water-Resources Investigations, book 4, chap. A3, 523 p.

Hem, J.D., 1985, Study and interpretation of the chemical characteristics of natural water (3d ed.): U.S. Geological Survey Water-Supply Paper 2254, 263 p.

Hinkle, S.R., Böhlke, J.K., Duff, J.H., Morgan, D.S., and Weick, R.J., 2007, Aquifer-scale controls on the distribution of nitrate and ammonium in ground water near La Pine, Oregon, USA: Journal of Hydrology, v. 333, p. 486-503.

Hinkle, S.R., Böhlke, J.K., and Fisher, L.H., 2008, Mass balance and isotope effects during nitrogen transport through septic tank systems with packed-bed (sand) filters: Science of the Total Environment, v. 407, p. 324-332.

Hively, W.D., Devereux, O.H., and Claggett, Peter, 2013, Integrating Federal and State Data records to report progress in establishing agricultural conservation practices on Chesapeake Bay farms: U.S. Geological Survey Open-File Report 2013-1287, 36 p., accessed December 15, 2015, at http://pubs.usgs.gov/of/2013/1287/.

Homer, C.G., Dewitz, J.A., Yang, L., Jin, S., Danielson, P., Xian, G., Coulston, J., Herold, N.D., Wickham, J.D., and Megown, K., 2015, Completion of the 2011 National Land Cover Database for the conterminous United StatesRepresenting a decade of land cover change information: Photogrammetric Engineering and Remote Sensing, v. 81 , no. 5, p. 345-354, accessed January 13, 2016, at http://www.mrlc.gov/nlcd2011.php.

Horizon Systems, 2010, NHDPlus documentation, version 1, accessed January 16, 2016, at http://www.horizon-systems. com/NHDPlus/NHDPlusV1_documentation.php.

Houlton, B.Z., Sigman, D.M., and Hedin, L.O., 2006, Isotopic evidence for large gaseous nitrogen losses from tropical rainforests - Proceedings of the National Academy of Sciences of the United States of America, v. 103, no. 23, p. 8745-8750, accessed December 16, 2015, at http://www.scopus.com/inward/record.url?eid=2-s2.033745031994\&partnerID=40\&md5=7b91 cb5b6c5ea941517 9abfe2f84239b.
Hubbard, D.A., Jr., 1983, Selected karst features of the northern Valley and Ridge province, Virginia: Virginia Division of Mineral Resources, Publication 441 p.

Hübner, H., 1986, Isotope effects of nitrogen in the soil and biosphere, in Fritz, P., and Fontes, J.C., eds., Handbook of environmental isotope geochemistry-The terrestrial environment, v. 2B: Elsevier, p. 361-425.

Hupp, C.R., Noe, G.B., Schenk, E.R., and Benthem, A.J., 2013, Recent and historic sediment dynamics along Difficult Run, a suburban Virginia Piedmont stream: Geomorphology, v. 180-181, p. 156-169.

Hyer, K.E., Hornberger, G.M., and Herman, J.S., 2001, Processes controlling the episodic streamwater transport of atrazine and other agrichemicals in an agricultural watershed: Journal of Hydrology, v. 254, p. 47-66.

Jackson, W.A., Böhlke, J.K., Andraski, B.J., Fahlquist, L., Bexfield, L., Eckardt, F.D., Gates, J.B., Davila, A.F., McKay, C.P., Rao, B., Sevanthi, R., Rajagopalan, S., Estrada, N., Sturchio, N.C., Hatzinger, P.B., Anderson, T.A., Orris, G., Betancourt, J., Stonestrom, D., Latorre, C., Li, Y., and Harvey, G.J., 2015, Global patterns and environmental controls of perchlorate and nitrate co-occurrence in arid and semi-arid environments. Geochimica et Cosmochimica Acta, v. 164, p. 502-522.

Jastram, J.D., 2014, Streamflow, water quality, and aquatic macroinvertebrates of selected streams in Fairfax County, Virginia, 2007-12: U.S. Geological Survey Scientific Investigations Report 2014-5073, 68 p.

Jastram, J.D., Moyer, D.L., and Hyer, K.E., 2009, A comparison of turbidity-based and streamflow-based estimates of suspended-sediment concentrations in three Chesapeake Bay tributaries: U.S. Geological Survey Scientific Investigations Report 2009-5165, 37 p.

Kemp, W.M., Boynton, W.R., Adolf, J.E., Boesch, D.F., Boicourt, W.C., Brush, G., Cornwell, J.C., Fisher, T.R., Gilbert, P.M., Hagy, J.D., Harding, L.W., Houde, E.D., Kimmel, D.G., Miller, W.D., Newell, R.I.E., Roman, M.R., Smith, E.M., and Stevenson, J.C., 2005, Eutrophication of Chesapeake Bay-Historical trends and ecological interactions: Marine Ecology Progress Series, v. 303, p. 1-29.

Kendall, C., Elliott, E.M., and Wankel, S.D., 2007, Tracing anthropogenic inputs of nitrogen to ecosystems, in Lajtha, K., and Michener, R.H., eds., Stable isotopes in ecology and environmental science ( $2 \mathrm{~d}$ ed.): Blackwell Scientific Publications, p. 375-449.

Killpack, S.C., and Buchholz, D., 1993, Nitrogen in the environment-Nitrogen replacement value of legumes: University of Missouri Extension, accessed January 13, 2016, at http://extension.missouri.edu/p/WQ277. 
Kreitler, C.W., 1975, Determining the source of nitrate in ground water by nitrogen isotope studies: University of Texas, Bureau of Economic Geology Report of Investigations, v. 83, p. 57.

Kreitler, C.W., Ragone, S.E., and Katz, B.G., 1978, N15/N14 ratios of ground-water nitrate, Long Island, New York: Ground Water, v. 16, no. 6, p. 404-408.

Landers, M.N., and Ankcorn, P.D., 2008, Methods to evaluate influence of onsite septic wastewater-treatment systems on base flow in selected watersheds in Gwinnett County, Georgia, October 2007: U.S. Geological Survey Scientific Investigations Report 2008-5220, 12 p., accessed December 16, 2015, at http://pubs.usgs.gov/sir/2008/5220/.

Langland, Michael, Blomquist, Joel, Moyer, Douglas, and Hyer, Kenneth, 2012, Nutrient and suspended-sediment trends, loads, and yields and development of an indicator of streamwater quality at nontidal sites in the Chesapeake Bay watershed, 1985-2010: U.S. Geological Survey Scientific Investigations Report 2012-5093, 26 p.

Law, N.L., Band, L.E., and Grove, J.M., 2004, Nitrogen input from residential lawn care practices in suburban watersheds in Baltimore County, Maryland: Journal of Environmental Planning and Management, v. 47, no. 5, p. 737-755.

Lehmann, M.F., Reichert, P., Bernasconi, S.M., Barbieri, A., and McKenzie, J.A., 2003, Modelling nitrogen and oxygen isotope fractionation during denitrification in a lacustrine redox-transition zone: Geochimica et Cosmochimica Acta, v. 67 , p. 2529-2542.

Lindsey, B.D., Phillips, S.W., Donnelly, C.A., Speiran, G.K., Plummer, N.L., Böhlke, J.K., Focazio, M.J., Burton, W.C., and Busenberg, E., 2003, Residence times and nitrate transport in ground water discharging to streams in the Chesapeake Bay Watershed: U.S. Geological Survey WaterResources Investigations Report 2003-4035, 201 p.

Lindsey, B.D., Berndt, M.P., Katz, B.G., Ardis, A.F., and Skach, K.A., 2009, Factors affecting water quality in selected carbonate aquifers in the United States, 1993-2005: U.S. Geological Survey Scientific Investigations Report 2008-5240, 117 p.

Liu, Z.J., Weller, D.E., Correll, D.L., and Jordan, T.E., 2000, Effects of land cover and geology on stream chemistry in watersheds of Chesapeake Bay: Journal of the American Water Resources Association, v. 36, p. 1349-1365.

Maizel, M.S., Muehlbach, G., Baynham, P., Zoerkler, J., Monds, D., Iivari, T., Welle, P., Robbin, J., and Wiles, J., 1997, The potential for nutrient loadings from septic systems to ground and surface water resources and the Chesapeake Bay: U.S. Environmental Protection Agency Report Number 903-R-97-006.
Mann, K.H., 1958, Annual fluctuations in sulfate and bicarbonate hardness in ponds: Limnology and Oceanography, v. 3, p. 418-422.

Martin, C., Aquilina, Gascuel-Odoux, C., Molenat, J., Faucheux, M., and Ruiz, L., 2004, Seasonal and interannual variations of nitrate and chloride in stream waters related to spatial and temporal patterns of groundwater concentrations in agricultural catchments: Hydrological Processes, v. 18, no. 7 , p. $1237-1254$.

Maryland Department of Agriculture, 2011, Upper Chester River Showcase Watershed Project farm assessment report, accessed December 22, 2014, at http://www.dcr.virginia. gov/laws_and_regulations/documents/chester-assessmentreport.pdf.

Maryland Department of the Environment, 2006, Total maximum daily loads of nitrogen and phosphorus for the Upper and Middle Chester River, Kent and Queen Anne's Counties, Maryland: submitted to Watershed Protection Division, U.S. Environmental Protection Agency, accessed June 24, 2015, at http://www.mde.state.md.us/ programs/Water/TMDL/ApprovedFinalTMDLs/Documents/ www.mde.state.md.us/assets/document/Chester_Rivermain_033106_final.pdf.

McCune, Bruce, Grace, J.B., and Urban, D.L., 2002, Analysis of ecological communities: Gleneden Beach, Oregon, MjM Software Design, 304 p.

McMahon, G., Bales, J.D., Coles, J.F., Giddings, E.M.P., and Zappia, H., 2003, Use of stage data to characterize hydrologic conditions in an urbanizing environment: Journal of the American Water Resources Association, v. 39, no. 6, p. $1529-1546$.

McMahon, P.B., and Böhlke, J.K., 1996, Denitrification and mixing in a stream-aquifer system-Effects on nitrate loading to surface water: Journal of Hydrology, v. 186, p. $105-128$.

McMahon, P.B., and Böhlke, J.K., 2006, Regional patterns in the isotopic composition of natural and anthropogenic nitrate in groundwater, High Plains, USA: Environmental Science \& Technology, v. 40, p. 2965-2970.

Meals, D.W., Dressing, S.A., and Davenport, T.E., 2010, Lag time in water quality response to best management practices-A review: Journal of Environmental Quality, v. 39, no. 1 , p. 85-96.

Meyer, J.L., Paul, M.J., and Taulbee, W.K., 2005, Stream ecosystem function in urbanizing landscapes: Journal of the North American Benthological Society, v. 24, p. 602-612. 
Millaleo, R., Reyes-Diaz, M., Ivanov, A.G., Mora, M.L., and Alberdi, M., 2010, Manganese as essential and toxic element for plants-Transport, accumulation and resistance mechanisms: Journal of Soil Science and Plant Nutrition, v. 10 , no. 4 , p. $476-494$.

Michalski, G., Scott, Z., Kabiling, M., and Thiemens, M.H., 2003, First measurements and modeling of D17O in atmospheric nitrate: Geophysical Research Letters, v. 30, no. 16, p. ASC 14.1-14.4, accessed January 29, 2016, at http://onlinelibrary.wiley.com/ doi/10.1029/2003GL017015/abstract.

Moyer, D.L., Hirsch, R.M., and Hyer, K.E., 2012, Comparison of two regression-based approaches for determining nutrient and sediment fluxes and trends in the Chesapeake Bay watershed: U.S. Geological Survey Scientific Investigations Report 2012-5244, 118 p.

Mueller, D.K., and Spahr, N.E., 2006, Nutrients in streams and rivers across the Nation-1992-2001: U.S. Geological Survey Scientific Investigations Report 2006-5107, $44 \mathrm{p}$.

National Research Council, 2011, Achieving nutrient and sediment reduction goals in the Chesapeake Bay-An evaluation of program strategies and implementation: Washington, D.C., The National Academies Press, accessed December 16, 2015, at https://download.nap.edu/ catalog.php?record_id=13131.

Nelms, D.L., and Moberg, R.M., Jr., 2010, Hydrogeology and groundwater availability in Clarke County, Virginia: U.S. Geological Survey Scientific Investigations Report 2010-5112, 119 p.

Noe, G.B., Hupp, C.R., Schenk, E.R., and Rybicki, N.R., 2013, Science summary-Sediment and nutrient trapping in the flood plain of Difficult Run, Virginia, and implications for the restoration of Chesapeake Bay, accessed January 13, 2016, at http://chesapeake.usgs.gov/documents/ss-sedimentnutrienttrapping.pdf.

Obama, Barack, 2009, Executive Order 13508Chesapeake Bay protection and restoration, accessed December 16, 2015, at http://executiveorder.chesapeakebay.net $/ \mathrm{EO} /$ file .axd?file $=2009 \% 2 \mathrm{f} 8 \% 2 \mathrm{fChesapeake+Exec}$ utive+Order.pdf.

Paul, M.J., and Meyer, J.L., 2001, Streams in the urban landscape: Annual Reviews of Ecology and Systematics, v. 32, p. 333-365.

Pennsylvania State University Environmental Resources Research Institute, 2001 (revised 2006), Total Maximum Daily Loads (TMDLs) plan for Conewago Creek watershed, accessed June 26, 2015, at http://www.epa.gov/reg3wapd/ tmdl/pa_tmdl/ConewagoRevised/ConewagoRevReport.pdf.
Petrovic, A.M., 2008, Report to the Pleasant Bay Alliance on the turfgrass fertilizer nitrogen leaching rate, accessed January 29, 2016, at http://www.chatham-ma.gov/public documents/ChathamMa_CWMPlan/Petrovicfinalreport.pdf.

Phillips, S.W., and Blomquist, J.D., eds., 2015, U.S. Geological Survey Chesapeake science strategy, 2015-2025Informing ecosystem management of America's largest estuary: U.S. Geological Survey Open-File Report 2015-1162, 43 p., accessed January 13, 2016, at http://dx.doi.org/10.3133/ofr20151162.

Plummer, L.N., Busenberg, E., Böhlke, J.K., Nelms, D.L., Michel, R.L., and Schlosser, P., 2001, Groundwater residence times in Shenandoah National Park, Blue Ridge Mountains, Virginia, USA-A multi-tracer approach: Chemical Geology, v. 179, p. 93-111.

Plummer, L.N., Michel, R.L., Thurman, E.M., and Glynn, P.D., 1993, Environmental tracers for age dating young ground water, in Alley, W.M., ed., Regional ground-water quality: New York, Van Nostrand Reinhold, p. 225-294.

Preston, S.D., Alexander, R.B., Schwarz, G.E., and Crawford, C.G., 2011, Factors affecting stream nutrient loads-A synthesis of regional SPARROW model results for the continental United States: Journal of the American Water Resources Association, v. 47, no. 5, p. 891-915.

Preston, S.D., and Brakebill, J.W., 1999, Application of spatially referenced regression modeling for the evaluation of total nitrogen loading in the Chesapeake Bay watershed: U.S. Geological Survey Water-Resources Investigations Report 99-4054, 12 p.

Rader, E.K., and Gathright, T.M., II, comps., 2001a, Geologic map of the Augusta, Page, and Rockingham Counties portion of the Charlottesville 30 X 60 minute quadrangle: Commonwealth of Virginia, Department of Mines, Minerals, and Energy, Division of Mineral Resources, Publication 159, scale 1:100,000.

Rader, E.K., and Gathright, T.M., II, comps., 2001b, Geologic map of the Front Royal 30 X 60 minute quadrangle-Portions of Clarke, Page, Rockingham, Shenandoah, and Warren Counties, Virginia: Commonwealth of Virginia, Department of Mines, Minerals, and Energy, Division of Mineral Resources, Publication 162, scale 1:100,000.

Rasmussen, P.P., Gray, J.R., Glysson, G.D., and Ziegler, A.C., 2009, Guidelines and procedures for computing time-series suspended-sediment concentrations and loads from in-stream turbidity-sensor and streamflow data: U.S. Geological Survey Techniques and Methods, book 3, chap. C4, 52 p. 
Révész, K., and Böhlke, J.K., 2002, Comparison of $\delta^{18} \mathrm{O}$ measurements in nitrate by different combustion techniques: Analytical Chemistry, v. 74, p. 5410-5413.

Ruddy, B.C., Lorenz, D.L., and Mueller, D.K., 2006, Countylevel estimates of nutrient inputs to the land surface of the conterminous United States, 1982-2001: U.S. Geological Survey Scientific Investigations Report 2006-5012, 17 p.

Runkel, R.L., Crawford C.G., and Cohn, T.A., 2004, Load estimator (LOADEST) - A Fortran program for estimating constituent loads in streams and rivers: U.S. Geological Survey Techniques and Methods, book 4, chap. A5, 69 p.

Rutledge, A.T., 1998, Computer programs for describing the recession of ground-water discharge and for estimating mean ground-water recharge and discharge from streamflow records-Update: U.S. Geological Survey Water-Resources Investigations Report 98-4148, 43 p.

Ryberg, K.R., 2006, Cluster analysis of water-quality data for Lake Sakakawea, Audubon Lake, and McClusky Canal, central North Dakota, 1990-2003: U.S. Geological Survey Scientific Investigations Report 2006-5202, 38 p.

Sanford, W.E., Nelms, D.L., Pope, J.P., and Selnick, D.L., 2012, Quantifying components of the hydrologic cycle in Virginia using chemical hydrograph separation and multiple regression analysis: U.S. Geological Survey Scientific Investigations Report 2011-5198, 152 p.

Sanford, W.E., Pope, J.P., Selnick, D.L., and Stumvoll, R.F., 2012, Simulation of groundwater flow in the shallow aquifer system of the Delmarva Peninsula, Maryland and Delaware: U.S. Geological Survey Scientific Investigations Report 2012-1140, 58 p.

Schenk, E.R., Hupp, C.R., Gellis, A., and Noe, G., 2013, Developing a new stream metric for comparing stream function using a bank-floodplain sediment budget - A case study of three Piedmont streams: Earth Surface Processes and Landforms, v. 38, no. 8, p. 771-784.

Schroeder, R.A., Martin, P., and Böhlke, J.K., 1993, Chemical, isotopic, and microbiological evidence for denitrification during transport of domestic wastewater through a thick unsaturated zone in the Mojave Desert: U.S. Geological Survey Water-Resources Investigations Report 93-414: 2. p. 917-926.

Shedlock, R.J., Denver, J.M., Hayes, M.A., Hamilton, P.A., Koterba, M.J., Bachman, L.J., Phillips, P.J., and Banks, W.S.L, 1999, Water-quality assessment of the Delmarva Peninsula, Delaware, Maryland, and Virginia - Results of investigations, 1987-91: U.S. Geological Survey WaterSupply Paper 2355-A, 41 p.
Sickles, J.E., II, and Shadwick, D.S., 2007, Changes in air quality and atmospheric deposition in the eastern United States-1990-2004: Journal of Geophysical Research, v. 112 , p. 1-18.

Sigman, D.M., Casciotti, K.L., Andreani, M., Barford, C., Galanter, M., and Böhlke, J.K., 2001, A bacterial method for the nitrogen isotopic analysis of nitrate in seawater and freshwater: Analytical Chemistry, v. 73, p. 4145-4153.

Turnipseed, D.P., and Sauer, V.B., 2010, Discharge measurements at gaging stations: U.S. Geological Survey Techniques and Methods book 3, chap. A8, 87 p. (Also available at http://pubs.usgs.gov/tm/tm3-a8/.)

U.S. Census Bureau, 2012, 2010 Census of population and housing - Population and housing unit counts-Virginia: Washington, D.C., U.S. Government Printing Office, 117 p.

U.S. Census Bureau, 2013, Guide to state and local geography-Virginia - Geography: U.S. Census Bureau, accessed January 20, 2015, at http://www.census.gov/geo/ reference/guidestloc/st51_va.html.

U.S. Census Bureau, 2015, TIGER/Line Shapefiles, accessed January 13, 2016, at https://www.census.gov/cgi-bin/geo/ shapefiles/index.php?year=2015\&layergroup=Roads.

U.S. Department of Agriculture, Farm Service Agency, 2016, CRP Practice Library, accessed July 25, 2016 at https:/www.fsa.usda.gov/programs-and-services/ conservation-programs/crp-practices-library/index.

U.S. Department of Agriculture, Natural Resources Conservation Service, 2013, Impacts of conservation adoption on cultivated acres of cropland in the Chesapeake Bay region, 2003-06 to 2011: $113 \mathrm{p}$.

U.S. Department of Agriculture, National Resources Conservation Service, 2016, Conservation practices, accessed January 4, 2016, at http://www.nrcs.usda.gov/ wps/portal/nrcs/detailfull/national/technical/cp/ ncps/?cid=nrcs143_026849.

U.S. Department of Commerce, U.S. Census Bureau, Geography Division/Cartographic Products Branch, 2014, Cartographic boundary file, for United States, 1:500,000, accessed January 13, 2016, at http://www2.census.gov/geo/ tiger/GENZ2014/shp/cb_2014_us_state_500k.zip.

U.S. Environmental Protection Agency, 2010, Chesapeake Bay total maximum daily load for nitrogen, phosphorus, and sediment: Annapolis, Md., Chesapeake Bay Program Office, accessed May 19, 2015, at http://www.epa.gov/ chesapeakebaytmdl/.

U.S. Environmental Protection Agency, undated, accessed January 29, 2016, at http://www.epa.gov/sites/production/ files/2015-07/documents/bay_tmdl_fact_sheet.pdf. 
U.S. Geological Survey, 2012a, Replacement of the simple speciation method for computation of carbonate and bicarbonate concentrations from alkalinity titrations: Office of Water Quality Technical Memorandum 2012.05, accessed September 16, 2012, at http://water.usgs.gov/admin/memo/ QW/qw12.05.pdf.

U.S. Geological Survey, 2012b, The StreamStats Program for Pennsylvania, accessed January 13, 2016, at http://water.usgs.gov/osw/streamstats/pennsylvania.html.

U.S. Geological Survey, 2013, National Hydrography Geodatabase-The National Map, accessed January 13, 2016, at http://viewer.nationalmap.gov/viewer/nhd.html?p=nhd.

U.S. Geological Survey, 2015, The National Elevation Dataset, accessed January 13, 2016, at http://viewer.nationalmap.gov/ viewer/nhd.html?p=nhd.

U.S. Geological Survey, variously dated, National field manual for the collection of water-quality data: U.S. Geological Survey Techniques of Water-Resources Investigations, book 9, chaps. A1-A9.

Virginia Department of Conservation and Recreation, 2016, Virginia Agricultural BMP and CREP database query form, accessed January 4, 2016, at http://dswcapps.dcr.virginia.gov/ htdocs/progs/BMP_query.aspx.

Virginia Department of Environmental Quality, 2014, 2014 Impaired Waters - 303(d) List, accessed January 20, 2015, at http://www.deq.virginia.gov/Portals/0/DEQ/Water/ WaterQualityAssessments/IntegratedReport/2014/ ir14_Appendix1a_Category5_List.pdf.

Virginia Tech Department of Biological Systems Engineering and University of Virginia Institute for Environmental Negotiation, 2009, Smith Creek watershed TMDL implementation plan, Rockingham and Shenandoah Counties, City of Harrisonburg, and Town of New Market, Virginia, accessed January 20, 2015, at http://www.deq.virginia.gov/Portals/0/ DEQ/Water/TMDL/ImplementationPlans/smithip.pdf.

Wagner, R.J., Boulger, R.W., Oblinger, C.J., and Smith, B.A., 2006, Guidelines and standard procedures for continuous water-quality monitors - Station operation, record computation, and data reporting: U.S. Geological Survey Techniques and Methods 1-D3, 51 p. +8 attachments.
Walsh, C.J., Roy, A.H., Feminella, J.W., Cottingham, P.D., Groffman, P.M., and Morgan, R.P., II, 2009, The urban stream syndrome - Current knowledge and the search for a cure: Journal of the North American Benthological Society, v. 24, p. $706-723$.

Weller, D.E., Jordan, T.E., Sellner, K.G., Foreman, K., Shenk, K., Tango, P., Phillips, S.W., and Dubin, M., 2010, Small watershed monitoring designs: Chesapeake Bay Program Scientific and Technical Advisory Committee, STAC Publication 10-004.

Wieczorek, M.E., and LaMotte, A.E., 2010a, Attributes for NHDPlus catchments (version 1.1) for the conterminous United States-Average atmospheric (wet) deposition of inorganic nitrogen, 2002: U.S. Geological Survey Digital Data Series DS-490-02, accessed December 15, 2015, at http://water.usgs.gov/GIS/metadata/usgswrd/XML/ nhd_atdep.xml.

Wieczorek, M.E., and LaMotte, A.E., 2010b, Attributes for NHDPlus catchments (version 1.1) for the conterminous United States-NLCD 2001 land use and land cover: U.S. Geological Survey Digital Data Series DS-490-15, accessed December 15, 2015, at http://water.usgs.gov/GIS/ metadata/usgswrd/XML/nhd_nlcd01.xml.

Wieczorek, M.E., and LaMotte, A.E., 2010c, Attributes for NHDPlus catchments (version 1.1) for the conterminous Unites States-Nutrient inputs from fertilizer and manure, nitrogen and phosphorus (N\&P), 2002: U.S. Geological Survey Digital Data Series DS-490-17, accessed December 16, 2015, at http://water.usgs.gov/GIS/metadata/ usgswrd/XML/nhd_nutrients.xml.

Wieczorek, M.E., and LaMotte, A.E., 2010d, Attributes for NHDPlus catchments (version 1.1) for the conterminous United States-Nutrient application (phosphorus and nitrogen) for fertilizer and manure applied to crops (cropsplit), 2002: U.S. Geological Survey Digital Data Series DS-490-08, accessed December 16, 2015, at http://water.usgs.gov/GIS/metadata/usgswrd/XML/ nhd_cropsplit02.xml.

Xue, Dongmei, Botte, Jorin, De Baets, Bernard, Accoe, Frederik, Nestler, Angelika, Taylor, Philip, Van Cleemput, Oswald, Berglund, Michael, and Boeckx, Pascal, 2009, Present limitations and future prospects of stable isotope methods for nitrate source identification in surface- and groundwater: Water Research, v. 43, no. 5, p. 1159-1170. 


\section{Appendix 1}
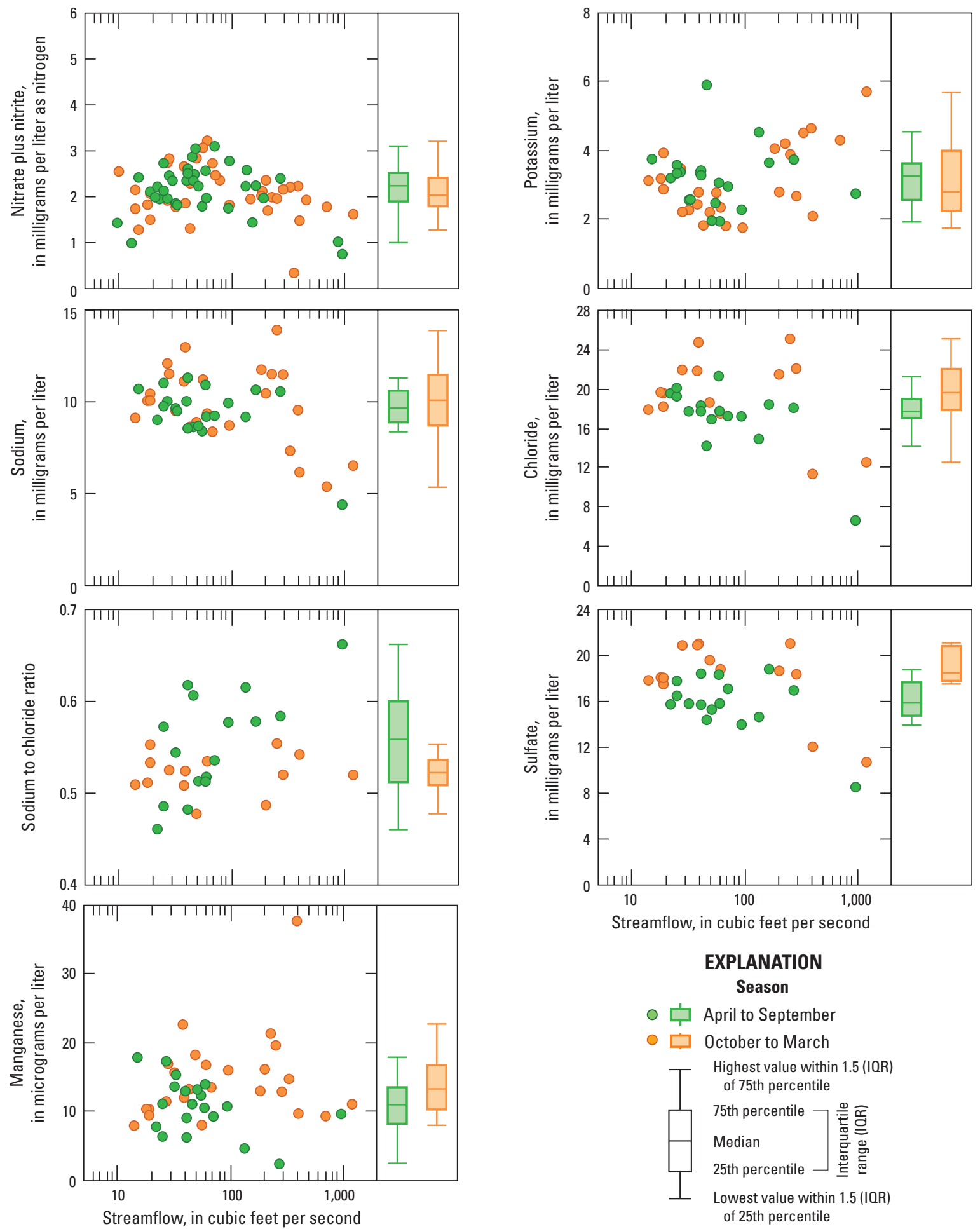

EXPLANATION

Season

○ Ф April to September

- $\square$ October to March

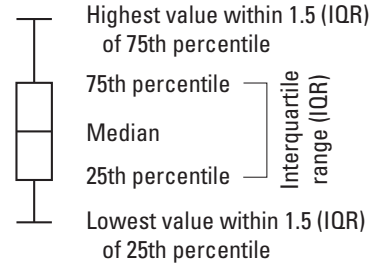

Figure 1-1. Concentration-discharge data for discrete samples from the Smith Creek streamgage by warm and cool season. 

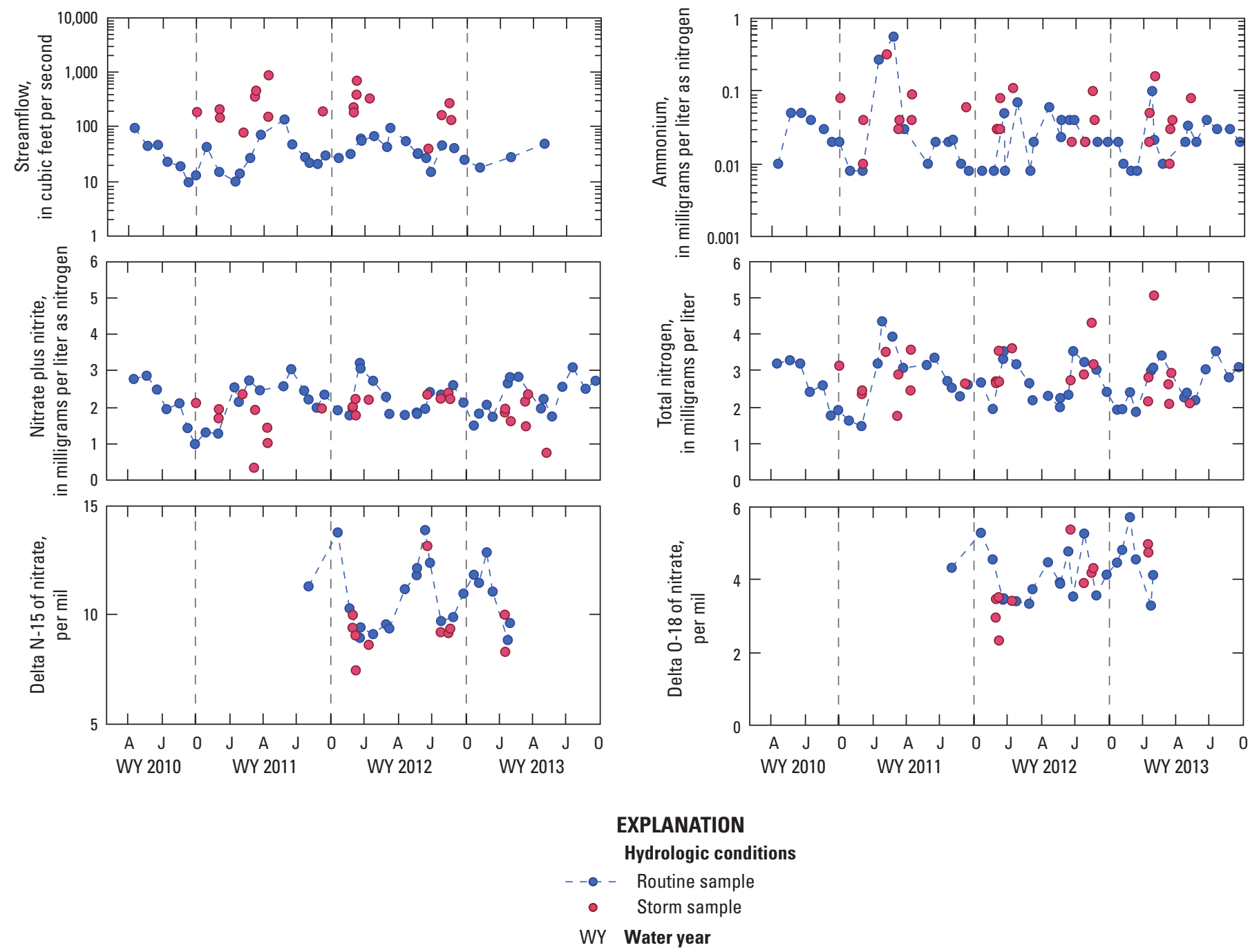

Figure 1-2. Concentrations of various constituents in discrete samples from the Smith Creek streamgage, 2011-2013. 

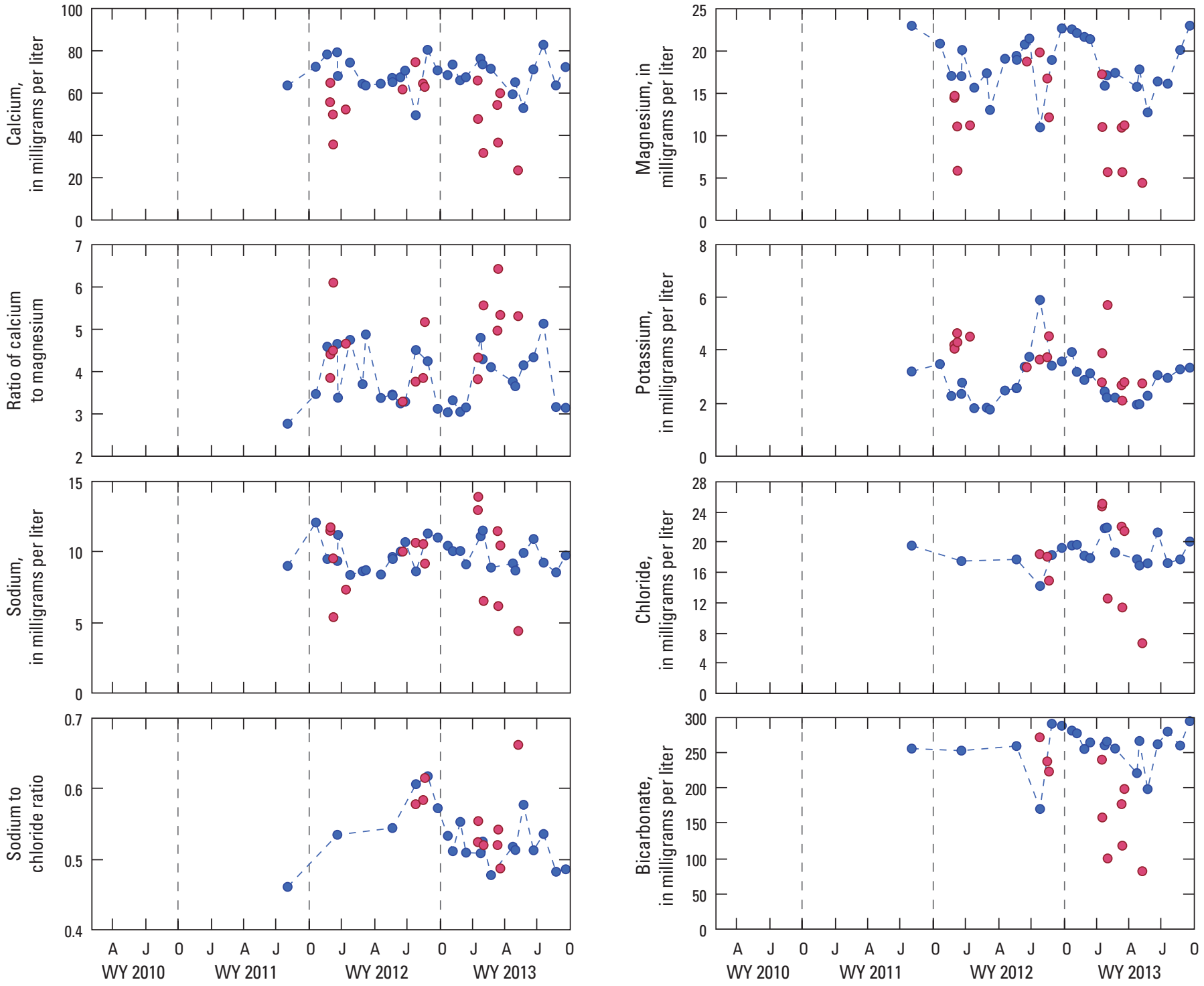

\section{EXPLANATION}

Hydrologic conditions

- - Routine sample

- Storm sample

WY Water year

Figure 1-2. Concentrations of various constituents in discrete samples from the Smith Creek streamgage, 2011-2013.-Continued 

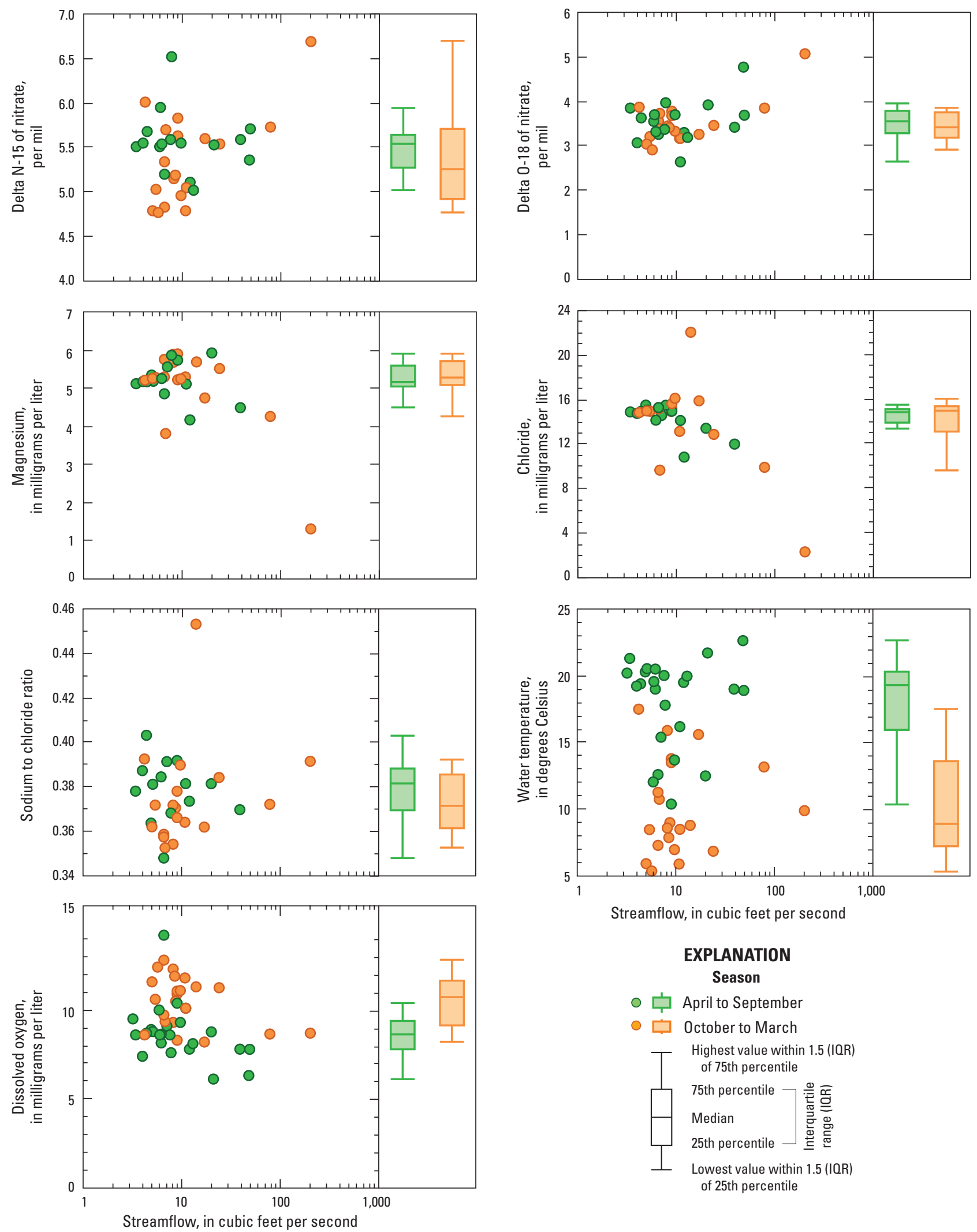

\section{EXPLANATION}

Season

- April to September

- $\square$ October to March

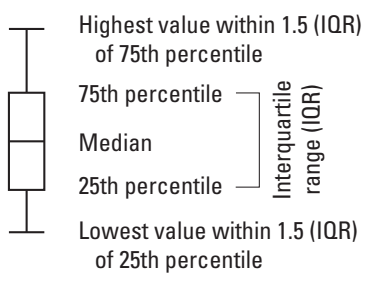

Figure 1-3. Concentration-discharge data for discrete samples from the Chesterville Branch streamgage by warm and cool season, 2011-2013. 

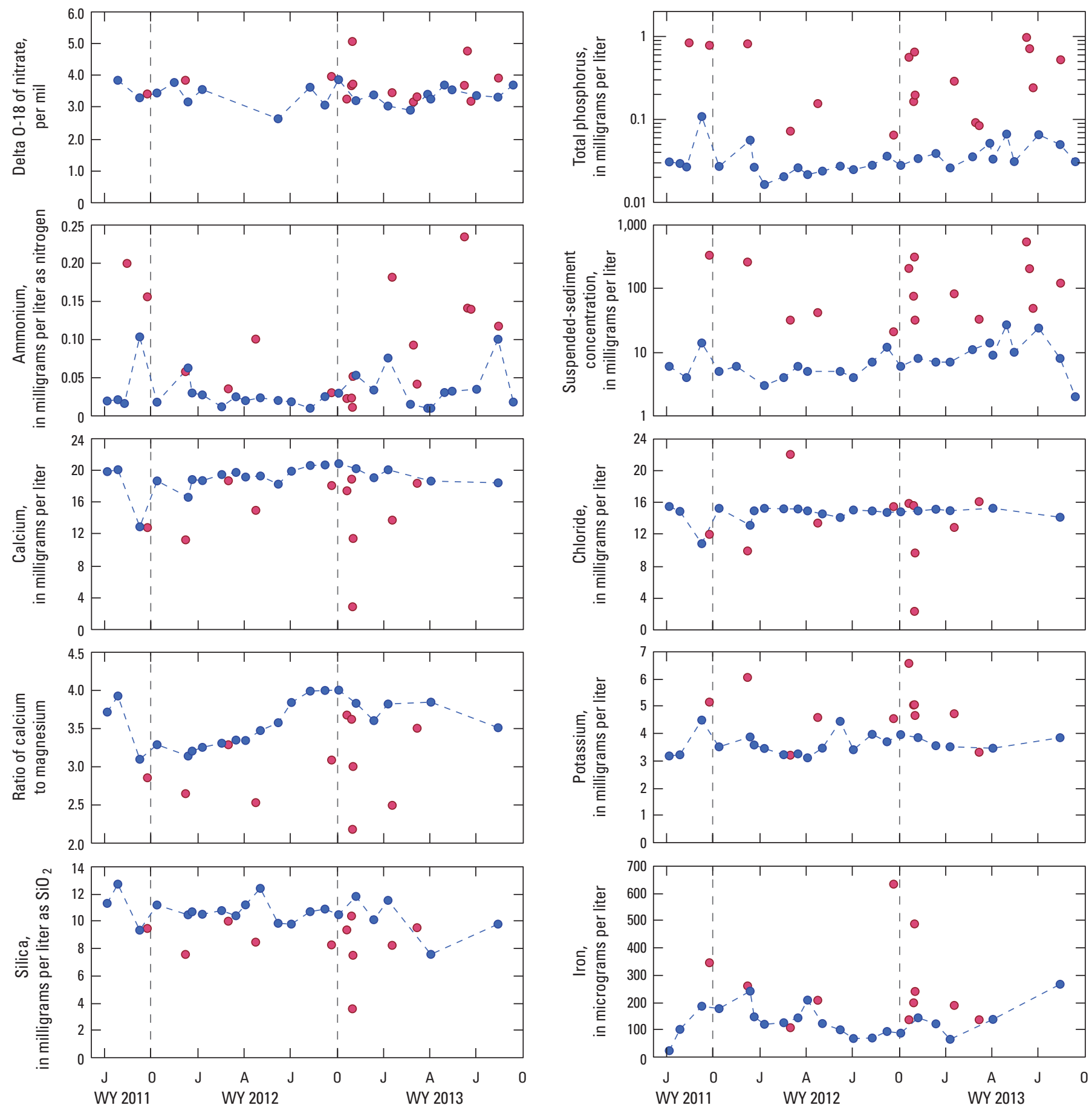

EXPLANATION

Hydrologic conditions

- - - Routine sample

- Storm sample

WY Water year

Figure 1-4. Concentrations of various constituents in discrete samples from the Chesterville Branch streamgage, 2011-2013. 

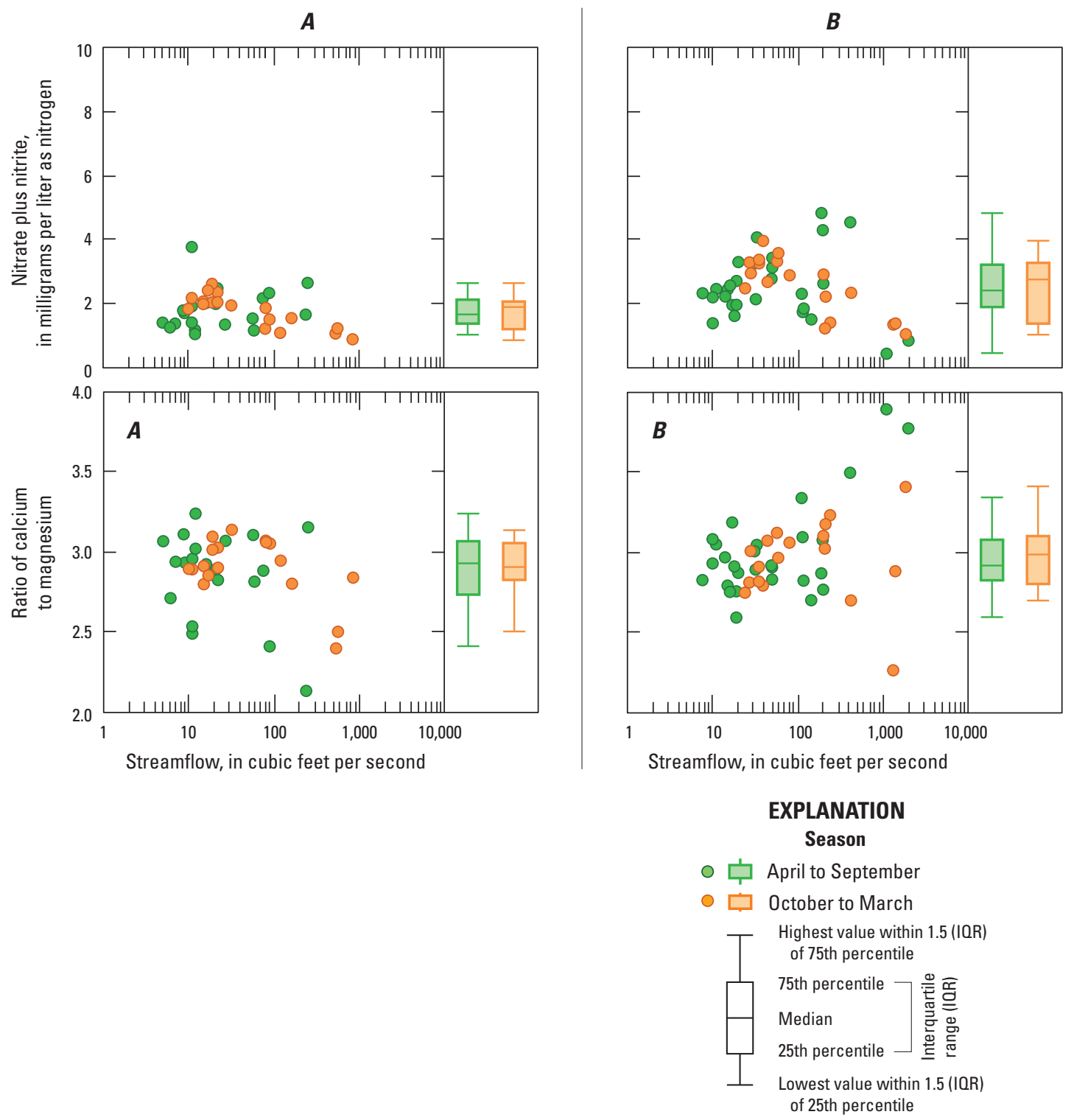

Figure 1-5. Concentration-discharge data for discrete samples from the Conewago Creek $(A)$ Bellaire and $(B)$ Falmouth streamgages by warm and cool season. 

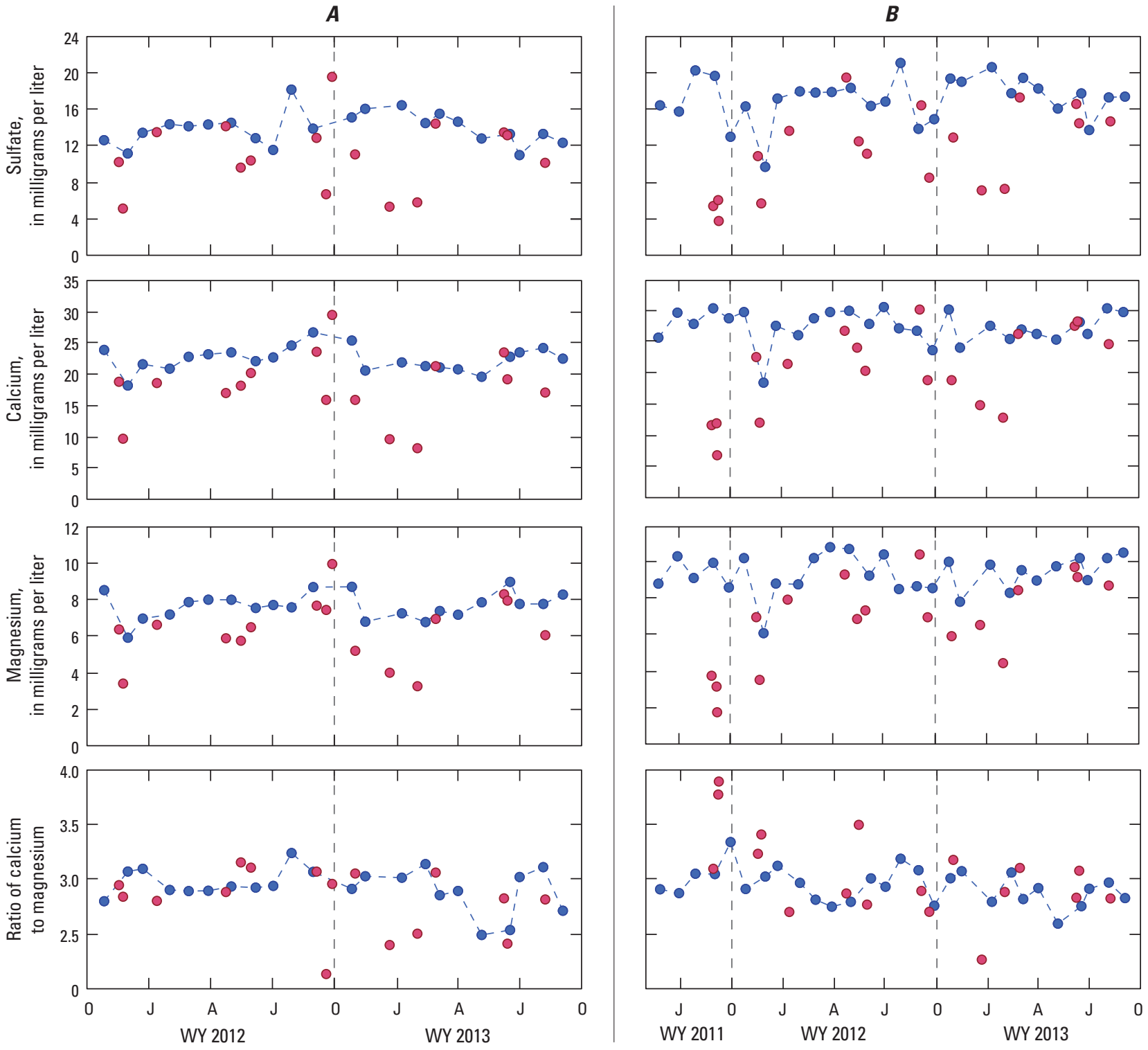

\section{EXPLANATION}

Hydrologic conditions

- - Routine sample

Storm sample

WY Water year

Figure 1-6. Concentrations of various constituents in discrete samples from the Conewago Creek $(A)$ Bellaire and $(B)$ Falmouth streamgages. 

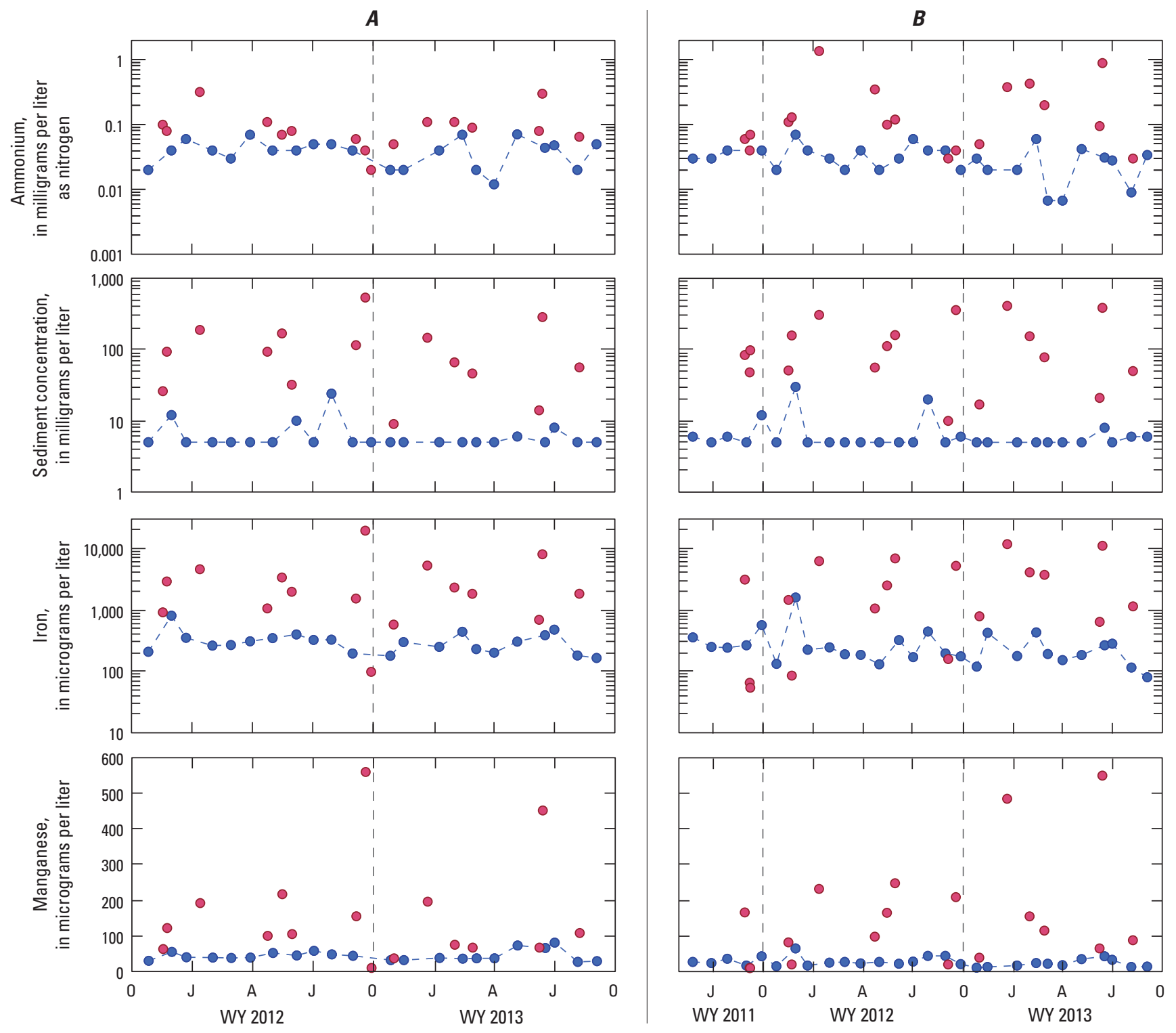

\section{EXPLANATION}

Hydrologic conditions

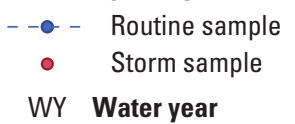

Figure 1-6. Concentrations of various constituents in discrete samples from the Conewago Creek $(A)$ Bellaire and (B) Falmouth streamgages.-Continued 

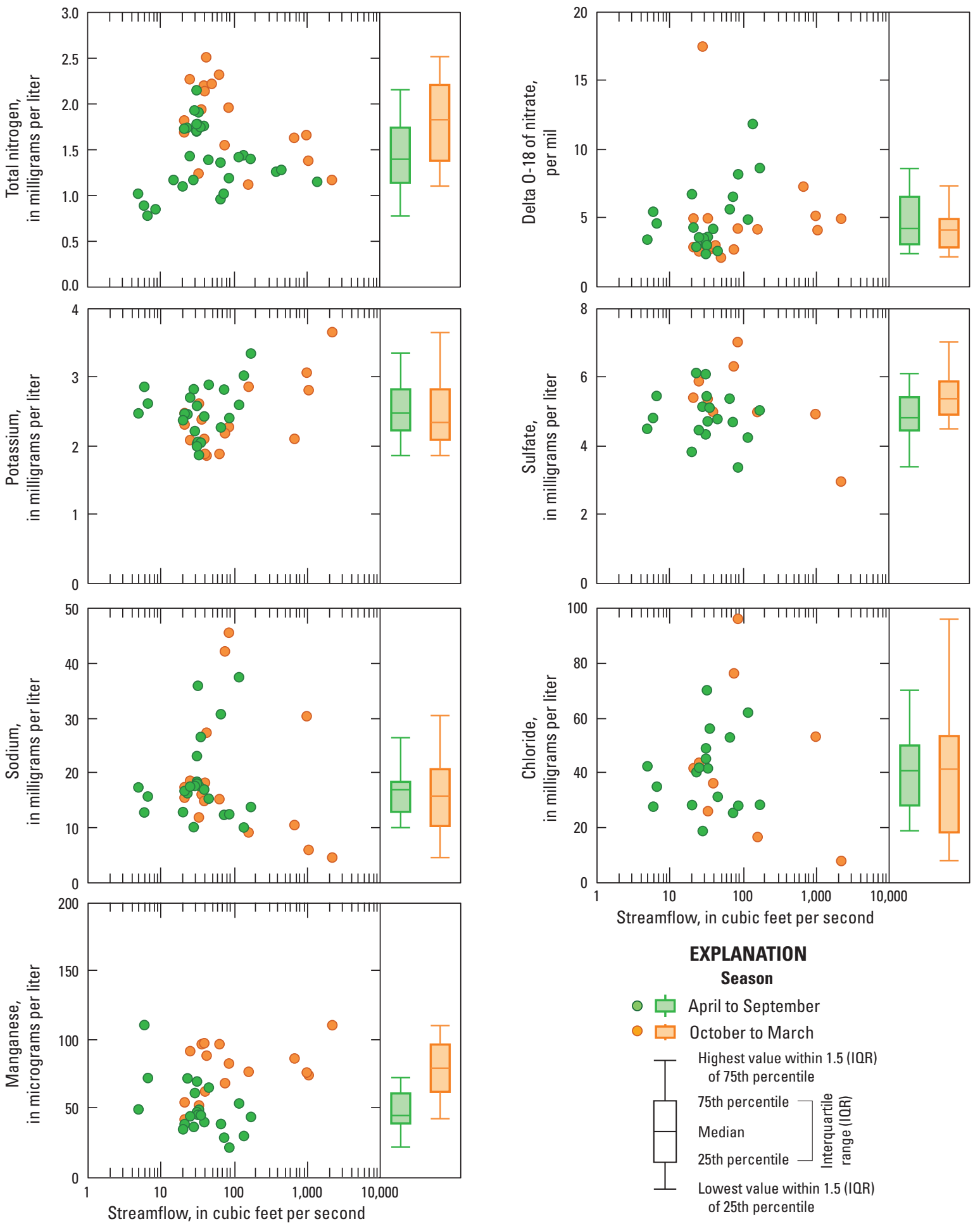

EXPLANATION

\section{Season}

○ April to September

○ $\square$ October to March

T Highest value within 1.5 (IOR) of 75 th percentile

75th percentile $\square$ 을 Median 25th percentile $\longrightarrow$ 亲 힌 of 25 th percentile

Figure 1-7. Concentration-discharge data for discrete samples from the Difficult Run streamgage by warm and cool season, 2011-2013. 

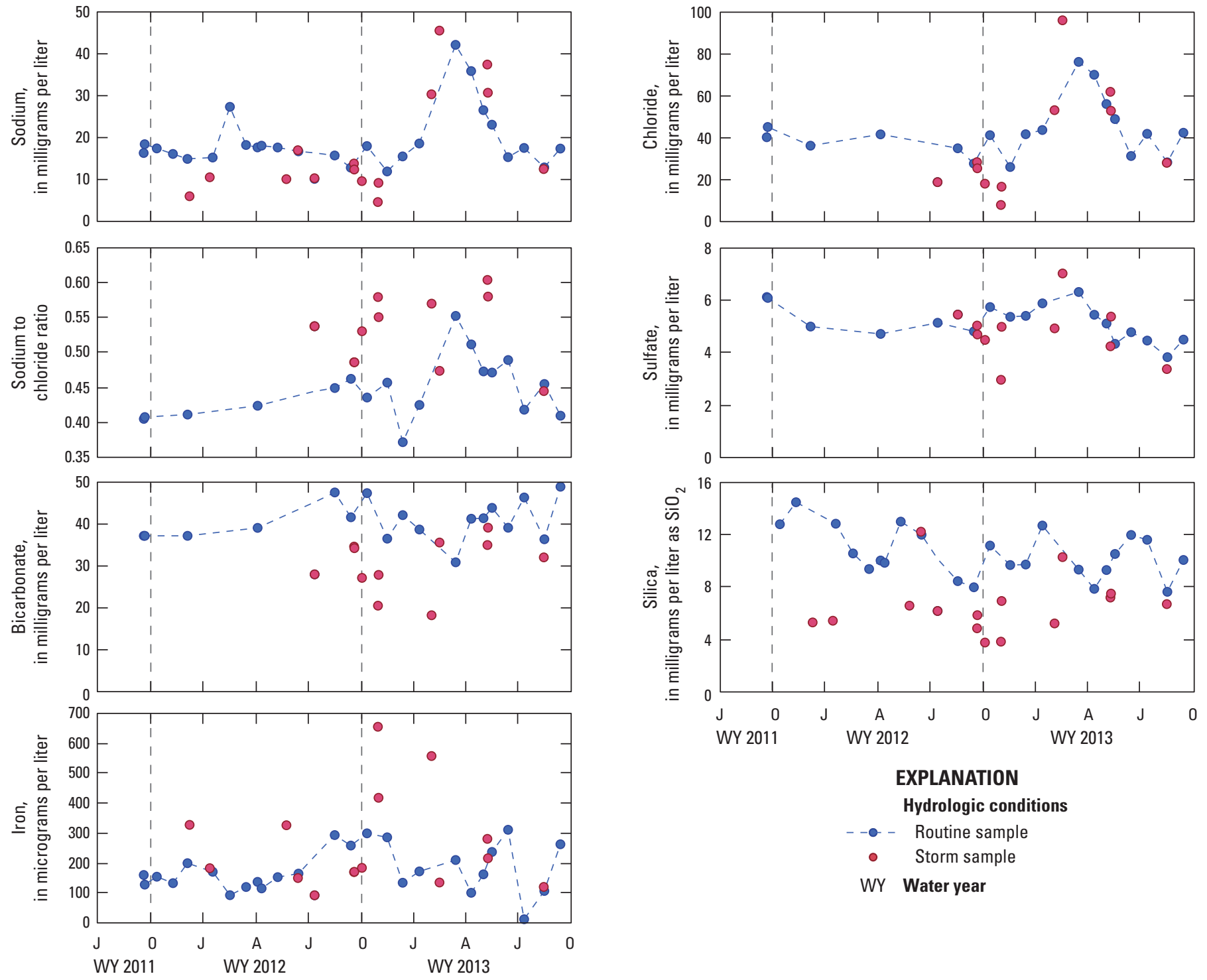

\section{EXPLANATION}

Hydrologic conditions

- - - Routine sample

- Storm sample

WY Water year

Figure 1-8. Concentrations of various constituents in discrete samples from the Difficult Run streamgage, 2011-2013. 

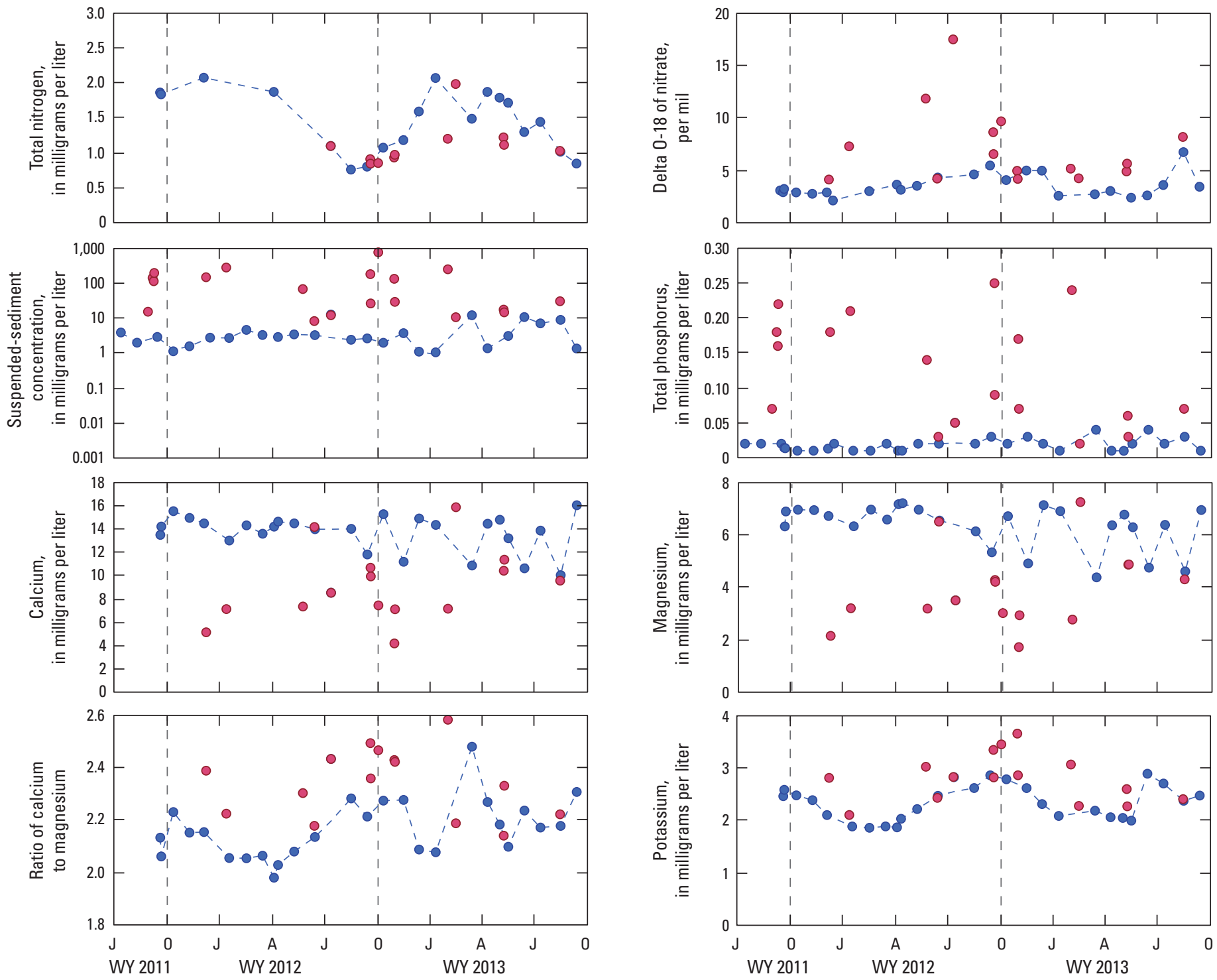

\section{EXPLANATION}

Hydrologic conditions

- - - Routine sample

Storm sample

WY Water year

Figure 1-8. Concentrations of various constituents in discrete samples from the Difficult Run streamgage, 2011-2013.-Continued 

Manuscript approved June 25, 2016

Prepared by the Reston and Lafayette Publishing Service Centers

For more information about this publication, contact: Director

U.S. Geological Survey

1730 East Parham Road

Richmond, VA 23228

(804) 261-2600

or visit our Web site at http://va.water.usgs.gov/ 


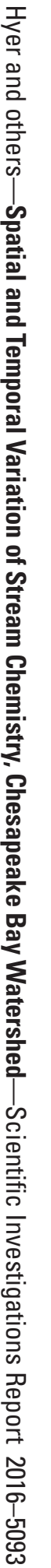

